
<smiles>C1C2CC3CC1C23</smiles> 






\section{THE FAUNA OF BRITISH INDIA,}

INCLUDING

\section{CEYLON AND BURMA.}

Published UNDER the AUTHortty OF the SECRETARY OF

State for Inda in Council.

EDITED BY LT,-COL, C. T. BINGHAM.

\section{O L E O P T ERA.}

CHRYSOMELIDE.

\section{VOL. I.}

BY

MARTIN JACOBY.

L O N D O N :

TAYLOR AND FRANCIS, RED LION COURT, FLEET STREET.

CALCUTTA AND SIMLA:

THACKER, SPINK, \& CO.

BURMA :

MYLES STANDISH \& CO., RANGOON.
BOMBAY:

THACKER \& CO., LIMITED.

BERLIN :

R. FRIEDLÄNDER \& $80 H N$, 11 CARLSTRASSE. 
$Q L$

$$
\begin{aligned}
& 596 \\
& 45 \\
& 53
\end{aligned}
$$

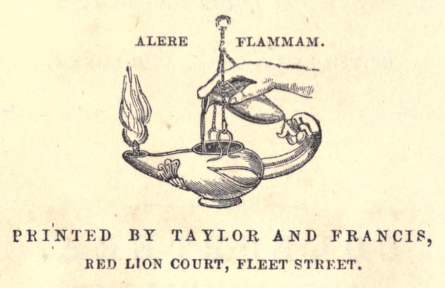




\section{PREFACE.}

THE present volume deals with a portion only of the vast number of forms contained in the family Chrysomelide as defined and characterized by Mr. Jacoby on pages 1, 2 and 3 of the work. I venture to hope, however, that the publication of the book will not only turn the attention of Collectors in India to this somewhat neglected but important group of Phytophagous Beetles, but prove of substantial assistance, enabling them to recognize the forms so far as they are recorded in the text and illustrations.

It is with the deepest regret I have to record the death of the Author, Mr. M. Jacoby, while the last proofs of the book were passing through the press, so that for the explanation of the terms used and also for much assistance during the progress of the work I am greatly indebted to Mr. C. J. Gahan.

\section{London,} C. T. BINGHAM.

January 1908. 



\section{LIST OF THE PRINCIPAL WORKS QUOTED IN THE SYNONYMY.}

A. M. N. H. Annals and Magazine of Natural History. London, 18381907.

Ann. Mus. Civ. Genova. Annali del Museo Civico di Storia Naturale. Genova, 1870-1907.

Ann. Soc. Ent. Belg. Annales de la Société Entornologique de Belgique. Bruxelles, 1857-1907.

Ann. Soc. Ent. France. Annales de la Société Entemologique de France. Paris, 1832-1907.

Baly, Descr. New Gen. \& Spec. Phytoph. Descriptions of New Genera and Species of Pbytophaga, by J. S. Baly. London, 1864.

Bull. Mosc. Bulletin de la Société Impériale des Naturalistes de Moscou. Moscow, 1829-1907.

Bull. Soc. Ent. Belg. Bulletin de la Société Entomologique de Belgique. (Bound up with the Annales, supra.)

Bull. Soc. Ent. France. Bulletin des Séances et Bulletin Bibliographique de la Société Entomologique de France. (Publisbed with the Aunales.) Paris, 1873-1907.

Chapuis, Gen. Coléopt. Histoire Naturelle des Insectes. Genera des Coléoptères, ou Exposé méthodique et critique de tous les genres proposís jusqu'ici dans cet ordre d'insectes, par 'Th. Lacordaire. 12 vols. Paris, 1854-1876. (Vols. x, xi, \& xii, by M. F. Chapuis.)

Cist. Ent. Cistula Entomologica. 3 vols. Lcndon, 1869-1884. (Of vol. iii. three parts only published.)

Clark, Cat. Phytoph. and App. Cat. Phytoph. A Catalogue of Phytophaga (Coleoptera, Pseudotetramera), by the Rev. Hamlet Clark, M.A., F.L.S., with an Appendix containing descriptions of New Species by H. W. Bates and Rev. H. Clark. London, 1866.

Curtis, Brit. Ent. British Entomology, by John Curtis. London, 18231840.

Deut. ent. Zeit. Deutsche entomologische Zeitschrift. Berlin, 1875-1907. ( $\Lambda$ continuation of the Berliner entomologische Zeitschrift.)

Drury, Ill. Exot. Ins. D. Drury, Illustrations of Natural History, \&c. Exotic Insects. 3 vols. London, 1770-1782.

Enc. Méth. Encyclopédie Méthodique-Insectes. (Vol. V, par A. G. Olivier.) Paris, 1790-1825.

Entomologist. The Entomologist. London, 1840-1907.

Ent. Month. Mag. The Entomologist's Monthly Magazine. London, 1864-1907. 
Fabr. Ent. Syst. Entomologia Systematica, emendata et aucta, secundum classes, ordines, genera, species; adjectis synonymis, locis, observationibus, descriptionibus. 4 vols. Johann Christian Fabricius. Hafniæ, 17921794. Index 1796 ; Supplement 1798.

Fabr. Mant. Ins. Mantissa Insectorum; sistens eorum species nuper detectas; adjectis characteribus genericis, differentiis specificis, emendationibus, observationibus. 2 vols. Johann Christian Fabricius. Hafniæ, 1787.

Fabr. Spec. Ins. Species Insectorum, exhibentes eorum differentias specificas, synonyma auctorum, loca natalia, metamorphosin; adjectis observationibus, descriptionibus. 2 vols. Johann Christian Fabricius. Hamburgi et Kilonii, 1781.

Fabr. Syst. Eleuth. Systema Eleutheratorum, secundum ordines, genera, species; adjectis synonymis, locis, descriptionibus et observationibus. 2 vols. Johann Christian Fabricius. Kiliæ, 1801.

Fabr. Syst. Ent. Systema Entomologiæ, sistens Insectorum classes, ordines, genera, species; adjectis synonymis, locis, descriptionibus, observationibus. Johann Christian Fabricius. Flensburgi et Lipsiæ, 1775.

Füessly, Arch. Ins. Archiv der Insectengeschichte, herausgegeben von Johann Gaspar Füiessly. Zürich, 1781-1786.

Geoffroy, Hist. Ins. Paris. Histoire abrégée des Insectes que se trouvent aux environs de Paris. 2 vols. Paris, 1762 .

Gray's Zool. Misc. The Zoological Miscellany, ed. by J. E. Gray. London, 1831-1s44.

Guér. Icon. Règne Anim., Ins. F. E. Guérin-Méneville, Iconographie du Règne Animal de G. Cuvier-Insectes. Paris, 1829-1844.

Gyllenh. Schönh. Syn. Insect. Gyllenhal in Synonymia Insectorum, oder: Versuch einer Synonynie aller bisher bekannten Insecten; nach Fabricii Systema Eleutheratorum geordnet; von O.J. Schönherr. 2 vols. Stockholm \& Skara, 1806-1817. (Appendix by Gyllenhal, Dalman, Swartz, \&c.)

Har. Coleopt. Coleopterologische Hefte. Herausgegeben unter mit Wirkung mehrerer Fachgenossen, vou E. V. Harold. Munich, 1867-1876.

Horæ Soc. Ent. Ross. Horæ Societatis Entomologicæ Rossicæ; (Called also Trudui Russkago entomologicheskago obschestva v. St. Petersburg). St. Petersburg, 1861-1907.

Hügel's Reise Kaschmir. Kaschmir und das Reich der Siek. Baron C. A. A. von Hügel. 4 vols. Stuttgart, 1840-1848.

Journ. Linn. Soc., Zool. Journal of the Proceedings of the Linnean Society, Zoology. London, 1857-1907.

Jour. of Entomology. The Journal of Entomology, descriptive and geographical. 2 vols. London, 1862-1866.

Knoch, Neue Beit. Insektenk. Neue Beyträge zur Insektenkunde mit Abbildungen von August Wilhelm Knoch. Leipzig, 1801.

Lacord. Mon. Phytoph. Monographie des Coléoptères Subpentamères de la Familles des Phytophages, par M. Th. Lacordaire. 2 vols. Bruxelles et Leipzig, 1845-1848.

Laicharting, Verz. Tyrol. Ins. Verzeichniss und Beschreibung der Tyroler Insecten, by Johann Nepomuk Elden von Laicharting. 2 vols. Zürich, 1781-1784. 
Latreille, Hist. Nat. Ins. P. A. Latreille, Histoire naturelle, générale et particulière des Orustacés et des Insectes, \&c. (Suites à Buffon.) 14 vols. Paris, 1802-1805.

Lefèv. Cat. Eumolp. Eumolpidarum hucusque cognitarum Catalogus, sectionum conspectu systematico, generum sicut et specierum nonnullarum novarum deseriptionibus adjunctis. Ed. Lefèvre. (Published in the Mémoires de la Société Royale des Sciences de Liége (2) xi, 1885.) Liége, 1843-1907.

Linn. Ent. Linnæa Entomologica. Zeitschrift herausgegeben von dem Entomologische Vereine in Stettin. Berlin \& Leipzig, 1846-1866.

Mém. Soc. Ent. Belg. Mémoires de la Société Entoınologique de Belgique. Bruxelles, 1892-1907.

Motsch. Étud. Ent. Motschoulsky, Etudes Entomologiques. Helsingfors et Dresden, 1853-1862.

Motsch. Reise Amur. or Motsch. Schrenck Reise Amur. Reisen und Forscbungen im Amur-Lande in den Jahren 1854-1856. Dr. Leopold v. Schrenck. 4 vols. St. Petersburg, 1858-1892.

Mus. Nat. Ac. Ups. Theses Museum Naturalium Acadomiæ Upsaliensis. Carol. Pet. Thunberg. 33 pts. Upsala [1787-1821].

Naturforscher. Der Naturforscher. Halle, 1774-1802.

Neue Schr. Naturf. Ges. Halle. Neue Schriften der naturforschenden Gesellschaft in Halle. Halle, 1809-1817.

Notes Leyd. Mus. Notes from the Royal Zoological Museum of the Netherlands at Leyden. Leyden, 1879-1907.

Novit. Zool. Novitates Zoologicæ. A journal of Zoology in connection with the Tring Museum. Tring, 1894-1907.

Oliv. Ent. Entomologie, ou Histoire Naturelle des Insectes, avec leurs caractères géuériques et spécifiques, leur description, leur synonymie, et leur figure enluminée, par M. Olivier. Texte 6 vols. Planches 2 vols. Paris, 1759-1808.

P. Z. S. Proceedings of the Scientific Meetings of the Zoological Society of London. London, 1830-1907.

Redtenb. Fauna Austr. Fauna Austriaca. Die Käfer, nach der analytischen Methode bearbeitet, von Ludwig Redtenbacher. Wien, 1858.

Rev. Ent. Silberm. Revue Entonılogique, par Gustave Silbermann. Strasbourg \& Paris, 1833-1837.

Rev. et Mag. Zool. Revue et Magasin de Zoologie pure et appliquée, par Guérin-Méneville et Ad. Focillon. 2nd Series. Paris, 1849-1879.

Rev. Zool. Revue Zoologique par la Société Cuvierienne, publié sous la direction de M. Guérin-Méneville. Paris, 1838-1848.

Schönh. Syn. Ins. ' See above, Gyllenh. Schönh. Syn. Insect.

Stephens, Illustr. Brit. Entom. Illustrations of British Entomology, or a Synopsis of Indigenous Insects, by J. F. Stephens. 7 vols. London, 18:8-1835.

Thomson, Skand. Col. Skandinaviens Coleoptera, Synoptiskt bearbetade. C. G. Thomson. 10 vols. Lund, 1859-1868.

Trans. Am. Ent. Soc. Transactions of the Anerican Entomological Socioty. Philadelphia, 1867-1907. 
Trans. Ent. Soc. Transactions of the Entomological Society of London. London, 1836-1907.

Trans. Linn. Soc. Transactions of the Linnean Society of London. London, 1791-1907.

Voy. Deless. Souvenirs d'un royage dans l'Inde exécuté de 1834-1839. A. Delessert. Paris, 1848.

Weber, Obs. Ent. Observationes Entomologicæ, continentes novorum que condidit generum characteres, et nuper detectarum specierum descriptiones. Friedrich Weber. Kiliæ, 1801. 


\section{EXPLANATION OF THE TERMS USED FOR THE PARTS OF A CHRYSOMELID BEETLE.}
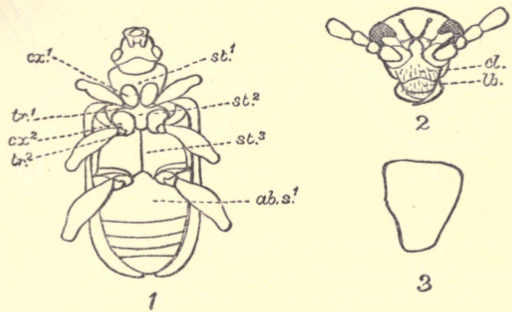

3

Fig. 1.-Lema quadripunctata, Oliv. (Eupodes.)

1. Underside of body.-st $t^{1}$, prosternum ; $s t^{2}$, mesosternum ; $s t^{3}$, metasternum ; $c x^{1}$, coxa of front leg; $t r^{1}$, trochanter of same; $c x^{2}$, coxa of intermediate leg; $t r^{2}$, trochanter of same; $a b . s^{1}$, first abdominal segment.

2. Front view of head.-cl., clypeus; $l b$., labrum.

3. Prothorax seen from the side.

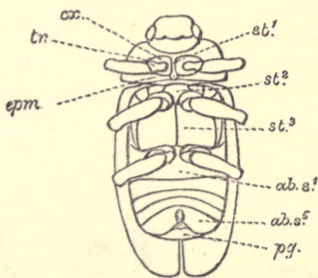

1
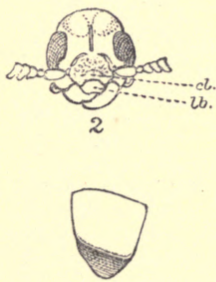

3

Fig. 2.-Clytra conformis, Lac. (Cамгтоsомеs.)

1. Underside of bedy. $-s t^{1}, s t^{2}$, and $s t^{3}$, pro-, meso-, and metasternum; epm., epimeron of prothorax; $c x$., coxa ; tr., trochanter; $a b . s^{1}, a b . s^{5}$, first and fith abdominal segments; $\mathrm{pg}$., pygidium (= last dorsal segment).

2. Front view of head.-cl., elypeus; $l b$., labium.

3. Side view of prothorax. 


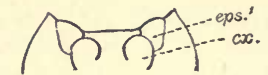

4

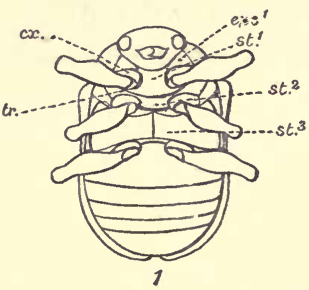

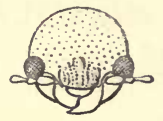

2

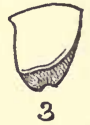

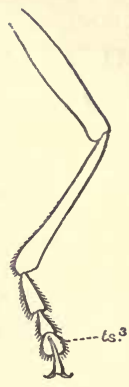

5

Fig. 3.-Colasposoma robustum, Jac. (Crchica.)

1. Underside of body.- $s t^{1}, s t^{2}$, and $s t^{3}$, pro-, meso-, and metasternum; $e p s^{1}$, episternum of prothorax (front margin straight); $c x$., cora ; $t r$., trochanter.

2. Front view of head. 3. Side view of prothorax.

4. Part of prothorax of Abirus igneicollis, Jac.-eps ${ }^{1}$, episternum (with front margin convex); cx., coxa.

5. Hind leg of Chrysomela gruti, Baly.- $t s^{3}$, third tarsal joint (which is entire).

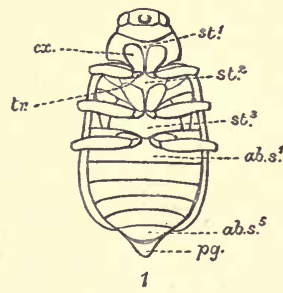

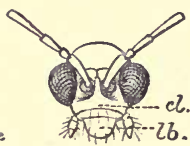

2

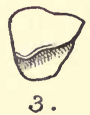

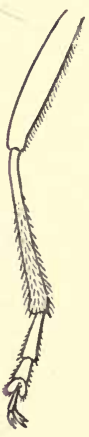

4

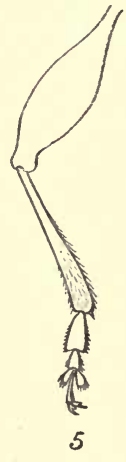

5

Fig. 4.-Aulacophora stevensi. (TR1cnostomes.)

1. Underside of body of $q .-s t .^{1}, s t^{2}$, and $s t^{3}$, pro-, meso-, and metasternum; $c x$., cora; tr., trochanter; $a b . s^{1}$ and $a h . s^{5}$, first and fifth abdominal segments; $p g .$, pygidium (= last dorsal segment).

2. Front view of head (showing approximated antennæ); $c l$., clypeus; $l b$., labrum.

3. Side view of prothorax. 4. Hind leg (showing bifid tarsal claws).

5. Hind leg of Haltica burmanensis, Jac. (showing thickened femur and appendiculate tarsal claws). 


\section{SYSTEMATIC INDEX.}

Order COLEOPTERA..... ${ }_{1}^{\text {Page }}$

Suborder Polyphaga ..... 1

Fam. Chrysomelid

Div. 1. Eupodes ........ 3

Subfam. 1. Sagrina ....... 3

1. Sagra, Fabr. ........ 4

1. femorata, Drury .... 4

2. longicollis, Lacord. . . 4

3. empyrea, Lacord. .... 5

4. nigrita, Oliv. ....... 5

5. brevipes, Jac. . . . . . . 6

6. jansoni, Baly ....... 6

7. longipes, Baly ..... 6

8. carbunculus, Hope $\quad$. 7

9. mouhoti, Baly ..... 7

10. multipunctata, Jac. .. 8

11. petelii, Lacord. ..... 8

Subfam. 2. Donacïne ..... 9

1. Donacia, Fabr. ...... 10

1. æraria, Baly ....... 10

2. delesserti, Guér. .... 10

3. recticollis, Jac. ..... 11

4. indica, Clark ........ 11

Subfam. 3. Criocerince ...... 12

1. Pedrillia, Westro. ..... 12

1. longicornis, Westiv. .. 13

2. murrayi, Clark ..... 13

3. flavipes, Jac. ...... 14
Page

2. Zeugophora, Kunze..... It

1. indica, Jac........ 14

2. andrewesi, Jac. ...... 14

3. Orsodacna, Latreille .... 15

1. indica, Motsch. ..... 15

4. Lema, Fabr. ........ 15

1. obliterata, Jac. ..... 16

2. fulvicornis, Jac...... 16

3. nigro-frontalis, Clark . 17

4. birmanica, Jac. ..... 17

5. semiregularis, Jac. .. 18

6. malabarica, Jac. .... 18

7. hopei, Jac......... 19

8. obscuritarsis, Jac. .... 19

9. balyana, Jac. ....... 20

10. horni, Weise ........ 20

11. globicollis, Baly .... 21

12. rotundicollis, Jac. . . . 21

13. epipleuralis, Jac. .... 21

14. ceylonensis, Jac. .... 22

15. intacta, Jac. ....... 22

16. præclara, Clark ..... 23

17. lacordairei, Baly .... 23

18. andamanensis, Jac. . . . 24

19. amethystina, Jac. .... 24

20. coromandeliana, Fabr.. 25

21. kandyensis, Weise .... 26

22. tibiella, Weise ..... 26

23. flavimana, Jac. ..... 27

24. tranquebarica, Fabr. . 27

25. atkinsoni, Jac. . . . . 28

26. rufo-brunnea, Jac. . . 28

27. peguensis, Jac. ..... 28

28. subtuberculata, Jac. .. 29

29. palpalis, Lacord. . . . 29

30. indica, Jac. ....... 30

31. yerburyi, Jac. $\quad$..... 30 
3.) crioceriodes, Jac. Page

33. greeni, Jac. ....... 31

34. mandibularis, Jac. . . . 32

35. singularis, Jac. . . . . 32

36. cariuata, Jac. ....... 33

37. simillima, Jac. ..... 33

38. wallardiensis, Jac. $\quad \ldots \quad 33$

39. palonensis, Jac. . . . . 34

40. subiridea, Jac. . . . . 34

41. fulvula, Lacor d. . . . . . 35

42. lacertosa, Lacord. . . . 35

43. rufo-testacea, C'lark .. 36

44. impotens, Lacord. . . . 36

45. castanea, Jac. ..... 37

46. cerea, Jac. ......... 37

47. antonii, Clavareau.... 38

48. longefemorata, Jıc. . . 38

49. rubiginea, Jac. . . . . 38

50. tharawaddyensis, Jac. . 39

51. mahéensis, Jac. ..... 39

52. rugifrons, Jac. ..... 40

53. feæ, Jac........... 40

54. assamensis, Jac. .... 40

55. pallide-testacea, Clark. 41

56. clypeata, Jac. ...... 41

57. decolorata, Jac...... 42

58. suturella, Baly ... . . 42

59. downesi, Baly ..... 43

60. juvenilis, Jac. ..... 43

61. viridi-suturata, Jac. . 43

62. trifasciata, Jac. ..... 44

63. lycaon, Jac. ....... 44

64. bretinghami, Baly.... 45

65. rufo-ornata, Clark.... 45

66. ornatipennis, Jac. . . . 46

67. constricto-fasciata, Jac. 46

68. difficilis, Jac. . . . . . . 47

69. lateralis, Jac. . . . . . . . 48

70. semivittata, Clark .... 48

71. rufo-tibialis, Jac. .... 48

72. medio-lineata, Jac. .. 49

73. spoliata, Jac. ....... 50

74. ornaticollis, Jac. .... 50

75. obscurifrons, Jac. .... 51

76. semifulva, Jac. ..... 51

77. occipitalis, Jac. ..... 52

78. histrio, Clark ..... 52

79. crassipalpis, Duviv. .. 53

80. cardoni, Jac, ...... 53

81. burmaensis, Jac. .... 54

82. bimaculata, Baly .... 54

83. quadripunctata, Oliv... 55

84. femoruta, Guérin .... 56

85. maindroni, Jac. ..... 56

86. signatipennis, Jac. . ... 57

87. dimidiatipennis, Jac...
Page

88. præusta, $F a b . . . . . .55$

89. terminata, Lacord. . . 59

90. chalybeo-notata, Clar\%. 59

91. admirabilis, Jac. .... 59

92. arrogans, Jac. ..... 60

93. momeitensis, Jac. ... 60

94. binghami, Jac. ...... 61

95. fulvofrontslis, Jac. . 61

96. fulvimana, Jac. . . . . 62

97. rufofrontalis, Jac. . . . 62

98. psyche, Baly ....... 63

99. paradoxa, Jac. . . . . 63

100. gahani, Jac. ... . . . 6:

101. cyanea, Fabr. . . . . . . 64

102. westwoodi, Jac. . . . . 64

103. cribricollis, Weise ... 65

104. pedestris, Jac. . . . . 65

105. crebrepunctata, Jac. . . 6i;

106. atro-cærulea, Clark .. 66

107. nitidissima, Jac. ... 67

108. nilgiriensis, Jac. .... 67

109. purpurea, Jac. ..... 68

110. nigro-violacea, Jac. . . 68

111. mandarensis, Jac. . . . 69

112. funerea, Jac. . . . . . . 69

113. nigricollis, Jac. . . . . . 69

114. belgaumensis, Jac. .. T)

115. crassicollis, Jac. . ... 70

116. macei, Lacord. ...... 71

5. Crioceris, Geoffroy ..... 71

1. malabarica, Jac...... 72

2. impressa, Fabr. . . . . 72

3. semipunctata, $\mathrm{Fabr}$. . . $7: 3$

4. pusilla, Clark....... 73

5. seminigra, Jac. . . . . 74

6. locuples, Clırk ..... 74

7. inconspicua, Clar $\%$... 75

8. semihirsuta, Jac. .... 75

9. semifoveolata, Jac. . . 76

10. flavipennis, Baly .... 76

11. semicostata, Jac. $\quad \ldots .77$

12. pulchella, Baly ...... 77

13. quadripustulata, $F a b r$. 78

14. adonis, Baly ....... 78

15. dohertyi, Jac. ..... 79

16. humeralis, Jac. ..... 79

17. cruciata, Guér. ..... 80

18. fasciatipennis, Jac. .. 80

19. hampsoni, Jac. ..... 81

20. nigro-ornata, $C l a r k \ldots 81$

21. multimaculata, Jac. . 82

22. cardoni, Jac. ....... 82

6. Pseudolema, Jac. ..... 83

1. suturalis, Jac. ..... 8:3

7. Manipuria, Jac. ....... 84

1. dohertyi, Jac. ..... 81 
Div. 2. Camptosomes .... 86

Subfam. 1. Megalopince .... 86

1. Temnaspis, Lacord. ... 87

1. bengralensis, Westiv. .. 87

2. nigripennis, Jac. ... 87

3. nigroplagiata, Jac. . . 88

4. downesi, Baly ..... 88

5. flavicornis, Jac. $\quad \ldots \quad 89$

6. clavareaui, Jac. ..... 90

7. oberthuri, Jac. ..... 90

8. assamensis, Jac. $\quad \ldots . .91$

2. Colobaspis, Fairm...... 91

1. nigriceps, Baly ...... 91

¿. insignis, Baly. . . . . . 92

3. speciosus, Baly ..... 92

4. quinquemaculatus, Baly $9: 3$

Subfam. 2. Clytrince ......

1. Labidostomis, Lacord. . . 96

1. indica, Jac. . ...... 96

2. cummingi, Jac. ..... 97

3. funerea, Fairm. . . . . . . 97

2. Merilia, Lacord. ........ 98

1. Iunulata, Fabr. ..... 98

3. Miopristis, Lacord. ' '... 99

1. bimaculata, Jac. . ... 99

4. Atheodactyla, Lacord. .. 100

1. lateralis, Lacord. . . . 100

5. Pseudoclytra, Jac. ...... 101

1. andrewesi, Jac. . . . . 101

2. plagiata, Duviv. . . . 102

6. Gynandrophthalma,Lacord.103

1. longicoruis, Jac. . . . 103

2. delesserti, Lacord. . . 104

3. frontalis, Jac. ..... 104

4. orientalis, Jac. ..... 105

5. apicipenuis, Jac. .... 105

6. laticollis, Duviv. . . . 105

7. cærulea, Jac. . . . . . 106

8. dohertyi, Jac........ 107

9. bohemani, Jac. ..... 107

10. cornuta, Jac. . . . . . . 108

11. signaticollis, Redtenb. . 109

12. affine, Jac. . . . . . . . 109

13. mungphuensis, Jac. . . 109

14. semipunctata, Duviv. . 110

15. cochinchinensis, Lefêv. 111

16. assamensis, Jac. .... 111

17. nagaensis, Jac. ..... 112

18. crassipes, Duviv. ... 112

19. planifrons, Jac. ...... 113

20. chrysomeloides, Lacord. 113
21. ceylonica, Jac. ...... 113

22. fuscitarsis, Jac. . . . . 114

¿3. fuscicornis, Lacord. . . 114

24. minuta, Jac. ....... 115

25. citrinella, Jac. ...... 115

26. nigrotibialis, Jac. .... 116

27. wallardiensis, Jac. .. 116

28. divisa, Jac. ...... 117

29. sikhima, Jac. . . . . . 117

30. nigrosuturalis, Jac. .. 118

31. crucipennis, Jac. .... 118

32. nilgiriensis, Jac. ... 119

33. striatipennis, Jac. . . . 119

34. imitans, Jac. . . .... 120

35. terminalis, Lefev. . . . 120

36. flavobasalis, $\check{J} a c . \quad \ldots .121$

37. subdivisa, Jac. ...... 12I

38. lævipennis, Jac. ... 122

39. fabrei, Lefêv. ........ 122

7. Atheomorpha, Lacord. . . 123

1. fallax, Lacord . . . . . 123

2. suturata, Jac. ..... 121

3. nigropicta, Lefèv. . . . 124

4. nigromarginata, Jac. . . 125

5. inornata, Jac. . . . . . 126

6. vinula, Weise ...... 126

7. sodalis, Lacord. . . . . . 127

8. cribellata, Jac. ..... 127

9. virgula, Jac. . . . . . 128

10. pictipennis, Jac. .... 128

11. unifasciata, Jac. .... 129

12. subrugosa, Jac. . . . . 130

13. 14-punctata, Jac. .... 130

14. tripunctata, Jac. . ... 131

15. assamensis, Jac. . ... 131

16. decemnotata, Jac. .... 132

17. parvula, Jac. ....... 132

18. maduraensis, Jac. . . . 133

8. Aspidolopha, Lacord. . . 134

1. cærulea, Jac. ....... 134

2. costata, Jac. ....... 135

3. apicalis, Jac. . . . . . 135

4. decora, Fabr. ........ 136

5. clavareaui, Jac. ...... 136

6. ventralis, Jac. . . . . 137

7. æneicollis, Jac. ..... 137

8. rugosa, Jac. ....... 138

9. distincta, Duviv. . . . 139

10. thoracica, Jac. ...... 139

11. trimaculata, Fabr..... 140

12. interrupto-fasciata, Jac. 141

13. ceylonica, Wreise .... 141

14. sublævicollis, Duviv. . . 142

15. nitidicollis, Juc. . . . 143

16. melanophthalma,

Lacord. . . . . . . . 144 
9. Epimela, Weise ....... 144

1. ornata, Redtenb. .... 144

2. viridicollis, Jac. .... 145

3. indica, Duviv. ..... 145

4. insularis, Weise . . ... 146

5. dilutipes, Jac. ..... 147

10. Pantocometis, Lacord. . . 147

1. hirsuta, Lacord. .... 148

2. subfasciata, Jac. .... 148

3. horni, Weise ....... 149

4. downesi, Baly ...... 149

11. Clytrasoma, Jac. ..... 149

1. palliata, Fabr. ..... 150

2. conformis, Lacord. . . 150

3. ceylonensis, Jac. .... 151

12. Clytra, Laich. ........ 152

1. succincta, Lacord. . . 152

2. chlorotica, Lefev. .... 153

3. flavotibialis, Jac. .... 153

4. dispar, Redtenb. .... 154

5. lefevrei, Jac. ....... 154

6. insularis, Lefev. . .... 155

7. duvivieri, Jac. ...... 155

8. annamita, Lefêv. .... 156

9. orientalis, Lefêv. .... 157

10. cardoni, Jac. . . . . 157

11. marginicollis, Jas. . . . 158

12. fasciato - punctata, Lacord. ........ 158

13. Miochira, Lacord. ..... 159

1. gracilis, Lacord. . . . 160

2. montana, Jac. ..... 160

3. indica, Jac. ....... 161

14. Diapromorpha, Lacord. . . 162

1. gigantea, Jac. ..... 162

2. obscuromaculata, Jac. . 163

3. pinguis, Lacord. . . . 163

4. melanocephala, Jac. . . 164

5. burmanica, Jac. .... 164

6. quadripunctata, Jac. . 165

7. dejeani, Lacord. . ... 166

8. sexmaculata, Jac. .... 167

9. octomaculata, Jac. $\quad$. 167

10. melanopus, Lacord. . . 168

11. capitata, Jac. ....... 169

12. turcica, Fabr. . . . . . 169

13. balteata, Lacord. . . . 170

14. indica, Jac. $\quad \ldots \ldots \ldots .171$

15. Ceratobasis, Lacord. .... 171

1. nair, Lacord. . ...... . 171

2. kœnigii, Fabr. ..... 172

3. ceylonensis, Jac. ... 173

4. opacipennis, Jac. . ... 174

16. Coptocephala, Lacord. . . 174

1. dimidiatipennis, Baly . 175

2. minuta, $\tilde{J}_{a c}$. ....... 175
Subfam. 3. Cryptocephalina .. 176

1. Dioryctus, Suffi. $\ldots \ldots 176$

1. porculus, Suffr. ..... 177

2. madurensis, Jac. $\quad \ldots 177$

3. glabricollis, Jac. .... 178

4. robustus, Jac. ..... 178

5. nigroplagiatus, Jac. . . 179

6. castaneus, Jac. ..... 179

7. analis, Jac. ......... 179

8. manipurensis, Jac. $\quad$. 180

9. semibrunneus, Jac. .. 180

10. abdominalis, Jac. .... 181

11. hauseri, Weise ..... 181

12. bifasciatus, Jac. ... 182

2. Cœnobius, Suffr. ..... 182

1. insularis, Weise ..... 183

2. lævicollis, Jac. ..... 183

3. manipurensis, Jac. . 184

4. andrewesi, Jac. . . . . . 184

5. burmanicus, Jac. .... 181

6. chalceus, Jac. ..... 185

7. seminigris, Jac. ..... 185

8. nigripes, Jac. ....... 186

9. dorsalis, Weise ...... 186

10. lateralis, Weise ...... 186

11. aterrimus, Jac. ...... 187

12. andamanensis, Jac. $\quad . .187$

13. discicollis, Jac. ..... 187

14. fulvicornis, Jac. ...... 188

15. fulvipes, Baly ..... 188

16. basalis, Jac. ....... 189

17. pallipes, Jac. . . . . . 189

18. integris, Jac. . . . . . 190

19. variegatus, Jac. . . . . . 190

20. strigicollis, Jac. . . . . . 191

21. semilævis, Jac. ...... 191

3. Cryptocephalus, Geoffi. . . 192

1. metallicus, Jac. ...... 192

2. submetallicus, Jac. . . 192

3. angustomarginatus, Jac. 193

4. circumductus, Suffr. . 193

5. semirufulus, Suffr. . . 194

6. inconstans, Jac...... 194

7. assamensis, Jac. ..... 195

8. exsulans, Suffr. ..... 195

9. unifasciatus, Jac. . ... 196

10. sinulans, Jac. . .... 197

11. posticalis, Jac. ..... 197

12. konbirensis, Duviv. . . 198

13. ensifer, Hope ....... 199

14. crucipennis, Suffr. . . 200

15. monachoides, Jac. . . . 200

16. rufofemoratus, Jac. . . 201

17. semiflarus, Jac. ...... 201

18. dilaticornis, Jac. .... 20\% 
19. flavocinctus, Jac. Page

20. quadrillium, Suffr. .. 203

21. sikhimensis, Jac. .... 203

22. elegans, Jac. . . . . . . 204

23. sutfriani, Jac. . . . . . . 204

24. durius, Suffr. . . . . . . 205

25. depressus, Suffr. . . . 205

26. ineditus, Jac. . . . . . . 206

27. feæ, Jac. . . . . . . . 206

28. signatellus, Jac. . . . 207

29. heraldicus, Suffr. . . . 207

30. sanguinolentus, Oliv. . . 208

31. bombayensis, Jac. . . . 208

32. belgaumensis, Jac. . . 209

33. spengleri, Fabr. . . . . 210

34. olivieri, Harold . . . . 210

35. rubripes, Hope ..... 210

36. latimanus, Oliv. .... 210

37. lundi, Fabr. . . . . . 211

38. octavius, Thunb. .... 211

39. decorus, Oliv. ..... 211

40. pusrensis, Jac. . . . . 211

41. obscuno-maculatus, Jac. 212

42. sandrocottus, Suffr. . . 212

43. calanus, Suffr. ..... 213

44. fenestratus, Suffi. . . . 213

45̃. gestroi, Jac. ....... 214

46. pallidipennis, Jac. . . . 214

47. hampsoni, Jac. ..... 215

48. cribricollis. Jac. . . . 216

49. hecticus, Fabr. . . . . 216

50. uniformis, Jac. . . . . 217

51. insignatus, Jac. . . . . . 217

52. subcostatus, Jac. .... 218

53. andrewesi, Jac. . . . . 219

54. fatuus, Suffr. . . . . . . 219

55. fraternus, Duviv. . . . 220

56. rufulus, Suffi: ..... 221

57. madrasæ, Jac. . . . . 221

58. mandarensis, Jac. . . . 221

59. subcylindricus, Suffr. . . 222

60. brahminus, Jac. . . . . . 223

61. dimidiatus, Suffi. . ... 223

62. lefevrei, Jac. . . . . . . 224

63. dimidiatipennis, Juc. . . 224

64. manipurensis, Jac. .. 225

65. insubidus, Sufr ${ }^{\circ}$. . . . 225

66. deliciens, Suffr. . . . . . 226

67. nigrolineatus, Jac. . . . 226

68. malleatus, Suffr. .... 227

69. lutulentus, Suffr. . . . 228

70. sehestedti, Fabr. .... 228

71. lucifer, Suffr. . . . . . . . 229

72. ovulum, Suffr. ..... 229

73. vittipennis, Suffr. . . . 230

74. poultoni, Jac. ....... 230
75. uncinatus, Suffr. .... 231

76. notogrammus, Suffr. . . 231

77. virguln, Suffr. ..... 232

78. præcox, Suffr. ..... 233

79. nigrosuturalis, Jac. .. 233

80. suavis, Duviv. ..... 234

81. rectofasciatus, Jac. .. 234

82. aberruns, Jac. ..... 235

83. longipes, Jac. . . . . . . 236

84. obliteratus, Suffr. ... 236

85. tricinctus, Redtenb. .. 237

86. maleficus, Suffr. .... 238

87. semidivisus, Jac. .... 238

88. angulato-fasciatus, Jac. 239

89. dichotomus, Suffr. .. 239

90. burmanicus, Jac. ... 240

91. sexsignatus, Fabr. . . . 241

92. bissexsignatus, Suffr. 242

93. indicus, Suffr. ..... 243

94. nilgiriensis, Jac. ... 244

95. leopardus, Jac. . . . . 244

96. divisus, Jac. . . . . . . 245

97. suillus, Suffr. . . . . . . 246

98. faustulus, Suffr. . . . . . 246

99. analis, Oliv. ....... 247

100. quadratus, Suffr. .... 248

101. oppositus, Jac. . . . . 249

102. kandyensis, Weise .... 249

103. laterimaculatus, Duviv. 250

104. stigmatipennis, Jac. . . 250

105. bowringi, Jac. ..... 251

106 sannio, Redtenb. .... 251

107. dodecaspilus, Suffr. .. 252

108. subgeminatus, Jac. .. 25.3

109. dohertyi, Jac. . . . . 254

110. vahli, Fabr. ....... 254

111. colon, Suffr. ....... 256

112. rajah, Jac. . . . . . . 256

113. ducalis, Jac. ....... 257

114. herbsti, Suffi:. ..... 258

115. pulvillatus, $S u f f r . \ldots .258$

116. floriger, Suffr. ..... 259

117. guttifer. Suffi. . . . . . 259

118. senarius, Suffr. ..... 260

119. obconicus, Suffi. . ... 261

120. kashmirensis, Jac. . . . 261

121. zonalis, Jac. ....... 262

122. darjilingensis, Jac. .. 263

123. decurio, Suffr. . . . . . $\approx 53$

124. corrosicollis, Jac. .... 264

125. abbreviatulus, Suffr. . 264

4. Pachybrachys, Suffr. .... 265

1. rubiginosus, Suffr. .. 265

2. pœcilopterus, Suffr. . . 266

5. Melixanthus, Suffr. ... 267

1. bians, Suffr. .......267 
Page

2. assamensis, Jac. .... 267

3. humeralis, Jac. . . . . . 268

4. malabarensis, Jac. . . . 268

6. Melinobius, Jac. . . . . . . . 269

1. longipes, Jac. . . . . . 270

Subfam. 4. Chlamydina .... 270

1. Chlamys, Knoch ....... 271

1. coromandeliana, Jac. . . 271

2. pallifrons, Jac. ..... 272

3. orientalis, Jac. ..... 272

4. feæ, Jac. ........ 273

5. integricollis, Jac. . . . 273

6. tenebrosa, Jac. . . . . 274

7. semibrunnes, Jac. . . . 274

8. nilgiriensis, Jac. ....275

9. flavitarsis, Jac. ..... 275

10. kunaraensis, Jac. ... 276

11. fulvipes, Baly ..... 276

12. indica, Jac. . . . . . 277

13. andrewesi, Jac. . . . . 278

2. Exems, Lasord. ........ 278

1. ceylonensis, Jac. ... 279

2. indica, Guér. ....... 279

3. Hymetes, Lacor d. ..... 280

1. indica, Chapuis ...... 280

Div. 3. Cyclica ........ 280

Subfam. 1. Lamprosomina .. 280

1. Lamprosoma, Kirby .... 281

1. assamensis, Jnc. ..... 281

2. nilgiriensis, Jac. . . . . . 282

3. ceylonensis, Jac. . . . 282

4. angustata, Jac. ..... 282

Subfam. 2. Eumolpince..... 283

Group Iphimeini. . . . . . . . 285

1. Chrysolampra, Baly .... 285

1. subænea, Jac. . . . . . . 285

2. flavipes, Jac. . . . . . 286

3. thoracica, Jac. . . . . 286

4. minuta, Jac. ....... 287

5. curvipes, Jac. . . . . . 287

6. varicolor, Jac. ..... 288

7. burmanica, Jac. . . . . 289

8. manipurensis, Jac. . . . 289

9. viridicollis, Jac. . . . . 290

10. bicolorata, Jac. . . . . 290

11. indica, Jac. . . . . . . . 291

Group Nodostomini ...... 291

1. Nodina, Motsch. . . . . . . 292

1. indica, Jac. . . . . . . . 292

2. crassipes, Jac. . . . . . . 293
Page

3. rufipes, Jac. ...... 293

4. nigrilabrum, Jac. . . . 293

5. parvula, Jac. ....... 294

6. ceylonensis, Jac. .... 294

7. pusilla, Motsch. . . .... 295

8. burmanica, Jac. ... 295

9. subcostata, Jac. .... 295

10. tarsalis, Duviv. . . . . 296

11. belgaumensis, Jac. . . 296

12. robusta, Jac. . . . . . 297

13. æneicollis, Jac. . . . . 297

14. hirta, Jac. . . . . . . . 298

15. subdilatata, Motsch. . 298

16. lævicollis, Motsch. . . 298

17. rotundata, Motsch. .. 299

2. Nodostella, Jac. . . . . . . 299

1. elongata, Jac. ..... 299

3. Autolampra, Jac. ...... 300

1. femorata, Jac. ..... 300

4. Nodostoma, Motsch. .... 301

1. denticolle, Jac. . . . . . 302

2. nobilitatum, Jac. ... 302

3. fulvicorne, Jac. . . . . . 303

4. capitatum, Jac. ..... 303

5. cyaneum, Lefèv. . . . . 304

6. pretiosum, Jac. . . . . 304

7. chalceum, Jac. ..... 305

8. splendens, Hope ... 305

9. semipurpureum, Jac. . 305

10. convexicolle, Jac. . . . 306

11. bhamoense, Jac. . . . 306

12. gracilipes, Jac. . . . . 307

13. fabrei, Lefèv. . . . . 308

14. semicæruleum, Jcc. . . 308

15. dubiosum, Jac. . . . . . 308

16. unipunctatum, Jac. . 309

17. anărewesi, Jac. . . . 303

18. geniculatum, Lefêv. . 310

19. longicorne, Juc. . . . 310

20. maculipenne, Jac. . . . 311

21. cardoni, Jac. ...... 312

22. concinnicolle, Baly . 312

23. duvivieri, Jac. ..... 313

24. bistrigatum, Jac. .... 313

25. violaceo-fasciatum,Jac. 314

26. quadrifasciatum, Jac. . 314

27. plagiosum, Baly .... 315

28. nigrocinctum, Jac. $\quad \ldots 315$

29. nigrofasciatum, Jac. . . 316

30. dharwarense, Jac. . 316

31. bipunctatum, Jac. .. 317

32. wallardiense, Jac. $\quad \ldots 317$

33. lewisi, Jac. ....... 318

34. bengalense, Duviv. . . 318

35. nigro-bimarginatum

Jac........... 319 
Page

36. hampsoni, Jac. ..... 319

37. latefasciatum, Jac. . . 319

38. andamanense, Jac. . . 320

39. obliteratum, Jac. . . . 320

40. puncticolle, Lefeve. . . 321

41. sylhetense, Jac. . . . 321

42. inconspicuum, Jac. . . 322

43. subdepressum, Jac. . . 322

44. semilævum, Jac. . . . 323

45. oblongo-punctatun, Jic. 323

46. separatum, Jac. . ... 324

47: fulvotibiale, Jac. . . . 324

48. intactum, Jac. . . . . 324

49. thoracicum, Jac. . . . 325

50. binghami, Jac. . . . . $326^{\circ}$

51. semistriatum, Jac. $\quad$. 326

52. fairmairei, Jac. … 326

53. bimaculicolle, Jac. . 327

54. clypeatum, Jac. . . . . 3 327

55. montanum, Jac. ... 328

56. weisei, Jac. . . . . . 328

57. congregatum, Jac. . . 329

58. aggregatum, Jac. . . . 329

59. bituberculatum, Jac. . . 330

60. mahéense, Jac. ..... 330

61. orientale, Jac. . . . . 330

62. haroldi, Jac. . . . . . 331

63. dormeri, Baly ..... 331

64. sikhimense, Jac. . . . 332

65. indicum, Jac. . . . . 332

66. femoratum, Jac. . . . 333

67. variabile, Duviv. . . . . 333

68. subcostatum, Juc. . . . 334

69. irregulare, Jac. . . . . . 335

70. waterhousei, Jac. .... 335

71. occipitale, Jac. . . . . 335

72. semiglabratum, Jac. . . 336

73. glabricolle, Jac. . . . 336

74. abdominalis, Jac. . . . 337

75. sublævipenne, Jac. . . 337

76. tuberosum, Jac. . . . . 337

77. lefevrei, Jac. . . . . . . 338

78. obscurum, Jac. . . . . 338

79. picimane, Jac. . . . . 339

80. imitans, Jac. . . . . . . . 339

81. angulicolle, Duviv. . . 339

82. feæ, Jac. ........ 340

83. nilgiriense, Jac. . . . 340

84. flavolimbatum, Jac. . . 341

85. terminatum, Jac. . . . 341

86. pubicolle, Jac. . . . . 342

87. hirsutum, Jac. ..... 343

88. cribricolle, Jac. . . . . . 343

89. antiquum, Jac. . . . . 343

90. maculiceps, Jac. ... 344

91. instabile, Jac. . . . . 344

92. dimidiatipes, Jac. . . 345

roL. 1 .
93. fulvofaciatum

93. fulvofasciatum, Jac. . . 345

94. momeitense, Jac. ... 345

95. discicolle, Jac. . . . . 346

96. impressipenne, Jac. . . 347

97. nigrolineatum, Jac. . . 347

98. obscuro-maculatum, Jac. 348

99. ornatuni, Jac. . . . . 348

100. tavoyense, Jac. . . . . 349

101. suturale, Motsch. . . . 349

102. viridipenne, Motsch. . . 349

103. pusillum, Gyllenh. .. 349

104. sculpturatum, Motsch. . 350

105. picturatum, Motsch. . . :'30

5. Pseudostonopa, Jac. .... 350

1. bicolor, Jac. ....... 351

2. biplagiata, Jac. . . . . 351

3. castanez, Jac. ..... 352

4. picea, Jac. . . . . . . 352

6. Chrysonopa, Jac. ..... 353

1. rotundicollis, Jac. . . . 353

2. viridis, Jac. . . . . . 354

3. longipes, Jac. . . . . . . 354

4. brunnea, Jac. ..... 355

Group Pagrini $\ldots \ldots \ldots \ldots$ 35

1. Pagria, Lefêv. ......... 356

1. flavo-pustulata, Baly . 356

2. signata, Motsch. ... 356

3. bipunctata, Lefèv. . . . . 357

4. ceylonensis, Jac. . . 357

5. costatipennis, Jac. . . . 358

6. restituens, Walker .. 359

7. lævifrons, Jac. . . . . . \$59

8. kanaraensis, Jac. . . . : :360

9. burmanica, Jac. .... 360

10. ænescens, Jac. ..... 361

11. conglomerata, Jac. . . 361

Group Callisini ......... 362

1. Callisina, Baly ...... 362

1. brunnea, Jac. . . . . . . 362

2. indica, Baly ....... 36:3

3. prominula, Jac. . . . . 363

4. assamensis, Jac. . . . . . 364

5. balyi, Jac. . . . . . . . 364

6. burmanica, Jac. . . . . 365

2. Edistus, Lefêv. ...... 365

1. cæruleus, Jac. . . . . 366

2. indicus, Jac. . . . . . 366

Group Colaspini ........ 367

1. Dermorhytis, Baly ..... 367

1. ornatissima, Baly ... 368

2. variabilis, Jac. ..... 368

3. kandyensis, Jac. . . . . . 369 
1. Page

4. igneo-fasciata, Baly .. 370

5. atkinsoni, Juc. . . . . .

7. imitans, Jac. . . . . . 371

8. ceylonensis, Jac. ... 371

9. lewisi, Jac. . . . . . . . . 372

10. cuprea, Jac. . . . . . . 372

11. biangulata, Jac. . . . . 373

12. rugosa, Jac. . . . . . 373

13. violacea, Jac. . . . . . . 374

14. punctatissima, Jac. . 374

15. fulvipes, Jac. . . . . . 375

16. andrewesi, Jac. . . . . 375

17. speciosa, Jac. . . . . . 376

18. costata, Juc. . . . . . 377

19. hirsuta, Jac. ...... 377

Group Metachromini....... 378

1. Rhyparida, Baly....... 378

1. khasianensis, Jac. ... 378

2 . bengalensis, Jac. ... 378

3. immaculata, Jac. .... 379

4. aterrima, Jac. . . . . . 379

5. bimaculata, Jac. .... 380

6. assamensis, Jac. . . . . . 381

7. quinquemaculata, Jac. 381

(iroup Scelodontini ....... 382

1. Scelodonta, Westw...... 382

1. vittata, Oliv. ....... 382

2. ænea, Motsch. ...... 383

3. alternata, Jac. ..... 383

4. indica, Duviv... . . . . . 383

5. areolata, Lefèv. . . . . . 384

6. dillwyni, Stephens. . . 385

7. nilgiriensis, Jac. . . . 385

8. strigicollis, Motsch. . . 386

9. subcostata, Jac. . . . . 386

10. granulosa, Baly ...... 386

11. immaculata, Jac. .... 387

12. longicollis, Jac. . . . . . 387

Group Heteraspini........ 387

1. Trichochrysea, Baly ... 387

1. bhamoensis, Jac. . . . 388

2. rufofemoralis, Jac..... 388

3. antennata, Jac. . . . . 389

4. vestita, Baly ... . . . 389

5. severini, Jac. . . . . . . 389

6. Jirta, Fabr. . . . . . . . . . 390

7. quadrifasciata, Jac. . . 390

8. clypeata, Jac. . . . . . . 391

9. viridis, Jac. . . . . . 392

10. parvula, Jac. ....... 392

11. variegata, Jac. ..... 392
Page

12. hebe, Baly ........ 39:3

13. nitida, Jac. . . . . . . . 394

14. purpureomaculata, Jac. 394

Group Leprotini. . . . . . . . . 395

1. Aoria, Baly ........... 396

1. nigripes, Baly ..... 394;

2. nigrita, Jac. ...... 397

3. bowringi, Baly ..... 397

4. semicostata, Jac. . . . 39s

5. fulvifrons, Jac. . . . . 398

2. Pseudaoria, Jac. ....... 399

1. burmanica, Jac. . . . . 399

2. cærulea, Jac. ....... 400

3. Trichotheca, Baly ..... 400

1. hirta, Baly ........ 400

2. basifemorata, Duviv. . 401

3. duvivieri, Jac. ..... 402

4. fusca, Jac. . . . . . . 402

4. Pseudopiomera, Jac. .... 403

1. pallidicornis, Jac. ... 403

2. ceylonensis, Jac. ... 404

3. andrewesi, Jac. . . . . 404

5. Xanthophorus, Jac. .... 404

1. Alavopilosus, Jac. . . . 405

2. andrewesi, Jac. ..... 401;

3. balyi, Jac. . . . . . . 4 40t;

4. pallidus, Jac. ....... 40t;

5. levicollis, Jac. ..... 407

6. fuscipennia, Jac. ...4 407

7. carinatus, Jac. .....4 408

8. nigricollis, Jac. . . . . 408

9. lemoides, Walker .... 408

10. nigripennis, Jac. . . . 40!

11. montanus, Jac. . .... 409

6. Aulexis, Baly ........ 410

1. nigripennis, Jac. ...4 411

2. tibialis, Juc. . . . . . 411

3. assamensis, Jac. . . . . 411

7. Lypesthes, Baly ...... 41:

1. indica, Jac. . . . . . . 412

8. Neculla, Baly ......... 413

1. pollinaria, Baly ..... 41:3

2. obscurata, Jac. . . . 4 414

9. Demotinella, Jac. ..... 414

1. pectoralis, Jac. . . . . 414

10. Leprotella, Jac. ...... 415

1. cashmirensis, Jac. . . . 415

11. Nephrella, Baly ...... 416

1. elongata, Baly .... 416

12. Hyperaxis, Lefêv. ......447

1. quadraticollis, Jac. .. 418

2. duvivieri, Jac. . . . . 418

3. fulvohirsuta, Jac. .... 418

4. foreolata, Jac. . . . . 419

5. distincta, Duviv. . . . 419 
Page

6. semifasciata, Jac. ... 420

7. feæ, Jac. ..........421

8. variegata, Jac. .....4421

9. penicillata, Jac. . . . . 422

10. mandarensis, Jac. . . . 422

11. malabarica, Jac...... 423

12. dubia, Jac. ......... 423

13. grisea, Jac. . . . . . . . 424

1:3. Pseudometaxis, Jac. . . . 424

1. serraticollis, Jac. ... 425

14. Leprotes, Baly ...... 425

1. kanaraensis, Jac. . . 426

15. Demotina, Baly ....... 427

1. modesta, Baly ...... 427

2. andrewesi, Jac. . . . . . 428

3. minuta, Jac. ....... 428

4. serraticollis, Baly ... . 429

5. balyi, Jac. ..... . . . 429

6. ceylonensis, Jac. . . . 430

7. lewisi, Jac. . . . . . . . . 430

8. thoracica, Jac. . . . . 431

16. Aulacolepis, Baly ..... 431

1. mouhoti, Baly ..... 432

Group Eubrachini . . . . . . . 432

1. Eubrachis, Baly ... . . . 433

1. indica, Baly ... . . . 433

2. rufotibialis, Jac. . . . . 433

3. andamanensis, Jac. .. 434

4. orientalıs, Jac. ..... 434

5. discoidalis, Jac. . . . . 435

6. himalayensis, Jac. . . . 436

7. bengalensis, Duviv. . . 436

2. Mesocolaspis, Jac. . . . . 437

1. indica, Jac. . . . . . . 437

2. nigrita, Jac. ......448

Group Eumolpini ......... 438

1. Colasposoma, Laporte . 439

1. albovillosum, Duviv... 439

2. villosulum, Lefêv. . . . . 440

3. lividipes, Jac. . . . . . . . 440

4. laticolle, Jac. . . . . . . 441

5. downesi, Baly ...... 442

6. rutipes, Jac. ........ 442

7. semicostatum, Jac. . 443

8. bicallosum, Lefêv. .... 443

9. clavareaui, Jac. ...... 444

10. coromandeliana, Jac. . . 444

11. serratulum, Lefèv. . . . .445

12. metailicum, Clark ....446

13. subopacum, Jac. ... 446

14. cœruleatum, Baly .... 447

15. transversicolle, Jac. . 448

16. multipunctatum, Jac. . 448

17. bicoloratum, Jac. ... 449
Paye

18. pretiosum, Baly ... . . 449

19. robustum, Jac. . . . . 450

20. nigriventre, Baly . . . 450

21. splendidum, Fabr. . . . 4.51

22. asperatun, Lefev. . . . 4.5 2

23. andrewesi, Jac. . . . . . 45:3

24. ornatum, Jac. . . . . . . 4.5:3

25. auripenne, Motsch. . . 454

26. aureovittatum, Baly .. 4.5.5

27. versicolor, Lefèv. .... 4.).)

Cromp Edusini ......... 456

1. Abirus, Chapuis ...... 456

1. angustatus, Lefêv. . . . 4.56

2. elongatus, Jac. . . . . 45 45

3. rubripes, Lefev. ..... 457

4. andamansis, Lefèv. . . . . 4ij7

5. igneicollis, Jac. . . . . 4 45

6. ceylonicus, Jac. . . . . 4.)?

(Group Myochroini ........ 45!)

1. Pachnepborus, Redtenb... 460

1. bretinghami, Baly .... 46()

2. impressus, Rosenh. .. 461

2. Acrothinium, Marshall .. 461

1. violaceum, Jac. . . . . 46:

3. Lophea, Brly ....... 46:

1. melancholica, Buly .. 46:3

4. 11eterotrichus, Chapuis .. 463

1. balyi, Chapuis .....4 464

5. Eurypelta, Leferv. . . . . 464

1. modesta, Fabr. ..... 464

Group Adoxini ......... 46;

1. Bromiodes; Jac. ....... 46i

1. indicus, Jac. . . . . . 465

Group Psendocolaspini .... . . 466

1. Pseudocolaspis, Laporte. . 46it

1. longicollis, Baly. . . . 4 4 $; 7$

Group Typophorini ....... 468

1. Paria, Leconte ........ 468

1. lefevrei, Jac. ...... 468

2. Tricliona, Lefêv. ...... 469

1. semivittata, Baly ....4 470

2. puncticeps, Duviv. . . 470

3. fævicollis, Jac. . . . . 4 47

4. glabricollis, Jac...... 471

5. inconspicua, Jac. ... 472

6. indica, Jac........ 472

7. variabilis, Jac. .... 47:

8. apicata. Jac. ...... 474

9. bifasciata, Jac. .....474

10. picen, Jac. . . . . . 47 
11. Page

12. ceylonensis, Jac...... 476

13. nigra, Jac. ......... 477

14. sulcipennis, Jac...... 477

15. marginata, Jac. ..... 478

16. subdepressa, Jac. ... 478

17. longicornis, Jac.. . . . . 479

3. Cleoporus, Lefév. ....... 479

1. maculicollis, Jac. ... 479

2. variegatus, Jac. . . . . 480

3. inornatus Jac. . . . . 480

4. lefevrei, Duviv. . . . . 481

5. plagiatus, Jac. .... 481

6. burmanicus, Jac. . . . 482

4. Cleorina, Lefêv. ....... 482

1. nigroviridis, Jac. . . 483

2. modesta, Jac. . . . . . . 483

3. lefevrei, Jac. ....... 484

4. nobilis, Lefêv. . . . . . 484

5 . bevani, Baly ....... 484

6. jacobyi, Duviv. ... . 485

7. indice, Jac......... 485

8. assamensis, Jac...... 486

9. manipurensis, Jac. . . 486

10. andamanensis, Jac. . . 487

11. oblonga, Jac. ....... 487

12. dohertyi, Jac.. . . . . . 487

13. aulica, Lefeve. . . . . . . 488

14. longicornis, Jac. . . . . 488

15. bicolor, Jae. ...... 488

16. fulva, Jac. . . . . . . . 489

17. saturata, Jac. . . . . . 489

๖. Mouhotina, Lefêv. . . . . . . 490

1. burmanica, Jac. . .... 490

2. rugifrons, Jac. .... 491

Group Corynodini ........ . 491

1. Corynodes, Hope....... 492

1. pyrophorus, Pariy. ... 492

2. decemnotatus, Baly . . 492

3. undatus, Oliv.........493

4. peregrinus, Fuessly.... 493

5. amethystiuus, Marshall 494

6. curvipes, Duviv....... 495

7. pyrospilotus, Baly.... 495

8. mouhoti, Baly ..... 496

9. ceylonensis, Jac. .... 496

10. sheppardi, Baly ..... 497
11. speciosus, Lefer. Pago

12. burmanicus, Jac.... 497

13. cavifrons, Jac. ..... 498

14. gratiosus, Baly ..... 498

15. impressicollis, Jac... . . 499

16. fulvicollis, Jac. . . . . 499

17. chrysis, Oliv. ....... 500

18. maluchiticus, Marshall 500

19. pretiosus, Baly ...... 501

20. Iateralis, Hope ..... 501

21. obesus, Jac. . . . . . . . 502

22. dilaticollis, Jac. . . . . . 502

23. andamanensis, Lefêv... 503

24. travancorensis, Jac. . . 503

25. asphodelus, Marshall.. 504

26. modestus, Jac. . . . . . 504

27. tridentatus, Jac.. . . . . 505

28. dohrni, Baly ....... 505

29. nitidus, Fabr. . . . . . 506

30. assamensis, Baly .... 507

2. Chrysochus, Redtenb.... 507

1. sikhima, Jac. ...... 507

2. nilgiriensis, Jac...... 508

3. siamensis, Jac. . . . . 509

4. pulcher, Baly....... 509

5. mouhoti, Baly ..... 510

Group Endocephalini ..... 510

1. Aemnestus, Jac. ....... 511

1. fulvitarsis, Jac. ..... 511

2. Heminodes, Jac. ....... 512

1. indicus, Jac. . ..... 512

2. unicolor, Duriv...... 513

3. antennatus, Jac...... 514

3. Colaspoides, Laporte ... . 514

1. subrugosa, Jac. ..... 515

2. melanocephala, Jac. . . 515

3. montana, Jac....... 515

4. semipicea, Jac. ..... 516

5. pallidula, Jac....... 5i 5 ;

6. glabricollis, Jac.. . . . 517

7. feæ, Joc. ........ 517

8. cupreicollis, Jac...... 518

9. falcata, Harold ...... 518

10. dohertyi, Jac....... 519

11. fulvimana, Jac. . . . . . 519

12. sublævicollis, Duviv. . 520

13. bengulensis, Duviv. . . 520 


\title{
Order COLE(OPTERA.
}

\author{
Suborder POLYPHAGA.
}

\section{Family CHRYSOMELIDÆ.}

General shape very variable; mentum generally transverse; labial palpi 3-jointed; maxillary palpi 4-jointed, cylindrical, rarely dilated. Head either prominent or inserted in thorax as far as eyes; the latter entire or emarginate, frequently kidney-shaped (Cryptocephalina, Chlamydince); clypeus generally separated from face; mandibles short (larger and robust in some Clytrince); labrum transverse. Antennæ variable in position and form, usually 11-jointed *, filiform, serrate or somewhat clavate. Thorax with or without distinct lateral margins. Elytra usually covering the pygidium but the latter is in some cases exposed (Camptosomes), epipleuræ sometimes strongly produced below shoulders. Abdomen with five segments of various proportions, the first much longer than the others as in the Eupodes, or all contracted at middle as in the Camptosomes. Legs very variable; hind femora frequently considerably enlarged, often with strong teeth below; tibiæ slender or short and compressed (Chlamydinae, Lamprosomina); tarsi 4-jointed, hairy beneath, third joint bilobed or entire, claws simple, appendiculate or bifid. Prosternum very variable, narrow and hidden to very broad and conspicuous.

The Chrysomelida form an immense complex of forms, most strongly developed in the tropical regions, but also represented by a considerable number in the temperate zones. The great variability of their shape and structure makes their study very laborious but highly interesting. The species in some of the groups greatly resemble certain Longicornia, from which they can only be distinguished by an intimate knowledge of the various forms. It may however, be taken as a general rule that in the Longicornia the shape is very elongate, the head projecting and prominent, the eyes oblique and more or less divided and the antennæ peduncular, these organs being at the same time rigid

* Eleven-jointed in all genera dealt aith in this volume.

vol. I. 
and tapering at the apex. All these structures are not as a rule found in the Chrysomelida.

In the larval state these insects are always found on or within plants, generally crawling on leaves or stems; this distinguishes them conspicuously from the larvæ of the Longicornia. In shape the larvæ are either elongate and subcylindrical or short and convex. The larvæ of the Honaciina live below the water on stems of water-plants; they are elongate in shape and have two spines at the end of the body which they insert into the plants, sucking the air out of the latter with the help of a large opening (stigma) situated at the base of each spine (Dewitz, Berlin. Zeitsch. 1888, p. 5).

Many of the larvæ of the other tribes construct a covering of their excreta, carrying it about with them and undergoing their metamorphosis within it (Camptosomes). Others construct a cocoon within the widenings of the stems (Sagrina). Of the majority of species inhabiting the tropics the larræ are not known.

The family Chrysomelida like the Curculionidae or Weevils comprises a vast number of species, but in the teeming vegetation of the tropics their depredations, though great, do not prominently at tract the notice of travellers. I am informed however, that they can be exceedingly destructive to plantations of young trees. In the temperate regions a few genera are injurious to certain agricultural products and the same may be said of some species in tropical parts where cultivated plants are concerned.

The sexes are not always easy to distinguish but in many genera the males have dilated anterior tarsi or longer hind femora. In others the head has curious excavations or projections and the antennæ have differently constructed joints. In the Camptosomes the female has a more or less deep excaration on the last abdominal segment. In a few genera of true Chrysomela the young caterpillars are hatched almost at the moment that the female deposits the eggs.

Chapuis (Gen. des Coléopt. x, 1874, p. 23) arranged the Chrysomelida under four great divisions :-

i. EUPodes in three subfamilies: Sagrinae, Donaciina, and Criocerinae.

ii. Самттоsomes in six subfamilies: Megascelince*, Megalopince, Clytrina, Cryptocephalina, Chlamydina, and Spharocharince* .

iii. Crclica in four subfamilies: Lamprosomince, Eumolpince, Chrysomelina, and Galerucince.

iv. Cryptostomes in two subfamilies: Hispince and Cassidince.

As will be seen from the subjoined key an arrangement in five divisions is adopted here, the Galerucina being separated from the Crchica to form a fifth division Trichostomes in two groups: Galerucine and Halticina.

* Not known from India. 
Key to the Divisions of the Chrysomelidx.

A. Mouth placed anteriorly.

a. Antennæ widely separated at base; elytra of hard texture.

$a^{\prime}$. Intermediate ventral segments not medially constricted; pygidium not exposed.

$a^{2}$. Thorax without distinct lateral margins, head produced, eyes prominent, prosternum exceedingly

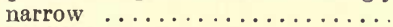

$b$. Thorax with distinet lateral margins (rarely without), head not produced, eyes not prominent, prosternum broad ...................

$b^{\prime}$. Intermediate ventral segments constricted; pygidium usually exposed..

b. Antennæ not widely separated at base, generally closely approximate; elytra more or less soft in texture .........

B. Mouth not normal, small, hidden or nearly so

Eupodes.

\section{Cyclica.}

Camptosomes.

Trichostomes *.

Cryptostomes*.

\section{Division EUPODES.}

Key to the Subfamilies.

A. Antennæ separated by entire front of head.

a. Posterior femora very strongly incrassate: large sized insects of brilliant metallic coloration .................... Sagrince.

b. Posterior femora only slightly incrassate: much smaller insects, less brilliant, rarely metallic ..................... Criocerino.

B. Antennæ not separated by entire front of head. Donaciizuce.

\section{Subfamily I. SAGRIN}

Head porrect, constricted at the neck; autennæ filiform with robust cylindrical joints; thorax not margined laterally; elytra at the base much wider than the thorax; legs robust with strongly thickened posterior femora, these in the of furnished beneath with one or more teeth; first abdominal segment twice as long as any of the following segments.

The Sagrince are the largest and most brilliantly coloured of all the. Chrysomelita. Most of them are beautifully metallic and in shape have a slight resemblance to certain species of Longicorns.

Little or nothing is known of their larval state or habits, and observations in these respects are greatly needed.

A single genus, Sagra.

* Not included in this volume. 


\section{Genus SAGRA.}

Sagra, Fabr. Ent. Syst. i, pt. 2, 1792, p. 51.

Type, S. femorata, Drury, from India, China and Ceylon.

Range. Africa; Madagascar; India; Ceylon; China and some of the Malayan Islands.

Characters those of the subfamily. The species included in this genus are sufficiently distinguished from the rest of the Chrysomelida by their large size, metallic colouring and peculiarly formed long hind legs.

1. Sagra femorata, Drury, Ill. Evot. Ins. ii, 1773, pl. 34, fig. 5; Fabr. (Alurnus) Spec. Ins. i, 1781, p. 115.

Sagra tridentata, Weber, Obs. Ent. 1801, p. 62, o".

Sagra druryi, Lacord. Mon. Phytoph. i, 1845, p. 32.

Cupreous metallic blue or green, generally more or less green on the elytra, sometimes entirely blue in specimens from India. Thorax subquadrate, the anterior angles slightly produced, the surface impunctate; elytra with a more or less distinct depression at the base near the suture; shoulders prominent with a fow short rows of fine punctures; rest of the disc nearly impunctate.$\checkmark$. With rather slender and very elongate femora to the posterior pair of legs, these extend well beyond the apex of the elytra and are armed with a large outer tooth near the apex with a smaller one beyond it; tibiæ of the posterior legs curved at the base, with a tooth near the apex on each side; first abdominal segment more or less pubescent.- ․ Femora of the posterior legs not, or very slightly, prolonged beyond the apex of the elytra, the apical teeth on them so prominent in the $\delta$ replaced by a toothed ridge on the underside.

Length ơ 우 16-20 mm. Java.

$H a b$. Throughout India and China; extending to Borneo and

\section{Sagra longicollis, Lacord. Mon. Phytoph. i, 1845, p. 35.}

Metallic greenish-blue. Antennæ reach to about the middle of the elytra; thorax elongate, its anterior angles prominent; elytra deeply depressed, below the base finely coriaceous, punctatestriate, the striæ often obsolete.- $\sigma$. Femora of the posterior legs elongate, the apex bidentate; apex of tibiæ mucronate, bidentate, the outer tooth large.

Length 20-22 mm.

Hab. "India orient." Assam (Atkinson).

Very closely allied to S. femorata, but distinguished from that and other species of the genus by the elongate thorax which is about one-fourth longer than its anterior width. Lacordaire described this species from two specimens contained in the Dejean 
Collection. A male specimen in the collection of the British Museum which I refer to this species came from the Atkinson Collection. It is of a dark violaceous colour and has the femora of the posterior legs very long and slender, with on the inner side a tomentose yellow patch near the apex, a point not mentioned by Lacordaire; the thorax of this specimen is considerably longer than that of any specimen of S. femorata or of allied species.

\section{Sagra empyrea, Lacord. Mon. Phytoph. i, 1845, p. 31.}

Metallic violaceous or blue; the sides of the elytra more or less purplish. Head distinctly punctured; antennæ extended to the middle of the elytra, first six joints blue, remainder black. Thorax about as long as broad, the anterior angles obtuse, not prominent, the surface impunctate. Elytra with eleven longitudinal rows of punctures that do not reach to the apex; the outer rows on each side arranged in pairs. Mesosternum widened in front, feebly tridentate at its posterior margin. Abdomen : first segment longitudinally depressed, punctured and clothed with fulvous pubescence.

Length $18 \mathrm{~mm}$.

Hab. Bengal.

4. Sagra nigrita, Oliv. Ent. v, 1807, p. 500, pl. 1, fig. 6 ; Lacord. Mon. Phytoph. i, 1845, p. 28.

o. Colour entirely black, exceptionally greenish-æneous. Antennæ long and slender. Thorax scarcely longer than broad, its anterior margin in the middle somewhat strongly produced the angles moderately prominent; the sides, viewed from above, straight; the surface entirely impunctate. Elytra more or less strongly narrowed posteriorly, deeply sulcate between the shoulders, distinctly depressed at base, the surface with short rows of punctures more or less arranged in pairs but for the most part invisible except under a lens, the interstices between the punctures finely wrinkled, coriaceous. Posterior femora very elongate, gradually widened at the middle with one large and one small tooth near the apex; posterior tibiæ curved at base, the apex produced into a tooth on each side. First abdominal segment depressed, impunctate, clothed with very short flavons pubescence that becomes visible only in certain lights. -9 . Thorax broader anteriorly, more transverse. Posterior femora short and stout, scarcely extended beyond the elytra and with a small tooth placed on a ridge on the underside near the apex.

Length $20 \mathrm{~mm}$.

Hab. Ceylon. Siam.

Baly thinks this species identical with S. dentipes, Fab., who gives "Africa" as the habitat, probably erroneous ('Trans. Ent. Soc. v, pt. vi, 1860, p. 236). 
5. Sagra brevipes, Jac. Ann. Mus. Civ. Genova, xxvii, 1889, p. 148.

đ. Obscure dark purplish-blue, opaque. Head rugose near the eyes, labrum with long fulvous pubescence; antennæ long and slender. Thorax slightly longer than broad, anterior angles strongly thickened, formed into a round blunt tubercle, the disc entirely impunstate. Elytra without basal depression, a double row of punctures at base, the rest impunctate, finely wrinkled. Intermediate tibiæ dilated at apex into a triangular tooth; posterior femora glabrous, very short, scarcely extended beyond the apex of the elytra, tridentate at apex; posterior tibiæ with a single mucronate tooth at apex; abdomen : first segment glabrous.

Length $16 \mathrm{~mm}$.

$\mathrm{Hab}$ Tenasserim : Kaukaraik (Fea).

This well-marked species is distinguished from all others belonging to the genus by its remarkably short posterior femora, by the dilated intermediate tibiæ and by the glabrous first abdominal segment.

\section{Sagra jansoni, Baly, Trans. Ent. Soc. (2) v, 1860, p. 243.}

Elongate, parallel-sided ; rufo-aureous, metallic green, or blue ; antennæ purple, their basal half metallic green. Head deeply punctured. Thorax slightly longer than broad, sides slightly concave, above profoundly but not closely punctured, transversely depressed in front of the basal margin. Elytra distinctly depressed below the base, their surface finely punctate-striate throughout, the interstices between the punctures finely vermiculate-reticulate. Body beneath more conspicuously metallic green. Anterior and intermediate femora moderately incrassate, tibiæ strongly curved.o. Intermediate femora produced beneath into a flattened acute tooth ; hinder femora extended beyond the apex of the elytra by a fourth of their length, elongate subovate, beneath notched at the apex and armed with two short stout teeth, the anterior tooth the larger; at the base there is a large patch of yellow pubescence on the inner side ; posterior tibiæ mucronate at apex and armed just before the apex externally with a stout spine, internally with a very short tooth; basal abdominal segment longitudinally excavate, coarsely punctured and covered with yellow pubescence.- $q$. Posterior femora not extended beyond apex of elytra and armed with a short denticulate ridge beneath.

Length 12-14 mm.

Hab. Madras.

7. Sagra longipes, Baly, Journ. Linn. Sic., Zool. xiv, 1878, p. 337.

Elongate-ovate, greenish-blue, shining. Antennæ three-fourths the length of the body in the $\delta$, shorter in the $q$; second joint in $\delta$ somewhat shorter than the third, the latter slightly longer 
than the fourth ; second joint in $ᄋ$ much shorter than the third, the latter equal to the fourth; basal six joints in both sexes shining metallic blue, the remainder opaque black. Thorax subquadrate, the anterior angles only slightly prominent, very obtuse, upper surface opaque. Elytra convex, depressed at base, finely punctate-striate, interstices indistinctly wrinkled, the striæ more or less obsolete below basal portion of each elytron.- $\delta$. Posterior femora only moderately thickened, extended well beyond the apex of the elytra, bidentate near the apex and with a patch of fulvous pubescence there; the first tooth stout; posterior tibiæ much curved at base, the apex bont, mucronate, armed with two spines; the interior spine large, placed at some distance from the apex, the outer dentate in form, apical.

Length ơ 20, 우 $18 \mathrm{~mm}$.

Hab. Burma.

8. Sagra carbunculus, Hope, A. M. N. H. ix, 1842, p. 248; id. Trans. Linn. Soc. xix, 1843, p. 112, pl. 10, fig. 9; Baly, Trans. Ent. Soc. (2) v, 1860, p. 244 ; Lacord. Mon. Phytoph. i, 1845, p. 68.

Metallic blue; elytra golden cupreous. Thorax quadrate, distinctly punctured; elytra closely and irregularly punctured, the interstices finely wrinkled.

đ. Posterior femora extended beyond the elytra, strongly thickened with a narrow stripe of fulvous pubescence at their lower edge near the base, the apex below denticulate, produced into a flattened tridentate plate, the middle tooth of which is elongate and slightly curved; tibiæ of the posterior legs arcuate at base, the apex mucronate, the outer edge beneath deeply emarginate near the apex, the inner edge obsoletely tuberculale ; basal segment of the abdomen flattened, remotely punctured and sparsely clothed with fulvous hairs. - $q$. Posterior femora do not extend up to the apex of the elytra, less thickened than in the $\sigma^{*}$, obsoletely dentate ; posterior tibiæ curved, simple.

\section{Length $9 \mathrm{~mm}$.}

$H a b$. Northern India; Assam; Sylhet.

One of the smaller species of the genus, can be distinguished at once by the violaceous thorax and coppery-coloured elytra.

\section{Sagra mouhoti, Baly, Jour. of Entomology, i, 1862, p. 193.}

Somewhat elongate; colour purplish-blue. Thorax subquadrate, strongly and closely punctured; elytra reddish-cupreous, their outer margin narrowly, the edges of the suture more broadly, purplish, the purple on the outer edge is not always present.

o. Posterior femora long, extended far beyond the apex of the elytra, clothed with yellow pile beneath, bidentate near the apex, the outer tooth acute; tibiæ curved, canaliculate, clothed with sinilar pubescence beneath, their apices mucronate, produced each 
into a short process; base of the abdomen distantly punctured, finely, pubescent.

Length 18-19 $\mathrm{mm}$.

Hab. Burma: Bhamo; Cambodia.

This species is closely allied to $S$. carbunculus, but is more elongate with the sides more parallel than in that species. It can be readily distinguished by the purplish sutural band which is gradually narrowed posteriorly; the upper surface of the elytra is covered with numerous rows of deep punctures which are more or less regular near the suture and confused and irregular at the sides. Thorax with a narrow medial line nearly free from punctures.

10. Sagra multipunctata, Jac. Ann. Mus. Civ. Genova, xxvii, 1889, p. 149.

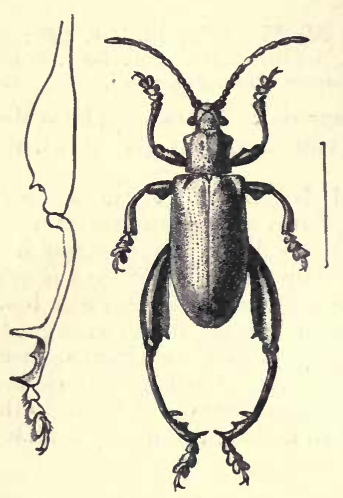

Fig, 1.-Sagra multipunctata.

Head closely and deeply punctured: antennæ more than half the length of the whole insect, dark blue, second joint very short, terminal four joints very long, punctured and opaque; thorax subquadrate, its anterior angles bluntly tuberculate, the lateral edges of the disc closely and strongly punctured, the middle less so ; elytra not depressed at base, punctate-striate near the suture, the sides irregularly punctured.o. Intermediate femora dilated so as to form a medial triangular tooth, posterior femora extended beyond the apex of the elytra, bidentate and tomentose at base; the tibiæ armed with long teeth near the apex, which is strongly produced. $-q$. Posterior femora not extended beyond the apex of the elytra, glabrous at the base; tibiæ simple.

Lenath 8-12 mm.

$H a \ddot{b}$. Upper Burma : Bhamo.

Easily distinguished by its narrow elongate shape, strong puncturation and the presence of a tomentose patch at the base of the posterior femora in the $\delta$.

11. Sagra petelii, Lacord. Mon. Phytoph. i, 1845, p. 44 ; var. $ᄋ$ pygmea, id.t. c. 1845, p. 53; Baly, Trans. Ent. Soc. (2) v, 1860, p. 236; id.t. c. (3) iv, 1865, p. 7.

Dark blue, greenish or cupreous; antennæ bluish-black, scarcely 
extending to middle of elytra, terminal joint very elongate. Head very finely punctured. Thorax subquadrate, sides concave, anterior angles prominent but blunt, surface rather closely and strongly punctured. Elytra subquadrately ovate, deeply

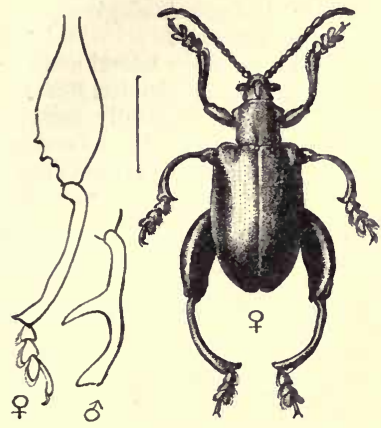

Fig. 2.-Sagra petelii. depressed below base and within shoulders behind basal margin, the latter raised into an acute ridge; entire surface finely punctate-striate, interstices finely aciculate and wrinkled. - $\delta$. Posterior femora strongly thickened at middle, not much extending beyond elytra, upper edge strongly convex, lower with two teeth near apex and a dense patch of yellow tomentose hairs; posterior tibiæ with a long tooth near apex, the latter strongly mucronate; intermediate tibiæ very strongly curved.- $q$. Smaller, posterior femora short, less

incrassate, a dentate ridge below, tibiæ simple.

Length 11-12 mm.

Hab. Burma: Rangoon; extending to Siam, China, and Japan.

I have included this species as a single specimen from Rangoon in Burma is in my collection. I have however, seen no other specimens from that or from other parts of India. In the variety pygmea the tibiæ have no tooth. The comparatively small size, colour, and the large tomentose femoral patch serve to distinguish this species. In some specimens the first tibial tooth is prolonged into a long process.

\section{Subfamily II. DONACIIN Æ.}

Elongate and narrow, more or less metallic, beneath strongly pubescent; the species resemble rertain Longicorn beetles and live on water-plants. Antennæ more closely approximate at base than in the subfamilies Criocerince or Sayrina, filiform; eyes round and entire; elytra punctured in rows; anterior coxæ nearly touching; basal segment of abdomen as long as or longer than following joints united; claws simple.

These insects agree with the Sagrinae in the elongate basal segment of the abdomen, but the prosternum does not separate the coxæ as in that group and the body beneath is clothed with short silvery pubescence. The posterior femora are frequently toothed. A single genus. 


\section{Genus DONACIA.}

Donacia, Fabr. Syst. Ent. 1775, p. 195; Thomson, Skand. Col. viii, 1866, p. 107.

Type, D. crassipes, Fab.

Range. Europe; N. America; Asia; India. A single species from Java, Australia and Madagascar respectively.

Characters those of the group; head with deep lateral and one central groove; eyes large and convex; antennæ slender, filiform. Thorax subquadrate, sides straight and angles generally pointed. Elytra wider at base than thorax, punctate-striate, interstices generally finely transversely wrinkled; third joint of tarsi deeply bilobed, claws simple.

12. Donacia æraria, Baly, Trans. Ent. Soc. (3) iv, 1865, p. 7 ; Jacoby, Ann. Mus. Civ. Genova, xxvii, 1889, p. 150.

Cupreous or greenish-æneous; head obscure fulvous, antennæ rufous, basal joints æneous, others stained with black.

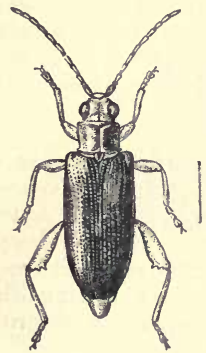

Fig. 3.

Cupreous or greenish-æneous; head fulvous; antennæ half the length of the body, obscure rufous, basal joints more æneous, the others more or less stained with black at the apex, second and third joints nearly equal, each half as long as the fourth joint. Thorax rather broader than long, sides nearly straight, anterior angles rectangular, not produced; upper surface transversely sulcate at the base, medial line impressed by a distinct longitudinal groove, much bruader and deeper towards its base; disc entirely covered with fine transrerse rugæ. Scutellum finely pubescent. Elytra with the sides straight and parallel at their Donacia eraria. anterior half, thence obliquely narrowed towards the apex, the latter truncate; upper surface flattened along the suture, deeply punctate-striate, interstices thickened and slightly raised, obsoletely transversely rugose.

Length 6-7 mm.

Hab. India ; Burma: Bhamo; Ceylon; Malay Peninsula: Tringganii ; Japan.

Whether this insect has in reality the great geographical distribution attributed to it by Baly is somewhat doubtful, as so many species of Donacia are very closely allied. The type was, however, described from Malay specimens.

13. Donacia delesserti, Guér. Icon. Règ. Anim., Ins. 1844, p. 258; Lacord. Mon. Phytoph. i, 1845, p. 116 ; Jacobson, Hor. Soc. Ent. Ross. xxvi, 189ะ, p. 419.

Very similar to $D$. araria, Baly, which may possibly be only a 
variety of the present species: the sole differences seem to be the rather longer antennæ of the latter, a somewhat more transversely shaped thorax in which the anterior angles are entirely obtuse and without traces of a tubercle and the reddish legs, the femora of which have a blackish spot at their outer side, they extend to the apex of the elytra and have two acute teeth below, the anterior of which is the longer. In the female the teeth are much smaller and the posterior tooth is more or less indistinct.

Length $7 \mathrm{~mm}$.

$H a b$. Nilgiris.

14. Donacia recticollis, Jac. Ann. Soc. Ent. Belg. xxxvii, 1893, p. 261 ; Wytsman, Genera Insect. part 21, 1901, fig. 6.

Fuscous, closely pubescent, antennæ and legs fulvous; thorax obscure æneous, very finely strigose; elytra dark fulvous, strongly punctate-striate, the interstices smooth, slightly convex.

Length $8 \mathrm{~mm}$.

Hab. India: Berhampur.

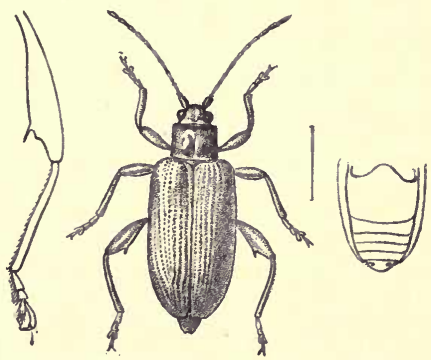

Fig. 4.-Donacia recticollis.

This species, although closely allied to $D$. delesserti, may be distinguished by the elongate third joint of the antennx, the straight sides of the thorax and the entirely smooth elytral interstices, also by the fulvous colouring.

\section{Donacia indica, Clark, App. Cat. Phytoph. 1866, p. 1.}

Black ; joints of the antennæ flavous at the base; thorax metallic green; elytra dark fulvous.

Head with a median impressed line, blackish-green, nonpubescent. - Thorax metallic green, subquadrate, the anterior angles prominent, the sides somewhat constricted towards the middle, finely confluently wrinkled, transversely rugose and with a distinct fovea at the middle. Scutellum clothed with testacenus pubescence. Elytra dark fulvous, truncate at the base, punctate- 
striate, the punctures small, the interstices smooth and convex. Body beneath clothed with fine pale pubescence.

Length $9 \mathrm{~mm}$.

Hab. Bengal.

Easily distinguishable by its coloration.

\section{Subfamily III. CRIOCERIN $\approx$.}

Species of more or less elongate shape, of medium or small size. Head frequently constricted behind the eyes and produced in front; antennæ widely separated at base, filiform, often with widened and flattened joints (Crioceris); eyes frequently notched, sometimes entire and generally preceded by a deep groove. 'Thorax subcylindrical or subquadrate, without lateral margins, the latter sometimes replaced by a tubercle, the sides more or less strongly constricted (Lema and Crioceris) forming a shallow or deep cavity at middle, the surface frequently transversely sulcate near base and connected with the lateral cavity. Elytra wider at base than thorax, punctate-striate, irregularly punctured in two genera (Pedrillia and Zeugophora), their epipleuræ indistinct or absent. Legs variable, the femora more or less thickened; claws either free (Crioceris) or joined at base (Lema); in one genus nearly bifid (Orsodacna), appendiculate in Pedrillia and Zeugophora. First ventral segment in most cases much longer than any of the others; prosternum very narrow but distinct.

Range. Universally distributed.

\section{Key to the Genera of the Criocerinx.}

A. Thorax laterally tuberculate.

a. Thorax with transverse groove near base .. Pedrillia, p. 12.

b. Thorax without transverse groove near base. ZeUGOPHORA, p. 14.

B. Thorax not laterally tuberculate.

a. Claws nearly bifid ................ Orsodacna, p. 15 .

b. Claws simple.

$a^{\prime}$. Head constricted posteriorly.

$a^{2}$. Claws joined at base ........... Lema, p. 15.

$b^{2}$. Claws not joined at base........... Crioceris, p. 71 .

$b^{\prime}$. Head not constricted posteriorly.

$a^{2}$. Head without grooves above eyes .... P. Pseudolema, p. 83.

$b^{2}$. Head with grooves above eyes ...... Manipuria, p. 84 .

\section{Genus PEDRILLIA.}

Pedrillia, Westw. Trans. Ent. Soc. (3) ii, 1864, p. 280 ; Chapuis, Gen. Coléopt. x, 1874, p. 94 ; Weise, Deut. ent. Zeit. 1900, p. 447.

Type, $P$. longicornis, Westwood, from India.

Range. Europe; Madagascar; India; Japan; N. America.

Of rather small shape, generally finely pubescent above; eyes distinctly notched or emarginate; clypeus separated from face by a deep transverse groove ; maxillary palpi slender, last joint strongly 
pointed ; antennæ filiform, the joints short, somewhat triangularly widened, the third and fourth rather longer. Thorax scarcely broader than long, the sides widened near middle into a more or less produced tubercle, the base with transverse sulcus. Elytra wider at base than the thorax, irregularly and closely punctured, rather convex, parallel, the apex rounded. Femora rather strongly incrassate, tarsi short, claws appendiculate; anterior coxæ nearly contiguous, intermediate coxæ slightly separated. First ventral segment twice the length of second.

Formerly placed in the Megalopince, with which it has nothing in common, as pointed out by Weise. Its true place is near Zeugophora, from which it differs but little.

16. Pedrillia longicornis, Westw. Trans. Ent. Soc. (3) ii, 1864, p. 280.

Fulvous above, black beneath; antennæ long and slender; head impunctate; thorax finely and remotely punctured, the sides tuberculate; elytra more strongly and closely punctured, elothed with long fulvous pubescence.

Head broad, entirely impunctate; mandibles robust, fulvous, the tips black; eyes deeply notched; antennæ extending to the middle of the elytra, black, the first joint fulvous, the fourth the longest, following joints subquadrately widened, slightly longer than broad. Thorax half as long as broad, strongly and abruptly constricted at the base, the anterior portion produced into a broad tubercle at the sides; the surface finely and remotely punctured, reddishfulvous, shining, clothed with long fulvous hairs. Elytra rather long, widened and thickened posteriorly but very gradually, the puncturation much more distinct and close than that of the thorax, the interstices furnished with long fulvous hairs. Beneath and the legs black or piceous.

Length $4 \mathrm{~mm}$.

$H a b$. India.

The antennæ in this species are, as the name implies, proportionately long, and the tubercle at the sides of the thorax is blunt and broad; specimens occur in which the eutire head and thorax are black.

17. Pedrillia murrayi, Clark, App. Cat. Phytoph. 1866, p. 87. Zeugophora apicalis, Motsch. Bull. Mosc. xsxix, 1866, p. 406.

Very similar to P. longicornis, but clearly differentiated by the black band at the apex of the elytra, the upper edge of which is concave; another difference is the greater amount of constriction of the thorax in P. murrayi, this is deeper and more marked than in the continental Indian species; whether the antennw likewise differ I am not able to say, since in all the specimens before me only two or three joints are present, the rest being broken off.

Length $4 \mathrm{~mm}$.

Hab. Ceylon. Type in Brit. Mus., also obtained by Doherty. 


\section{Pedrillia flavipes, sp. $n$.}

Eutirely pale flavous, antennæ piceous, basal joints flavous.

c. Head impunctate, shining, clypeus separated by a deep transverse groove; antennæ with basal two joints flavous, rest nearly black, third and fourth elongate, following joints thickened and much shorter. Thorax transverse, sides produced into a broad prolongation, obliquely constricted at base, surface finely and remotely punctured and sparingly pubescent. Elytra closely and strongly punctured and finely pubescent. Underside and legs coloured like the upperside, finely punctured. Posterior femora thickened, their tibiæ curved, tarsi broad.

Length $4 \mathrm{~mm}$.

Hab. Nilgiris (H. L. Andrewes). Type in Coll. H. E. Andrewes.

Differs from $P$. murrayi in the colour of the elytra, underside and legs, and may possibly represent only a local race of that species.

\section{Genus ZEUGOPHORA.}

Zeugophora, Kunze, Neue Schr. Naturf. Ges. Halle, ii, pt. 4, 1818, p. 17 ; Lacord. Mon. Phytoph. i, 1845, p. 233.

Type, Z. subspinosa, Fabr., from Europe.

Range. Europe; India.

Differs only from Pedrillia in the absence of a transverse sulcus at base of thorax.

19. Zeugophora indica, Jac. Ann. Soc. Ent. Belg. xlvii, 1903, p. 81.

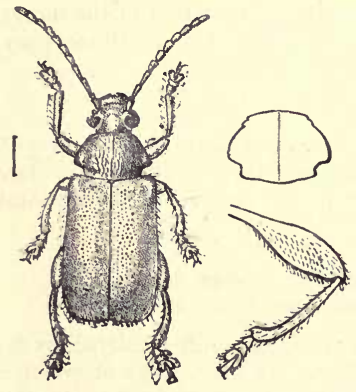

Fig. 5.-Zeugophora indiea.

Pale fulvous, finely pubescent ; antennæ flavous.

Head impunctate, antennæ flavous, thorax finely punctured and pubescent; elytra much wider at the base than the thorax, rather closely and strongly punctured, clothed with fulvous pubescence; apex of each elytron subtruncate. Beneath pale fulvous. Femora thickened, the intermediate and the posterior tibiæ strongly curved at the apex, rather thick; tarsi broad.

Length $5 \mathrm{~mm}$.

Hab. Nilgiris (Coll. Jacoby).

20. Zeugophora andrewesi, Jac. Ann. Soc. Ent. Belg. xlvii, 1903, p. 82.

Fulvous, the antennæ (the basal joint excepted), the breast and the legs black. Thorax with the sides moderately tuberculate. 
The posterior tibiæ strongly curved. Smaller than the preceding species, the antennæ black as well as the breast and the legs; the thorax much longer and less strongly tuberculate, the last abdominal segment and the pygidium black.

Length $4 \mathrm{~mm}$.

Hab. Nilgiris (Coll. H. E. Andrewes).

\section{Genus ORSODACNA.}

Orsodacna, Latreille, Hist. Nat. Ins. iii, 1802, p. 223.

Type, O. cerasi, Linn., from Europe.

Range. Europe; North and South America; Cevlon.

Of narrow, elongate shape. Eyes large; antennæ filiform, the termial joints slightly widened; fourth joint of maxillary palpi as long as or longer than the second joint. Thorax as broad as long, sometimes broader, more or less constricted at the base, much narrower than the elytra, the latter irregularly punctured. Legs moderately stout, the posterior femora not thicker than the others; tibiæ gradually widened towards the apex, armed at the latter place with two small spines; the first joint of the posterior tarsi nearly as long as the following two joints united; claws almost bifid.

21. Orsodacna indica, Motsch. Bull. Mosc. xxxix, 1866, p. 406.

"About one-third smaller than the European O.cerasi, parallel, rufo-testaceous, the elytra and legs paler, the antennæ, scutellum and the suture black, tarsi fuscous. Elytra rugosely punctured, sparingly pubescent."

Length $3 \mathrm{~mm}$.

$H a b$. Ceylon.

The above is all the description given by Motschulsky of this insect, the true place of which can only be determined by an examination of the type.

\section{Genus LEMA.}

Lema, Fabr. Ent. Syst. Suppl. 1798, p. 90 ; Lacord. Mon. Phytoph. i, 1845, p. 303; Chapuis, Gen. Coléopt. x, 1874, p. 72.

Type, L. cyanella, Linn., from Europe.

Range. Of universal distribution; New Zealand excepted, so far as is known.

Characters those of the group. Head generally constricted posteriorly ; antennæ fliform ; thorax generally with one, sometimes with two, sulci, an anterior and a posterior one. Elytra punctate-striate. Legs elongate, femora moderately thickened, claws united at base as far as the middle.

The species of this genus are very numerously represented in India and the tropics in general; they vary greatly in size and 
coloration, but none can be called large. They may be best recognized by the constriction at sides of the thorax and by the partly united claws at the base.

The larvæ of the European species are remarkable for making a covering out of their own excreta; this is facilitated by the apex of the anal segment which is turned upwards; the frass is pushed forward little by little and hardens over the upper surface of the larva. This covering is, however, discarded when the larræ bury themselves in the ground to pupate, a cocoon being substituted for it.

\section{Section I.}

Fulvous. Thorax not longer than broad, with single transverse basal sulcus; elytra metallic blue or green; labrum black.

\section{Lema obliterata, sp. n.}

Head and thorax fulvous, antennæ and legs paler, labrum black : elytra metallic greenish-blue; underside black.

Head dark fulvous, impunctate, the vertex highly raised, the elevation divided by a deep groove, each division broadly rounded above; labrum black; antennæ pale fulvous, joints two to four gradually elongate, following joints longer. Thorax dark fulvous, with strongly widened and convex anterior portion, deeply constricted; lateral excavation scarcely wider than the basal sulcus, bounded by a short ridge above, the basal groove very deep; surface inpunctate. Scutellum black, subquadrate. Elytra with a deep fovea or excavation below the base, the latter raised; shoulders bounded within by a deep sulcus, the latter strongly punctured; rest of the surface very finely punctate-striate, the punctures rather distantly placed. Breast and abdomen black; legs fulvous, slender and elongate.

Length $6 \mathrm{~mm}$.

Hab. India: Manipur.

The very deep elytral depression and their sculpture will easily separate this species from others with similar coloration; the shoulders are very prominent and bounded on both sides by a deep sulcus.

23. Lema fulvicornis, Jac. P.Z. S. 1887, p. 66; Weise, Deut. ent. Zeit. 1903, p. 23.

Fulvous; labrum black; elytra dark metallic blue; underside fulvous.

Head with the intraocular space.strongly swollen and finely punctured, lateral sulci very deep; labrum and upper part of clypeus black, the labrum with some transversely-placed punctures. Antennæ rather more than half the length of the body, entirely fulvous; fourth joint very slightly longer than the third, the following joints elongate, cylindrical, and not increasing in thickness. Thorax scarcely longer than broad, deeply 
constricted at the sides, the basal groove likewise deep, anterior angles slightly pointed but not tuberculate; the surface convex and swollen, impunctate. Elytra broad, subquadrate, the base scarcely depressed, the puncturation deep and not very closely placed anteriorly, much more closely posteriorly, the punctures on that portion run into striæ; the interstices costate. Underside fulvous, clothed with yellow pubescence. Legs fulvous, robust.

Length $6 \mathrm{~mm}$.

$H a b$. Ceylon.

Can be at once separated from $L$. subobliterata by the feeble elytral depression and their different sculpture.

\section{Lema nigro-frontalis, Clark, App. Cat. Phytoph. 1866, p. 40.}

Head, thorax and legs rufous; labrum and underside piceous or black; antennæ fuscous; elytra metallic blue.

Head with the frontal elevations strongly raised, divided posteriorly, sparingly punctured; antennæ with the lower two or three joints rufous, rest nearly black or fuscous, fifth and following joints elongate, third and fourth equal. Thorax with anterior angles not tuberculate; the lateral constriction forms a deep cavity, bounded above by a perpendicular ridge; basal sulcus deep, foveolate at middle. Elytra with short and moderately deep depression below base, punctures closely placed and rather deep anteriorly.

Length $6 \mathrm{~mm}$.

$H a b$. Northern India; Nepal ; Bengal.

Differs from the preceding species in the dark antennæ and closely placed elytral punctures; the thorax has two rows of fine punctures.

25. Lema birmanica, Jac. Ann. Mus. Civ. Genova, xxxii, 1892, p. 872.

Reddish-fulvous, labrum black; elytra dark blue, extreme apex fulvous.

Head impunctate, not constricted posteriorly, the frontal elevations distinct, divided by a narrow longitudinal groove; labrum bluish-black; antennæ extended to half the length of the elytra, entirely fulvous. Thorax slightly broader than long, moderately constricted at the sides, the basal sulcus very deep followed by another more obsolete transverse groove, the surface impunctate. Scutellum fulvous. Elytra slightly depressed below the base, the punctures deep and large anteriorly, gradually diminishing towards the apex, the latter narrowly fulvous.

Length $6 \mathrm{~mm}$.

$H a b$. Burma: Palon; Tenasseriun : Malewoon.

Very closely allied to $L$. stevensi, Baly and has nearly the same colouring, but the head is not constricted; the thorax is entirely inpunctate, as are also the elytral interstices, which differ in colour from those of the preceding species.

TOL. I. 


\section{Lema semiregularis, sp. $\mathrm{n}$.}

Fulvous; labrum black; elytra metallic violaceous; underside and legs fulvous.

Vertex of head triangularly raised, very slightly grooved, the base not constricted behind the eyes; labrum black; antennæ very long and slender, the third joint shorter than the fourth, terminal joints very elongute. Thorax moderately constricted at the sides, the anterior portion not much widened, the basal sulcus very deep; the surface impunctate, fulvous. Scutellum fulvous. Elytra with a short but rather deep depression below the base and there very strongly punctured, with the interstices transversely wrinkled, the puncturation as usual, gradually finer posteriorly yet very distinct. Beneath and the legs fulvous.

Length $6 \mathrm{~mm}$.

Hab. Manipur (Doherty). Type in Brit. Mus. Malabar coast (Coll. Jacoby).

Amongst the fulvous species with blue elytra, the present form may be known by the unequal size of the third and fourth joints of the antennæ and the coarse puncturation at the base of the elytra, which looks somewhat confused on account of the transversely rugose interstices. A specimen with partly black elytra does not seem to differ in any other respects, but two specimens from Mahé (Malabar) in my collection are rather larger and more robust, the vertex is more strongly raised and the punctures at the base of the elytra are rather less confused; but these differences do not seem to me important enough to be considered specific.

\section{Lema malabarica, sp. $n$.}

Rufous; the antennæ (basal joint excepted), clypeus, labrum, apex of tibiæ and the tarsi black; elytra metallic blue, extreme apical margins fulvous.

Head impunctate, intraocular space highly raised and deeply longitudinally divided; eyes acutely notched; clypeus and labrum black; antennæ with the basal joint rufous, the following five joints black (the rest in the type and only specimen wanting), third and fourth joints equal, twise as long as the second joint. Thorax broader than long, the anterior portion strongly transverse, the angles prominent but not tuberculate; basal sulcus deep, sinuately widened at the lateral constriction but not forming a deep excavation nor bounded by a ridge above; surface with a few minute punctures on the middle. Scutellum fulvous. Elytra feebly transversely depressed below the base, closely and deeply punctured, the punctures round, the spaces dividing them much smaller at the basal portion than the punctures, the latter gradually diminishing in size posteriorly.

\section{Length $5 \mathrm{~mm}$.}

Hab. Malabar: Mahé (Coll. Jacoby).

To be separated from other very similarly coloured species with black clypeus and labrum by the colour of the tibiæ and the tarsi and by the closely approximate large puuctures at base of elytra in connection with the general size. 


\section{Lema hopei, sp. n.}

Fulvous; clypeus and labrum black; elytra metallic dar greenish ; legs fulvous.

Head impunctate, intraocular space highly raised and deeply divided; eyes very prominent, triangularly but only moderately deeply notched; clypeus and labrum black; antennæ with the basal six joints fulvous, the rest in the type and only specimen wanting, third and fourth joints equal, fifth and sixth elongate. Thorax moderately constricted at the sides, the constriction bounded above by a perpendicular ridge; basal sulcus deep, the space below with a transverse raised line or ridge; anterior angles rounded, the middle of the disc with a few minute punctures anteriorly. Scutellum fulvous. Elytra with a very shallow depression below the base, deeply and strongly punctate-striate, the punctures finer towards the apex, the interstices at the latter place slightly convex. Underside and the legs fulvous, clothed with fine yellow pubescence.

Length $5 \mathrm{~mm}$.

$H a b$. India (Coll. Jacoby).

Distinguished by the rounded, not pointed, anterior angles of the thorax, fulvous antennæ and underside. The species is closely allied to L. fulvicornis, Jac., from Ceylon, but is less broad than that insect and generally of smaller size, while the elytral puncturation is different.

29. Lema obscuritarsis, Jac. Ann. Mus. Civ. Genova, xxxii, 1892, p. 872.

Fulvous; the labrum and antennæ (the first joint excepted) black; elytra metallic dark blue; tarsi more or less fuscous.

Head not constricted behind the eyes, inpunctate, the frontal tubercles divided by a longitudinal groove; eyes deeply notched; labrum black; antennæ black, extending to about half the length of the elytra, the first joint fulvous, the fourth longer than the third joint. Thorax only moderately constricted at the sides, the transverse groove distinct, the surface with a few fine punctures anteriorly and at the sides only. Scutellum fulvous. Elytra rather flattened, obsoletely depressed below the base, dark blue, distinctly and regularly punctate-striate, the interstices convex near the apex. Legs fulvous, tarsi obscure fuscous.

Length $5 \mathrm{~mm}$.

Hab. Burma: Palon; Assam: Patkai Mts.

Nearly allied to $L$. mouhoti, Baly, but snialler, the head not constricted behind and the antennæ and tarsi black instead of fulvous; the first-named parts have the fourth joint longer than the third, in which they differ from $L$. malaburica; the elytra have no fulvous apical margins as in that form. Thorax differently sculptured from that of $L$. hopei; antennæ black. 


\section{Lema balyana, sp. $n$.}

Black; upper portion of head and the thorax fulvous; elytra metallic blue.

Head not constricted posteriorly, the vertex with two broad, rather highly raised elevations; eyes narrowly notched ; the clypeus and labrum black, both rather elongate; antennæ black, pubescent, extended to the middle of the elytra, the third joint slightly shorter than the fourth, the following elongate cylindrical. Thorax rather transverse, the anterior angles barely prominent, the lateral constrictions sulciform and connected with the basal sulcus, the latter placed at some distance from the basal margin; the anterior portion of the thorax with a slight transverse depression at the sides, only seen in certain lights, the disc with a few very minute punctures. Scutellum fulvous or black. Elytra narrowed towards the apex, subcylindrical, with a short but not deep basal depression, metallic blue; the punctures regular, only slightly larger at the base than posteriorly, the rows closely placed, the interstices at the apex not costate. Underside and legs black, the latter elongate and slender.

Length $5 \frac{1}{2} \mathrm{~mm}$.

$H a \dot{b}$. Travancore: Wallardi (Coll. Jacoby); Nilgiris (H. L. Andrewes).

Principally distinguished by the black antennæ, underside and legs, as well as the clypeus and labrum. The species is closely allied to L. rothschildi, Clavar. (nigrilabris, Jac.), from Nyassaland, but differs in the entirely black antennæ and the non-tuberculate anterior portion of the thorax, also in the non-costate elytral interstices.

\section{Lema horni, Weise, Deut. ent. Zeit. 1903, p. 21.}

Rufo-testaceous; the labrum, antennæ, and the legs more or less fuscous; breast and abdomen piceous; elytra black, with a slight bluish tint.

A small and slender-shaped species with but slightly convex black elytra, the latter with a bluish gloss and not very shining. Frontal elevations of the head punctured and pubescent, feebly divided. Thorax closely and very finely punctured, with two rows of punctures at the middle; the basal sulcus deep, widened into a deep cavity at the sides which strongly constricts the thorax, the anterior angles rounded. Scutellum reddish, smooth. Elytra scarcely depressed below the base, regularly punctatestriate, the interstices convex at the apex and sides only. Legs reddish, the tibiæ and tarsi darker, sometimes the femora also dark.

Length $4-4 \frac{1}{2} \mathrm{~mm}$.

$H a b$. Ceylon : Anuradhapura. 
32. Lema globicollis, Baly, Ann. Mag. Nat. Hist. (3) iv, 1865, p. 168. Lema bengalensis, Duviv. Ann. Soc. Ent. Belg. xxxv, C. R. 1891, p. xxvi ; Weise, Deut. ent. Zeit. 1903, p. 23.

Piceous, the mouth and antennæ black; breast, scutellum and thorax rufous; elytra cyaneous.

Head short; face triangular, concave between the eyes, the latter very prominent, globular; forehead nearly impunctate; antennæ scarcely equal in length to half the body, robust, increasing in thickness towards their apices, basal joints piceous. Thorax rather longer than broad, deeply impressed with subremote large punctures at middle aud sides; a longitudinal space on either side of the disc smooth, impunctate. Elytra strongly and closely punctured, interstices flat.

Length $4 \mathrm{~mm}$.

$H a b$. India.

Separated by the subglobular shape of the anterior portion of the thorax. The puncturation of the thorax occupies the middle of dise and sides; femora obscurely stained with metallic blue.

\section{Lema rotundicollis, sp. $\mathrm{n}$.}

Black; head and thorax fulvous; elytra dark blue.

Head impunctate, labrum black; antennæ black, extending to middle of elytra, basal joint fulvous, terminal joints strongly thickened but longer than broad. Thorax subcylindrical, anterior portion strongly thickened and rounded, sides only slightly constricted; basal sulcus deep, continued on the sides; surface strongly punctured near anterior angles, in the middle with two rows of fine punctures. Scutellum piceous. Elytra subcylindrical, scarcely depressed below base; puncturation very deep and close, the punctures slightly elongate; interstices feebly raised, slightly rugose below base. Underside and legs black.

Length $3 \frac{1}{2} \mathrm{~mm}$.

$H a b$. Nilgiris (H. L. Andrewes).

Closely allied to L. globicollis, Baly, but smaller, the antennæ are longer, the terminal joints less strongly transverse but longer, also thickened; the thorax has only two central rows of punctures and the elytral interstices are slightly convex.

\section{Section II.}

Labrum fulvous. General colouring as preceding species.

\section{Lema epipleuralis, sp. $n$.}

Fulvous; antennæ and breast black; elytra metallic dark blue, their epipleuræ fulvous at base.

Head finely punctured at the vertex, fulvous; eyes widely separated, broadly but not deeply notched, the intermediate space 
only moderately raised; antennæ black, short and robust, the basal joint fulvous, second joint very small, third and fourth each about twice as long, more or less fulvous below, the rest subquadrately widened, robust, terminal joint obscure fulvous. Thorax only moderately constricted at the sides, the constriction gradually joined on to the basal sulcus, the latter deep; the middle of the disc with a few fine punctures. Scutellum black. Elytra metallic blue, subcylindrical, with only slight indication of a basal depression, the punctures round and deep, closely placed, slightly smaller posteriorly; the epipleuræ from the base to the middle fulvous, the extreme basal margin likewise more or less fulvous. The breast black, rest of the underside and the legs fulvous.

Length $4 \mathrm{~mm}$.

Hab. Bengal: Mandar (Coll. Jacoby).

I only know of a single specimen of this species obtained by M. Cardon. The short and robust subquadrate joints of the antennæ and the colour of the elytral epipleuræ will help to distinguish the species from its numerous allies.

35. Lema ceylonensis, Jac. P. Z. S. 1887, p. 65; Weize, Deut. ent. Zeit. 1903, p. 22.

Fulvous ; antennæ black, the basal and apical two joints fulvous ; elytra metallic green or blue.

Head eutirely fulvous and impunctate, the intraocular space moderately swollen and divided by a shallow groove; antennæ rather more than half the length of the body; third and fourth joints equal, following joints more elongate. Thorax subquadrate, moderately constricted at the sides, the basal sulcus deep; the surface scarcely perceptibly punctured. Scutellum fulvous. Elytra bright metallic yellowish-green or blue, with a very deep fovea below the base, finely and rather remotely punctate-striate, the punctures obsolete towards the apex. Legs fulvous, the posterior tibiæ slightly curved.

Length $4 \mathrm{~mm}$.

Hab. Ceylon.

Differs from other similarly coloured species by the colour of the antennæ, the deep elytral forea, and the remotely placed elytral punctures, also by the flat interstices and general size.

\section{Lema intacta, sp. $n$.}

Fulvous ; the antennæ and tarsi black ; elytra metallic blue.

Head entirely fulvous, impunctate; intraocular space swollen, undivided; eyes not very deeply notched; antennæ black, extended to the middle of the elytra, third and fourth joints equal, all the following joints elongate and slender. Thorax subquadrate, the constriction at the sides moderate, the anterior portion not much widened, with the angles very slightly pointed; the disc with 
a few fine punctures; basal sulcus not very deep except near the sides, placed rather close to the basal margin. Scutellum fulvous. Elytra obliquely and distinctly depressed below the base and within the shoulders, the punctures large and deep within the depression, the interstices there also somewhat rugose, slightly costate near the apex. Body beneath and the legs fulvous; tarsi black.

\section{Length $5 \mathrm{~mm}$.}

Hab. Travancore: Wallardi (Coll. Jacoby).

Closely allied to $L$. obscuritarsis, Jac. and $L$. balyana, Jac., but distinguished from both by the non-sulcate vertex of the head and the less deeply notched eyes, also from the first-named species by the black antennæ and from the second by the fulvous clypeus.

\section{Section III.}

Thorax longer than broad; coloration as preceding sections.

37. Lema praeclara, Clark, App. Cat. Phytoph. 1866, p. 38. Lema praeclarior, Clark, Cat. Phytoph. 1866, p. 27.

Flavous; elytra dark violaceous.

Flarous. Parallel-sided, cylindrical ; head strongly constricted posteriorly; intraocular space highly raised in the shape of two tubercles, joined in front; antennæ robust, extended slightly beyond the base of the elytra. Thorax elongate and subcylindrical, with rounded anterior angles; the surface convex, extremely minutely punctured; the basal sulcus very shallow; the lateral constrictions form deep triangular cavities. Scutellum fulvous. Elytra without basal depression, dark violaceous, the punctures deep and slightly elongate at the base, much finer posteriorly, the interstices at the latter place strongly costate. Underside and legs flavous, the latter very robust.

Length $8 \mathrm{~mm}$.

$H a b$. India.

A large and elongate species, with an elongate and subcylindrical thorax, its sulcus shallow. The above description is taken from the type in the British Museum.

38. Lema lacordairei, Baly, Trans. Ent. Soc. (3) iv, 1865, p. 23.

Lema cyanipennis, Lacord. (nec Fabricius) Mon. P'hytoph. i, 1845, p. 370 .

Rufous; elytra metallic blue.

Head and thorax very shining; antennæ robust, slightly less than half the length of the body. Thorax one-fourth longer than broad anteriorly, smooth or with some minute punctures at middle of disc. Elytra strongly punctate-striate at base, finely so towards apex, interstices smooth. Legs rather short; claws black.

The differences pointed out by Baly between this species and the true $L$. cyanipennis Fabr. consist principally in the always 
distinctly longer antennæ of the last-named insect; the latter is found in Borneo, Sumatra, \&c., but has not been recorded from India, where $L$. lacordairei takes its place.

Length $7 \mathrm{~mm}$.

$H a b$. Southern India : Malabar; Nilgiris ; Burma.

\section{Lema andamanensis, sp. $n$.}

Fulvous; elytra metallic blue.

Head with an interrupted median groove, without frontal elevations, impunctate, the lateral sulci very deep; eyes large, acutely but not very deeply notched; clypeus elongate, wedgeshaped, convex and impunctate, fulvous as is also the labrum. Antennæ robust, with cylindrical joints, entirely fulrous; basal joint short, subquadrate, second moniliform, third and fourth short, equal, fifth joint but slightly longer than the following, which are covered with very fine fulvous pubescence. Thorax slightly longer than broad, moderately constricted at the sides; the basal sulcus well marked, ending laterally in a deep cavity, the latter blackish and bounded above by a short perpendicular ridge; the surface entirely impunctate. Scutellum subquadrate, fulvous. Elytra with short but deep humeral sulci, the punctures round and deep, rather distantly placed, the first sutural row not double anteriorly, the posterior portion more finely punctured; the sutural and the three or four lateral interstices more or less convex, the others with some fine and distant punctures. Body beneath and the legs fulvous, very sparingly clothed with short yellow pubescence.

\section{Length $6 \mathrm{~mm}$.}

Hah. Andaman Islands (Coll. Jacoby).

Differs from L. fulvicornis, Jac. in the fulvous, not black, labrum, in the vertex of the head, which is not swollen nor punctured, also in the shorter terminal joints of the antennæ which are subquadrately flattened, although longer than broad. L. cyanipennis, Fab. has a longer thorax, a deep elytral depression, and is much more finely punctured. In $L$. mouhoti, Baly, the thorax is more swollen and the elytra are deeply depressed below the base.

\section{Lema amethystina, sp. n.}

Ferruginous; clothed with goldenpu bescence beneath; elytra violaceous.

Elongate and parallel-sided, the bead constricted posteriorly, entirely impunctate, the vertex, not divided ; antennæ pale ferruginous, extended to just below the base of the elytra, the joints robust, the third distinctly shorter than the fourth. Thorax slightly longer than broad, strongly constricted at the middle, the lateral cavities very deep, anterior angles thick and rounded, basal sulcus only indicated; the disc with a few very minute punctures 
at the middle when seen under a strong lens. Scutellum ferruginous. Elytra with a deep basal depression, the basal portion and the depression impressed with deep round punctures, the latter very fine posteriorly and formed into striæ, the interstices convex towards the apex. Body beneath and legs ferruginous.

Length $9 \mathrm{~mm}$.

Hab. Assam. Type in Brit. Mus.

I cannot look upon this species, of which a single specimen only is contained in the Brit. Mus., as a variety of $L$. lacordaire $i$, Baly (cyanipennis, Lac.) on account of its very much larger size, the impunctuate head, deep elytral depression and impunctate interstices as well as their dark violaceous colour. It is also a larger species than the preceding one.

\section{Section IV.}

Thorax with anterior and posterior sulcus, the former sometimes feeble. Coloration as in preceding sections.

41. Lema coromandeliana, Fabr. (Leptura) Ent. Syst. Suppl. 1798, p. 154; Lacord. Mon. Phytoph. i, 1845, p. 37\% ; Baly. Trans. Ent. Soc. (3) iv, 1865, p. 24 ; Jacoby, Notes Leyd. Mus. 1๕81, p. 199; Weise, Deut. ent. Zeit. 1892, p. 387.

Var. gangetica, Weise, t. c. 1903, p. 20.

Rufous; antennæ black; anterior portion of head, sides of breast and legs greenish-black; elytra metallic blue.

Head with punctured and pubescent elevation between eyes, divided posteriorly by a groove; antennæ slender, extended to middle of elytra. 'Thorax with anterior angles pointed, impunctate ; surface with anterior medially interrupted and posterior deep sulcus. Elytra with shallow basal depression, strongly punctatestriate, metallic blue or greenish as are the legs and the sides of the breast. $-\delta$. Intermediate tibiæ with triangular tooth before apex.

Var. gangetica, Weise. Rufous, sides of breast black. (L. melanocera, Lac.?)

Length 5-6 mm.

$H a b$. India ; Ceylon; Sumatra ; Java.

The correct synonymy of this species is not at all understood at present; the true $L$. coromandeliana of Fabricius was described from Coromandel. Since then many other closely allied forms, or it may be varieties, have been united by Baly; more lately Weise has defined the differences between this and allied species, but neither he nor Baly, so far as I am aware, had specimens before them from Coromandel, and it remains to be seen whether the Malayan insects with dentate tibiæ in the male or those from Ceylon with or without similar structure are all one species. At present Lacordaire's description (he was the first to give a detailed one of $L$. coromandeliana) must be accepted, since he receired the 
insect from the original locality. This author makes, however, no mention of any toothed tibiæ.

Size, coloration and the bisulcate thorax principally characterise this species. Weise has named the variety in which the tibial tooth, as well as the anterior thoracic sulcus, is very small or entirely absent, and in which the breast and abdomen is quite bluish or greenish-black, but such specimens cannot be distinguished from several others of similar coloration, except perhaps by the punctured and pubescent frontal tubercles.

From Calcutta and other parts of India I have specimens with entirely fulvous or rufous antennæ and legs as well as similarlycoloured underside (the sides of the breast excepted). I cannot distinguish these specimens structurally from $L$. coromandeliana; they answer very nearly to $L$. melanocera, Lac., but that author gives the lower joints of the antennæ as black and the underside as entirely fulvous: the locality for his species also is Java.

\section{Lema kandyensis, Weise, Deut. ent. Zeit. 1903, p. 20.}

Rufous; the head more or less æneous anteriorly; antennæ, breast, abdomen and legs black; elytra metallic green or blue.

Head and thorax rufous, with a violet tint above, the clypeus and the labrum (the first-named at least at the margin) metallic bluish; mandibles black; frontal elevations convex, not closely punctured or pubescent, divided by a rather broad sulcus. Antennæ black. Thorax strongly constricted below the middle, the anterior sulcus deep, terminating at the sides in a large fovea which is clearly bornded above by a ridge, the basal sulcus rather deep; the surface with a few punctures at the middle and anteriorly, the anterior angles pointed. Scutellum finely pubescent, blackish or partly red. Elytra strongly metallic blue or green, the inner rows of punctures obsolete behind the middle; interstices nearly smooth, finely granulate, the two sutural and the three marginal interstices convex.

The male has a fine median raised line on the first abdominal segment, which is much more feeble and shorter than the corresponding structure in L. coromandeliana.

Length 5-6 mm.

Hab. Ceylon: Kandy.

\section{Lema tibiella, Weise, Deut. ent. Zeit. 1903, p. 20.}

o. Rufous; antennæ and labrum black; clypeus, breast, abdomen and legs dark æneous; elytra æneous.

This also is closely allied and resembles $L$. coromandeliana, but is rather more slender, the breast and abdomen are greenish-black. The thorax more closely punctured and the large and pointed tibial tooth placed before, not behind the middle. 
All this agrees with a specimen from Ceylon in my collection, but the colour of the abdomen is entirely fulvous, not dark as Weise gives it.

Length 5-6 $\mathrm{mm}$.

$H a b$. Ceylon: Bandarawella.

\section{Lema flavimana, sp. $n$.}

Flavous, clypeus and breast black; elytra violaceous blue.

Head with the swollen portion at the vertex distinctly punctured and with a short and deep groove; clypeus with its lower portion and the labrum black with bluish gloss; antennæ rather short, flavous, the third and fourth joints equal, terminal joints slightly thickened and rather short. Thorax rather transverse, the anterior angles tuberculate; basal sulcus very deep, placed at some distance from the base; lateral cavities broad at their upper portion, bounded by a strong ridge above; anterior portion of the thorax with a deep transverse sulcus at sides, very minutely punctured. Scutellum flavous. Elytra very strongly punctured at the base only, the posterior portion finely punctate-striate. Legs flavous, the femora robust.

Length $5 \frac{1}{2} \mathrm{~mm}$.

Hab. India : Bandra. Type in Brit. Mus.

Amongst those with blue elytra the present species may be known by the all but entire absence of an elytral depression, the flavous or pale fulvous colour of the antennæ and their rather short joints, the position of the thoracic basal sulcus and its minutely punctured surface, when seen under a strong lens, the punctured vertex of the head and the black breast. L.epipleuralis, Jac. is smaller and has black antennæ.

45. Lema trazquebarica, Fabr. Ent. Syst. Suppl. 1798, p. 92 ; Lacord. Mon. Phytoph. i, 1845, p. 376.

Ferruginous; labrum, sides of breast, and elytra black.

Head smooth; antennæ pale ferrugineous, extending slightly below the middle of the elytra. Thorax subquadrate, impunctate, the basal sulcus rather shallow, an oblique but feeble depression at each side before the middle. Elytral puncturation not strong, with impunctate interstices, the latter convex at the apex. Legs ferruginous.

Length $4 \frac{1}{2} \mathrm{~mm}$.

Hab. Coast of Coromandel.

A much smaller species than $L$. cyanipennis, with black elytra and similarly coloured sides of the breast. Whether this is the true insect described by Fabricius under that name is doubtful, since this author's description is too short to be conclusive and applies to several closely allied forms. It may be only another variety of $L$. coromandeliana in the description of which Fabricius has substituted black for blue as the colour of the elytra. 


\section{Section V.}

Thorax with single basal sulcus. Colour above testaceous, pale or dark fulvous. Species of large size $(7-10 \mathrm{~mm}$.).

\section{Lema atkinsoni, sp. n.}

Broad and robust; antennæ (basal two joints excepted), tibiæ and tarsi black.

Head constricted posteriorly, impunctate; eyes large, deeply notched, the vertex with an obsolete groove, scarcely raised, the lateral grooves deep. Antennæ black, extend to slightly beyond the base of the elytra, the basal two joints flavous, the third and fourth short and equal, basal four joints shining, the rest opaque, pubescent, terminal joints subcylindrically widened, twice as long as broad. Thorax broad and flat, deeply constricted at the sides, the anterior angles strongly produced and rounded, the lateral cavities bounded by an acute ridge above; the disc with several rows of fine punctures, otherwise impunctate. Scutellum narrow, flavous. Elytra with the shoulders oblique, the basal portion neither raised nor depressed, the inner four or five rows of punctures at the base strong, rest of the surface finely punctured, all the rows consist of single punctures, the interstices sparingly and minutely punctate.

Length $10 \mathrm{~mm}$.

Hab. Sikhim: Mungphu. Type in Brit. Mus.

Allied to L. bohemanni, Clark, from China (russula, Boh.), from which species the insect described above differs as follows:- no basal depression near the suture; interstices not smooth but finely punctured.

\section{Lema rufo-brunnea, sp. n.}

Dark brown; the antennæ, tibiæ and tarsi black.

This is so closely allied to the preceding species that it will be sufficient to point out the differences. It has nearly the same broad and robust shape but is of a dark brown, not flavous, colour; the antennæ are entirely black and of a rather more slender shape; the thorax is somewhat longer and not nearly so deeply constricted nor widened anteriorly as in $L$. atkinsoni, and the elytra are rather more strongly punctured; in all other respects the two species are alike.

Length $9 \frac{1}{2} \mathrm{~mm}$.

Hab. Assam: Patkai Mts. Type in Brit. Mus.

\section{I.ema peguensis, sp. $n$.}

Dark brown, head and thorax nearly black.

Of rather flattened shape. Head distinctly bituberculate at the vertex, eyes moderately deeply notched; antennæ stout and rather 
long, nearly black, the third joint one half as long as the fourth, all the joints thickened but elongate. Thorax slightly longer than broad, concave at the middle of the sides if looked at from above; lateral cavities deep with the usual ridge above, basal sulcus only indicated at the sides; the disc impunctate with a small fovea near the base, anterior angles obsolete. Elytra dark brown, closely impressed with large and deep foveolate punctures, the interstices transversely convex, the punctures absent on the apical third portion where the interstices are strongly longitudinally costate. Body beneath and the legs nearly black.

Length $10 \mathrm{~mm}$.

Hab. Burma: Pegu. Type in Brit. Mus.

A large and very distinct species, with more strongly punctured elytrathan any of its congeners and the sculpturing altogether different; also the shape of the thorax.

\section{Lema subtuberculata, sp. n.}

\section{Entirely fulvous.}

Head constricted behind the eyes, neck long; intraocular space strongly bituberculate; antennæ fulvous, the third joint much shorter than the fourth, the following joints elongate and slender. Thorax with the anterior portion rather strongly obliquely widened, the lateral constrictions form a deep cavity with the usual ridge above, the surface with a very small tubercle at each side close to the anterior margin followed by a short elongate fovea, the rest of the surface impunctate; the basal sulcus deep and placed at some distance from the base. Scutellum rather small, subquadrate. Elytra with a shallow basal depression, the punctures very fine except on the basal portion, the tirst sutural row simple, the interstices at the sides feebly and broadly raised. Below and the legs fulvous, not pubescent.

Length $9 \mathrm{~mm}$.

$H a b$. Assam : Patkai Mts. Type in Brit. Mus.

Whether the peculiar structure of the thorax is aberrational or not it is impossible to say, as only a single specimen is before me; this coupled with the elongate neck should prevent its being confounded with any other species.

\section{Lema palpalis, Lacord. Mon. Phytoph. i, 1845, p. 315.}

Entirely pale flavous.

Head raised between the eyes, the elevation divided by a groove; last joint of palpi strongly swollen; antennæ filiform, flavous, third joint half length of fourth, fourth and the following joints equal. Thorax subquadrate, impunctate; lateral constriction very deep, separated from the basal sulcus by a distinct perpendicular ridge, anterior portion rather strongly widened, the angles somewhat prominent but not tuberculate. Elytra with feeble basal depression, the punctures strong within the latter, rest of surface 
finely punctate, interstices slightly raised from the middle downwards.

Length $8 \mathrm{~mm}$.

Hab. Bengal; Western India: Kanara; Andaman Islands; Sumatra; Java.

This species is principally distinguished by the swollen last joint of the palpi in connection with its size and uniform coloration. Lacordaire gives the thorax as longer than broad but this is not the case in any of the specimens before me, which agree in every other respect with the author's description. L. crassipalpis, Duviv. differs in the thorax which is spotted and other details of coloration. The type was obtained in Java, but I cannot separate the Andaman Island and Indian specimens in any way.

\section{Lema indica, Juc. Ann. Soc. Ent. Belg. xxxix, 1895, p. 252.}

Head flavous or testaceous, not tuberculate between the eyes, but with a fine central groove, the neck rather strongly constricted; eyes very prominent; antennæ robust, only extend to the base of the elytra, fuscous or flavous or partly of either colour, third and fourth joints short, equal. Thorax subquadrate, deeply excavated at the sides, the excavation scarcely separated from the basal sulcus, the latter somewhat shallow, the disc with several rows of fine punctures. Elytra with the basal portion slightly convex, deeply punctate-striate anteriorly, the punctures placed in striæ very fine posteriorly, the interstices very minutely punctured, the first subsutural row of punctures simple. Posterior femora strongly incrassate, claws black.

Length 7-8 mm.

$H a b$. Burma: Tharrawaddy.

This is a broad and robust species which might easily be mistaken for a Crioceris but for the claws being united at the base; as the first row of elytral punctures are simple, the species would find its place in Weise's genus Bradylema, which I look upon as a section of Lema only.

\section{Lema yerburyi, sp. n.}

Pale flavous, claws black.

Head deeply constricted posteriorly, the vertex with deep central groove, lateral sulci very deep; eyes very large and prominent, broadly, deeply emarginate; antennæ flavous, short and robust, the second joint moniliform, third and fourth very short, equal, the others about twice as long as broad, rather widened. Thorax deeply constricted at the sides, the cavity bounded by a perpendicular ridge above; basal sulcus narrow but deep, curved, placed close to the basal margin; surface impunctate, convex. Elytra with the basal portion raised, then feebly depressed, the second and third row of punctures at the base rather deep, the 
rest fine and placed in striæ, the interstices longitudinally convex from the middle downwards. Beneath and the legs entirely flavous, claws black.

Length $9 \mathrm{~mm}$.

Hab. Ceylon (Yerbury). Type in Brit. Mus.

A large species of entirely flavous shining coloration, the first row of elytral punctures simple (Bradylema, Weise). It is larger than $L$, indica, has the antennæ entirely flavous, and the thorax different in shape and structure.

53. Lema criocerioides, Jac. Ann. Soc. Ent. Belg. xxxvii, 1893, p. 271. L. robusta, Jac. Ann. Mus. Genova, xxxii, 1892, p. 869.

Beneath black, above fulvous, pygidium fulvous above.

Robust and broadly subcylindrical, the head deeply constricted posteriorly, impunctate, supraocular grooves very deep; eyes deeply notched ; antennæ black, only extend a little beyond the base of the thorax, the basal joint fulvous, the third and following joints widened and compressed, opaque, the apex of the terminal joint fulvous. Thorax subquadrate, moderately constricted at the sides, the basal sulcus distinct but not deep, the surface minutely and sparingly punctured. Elytra rery convex, without basal depression, strongly and deeply punctured anteriorly, more finely so posteriorly. Underside and legs black, sparingly clothed with silvery pubescence, the prgidium fulvous above.

Length $7 \mathrm{~mm}$.

Hab. Burna : Teinzo.

Principally distinguished by the short and flattened antennæ similar to many species of the genus Crioceris.

\section{Lema greeni, sp. n.}

Fulvous.

Head strongly constricted posteriorly; eyes deeply notched, intraocular space scarcely raised, with a longitudinal fine groove; autennæ short, fulvous, second joint very small, third slightly shorter than fourth, the following joints widened, the terminal three joints narrower again. Thorax distinctly longer than broad, the anterior angles rounded, the basal sulcus placed at some distance from the base, deep; lateral cavities broad, bounded above by the usual ridge; the surface entirely impunctate. Scutellum rather convex and broad. Elytra with a distinct but gradual basal depression, the punctures within the latter deep, the rest fine, nearly obsolete at the sides and from the middle downwards, the interstices perfectly flat, lateral margins strongly thickened. Body beneath shining, the sides of the breast clothed with golden pubescence; abdominal segments with fine patches of similar hairs; femora short and thick.

Length $8 \mathrm{~mm}$.

$H a b$. Ceylon: Kandy (E. Green, Coll. Jacoby). 
I have received a single specimen from Mr. E. Green from Ceylon. The species is distinguished by the moderately widened intermediate joints of the antennæ and the nearly impunctate posterior portions of the elytra.

55. Lema mandibularis, Jac. Ann. Mus. Civ. Genova, xxxii, 1892, p. 870 .

Fulvous; antennæ (basal two joints excepted), labrum and tarsi black.

Head not constricted posteriorly; the eyes elongate, impunctate, the vertex with two smooth tubercles, the ocular grooves rather feebly marked; labrum, clypeus and mandibles black, the latter very robust and strongly produced; antennæ black, scarcely extend to half the length of the elytra, the basal two joints fulvous, third and fourth joints equal. Thorax slightly broader than long, the sides only moderately constricted, the basal sulcus deep; the surface impunctate, fulvous. Elytra fulvous with a slight æneous lustre, the base very slightly depressed at the suture; the punctures as usual, much finer posteriorly ; the interstices flat, impunctate, slightly costate at the sides and apex. Underside clothed with fulvous pubescence, tarsi black.

Length $6 \mathrm{~mm}$.

Hab. Burma: Palon.

The produced anterior portion of the head and the strongly developed mandibles distinguish this species from any other Eastern form with which I am acquainted.

\section{Lema singularis, sp. $\mathrm{n}$.}

Entirely fulvous.

Head constricted behind the eyes, the latter very large and prominent, the sulci deep; the vertex not tuberculate, with the usual short groove; penultimate joint of palpi distinctly thickened, its apex acute ; antennæ fulvous, long and slender, the third joint distinctly shorter than the fourth. Thorax slightly longer than broad, the anterior angles with an extremely small tubercle, lateral constrictions moderate, deeply excavate at the sides with an acute ridge above; basal sulcus rather deep; placed at some distance from the base. Scutellum subquadrate. Elytra with a feeble basal depression, the punctures strong at the base, fine from before the middle to the apex, rather remotely placed, the shoulders very prominent.

Length $6 \mathrm{~mm}$.

Hab. Assam : Patkai Mts. (Doherty). Type in Brit. Mus.

The incrassate palpi, the elytra only slightly depressed at the base and the proportionately long thorax clearly distinguish this species, of which three examples are before me. It is one of the few Indian Lemas which have the third joint of the antennæ perceptibly shorter than the fourth; the thorax is distinctly longer than that of $L$. palpalis. 


\section{Lema carinata, sp. n.}

Fulvous with slight purplish gloss.

Head not constricted posteriorly, impunctate, intraocular space raised in shape of a high transverse ridge, ocular sulei deep, anterior portion finely pubescent; labrum black; antenuæ fulvous, slender, extended to the middle of the elytra, third joint slightly shorter than fourth, following joints elongate and slender. Thorax rather strongly widened in front, anterior portion convex, its angles rounded, basal sulcus deep as also the lateral constrictions, forming a cavity at each side bounded by a perpendicular ridge above, the surface impunctate, fulvous. Elytra fulvous, with a slight purplish gloss; a slight basal depression, strongly and closely punctured anteriorly, the interstices somewhat rugose within the depression.

\section{Length $6 \mathrm{~mm}$.}

Hab. Western India : Malabar coast, Mahé.

Can be separated at once by the transverse ridge of the head; there are however, some specimens which bave the carina of the head divided or distinctly tuberculate, but this is the only variation. The species is always comparatively broad and subdepressed in shape, with a strong puncturation and a slight purplish gloss.

\section{Lema simillima, sp. $\mathrm{n}$.}

Testaceous.

Head constricted posteriorly, the vertex strongly raised but not bituberculate; eyes very large, more than usually prominent, preceded by very deep sulci; antennæ rather robust, the basal joint subglobular, the second to the fourth joints gradually lengthened, terminal joints elongate and slightly thickened. Thorax with the anterior portion strongly widened, deeply constricted at the sides, anterior angles somewhat pointed, basal sulcus deep, placed close to the posterior margin. Elytra rather flattened, without any basal depression, the punctures comparatively small, round and placed in very regular rows, the first sutural row in part deeply striate below the base. Underside and legs rather darker.

Length $6 \mathrm{~mm}$.

$H a \dot{b}$. Burma. Type in Coll. H. E. Andrewes.

This species is distinguished by the extremely large and prominent eyes, which may be called almost sessile, the deeply constricted thorax and its basal sulcus placed very low down, also by the non-impressed and finely punctured elytra.

\section{Lema wallardiensis, sp. $\mathrm{n}$.}

Testaceous; two small spots on thorax and sides of breast black.

VOL. I. 
Head constricted posteriorly, the vertex with a deep central groove; eyes extremely large, deeply sulcare in front, palpi distinctly thickened; antennæ flavous, extended to the middle of the elytra, the third joint half as long as the fourth, following joints elongate. Thorax strongly convex anteriorly but only moderately widened, slightly longer than broad, the basal sulcus very deep and placed close to the posterior margin, separated from the lateral excavations by a short perpenáicular ridge, the disc impunctate, with a small black spot on each side, close to the anterior margin. Elytra subcylindrical, very slightly depressed below the base at the suture, the punctures on that portion strong but very fine towards the apical part, the interstices convex at the sides behind the middle. Body beneath and the legs testaceous, the sides of the breast with a narrow black longitudinal streak.

Length $6 \mathrm{~mm}$.

$H a b$. Travancore: Wallardi (Coll. Jacoby).

This is another species with thickened palpi, but with thoracic spots and black sides to the breast; the puncturation is finer than in most other similarly coloured species.

60. Lema palonensis, Jac. Ann. Mus. Civ. Genova, xxxii, 1892, p. 873.

Fulvous; terminal joints of antennæ fuscous, apex of tarsal joints obscure piceous.

Head moderately constricted posteriorly with the usual elevations at the vertex, divided by a longitudinal groove, supraocular grooves deep; eyes deeply notched; clypeus sparingly pubescent; antennæ fulvous, extended to rather more than half the length of the body, the sixth to the tenth joints obscure fuscous, pubescent. Thorax subquadrate, moderately constricted at the sides, the basal sulcus rather deep, the surface entirely impunctate. Elytra deeply depressed within the shoulders and below the base, the punctures not very closely placed and much deeper within the depression. Underside clothed with yellow pubescence, the apex of the tarsal joints obscure piceous.

Length $5 \mathrm{~mm}$.

Hab. Burma: Palon.

Smaller than the preceding species; the antennæ with dark terminal joints, the elytral depression deep.

61. Lema subiridea, Jac. Mém. Soc. Ent. Belg. vii, 1900, p. 97.

Beneath bluish-black, above fulvous; elytra with distinct purplish gloss; legs fulvous or black.

Head impunctate, vertex convex but not tuberculate, space behind eyes constricted, the latter triangularly and not deeply notched; clypeus broad and thick, black like the labrum ; antennæ slender, fulvous, apical joint blackish, third and fourth joints equal, 
following joints very elongate. Thorax subquadrate, anterior angles not produced but slightly pointed, basal sulcus deep, lateral constrictions sulciform, surface impunctate. Scutellum fulvous or obscure piceous. Elytra rather depressed, broad at base, with shallow though well-marked depression below latter; punctures moderately strong on basal portion, rather fine towards apex. Body beneath black, legs fulvous.

Var. Antennæ (basal joint excepted) and legs black. Elytra fulvous with apical blue portion.

\section{Length $4 \frac{1}{2} \mathrm{~mm}$.}

Hab. Bombay; Travancore; Nilgiris (Capt. Downing).

Of this species specimeus have lately been obtained by Capt. Downing on the Nilgiris at about $6000 \mathrm{ft}$. elevation; one of these specimens looks at first sight like $L$. chalybeo-notata, Clk., as it has the apex of the elytra metallic blue as in that species; this specimen however differs by its fulvous legs. In spite of these differences I have no doubt that this form and those with black legs all represent the same species, to be distinguished by the purplish iridescence of the elytra. In this respect they all differ from Clark's species and may be further distinguished by the nontuberculate thoracic anterior angles, its deep basal sulcus, and the broader and more depressed elytra. L. fulvo-brunnea, Jac. is a more narrow and subcylindrical species, the head has two strongly raised tubercles and the elytral punctures are more numerous and more closely placed.

62. Lema fulvula, Lacord. Mon. Phytoph. i, 1845, p. 338; Weise, Deut. ent. Zeit. 1892, p. 387.

Yellowish-red; breast and abdomen black; apex of tibiæ and tarsi fuscous.

Head clothed with fine and short pubescence, the vertex nearly flat, with a short and thin central groove; eyes strongly and deeply emarginate. Thorax as long as broad, entirely impunctate, with a basal very distinct transverse sulcus and an anterior more obsolete transverse depression. Elytra with smooth interstices, slightly costate at the apex; tibiæ at the apex and the tarsi more or less fuscous.

Length $4 \frac{1}{2}-5 \mathrm{~mm}$.

$H a b$. Bengal ; Coromandel ; Ceylon; Sumatra ; Nias Island.

Separated from other species of this group by the pubescent head and the colour of the tibiæ and tarsi.

63. Lema lacertosa, Lacord. Mon. Phytoph. i, 1845, p. 339 ; Baly, Trans. Ent. Soc. (3) iv, 1865, p. 11.

Dark rufous; the abdomen marked with black, anterior legs testaceous, the others and the breast black.

Head feebly constricted posteriorly the vertex flat with a fine 
groove ; eyes prominent, not deeply notched. Thorax subquadrate, with a well-marked sulcus, the base obsoletely wrinkled, the other portions impunctate. Elytra without any basal elevation, moderately strongly punctured, the interstices, if examined under a strong lens, finely rugose. Breast and the base of the abdomen as well as the intermediate and posterior legs black, the others fulvous.

Length $5 \mathrm{~mm}$.

$H a b$. Bengal; Malay Peninsula; China.

Distinguished chiefly by the colour of the underside and that of the legs.

\section{Lema rufo-testacea, Clark, App. Cat. Phytoph. 1866, p. 29.}

Testaceous; elongate and parallel. Head impunctate; frontal elevation smooth, moderately raised, divided posteriorly only; antennæ entirely fulrous, the fifth and following joints slender, elongate. Thorax slightly broader than long, the anterior angles rounded; the lateral constrictions are deep, bounded above by a short, perpendicular ridge and join the very deep basal sulcus, the latter with a rather deep fovea at the middle; the surface impunctate or with a few minute punctures. Scutellum smooth. Elytra with a deep humeral sulcus and another short very deep basal depression near the suture that occupies the second to the fourth row of punctures on that portion, the punctures themselves very deep at the base and rather distantly placed, those behind the middle much finer, all the interstices at the apex and the outer two at the sides costate.

Length $5 \mathrm{~mm}$.

Hab. Decean; Malabar : Mahé; Assam : Patkai Mts.; Burma : Momeit.

Allied to $L$. fulvula, Lac. and $L$. lacertosa, Lac., but with more slender antennæ, differently coloured underside, and depressed general shape.

\section{Lema impotens, Lacord. Mon. Phytoph. i, 1845, p. 335.}

Flavo-testaceous; antennæ and legs very pale.

" Head only slightly constricted posteriorly, the vertex smooth, with a short groove posteriorly ; eyes deeply emarginate; antennæ slender, half the length of the body. Thorax moderately constricted, entirely impunctate, with some obsolete transverse ridges behind the basal sulcus. Elytra with a semicircular basal depression which nearly unites with the intrahumeral sulcus and has the usual strong puncturation at the base."

Length 4-5 mm.

Hab. Bengal: Calcutta.

A somewhat doubtfully distinct species, of which the description 
is scarcely detailed enough for certain recognition amongst so many similar forms, but evidently closely allied to, if not identical with, L. rufo-testacea, Clk.

\section{Lema castanea, sp. $\mathrm{n}$.}

Dark fulvous; the labrum, antennæ, legs and the underside black; the anterior femora more or less fulvous beneath.

Head not coustricted, the vertex raised, with the usual central groove posteriorly; eyes deeply notched, supraocular grooves very deep; labrum black; antennæ black, long and slender, the basal two joints more or less fulvous beneath or entirely fulvous, third and fourth joints equal. Thorax moderately constricted, the lateral cavities rather elongate and narrow with the usual ridge above, the basal sulcus deep, placed near the basal margin. Elytra rather depressed, with the shoulders moderately prominent, the basal portion slightly raised, the depression deep and short and as usual more strongly punctured than the rest of the surface, the interstices flat except near the lateral margins. Legs slender and elongate, femora thickened, the anterior pair fulvous beneath.

Length $4 \frac{1}{2} \mathrm{~mm}$.

Hab. Assam : Sadiyn, Patkai Mountains.

Smaller than $L$. lacertosa, Lac., the labrum black, the basal portion of the elytra raised and their puncturation finer, the general colour above dark fulvous brown.

\section{Lema cerea, sp. $n$.}

Pale fulvous; antennæ (basal joint excepted) and tarsi black.

Head not constricted, impunctate, the intraocular space swollen but not divided; eyes triangularly and moderately deeply notched; clypeus and labrum fulvous; antennæ black, long and slender, the basal two joints fulvous, third joint slightly shorter than fourth. Thorax transverse, the anterior portion rather strongly dilated, the angles rounded, the basal sulcus very deep and placed immediately behind the middle, the lateral cavities scarcely wider than the sulcus and bounded above by the usual ridge; the disc impunctate. Elytra with prominent shoulders, the latter impressed with a narrow but deep groove within, which nearly joins the foveolate depression near the suture; the puncturation very fine and not very closely placed behind the middle, the anterior portion as usual much more deeply and strongly punctured; the interstices only costate at the sides near the apex.

Length $5 \mathrm{~mm}$.

Hab. Travancore: Wallardi (Coll. Jacoby); Nilgiris (Coll. Andrewes).

Of somewhat wax-like appearance, with the antennæ, except the basal two joints, and the tarsi black; the elytra with a foveolate, rather sudden depression and finely punctured posterior portion. 
68. Lema antonii, Clavareau, in Wytsman, Genera Insect. part 23, 1904, p. 6.

Lema duvivieri, Jac. Mém. Soc. Ent. Belg. vii, 1900, p. 96.

Obscure fulvous, with slight metallic gloss; antennæ fuscous.

Head impunctate; the eyes small and nearly entire; labrum black; antennæ black, the basal three or four joints fulvous. Thorax with the anterior portion rounded and thickened, basal sulcus rather shallow. Elytra feebly depressed below the base, strongly and elosely punctured, the punctures more widely arranged anteriorly than behind the middle where they are much smaller and very closely placed, the interstices near the apex costate. Legs more or less æneous.

Length 5-5 $\frac{1}{2} \mathrm{~mm}$.

$H a b$. Bengal : Mandar.

Closely allied to $L$. globicollis, Baly, but differs in coloration, in the finely punctured thorax, the feeble basal elytral depression and the much more closely placed rows of pinctures.

\section{Lema longefemorata, sp. $n$.}

Fulvous; labrum, antennæ, apex of tibiæ and tarsi black.

Head strongly convex between the eyes, with a deep posterior groove; clypeus and labrum black; antennæ black, long and slender, the basal joint flavous, third and fourth joints equal, following joints elongate. Thorax strongly constricted at middle, the anterior portion much widened, the angles produced into a very small tubercle, basal sulcus deep; the surface impunctate, fulvous. Scutellum fulvous. Elytra moderately, and gradually depressed below the base, subcylindrical behind the depression, strongly and very closely punctate-striate, the punctures very fine at the apex. Body beneath clothed with very fine yellow pubescence.

Length $4 \frac{1}{2} \mathrm{~mm}$.

Hab. Malabar coast : Mahé (Coll. Jacoby).

Principally distinguished by the colour of the legs and the long posterior femora, which extend quite to the apex of the elytra, also by the black antennæ and clypeus.

\section{Lema rubiginea, $\mathrm{sp.} \mathrm{n}$.}

Fulvous; head, antennæ, thorax and legs black ; elytra reddishfulvous ; sides of breast black.

Subcylindrical. The head not constricted, impunctate, the vertex not raised, a short central groove, its anterior portion ridge-shaped; eyes large, moderately deeply notched; antennæ black, long and slender, the intermediate joints elongate, terminal joints slightly shorter. Thorax longer than broad, the anterior portion somewhat subglobular; lateral constrictions deep, bounded by a ridge above; basal sulcus deep, the space bebind it sometimes 
obscure fulvous; rest of the surface black with a few punctures anteriorly and medially. Scutellum black. Elytra with a small sutural depression below the base, narrowed posteriorly, the punctures fine except within the depression, closely placed; the interstices costate at the apex. Sides of the breast and the legs black, the latter rather slender, rest of the underside fulvous.

Length $3 \mathrm{~mm}$.

Hab. Burma : Ruby Mines (Doherty). Type in Brit. Mus.

One of the smallest members of the genus and well distinguished by its coloration.

\section{Lema tharawaddyensis, sp. $\mathrm{n}$.}

Obscure fulvous.

Supraocular grooves of the head very deep, the intermediate space raised, but undivided by a groove; last joint of palpi thickened; antennæ fulvous, rather short, the third joint orily half the length of the fourth, the following joints elongate. Thorax distinctly longer than broad; the anterior angles very slightly pointed; the lateral constrictions deep; basal sulcus moderately deep, placed at some distance from the margin. Elytra broadly and slightly depressed at the basal portion, the puncturation rather fine, more strongly marked at the base, the interstices from the middle downwards slightly costate. Body beneath and legs fulvous.

Length $6 \mathrm{~mm}$.

Hab. Burma (Coll. H. E. Andrewes).

The thickened last joint of the palpi, a thorax longer than broad, the flattened, scarcely transversely impressed elytra at the base, and the structure of the antennæ will help in the recognition of this unicolorous species.

\section{Section VI.}

\section{Thorax with two transverse sulci. Colour as in preceding section.}

\section{Lema mahéensis, sp. $n$.}

Fulvous; labrum and sides of breast black.

Head impunctate, intraocular space highly raised, divided by a longitudinal groove; eyes very deeply notched; anterior portion of the clypeus and the labrum black; antennæ fulvous, terminal joints rather short and thick. Thorax very slightly broader than long, anteriorly the angles rather acute, in shape of very small tubercles; the disc with an anterior and posterior transverse sulcus, the former more shallow than the latter, but very distinct and extending across the disc, posterior sulcation with a small central fovea; sides of the thorax only moderately constricted, the cavity of the constriction bounded ahove by a short perpendicular rldge. Elytra very feebly depressed below the base, the punctures round and rather closely placed, gradually diminishing in size towards the apex. Beneath and the legs fulvous, sides of the breast black. 
Length $5 \mathrm{~mm}$.

Hab. Malabar: Mahé (Coll. Jacoby).

Differs from $L$. fece in the black clypeus and labrum, the feeble elytral depression and differently coloured underside.

73. Lema rugifrons, Jac. Ann. Mus. Civ. Genova, xxvii, 1889, p. 151.

Pale testaceous; labrum, antennæ (basal and apical joints excepted) and tarsi fuscous.

Head broader than long, not constricted posteriorly; eyes large and deeply notched, intraocular space not raised, with a short central groove, finely rugose and pubescent; labrum black; antennæ with the basal and apical joints fulvous, the others fuscous, third and fourth joints equal. Thorax slightly broader than long, the sides with a rather deep excavation, the latter joined to the basal sulcus which is deep and placed near the base, anterior portion rather strongly widened, with another transverse sulcus at each side; the surface impunctate or with a few fine punctures at middle. Elytra without basal depression, strongly and closely punctate-striate, the punctures very closely placed; extreme apex of the tibiæ and the tarsi more or less fuscous.

\section{Length $4 \mathrm{~mm}$.}

Hab. India : Calcutta ; Burma : Rangoon.

The sculpture and pubescence of the head will at once separate this species from any other placed in this section.

74. Lema feæ, Jac. Ann. Mus. Civ. Genova, xxxii, 1892, p. 873.

Fulvous; the breast and the abdomen (partly), black.

Head not constricted posteriorly; eyes large, deeply notched and margined by deep lateral grooves; lower portion of face testaceous; antenna fulvous, about half the length of the body, the eighth joint slightly concave at its upper edge. Thorax slightly broader than long, moderately constricted at the sides, the disc with an anterior and posterior transverse sulcus, entirely impunctate. Scutellum truncate at the apex. Elytra deeply depressed below the base, deeply punctured within the depression, the posterior portion more finely punctate, the punctures surrounded by a piceous ring; the interstices impunctate, strongly thickened at the apex. Underside black, the last four abdominal segments fulvous.

Length $5 \mathrm{~mm}$.

Hab. Burma: Karennee.

Can be known by the colour of the breast and abdomen, in connection with the deep elytral depression.

75. Lema assamensis, Jac. The Entomologist, Suppl. 1891, p. 31.

Black; last abdominal segments margined with fulvous, surface above rufous.

Head impunctate, with deep lateral grooves, the intermediate 
space undivided; labrum piceous; antennæ long, black. Thorax nearly subquadrate with an anterior and posterior transverse sulcus, the latter not very deep, the disc entirely impunctate. Elytra with a deep subquadrate sutural depression below the base, the punctures not very deep at the base, gradually diminishing posteriorly. Underside black, entirely glabrous, the last abdominal segments margined more or less with dark fulvous. Legs black.

Length 7-8 $\mathrm{mm}$.

Hab. Assam (Coll. Jacoby).

This species, although closely allied to L. hamatomelas, Lac., is larger than the latter and the elytral depression is much deeper; the thorax also is somewhat longer; from other similarly coloured species the two thoracic depressions and the black underside will separate the present insect.

\section{Lema pallide-testacea, Clark, App. Cat. Phytoph. 1866, p. 28.}

Pale testaceons; labrum and antennæ black; legs piceous.

Head sparingly punctured at the vertex, with a deep central groove, lateral sulci deep; labrum black; antennæ extended slightly beyond the base of the elytra, third and fourth joints nearly equal, intermediate joints elongate, terminal joints shorter. Thorax with a few fine punctures at middle, the anterior angles rather pointed, basal sulcus deep, anterior portion with another shallow transverse groove. Elytra parallel, with basal depression, the punctures round and distantly placed.

Length $6 \frac{1}{2}$ nim.

$H a b$. East India.

Described from a single specimen, now in the British Museum. The species is of elongate, parallel shape, pale testaceous, with dark antennæ and legs and a bisulcate thorax. The exact locality of this insect is doubtful as Clark gives only the above habitat, which may mean any part of the East.

\section{Lema clypeata, sp. n.}

Fulvous; the antennæ, parts of the breast and the legs black.

Head not constricted, the intraocular space finely punctured, with a deep central fovea; the emargination of the eyes and the clypeus closely pubescent, the latter bluish-black ; antennæ black, rather short, gradually widened at the terminal joints. Thorax quadrate, the anterior angles with a small tubercle, lateral excavations deep, blackish, furnished with a ridge above, basal sulcus deep, anterior sulcus distinct at the sides only, another narrow transverse groove is placed below the basal sulcus near the basal margin. Scutellum broadly ovate. Elytra subcylindrical, dark fulvous with a slight iridescent gloss, without trace of a basal depression; the punctures large and round, closely placed at the base, where the interstices are also transversely rugose, the posterior portion more finely and more closely punctured, the 
interstices costate at the sides. The sides and anterior edge of the breast and the legs bluish-black, closely covered with fine yellowish pubescence; abdomen fulvous with similar pubescence.

\section{Length $6 \mathrm{~mm}$.}

Hab. Burma: Ruby Mines (Doherty). Type in Brit. Mus.

A very distinct species on account of the pubescence in the emargination of the eyes and on clypeus, the short and subquadrate terminal joints of the antennæ and the absence of an elytral depression.

\section{Lema decolorata, sp. n.}

Fulvous; antennæ (basal joints excepted) and tarsi obscure fuscous; underside black.

Head very finely and rather closely punctured at vertex; the latter with a short longitudinal groove, lower portion clothed with yellow pubescence; eyes deeply notched; antennæ fulvous, rather long and stout, all joints stained with fuscous above, third and fourtl short, equal. Thorax slightly broader than long, anterior portion rather strongly widened, basal sulcus deep, middle of surface with another deep sulcus at sides joining the basal one; middle of dise with several rows of fine punctures. Scutellum finely pubescent. Elytra parallel, subcylindrical, without trace of basal depression, moderately, strongly and very regularly punctate-striate, puncturation gradually finer towards apex, ninth row of punctures not interrupted, first row near suture double on the basal portion. Extreme apex of tibiæ and of the tarsi fuscous. Body beneath clothed with fine yellow pubescence.

Length $4 \frac{1}{2}-5 \mathrm{~mm}$.

Hab. Nilgiris. Type in Coll. H. E. Andrewes.

\section{Section VII.}

Elytra pale; suture blue or black; in one case with additional discoidal stripe or small spots.

Thorax with one or two sulci.

79. Lema suiurella, Baly, A. M. N. H. (3) xvi, 1865, p. 156.

Fulvous; tibiæ and tarsi fuscous; breast and abdomen at base black; antennæ (base excepted) fuscous; elytra with suture narrowly blue.

Thorax less swollen than in $L$. clownesi, irregularly punctured; a longitudinal space down the middle of the disc and the sides in front, more coarsely punctured than the rest of the surface Third joint of the antennæ distinctly longer than the fourth.

Length $4 \mathrm{~min}$.

$H a b$. Bengal.

'Ihe antennæ in this species have their joints rather short, the thoracic sulcus is placed close to the base and the elytral sutural stripe is of equal width and does not extend quite to apex. 
80. Lema downesi, Baly, A. M. N. H. (3) xir, 1865, p. 156.

Lema nigro-suturalis, Clark, App. Cat. Phytoph. 1866, p. 37 ; Weise, Deut. Ent. Zeit. 1903, p. 19.

Pale fulvous; antennæ (the basal joint excepted) and the tarsi fuscous; scutellum black. Elytra with a black sutural band abbreviated before the apex.

Thorax elongate, transversely sulcate at the base, the anterior portion subglobose, smooth, strongly punctured as is also the middle of the disc. Elytra strongly depressed below the base, very deeply punctate-striate, the interstices at the apex costate, the second and eighth interspace united at the apex and swollen.

Length $4 \mathrm{~mm}$.

Hab. Bengal; Bombay : Malabar coast.

Thorax smoother and more swollen than in L. suturella, Baly ; third joint of the antennæ half as long again as the second and equal in length to the fourth.

\section{Lema juvenilis, sp. $n$.}

Fulvous; antennæ black, basal joints fulvous. Elytra with a narrow greenish-black sutural band which does not extend to the apex.

Head with a feeble groove at the vertex; the clypeus and labruı piceous; antennæ extended nearly to the middle of the elytra, basal four joints fulvous, apex of each piceous, following joints entirely dark, third and fourth equal, the others cylindrically. elongate, slightly thickened. Thorax rather transverse, the anterior portion dilated and produced into a point at the angles; the lateral constrictions with a distinct ridge above; basal suleus placed immediately behind the middle, deep, slightly foveolate at its centre. Scutellum fulvous. Elytra with a rather deep though gradual depression below the base, the latter slightly raised, strongly and closely punctate-striate, rest of the surface more finely punctured; a narrow greenish-black sutural stripe, slightly widened posteriorly and not extended to the apex. Body beneath and the legs fulvous, the breast piceous.

Length $+\mathrm{mm}$.

Hab. Malabar coast: Mahé (Coll. Jacoby).

Coloration similar to L. suturella, Baly, but the antennæ much longer, the thorax with pointed anterior angles, its sulcus placed nearly at the middle; the elytra with distinct basal depression.

\section{Lema viridi-suturata, sp. $n$.}

Fulvous; terminal joints of antennæ, breast and abdomen black. Elytra with broad sutural greenish-black band.

Head not constricted posteriorly, impunctate, sparingly pubescent; intraocular space strongly raised but not tuberculate, divided by a fine groove; eyes moderately prominent, triangularly' 
but not deeply notched; antennæ slender, fulvons, with the apex of each joint more or less black or with the terminal joints entirely of that colour. Thorax with the anterior portion rather strongly widened and the angles slightly tuberculate; the sides only moderately constricted, the constriction forms a sulcus, not a cavity ; the disc with two short rows of punctures in the middle, the basal sulcus deep. Scutellum fulvous. Elytra fulvous, with a shallow sutural depression below the base, strongly and closely punctured anteriorly, with a rather broad greenish sutural band of nearly equal width and either extended to the apex or slightly shorter. Beneath black; legs fulvous, the tarsi blackish at the apex of each joint, posterior femora extended to the end of the elytra.

Length $4 \frac{1}{2} \mathrm{~mm}$.

Hab. Malabar coast: Mahé (M. Maindron-Coll.Jacoby).

\section{Lema trifasciata, sp. $n$.}

Fulvous; the antennæ, clypeus and the tarsi black. Elytra flavous, the sutural and lateral margins and a narrow, longitudinal, oblique stripe from the shoulders to below the middle metallic blue.

Head bituberculate at the vertex, with a deep central depression anteriorly, each elevation with another very small black tubercle at the top laterally; clypeus black; eyes deeply notched; the antennæ black, not extended to the middle of the elytra, the basal two joints fulvous, terminal joints elongate. Thorax very moderately constricted at the sides, anterior portion only slightly widened, the angles rounded, lateral excavations rather narrow, with the usual ridge above, basal sulcus deep, followed by a narrow transverse ridge; the surface impunctate, reddish-fulvons. Scutellum fulvous, concave. Elytra subcylindrical, slightly narrowed posteriorly; the punctures round, deep and closely placed at the base; the interstices at the same place transversely wrinkled; a very narrow sutural stripe, another stripe obliquely extended from the shoulders to behind the middle and the lateral margins metallic blue. Beneath and the legs fulvous, the extreme apex of the tibiæ and the tarsi black.

Length $4 \mathrm{~mm}$.

Hab. India: Sylhet (Bowring). Type in Brit. Mus.

There is no other similarly marked species of Indian Lema. The present species may be at once recognized by the discoidal elytral stripe, halfway between the lateral and sutural margins, while the structure of the vertex of the head further characterizes this species of which I have seen two exactly similar specimens.

\section{Lema lycaon, sp. $n$.}

Fulvous; antennæ and underside fuscous. Elytra with sutural margins, a humeral and apical spot greenish-black. 
Head not constricted; the intraocular space finely punctured, with a fine central groove; eyes moderately prominent, feebly notched; antennæ short, the terminal joints gradually subquadrately widened, black, basal four joints more or less fulvous, third and fourth equal, slightly larger than the second. Thorax only slightly widened at the anterior portion, the lateral constrictions rather feeble but bounded by a short ridge above, basal sulcus rather deep, the surface with a few punctures near the anterior angles. Scutellum black. Elytra with a very slight sutural depression below the base, very regularly punctate-striate, the punctures round and closely placed, the interstices flat, the sutural stripe narrow, the humeral and subapical spots short and narrow, the latter placed near the lateral margins. Legs fulvous, the posterior femora with an obscure fuscous spot; breast and abdomen of the latter colour.

Length $4 \mathrm{~mm}$.

Hab. Bombas : Belgaum. Type in Coll. H. E. Andrewes.

Allied to L. ornatipennis, Jac. and L. rufo-ornata, Clk., but the vertex of the head punctured, the puncturation of the elytra finer and the interstices smooth, their pattern also different.

85. Lema bretinghami, Baly, Journ. of Entom. i, 1862, p. 278; Trans. Ent. Soc. (3) iv, 1865, p. 24 (coromandeliana var. sec Baly).

Beneath and the antennæ black; the breast and abdomen fuscous; above obscure fulvous. Elytra with a broad sutural vitta from below the base to the apex, obscure cærulean.

Clypeus and antennæ black, the latter moderately robust, nearly filiform, two-thirds the length of the body, forehead with an oblong fovea. Thorax quadrate, sides deeply constricted at the middle; upper surface smonth, impunctate, impressed with two transverse grooves, the first shallow, interrupted at the middle, the second deeply sulcate. Elytra strongly punctate-striate.

Length $6 \mathrm{~mm}$.

Hab. India.

Baly has, since the above description was published, united this species with $L$. coromandeliana as a variety, but there is no evidence at all that it is conspecific with that species. This species is larger than $L$. coromandeliana as a rule, which latter has always metallic blue eiytra. No intermediate form has come under my observation. The question of identity, however, can only be settled when sufficient material is available.

\section{Section VIII.}

Elytra blue or black with longitudinal fulvous bancls.

86. Lema rufo-ornata, Clark, App. Cat. Phytoph. 1866, p. 30.

Var. Lema sinuato-vittata, Clark, t. c. p. 31; Weise, Deut. ent. Zeit. 1903, p. 19. 
Rufous; elytra black, the basal margins, a lateral band from shoulders to apex, and the apex itself rufous.

The elytra in this species are either black, with metallic green lustre and with a basal and apical fulvous band or spot, or pale fulvous, with a metallic green sutural and marginal band of variable width,or again entirely blackish-green without any lighter markings. Typical rufo-ornata has the elytra black, with a short fulvous mark at the base and the apex of the same colour; the anterior angles of the thorax are rather pointed or subtuberculate, the disc has some double rows of well-marked punctures, and the elytra have a distinct basal depression and are strongly punctured.

Length $4 \mathrm{~mm}$.

$H a b$. Ceylon.

In the variety $L$. sinuato-vittata the body beneath is rufo-fuscous.

\section{Lema ornatipennis, sp. n.}

Obscure flavous; the labrum, antennæ and the abdomen (partly) black. Thorax with two blackish narrow bands; elytra metallic blue, a narrow elongate fulvous band along the middle; tibiæ and tarsi fuscous.

Head not constricted, impunctate; the vertex only slightly convex, scarcely grooved; antennæ black, slender, moderately long, third and fourth joints equal. Thorax with the anterior portion strongly convex and widened, deeply constricted near the base; the lateral cavities deep, bounded above by a ridge; basal sulcus deep; the surface impunctate, with a short piceous stripe at each side. Scutellum broad, subquadrate, obscure fulvous. Elytra rather deeply depressed below the base, impressed with large and deep punctures, closely placed, the interstices more or less rugose near the base and to a less extent posteriorly, the blue colour divided by a longitudinal fulvous stripe from the middle of the base to the apex, this stripe is narrower than either of the blue portions on each side of it and curves slightly outwards posteriorly.

Length $4 \frac{1}{2} \mathrm{~mm}$.

Hab. Nilgiris. Type in Coll. H. E. Andrewes.

Very similar in coloration to L. rufo-ornata, Clk., but evidently distinct, as it differs in the following points :- the antennæ as well as the labrum are entirely black, the thorax has rounded not pointed anterior angles, the disc is impunctate and furnished with two black stripes, the elytral puncturation is much stronger and the fulvous band narrower.

\section{Lema constricto-fasciata, sp. $n$.}

Flavous; head and thorax fulvous, breast black, antennæ fuscous. Elytra with sutural and lateral stripes metallic blue.

Head not raised at the vertex, the latter closely punctured, fulvous, the emargination of the eyes pubescent; antennæ fuscous, the terminal joint fulvous, third and fourth joints short, equal, the succeeding joints more elongate, widened, about twice as long as 
broad. Thorax subquadrate, fulvous, the anterior angles pointed, distinctly but sparingly punctured, the dise with a double row of punctures, the basal sulcus deep. Elytra rather flattened, scarcely perceptibly impressed below the base, regularly and rather strongly punctate-striate, the punctures scarcely smaller on the posterior portion; the suture with a metallic blue band, the sides with a similar band which is greatly constricted below the shoulders, neither of the bands extends to the apex and the lateral bands leave the extreme margins of the ground-colour; the rest of the surface as well as the abdomen flavous. Legs slightly darker; the breast black.

Length $4 \mathrm{mul}$.

$H a \dot{b}$. Northern India. Type in Coll. Jacoby.

This little species cannot be mistaken for $L$. rufo-ornuta, var. sinuato-vittatc, Clk. and I. ornatipennis, Jac., with which it nearly agrees in coloration, as the punctured and not raised vertex of the head, the pointed anterior angles of the thorax, shape of the elytral lateral blue band and structure of the antennæ, which have the joints short and stout instead of slender and elongate, are more than sufficient to differentiate it from them.

\section{Lema difficilis, Jac. P. Z. S. 1887, p. 67 .}

Body beneath and antennæ black; head and thorax fulvous; elytra metallic blne; legs obscure fulvous.

Head impunctate, fulvous ; intraocular space strongly triangularly raised and divided by a longitudinal groove, impressed with some fine punctures; eyes deeply triangularly emarginate; labrum. fulvous; antennæ black, the third joint slightly shorter than the fourth, terminal joints slender and elongate. Thorax subquadrate, the anterior angles prominent, subtuberculate, the basal sulcus deep, lateral constrictions moderately deep, not in shape of a round excavation but gradually uniting with the basal sulcus, not bounded by a perpendicular ridge above; the surface with two rows of fine punctures at the middle and other punctures near the anterior angles. Scutellum black. Elytra dark blue, with a very shallow sutural depression below the base, very deeply and strongly punctured anteriorly, the punctures, as usual, gradually diminishing in size towards the apex, the interstices on that area costate. Underside black, very finely pubescent, the edge of the abdominal segments fulvous. Legs likewise fulvous, the posterior femora stained with æneous at the middle.

Length $4 \mathrm{~mm}$.

Hab. Ceylon (Coll, Jacoby).

Var. Elytra fulvous with blue sutural and lateral bands.

It is quite possible that this species represents only another variety of $L$. rufo-ornata, Clark, in which the underside is dark instead of fulvous. Clark has described his species with black elytral bands; this is incorrect, they are metallic blue as can be seen by an examination of the type in the British Museum. 
90. Lema lateralis, Jac. Ann. Soc. Ent. Belg. xxxvii, 1893, p. 265.

Dark metallic blue; antennæ black, the upper part of the head, the thorax and the abdomen fulvous; elytra metallic blue, the sides with a fulvous longitudinal band.

Head not constricted posteriorly, impunctate, the vertex fulvous, the lower portion and the space surrounding the eyes bluishblack, the latter deeply notched; antennæ black, not extended to half the length of the elytra, the terminal joints gradually widened. Thorax subquadrate, fulvous, sides only moderately constricted in the middle, the basal sulcus deep and placed nearly at the middle, the surface nearly impunctate. Scutellum piceous. Elytra meiallic blue, without basal depression, with deep punctures, the latter gradually diminisbing in size posteriorly, the interstices slightly convex at the apex; the sides with a fulvous band that commerices at the shoulders, is strongly widened at the middle and abbreviated at the apex. Breast and legs bluish-black, abdomen fulvous.

Length $5 \mathrm{~mm}$.

$H a b$. India.

This may be only a variety of $L$. semifulva, Jac., in which the amount of fulvous colour of the elytra is larger and black substituted for blue.

\section{Lema semivittata, Clark, App. Cat. Phytoph. 1866, p. 31.}

Cærulean blue; elytra with marginal bands at middle and apex rufo-flavous; underside rufo-fuscous; legs flavous; autennæ fuscous.

Ely tra parallel and robust; the head rugose anteriorly, transversely foveolate between the eyes, smooth behind the latter. Thorax as long as broad, the anterior angles moderately rounded, the sides deeply constricted, the basal sulcus distinct, the surface sparingly punctured. Elytra cærulean blue, with a short basal fovea, strongly punctured, the interstices convex near the apex; the lateral band constricted between the second and sixth rows below the shoulders, terminates posteriorly between the fourth and fifth rows.

\section{Length $4 \mathrm{~mm}$.}

$H a b$. Northern India.

This species is comparatively easy to discriminate on account of the metallic blue upper surface and the markings of the elytra.

\section{Lema rufo-tibialis, sp. n.}

Greenish-black beneath; head and thorax fulvous; labrum and antennæ black ; elỵtra metallic blue, the base, the sides, tibiæ and tarsi fulvous.

Head not constricted posteriorly, strongly punctured and sparingly pubescent on the vertex, the latter with the usual 
central groove, not tuberculate; eyes deeply notched; clypeus and labrum black; antennæ short and robust, scarcely extended to the base of the elytra, the terminal joints subquadrately widened, third and fourth joints equal. Thorax with a deep lateral constriction, the cavity bounded by an acute ridge above, its lower portion greenish-æneous, anterior angles very slightly tuberculate, basal sulcus deep, middle of the disc rather closely punctured. Scutellum fulrous. Elytra with a short but rather deep basal depression, the punctures very large and closely placed on the basal portion, much finer posteriorly, the suture occupied by a broad metallic blue band that commences below the base and terminates before the apex. Beneath greenish-black, metallic; extreme sides of the abdomen and the tibiæ and tarsi fulvous.

Length $6 \mathrm{~mm}$.

$H a b$. India. Type in Brit. Mus.

This species cannot be considered a variety of either $L$. bretinghami, Baly, or L. lateralis, Jac., on account of the very short and robust antennæ, colour of the legs, besides other slight differences.

\section{Section IX.}

Elytra fulvous with sutural or lateral black bands, or black with fulvous bands.

\section{Lema medio-lineata, sp. $\mathbf{n}$.}

Fulvous; labrum, antennæ, the sides of the breast, the abdomen and the legs partly, black; thorax with a central black band; elytra fulvous, the extreme lateral margins and a broad sutural band black.

Head slightly constricted, fulvous; the vertex strongly punctured and finely pubescent, only slightly raised and not divided; eyes deeply notched; clypeus and labrum black; antennæ long and slender, the terminal joints elongate. Thorax rather broader than long, the anterior angles prominent; the disc with two transverse sulci, the anterior sulcus rather deep, extended across the dise, the posterior sulcus still more strongly marked, the lateral cavities moderately deep, partly black as are the flanks of the thorax; a narrow longitudinal black band is placed at the middle of the disc and extends quite to the base; rest of the surface impunctate. Scutellum black. Elytra distinctly and obliquely depressed below the base, extremely closely and strongly punctured; the interstices everywhere transversely wrinkled. strongly longitudinally costate at the apex. Underside and legs black, middle of breast and base of femora fulvous.

Length $5 \mathrm{~mm}$.

Hab. Burma : Ruby Mines (Doherty). Type in Brit. Mus.

A very distinct species; the puncturation aud sculpture of the elytra and the system of coloration differ from that of any other known Indian Lema.

VOL. I. 


\section{Lema spoliata, sp. $\mathrm{n}$.}

Fulvous; labrum, antennæ, underside and the legs partly black.

Head not constricted, convex at base ; intraocular space triangularly raised, undivided, smooth ; labrum black ; antennæ black, scarcely extended to middle of elytra, basal two joints fulvous beneath, fifth and following joints very elongate. Thorax subquadrate, lateral constriction deeply sulciform, continued to basal sulcus, anterior angles rather rounded; the surface entirely impunctate, reddish-fulvous. Scutellum black, rather broadly subquadrate. Elytra with a deep foveolate depression below the base, the punctures strong within the depression, fine on the rest of the surface and nearly obsolete behind the middle; the disc crossed by a broad black longitudinal band, rather suddenly narrowed at the base, the sides fulvous, this portion gradually narrowed towards the apex. Beneath and the legs black, the anterior femora fulrous at the apex.

\section{Length $5 \mathrm{~mm}$.}

Hab. Assam : Patkai Mts. (Doherty). Type in Brit. Mus.

Distinguished by the colour of the antennæ and their structure, also by the thoracic constriction which does not form a cavity but only a narrow sulcus.

\section{Lema ornaticollis, sp. n.}

Testaceous; antennæ and underside partly blackish. Thorax with a lateral stripe and two elongate spots on disc black. Elytra with broad sutural and marginal longitudinal bands greenishblack. Legs marked with blackish bands.

Head impunctate, testaceous, strongly constricted posteriorly ; the neck with a black stripe at sides; supraocular grooves very deep; eyes deeply notched; antennæ black, long and slender, basal joint more or less pale, third and fourth equal, terminal joints elongate. Thorax not longer than broad, anterior angles rather blunt, basal sulcus deep, placed at some distance from basal margin; disc with a few fine punctures anteriorly; sides with a broad black stripe, two shorter stripes placed close together near middle anteriorly, sometimes extended downwards as far as the sulcus. Scutellum flavous or piceous. Elytra somewhat broadly flattened anteriorly with shallow depression below base at suture, strongly and closely pinctate-striate, punctures finer at apex and there placed in striæ with narrowly costate interstices; sutural band slightly constricted at middie, extended to apex, lateral bands widened at middle, not extended to apex. Femora above with a black stripe; outer edga of tibiæ. tarsi and abdomen more or less black.

Length $4 \mathrm{~mm}$.

$H a b$. Nilgiris (H. E. Andrewes).

Easily recognized by the markings of the head, thorax and elytra. 


\section{Lema obscurifrons, sp. n.}

Head and thorax flavous; the labrum, intraocular space and three longitudinal bands on the thorax greenish-black. Elytra metallic dark green, extreme apex testaceous; antennæ black; legs testaceous with dark stripes.

Head impunctate, vertex strongly constricted, neck with a black stripe on the sides, base and apex of clypeus and the labrum greenish-black; antennæ with basal joint flavous beneath, third and fourth equal, terminal joints slightly thickened, last four equal, about twice as long as broad. Thorax subquadrate, moderately constricted at sides; dise with some fine punctures arranged in rows on the niddle, basal sulcus deep, anterior portion with another more shallow sulcus, more distinct on the sides; the sides with a broad blackish band, middle of dise with another elongate posteriorly pointed streak that extends to the basal sulcus. Scutellum black. Elytra gradually narrowed posteriorly, distinctly depressed, below base strongly punctate-striate; punctures closely placed, finer at apex, the latter with a narrow subtriangular flavous spot. Femora with black streak above; tarsi, sides of breast and abdomen greenish-fuscous.

Length $4 \mathrm{~mm}$.

Hab. Nilgiris (Andrewes). Type in Coll. H. E. Andrewes.

Not unlike $L$. ornaticollis, Jac., but the thorax has two sulci and one central streak, not two; elytra, apex excepted, entirely green.

97. Lema semifulva, Jac. Ann. Mus. Civ. Genova, xxrii, 1889, p. 152.

Fulvous; antennæ, labrum, breast and legs black. Elytra with broad longitudinal black band on dise, sides narrowly fulvous.

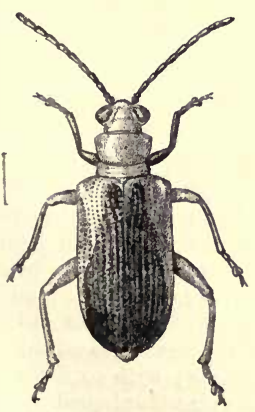

Fig. 6. - Lema semifulva.

Head impunctate, the intraocular space swollen, with a central fovea; eyes deeply notched; labrum black; antennæ black, two-thirds the lengtli of the body, third and fourth joints equal. Thorax broader than long but slightly constricted at the middle; the surface impunctate, with the basal sulcus deep and another more shallow transverse groove at the sides before the middle. Elytra deeply punctate-striate, interstices costate from middle to apex.

Length $5 \mathrm{~mm}$.

Hab. Burma : Bhamo.

Differs from $L$. spoliata in the black underside, black antennæ, anterior thoracic depression and costate elytral interstices. 


\section{Lema occipitalis, sp. $n$.}

Fulvous; the sides and anterior portion of the head and the antennæ black; elytra black, the disc with a regular flavous band from base to apex; the breast, knees, the tibia and tarsi black.

Head: the intraocular space slightly convex and sparingly punctured, with a small central fovea, the space in front of the eyes and the entire anterior portion black; antennæ black, rather long and slender, the basal joint obscure fulvous, terminal joints slender. Thorax with the anterior portion strongly convex and rather widened, the angles rounded, the lateral cavities sulciform, connected with the very deep basal sulcus, the surface entirely impunctate. Scutellum black. Elytra with the basal portion not deeply but distinctly depressed, the punctures at that place deep and very closely placed, with the interstices transversely rugose; a sutural and a lateral band black, of equal width, but the lateral one slightly widened at the middle; between these bands is a flavous vitta of nearly similar width. The breast, the apex of the femora and the tibiæ and tarsi black.

Length $4 \frac{1}{2} \mathrm{~mm}$.

$H a b$. Assam : Sadiya (Doherty). Type in Brit. Mus.

Coloration similar to that of L. mufo-ornata, var. sinuato-vittata, Clk., but the space round the eyes is black, the elytral bands are likewise black not blue, and the legs differently coloured.

\section{SECTION $\mathrm{X}$.}

Above fulvous or flavous, elytra with black or blue spots or markings.

99. Lema histrio, Clark, App. Cat. Phytoph. 1866, p. 29.

Lema jansoni, Baly, Journ. Ent. 1861, p. 277.

Fulvous; marked variously with black spots. Body beneath

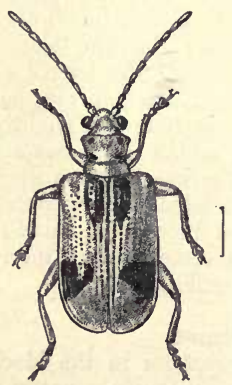

Fig. 7.-Lema histrio. and legs flavous; thorax often with 4 spots; elytra with a humeral and a post-median round spot.

Head impunctate, labrum black, posterior portion of vertex strongly constricted; frontal tubercles strongly raised, scarcely divided; antennæ fulrous, scarcely extended to middle of elytra, second to fifth joints gradually lengthened, terminal joints twice as long as broad. Thorax rather widened anteriorly, wit'̀ pointed angles, sides moderately constricted in the middle, basal sulcus deep, surface impunctate; with or without four small black spots placed subquadrately, two at each side. Elytra with shallow depression below base at suture, very strongly 
punctate-striate anteriorly within the depression, more finely so at sides and apex, base with a semicircular black spot at shoulders that does not quite extend up to suture, a round spot below the middle.

Var. a. Thorax with 4 black spots.

Var. $b$. Elytra nearly black, with cross-like fulvous pattern.

Var. c. Elytra with 5 spots, one below scutellum, two near the shoulders, and two below middle. Thorax with 2 spots.

Var. $d$. Thorax with 4 spots, elytra with one large sutural $\mathbf{s p o}^{t}$ (L. jansoni, Baly).

Var. e. Elytra black, apex rutous, thorax partly black.

Var. $f$. Thorax as in var. $a$; elytra entirely black.

Length $4 \frac{1}{2}-7 \mathrm{~mm}$.

$H a b$. Eastern India; Siam.

100. Lema crassipalpis, Duviv. Ann. Soc. Ent. Belg. xxxv, Bull. 1891, p. xxvi.

Testaceous; labrum, four spots on the thorax, meso- and metasternum and the base of the first abdominal segment, black; elytra flavous, with two large black markings.

Head smooth, strongly constricted posteriorly; eyes prominent, deeply emarginate; palpi incrassate; vertex with a fovea ; antennæ testaceous, rather robust, filiform, extended to the middle of the elytra. Thorax subquadrate, strongly constricted in the middle, transversely sulcate near the base, anterior angles pointed, the anterior and posterior margins with a fine border; the surface with some very fine punctures and others near the anterior angles; two black spots on each side, one near the anterior augles, the other near the constriction. Elytra testaceous, with a transverse depression below the base, strongly punctate-striate anteriorly, the interstices near the apex also very finely punctured and costate, a large triangular patch occupies the anterior twofifths, another patch almost covers the posterior half without extending to eitler margin, this is prolonged laterally into a narrow stripe and extends upwards as far as the shoulders. Beneath clothed with short grey pubescence.

Length $6 \frac{1}{2} \mathrm{~mm}$.

$H a b$. Western India: Konbir.

Allied to $L$. histrio, Clark, but probably distinct on account of the different sculpture of thorax and elytra.

101. Lema cardoni, Juc. Ann. Soc. Ent. Belg. xli, 1897, p. 420.

Fulvous; the labrum black; elytra with a subquadrate large spot on the shoulders and a rounded spot near the apex, metallic blue.

Head with a few punctures on the vertex, the supraocular grooves and the clypeus furnished with golden-yellow hairs; labrum 
black; antennæ robust, fulvous (the last two joints in the type and only specimen arailable broken off), fourth and fifth joints elongate. Thorax subquadrate, the sides deeply constricted in the middle; basal sulcus very deep; the dise with a few minute punctures in the middle and anteriorly. Scntellum fulvous. Elytra very feebly depressed below the base, deeply punctatestriate; the punctures round and large, closely placed near the suture, more distantly so at the sides; a large subquadrate blue spot occupies the shoulders and extends to the lateral but not to the sutural margins. Underside and legs fulvous, clothed with golden pubescence.

\section{Length 5-6 $\mathrm{mm}$.}

$H a b$. Bengal: Mandar.

Also allied to $L$. histrio, Clark, but the elytra differently marked and the spots blue not black, the puncturation more closely placed and the underside clothed with yellow pubescence.

\section{Lema burmaensis, sp. $\mathrm{n}$.}

Clypeus, antennæ, legs and the underside black; above fulrous; elytra with a small black spot before and another behind the middle.

Head strongly raised between the eyes, the elevation with a central rather deep groove posteriorly extended as far as the middle, finely pubescent, area behind the eyes not constricted ; eyes rather deeply emarginate, the space within sparingly pubescent; antenna and clypeus black, third joint of the antennæ rather smaller than the fourth, the following joints elongate. Thorax not longer than broad, moderately constricted, the anterior angles with a very small tubercle, the disc impunctate, basal sulcus very deep, placed rather close to the posterior margin. Elytra with a short but rather deep depression below the base, the punctures moderately strong at the latter place, much finer posteriorly; a black spot placed within the depression and another one behind the middle, slightly more outwards than the first spot. Body beneath and legs black, clothed with fine grey pubescence.

\section{Length $5 \mathrm{~mm}$.}

Hab. Burma : Tharrawaddy. Type in Coll. H. E. Andrewes.

Of this distinctly marked species I have seen only a single specimen; the black antennæ, legs, and underside separate it at once from $L$. histrio.

\section{Lema bimaculata, Baly, Ent. Month. Mag. 1888, p. 85 .}

Fulvous; antennæ (the base excepted) and an elytral spot behind the middle black.

Head strongly constricted behind the eyes, broader than long; eyes very large, deeply and acutely notched, lateral sulci very deep, intraocular space not divided, impunctate; palpi robust; antennæ 
with the basal three or four joints fulvous, the rest black. Thorax with the disc rather strongly swollen, the sides with a deep cavity bounded above by a short perpendicular ridge, basal sulcus comparatively shallow and broad, the surface entirely impunctate. Elytra depressed below the base, strongly punctured anteriorly only, rest of the surface tinely punctate, each elytron with a black, transversely shaped spot behind the middle. Beneath and the legs fulvous.

\section{Length $6 \mathrm{~mm}$.}

Hab. Andaman Islands.

The above detailed description is founded on a specimen in my collection named by Baly himself; the species is clearly differentiated by the two black elytral spots and colour of the antennæ.

\section{Lema quadripunctata, Oliv. Ent. vi, 1795 , p. 731 , pl. i, fir. 5 Lacord. Mon. Phytoph, i, 1845, p. 318.}

Fulvous; eighth and ninth joints of antennæ and tarsi black. Elytra each with two black spots; breast sometimes black.

Head strongly bituberculate between the eyes; antennæ robust, fulvous, the eighth and ninth joints black, third joint shorter than the fourth, the following joints subquadrately elongate. Thorax with a very small tubercle at the anterior angles, the lateral constriction deep, bonnded by a ridge above, the surface impunctate, the basal sulcus placed directly behind the middle, with a fovea at the middle. Elytra with very deep and closely placed punctures anteriorly, the interstices at the base more or less strongly transversely rugose, costate at the apex, a transversely shaped spot at the middle and another at some distance from the apex and below the first spot, black. Sides of the breast more or less black. Posterior femora strongly incrassate in the male, less so in the female. Underside clothed with short yellow pubescence.

$\nabla$ ar. Antennæ and femora black.

Length 7-10 mm.

Hab. Ceylon; Burına; Andaman Islands; Sumatra; Java.

This is evidently a very variable species, if indeed all those from different localities really represent the same insect; the species may be recognized by the four elytral black spots and usually by its large size. The latter is however, very variable. From Ceylon I have seen specimens with entirely black antennæ and breast; these have the elytral spots much larger and the posterior femora very strongly incrassate in the male, in size they are larger than any of the other specimens from India or Sumatra, and it is quite possible that these Ceylon forms represent an allied species. 
105. Lema femorata, Gutrin, Icon. Regne Anim., Ins. 1844, p. 259 ; Lacord. Mon. Phytoph. i, 1845, p. 316 ; Jacoby, Ann. Mus. Civ. Genova, xxvii, 1889, p. 150.

Fulvous; eighth and uinth joints of the antennæ black;

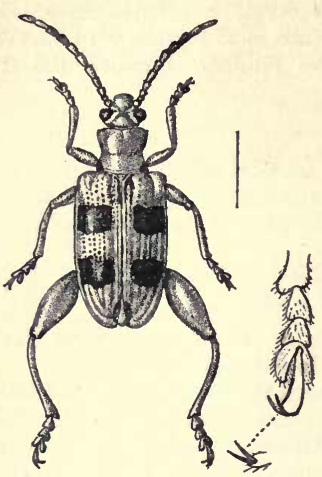

Fig. 8.-Lema femorata. thorax with black spot at sides. Elytra with sutural and apical spots, a transverse band before and another behind the middle, black.

Closely allied to the preceding species but can be distinguished by the black spot at the base of the thorax and on the sides and by the extra sutural basal and small apical spot on the elytra; the antennæ are longer and more slender, and the posterior femora extend beyond the apex of the elytra; the thorax in addition to the basal sulcus has also another transverse more or less distinct groove placed near the anterior margin.

Length 8-9 min.

Hab. Assam; Sumatra; Borneo.

\section{Lema maindroni, sp. n.}

Fulvous; antennæ, extreme apex of tibiæ and the tarsi black. Elytra with a spot near scutellum and a short elongate band near apex bluish.

Head not constricted posteriorly, fulvous, strongly bituberculate

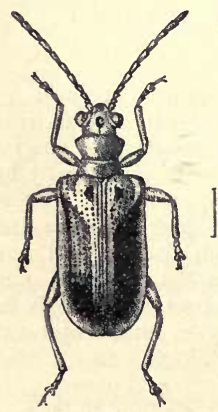

Fig. 9.

Lema maindroni. between the eyes, the elerations divided posteriorly only; eyes moderate, deeply notched; clypeus and labrum black; antennæ slender at the base, gradually but slightly thickened towards the apex, basal four joints fulvous, the third and fourth black above, the others entirely of that colour. Thorax subquadrate, the anterior portion only moderately widened, the constriction not deep and sulciform but bounded above by a short perpendicular ridge, the disc not perceptibly punctured. Elytra fulvous with a very short and feeble basal depression, closely and strongly punctate-striate, the punctures round; a round spot near the scutellum and a rather broad stripe from the middle to near the apex, between the third and sixth row of punctures (sometimes in shape of an elongate spot), metallic bluish. Beneath

and the legs fulvous. 
Length $4 \frac{1}{2}-5 \mathrm{~mm}$.

Hab. Malabar: Mahé (M. Maindron); Nilgiris (H. L. Andrewes).

This cannot be a variety of $L$. histrio as the thorax in the latter insect has the sulcus placed close to the base; in the present insect the sulcus is deep and directly behind the middle, the elytral markings also are different.

\section{Section XI.}

Fulvous or flavous; elytra with apical portion and sometimes with aditional spots blue or black.

107. Lema signatipennis, Jac. Mém. Soc. Ent. Belg. vii, 1900, p. 95 .

Fulvous; antennæ and uuderside partly black. Elytra with basal spot and posterior half metallic blue.

Head impunctate, with two strongly raised tubercles; clypeus and labrum black; antennæe black, the basal joint stained with fulvous. Thorax subquadrate, the sides very moderately constricted, anterior angles lounded, basal sulcus very deep; the surface impunctate, fulrous. Elytra with a distinct basal depression, closely and strongly punctate-striate, the interstices slightly costate at the sides, the base with a triangular metallic blue patch that surrounds the scutellum, the posterior portion nearly to the middle likewise metallic blue, this colour does not quite extend to the lateral margius and has its anterior edge deeply notched and convex. Bbreast and legs black, abdonien aud sides of the breast fulvous.

Var. Legs fulvous.

Length $5 \mathrm{~mm}$.

Hab. Bengal: Maudar, Burway.

Closely allied to L. histrio, Clk., L. chalybeo-notata, Clk., and L. gestroi, Jac., but with differently shaped thorax, the elytral markings blue instead of black aud different in shape.

108. Lema dimidiatipennis, Jac. Ann. Mus. C'iv. Genova, xxxii, 1892, p. 871 .

Fulvous; labrum black. Elytra with anterior half fulvous, pusterior half black.

Head impunctate, the intraocular space triangularly raised, the lateral grooves deep; ejes triangularly notched; labrum black; antennæ slender, filiform, the second to the fifth joints gradually lengthened. Thorax scarcely longer than broad, deeply coustricted at the sides, the constriction bounded above by a distinct ridge, basal sulcus deep, the surface with a few minute punctures on the disc and anteriorly. Scutellum fulvous. Elytra with a conspicuous depression below the base, deeply punctured anteriorly, more finely and gradually towards the apex, anterior half fulvous, the 
posterior half black or violaceous, the anterior edge of the latter colour convex. Underside and legs fulvous.

Length $7 \mathrm{~mm}$.

Hab. Burma : Palon.

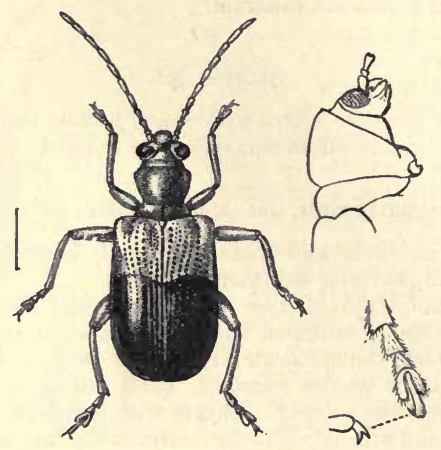

Fig. 10.-Lema dimidiatipennis.

The species resembles in coloration $L$. papuana, Lac., but besides the quite different elytral sculpture the extent of the dark coloured portion of the elytra is much less than in that insect.

109. Lema præusta, Fab. (Crioceris) Ent. Syst. i, pt. 2, 1792, p. 8; Lacord. Mon. Phytoph. i, 1845, p. 340.

Dark fulvous; labrum black; elytra with the apical third dark blue.

Head slightly constricted posteriorly, the vertex smooth, raised into two tubercles; labrum black; antennæ filiform, slightly shorter than half the length of the body. Thorax slightly shorter than broad, entirely impunctate, the basal sulcus deep, the anterior sulcus only feebly marked. Elytra slightly convex, the shoulders prominent, the puncturation strong at the base, finer posteriorly, the apical third metallic blue, this colour rounded at the sides and emarginate anteriorly near the suture. Legs rather long.

Length $5 \mathrm{~mm}$.

$H a b$. Coromandel.

It is quite possible that this and the following species may be only varieties of $L$. coromandeliana, as they seem to differ sulely in coloration. 
110. Lema terminata, Lacord. Mon. Phytoph. i, 1845, p. 341.

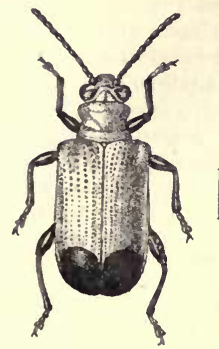

Fig. 11.

Dark reddish; the head anteriorly, antennæ, the sides of the breast and the legs black; elytra with the apical third blue.

I am doubtful whether this can be separated from the preceding species. The differences pointed out by Lacordaire between it and $L$. prousta are so slight that taking into consideration the similarity of the locality of both, it is more than probable that the present insect is only a variety of the other, a variety in which the sides of the breast as well as the legs are black; all the other marks of distinction quoted are evidently only individual.

Length $5 \mathrm{~mm}$.

$H a b$. Coromandel.

Lema terminata.

111. Lema chalybeo-notata, Clark, App. Cat. Phytoph. 1866, p. 37 ; Weise, Deut. ent. Zeit. 1903, p. 18.

Fulvous or rufous; antennæ fuscous, base rufous; elytra with the greater part of their apical portions dark blue; legs flavous, tibiæ and tarsi fuscous.

Head impunctate; antennæ long, first two joints fulvous. Thorax with anterior angles prominent and tuberculate, moderately constricted at sides, basal sulcus shallow, extended to the sides, surface impunctate. Elytra jarallel, punctures large at base, gradually smaller towards apex, somewhat elongate, interstices convex at apex.

Length $4 \mathrm{~mm}$.

$H a b$. Ceylon.

Similar in coloration to L.terminata, Lac., and L. prousta, Lac., but smaller, thorax with single sulcus only, frontal elevations smooth, tibiæ at outer edge and tarsi piceous. The blue portion of the elytra varies greatly in extent and sometimes nearly reaches the base, leaving at that place only a small fulvous spot and similarly coloured lateral margins (var. ingloria, Weise).

The above description is drawn from Clark's type in the Brit. Mus., and differs somewhat fiom that of the author, which is misleading.

\section{Lema admirabilis, sp. $n$.}

Black; thorax with purplish gloss; elytra fulvous, an elongate sutural spot at the base and the posterior third metallic blue.

Head impunctate, black; intraocular space not divided or tuberculate, the extreme base with two obscure fulvous spots; eyes very large, not deeply notched, the space in front of them rugose, deeply sulcate at the sides; antennæ black, extended to 
below the niddle of the elytra, the third and following joints very elongate and cylindrical. Thorax rather broader than long, the anterior portion much widened, with a very small tubercle at the anterior angles; the disc strongly convex with rows of very fine punctures at the middle, sometimes obsolete; basal sulcus very deep, the space below it with another more shallow transverse groove. Scutellum black. Elytra very obsoletely depressed below the base, deeply and closely punctate-striate, the interstices strongly costate near the apex, the shoulders smooth; a pear-shaped elongate metallic-blue spot is placed below the scutellum and extends to the middle of the suture, while a similarly coloured band occupies the entire apex of the posterior third portion. Underside and legs black.

\section{Length $6 \mathrm{~mm}$.}

Hab. Malabar Coast; Nilgiris.

Of almost similar elytral coloration and pattern to L. signatipennis, Jac., but larger, the head and thorax black, not fulvous, and the posterior elytral blue portion of a different shape.

\section{Lema arrogans, sp. $n$.}

Black; thorax purplish; elytra fulvous, apex purplish-blue.

Head black, strongly constricted posteriorly, vertex with two transverse flavous spots; eyes very large and prominent, feebly notched ; antennæ very long and slender, third joint shorter than fourth. Thorax not longer than broad, strongly constricted at sides, anterior angles slightly pointed, basal sulcus very deep, not widened into a cavity at sides, the basal portion with some obscure transverse ridges black, anterior portion purplish, a few fine punctures on middle of disc. Elytra fulvous with slight purplish gloss, broad, rather flat, shoulders prominent; basal portion with distinct depression, strongly and closely punctate-striate, apical portion to the extent of one-fourth metallic purplish-blue, anterior edge of this colour irregularly dentate. Legs long and slender, black, and like the underside finely pubescent.

Length $5 \frac{1}{2} \mathrm{~mm}$.

$H a b$. Nilgiris (Andrewes). Type in Coll. H. E. Andrewes.

Elytra coloured like those of $L$. preusta, Lac., but the thorax is purplish, with a single sulcus only. Smaller than L. admirabilis, Jac., and without the sutural purplish spot, apex less broadly of that colour.

\section{Lema momeitensis, sp. $\mathrm{n}$.}

Fulvous; the labrum black; elytra fulvous, the posterior balf from the middle metallic blue.

Head not constricted posteriorly, impunctate; the vertex with two highly raised tubercles, deeply divided posteriorly; eyes prominent, feebly notched; labrum black; antennæ long and slender, fulvous, the third joint slightly shorter than the fourth, 
the following joints not thickened. Thorax subquadrate, the anterior portion strongly widened, the anterior angles subtuberculate; the disc with a few minute punctures when seen under a very strong lens, deeply transversely sulcate, lateral excavation deep, bounded by an acute ridge above. Elytra fulvous, with a small depression near the suture below the base, strongly and closely punctate-striate, the interstices costate from the middle downwards; the blue portion commences slightly before the middle and extends to the apex. Beneath and the legs fulvous, the latter rather slender, the underside clothed with very short pubescence.

Length $6 \mathrm{~mm}$.

Hab. Burma: Momeit (Doherty). Type in Brit. Mus.

Can be distinguished from L. proeusta by the want of the anterior thoracic groove and the much larger extent of the blue colour of the elytra, the colours on the elytra are sharply divided. The fulvous head and other details separate the species from L. admirabilis.

\section{SECTION XII.}

Thorax black or bluish; elytra metallic blue.

\section{Lema binghami, sp. $n$.}

Black; head with a fulvous band at vertex; elytra metallic blue.

Head black; intraocular space strongly raised, undivided; immediately behind is a narrow obscure fulvous transverse band; eyes subtriangularly but feebly notched, very large and promineut; antennæ black, extended beyond the middle of the elytra, very slender, the third joint scarcely shorter than the fourth, following joints very elongate. Thorax with the anterior angles rounded but with a very small tubercle at the apex, the basal sulcus very deep, placed at some distance from the base, the surface nearly black with bluish gloss, the disc with two short-rows of very fine punctures. Scutellum black. Elytra with the shoulders rather prominent, depressed, but gradually so below the base, gradually narrowed towards the apex, the puncturation rather strong and of nearly equal depth and size. Beneath and the legs black.

Length $5 \frac{1}{2} \mathrm{~mm}$.

Hab. Malabar coast: Mahé (Coll. Jacoby).

This is another nearly unicolorous species, which is separable from allied forms by the undivided vertex of the head and its fulvous band, the long antennæ and the rather feebly inpressed elytra, the puncturation of which is rather stronger and more continued than in most of the allied species.

116. Lema fulvofrontalis, Jac. Mém. Soc. Ent. Belg. vii, 1900, p. 97.

Black; vertex of the head fulvous; elytra dark metallic blue.

Head impunctate, black, the vertex with two strongly raised fulvous elevations which unite in front; eyes deeply notched; 
labrum black; antennæ black, long and slender. Thorax slightly broader than long, the sides only moderately constricted; basal sulcus very deep, the space behind it with another obsolete transverse wrinkle; the surface impunctate, very shining, black. Elytra rather flat, with a short but deep sutural depression below the base, strongly and closely punctate-striate anteriorly, the punctures somewhat elongate in the middle, much finer towards the apex, the interstices costate at the latter place and at the sides. Beneath black, clothed with fine silvery pubescence.

Length $5 \mathrm{~mm}$.

Hab. India (Coll. Jacoby).

A small species which may be known by the fulvous tubercles of the head, the deep elytral depressiou and the black underside and legs.

117. Lema fulvimana, Jac. Mém. Soc. Ent. Belg. vii, 1900, p. 98.

Black; vertex of head and legs fulvous; thorax and elytra blackish-blue.

Closely allied to L. fulvofrontalis but differs in the following details :-The vertex, although of fulvous colour is not raised into a divided elevation but is flat and the black colour of the lower portion extends upwards between the eyes, the latter are very feebly notehed; the thorax is dark blue, not black, and has some fine punctures on the middle and anteriorly; the elytral depression is less deep and more obsoletely limited; the legs are fulvous and the tarsi fuscous.

Length $6 \mathrm{~mm}$.

Hab. Bengal (Coll. Jacoby).

\section{SeCtion XIII.}

Thorax and elytra metallic blue or greenish; species rather large.

\section{Lema rufofrontalis, sp. $\mathrm{n}$.}

Body beneath, the head, antennæ and thorax black with a bluish tint; elytra metallic greenish-blue; head with two high rufous tubercles.

Amongst the unicolorous metallic species the present insect is principally distinguished by the subeylindrical elytra without basal depression, the puncturation below the base being more marked and very deep, all the punctures are closely set and as usual get finer posteriorly. The head is entirely black and has two highly raised rufous tubercles between the eyes; the antennæ are rather short and black with only moderately elongate joints, the third distinctly shorter than the fourth. The thorax is very moderately constricted and has the anterior angles produced into a small point, the basal sulcus is deep and placed at some distance from the nargin, the surface is black and impunctate. The puncturation at the base of the elytra is rather irregular near the suture with the interstices obsoletely rugose.

Length $6 \mathrm{~mm}$.

$H a b$. India. 
I have a single specimen without detailed locality. The species is much larger than $L$. nilgiriensis and the elytra have no basal depression.

\section{Lema psyche, Baly, A. M. N. H. (3) xvi, 1865, p. 157.}

Metallic blue; antennæ and legs black; elytra purplish.

Thorax subtransverse, eylindrical, moderately constricted, the disc finely punctured. Elytra robust, transversely depressed below the base, strongly punctate-striate, the interstices costate near the apex. Antennæ slender, the third and fourth joints equal.

Length $6 \mathrm{~mm}$.

$H a b$. Northern India.

The head is coarsely punctured on the vertex ; antennæ twothirds the length of the body; the transverse elytral depression shallow, obsoletely wrinkled; the elytra broad and robust. These characters and the sculpture of the liead together with the coloration distinguish this species from any other.

\section{Lema paradoxa, Jac. Ann. Soc. Ent. Belg. xlviii, 1904, p. 380.}

Beneath bluish-black, above metallic green or blue.

Head deeply longitudinally sulcate on the vertex, supraocular grooves very deep; clypeus with a row of fine punctures; labrum similarly punctured; antennæ black, not extended to middle of elytra, second to fourth joints gradually lengthened, terminal joints rather robust. Thorax subquadrate, anterior angles distinctly tuberculate, basal sulcus deep, another nearly equally deep sulcus before middle, a few fine punctures in front of latter, rest of disc impunctate. Elytra with deep sutural depression below base, another depression near apex at junction of fourth and eighth row of punctures, last two interstices at sides costate. Legs very slender, bluish.

Length $7 \mathrm{~mm}$.

$H a b$. Southern India: Pondicherry ; Nilgiris.

Allied to L. cyanella, Fab. from Europe, but much larger, thorax more distinctly tuberculate at the anterior angles and deeply bisulcate; elytral interstices not rugose.

"Found on herbage from May till July and in November and December." (Andrewes.)

\section{Lema gahani, Jac. The Entomoloyist, xxxii, 1899, p. 67.}

Dark metallic blue; antenuæ, tibiæ and tarsi black.

Head impunctate, the base with a small fulvous spot, intraocular space strongly convex, divided by a short groove; eyes very deeply notched; clypeus impunctate; antennæ short, black, the third joint twice as long as the second but shorter than the fourth, fifth and following joints more elongate, stout and strongly thickened. Thorax longer than brosd, with rounded anterior 
angles, basal sulcus deep and sinuate, the disc extremely minutely but remotely punctured. Scutellum black. Elytra parallel, strongly punctured on the anterior portion, from the middle downwards their places occupied by striæ.

Length $6 \mathrm{~mm}$.

Hab. Assam : Khási Hills. Type in Coll. Jacoby.

Of uniform metallic blue colour and distinguished by the proportionately elongate thorax and the peculiar sculpture of the elytra.

122. Lema cyanea, Fabr: Suppl. Ent. Syst. 1798, p. 92; Lacord. Mon. Phytoph. i, 1845, p. 349; Weise, Deut. ent. Zeit. 1903, p. 22.

Lema wallacei, Jac. Notes Leyd. Mus. 1884, p. 10; Ann. Mus. Civ. Genova, xxvii, 1889, p. 151.

Metallic dark blue; antennæ and legs black.

Short and rather broad. Head with a few fine punctures, vertex only slightly convex, with short central groove; antennæ slender, third and following joints elongate, the third joint half the length of the fourth. Thorax somewhat broader than long, deeply constricted near base, anterior angles nontuberculate; surface with deep transverse sulcus near base, impunctate. Scutellum rather broad. Elytra with deep transverse oblique depression across suture below base, the latter broad, with prominent shoulders; surface strongly and closely punctate-striate, punctures rery closely placed, interstices slightly transversely wrinkled. Underside clothed with short silvery pubescence.

Length 4-5 mm.

Hab. Coromandel ; Nilgiris ; Assam ; Burma ; Siam ; Sumatra.

The Burmese specimens formerly named by me wallacei do not really seem to differ from Fabricius' species under which wallacei must stand as a synonym.

123. Lema westwoodi, Jac. The Entomologist, xxxii, 1899, p. 68; Weise, Deut. ent. Zeit. 1903, p. 22.

Metallic dark blue; abdomen flavous.

Head not constricted posteriorly, the neck rather swollen, intraocular space not tuberculiform, nearly plane, with a short central groove, vertex finely punctured; eyes large, subquadrately emarginate, the surrounding space rugose; antennæ black, long and slender, third and fourth joints subequal*. Thorax not longer than broad, sides nearly straight when viewed from above, widened towards the apex, the anterior angles very minutely tuberculiform; the disc obsoletely sulcate near the base, the latter finely rugosely punctured, the middle of the disc with a few fine punctures and others anteriorly. Scutellum broader than long.

* In the original description these juints are erroneously described as equal. 
Elytra strongly foveolate near the suture below the base, the punctures strong anteriorly, much finer and more elongate posteriorly. Legs nearly black; abdomen flavous.

Length $5 \mathrm{~mm}$.

Hab. Ceylon (Colls. Oxford Mus. \& Jacoby).

The peculiar sculpturing of the thorax and the flavous abdomen distinguish this species from any other of nearly similar coloration.

\section{Lema cribricollis, Weise, Deut. ent. Zeit. 1903, p. 18.}

Beneath testaceous; sides of metasternum and first abdominal segment blackish-æneous; antennæ ferruginous, second to nintl joints fuscous. Head black and ferruginous. Thorax æneous. Elytra metallic blue.

Head piceous, fulvous between the eyes, closely punctured and pubescent, convex, with a smooth slightly raised median line. Antennæ with the basal five joints fulvous, the second and the fifth above more or less black, the sixth to the ninth entirely fuscous black, tenth and eleventh yellowish. Thorax subquadrate, anterior margin formed into a transverse raised fold, interrupted at the middle, the basal sulcus fine, another transverse depression placed at the dise which ends in a fovea at the middle; the surface transversely wrinkled, with numerous punctures at the interstices; two rows of stronger punctures are also placed on the middle of the disc. Scutellum black, finely pubescent. Elytra greenish-blue, with cupreous gloss at the base and suture, a deep round depression below the base; the surface punctate-striate anteriorly, behind the middle striately punctured, the third and eighth rows unite before the apex and form a deep fovea.

Length $4 \mathrm{~mm}$.

Hab. Ceylon: Kandy.

Allied to $L$. westwoodi, Jac., but differs in the strongly constricted neck and the rugosely punctured thorax.

\section{Lema pedestris, sp. $n$.}

Dark metallic blue; antennæ black, labrum fulvous. Body beneath bluish-black.

Head fulvous, deeply constricted behind the eyes, the latter extremely prominent, triangularly notched, the intermediate space highly raised but not tubereuliform, with a short posterior central groove, the extreme base obscure fulvous; clypeus metallic blue; labrum fulrous; antennæ black, the intermediate joints slightly subquadrately widened, third and fourth equal, short. Thorax slightly longer than broad, with a deep lateral excavation, bounded by an acute ridge above, the basal sulcus deep, placed close to the basal margin, the anterior portion of the thorax with rounded angles; the surface with a few fine punctures at the middle and near the anterior angles. Elytra narrow and parallel,

rol. I. 
with a small transverse impression below the base, finely punctate-striate except at the base where the punctures are larger, the first row near the suture single, the interstices with some minute punctures here and there, slightly costate near the apex. Legs rather short, bluish-black. Underside clothed with fine grey pubescence.

Length $5 \mathrm{~mm}$.

$H a b$. Tenasserim (Doherty); Andaman Islands (Roepstorff). Type in Brit. Mus.

A narrow, elongate species, of more or less dark blue colour, distinguished by the fulvous labrum, the widened intermediate joints of the antennæ and the punctured elytral interstices; there are some slight differences present in the Andaman specimens but these are not sufficient to justify separation. Thus the thorax is not perceptibly punctured, the elytral depression is very small and feeble and their puncturation finer, but these differences are probably racial not specific ; all other characters are identical.

\section{Lema crebrepunctata, sp. $n$.}

Metallic dark blue; antennæ black.

Rather flattened above; the head not constricted, the vertex convex, not tuberculate, with a short deep central groove anteriorly; eyes very prominent, not very deeply notched; lower portion of face æneous; antennæ long and slender, third and fourth joints short, equal, following joints very elongate. Thorax quadrate, the lateral constrictions deep, furnished within with short perpendicular ridges, the basal sulcus deep; the anterior portion æneous, the base blue, anterior angles very slightly tuberculate. Scutellum rather broad, æneous. Elytra slightly narrowed posteriorly, with a small, rather shallow basal depression; the punctures large, round and deep, very closely placed, the interstices costate over the greater portion of the disc. Underside and legs bluish-black.

Length $4 \mathrm{~mm}$.

Hab. Burma: Ruby Mines (Doherty).

Allied to L.cyanea, Fabr., but of narrower, more cylindrical shape, generally of smaller size; the thoracic constriction furnished with ridges, the elytral puncturation much stronger and the interstices more or less costate.

\section{Lema atro-cærulea, Clark, App. Cat. Phytoph. 1866, p. 32.}

Black; elytra with slight bluish gloss.

Head impunctate, intraocular space not strongly raised, lateral sulci rather feeble; palpi fulvous; antennæ black, long and slender, the third joint shorter than the fourth, the following joints very elongate, terminal three joints shorter. Thorax with the anterior angles pointed but not tuberculate, black, shining, the surface not perceptibly puuctured, basal sulcus very deep. Elytra with a very 
slightly marked depression, the punctures deep on the anterior portion, much finer posteriorly. Underside and legs clothed with fine testaceous pubescence.

Length $5 \frac{1}{2} \mathrm{~mm}$.

$H a b$. Eastern India.

Nearly black (not dark blue as Clark gives), the antennæ long and slender, the thorax impunctate. The above description is taken from the type.

\section{Lema nitidissima, sp. $\mathrm{n}$.}

Metallic blue, very shining; the antennæ, tibiæ and tarsi black.

Head constricted behind the eyes, impunctate; the vertex with a short but deep groove, not tuberculiform; ocular sulci very deep; the antennæ not extended to the middle of the elytra, third joint but little longer than the second, much shorter than the fourth, fifth and following joints slightly thickened, elongate, terminal joints shorter again. Thorax somewhat longer than broad, the anterior portion very moderately widened, the angles rounded, not produced; lateral excavations rather deep, bounded by distinct ridges above; basal sulcus very distinct, the space behind nearly smooth; the surface rather convex, either impunctate or with some very minute punctures. Scutellum black. Elytra subcylindrical and parallel, the basal depression well marked, not gradual, extended nearly to the shoulders, the punctures closely placed, the interstices with a few minute punctures, slightly convex at the apex near the sides. Body beneath as well as the femora dark blue; abdomen non-pubescent.

Length $5 \frac{1}{2} \mathrm{~mm}$.

$H a b$. Travancore: Wallardi (Coll. Jacoby).

A rather elongate and subcylindrical species, with a proportionately elongate thorax, rounded and little widened anterior angles and very short third antennal joint.

\section{Lema nilgiriensis, Jac. Ann. Soc. Ent. Belg. xlvii, 1903, p. 80.}

Metallic blue; head with two fulvous spots at vertex; anteunæ, tibiæ and tarsi black.

Head not constricted posteriorly (in the original description the opposite is given, but incorrectly), the vertex marked with two more or less rufous spots, convex, with a short central groove posteriorly; space in front of the eyes rugosely punctured, the latter large and prominent; antennæo with the second to the fourth joints gradually lengthened, terminal joints slightly thickened but much longer than broad. Thorax subquadrate, more or less distinctly punctured on the middle and anteriorly. Elytra with a deep subquadrate sutural depression below the base, rather strongly punctate-striate, the punctures however somewhat distantly placed, the interstices flat. Beneath clothed with fine white pubescence. 
Var. andrewesi, Jac.(Ann. Soc. Ent. Belg. 1903,p. 81). Antennæ and legs more or less fulvous.

Lenyth $4 \mathrm{~mm}$.

Hah. Nilgiris (H. L. Andrewes).

Specimens of this species lately obtained by $\mathbf{M}_{\boldsymbol{i}}$. Andrewes in different parts of the Nilgiris show a finer thoracic puncturation, but do not differ in other respects from the type. The species is closely allied to $L$. cyanea, Fabr., but has constantly two fulvous spots on the sides of the vertex of the head, these are not raised as in some other species; the punctures of the elytra also differ from $L$. cyanea, they are smaller and less closely placed; all the specimens agree in these respects.

\section{Lema purpurea, sp. n.}

Purplish-violaceous; the antennæ and tarsi black.

Head with a few minute punctures, the vertex scarcely raised, with a short central groove; eyes round, not deeply notched; clypeus bluish; antennæ very long and slender, the third joint slightly shorter than the fourth, the following joints very elongate. Thorax obliquely widened in front, the anterior angles tuberculate, the lateral constrictions deep so as to form a broad cavity, within they are studded with numerous short ridges; the basal sulcus deep. Scutellum slightly broader than long. Elytra with a short but rather deep basal depression, the latter more deeply punctured than the rest of the surface, the punctures very regularly placed, the interstices costate near the apex. Beneath and the legs purplish-black.

Length $5 \mathrm{~mm}$.

Hab. Manipur (Doherty). Type in Brit. Mus.

Principally distinguished by its entirely purplish coloration, the flat vertex to the head and the long antennæ.

\section{Lema nigro-violacea, sp. $\mathrm{n}$.}

Dark purplish-blue; antennæ, underside and legs black.

Head very convex at base, impunctate, ocular sulci deep; eyes large and promivent, deeply triangularly notched; clypeus swollen, impunctate; antennæ rather robust, fifth and following joints thickened, twice as long as broad, third and fourth equal, shorter than fiftli. Thorax subquadrate, broadly and deeply excavate at sides; transverse sulcus deep, placed immediately behind the middle, anterior angles with a very small tubercle; surface with a few remotely placed punctures over the middle of the disc. Scutellum subquadrate. Elytra with very deep depression below base near suture, finely punctate-striate, the punctures proportionately widely separated, interstices perfectly flat.

Length $3 \frac{1}{2}-4 \frac{1}{2} \mathrm{~mm}$.

Hab. Nilgiris (H. L. Andrewes).

Differs from $L$. purpurea, Jac. in the strongly convex rertex of 
head, shorter and more robust antennæ and their thickened joints, the position of the thoracic sulcus and the entirely flat elytral interstices.

132. Lema mandarensis, Jac. Ann. Soc. Ent. Belg. xli, 1897, p. 421.

Bluish-black; vertex with two rufous spots.

Head impunctate on the vertex, the latter with two more or less distinct rufous spots, not constricted posteriorly, lower portion of face sparingly pubescent; antennæ black, short and robust, not extended much beyond the base of the thorax, the terminal joints strongly thickened but longer than broad. Thorax subcylindrical, longer than broad, the basal sulcus distinct but not very deep, the disc with two rows of strong punctures, others placed near the anterior angles. Elytra wider at base than the thorax, parallel and subcylindrical, scarcely perceptibly depressed below the base, very deeply punctate-striate, the punctures slightly elongate, interstices costate at sides and apex. Underside and legs nearly black, with slight bluish gloss.

Length $4 \mathrm{~mm}$.

Hab. Bengal: Mandar ; Malabar: Mabé.

Differs from L. globicollis, Baly in the colour of the head and thorax, but otherwise similar in the shape of the latter.

\section{Lema funerea, sp. n.}

Bluish-black; narrowly elongate. Head rugosely punctured, interstices with some short grey hairs, ocular sulci obsolete; eyes sinuate but not notched; antennæ short and robust, basal joint round and thick, second moniliform, third and fourth trigonal, equal, following joints subquadrately widened. Thorax elongate and subcylindrical, slightly narrowed at base, sides without constriction or sulcus, surface obsoletely depressed at base in front of margin, the latter thickened, finely rugose, middle of disc with two rows of punctures, anterior angles likewise punctate. Scutellum small, ovate. Elytra narrow, parallel and cylindrical, very closely punctate-striate, punctures elongate, interstices feebly costate at sides. Underside and legs black; claws joined at base.

Length $4 \frac{1}{2} \mathrm{~mm}$.

$H a b$. Nilgiris (H. L. Andrewes).

A very aberrant species; possibly belongs to Fairmaire's African genus Sigrisma, but the thorax is entirely subcylindrical. Of the Indian species the preserit form is the narrowest and most elongate so far as the sliape of the thorax goes.

\section{Lema nigricollis, Jac. The Entomologist, Suppl. 1891, p. 31.}

Black, head with two fulvous spots; elytra fulvous.

Head black; intraocular space highly convex, fulvous, divided by a groove; antennæ black, extended to middle of elytra, third and 
fourth joints equal, following joints elongate and slender. Thorax subquadrate, deeply constricted at the middle, anterior angles blunt but strongly produced at sides, basal sulcus placed at some distance from base; surface entirely impunctate, black, shining. Scutellum truncate at apex, black. Elytra with short and rather deep depression near suture below base, finely punctate-striate except within the depression. Body beneath and legs black.

Length $6 \mathrm{~mm}$.

Hab. Assam; Burma : Ruby Mines.

Rather smaller than L. assamensis, Jac.: the head black, with fulvous tubercles; the antennæ shorter with more slender joints; the thorax with a single sulcus.

\section{Lema belgaumensis, sp. $n$.}

Fulvous; clypeus, antennæ, legs partly and elytra black; base of tibiæ flavous.

Head not constricted posteriorly, fulrous, bituberculate on the vertex; the clypeus and labrum black; antennæ long and slender, third and fourth joints equal. Thorax subquadrate, with the basal sulcus deep and placed at some distance from the base, the anterior portion with another very obsolete transverse depression at the sides; lateral constrictions deep, entirely sulciform, but with the usual short perpendicular ridge above, middle of the disc with a few minute punctures. Scutellum fulvous. Elytra with a distinct transverse depression below the base, the lower portion subcylindrical; the surface strongly punctate-striate, the shoulders angularly prominent, deeply punctate-striate in front, the punctures extended quite to the base; the colour black, with a very slight violaceous tint. Body heneath fulvous, the sides of the breast and the upper edge of the first abdominal segment black; legs black, the upper edge of the posterior femora and the base of the tibiæ flavous.

Length $4 \frac{1}{2} \mathrm{~mm}$.

$H a b$. Western India: Belgaum (Coll. H. E. Andrewes).

A peculiarly marked species which may possibly represent a variety of one of the smaller forms, but so far as colouring goes, it appears to be quite distinct.

\section{Lema crassicollis, Jac. P. Z. S. 1887 , p. 66 ; Weise, Deut. ent.} Zeit. 1903, p. 22.

Beneath blackish-blue; upper part of the head, the thorax and the last two joints of the antennæ fulrous; elytra metallic blue, a small spot above the shoulders fulvous.

Head finely punctured on the vertex, the mouth-parts black; antennæ black, more than half the length of the body, the last two joints fulrous, third and fourth short, equal. Thorax not longer than broad, the anterior portion strongly swollen, its angles tu ber- 
culiform when seen from above with a single seta on each, surface entirely impunctate. Elytra deeply foveolate below the base, the basal portion convex; the surface rather deeply punctured, the punctures not very closely placed diminish in size towards the apex, the interstices finely transversely wrirkled; longitudinally costate near the apex; just above the shoulders is placed a small fulvous spot. Legs black, the inner side of all the femora fulvous. In a variety the entire elytral margin and apex are of that colour, the femora beneath testaceous.

\section{Length $4 \mathrm{~mm}$.}

$H a b$. Ceylon.

The strongly swollen anterior portion of the thorax and colous of the antennæ are sufficient to separate this species.

\section{Lema macei, Lacord. Mon. Phytoph. i, 1845, p. 387.}

Rufous; a black spot near anterior angles of thorax; elytrw black, apex narrowly flavous.

Rather short, parallel-sided and only slightly convex. Head impunctate, ocular sulci very deep, eyes deeply notched. Thorax slightly longer than broad, impunctate, basal sulcus rather deep. Elytra moderately strongly punctured, interstices strongly costate at posterior third. Legs slender, rather short.

Length $6 \frac{1}{2} \mathrm{~mm}$.

$H a b$. Bengal.

Lacordaire's type in the Paris Museum was minus the antennæ.

The following two species have been omitted:-

Lema bicolor, Fabr. Syst. Eleuth. i, p. 476.

The description of Fabricius does not admit of a recognition of this species.

Lema solani, Weber, Obs. Ent. p. 58 (1801).

Lema weberi, Har. Coleopt. Hefte, xiii, p. 185 (1875).

Weber gives India as the " habitat" of this species ; his description, however, agrees entirely with $L$. solani, Fab., which is a N. American species.

\section{Genus CRIOCERIS.}

Crioceris, Geoffroy, Hist. Ins. Paris, i, 1762, p. 237 ; Lacord. Mon. Phytoph. i, 1845, p. 546; Chapuis, Gen. Col. x, 1874, p. 76.

Anchenia, Thunberg (part.), Charact. Gen. Ins. 1789, p. 21.

Lewa, Fabr. (part.) Ent. Syst. Suppl. 1798, p. 90.

The principal differences between this genus and Lema are the free or separated not joined claws, and the generally shorter and more robust antennæ. As a rule the thoracic basal sulcus is also 
feeble and an anterior sulcus is also generally absent; other characters as in Lema.

Type, C. merdigera, Fabr., from Europe.

Range. Universally distributed.

\section{Section I.}

Above pale or dark fulvous, or with partly fulvous and black elytra.

138. Crioceris malabarica, Jac. Ann. Soc. Ent. Belg. xlviii, 1904, p. 381.

Dark fulvous ; beneath black, knees obscure fuscous.

Head deeply constricted behind the eyes, sparingly punctured on the vertex; eves very deeply notched, this portion and the space in front pubescent, lateral grooves very deep; antennæ dark fulvous, extended to the base of the elytra only, terminal joints scarcely longer than broad. Thorax subquadrate, moderately constricted at the middle, the surface with a few punctures near the anterior margin and a single row on the middle. Scutellum narrow, fulvous. Elytra reddish-fulvous, with a shallow transverse depression below the base, finely punctate-striate except near the shoulders where the punctures are absent, the puncturation much stronger at the base near the suture, the lateral margins strongly raised. Underside black, clothed with yellow pubescence; legs fulvous, knees darker.

Length $9 \mathrm{~mm}$.

Hab. Malabar.

Separated by the regular puncturing of the elytra from those species with only partly regular sculpture; also by the different colour of the underside and legs from C. badia, Lac. and C. omophloides, Lac.

139. Crioceris impressa, Fabr. Mant. Ins. i, 1787, p. 88; id. Ent. Syst. i, pt. 2, 1792, p. 6 ; Olivier, Enc. Méth. vi, 1791, p. 197; id. Entom. vi, 1808, p. 730, pl. 1, fig. 4 ; Lacord. Mon. Phytoph. i, 1845, p. 562; Baly, Trans. Ent. Soc. Lond. 1865, p. 32.

Var. castanea, Lacord. Mon. Phytoph. i, 1845, p. 564.

Var. crassicornis, Oliv. Ent. vi, 1808, p. 731, pl. 1, fig. 6.

Var. omophloides, Lacord. Mon. Phytoph. i, 1845, p. 564.

Beneath fulvous or piceous with silvery patches; thorax fulvous or black ; elytra fulvous or flavous.

This is one of the most variable and widely distributed of all the species of the Chrysomelidce, scarcely two specimens are ever alike, and this does not only apply to coloration but also to sculpture. Some specimens are much narrower than others; the head is either fulvous or black; the antennæ are sometimes much shorter than is the rule, also equally variable in colour as the other parts; the puncturation of the thorax is generally rather close over the middle of the dise, but occasionally there are only 
one or two rows of punctures visible; the elytral puncturation is equally variable but generally rather strong over the base, gradually diminishing posteriorly. The colour varies from flavous or fulvous to piceous, and this applies equally to all the parts. The general shape of the insect is broad and robust; the thorax has rounded anterior angles but sometimes these are furnished with a tubercle, almost justifying the separation of the specimens so modified as different species; however, so many intermediate varieties occur that nothing is gained by dividing these forms. This species has an enormously extended range which makes it all the more difficult to fix on characters which are so variable, and which increase of material seems only to multiply.

Length 7-10 $\mathrm{mm}$.

$H a \dot{b}$. The whole continent of India ; Ceylon ; Andaman Islands ; Nicobar Islands; Malayan Islands ; Philippines ; China ; Siam.

140. Crioceris semipunctata, Fabr. Syst. Eleuth. i, 1801, p. 472; Jac P. Z. S. 1887, p. 68; Baly, Trans. Ent. Soc. (3) iv, 1865, p. 29, pl. 1, fig. 1.

Lema dehaani, Guér. Icon. Rìgne Anim., Ins. 1844, p. 261 ; Lacord. Mon. Phytoph. i, 1845, p. 5.59.

Of brick-red or flavous colour; the antennæ, body beneath and the legs piceous.

Head strongly constricted posteriorly; the vertex convex with a deep central groove; antennæ very robust, the terminal joints strongly subquadrately widened, the second to the fourth joints gradually broader. Thorax rather less depressed than in $C$. impressa, the anterior angles thickened and tuberculate at the sides, the disc with a single row of punctures (sometimes absent). Elytra with the basal portion strongly raised, this portion with several rows of strong punctures (each row of about 5 or 6 punctures), the rest of the surface very finely punctate, the sides and apex nearly impunctate. Abdomen with patches of goldenyellow pubescence.

Lenyth 8-9 mm.

Hab. India; Ceylon; Java.

This species seems nearly as variable in regard to coloration and partly in sculpture as $C$. impressa. The Indian specimens cannot be separated as so many intermediate forms occur; the smooth sides and apex of the elytra will however, best distinguish this species, but in Javan specimens the basal portions of these parts are generally more bighly raised than in those from India.

\section{Crioceris pusilla, Clark, App. Cat. Phytoph. 1866, p. 68.}

Reddish-brown; femora stained with æneous.

Head with a deep central groove, the vertex slightly raised, with a few fine punctures; antennæ with the third and fourth joints transversely subquadrate, the following three joints subquadrately widened, twice as long as broad (the rest, in the only 
specimen available for examination, wanting). Thorax not longer than broad, very moderately constricted, the anterior portion broadly rounded, only slightly prominent, bounded at the sides by a short transverse sulcus, the basal grooves shallow, placed rather close to the base, the surface with two rows of punctures on the middle. Scutellum nearly black, covered with yellow pubescence. Elytra without any basal depression, the punctures moderately strong at the base, rather fine below the latter but distinct up to the apex, rather distantly placed, the interstices flat. Body beneath clothed with dense golden-yellow pubescence; the legs dark fulvous; the apex of the posterior and the upper edge of the anterior femora piceous.

Length $6 \mathrm{~mm}$.

$H a b$. India.

A rather small species of dark brown colour, the elytra without distinct depression, the thorax without prominent angles and the legs bicolorous.

142. Crioceris seminigra, Jac. Ann. Mus. Genova, xxvii, 1889, p. 153.

Black beneath; abore fulvous or with anterior portion of elytra black.

Head strongly constricted behind the eyes, lateral grooves deep, vertex of the head with a narrow central groove; eyes deeply notched; antennæ extended to just below the base of the elytra in the male, shorter in the female, the basal four joints short, the next and following joints suddenly and strongly transversely widened. Thorax scarcely longer than broad, deeply and broadly excavated at the sides, the cavity not bounded by a ridge above, anterior angles rounded, with a minute tubercle, the basal sulcus shallow, the disc with a single row of fine punctures at middle. Scutellum rather elongate. Elytra with a feeble depression below the base, strongly punctured at the base, more or less finely posteriorly, a subquadrate space below the shoulders impunctate. Beneath and the legs fulvous, more or less marked with or nearly all black.

Hab. Burma : Bhamo, Teinzo, Rangoon; Tenasserim: Meetan.

Independent of the coloration, this species may be known by the strongly enlarged fifth and following joints of the antennæ, which is much more pronounced in it than it is in C. semipunctata or C. impressa; these organs are also very short in the female, scarcely extended to the base of the thorax, and only slightly longer in the male.

143. Crioceris locuples, Clark, App. Cat. Phytoph. 1866, p. 64.

Dark brown; autennæ fulvous.

Head strongly constricted posteriorly, the vertex with a shallow groove and a few punctures; antennæ very long and slender, the third joint much shorter than the fourth, the following joints elongate, cy indrical. Thorax somewhat longer than 
broad, only slightly constricted at the middle, the anterior portion rounded and slightly prominent; the surface rather flat, impunctate and not or searcely perceptibly sulcate near the base; lateral cavities rather deep, bounded by a blunt ridge above. Scutellum narrowly elongate. Elytra very elongate and parallel, without any basal depression, finely and remotely punctured at the base, the punctures gradually disappearing from the middle downwards, the sutural margin from the middle and the lateral margins throughout strongly thickened. Breast and the anterior segments of the abdomen black, the posterior segments and the legs fulvous.

Length $9 \mathrm{~mm}$.

$H a b$. India.

An easily distinguished species on account of the more than usually long and slender antennæ, fine and sparing elrtral puncturation and black underside.

\section{Crioceris inconspicua, Clark, Alp. Cat. Phytoph. 1866, p. 68.}

Dark brown; antennæ, sides of breast and abdomen black.

Head with a short central groove between the eyes, this area slightly raised, marked by one or two punctures; eyes deeply notched; antennæ rather long, third and fourth joints short, subquadrately widened, the following joints about twice as long, gradually dilated. Thorax of the same shape as the preceding species, obsoletely sulcate anteriorly at the sides only, the basal suleus very shallow and placed at some distance from the base, the surface with a few punctures near the anterior angles. Scutellum black, broadly subtriangular. Elytra parallel, with a very shallow depression below the base, this portion as usual more strongly punctured than the rest of the surface, the latter dark brown, all the punctures piceous. Body beneath black, closely covered with yellow pubescence; middle of the breast and the legs fulvous.

Length $6 \frac{1}{2} \mathrm{~mm}$.

$H a b$. India.

\section{Crioceris semihirsuta, sp. n.}

Obscure fulvous; beneath densely corered with yellowish pubescence; above testaceous ; antennæ and legs piceous; thorax fulvous, the base flarous.

Subcylindrical and parallel-sided. The head fulvous; the vertex remotely punctured, rather convex, obsoletely grooved at the middle ; emargination of the eyes clothed with yellow pubescence; lower portion of face sparingly pubescent; antennæ extended to the base of the elytra, the third and fourth joints equal, transversely subquadrate, the following joints moderately widened and of equal width, distinctly longer than broad. Thorax about as long as broad, very moderately constricted at the sides, the 
constriction sulciform, black within, the dise with two rows of fine punctures; fulvous, the base with a distinct transverse sulcus, flavous behind the latter. Scutellum triangular, closely covered with yellow pubescence. Elytra rather deeply depressed below the base, the shoulders prominent, somewhat angular; the basal portion strongly, the posterior portion much more finely punctured, puncturation very distinct to the apex, the interstices flat. Underside densely clothed with yellow silky pubescence; legs obscure piceous, finely pubescent, the apex of the femora more or less fuscous.

Length $6 \mathrm{~mm}$.

$H a b$. India. Type in Brit. Mus.

A rather small but very distinct species on account of the pubescent scutellum and underside, where the hairs are dense and silky in appearance. Two exactly similar specimens are contained in the Museum collection.

\section{Crioceris semifoveolata, sp. $n$.}

Dark piceous; thorax with two obscure dark bands on the middle of disc ; tarsi fulvous.

Rather short and broad. The head strongly constricted, the vertex with two elongate deeply divided tubercles; antennæ short and robust, the fourth and the following joints strongly subquadrately widened, terminal joints broader than long, the last joint pointed, reaches to the base of the elytra. Thorax subcylindrical, longer than broad, the lateral constriction sulciform, basal sulcus only indicated by a small central fovea; the surface with a central row of fine punctures and another small lateral depression anteriorly, obscure piceous or dark fulvous, with two elongate obscure dark bands on the middle of the disc. Scutellum narrow. Elytra broad at the base, the latter strongly raised, with about twelve deep foveolate punctures, irregularly placed; the sides and apex with similar foveæ, leaving the sutural portion smooth in the middle. Beneath somewhat darker, non-pubescent; the tarsi fulvous.

Length $7 \mathrm{~mm}$.

Hab. Manipur (Doherty). Type in Brit. Mus.

Closely allied to C. dromedarius and C. gibba, Baly, from China, but differs in colour and the arrangement of the elytral punctures from the first named, and in the short antennæ, general smaller size and the sulciform constriction of the thorax from C. gibba.

\section{Sectrox II.}

Metallic blue; elytra favous or fulvous.

147. Crioceris flavipennis, Baly, Trans. Ent. Soc. (2) v, 1859, p. 151.

Metallic blue; antennæ long and slender; thorax strongly 
constricted. Elytra finely punctured, pale yellow; puncturing irregularly arranged in striæ, confused near the outer border.

Oblong-elongate. Head smooth, posterior portion of neck obliquely strigose; face elongate, with a deep central fovea ; antennæ slender, nearly equal to the body in length, third and fourth joints nearly equal. 'Thorax slightly broader than long, above smooth, obliquely impressed on either side near the base; posterior half of disc longitudinally grooved. Scutellum smooth. Elytra convex, their surface minutely punctured. Legs elongate, slender.

Length $13 \mathrm{~mm}$.

$H a b$. Northern India.

A very large species and easily distinguished by its coloration and size.

\section{Crioceris semicostata, sp. n.}

Metallic blue; antennæ black; elytra flavous.

Head impunctate, metallic violaceous blue, the vertex with a deep elongate pear-shaped sulcus; eyes entire, the space behind strongly constricted; antenno long and slender, pubescent, the third joint slightly shorter than the fourth, the following joints elongate but robust. Thorax very slightly constricted near the base, the anterior angles not prominent, the middle with a transverse sulcus, very distinct at the sides, entirely obsolete in the middle; surface impunctate, the basal margin thickened and sinuate. Scutellum black, very small and elongate. Elytra convex, without any depression, regularly and moderately strongly punctured, the puncturation very fine towards the apex, the interstices sligbtly convex. Legs and tarsi robust and the body beneatl dark blue.

Length $9 \mathrm{~mm}$.

$H a b$. Manipur. Type in Brit. Mus.

Of similar coloration to $C$. flavipennis, Baly, but a very distinct species, of half the size, the anterior portion of the thorax not produced, the elytral puncturation much stronger and regular and the interstices slightly raised longitudinally.

149. Crioceris pulchella, Baly, Trans. Ent. Soc. (2) v, 1859, p. 15:.

Metallic blue; elytra rufous.

Elongate, convex, shining metallic blue. Head deeply constricted behind the eyes; forehead longitudinally grooved; antennæ more than two-thirds the length of the body, filiform, moderately robust, third joint scarcely longer than the fourth. Thorax subquadrate, subcylindrical, sides deeply constricted at their middle, armed near the apex with an obtuse tubercle; above smooth, impunctate, apex narrowly margined; immediately behind the middle is a deep transverse groove that terminates laterally in the 
lateral constrictions; on each side in front is a short transverse inpression. Scutellum subtrigonal. Elytra much broader than the thorax, more than four times its length, slightly sinuate on the sides below the shoulders, each elytrou with eleven rows of distinct punctures, the first abbreviated. Body beneath clothed with adpressed yellowish-white hairs.

Length $9 \mathrm{~mm}$.

$H a b$. Northern India.

Differs from C. semicostata in the fiattened elytral interstices and in the different structure of the thorax and its anterior tubercle.

\section{Section III.}

Elytra blue or black, with flavous patches or spots.

150. Crioceris quadripustulata, Fabr. Mant. Ins. i, 1787, p. 88 ; Oliv. Entom. vi, 1808, p. 729, pl. 1, tig. $2 a, b ;$ Lacord. Mon. 1'hytoph. i, 1845, p. 558; Baly, Trans. Ent. Soc. (3) iv, 1865, p. 28. Attelabus speciosa, Fabr. Ent. Syst. i, pt. 2, 1792, p. 384.

Black; elytra with a large subquadrate patch at base and a transverse spot near apex, flavous.

Head strongly constricted posteriorly, the vertex bituberculate, impunctate; antennæ black, reach to the base of the elytra, second joint moniliform, third and fourth short and equal, shining, the following subquadrately elongate and widened. Thorax black or piceous, slightly longer than broad, moderately constricted, the anterior angles tuberculate, the sides deeply excavated; surface subyclindrical but rather broad, sometimes with a few minuto punctures. Scutellum black. Elytra black, with a single row of punctures near the suture and another short row near the first at the base, the rest of the surface impunctate; the basal portion raised and occupied by a large subquadrate flavous patch, another more transverse band placed below the middle.

Length $10 \mathrm{~mm}$.

Hab. Tenasserim; Siam; Java.

Conspicuous by its large size and by the two flavous elytral patches. The insect is probably distributed over other parts of India.

\section{Crioceris adonis, Baly, Tranx. Ent. Soc. (2) v, 1859, p. 150.}

Cærulean blue; antennæ black; elytra each with large flavous patch from base to beyond middle.

Deep metallic blue. Head with a deep fovea anteriorly; antennæ nearly as long as the body, filiform. 'Thorax as broad as long, constricted at the sides, above smootlı and shining, finely punctured, with some more regular rows of punctures at the middle of the disc, the base with a shallow fovea at middle. Elytra very much broader than the thorax, four times as long, indistinctly transversely depressed on the suture below the base; each elytron 
with eleven regular rows of punctures, the first row abbreviated, interstices with a row of finer impressions; each elytron with a bright yellow patch from the base to beyond the middle and transversely from the outer margin nearly to the suture, its inner edge deeply emarginate. Beneath dark blue, abdomen with a double row of patches of adpressed white hairs.

Length $10 \mathrm{~mm}$.

Hab. Northern India: Manipur (Doherty).

A large and handsome species, easily known by its coloration.

\section{Crioceris dohertyi, sp. n.}

Black. Elytra with a subquadrate flavous patch at base nearly extending to middle.

Head strongly constricted posteriorly; intraocular space convex, with a central groove, the area in front of the eyes finely rugose; antennæ reaching to the base of the thorax, the terminal joints strongly widened and flattened, third and fourth equal, short. Thorax as broad as long, very slightly constricted at the sides, the latter with a deep triangular cavity, bounded above by a perpendicular ridge, anterior angles tuberculiform; basal sulcus only indicated; the space behind with some fine transverse ridges; the dise with two double rows of fine punctures. Elytra narrowed posteriorly, the basal portion raised, marked with five short rows of deep punctures, the latter very widely placed, the rest of the disc black ; entirely impunctate, witb a large subquadrate flavous patch at the base that does not extend to the suture nor quite to the middle, its inner margin oblique. Legs robust, black.

Length $13 \mathrm{~mm}$.

Hab. Assam: Patkai Mts. Type in Brit. Mus.

Allied to C. adonis, Baly, but inuch larger and biack instead of blue, the elytra differently sculptured and the flavous patch smaller; the antennæ with broadly dilated terminal joints. The same differences in size and other details separate the insect from C.ornata, Baly.

153. Crioceris humeralis, Juc. Ann. Mus. Civ. Cienota, xxxii, 1892, p. 874.

Piceous; each elytron with a large subquadrate humeral fiavous spot.

Head elongate, impunctate; the eyes deeply triangularly notched, the lateral grooves deep; antennæ not extending much beyond the base of the elytra, dark chestnut or piceous, gradually widened towards the apex, the basal four joints small, nearly equal, shining, the others opaque, scarcely longer than broad. Thorax slightly longer than broad, moderately constricted at the sides, subcylindrical; the disc with two rows of fine punctures on the middle. Scutellum small. Elytra with the basal portion strongly raised, the punctures fine, much stronger in the first three 
rows near the suture, but disappearing altogether near the apex; a few widely-placed punctures also lie along the lateral margin; the humeral flarous spot extends downwards nearly to the middle but not to the suture: this patch is entirely impunctate and surrounded by a darker margin. Legs clothed with fine yellowish pubescence.

Length $6 \mathrm{~mm}$.

Hab. Burma: Karennee.

Somewhat resembles C. scapularis, Baly.

\section{Section IV.}

Elytra pale with black transverse bands or spots, or entively black.

154. Crioceris cruciata, Guér. Rev. Zool. 1840, p. 41; Lacord. Mon. Phytoph. i, 1845, p. 557.

Piceous or rufous; sides of breast narrowly black. Elytra pale flavous, suture and narrow transverse

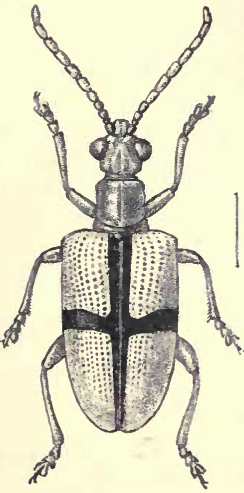

Fig. 12.-Crioceris cruciata. band at middle black.

Elongate; the head finely rugose and pubescent, rufous; lateral sulci very shallow ; antennæ robust, rufous, third and fourth joints nearly quadrate, short and equal, following joints subquadrately elongate. Thorax subcylindrical, slightly longer than broad, obsoletely sulcate before and in the middlevery finely rugose, the surface uneven, rufous, basal margin sometimes blackish. Elytra flavous, the basal portion raised, the dise obsoletely longitudinally sulcate; sometimes impunctate, the suture and a transverse regular band narrowly black. Sides of the meso- and metasternum black, rest of under surface and the legs rufous.

Length 8-10 mm.

$H a b$. Nilgiris.

Easily distinguished by the narrow their pale flarous ground-colour. cross-like markings of the elytra and

155. Crioceris fasciatipennis, Jac. Ann. Soc. Ent. Bely. xlviii, 1904, p. 381.

Flavous; the head, antennæ and legs piceous; thorax with the base black; elytra flavous, a narrow transverse band at the middle and a small spot near the apex, black.

Head piceous, impunctate, pubescent near the eyes; antennæ 
reach below the base of the elytra, the basal seven joints obscure fulvous, the others black, third and fourth joints equal, each about as large as the basal joint, the following joints thickened, slightly longer than broad. Thorax subcylindrical, sligbtly constricted at middle, anterior angles obtuse and rounded, the base with an obsolete sulcus; the space behind the latter black, rest of the surface flavous, entirely impunctate. Scutellum black, longer than broad. Elytra impunctate with the exception of two or three punctures near the suture below the base, the latter slightly convex; the surface flavous with a narrow transverse band below the middle, a small spot near the apex and the extreme apical margins black. Underside obscure flavous; abdomen clothed with yellow pubescence; legs piceous; mesosternum raised, perpendicular.

\section{Length $10 \mathrm{~mm}$.}

Hab. India (Colls. M. Clavareau and Jacoby).

Allied in coloration to C. cruciata but with an entirely differently shaped thorax, the latter with a black band at the base and the elytra with a subapical spot.

\section{Crioceris hampsoni, sp. n.}

Flavous; bead and antennæ obscure piceous. Elytra testaceous, each elytron with three black spots.

Head finely punctate near the eyes, fulvous with two piceous lateral stripes; intraocular space not convex, with a small groove; lower part of face finely pubescent, fulvous; antennæ short and robust, the basal four joints small, black, the others transversely widened, piceous. Thorax broader than long, the anterior portion subcylindrical, the sides very slightly constricted near the base, the latter with a distinct transverse sulcus placed close to the basal margin; the disc testaceous, with two rows of fine punctures. Scutellum brouder than long, testaceous, margined with piceous. Elytra subcylindrical, very slightly depressed below the base, the puncturation strong and regular, more fine towards the sides and apex, the sutural margins and three small spots on each elytron black ; of these one is placed on the shoulders, the second immediately behind the middle, rather nearer to the lateral than to the sutural margin, and the third below the second spot near the apex. Beneath and the legs testaceous, the tarsi stained with piceous at the apex of each joint.

Length $4 \frac{1}{2}$ min.

Hab. Nilgiris (G. Hampson). Type in Brit. Mus.

157. Crioceris nigro-ornata, Clark, Cat. Phytoph. 1866, p. 40. Crioceris nigropicta, Clark, App. Cat. Phytoph. 1866, p. 70.

Flavous; head black, rufous between the antennæ, the latter black; elytra flavous, the suture and four spots black; underside black; legs flavous, the knees and tarsi black.

vOL. I. 
Head black, impressed with a central fovea, the space between the antemnæ rufous. Thorax rufo-flavous, slightly constricted at the base, the middle and the anterior angles with some punctures. Scutellum black. Elytra parallel, flavous; of the black markings a spot is placed on the shoulders, a pear-shaped elongate mark from below the humeral spot to behind the middle, another small spot below the humeral spot, and one near the apex of each elytron. The antennæ black, short and robust.

Lengih $6 \mathrm{~mm}$.

$H a \dot{b}$. India. Type in Brit. Mus.

A well-marked species, easy to recognize by the peculiar pattern of the elytra.

158. Crioceris multimaculata, Jac. Ann. Soc. Ent. Belg. xlii, 1898, p. 185.

Flavous; antennæ and breast black, head with a black spot; elytra flavous, a sutural stripe, widened before and after the middle, a humeral spot, another below the shoulders, a round spot behind the middle, and another near the apex, black; tibiæ at apex and tarsi black.

Head fulvous; the vertex with a black spot, impunctate, the lower portion pubescent; antennæ black, short and stout, the terminal joints strongly thickened and widened. Thorax subcylindrical, constricted near the base, the basal sulcus shallow, the sides rounded and widened at the niddle, the disc fulvous with one row of punctures and others near the anterior angles. Scutellum black. Elytra flavous, strongly and deeply punctate-striate, the suture at the middle black, widened into a spot anteriorly and posteriorly; a spot on the shoulders, followed by a smaller one near the lateral margins, a round spot behind the middle and another larger one near the apex, black; sides of the breast, the knees, apex of the tibiæ and the tarsi black.

Length $2 \frac{1}{2} \mathrm{~mm}$.

$H a b$. Bengal: Mandar.

Allied to C. nigro-ornata, Clark (nigropicta, Clk.), but flavous beneath instead of black, and without the pear-shaped spot below the shoulders, also with an extra spot behind the middle, the head pubescent, the size generally smaller.

\section{Crioceris cardoni, sp. $n$.}

Entirely black.

Head rugose-punctate and finely pubescent; the vertex with a short but deep longitudinal groove; eyes very large and prominent; antennæ short, the terminal joints strongly thickened and widened, broader than long, the basal four joints shining, the others pubescent, third joint longer than the fourth. Thorax subglobose, very slightly longer than broad, the anterior angles rounded, the middle widened at the sides, the base very slightly constricted, with a narrow transverse groove, placed close to the 
basal margin, the middle of the disc with two longitudinal rows of deep punctures, the anterior angles likewise strongly puuctured. Elytra with a feeble depression below the base, very regularly punctate-striate, the punctures stronger anteriorly than at the lower portion, the interstices flat.

Lenyth $5 \mathrm{~mm}$.

$H a b$. India: Barway (Cardon) (Coll. Jacoby).

A small species of entirely black colouring and with a subglobular thorax much resembling Lema globicollis, Baly, but a true Crioceris with divided claws.

\section{Genus PSEUDOLEMA.}

Pseudolema, Jac. Ann. Soc. Ent. Belg. xlvii, 1903, p. 82.

Type, $P$. suturalis, Jacoby.

Range. Southern India.

Elongate and parallei-sided; the head not constricted posteriorly, without ocular or other grooves; eyes small and entire, widely separated; antennæ short and stout, the basal joints submoniliform, the rest subcylindrical, robust. Thorax subcylindrical, not constricted at the sides, with indications of a sulcus. Elytra punctatestriate, the interstices costate. Legs moderately long, the femora thickened, the first joint of the posterior tarsi triangularly elongate, one half longer than the second joint, third joint deeply

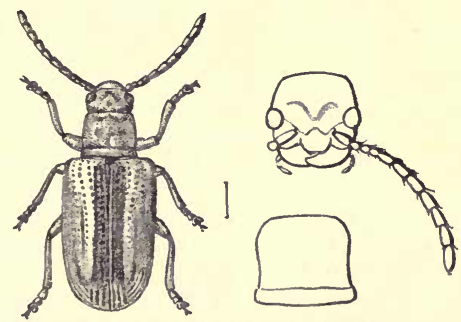

Fig. 13.-Pseudolema suturalis.

bilobed, claws simple. Prosternum not visible between the coxæ; first abdominal segment longer than the following two.

The broad, posteriorly not narrowed head, small and entire eyes and the subcylindrical non-constricted thorax at once separate this genus from Lema and Crioceris. The head especially is of totally different shape with small eyes but the antennæ are not unlike those of the last-named genus.

160. Pseudolema suturalis, Jac. Ann. Soc. Ent. Belg. xlvii, 1903, p. 83.

Pale testaceous; the head finely pubescent with a slight æneous gloss; thorax closely rugosely punctured; elytra testaceous, very 
strongly punctate-striate, the interstices finely longitudinally costate, a narrow sutural band and a small humeral and apical spot fusco-æneous.

Head longer than broad, of equal width, the neck more or less dark æneous, the other parts with a slight metallic gloss, finely and somewhat rugosely punctured and clothed with short pubescence; the space between the antennæ raised into a feeble tubercle; antennæ short and robust, obscure fulvous, the basal three joints submoniliform, nearly equal, the others longer than broad, subquadrately widened. Thorax very feebly narrowed at base and apex, subcylindrical, without lateral margirs, the surface finely rugosely punctured; scutellum subquadrate, piceous. Elytra subcylindrical, not depressed below the base, the punctures round and very closely placed, the interstices raised with some very fine punctures, a sutural regular fusco-æneous stripe extends laterally as far as the first two rows of punctures but does not quite reach the apex. Underside and legs pale testaceous.

\section{Length $4 \mathrm{~mm}$.}

Hab. Nilgiris.

In the specimens obtained by Mr. Andrewes the small elytral spots are absent; in those collected by Sir G. Hampson each elytron has a swall humeral and apical spot.

\section{Genus MANIPURIA, nov.}

Type, M. dohertyi, Jacoby.

Range. Manipur.

Elongate and subcylindrical; the head longer than broad, not constricted posteriorly but with a projecting triangular point or tooth beneath at each side anteriorly; eyes not prominent, emarginate; antennæ robust, terminal joints subquadrately widened. Thorax similar to that of Lema or Crioceris. Scutellum trigonal. Elytra wider at the base than the thorax, punctatestriate. Legs elongate, the posterior femora strongly thickened, claws divided at the base.

This interesting genus has the general appearance and most of the structural characters of Lema or Crioceris and agrees with the last-named genus in the divided claws and structure of the antennæ, but in buld and general shape of the head it differs entirely from either genus or any other of the Chrysomelidae on account of the peculiar tooth-like prolongation on the under surface in front of the mandibles; also there are no supraocular grooves.

\section{Manipuria dohertyi, sp. $n$.}

Obscure æneous; the antennæ, tibiæ and tarsi black; elytra with a fulvous transverse spot below the shoulders and another near the apex.

Head elongately subquadrate; the space between the eyes 
obscure cupreous, finely rugose, thickened, deeply grooved at each side, the grooves meeting in front; the intermediate space lanceolate in shape, smooth and bluish, with a short central groove; eyes round and rather small, distinctly notched; labrum fulvous; mandibles broad and robust, their apices dentiform ; last joint of maxillary palpi ovately thickened; antennæ black, extended to about the base of the elytra, basal joint short and thick, second very short, third and fourth equal, subquadrately transverse, the others longer, strongly subquadrately widened. Thorax not longer than broad, constricted at the middle, the constriction forms a deep sulcus at the sides which gradually diminishes

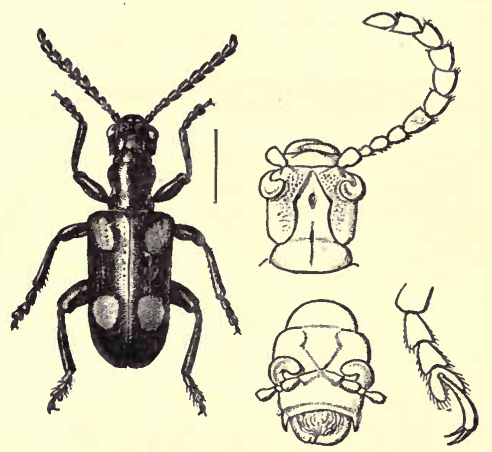

Fig. 14.-Manipuria dohertyi.

towards the middle, another transverse sulcus is placed near the base, the surface impunctate, metallic greenish-æneous. Elytra with the basal portion raised and behind that depressed, finely punctate-striate, the punctures more strongly marked within the depression, the apex impunctate, lateral margins thickened, accompanied by a row of closely placed punctures; the surface obscure æneous, almost black, very metallic, with a subquadrate fulvous spot immediately below the shoulders and another more rounded spot near the apex. Beneath and the legs dark æneous; prosternum extremely narrow.

Length $9 \mathrm{mn}$.

Hab. Iudia: Manipur (Doherty) (Coll. Brit. Mus.). 


\section{Division CAMPTOSOMES.}

Key to the Subfamities.

A. Antennæ short, the joints serrate.

$a$. Thorax without grooves on flanks; elytra not tuberculate.

$a^{\prime}$. Last joint of maxillary palpi pointed, posterior femora with one or two teeth, claw-joint very long ......

$b^{\prime}$. Last joint of maxillary palpi more or less truncate, posterior femora without teeth, claw-joint normal. .

b. Thorax with grooves on flanks for reception of antennæ; elytra tuber-

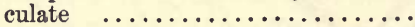

B. Antennæ long and generally filiform, never serrate, sometimes shorter with terminal joints thickened ..........

Megalopina.

Clytrina.

Chlamydina.

Cryptocephatina.

\section{Subfamily I. MEGALOPIN E.}

Body elongate, often flattened above; head frequently but not always constricted behind the eyes, the latter of variable size, deeply emarginate; the terminal joint of the palpi elongate and pointed; antennæ short, the terminal joints more or less transversely widened, sometimes dentate, the basal joint inserted in front of the eyes, close to the inner margin. Thorax transverse, without lateral margins, often with an anterior and posterior groove, occasionally tuberculiform at sides. Elytra irregularly punctured and frequently pubescent, their epipleuræ absent. Prosternum very narrow or indistinct, the mesosternum either extremely narrow and linear or entirely hidden. The metasternum sometimes raised at each side into a bigh elevation often of conicotruncate shape. The legs robust, with the posterior femora strongly incrassate and often armed with a tooth in the male; the tarsi widened, pubescent, the claws very long and simple.

This subfamily is more fully represented in South and Central America than in the East whence only two genera and a small number of species are known at present. These insects may be distinguished from those belouging to any of the preceding subfamilies by the short antennæ, which have their terminal joints more or less strongly transverse and serrate. In this respect they resemble the Clytrince in which there is, howerer, a distinct lateral thoracic margin which is absent in this.

\section{Key to the Generc of Megalopinæ.}

$a$. Thorax with anterior and posterior sulcus, sides without tooth .................. Temnaspis, p. 87 .

b. Thorax with tooth near base at sides ....... Colobaspis, p. 91 . 


\section{Genus TEMNASPIS.}

Temnaspis, Lacord. Mon. Phytoph. i, 1845̃, p. 716; Chapuis, Gen. Coléopt. x, 1874, p. 92.

Type, $T$. javana, Guérin, from Java.

Range. Nepal; Bengal; Burma; the larger islands of the Malayan Subregion. Madagascar, Africa.

Eyes comparatively small, not prominent; antennæ rather long, third joint longer than fourth, terminal six trigonal, dentate on their inner sides. Thorax narrower than elytra, transversely subquadrate, with an anterior and posterior sulcus. Elytra more or less pubescent; posterior femora strongly incrassate, armed with one or several strong spines in the male. Metasternum strongly raised on each side into a pointed elevation.

162. Temnaspis bengalensis, Westw. Trans. Ent. Soc. Lond. (3) ii, 1864, p. 276.

Fulvous; clothed with pale yellowish hairs; the head with the posterior margin and a spot anteriorly, brownish. Thorax with two large black spots before the middle of the disc and another smaller spot near the base. Scutellum fulvous. Elytra strongly punctured, the shoulders and a large spot behind the middle of each elytron black; the flanks of the thorax with two black spots; the metasternum entirely and a band at the apex of the abdomen black. Legs fulvous, the posterior femora fulvous at apex, black at base, armed below with two spines.

Length $8 \mathrm{~mm}$.

$H a b$. Bengal.

163. Temnaspis nigripennis, Jac. Ann. Mus. Civ. Genova, xxvii, 1889, p. 155.

Flavous; clothed with stiff black pubescence; antennæ flavous ; elytra black; legs fulvous, posterior femora with an acute spine.

Head with a small but deep fovea on the vertex, clothed with stiff black hairs, labrum and palpi fulvous; antennæ reach to the base of the elytra, the basal four joints shining, fulvous, the others opaque, flavous, closely pubescent, transverse and dentate on their upper margins. Thorax twice as broad as long, narrowed in front, the posterior angles oblique, the anterior portion with a narrow groove on each side; the surface sparingly punctured, clothed with stiff black pubescence. Scutellum flavous. Elytra punctured and pubescent like the thorax. Beneath pale flavous, clothed with yellow pubescence, the anterior tarsi black; metasternum raised on each side into a conical elevation.

Length 8-10 $\mathrm{mm}$.

Hab. Burma: Shwègu.

Both sexes possess a femoral spine but in the male this is longer 
and the posterior tibiæ are curved and widened at the apex. Very closely allied and perhaps only a variety of $T$. insignis, Baly, but with entirely black elytra.

\section{Temnaspis nigroplagiata, Jac. Ann. Mus. Civ. Genova, xxxii, 1892, p. 876.}

Fulvous; a spot on the head, another on the middle of the thorax, one or two on the posterior femora and the metasternum, black; elytra with a transverse spot at the base and another behind the middle black, the apex flavous.

Head finely rugosely punctured with a triangular central black spot and a smaller spot between the antennæ, the latter obscure fulvous, the first four joints shining, the others opaque. Thorax rather strongly narrowed in front, about half as broad as long, the posterior angles oblique; the surface rather closely and irregularly punctured, longitudinally depressed at the middle, a round spot on the sides and a more elongate subtriangular spot on the middle of the disc, black; the latter clothed with silky greyish pubescence. Scutellum black, pubescent. Elytra very closely and finely punctured anteriorly, the puncturation nearly obsolete near the apex, the disc fulvous, a transverse oblique band at the base slightly narrowed at the suture and another slightly more rounded band behind the middle, also the lateral margins near the apex, black, the space below the second band flavous. Breast, metasteruum, and the abdominal segments on the middle (the apical segment excepted) as well as a spot on the anterior coxæ and the posterior and intermediate femora, black; extreme apex of the latter flavous, the anterior portion fulvous; the intermediate and posterior tibiæ strongly curved; the metasternum conically raised on each side; posterior femora toothed on each side near the apex.

Length $9 \mathrm{~mm}$.

Hab. Burma: Karennee.

The amount of black on the underside is variable. The species is very closely allied to $T$. quinquemaculata, Baly, and differs only in the black spot on the head and in the colour of the legs. It is possibly only a local race of that insect.

\section{Temnaspis downesi, Baly, A. M. N. H. (2) v, 1859, p. 205,} pl. $v$, fig. 5 .

Fulvous; pubescent; apical joints of antennæ, a spot on the thorax and another oblique spot on each elytron, the pleuræ, an abdominal spot and a spot on the posterior femora, black.

Shining fulvous, the whole body covered with coarse fulvous hairs; the seven terminal joints of the antennæ, an oblong vitta on the disc of the thorax and a large subquadrate patch across the middle of the elytra black. Head closely punctured, impressed between the eyes by a deep longitudinal fossa. Thorax rather broader than 
long, transversely grooved at the base and apex, each side of the dise with a thick longitudinal elevated ridge, the inner margin of which is bounded by a shallow fossa,

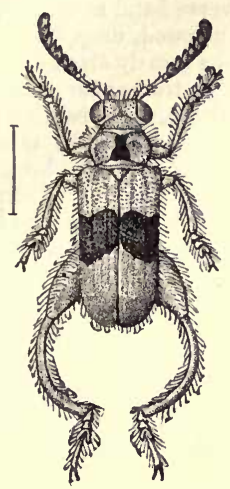

Fig. 15.-Temnaspis downesi. surface distinctly but less closely punctured than the head; middle of the disc with a broad vitta, rather broader behind, abbreviated at the base and apex. Scutellum triangular, its apex entire. Elytra subelongate, sides parallel, above subdepressed along the back, convex at the sides and apex, surface closely punctured, each elytron with two indistinct longitudinal ridges, fulvous; a broad black subquadrate patch extends across the middle of each elytron and is abbreviated at the extreme outer margin; this patch forms a common transverse fascia, emarginate on the suture at its base and apex, the hairs on its surface concolorous. Beneath shining, a large irregular patch on the pleuræ, another transverse one across the middle of the abdomen and a large spot on the outer surface of the posterior thighs, black; hinder femora much incrassate, ovate, armed at their lower edge in the middle with an obtuse tooth.

Length $7 \mathrm{~mm}$.

$H a b$. Northern India.

166. Temnaspis flavicornis, Jac. Ann. Mus. Cin. Genova, xxxii, 1892, p. 875 .

Reddish-fulvous; antennæ flavous, anterior, intermediate tibiæ and the tarsi black. Elytra black.

Broad and robust in shape; the head remotely punctured on the vertex, closely near the eyes, and sparingly clothed with black hairs; clypeus transversely sulcate; antennæ flavous, extending to the base of the elytra, the basal four joints shining, the others opaque, strongly flattened and widened. Thorax narrowed towards the apex, the posterior angles produced into a blunt tubercle; the disc rather depressed at the middle, very sparingly punctured and pubescent. Scutellum fulvous. Elytra slightly constricted posteriorly, the shoulders prominent and obliquely shaped, the surface shining, finely punctured and furnished with black pubescence. The posterior femora with two stout teeth, the outer margin of the tibire and the tarsi black; metasternum raised at the sides into a conical protuberance.

Length $10 \mathrm{~mm}$.

$H a b$. Burma : Karennee. 


\section{Temnaspis clavareaui, sp. $\mathrm{n}$.}

Flavous; antennæ (basal joints excepted), tibiæ and tarsi blackish. Elytra with a broad black transverse band at middle.

Head closely and finely punctured, with a round, deep fovea on the middle; anterior margin of the clypeus nearly straight, the latter deeply separated from the face by a transverse groove; antennæ extended to the base of the elytra, the basal two joints flavous, the following two piceous, all shining, the others transversely widened, opaque. Thorax about one-half broader than long, the dise slightly swollen on each side, without distinct sulci, posterior angles not produced, slightly tuberculiform, the surface rather strongly and remotely punctured. Scutellum broader than long, the apex with a longitudinal groove. Elytra pale fulvous, with some sparingly distributed black stiff hairs, scarcely more strongly punctured than the thorax, with a broad black band from before the middle to behind the latter that extends down some distance at the lateral margins, its lower edge deeply dentate. Beneath and the femora flavous, tibiæ and tarsi black; posterior femora with one long and a shorter tooth near the apex.

Length. $9 \mathrm{~mm}$.

Hab. Bengal : Mandar. Type in Mus. Brussels.

168. Temnaspis oberthuri, Jac. (Leucastea), Ann. Soc. Ent. Belg. xxxix, 1895, p. 253.

Fulvous, pubescent; antennæ and tarsi black; the head with two, the thorax with four black spots; elytra clothed with fulvous and black pubescence, a spot on the shoulders, another at the middle, and a third at the apex, black.

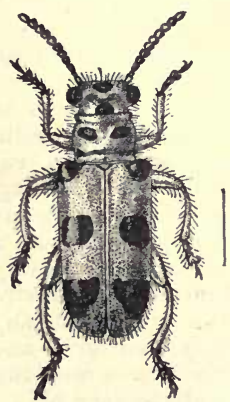

Fig. 16.

Temnaspis oberthuri.

Parallel-sided; the bead clothed with stiff black hairs, an elongate triangular depression and a large black transverse spot in the middle; the vertex with another rounded spot; eyes triangularly notched; antennæ black, the basal joint fulvous beneath, third joint longer than the second. Thorax twice as broad as long, the sides rounded, the surface with a deep transverse anterior and posterior sulcus and four black spots placed one below the other on the sides, the anterior spots of which are much larger and more transverse in shape than those placed near the base. Elytra finely punctured, clothed with fulvous pubescence, intermixed with black stiff hairs; each elytron with three black spots, one of which is placed on the shoulder, one transversely on the middle, not extending to the suture, and the third spot larger and more triangular in shape near 
the apex. Underside and legs fulvous, tarsi black, posterior femora strongly incrassate, unarmed ( 9 ?)

\section{Length $9 \mathrm{~mm}$.}

Hab. Burma: Momeit.

Differs from $T$. nigroplagiata, Jac. in the number and position of the elytral spots.

\section{Temnaspis assamensis, sp. $\mathrm{n}$.}

Flavous; antennæ, two spots on head and some small spots on sides of thorax, shoulders and an elongate spot at middle of elytra, black ; sides of breast, a femoral spot and tarsi black.

Surface clothed with black stiff hairs mixed with fulvous shorter pubescence; head closely punctured near eyes, a black spot at base and middle; antennæ black, basal joint flavous below. Thorax subquadrately transverse, bisulcate, sides with a black spot at anterior angles, a longitudinal depression at each side, surface nearly impunctate. Elytru finely and somewhat closely punctured; posterior femora with a small tooth below and a large elongate black spot on outer side.

Length $7 \frac{1}{2} \mathrm{~mm}$.

Hab. Assam (Coll. Jacoby).

Of nearly similar coloration as $T$. downesi, Baly, but smaller, the head more finely and sparingly punctured, the thorax impunctate, and the elytra much more remotely punctured, the tarsi black.

\section{Genus COLOBASPIS.}

Colobaspis, Fairm. Ann. Soc. Ent. Belg. xxxviii, 1894, p. 225.

Pœcilomorpha (part.), Westwood, Baly, Jacoby.

Type, C. flavonigra, Fairm., from Tibet.

Range. India; China; Africa.

Most of the characters like those of Temnaspis, but the thorax with a more or less strongly marked tooth at sides near base.

\section{Colobaspis nigriceps, Baly (Temnaspis), A. M. N. H. (3) iii,} 1859, p. 207.

Rufo-fulvous, pubescent; head and pleuræ nigro-piceous; the lower portion of the face, the antennæ, thorax, the anterior and intermediate femora, the tibiæ and tarsi flavous ; elytra purplishblack, a spot at the apex fulvous.

Head coarsely punctured, front impressed between the eyes with a deep fovea, shining black ; lower portion of face and the antennæ yellow, the latter more than half the length of the body, basal four joints shining, sparingly covered with long hairs, the rest covered with a short, adpressed concolorous pile. Thorax broader than long, subcylindrical, sides slightly rounded, constricted at the extreme base and front, produced near the former into an indistinct protuberance, above shining yellow, grooved at the apex and narrowly so at the extreme base, anterior groove dilated and 
slightly angulate in the middle; surface deeply but not very closely punctured, covered with coarse erect hairs. Scutellum triangular, its apex emarginate, sparsely punctured, shining black, edge fulvous. Elytra broader than the thorax, apex rounded, dehiscent at the suture, above convex, deeply punctured, covered with long subdepressed hairs; shining, a narrow semilunate apical patch rufo-fulvous. Beneath : shining rufo-fulvous, pleuræ nigropiceous; legs (the posterior femora excepted) pale yellow; hinder femora strongly incrassate, ovate, armed near the apex beneath with two acute spines.

Length $8 \mathrm{~mm}$.

Hab. Nepal.

171. Colobaspis insignis, Baly (Temnaspis), A.M. N. H. (3) iii, 1859, p. 208.

Fulvous, villose; the anterior and intermediate tarsi piceous; elytra purplish-black, a narrow semilunate patch at their apices rufo-fulvous.

Elongate, parallel-sided, shining fulvous, pubescent; head deeply punctured, sparsely so on the face, front impressed with a deep fovea; antennæ more robust than in $C$. nigriceps. Thorax subcylindrical, sides constricted in front and at the base, produced near the latter into an obtuse tubercle, above shining, grooved at the apex and at the extreme base, anterior groove dilated and angulate at the middle; surface deeply but not closely punctured, sparingly covered with erect hairs. Elytra longer than in U. nigriceps, broader than the thorax, above convex, less deeply and closely punctured than in the last species, covered with long subdepressed hairs, apical margin rufo-fulvous. Posterior femora as in the preceding species.

Length $10 \mathrm{~mm}$.

$H a b$. Northern India.

Longer and narrower than the preceding insect.

172. Colobaspis speciosus, Baly (Temnaspis), A. M. N. H. (3) ii, 1859, p. 204.

Black, sparingly pubescent; base and apex of abdomen, the metasternal tubercles, sides of thorax and the elytra, flavous; a spot on the shoulders, another near apex and a band at middle, black.

o. Posterior femora strongly incrassate, bispinose.

․ Posterior femora scarcely thickened, armed with one spine; abdomen flavous with central black patch.

Elongate, parallel-sided, subdepressed along the suture, shining black, sparingly covered with short hairs, the pubescence on the under surface longer and more distinct. Head shining, sparsely punctured on the vertex, transversely grooved between the eyes, anterior margin of clypeus fulvous, edge of labrum clothed with fulvous hairs; antennæ black, rather longer than the head and thorax. Thorax scarcely broader than long, subcylindrical, sides 
constricted in front and at their base, produced just behind the middle into a stout subacute process; above shining, grooved in front and on either side at the base, the anterior groove widened and angulate in the centre, sloping backwards down the disc nearly to its middle; surface finely and distantly punctured, the

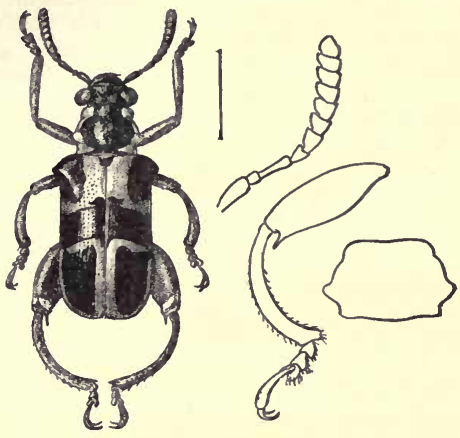

Fig. 17.-Colobaspis speciosus.

lateral margins yellow. Scutellum black, its apex notched. Elytra slightly depressed along the suture, shoulders prominent, surface distinctly punctured, sparingly covered with fulvous hairs; an ovate patch on the shoulders, a broad transverse band across the middle, produced slightly along the suture anteriorly and posteriorly, and a large subtrigonal patch behind the middle, black. Beneath black, abdomen (a large central patch excepted) yellow; the metasternal tubercles at the base with a small black spot. Femora piceous, their apices with several yellow spots.

Length 10-12 $\mathrm{mm}$.

$H a b$. Northern India.

173. Colobaspis quinquemaculatus, Baly (Temnaspis), A. M. N. H. (3) iii, 1859 , p. 206.

Megalopus 7-punctatus, Hope, Gray's Zool. Miscell. 1859, p. 28.

Fulvous, pubescent; thorax with one, elytra with two black spots each, the pleurre, a spot on the abdomen and on the posterior femora, black.

Elongate, parallel-sided, convex, covered with coarse hairs; head coarsely punctured, front excavate. Thorax one-third broader than long, sides narrowed anteriorly, constricted at the apex and extreme base, produced near the latter into an indistinct obtuse protuberance; above convex, grooved at the base and apex on either side; surface irregular, shining fulvous, coarsely and subremotely punctured, central portion gibbous, covered with a large 
black patch. Scutellum black, shining, triangular, its apex emarginate. Elytra broader than the thorax, sides parallel, apex rounded, dehiscent at the suture, above convex, coarsely punctured and covered with coarse pubescence, the puncturation finer and more sparse towards the apex; each elytron with two transverse bands, abbreviated at the suture and outer margin, one placed before, the other behind the middle. Beneath shining fulvous, two spots on either side of the thorax, the pleuræ, a transverse patch on the centre of the abdomen and an ovate spot on the outer surface of the posterior femora, black; hind femora incrassate, ovate, armed at their apices with two acute teeth.

Length $8 \mathrm{~mm}$.

$H a b$. Northern India.

The one line description of 7-punctata given by Hope probably applies to this species but is useless for identification. His name, therefore, cannot have priority.

The following species has been omitted as being unidentifiable by the description given :-

Pacilomorpha nigrocyanea, Motsch. Bull. Mosc. 1866, p. 406. Ceylon.

\section{Subfamily II. CLYTRINæ.}

A large subfamily, containing many closely allied genera, and distinguished by the short antennæ and their transverse serrate joints. The head is deflexed or perpendicular, the eyes large and oval ; the intermediate space generally depressed, sometimes rugose and pubescent. Thorax transverse, as broad at the elytra as at the base. Scutellum triangular. Elytra cylindrical, generally covering the abdomen, sometimes leaving the pygidium free. The anterior coxæ rather highly raised and closely approximate, or separated by a very narrow prosternum. The species generally may be recognized by the cylindrical and elongate shape and the coloration, which is usually fulvous above with or without black spots or bands; sometimes the thorax is black and in many cases the underside also, which latter is always more or less densely pubescent. The structure of the antennæ is similar to that of the Chlamydince and Lamprosomina, but these latter comprise short and generally metallic species of totally different shape.

This subfamily has been divided into numerous genera and subgenera by Lacordaire, many of them founded on male structural characters only and these frequently variable, but no better classification has beeu suggested or found practicable and the subfamily Clytrince remains one of the most difficult for a systematic arrangement of the numerous forms included in it. 


\section{Key to the Genera of the Clytrinæ.}

A. Posterior angles of thorax more or less raised in $\delta$; posterior margin strongly sinuate.. LABIDostonis, p. 96.

B. Posterior angles of thorax not raised in $\sigma^{\circ}$; posterior margin nearly straight.

a. Elytral epipleuræ strongly lobed at base, pygidium exposed.

$a^{\prime}$. Thorax above glabrous.

$a^{2}$. Shape robust, subcylindrical ; thorax not narrowed in front..........

$b^{2}$. Shape less robust, rarely subcylindrical; thorax narrowed in front.

$a^{3}$. Eyes large, preceded by a pubescent space...................

$b^{3}$. Eyes small, not preceded by a pubescent space .............

$b^{\prime}$. Thorax above pubescent ............

b. Elytral epipleuræ not or very slightly lobed at base; pygidium not exposed.

$a^{\prime}$. Body above pubescent ............

$b^{\prime}$. Body above glabrous.

$a^{2}$. Anterior legs not longer than others.

$a^{3}$ Antennæ more than usually transverse and serrate; elytra strongly dilated in $\delta$..............

$b^{3}$. Antennæ normal, less strongly transverse and serrate; elytra not dilated in $\sigma^{*}$.

$a^{4}$. Tarsi extremely short, subtriangular; body very narrow ..

$b^{4}$. Tarsi not so short, broad, not subtriangular; body broad; species generally large ............

$c^{4}$. Tarsi elongate, more slender, species generally small ......

$b^{2}$. Anterior legs considerably more elongate than others.

$a^{3}$. Elytral epipleuræ and tarsi covered with long hairs; scutellum large.

$b^{3}$. Elytral epipleuræ and tarsi not covered with long hairs; scutellum small.

$a^{4}$. Head strongly produced in front; eyes entire .............

$b^{4}$. Head normal; eyes notched ..

$c^{2}$. Anterior legs only slightly longer than others.

$a^{3}$. First tarsal joint of intermediate legs not broader than that of anterior legs.

$a^{4}$. Head broader than long; clypeus deeply emarginate ..........

64. Head not broader than long; clypeus not deeply emarginate.

$b^{3}$. First tarsal joint of intermediate legs broader than that of anterior legs..$\ldots \ldots \ldots \ldots \ldots \ldots \ldots$

Diapromorpha, p. 162.

Aspidolopina, p. 134.

ETHeomorPha, p.123.

Epimela, p. 144.

Pantoconetis, p. 147.

Clytrasoma, p. 149.

Miochira, p. 159.

Clytra, p. 152.

Gynandrophthalma, [p. 103.

Pseudoclytra, p.101.

Merilia, p. 98.

Miopristis, p. 99.

Coptocephala, p. 174.

Ceratobasis, p. 171.

Atheodactyla,

[p. 100. 


\section{Genus LABID0STOMIS.}

Labidostomis, Lacord. Mon. Phytoph. ii, 1848, p. 30.

Type, L. toxicornis, Fabr., from Europe.

Range. Europe, Asia.

Body metallic blue or green, the elytra reddish or yellowish
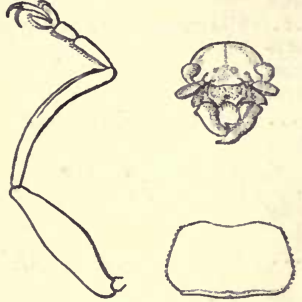

Fig. 18.-Labidostomis toxicornis. with or without one or two black spots; head with the middle portion concave. Thorax transverse, the anterior angles strongly deflexed, invisible from above, the posterior angles acute, produced posteriorly, the basal margin higher than the elytra, the surface with an anterior and posterior transverse depression and a slight projection in front of the scutellum. Legs coloured like the body, moderately slender. The male has the head and thorax very broad, the mandibles very elongate, robust antennæ and much elongate anterior legs. In the female all these parts are reduced.

174. Labidostomis indica, Jac. Ann. Soc. Ent. Belg. xxxix, 1895, p. 254.

Metallic greenish-blue; basal three or four joints of antennæ fulvous. Elytra testaceous, a humeral spot and the middle of disc obscure fuscous.

Head metallic greenish, closely and finely punctured, finely rugose between the eyes; anterior margin of the clypeus only slightly

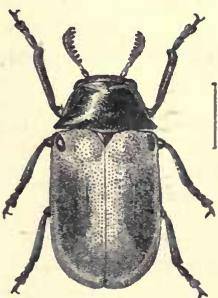

Fig. 19.-Labidostomis indica, q. concave; labrum black; antenna purplish, do not quite extend to the base of the thorax, the basal three joints more or less fulvous, the third joint one-half longer than the second, the fifth and following joints strongly transversely serrate. Thorax more than twice as broad as long, the anterior margin concave, the sides rounded, posterior margin prominent and raised at the angles, median lobe broadly produced; the surface very minutely and closely punctured near the base and on the sides, sparingly punctate on the disc, the latter shining, metallic greenish, with a narrow transverse depression near the anterior margin. Scutellum blackish, its apex truncate, impunctate. Elytra parallel-sided, very closely and strongly punctured, the interstices tinely transversely rugose or wrinkled, the entire disc fuscous, 
leaving only a narrow space surrounding the scutellum, the apex broadly and the lateral margins narrowly testaceons or pale fulvous ; underside and legs metallic greenish, finely pubescent.

Length $6 \mathrm{~mm}$.

$H a b$. Himalayas : Dalhousie; Kashmir.

The obscure markings of the elytra are the same in the tro specimens before me but in one the humeral spot is absent. In the male the characteristic elevation of the posterior thoracic angles is strongly marked.

\section{Labidostomis cummingi, sp. $\mathrm{n}$.}

Fuscous with slight æneous gloss; basal joints of antennæ fulvous. Elytra testaceous.

o. Head broad; mandibles very large, deeply excavated. Anterior legs extremely elongate, their coxæ enormously enlarged, perpendicular.

․ Head and legs normal. Elytra with small humeral spot. Beneath greenish.

Head deeply depressed and finely rugose between the eyes, anterior edge of the clypeus deeply bi-emarginate, the angles dentiform; antennæ with the basal joints pale, the others darker fulvous, fourth joint elongate, triangularly widened, fifth and following joints transverse, strongly pointed and produced. Thorax fuscous, with a slight æneous gloss, about twice as broad as long, of even width, the sides strongly rounded in the middle, oblique near the base, posterior angles only slightly pointed but not produced; surface minutely punctured and clothed with fine grey hairs. Scutellum obscure piceous, finely pubescent, the apex with a short central ridge. Elytra testaceous, opaque, finely and closely punctured, with slight traces of longitudinal lines. Body beneath finely pubescent. The anterior coxæ highly raised and very thick ; the femora elongate, widened towards the apex and angulate below, their tibiæ curved, the apex produced; the first joint of the tarsi as long as the following two joints united, posterior metatarsus shorter.

Length 7-8 $\mathrm{mm}$.

Hab. Baluchistan : Ormarah (Cummings). Type in Brit. Mus.

It is possible that the male specimen before $m e$ is immature, judging from the fuscous colour of the head, thorax and underside, and that these parts are normally metallic green as in the female. As both sexes were obtained at the same locality I bave no doubt as to their belonging to the same species. The distinct pubescence of the head and thorax and their puncturation, the coloration of the elytra etc., separate this species from the preceding.

176. Labidostomis funerea, Fairm. Ann. Soc. Ent. Belg. xxxv, 1891, p. 103.

Bluish-black ; labrum rufous. Head smooth, impressed between voL. I. 
the eyes; antennæ short, obtusely serrate, basal two joints rufopiceous. Thorax transverse, posterior angles acute, surface smooth.

\$. Head broad, antennæ widened. Thorax slightly wider than elytra, feebly narrowed anteriorly, sides rather rounded. Scutellum triangular, opaque, apex with short ridge. Elytra parallel, short, finely punctured. Underside finely pubescent. Anterior legs elongate, apex of tibiæ strongly curved, pubescent below.

†. Strongly widened posteriorly, head smaller; thorax narrowed from apex to base. Scutellum acute. Elytra more strongly punctured.

Length $4 \frac{1}{2} \mathrm{~mm}$.

$H a b$. Kashmir.

Closely allied to $L$. hordei, Fabr., but larger, much less strongly punctured; mandibles of $\delta$ much less strongly developed. Thorax less rounded at sides; clypeus without tooth at middle of anterior margin.

\section{Genus MERILIA.}

Merilia, Lacord. Mon. Phytoph. ii, 1848, p. 1E5; Chapuis, Gen. Colépt. x, 1874, p. 112.

Type, M. lunulata, Lacord.

Range. India; Africa.

đ. Elongate, subcylindrical; head perpendicular, anterior portion subquadrately produced; eyes round and convex, entire; antennæ with fourth joint elongate-triangular, following joints very strongly subquadrately transverse. Thorax strongly transverse, posterior angles rounded, margin sinuate at sides, surface glabrous. Scutellum subquadrate, its apex truncate, raised. Elytra with rather distinct, rounded, epipleural lobes. Legs elongate, the anterior legs much longer than the others, their tarsi very elongate and slender.

The only species known of this genus from India is not difficult to recognize on account of the characters pointed out above and by its coloration. In the female these characters are, as usual, much modified; the head is less strongly produced and the legs are less elongate.

177. Merilia lunulata, Fabr. (Cryptocephalus) Spec. Ins. i, 1781, p. 138; Oliv. (Clytra) Ent. vi, 1808, p. 855, pl. 3, f. 35; Lacord. (Merilia) Mon. Phytoph. ii, 1848, p. 127.

ð. Dark blue or violaceous; pubescent beneath; the head finely rugose and pubescent throughout, depressed in the middle; clypeus feebly emarginate; antennæ black, rather stout, slightly shorter than the thorax, the basal three joints fulvous. Thorax twice as broad as long, subcylindrical, the sides nearly straight, the posterior angles rounded, the surface black and shining, entirely impunctate. 
Scutellum black, oblong, slightly raised. Elytra nearly parallel very obsoletely punctured, flavous or fulvous, below the base is a

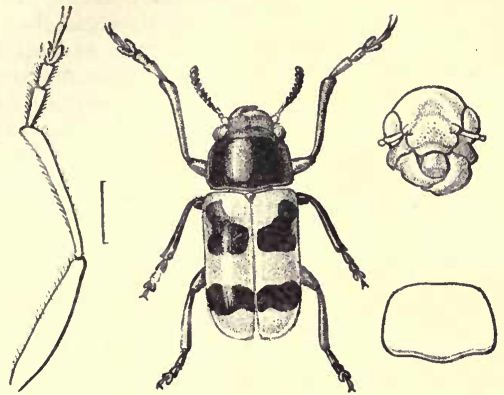

Fig. 20.-Merilia lunulata, ơ.

black subtriangular large spot or patch that has its upper and lower margin deeply emarginate, and a transverse black band of curved shape near apex.

Length 6-7 mm.

$H a b$. India generally : Madras, Coromandel Coast, etc.

This is evidently a not uncommon species which may be known by its black and shining thorax and the peculiar emarginate black spot below the base of the elytra. The $\delta$ has very prominent and thickened mandibles and the head is prolonged anteriorly and subquadrate. The anterior legs and tarsi are very elongate. In the $q$ all these parts are normal.

\section{Genus MIOPRISTIS.}

Miopristis, Lacord. Mon. Phytoph. ii, 1848, p. 25; Chapuis, Gen Coléopt. x, 1874, p. 109.

Type, M. lepida, Lacord., from Africa.

Range. Africa; India.

Characters mostly those of Merilia but the head not more than usually produced, the eyes notched, the thorax more transverse and of different shape. The only Indian species seems to fall better under this than under any other genus, although the anterior tarsi are not so elongate as in its African congeners.

178. Miopristis bimaculata, sp. $\mathrm{n}$.

o. Fulvous; the labrum, apical joints of antennæ, breast and abdomen black. Elytra with a transverse black spot near apex. 
Head impunctate, feebly transversely grooved between eyes; clypeus rather strongly semi-

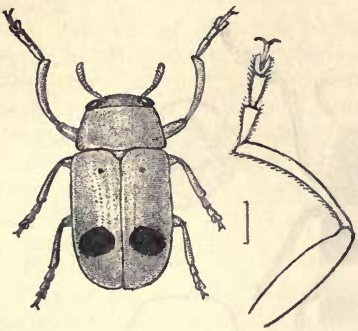

Fig. 21.-Miopristis bimaculata. circularly emarginate at apex, extreme margin black as are also the labrum and apex of mandibles; antennæ extended to base of thorax, fourth and following joints very moderately transversely widened. Thorax twice as broad as long, lateral margins nearly straight, posterior angles distinct, posterior margin sinuate at sides, median lobe feeble, straight, surface entirely impunotate. Scutellum triangular. Elytra subcylindrical, parallel - sided, opaque, very finely punctured in indistinct rows, nearly obsolete posteriorly, the black spot placed near the suture and apex. Anterior legs elongate with elongate tarsi, first joint of latter longer than second. Breast and abdomen very finely pubescent.

Length $4 \frac{1}{2} \mathrm{~mm}$.

$H a b$. India : Chupra (Coll. Jacoby).

In the female the legs are, as usual, shorter and of equal length. The elytra show occasionally another very small obsolete spot below the base.

\section{Genus E2THEODACTYLA.}

Etheodactyla, Lacord. Mon. Phytoph. ii, 1848, p. 188 ; Chapuis, Gen. Coléopt. x, 1874, p. 130.

Type, $E$. lateralis, Lacord., from India.

Range. India.

Oblong, glabrous above; head short and ovate; eyes very large, elongate, nearly entire; mandibles short. Thorax subcylindrical, narrowed in tront, sides straight, posterior angles obtuse, feebly lobed in the middle. Scutellum very large. Legs rather long and robust, anterior legs distinetly longer thau the others; first joint of tarsi as long as the following two united, first joint of second pair of tarsi very large and convex, that of the posterior legs less so.

Erected for an insect that has most of the structural characters that belong to the genus Clytra. The first joint of the tarsus of the intermediate legs is, however, different in both sexes in .Etheodactyla.

179. Etheodactyla lateralis, Lacord. Mon. Phytoph. ii, 1848, p. 189.

Reddish-fulvous ; breast, abdomen and legs black. Elytra with a large triangular black patch at lateral margins near apex.

Head nearly smooth, depressed between the eyes; antennæ 
fuscous, as long as the thorax, the basal four joints fulvous. Thorax twice as broad as long, narrowed in front, the sides straight, the posterior angles rounded, the median lobe only indicated, the disc entirely impunctate. Scutellum large, triangular. Elytra feebly lobed below the shoulders at the margins, with traces of two or three short sulci near the apex, when seen in certain lights; each elytron with a large subtriangular black patch on the lateral margin near the apex. The feniale has shorter legs and a shallow fovea on the last abdominal segment.

Length 8-10 mm.

$H a b$. Malabar.

In most specimens the base of the femora is more or less fulvous. This is a large species, much resembling one belonging to the genus Clytra.

\section{Genus PSEUDOCLYTRA, nov.}

Type, $P$. andrewesi, Jac., from Western India.

Range. India.

$\sigma^{*}$. Elongate and subcylindical; head normal; eyes large; antennæ rather robust, third joint much smaller than second, fourth trigonal, following joints very strongly transversely widened. Thorax half as broad again as long, sides rounded, slightly narrowed in front, very narrowly margined, basal margin with median lobe broad, very slightly produced and truncate. Scutellum very broad, triaugular. Elytra elongate, covering the pygidium, sides without humeral produced lobes; epipleuræ clothed with long pubescence. Anterior legs elongate, their tarsi also longer than ordinary, furnished like the underside with long pubescence.

This genus is proposed for two species from India that have the general appearance of Clytra, but belong to the group that possesses elongate anterior legs and tarsi ; the long pubescence of the elytral epipleuræ and of the tarsi is not found in any other genus of the Clytrince.

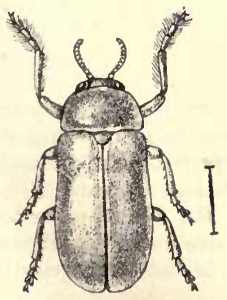

Fig. 22.

Pseudoclytra andrewesi.

180. Pseudoclytra andrewesi, Jac. (Titubœa) Ann. Soc. Ent. Belg. xxxix, 1895, p. 258.

Entirely of fulvous colour.

Head depressed between the eyes, closely punctured and longitudinally strigose, anterior edge of clypeus angularly emarginate, apex of mandibles black; antennæ fulvous, third joint small, fourth broader, following joints strongly transverse. Thorax less than twice as broad as long, slightly narrowed anteriorly, posterior angles strongly rounded, median lobe scarcely produced, surface impunctate with the exception of some small punctures placed on the 
basal lobe. Scutellum large. Elytra parallel-sided, subcylindrical, minutely and sparingly punctured, with a very shallow transverse depression below base; beneath clothed with long fulvous pubescence. First joint of posterior tarsi as long as the following two joints united, first joint of anterior tarsi more elongate.

Length 6-8 $\mathrm{mm}$.

$H a b$. Southern Bombay: Kanara, Belgaum.

181. Pseudoclytra plagiata, Duviv.(Clytra) Ann. Soc. Ent. Belg. xxxv, 1891, p. 29.

Var. minor, Duvin. t.c. p. 30.

Flavous; elytra with a broad transverse black band behind the middle; underside and legs clothed with very long fulvous hairs.

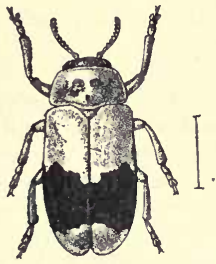

Fig. 23.

Pseudoclytra plagiata.

$\delta^{*}$. The anterior legs and their tarsi elongate.

Head finely punctured on the vertex, transversely grooved between the eyes, the latter large, very slightly notehed at their lower edge; antennæ comparatively long, fulvous, the fourth and following joints transversely serrate, the terminal three joints much smaller. Thorax about one and a half times broader than long in the male, twice as broad as long in the female, the sides gradually narrowed in front; the disc rather convex, impunctate, with the exception of a few punctures in front of the scutellum, the anterior margin with a fringe of long fulvous hairs. Scutellum broad. Elytra flavous, shining, impunctate, scarcely lobed below the shoulders, covering the pygidium; the posterior black band broad, its posterior margin concave leaving the apex in shape of a rounded flavous spot, anterior edge of the band irregularly notched.

Length $7 \frac{1}{2} \mathrm{~mm}$.

$H a b$. Southern India : Madras.

On account of the elongate tarsi, pubescent legs and elytral epipleuræ, this species cannot remain in Clytra and must find its place in the present genus. Duvivier had probably only female specimens before him, in which the tarsi are less elongate. The variety minor is less than half the size and the entire posterior portion of the elytra is black. The pubescence on the epipleuræ can only be seen in perfect specimens, as it is not unfrequently rubbed off. 


\section{Genus GYNANDROPHTHALMA.}

Gynandrophthalma, Lacord. Mon. Phytoph.ii, 1848, p. 256; Chapuis, Gen. Coleopt. x, 1874, p. 12.

Type, $G$. nigropunctata, Lacord., from South America.

Range. Distributed more or less over both hemispheres.

Size generally rather small; shape elongate and subcylindrical or shorter and more ovate; above nearly always glabrous.

Head rather short; mandibles small; eyes variable; antennæ comparatively slender, second and third joints short and equal, the following joints transversely serrate. Thorax transverse, short, variable, posterior angles distinct or rounded. Elytra generally without distinct epipleural lobes. Leys rather short, the anterior legs often slightly longer than the others. Tarsi variable, first joint longer than the second.

This is not a well-defined genus owing to the variability of the structural characters, but may be recognized by the absence of elytral lobes (indicated in a few cases), generally small size, and by the other characters given above.

\section{Elytra black with apex pale.}

182. Gynandrophthalma longicornis, Jac. (Damia) Ann. Soc. Ent. Belg. xli, 1897, p. 422.

ऽ. Fulvous; apical joints of antennæ black; elytra black, extreme apex fulvous. Elongate and parallel-sided; head broad, impunctate, with a very shallow groove between the eyes, the latter round and entire; clypeus separated from the face by a semicircular row of foveæ, anterior margin subtriangularly emarginate, sides below the eyes thickened; mandibles broad and robust, the left mandible excavated at base, apex black ; antennæ fuscous, comparatively long and slender, basal four or five joints flavous, second and third small, fourth and following triangularly widened. Thorax generally twice as broad as long, sides and posterior angles rounded, anterior margin only slightly narrower than the posterior margin; surface impunctate; median lobe scarcely indicated, preceded by a short impressed line. Scutellum fulvous, apex raised and thickened. Elytra very slightly narrowed at base, scarcely lobed at the sides, sparingly and minutely punctured, the punctures arranged in irregular rows; apical margins narrowly flavous. Legs elongate, first joint of tarsi double the length of the second (in the original description this joint is erroneously described as "scarcely longer than the second"); last abdominal segment of female with a deep fovea.- $q$. Antennæ shorter, head and thorax narrower, legs less elongate.

Length $5 \mathrm{~mm}$.

Hab. Bengal : Mandar.

Much larger than $G$. delesserti, Lacord., and without thoracic black band, head differently coloured. 
183. Gynandrophthalma delesserti, Lacord. Mon. Phytoph. ii, 1848, p. 267.

Black; head with a fulvous spot. Thorax flarous with a blueblack central band. Elytra black, with the apex flavous.

․ Flougate, slightly narrowed at apex. Head small, ovate, black, shining, with triangular fulvous spot anteriorly, smooth, with a small fovea or deep puncture between the eyes; clypeus feebly emarginate in front; eyes rather large, oblong, entire; antennæ black, comparatively robust, extending slightly beyond the thorax. Thorax twice as broad as long, cylindrical, sides straight, posterior angles rounded, surface entirely smooth, very shining, the central band of regular shape. Scutellum small. Elytra very finely and rather regularly punctured in striæ; the apical spot rounded, fulvous, or ivory coloured. Body beneath with fine grey pubescence. Legs rather long and slender like the tarsi, first joint of latter as long as the following two joints united.

Length $2 \frac{1}{2} \mathrm{~mm}$.

$H a b$. Nilgiris.

The author gives the elytra as black in the diagnosis but as blue in his description.

Elytra blue with apex pale.

184. Gynandrophthalma frontalis, sp. $n$.

o. Fulvous; base of head, apical joints of antennæ, breast and pygidium black. Elytra metallic blue, apex fulvous.

Head impunetate, with three shallow foveæ, upper portion black, this colour extending to middle of eyes, anterior portion and labrum fulvous; antennæ not extended to the base of the thorax, basal four joints fulvous, rest black, fourth and following joints strongly transverse. Thorax twice as broad as long or slightly broader, sides rounded and somewhat narrowed in front, angles distinct, surface entirely impunctate, fulvous. Scutellum strongly pointed, triangular, black and shining. Elytra parallel-sided, regularly punctate-striate, punctures stronger near suture, sides and apex nearly impunctate, the latter in appearance like a rounded pale fulvous spot. Underside and legs fulvous, clothed with short silvery pubescence. First joint of anterior tarsi twice as long as second.

Length $3 \mathrm{~mm}$.

$H a b$. Nilgiris. Type in Coll. H. E. Andrewes.

Closely allied in coloration to G. apicipennis, Jac., but with base of head and scutellum black, the elytra tinely punctured with the rows more widely separated, the pygidium black, size generally smaller. 
185. Gynandrophthalma orientalis, Jac. Ann. Soc. Ent. Belg. xl, 1896, p. 302.

Black; basal joints of antennæ and the anterior legs fulvous; thorax flavous; elytra dark blue, apex yellow.

Narrow and elongate; head finely and sparingly punctured, not transversely depressed; clypeus not separated from face, anterior margin triangularly emarginate ; labrum and palpi obscure flavous ; antennæ fuscous, basal two or three joints flavous, second and third very small, terminal joints transverse. Thorax very short, more than twice as broad as long, sides nearly straight, posterior augles rounded, basal margin scarcely produced at middle, preceded by a narrow transverse groove, surface with a few minute punctures. Scutellum broad, piceous. Elytra very closely and distinctly punctured, interstices finely rugose, apex with an elongate bright yellow spot on each elytron. Below finely pubescent. Legs elongate, tarsi, the claw-joint included, very slender.

Length $2 \mathrm{~mm}$.

Hab. Bombay ; Belgaum.

\section{Gynandrophthalma apicipennis, sp. n.}

ð. Fulvous; apical joints of antennæ black. Elytra dark blue, apex fulvous.

Narrowly elongate; head impunctate, vertex with an elongate fuscous spot on each side, two small fover between the eyes; clypeus feebly emarginate in front; eyes large; antennæ extending to the base of the thorax, basal three joints fulvous, rest nearly black, fourth and following joints strongly transversely widened. Thorax twice as broad as long, of equal width, sides rounded; surface fulvous, impunctate and very shining. Scutellum triangular, strongly pointed, fulvous. Elytra parallel-sided, rather strongly punctured in closely approximate rows, apical portion impunctate, punctures near suture rather more irregularly placed, the apical portion to the length of about one-fourth of the elytra fulvous. Underside fulvous clothed with silvery pubescence, legs fulvous, sides of breast fuscous.

Length $3 \frac{1}{2} \mathrm{~mm}$.

Hab. Nilgiris (Capt. Douning). Type in Coll. Andrewes.

Larger than $G$. orientalis, head not punctured, elytra not rugose.

\section{Metallic Species.}

187. Gynandrophthalma laticollis, Duviv. Ann. Soc. Ent. Belg. xxxvi, 1892, p. 399.

Head, thorax, prosternum, mesosternum and legs fulvous. Elytra bright blue. Scutellum, metasternum and abdomen black. 
Head smooth, very shining, with a feeble depression on the vertex, some longitudinal ridges near the inner borders of the eyes; clypeus emarginate; antennæ black, extending slightly below the base of the thorax, basal four joints fulvous, apical seven transverse. Thorax extremely short, at least three times as broad as long, feebly rounded at the sides, smooth with the exception of some small punctures near the base. Scutellum large, smooth, triangular. Elytra very slightly dilated posteriorly, moderately convex, very shining, very deeply and closely punctured, the puncturation regularly arranged with the interstices subconvex near the suture. Beneath finely pubescent. $-q$ with a fovea on the last abdominal segment.

Length $3 \mathrm{~mm}$.

Hab. Sikhim : Kurseong.

Differs from $G$. dohertyi, Jac., in being much shorter and smaller and in the strongly transverse thorax and elytral puncturation.

188. Gynandrophthalma cærulea, Jac. (Diapromorpha) Ann. Mus.Civ. Genova, xxxii, 1892, p. 877.

Beneath fulvous; antennæ (basal joints excepted), breast and tarsi black; above metallic blue; legs fulvous.

Elongate and subcylindrical; vertex of head swollen, impunctate, lower part of face flattened, finely punctured, separated from vertex by a well-marked transverse groove; labrum and palpi piceous; base of mandibles fulrous; antennæ black, not quite extending to base of thorax, basal three joints fulvous, basal joint subquadrate, second rounded, short, third very small, fourth and following joints transversely widened. Thorax rather more than twice as broad as long, sides moderately rounded and narrowed in front, very finely margined, posterior angles distinct; surface obliquely depressed near latter, impunctate at disc, the depressions finely punctured; median lobe rounded, gradually but not strongly produced. Scutellum triangular, pointed. Elytra with moderately strong epipleural lobes, finely and closely punctured; pygidium free, finely pubescent, bluish. Beneath finely pubescent; tibiæ darkened at apex. First joint of posterior tarsi longer than the second.

Length $7 \mathrm{~mm}$.

$H a b$. Burma: Karennee.

This species is better placed in Gynandrophthalma than in Dicpromorpha, as it much resembles in size and colour $G$. togoensis, Jac., from Africa, but, besides structural differences, the underside and legs in that species are different in colour. It is the largest and most elongate of the Indian species. 


\section{Gynandrophthalma dohertyi, sp. n.}

Black; basal joints of the antennæ and base of tibiæ fulvous, elytra metallic dark blue.

Elongate and parallel-sided; the head impunctate, obsoletely longitudinally depressed in the middle; labrum and mandibles obscure fulvous ; antennæ black, basal three joints fulvous, second joint small, third elongately subtriangular, the following joints transverse. Thorax more than twice as broad as long, the lateral margins straight anteriorly, slightly rounded near the base as well as at the posterior angles, the sides with a narrowly reflexed margin that widens gradually near the base, the surface entirely impunctate. Scutellum broad, pointed, blackish, the apex fulvous. Elytra elongate, very feebly lobed below shoulders, slightly transversely depressed below the base, very closely and finely punctured in irregular rows. Body beneath finely pubescent. Last abdominal segment of female with a deep fovea. Male unknown.

Length $4 \frac{1}{2} \mathrm{~mm}$.

Hab. Assam: Patkai Mts. (Brit. Mus.).

Easily distinguished by its coloration.

Pale with black spots or bands.

\section{Gynandrophthalma bohemani, sp. n.}

Flavous; base of head black. Thorax with two transverse sinuous bands. Elytra with four small black spots each (2.2); breast and abdomen stained with black.

Rather robust and subcylindrical; the head with some obsolete depressions between the eyes, impunctate, a transverse black band on the vertex; eyes large and entire; antennæ fuscous, extending to about half the length of the thorax, the basal three joints flavous, fifth and following joints broadly triangularly dilated. Thorax broad and transverse, twice as broad as long in the male, still broader in the female, the sides rounded, the posterior angles distinct, anterior portion slightly narrowed; surface impunctate, flavous, with two well separated transverse bands at the base, each rather deeply constricted in the middle. Scutellum black $(\delta)$ or fulvous ( $q$ ), the apex pointed. Elytra extremely closely and distinctly punctured, not covering the pygidium, two small spots placed transversely immediately below the base and two behind the middle, bluish-black. Body beneath clothed with grey pubescence, breast black, abdomen more or less blackish. Legs black in male, flavous in female, tarsi rather short and broad.

Var. Elytra each with two spots at base.

Length 6-7 $\frac{1}{2} \mathrm{~mm}$.

$H a b$. Southern India. Type in Brit. Mus. 
Whether the differences in coloration of the scutellum and legs are constant in the two sexes it is impossible to say, as only two specimens are before me. The species much resembles G. 8-maculata, Jac., but may be known by the black vertex of the head and the niarkings of the thorax; another difference is in the position of the elytral spots; in the present species the lower two are nearer together and placed immediately behind the middle, in $G$. 8-maculata the corresponding spots are wide apart and placed lower down.

191. Gynandrophthalma cornuta, Jac. (Titubœa) Ann. Soc. Ent. Belg. xxxix, 1895, p. 259.

Fulvous, more or less black beneath ; base of head and two transverse spots ou thorax blackish blue. Elytra with a lozenge-shaped spot at base, an elongate spot on shoulders, a transverse dentate band behind the middle and a sutural spot at apex, dark blue.

$\sigma^{*}$. Head with an acute horn-like projec-

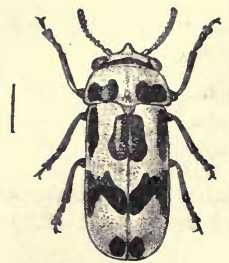

Fig. 24.

Gynandrophthalma cornuta. tion between the eyes, entirely impunctate; clypeus not separated from face; labrum fulvous, mandibles robust, broad, concave above and angular; antennæ scarcely extending to base of thorax, basal four joints fulvous; the others fuscous, fifth and following joints moderately widened. Thorax nearly three times as broad as long, sides feebly rounded, angles distinct, posterior angles more obtuse, disc impunctate. Elytra feebly lobed at base, very finely and rather closely punctured, a sutural spot below the scutellum, the other markings as given above. Base of femora and abdominal segments more or less fulvous; anterior legs and the metatarsus rather elongate.

Var. $a$. Humeral spot prolonged to apex and joined to posterior band, both very broad.

Var. $b$. Humeral spot obscure, all other markings absent.

Length 6-8 $\mathrm{mm}$.

$H a b$. Kanara, Belgaum.

In the female the head is simple and the thorax less transverse. In both sexes the first joint of the anterior tarsi is as long as the following two joints united. It is a large species subcylindrical in shape, well distinguished by the shape of the elytral inarkings. The unspotted variety can be distinguished from $G$. fuscitarsis, Jac. by the shape of the thorax, which is widened at the sides posteriorly in the last named species but of equal width in the present insect. The species cannot remain in Tituboea (Miopristis) as the anterior legs are only slightly more elongate than the others. The structure of the head of the male is quite unique. 
192. Gynandrophthalma signaticollis, Redtenb. (Coptocephala) Hïgel's Reise Kaschm. 1846, p. 561; Lacord. Mon. Phytoph. ii, 1848, p. 267.

․ Black; thorax flavous, a central broad band and a spot at sides black. Elytra flavous, a large spot at base, a broad band at middle, posterior portion of suture and apex black. Rather elongate, subcylindrical, clothed with fine grey pubescence beneath. Head smooth and shining; eyes moderately large; anteunæ slender extending to the apex of the thorax, basal joint pale fulvous. Thorax twice as broad as long, very regularly cylindrical, sides nearly straight, posterior angles rounded, feebly lobed at base, surface very smooth. Scutellum black, smooth, Elytra very finely and superficially punctured, the black band very broad, placed immediately behind the middle, widened at the suture anteriorly, the basal spot not extending to either margin. Legs black, first joint of anterior tarsi longer than second.

Length $4 \frac{1}{2} \mathrm{~mm}$.

$H a b$. Kashmir.

193. Gynandrophthalma affine, Jac. (Melitonoma) Ann. Mus. Civ. Genova, xxvii, 1889, p. 158.

Fulvous; antennæ black, three or four basal joints fulvous. Elytra with a humeral spot, one near the suture and two behind the middle, black. Head slightly transversely depressed between

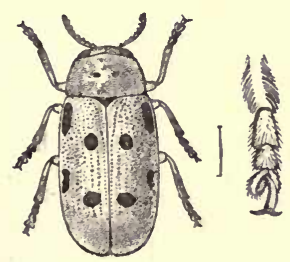

Fig. 25.-Gynandrophthalma affine. eyes; eyes slightly notched, surface impunctate; antennæ nearly extending to the base of the thorax. Thorax about one half as broad again as long, sides strongly deflexed, surface with more or less distinct depressions at sides, impunctate. Scutellum pointed. Elytra narrowly elongate, finely semipunctate-striate, a spot on shoulders, another near suture before middle and two slightly larger spots placed obliquely behind the middle, black. Underside fulvous or partly black, tarsi and a small spot at apex of tibix piceous ; first joint of tarsi twice as long as second.

Length 4-5 mm.

Hab. Burma: Teinzo, Shwègu.

The tibir (with the exception of their base) and the tarsi sometimes entirely black.

194. Gynandrophthalma mungphuensis, sp. n.

Beneath black; above fulvous, vertex of head black. Thorax with central black spot. Elytra with a round spot below base and another near suture black. Legs fulvous. 
Head with a central fovea, the vertex finely longitudinally strigose; clypeus separated from the face by a transverse curved depression, its anterior border feebly emarginate ; antennæ fuscous, not extending to the base of the thorax, basal three joints flavous, fourth to terminal joint transversely widened. Thorax two and a half times as broad as long, the sides straight, slightly narrowed anteriorly, the posterior angles distinct; median lobe broadly and distinctly produced, with two punctured small foveæ at the base in front of the scutellum; the disc impunctate, with a triangular black spot at middle, pointed posteriorly. Scutellum broadly triangular, pointed, black. Elytra distinctly lobed below the shoulders at the margins, subcylindrical and parallel-sided, finely and closely punctured; each elytron with two black spots, the first below the base, round, the second rather larger and of similar shape, placed behind the middle, apical space of elytra nearly impunctate. First joint of posterior tarsi longer than second.

Length $4 \mathrm{~mm}$.

Hab. Sikhim: Mungphu. Type in Brit. Mus.

195. Gynandrophthalma semipunctata, Duviv. Ann. Soc. Ent. Belg. xxxv, Bull. 1891, p. xxxiii.

Pale flavous; antennæ (base excepted), sides of metasternum and of abdomen black. Elytra with humeral spot and transverse band, narrowed at suture, black.

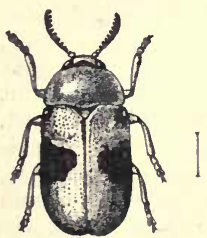

Fig. 26.

Gynandrophthalma semipunctata.

Oblong; head smooth, with some strigæ near the eyes and a rounded fovea between them; clypeus with a few fine punctures; antenn: extending to the base of the thorax, basal four joints testaceous, rest black, triangularly widened. Thorax two and a half times broader than long, narrowed in front, sides broadly rounded, impunctate. Scutellum large, round at apex, smooth. Elytra oblong-ovate, slightly widened posteriorly, broadly rounded below shoulders at margins, moderately strongly punctured, the punctures semi-regular on the anterior half, nearly obsolete posteriorly and on the sides; a small humeral spot and a transverse band strongly widened at the sides where it extends to the anterior fourth of the elytra in front and to the apical fourth posteriorly; near the suture it is narrowed to half its width. First joint of tarsi a little longer than second.

\section{Length $4 \frac{1}{2} \mathrm{~mm}$.}

$H a b$. Bengal: Konbir.

Seems closely allied to $G$. cochinchinensis, Lefèv., if not identical with it. 
196. Gynandrophthalma cochinchinensis, Lefèv. Ann. Soc. Ent. France, 1889, p. 290.

Gynandrophthalma birmanica, Jac. Ann. Mus. Civ. Genova, xxxii, 1892, p. 885.

Fulvous; breast, apex of abdomen and pygidium blackish ; elytra with two round bluish-black spots (one humeral and one between shoulders and scutellum), also a transverse

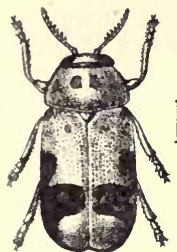

Fig. 27. Gynandrophthalma cochinchinensis. broad patch, more or less widened at the sides; legs fulvous.

Head obsoletely bi-impressed between the eyes; antennæ black, basal two joints fulvous. Thorax smooth. Elytra rather strongly and irregularly punctured, punctures obsolete behind the middle.

Length 5-51 $\mathrm{mm}$.

Hab. Burma; Cochinchina.

Allied to $G$. malayana, Baly, but the elytra much more strongly punctured and differently marked. Although in the Burmese variety ( $G$. birmanica, Jac.) the head is sometimes marked with black at the vertex and the elytral puncturation is rather more strongly impressed, I think it cannot be specifically separated on such slight variations.

\section{Gynandrophthalma assamensis, sp. n.}

Testaceous; labrum black; antennæ with terminal fuscous joints. Thorax with four obsolete spots. Elytra with three spots at base, two at middle, lateral margins posteriorly and suture black. Legs testaceous, tarsi fuscous.

Head impunctate, with a round deep fovea between the eyes, the vertex with an obscure black spot at the base; eyes very large; clypeus not separated, its anterior margin feebly concave; labrum black; antennæ fuscous, with the fourth and following joints strongly transversely serrate, the basal three joints testaceous. Thorax neurly three times as broad as long; the sides rounded, posterior angles distinct, the median lobe feebly but broadly produced; the disc impunctate, with four obscure piceous spots, placed transversely. Scutellum very broad, its apex obtusely rounded, piceous. Elytra subquadrately oblong, strongly and closely punctured anteriorly, very finely and much more distantly so towards the middle; each elytron with five black spots, of which one is placed on the humeral callus, a more elongate one between the first spot and the suture and the third at the lateral margin, the other spots are placed on the middle and are of more transverse shape, the outer spot, is attached to the black margin, the latter surrounds the apex; the sutural margins are likewise black and this colour widens into a short stripe below the scutellum. Tarsi fuscous, the first joint slightly longer than 
any of the following joints; apex of the pygidium and the last abdominal segment partly, black.

Length $4 \mathrm{~mm}$.

Hab. Assam. Type in Brit. Mus.

\section{Gynandrophthalma nagaensis, sp.n.}

Testaceous; terminal joints of antennæ fuscous. Elytra very pale, a humeral, another spot near scutellum and two at middle placed transversely, black.

Similar to the preceding species, of the same shape, but smaller; the labrum testaceous, the antennæ similar as well as the thorax (in one specimen with an indication of four small spots). Elytra much less strongly punctured, the punctures more regularly placed, the spots of different shape, those at the base connected, the humeral spot small and round, the inner one much larger and subtriangular in shape; of the lower spots one is attached to the lateral margin and is oblong, the other is placed close to the suture, somewhat subtriangular. Beneath and the legs testaceous, finely clothed with yellow hairs; the tarsi slightly fuscous, their first joint distinctly longer than the others.

\section{Length $5 \mathrm{~mm}$.}

Hab. Assam: Nága Hills (Doherty). Type in Brit. Mus.

The design on the elytra and the shape and position of the spots are quite different from those in the preceding insect, as is also the puncturation.

199. Gynandrophthalma crassipes, Duviv. (Clytra) Ann. Soc. Ent. Bely. 1891, p. 31.

Fulvous : antennæ (basal joints excepted),

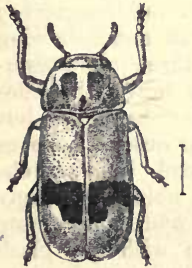

Fig. 28.

Gynandrophthalma crassipes. mandibles, breast and apex of abdomen black; elytra with an oblong transverse patch near middle, emarginate at lower end, greenishblack.

o. Head flat, nearly smooth with two oblique depressions at middle; clypeus not separated; antennæ scarcely reaching to base of thorax, fourth and following joints transverse. Thorax transversely convex, rather more than twice as broad as long, finely punctured throughout. Scutellum very convex. Elytra oblong, subparallel, very finely rugose and punctured. Body beneath clothed with silvery pubescence. Ĺegs very robust, femora strongly developed.

․ Legs considerably less robust, surface shining.

Length 6-7 mm.

$H a b$. Bengal : Konbir. 
This species, of which I received a typical specimen, seems best placed in the present genus. The elytral spot or patch is subject to enlargement and in this case the species resembles Clytra (Psendoolytra) plagiata, Duv., but differs from it in shape and elytral puncturation.

\section{Elytra flavous or fulvous.}

\section{Gynandrophthalma planifrons, sp. n.}

Flavous ; base of head, a spot on anterior part of thorax, scutellum, margins of elytra and breast black.

Narrowly elongate, head very broad and flat, impunctate, vertex crossed by a black transverse band; clypeus not separated from face; antennæ black, basal four joints flavous, fifth aud following joints strongly transverse. Thorax rather more than twice as broad as long, sides rounded, narrowly margined; surface impunctate, transversely depressed in front of scutellum, a large black patch on the middle of the anterior margin extending downwards nearly to the base. Scutellum very broad, pointed. Elytra slightly depressed below base across suture, not perceptibly punctured, all the margins narrowly black, this black border indistinctly widened at apex. Legs and abdomen flavous; breast black.

Length $2 \frac{1}{2} \mathrm{~mm}$.

$H a b$. Nilgiris. Type in Coll. H. E. Andrewes.

A very small species not difficult to recognize by its peculiar coloration.

201. Gynandrophthalma chrysomeloides, Lacord. Mon. Phytoph. ii, 1848, p. 268.

오. Entirely pale flavous; moderately elongate, rather convex and parallel-sided. Head produced, alutaceous; clypeus semicircularly emarginate; eyes very large and convex; antenuæ slender, feebly dentate, distinctly longer than the thorax. Thorax at least twice as broad as long, subcylindrical, feebly rounded at the sides; median lobe large but very short, posterior angles distinct; surface entirely impunctate. Scutellum smooth, subtriangularly elongate and raised. Elytra scarcely sinuate at sides, very tinely punctured in rows. Legs short, slender; tarsi very short, the first two joints trigonal, equal.

Length $5 \mathrm{~mm}$.

Hab. India.

Closely resembles at first sight certain species of true Chrysomela.

\section{Gynandrophthalma ceylonica, sp. $n$.}

o. Flavous; elytra fulvous. Head flat, without depressions; clypeus not separated from face, its anterior border triangularly

vOL. I. 
emarginate; apex of mandibles black; antennæ flavous, second and third joints small, fourth and following strongly triangularly widened and serrate, apical joint elongate and pointed. Thorax twice as broad as long or rather broader, sides rounded, posterior angles somewhat indistinct, median lobe slightly produced, straight, surface entirely impunctate. Scutellum pale fulvous, trigonal. Elytra without lateral lobes, entirely smooth and impunctate. Legs flavous, tarsi short, nearly equal in length; in male anterior legs slightly longer than the others.

Length $5 \mathrm{~mm}$.

Hab. India: Kanara (Coll. H. E. Andrewes). Ceylon (Brit. Mus.).

I have seen two specimens of this species, distinguished by its flavous head and thorax and the fulvous elytra as well as by the entirely impunctate upper surface.

203. Gynandrophthalma fuscitarsis, Jac. (Dania) Mém. Soc. Ent. Belg. vii, 1900, p. 99.

Fulvous; terminal joints of antennæ and the tarsi black.

o. Elongate and parallel-sided; head impunctate; vertex convex; space between eyes depressed, with three foveæ placed triangularly; eyes round, very slightly notched at lower margins; clypeus semicircularly emarginate; antennæ black, extending to the base of the thorax, basal four joints flavous, fourth and following joints strongly triangularly dilated. Thorax about one half as broad again as long, twice as broad in female, of even width, sides strongly rounded, narrowly margined, median lobe only indicated, posterior angles rounded; surface rather convex, impunctate, very shining. Scutellum triangular, apex raised and truncate. Elytra parallel, slightly narrower at base than thorax, with very short epipleural lobes, surface very closely and finely punctured in irregular rows. Legs rather long and robust, first joint of tarsi twice as long as second. Body beneath densely covered with silvery pubescence.

Length $6 \mathrm{~mm}$.

Hab. Burma.

Of very shining fulvous colour, principally distinguished by the black tarsi and the strongly transverse thorax.

204. Gynandrophthalma fuscicornis, Lacord. (Damia) Mon. Phytoph. ii, 1848, p. 386.

Obscure fulvous; antennæ fuscous.

․ Oblong-parallel, head smooth; front with a subtriangular deep impression; clypeus feebly emarginate; eyes large, elongate, distinctly notched; antennæ rather robust, slightly shorter than the thorax, basal four joints fulvous. Thorax one and a third times broader than long, subcylindrical, base straight, median 
lobe large, very short and truncate, surface entirely impunctate. Scutellum large, triangular. Elytra feebly lobed at the sides, finely but distinctly punctured. Legs subequal, rather robust, tarsi robust. Body beneath clothed with fine white pubescence. Length $6 \mathrm{~mm}$.

$H a b$. India.

\section{Gynandrophthalma minuta, sp. n.}

Flavous; breast and abdomen black.

Head with a small fovea between the eyes; clypeus not separated from the face; antennæ extending to the base of the thorax, basal three joints flavous, rest slightly darkened, fourth and following joints strongly serrate. Thorax two and a half times broader than long, sides rounded, posterior angles obtuse, surface impunctate. Elytra parallel-sided and subcylindrical, finely punctatestriate; legs flavous.

Lenyth $2 \frac{1}{2} \mathrm{~mm}$.

Hab. India: Belgaum (Coll. H. E. Andrewes).

One of the smallest species of the genus known to me and easily recognized on that account and by the finely punctate-striate elytra; the elytra are not lobed at the sides and cover the pygidium. A single specimen is contained in Mr. Andrewes's collection.

\section{Gynandrophthalma citrinella, sp. n.}

Elongate, parallel-sided; bright flavous. Elytra finely punctatestriate.

Head very finely and closely punctured on the lower portion, the middle with a fovea; eyes very large, black; antennæ: the second joint thick, moniliform, third very short, fourth slightly, fifth and following three joints strongly transverse, the rest wanting in the type-specimen. Thorax two and a half times as broad as long, of equal width, lateral margins feebly rounded near base, posterior angles distinct, surface minutely and irregularly punctured with the interstices still more finely punctate. Scutellum broad, triangular, impunctate. Elytra without traces of lateral lobes, very elongate and parallel with about twelve rows of fine punctures, rather irregularly placed, these rows continue to the apex, interstices with some minute punctures here and there. Legs and tarsi very short.

Length $6 \mathrm{~mm}$.

Hab. Northern India (Brit. Mus.).

A narrow and elongate species of bright flavous coloration and distinguished by the finely punctate-striate elytra. A single (apparently female) specinen is before me in which the last abdominal segment has a small but deep fovea. 


\section{Gynandrophthalma nigrotibialis, sp. $n$.}

o. Bods beneath, antennæ (basal joints excepted), tibix and tarsi black; above fulvous, shining.

Elongate and subcrlindrical; head entirely impunctate, clypeus at base impressed with some small forer placed semicircularly, anterior margin rather deeply subquadrately emarginate; labrum nearly black ; antennæ comparatively long, basal four joints fulvous, rest black, third joint as long as the fourth, thinner but scarcely longer than the second, following joints subquadrately widened. Thorax very short and transverse, nearly three times as broad as long, sides obliquely narrowed anteriorly, posterior angles rounded, posterior margin sinuate near middle, median lobe broad but slightly produced, surface impunctate. Scutellum slightly longer than broad, apex truncate. Flytra conrex, parallel-sided, without humeral lobes, scarcely perceptibly punctured. Legs elongate, the anterior pair slightly longer than the others, their tarsi rather long.

Length $4 \frac{1}{2} \mathrm{~mm}$.

Hab. Nilgiris (Andrences). Type in Coll. H. E. Andrewes.

The deeply emarginate clypeus, strongly transverse thorax, and rather elongate legs are more characteristic of the African genus Damia than of the present one; since these differences, however, are apparently sexual only, I have left the species in Gynandrophthalma. It is a much smaller species than $G$. wallarliensis.

\section{Gynandrophthalma wallardiensis, sp. n.}

Above pale fulvous, beneath black; tibiæ black, extreme base fulvous.

Head longitudinally grooved between the eyes, rather elosely but irregularly punctured; clypeus transversely depressed, anteriorly feebly emarginate; antennæ with the basal three joints fulvous, the rest black, very broadly transversely dilated. Thorax strongly transverse and short, the sides and the posterior angles feebly rounded, median lobe very broad but feeble and straight; the disc sparingly and very minutely punctured at the sides, with several short transverse depressions near the base seen anteriorly, only in certain lights. Scutellum broadly triangular, pointed. Elytra elongate, without humeral lobes, very finely punctured in irregular rows which are entirely obsolete near the apex. Beneath black. The first joint of the tarsi longer than the second.

Length $6 \frac{1}{2} \mathrm{~mm}$.

$H a b$. Travancore: Wallardi (Coll. Jacoby).

This is a very elongate, subcylindrical species. It agrees with Etheomorpla in that the first joint of the tarsi is longer than the second, but differs in the absence of elytral humeral lobes; the antennæ are rather long, extending to the base of the thorax, the latter, on the contrary, is short and transverse; there is an entire absence of any spots on the upper surface. 
209. Gynandrophthalma divisa, Jac. Ann. Mus. Civ. Genova, xxvii, 1889, p. 156.

Gynandrophthalma indica, Jac. Ann. Soc. Ent. Belg. xxxix, 1895, p. 263.

Pale fulvous; antennx (the basal joints excepted) and tarsi black; posterior portion of the elytra more or less pale.

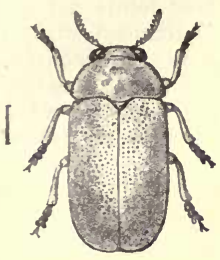

Fig. 29.-Gynaulrophthalma divisa.

Head shining, impressed with a few very minute punctures, a fovea between the eyes; anterior margin of clypeus concavely emarginate; antennæ extending to the base of the thorax, basal four joints fulvous, third joint very small, much smaller than second. Thorax quite twice as broad as long, sides strongly rounded and narrowed in front, angles obsolete, posterior margin straight at sides, median lobe very slightly produced, surface entirely impunctate, shining. Scutellum triangular, pointed. Elytra parallel-sided, finely punctured in irregular rows that diminish in depth towards apex. Body beneath clothed with yellowish pubescence, the breast often darker.

Length 3-5 mm.

Hab. Southern Bombay: Belgaum; Malabar Coast; Ceylon. Burma : Bhamo, Karennee.

This species has by an oversight been described under two different names, the first of which only can stand; the pale colour, elytral puncturation arranged in rows and the black tarsi well distinguish the insect.

210. Gynandrophthalma sikhima, Jac. Ann. Soc. Ent. Bely. xlvii, 1903, p. 86 .

Pale fulvous above and beneath; the tarsi black.

Elongate, subcylindrical; head with deep central fovea, impunctate; clypeus subtriangularly emarginate, in front very finely strigose; eyes very large; antennæ black, extending to the base of the thorax, basal three joints flavous, fourth and following joints strongly triangularly widened. Thorax ratber more than twice as broad as long, sides rounded, median lobe truncate, feebly produced, angles rather obtuse, surface impunctate, very obsoletely marked with five or six fuscous spots. Scutellum raised, apex thickened but pointed. Elytra very finely and rather closely punctured.

Length $6 \mathrm{~mm}$.

$H a b$ Sikhim.

Allied to G. chrysomeloides, Lacord. but larger, the tarsi black, elytra not punctate-striate; differs from $G$. indica in the black underside and other details. 


\section{Pale with darker longitudinal stripes.}

\section{Gynandrophthalma nigrosuturalis, sp. $n$.}

Flavous; antennæ, tibiæ, tarsi and breast more or less black. Elytra with suture and margins deep black.

Head impunctate; eyes large; labrum black; clypeus with some narrow sinuate depressions at base that indicate the separation from the face; antennæ black, basal two or three joints flavous. Thorax nearly three times as broad as long, sides rounded, surface very shining, impunctate. Scutellum black, broad and convex. Elytra subcylindrical and elongate, very finely and rather remotely punctured, punctures here and there arranged in irregular rows, the sutural black stripe angularly widened below base, the lateral stripe gradually but slightly widened at middle and at apex.

Length $3 \mathrm{~mm}$.

Hab. Nilgiris (H. L. Andrewes).

Larger than $G$.planifrons; head and thorax without band and spot, elytral black margins broader and deep black.

\section{Gynandrophthalma crucipennis, sp. n.}

Fulvous; the head and breast black ; elytra flavous, a marginal band, widened at the base and apex, and a sutural spot behind the middle black; legs flavous, tarsi fuscous.

Head black on the upper portion, the middle with a punctured depression of elongate shape, lower portion fulvous, labrum black; eyes large; antennæ black, extending to the base of the elytra ( 9 ), the basal two or three joints fulvous; fourth and following joints strongly transverse. Thorax scarcely twice as broad as long, fulvous, shining, the lateral margins straight, the posterior angles rounded, the basal margin with a scarcely perceptibly produced median lobe; the surface impunctate, very shining, fulvous. Scutellum broad, trigonal, impunctate, black. Elytra rather elongate, slightly transversely depressed below the base, very feebly lobed at the shoulders, finely punctured in closely approximate irregular rows, a black longitudinal stripe along the sides that widens at the base into a large spot and at the apex into a transverse band, the suture is likewise narrowly black and a transverse short band extends across it behind the middle. Body below finely pubescent, the breast black, the abdomen more or less fulvous but stained with piceous; apex of the tibiæ and the tarsi slightly stained with fuscous, the first joint of the latter rather elongate, about as long as the following two joints united; anterior legs of the male longer than the others.

Length $2 \frac{1}{2} \mathrm{~mm}$.

Hab. Burma : Ruby Mines (Doherty). Type in Brit. Mus.

The above description is that of the male; in the female the entire head is black, the antennæ and legs are shorter and the elytra are more strongly punctured. In both sexes the pygidium is covered by the elytra, but in the male it is of a more elongate subcylindrical shape. 
213. Gynandrophthalma nilgiriensis, Jac. Ann. Soc. Ent. Belg. xlvii, 1903, p. 85.

Flavous; antennæ and sides of breast blackish, scutellum black; elytra with a broad sutural band, widened at the middle, and a short stripe near lateral margins black.

Head impunctate, shining, transversely

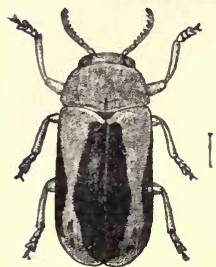

Fig. 30.-Gynandrophthalma nilgiriensis. grooved between the eyes, the latter very slightly notched; clypeus obsoletely separated, deflexed anteriorly, its anterior border feebly emarginate; antenuæ short, black, basal three joints flavous, fourth and following transversely widened, terminal joint pointed. Thorax quite twice as broad as long, sides rather rounded towards base, angles distinct, median lobe very slight, surface impunctate. Scutellum broad, pointed, its extreme apex fulvous. Elytra elongate, subcylindrical, slightly widened posteriorly, finely and obsoletely punctured, the black sutural band occupies the greater portion of the disc and extends from base to apex: marginal band narrow, slightly widened at middle, extends from below the shoulders to near the apex. Legs flavous.

Length $4 \mathrm{~mm}$.

$H a b$. Nilgiris.

Quite differently marked from any other Indian species of the genus.

214. Gynandrophthalma striatipennis, Jac. Ann. Soc. Ent. Belg. xlvii, 1903, p. 85.

o. Head metallic green; antennæ and breast black; thorax fulvous, with central greenish patch; elytra

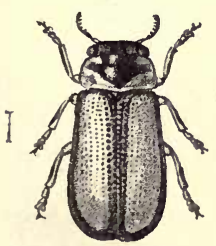

Fig. 31.-Gynandrophthalma striatipennis.

flarous, suture and sides metallic greenish; abdomen and legs fulrous.

Narrow and elongate; head impunctate, obsoletely transversely grooved between the eyes; base of clypeus with two deep forer, its anterior portion and labrum flavous; antennæ with basal three joints fulvous, fourth and following joints transversely widened. Thorax more than twice as broad as long, sides nearly straight, angles obtuse ; disc with an anterior and posterior transverse sulcus, the latter interrupted in the middle, impunctate; a large greenish patch in the middle strongly pointed at base, sides fulvous. Scutellum metallic green. Elytra strongly and regularly punctate-striate, all the margins narrowly greenish. Body beneath clothed with white pubescence. Femora in the 
middle and tibiæ at apex greenish ; tarsi rather slender, first joint twice as long as the second.

․ Larger, central patch of thorax wider and subquadrate; elytra entirely greenish or blue, puncturation much finer.

Length 3-4 mm.

$H a b$. Nilgiris.

Well separated from any of its allies by the bisulcate thorax and system of coloration.

215. Gynandrophthalma imitans, Jac. Ann. Soc. Ent. Belg. xlvii, 1903 , p. 84.

Flavous ; vertex of head, antennæ, breast and tarsi black ; thorax

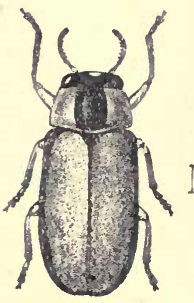

Fig. 32.-Gynandrophthalma imitans. with a very large medial black spot; elytra flavous, narrowly margined with black.

Head black, impunctate, very shining, lower portion and labrum flavous, upper purtion convex, a small fovea between the eyes; antenns with the basal three joints flavous, fourth and following strongly transverse. Thorax more than twice as broad as long, sides nearly straight, slightly narrowed towards the apex, surface impunctate, median lobe scarcely indicated. Scutellum very broad, black, apex raised and pointed. Elytra narrow and parallel, suture narrowly, sides more broadly black; epipleuræ of the flavous ground-colour. Legs flavous, apex of tibiæ and the tarsi black, latter slightly elongate, anterior legs longer than the others.

Length $3 \mathrm{~mm}$.

$H a b$. Nilgiris.

Smaller than $G$. striatipennis, thorax without sulci, elytra irregularly punctured.

Elytra pale, posterior portion move or less black or blue.

216. Gynandrophthalma terminalis, Lefev. Bull. Soc. Ent. France, 1883 , p. cxii.

Rufo-testaceous; antennæ and legs fuscous; elytra with a large posterior patch that extends to the apices black.

"Subelongate, ovate, convex, clothed with grey pubescence beneath, above shining. Thorax smooth. Elytra scarcely perceptibly punctured.

Length $4 \frac{1}{2}-6 \mathrm{~mm}$.

$H a b$. Ramnad, India."

The above brief description is all that the author has given. 


\section{Gynandrophthalma flavobasalis, sp. $n$.}

o. Flavous; elytra with the posterior portion black.

Elongate and parallel-sided; head with a deep elongate depression between the eyes and a shallow transverse groore above the latter; palpi robust and thickened; antennæ not extending to base of thorax, flavous, third joint elongate, triangular, following joints strongly transverse. Thorax twice as broad as long, sides feebly rounded, a finely punctured short transverse groove on the middle behind anterior margin, posterior angles obtusely rounded; median lobe straight; surface impunctate, some shallow transverse depressions on the sides. Scutellum broadly triangular. Elytra not lobed at sides, not perceptibly punctured, the flavous portion extends to nearly the middle, rest of surface black. Body beneath clothed with long fulvous pubescence. Anterior legs longer than the others, tarsi short.

Length $6 \mathrm{~mm}$.

$H a b$. Southern India (Brit. Mus.).

Whether this species is identical with G.terminalis, Lefèr. from Hindustan it it impossible to say, as the anthor has not given any structural details; he describes his species, however, as having darkened antennæ and legs, an elytral apical large spot and scarcely perceptibly puncturing; none of these characters applies to the single male specimen before me.

\section{Othervise marked.}

218. Gynanḋophthalma subdivisa, Jac. Mém. Ent. Soc. Belg. vii, 1900 , p. 98.

Black; lower portion of head flavous, disc of thorax piceous,

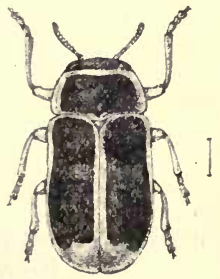

Fig. 33.-Gynandrophthalma subdivisa. margins flavous; elytra nearly black, margins narrowly, apex more broadly and an obscure transverse stripe at middle, flavous.

Head impunctate, shining, upper portion black, obsoletely transversely depressed between the eyes; clypeus flavous, separated from the face by a triangular depression, anterior edge deeply triangularly emarginate; labrum piceous; antennre black, not extending to the middle of the thorax, basal two or three joints flavous. Thorax transverse, twice as broad as long, sides nearly straight as are the anterior and posterior margins, surface entirely impunctate, shining. Scutellum piceous, triangular. Elytra finely and irregularly punctured in rows; legs flarous, femora more or less black.

Lenyth $5 \mathrm{~mm}$. 
$H a b$. India ; Assam : Shillong.

Can be distinguished by the nearly black disc of the thorax and by the elytra having the margins narrowly flavous, also by an indication more or less distinctly marked of the elytral black portion being divided at the middle into two parts.

\section{Gynandrophthalma lævipennis, sp. n.}

đ. Fulvous; elytra black, a triangularly elongate space below the scutellum and the lateral margins anteriorly more or less fulvous.

Elongate; head with a few fine punctures and a central fovea which forms the middle of $\Omega$ shallow transverse groove; clypeus rather slightly emarginate in front; antennæ fulvous, the terminal joints strongly transverse. Thorax twice as broad as long, sides feebly rounded, posterior angles distinct; median lobe only indicated. Elytra nearly parallel-sided, without any trace of puncturation, very shining, very feebly lobed at the sides. Body beneath shining fulvous; abdomen clothed with rather long fulvous pubescence. Tarsi short, the first joint scarcely longer than the second. Pygidium entirely covered.

Length $5 \frac{1}{2} \mathrm{~mm}$.

$H a b$. Southern India (Bvit. Mus.).

In one specimen, the black colour of the elytra extends higher upwards to the base and sideways, leaving the lateral margins fulvous only at their apices.

220. Gynandrophthalma fabrei, Lefêv. Bull. Soc. Ent. Franct, 1883, p. cxi.

"Fulvous above, black beneath; antennæ with basal three joints fulvous, rest black. Elytra with a very broad transverse band from before middle to near apex, cyaneous. Legs fulvous, base of femora, apex of tibiæ and tarsi more or less dark. Thorax smooth, elytra very finely punctured.

Var. Elytra each with two blue spots, sometimes confluent behind the middle.

Length 5-6 $\mathrm{mm}$.

Hab. India : Ramnad."

Clytra duvivieri, Jac. seems a very closely allied species, but the elytral band is much smaller and the legs are entirely flavous. Lefèvre's description of $G$. fabrei, quoted above, is not detailed enough for certain recognition. 


\section{Genus ETHEOMORPHA.}

Etheomorpha, Lacord. Mon. Phytoph. ii, 1848, p. 311; Chapvis, Gen. Coleopt. x, 1874, p. 123.

Type, A. nematoides, Lacord., from Africa.

Range. Africa, India, and Australia.

Of variable shape, sometimes cylindrical, sometimes subovate.

Head small, very short, smooth, perpendicular ; mandibles very short; eyes rather small, not pubescent near margin; antenna more or less robust, second and third joints short, subconical, following joints triangular. Thorax variable, posterior angles generally distinct. Scutellum large. Elytra more or less strongly lobed at sides. Legs feeble, tarsi short, the first joint longer than the second, third small, fourth slender. Pygidium exposed.

Very closely allied to Gynandrophthalma; the antennæ more robust; the elytra with more or less distinct epipleural lobes and shorter tarsi, the pygidium not covered by elytra. The genus is also closely allied to Aspidolopha and Peploptera; the species are however, variable in appearance and shape generally; the thorax especially varies greatly. The species of AEtheomorpha are not generically well defined but represent rather transitional forms.

\section{Elytra punctate-striate.}

221. Etheomorpha fallax, Lacord. Mon. Phytoph. ii, 1848, p. 314.

" $\delta$. Entirely flavous, short and oblong; bead smooth, with three fover placed triangularly between the eyes; clypeus feebly enarginate; eyes large, nearly entire; antennæ fulvous, rather longer than the thorax. Thorax more than twice as broad as long, subcylindrical, sides straight, posterior angles strongly rounded, scarcely lobed at middle, very smooth and impunctate. Scutellum large, triangular. Elytra rather strongly lobed at the sides, with ten rows of deep punctures, entirely obsolete near apex, another short row near suture at base. Legs short and slender like the tarsi." (Lacorclaive.)

Length $4 \mathrm{~mm}$.

Hab. India (Lacord.). Malabar Coast: Mahé (Coll. Jacoby).

Lacordaire gives the shape of the female as short and slightly narrowed posteriorly; my specimens, which agree in all other respects with the type, are more elongate and posteriorly widened; the antennæ do not extend to the base of the thorax. The species may be known principally by the strong and regularly punctatestriate elytra, impunctate thorax, and unicolorous upper-and underside. 
222. Etheomorpha suturata, Jac. (Clytra) Ann. Ent. Soc. Belg. xlii, 1898 , p. 185.

Var. Atheomorpha multiplagiata, Jac. Ann. Ent. Soc. Belg. xlvii, 1903 , p. 87.

Fulvous; thorax with three spots; elytra with a sutural, posteriorly wideped band, sides and apex, a transverse band behind the middle, a humeral and central spot near margins, black; tibiæ at apex and tarsi black.

Narrow and parallel-sided; vertex of head black, impunctate; clypeus concavely emarginate at the anterior edge; antennæ extending to the base of the thorax, basal three joints fulvous, rest fuscous. Thorax short and transverse, more than twice as broad as long, sides straight, posterior angles obtuse; surface extremely minutely punctured, a round black spot on each side and a somewhat heart-shaped one on the middle. Scutellum black. Elytra with a slight basal depression at suture, distinctly and regularly punctate-striate, the suture with black band from base to middle, its end suddenly widened, sides with another band to which is attached a humeral and a median black spot and a transverse band behind the middle; pygidium partly uncovered by the elytra, epipleural lobes of latter feeble. Body beneath clothed with silvery pubescence, breast more or less fuscous; anterior femora, apex of the others and base of tibiæ fulvous; tarsi rather broad.

Length 3-4 $\frac{1}{2}$ mm.

Hab. Bengal: Mandar, Barway; Nilgiris; Malabar Coast: Mahé.

This species is neither typical of Etheomorpha nor of Clytra, having some of the characters of each; it is more elongate and narrower than $\mathbb{E}$. fallax, Lacord. but agrees with the latter in the punctate-striate elytra. The above description is that of a strongly marked specimen; in many others all the markings are greatly reduced and in some only the lateral elytral stripes and a small sutural spot behind the middle remain; many are intermediate. I have placed it in Etheomorpha on account of the elytral lobe and the partly free pygidium, but as a matter of fact the latter character only applies to some specimens, in others it is quite covered by the elytra. The species must stand as $\mathcal{E}$. suturate with $E$. multiplagiata as a variety.

\section{Elytra not or very slightly punctate-striate.}

223. Eetheomorpha nigropicta, Lefèv. (Gynandrophthalma) Bull. Soc. Ent. Belg. xxxv, 1891, p. cclii.

Etheomorpha cincta, Weise, Deut. ent. Zeit. 1903, p. 28.

Testaceous ; antennre (the basal three joints excepted), sides of breast and apical abdominal segment partly blackish; elytra with a black lateral stripe and a spot in front of and posterior to the middle near the suture. 
Rather broad and convex; head, thorax and scutellum as in E. fullax. Elytra with the

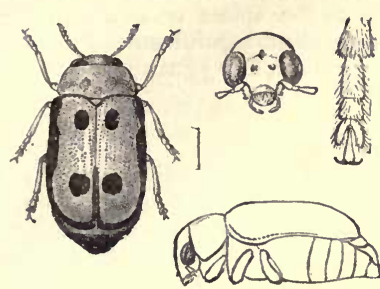

Fig. 34.-Etheomorpha nigropicta. black lateral band of unequal width, as if composed of three confluent spots, of which the first is placed on the shoulders, the second just before the middle and the third at the apex; of the other spots the first is situated below the base, longer than broad and ovate, the other posterior to the middle and close to the suture, irregularly rounded

or transverse and with a tendency to join the second dilatation of the marginal stripe. Beneath obscure pale fulvous ; sides of breast, abdomen and the pygidium blackish.

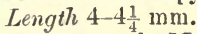

Hab. Bengal : Mandar; Tranquebar, Kanara, Belgaum; Ceylon.

This species seems subject to great variation in regard to the elytral markings, which in some specimens are only indicated and even entirely absent; the elytra are finely and irregularly striatepunctate, nearly smooth near apex. In some of the Indian specimens, which are of rather more elongate shape, the elytral stripe is interrupted and the second spot unites with it. AE. pictipennis, Jac. closely resembles the present species, but may be distinguished by the 4-spotted thorax and strong elytral puncturation.

There is but little doubt that $E$. cincta, Weise, is identical with Lefèvre's species; the only difference seems to lie in the sutural spot which in Weise's species is separated instead of confluent, but the genus in which Weise has placed the insect is no doubt the correct one.

\section{Elytra with longitudinal bands.}

\section{Ettheomorpha nigromarginata, sp. n.}

*. Flarous; the base of the head, the scutellum and the underside black. Elytra with a marginal black stripe from base to apex.

Subcylindrical and parallel-sided; the head with three more or less distinct fover, placed triangularly, nearly impunctate, the upper portion as far as the eyes black, the rest flavous; clypeus feebly emarginate; antennæ fuscous, extending to the base of the elytra, basal two or three joints flavous, fourth and following joints transverse. Thorax about two and a balf times broader than long, sides nearly straight, posterior angles rather indistinct, surface impunctate, with an obsolete transverse depression near the posterior angles. Scutellum trigonal, impunctate, apex slightly truncate. Elytra feebly lobed below the shoulders, the 
puncturation fine and arranged in irregular rows, the black stripe placed close to the lateral margins, in width about one-fourth that of the elytra either extends to the apices or is abbreviated before that point. Body finely pubescent, legs fulvous. Pygidium not covered or only partly so. Tarsi short, first joint slightly longer than the second.

Length of $3 \frac{1}{2} \mathrm{~mm}$. ; 우 $4 \frac{1}{2} \mathrm{~mm}$.

$H a b$. Pondicherry (Coll. Jacoby).

In three male specimens before me there is no difference of any importance, but in the female, which is of a more robust shape and larger, the lateral elytral stripe is represented by a small humeral spot and a median short stripe; the head has the three foveæ more strongly marked.

\section{Elytra unicolorous fulvous or flavous, sometimes spotted.}

225. Etheomorpha inornata, sp. n.

Fulvous; terminal joints of antennæ black; disc of elytra paler than the sides.

Short and broad; head impunctate, with two deep depressions between the eyes; clypeus with a few fine punctures; autennæ extending to the base of the thorax, basal four joints fulvous, rest black, fifth and following joints strongly triangularly widened. Thorax very short and strongly transverse, three times as broad as long; sides rather strongly rounded; basal margin preceded by a narrow groove; surface entirely impunctate. Scutellum broadly triangular. Elytra oblong, slightly widened posteriorly, irregularly closely and rather strongly punctured, punctures slightly finer towards apex, sides of darker colour than disc; beneath finely pubescent. Legs pale, first joint of tarsi slightly longer than the second.

Length $3 \frac{1}{2} \mathrm{~mm}$.

$H a b$. Nilgiris (H. L. Andrewes).

A species rather remarkable on account of the short and more than usually transverse thorax; in one specimen the depressions of the head are but feebly marked and the thorax has a short transverse sulcus near the posterior angles.

\section{Extheomorpha vinula, Weise, Deut. ent. Zeit. 1903, p. 29.}

c. Beneath obscure ferruginous; antennæ and legs testaceous; head and thorax yellowish-white; scutellum and elytra rufous.

Head and thorax nearly impunctate, vertex feebly convex, the usual three foveæ only indicated; antennæ widened from the fifth joint onwards. Thorax nearly smooth. Elytra very obsoletely punctured in irregular rows, the interstices minutely punctured; pygidium evenly rounded at margin.

Length $4 \frac{1}{2} \mathrm{~mm}$.

$H a b$. Ceylon: Kandy.

Of similar shape to $\mathscr{E}$. cincta, slightly broader anteriorly, rather 
more cylindrical, less rounded posteriorly; the anteunæ widened from the fifth joint only.

227. Etheomorpha sodalis, Lacord. Mon. Phytoph. ii, 1848, p. 313.

Fulvous, opaque; breast, abdomen and legs black, finely pubescent.

$\delta$. Moderately elongate and robust; head very flat and smooth; clypeus slightly triangularly emarginate; eyes large; basal seven joints of antennæ robust, black, base fulvous, the rest wanting in the only specimen I have seen. Thorax two and a half times broader than long, nearly straight at sides, posterior angles rounded, median lobe feeble, surface impunctate. Scutellum triangularly elongate, smooth. Elytra rather strongly lobed at the sides, finely and irregularly punctured. Legs moderately robust; last ventral segment of the abdomen with a small fovea.

Length $6 \mathrm{~mm}$.

$H a b$. India.

Resembles at first sight Diapromorpha melanopus, but the eyes and shape of head are very different, the latter is rounded.

\section{Etheomorpha cribellata, sp. n.}

§. Black; basal joints of antennæ, labrum, tibiæ and tarsi flavous. Thorax black anteriorly, fulvous at base. Elytra fulrous or with two spots before and a band behind the middle black.

Elongate, subcylindrical; head shining, vertex nearly impunctate, finely strigose above the eyes, space between latter rather deeply depressed, strongly punctured; clypeus finely and closely punctured and wrinkled; labrum flavous; antennæ black, not extending to base of thorax, basal four joints flavous, second and third

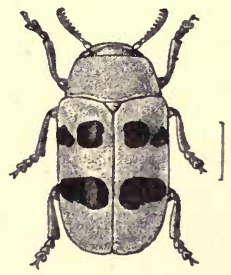

Fig. 35.-Atheomorpha cribellata.

very small, following joints strongly transversely serrate; eyes very large. Thorax rather more than twice as broad as long, sides rounded, angles distinct, sides near base with a transverse depressiou; surface very minutely and closely punctured, interstices finely granulate. Scutellum broadly elongate, apex truncate. Elytra subcylindrical, with feebly developed but distinct humeral lobes, entire surface finely punctured and transversely wrinkled, 
opaque. Underside and legs clothed with long silvery pubescence ; tarsi rather robust, first joint scarcely twice as long as second, triangularly widened.

6. Elytra with two spots below base and transverse band behind the middle, not extending to margins, black. Thorax and legs black.

$\checkmark a$. Elytra entirely fulvous.

Length $5 \frac{1}{2}-6 \frac{1}{2} \mathrm{~mm}$.

Hab. Nilgiris (Capt. Downing).

The peculiar finely wrinkled and opaque elytra differ from those of any other species of the genus. Which of the forms, the one with spotted or the one with the unspotted elytra, is the normal one cannot be decided at present for lack of material. Of the male only a single specimen is before me; of the female there are four unspotted and one spotted examples, in all these the legs are entirely black.

\section{Elytra with transverse bands.}

\section{Ettheomorpha virgula, sp. n.}

Pale fulvous; terminal joints of antennæ, the breast and the pygidium blackish; elytra with a spot near the scutellum and a transverse band near the apex black, the latter strongly widened near the outer margins.

In shape elongate, posteriorly slightly widened. Head impunctate, with three small foveæ placed triangularly; antennæ extending to the base of the elytra, the basal four joints flavous, the rest nearly black; third and following joints transverse. Thorax about twice as broad as long, slightly narrowed anteriorly; posterior angles distinct, the sides nearly straight, the surface entirely impunctate, without any depressions; median lobe very slightly produced, perfectly straight. Scutellum broadly triangular, smooth. Elytra strongly punctured in very closely arranged irregular rows; they do not cover the pygidium but have distinct humeral lobes; a round spot near the scutellum and a posterior band black, the latter abruptly and strongly widened at the sides extends upwards along the lateral margins as far as the middle. Abdomen strongly swollen, finely pubescent, fulvous or black; the pygidium of the latter colour in the dark specimens.

$V a r$. Elytral spot absent, body beneath black.

Length $4 \frac{1}{2} \mathrm{~mm}$.

$H a b$. Northern India. Type in Brit. Mus.

230. Ettheomorpha pictipennis, Jac. (Gynandrophthalma) Ann. Mus. Civ. Genova, xxxii, 1892, p. 883.

Fulvous; base of head and terminal joints of antennæ black; thorax with four black spots; elytra with a sinuate transverse band at base, another behind the middle and the lateral and apical margins, black.

Short and broadly ovate; head with a few minute punctures between eyes; clypeus fulvous; antennæ not extending to base 
of thorax, basal four joints fulvous, rest black. Thorax strongly transverse, sides rounded; posterior margin straight at sides, scarcely produced at middle and truncate at the latter place; surface entirely impunctate, with four black spots placed transversely, the intermediate spots generally larger and of triangular shape. Scutellum piceous or black, apex truncate. Elytra rather strongly and irregularly punctured, the puncturation gradually diminishing, entirely obsolete at apex; the transverse band narrow, rather deeply sinuate along the lower border, placed at base and extended to the nuargins; second band immediately behind the middle and connected with the black margins at sides and apex. Underside more or less marked with black, thickly pubescent; legs fulvous, apex of tibiæ and the tarsi fuscous.

Length $4 \mathrm{~mm}$.

Hab. Burma : Karen Hills; Palon.

The black markings of this species vary greatly ; in some specimens the middle spots of the thorax are joined and form a short transverse band; the elytral basal band does not extend to suture and the second band is of regular shape, not only connected at the sides with the marginal stripe, but also at posterior portion of suture which is likewise black. Sometimes the head is almost entirely fulvous, while one or more of the thoracic spots are obsolete. The species by its distinctly lateral elytral lobes and strongly inflated abdomen is placed in Etheomorpha.

\section{Etheomorpha unifasciata, sp. n.}

Black; thorax with margins and disc more or less fulvous; elytra flavous, with a short transverse black band near apex.

Elongate and subcylindrical. Head transversely grooved between the eyes, these very large; lower portion of face more or less fulvous, rather closely and strongly punctured; anterior margin of clypeus emarginate. Antennæ not extended to base of thorax, pale fulvous, second and third joints small, equal ; fourth and following joints transverse, but not serrate or toothed; terminal two joints smaller and ovate. Thorax twice as broad as long, subcylindrical, sides strongly deflexed, lateral margins feebly rounded, posterior angles distinct, sides with a distinct oblique groove near the base; surface closely and finely punctured, the whole dise more or less black in appearance as if crossed by a broad transverse band. Scutellum fulvous. Pygidium partly uncovered. Body and legs clothed with silvery pubescence. First joint of tarsi distinctly longer than the second.

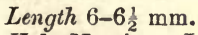

Hab. Northern India; Bengal (Brit. Mus.).

The markings of the thorax are obscure in the specimens before me, but may probably be better defined in others; the elytral band is narrow and does not quite extend to the extreme margins. 


\section{Ettheomorpha subrugosa, sp. n.}

Elongate, flavous ; anterior portion of head black ; thorax with a transverse black band; scutellum black; elytra with a transverse band before middle, surrounding the shoulders, another band behind the middle and the apex bluish-black.

Head impunctate; the entire upper portion as far as the lower portion of the eyes black, the rest flavous; a shallow transverse groove between the eyes, followed by two obsolete foveæ; antennæ wanting in the type and only specimen. Thorax two and a half times broader than long, the sides rather rounded, a deep transverse groove at each side near the base; surface impunctate, flavous with a broad transverse band at base; not quite extending to the lateral margins and with an indentation in the middle of the anterior border. Scutellum black. Elytra very closely and strongly punctured with interstices finely rugose, not covering the pygidium; the first band not extending quite to suture, deeply indented above and reaching to the base at the sides, second band broad and nearly regular, extending across the suture to either margin; apical spot subtriangular. Breast and pygidium black; legs slightly stained with black. First joint of posterior tarsi much longer than the second.

Length $5 \mathrm{~mm}$.

Hab. Assam (Brit. Mus.).

Distinguished principally by the rugosely punctured elytra.

\section{Elytra fulvous with black spots.}

233. Etheomorpha 14-punctata, Jac. (Aspidolopha) Ann. Soc. Ent. Belg. xxxix, 1895, p. 260.

Fulvous; head black; thorax with four black spots, placed transversely; elytra each with five spots (2.2.1); beneath sometimes spotted with black.

Head impunctate or nearly so, space in front of eyes pubescent, obsoletely foveolate at middle; anterior margin of clypeus nearly straight; antennæ fuscous, not extending to base of thorax, basal three joints fulvous, third joint much longer than second. Thorax three times as broad as long, narrowed in front, sides and the posterior angles moderately rounded, posterior margin sinuate at the sides; median lobe scarcely prominent; surface entirely impunctate. Scutellum black, broad, apex truncate, base pubescent, rest of surface smooth. Elytra distinctly lobed at base of epipleuræ, punctured in rather closely approximate and distinct rows; a humeral spot, one near scutellum, two transversely posterior to the middle and one at extreme apex of each elytron. Beneath clothed with long grey pubescence, breast and some spots 
on abdomen black. First joint of tarsi double the length of second. Pygidium free.

\section{Length $4 \mathrm{~mm}$.}

$H a b$. S. Bombay : Kanara.

This species, on account of the transverse thorax and length of the tarsi, agrees better with the characters of Aitheomorpha than with those of Aspidolopha. The extreme apical elytral spot is absent in some specimens.

\section{E⿰theomorpha tripunctata, sp. n.}

Fulvous; terminal joints of antennæ, breast and abdomen black; elytra with three small black spots on each (2.1).

Rather broadly subcylindrical; head impunctate, with three deep foveæ, placed triangularly; eyes large; clypeus moderately emarginate in front; antennæ short, basal three joints fulvous, rest black, fourth and following joints strongly transverse. Thorax about two and a half times broader than long, lateral margins rather strongly rounded, posterior angles indistinct, median lobe very short; surface convex, impunctate, with an irregularly shaped fovea at each side near base. Scutellum pointed, broad. Elytra distinctly lobed at the sides behind the shoulders, convex, finely punctured in closely approximate rows; apex nearly impunctate; each elytron with a small humeral spot, another near the scutellum and a third on the middle close to the lateral margins. Abdomen strongly inflated, finely pubescent, breast also pubescent; legs fulvous. First joint of tarsi twice as long as second. Pygidium uncovered.

Length $4 \frac{1}{2} \mathrm{~mm}$.

Hab. Nilgiris (Coll. H. E. Andrewes).

Described from a single specimen.

\section{Extheomorpha assamensis, sp. $n$.}

Flavous; labrum, antennæ and scutellum black; elytra yellowish, the margins narrowly and three spots, one below the other, on each elytron, black.

Subcylindrical, nearly parallel-sided; the head impunctate, with three small foveæ, placed triangularly; antennæ with the basal three joints flavous, fourth and following joints transverse. Thorax nearly three times as broad as long, the sides nearly straight, the posterior angles indistinct, surface impunctate, with a short transverse depression near posterior angles. Scutellum broadly triangular, impunctate. Elytra with short lateral humeral lobes, very strongly punctured, the punctures form rather irregular but distinct rows and get minute towards the apex, all the margins narrowly black; of the spots, one is placed on the humeral callus, the other on the middle and the 
third near the apex. Body beneath flavous, the upper portion of the breast, the apex of the tibiæ and the tarsi more or less black. Pygidium not covered by the elytra, its lower portion black.

Length $3 \frac{1}{2} \mathrm{~mm}$.

Hab. Assam; Siam. Type in Brit. Mus.

A small species that differs from all its allies in the number and position of the elytral spots.

236. सtheomorpha decemnotata, Jac. (Gynandrophthalma) Ann. Mus. Civ. Genova, xxxii, 1892, p. 884.

Fulvous; base of head, terminal joints of antennæ, scutellum, and underside (partly) black. Elytra each with two spots at base, two behind the middle and one near apex, black.

Oblong-ovate, rather broad; head impunctate, upper half black, lower portion fulvous, the two colours separated by a transverse sulcus, at base of which

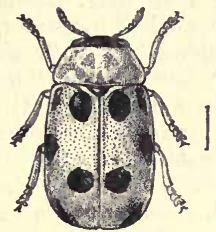

Fig. 36.--Ethecmorpha decemnotata. are three small depressions placed triangularly; eyes large and elongate, nearly entire; clypeus feebly emarginate, broad; labrum fulvous; antennæ rather long and robust, extending to the base of the elytra, basal three or four joints fulvous, rest black, third joint extremely small, fourth and following transversely dilated. Thorax nearly three times as broad as long, sides rounded, slightly narrowed anteriorly, impunctate, fulvous, sometimes with obscure fuscous markings. Scutellum triangular. Elytra very closely and rather strongly punctured in irregular rows, apex very obsoletely punctate ; each elytron with five black spots, one on the shoulders, another near the scutellum, one on the middle near the lateral margin, the fourth near the suture behind the middle, and the fifth narrow and elongate near the apical margin on the side. Body beneath clothed with silvery pubescence; legs fulvous. First joint of anterior tarsi longer than the second.

Length 4-5 mm.

Hab. Burma : Karen Hills.

Differs from $2 E$. 14-punctata, Jac., in the absence of thoracic spots and in the number and position of those on the elytra.

\section{Etheomorpha parvula, sp. n.}

Pale fulvous; head with a transverse black band; elytra with two spots near suture behind the middle, a humeral spot and a narrow marginal band near the middle of each elytron, blackishblue. 
Head transversely grooved and finely rugose between the eyes, this portion has the appearance as of a transverse black band across it, rest fulvous; vertex impunctate; clypeus with a few punctures; antennæ fuscous, extending

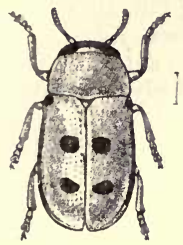

Fig. 37.

Etheomorpha parvula. to the base of the thorax, basal three joints fulvous. Thorax twice as broad as long, lateral margins feebly rounded, posterior angles distinct; surface with two indistinct depressions near the base at the sides, microscopically punctured. Elytra scarcely lobed at base, very finely rather regularly and closely punctured anteriorly, apex nearly smooth, the two spots on each elytron together form a square near the suture; the laterai stripe abbreviated anteriorly and posteriorly, beginning and terminating in line,with the spots. "Body beneath densely pubescent; legs fulvous, tibiæ black in the middle, tarsi short.

Length $3 \frac{1}{2} \mathrm{~mm}$.

$H a b$. Southern Bombay : Kanara (Coll. H. E. Andrewes).

A very small species, distinguished by the elytral markings and position of the same.

\section{Elytra pale with disc black.}

238. Etheomorpha maduraensis, sp. $n$.

o. Fulvous; terminal joints of antennæ and breast black. Elytra with base and apex pale fulvous, rest of disc black.

Head impunctate, with a central nar-

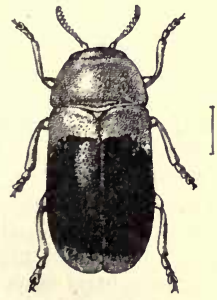

Fig. 38.

Etheomorpha maduraensis. row groove on the vertex, latter separated from lower portion by a deep transverse groove; intraocular space with three deep foreæ placed triangularly; clypeus nearly smooth, feebly emarginate in front; eyes large, ovate, nearly entire; antennæ robnst, extending to base of thorax, basal four joints fulvous, rest black, fourth and following joints very strongly transversely serrate. Thorax twice as broad as long, narrowed anteriorly, sides feebly rounded, posterior angles distinct, median lobe broad, very slightly marked; surface very minutely granulate and finely punctured. Scutellum broadly triangular. Elytra elongate, rather strongly lobed at the sides and with irregular rows of very fine punctures. 
Body beneath clothed with dense yellow pubescence. Tarsi broad and robust, first joint twice as long as second.

Length $4 \frac{1}{2} \mathrm{~mm}$.

$H a b$. Southern Bombay: Madura. Type in Coll. H. E. Andrewes.

In coloration similar to Gynandrophthalma fabrei, Lefèv., but the entire disc of the elytra is black, the antennæ and legs are differently coloured, and the thorax is finely granulate and punctured.

\section{Genus ASPIDOLOPHA.}

Aspidolopha, Lacord. Mon. Phytoph. ii, 1848, p. 252; Chapuis, Gen. Coléopt. x, 1874, p. 122.

Type, A. trimaculata, Fabr., from India.

Range. India and Malayan Islands.

Body short and robust, more or less narrowed posteriorly. Head generally with a band of pubescence in front of the eyes. Thorax short, strongly transverse and narrowed in front. Scutellum large, often carinate at apex. Elytra with very strongly produced epipleural lobes, not covering the pygidium. Abdomen often greatly inflated, protruding beyond the elytra at the sides. Legs feeble, tirst joint of tarsi slightly longer than the second.

Of somewhat peculiar short and compact shape, distinguished by the short and anteriorly narrowed thorax, the strong epipleural lobes of the elytra, carinate scutellum, and free pygidium.

239. Aspidolopha cærulea, Jac. Ann. Mus. Civ. Genova, xxxii, 1892, p. 882.

Head, breast, apex of tibiæ and the tarsi black; thorax flavous with central black band; elytra metallic dark blue; beneath fulvous; pygidium fuscous in the middle.

Head smooth, impunctate, with three small foveæ placed triangulariy ; labrum black; antennæ extending to the base of the thorax, basal three joints flavous. Thorax transverse, very short, more than twice as broad as long, sides rounded, narrowed in front, posterior margin only slightly produced in the middle; surface entirely impunctate, flavous at the sides; middle area with a longitudinal medially widened black band. Scutellum large, smooth. Elytra fulvous, with a triangular large central fuscous band, moderately convex, puncturation scarcely perceptible, basal lobe slightly produced, pygidium not covered. Abdominal segments with or without fuscous spots on the sides and middle.

Length $4 \mathrm{~mm}$.

Hab. Burma : Karennee. 
240. Aspidolopha costata, Jac. Ann. Mus. Civ. Genova, xxxii, 1892, p. 881.

Metallic blue; antennæ more or less piceous; elytra with a flavous transverse band behind the middle.

Broadly convex and nearly parallel-sided; head finely rugose between the eyes with a rather deep rounded depression; antennæ with the basal three joints obscure fulvous, third joint very small, rest triangularly dilated. Thorax strongly transverse, narrowed in front, posterior angles rounded; median lobe strongly produced, rounded; surface obliquely depressed at the sides near the base, sparingly punctured on the disc, very closely and strongly on the sides. Ścutellum very large, pubescent, bluish, apex longitudinally carinate. Elytra blue, very convex, subcylindrical, with ten rows of longitudinal costr, interstices strongly geminately punctured; the fulvous band broad, regular in shape and slightly oblique, placed immediately behind the base and extending to the middle. Underside sparingly pubescent; abdomen strongly inflated. Pygidium closely punctured, with a central ridge.

Var. Elytra flavous, the basal margin narrowly, the apex broadly blue.

Length $6 \mathrm{~mm}$.

$H a b$. Burma : Karennee. Tenasserim.

A. costata differs from all of its congeners by the sculpture of the elytra.

\section{Aspidolopha apicalis, sp. $n$.}

Blackish-blue; tibiæ and tarsi and the apex of the elytra fulvous.

Head finely punctured between the eyes, the latter very large, a narrow band of pubescence in front of their interior edge; labrum piceous; palpi fulvous; antennæ extending to the base of the thorax, black, basal three joints fulvous, fourth and following joints strongly transverse. Thorax about twice as broad as long, sides feebly rounded, base with a short depression near the posterior angles; surface strongly punctured at the sides and near the basal margin. Scutellum with a strongly raised central ridge at apex and a few punctures at base. Elytra closely and almost rugosely punctured, the puncturation much finer near the apex, the latter itself fulvous, the colour forming a round spot: rest of the surface dark blue. Body beneath closely covered with silky grey pubescence. Pygidium with a central ridge in the female. This sex has a broader shape and a more inflated abdomen.

Length 4-5 mm.

Hab. Assam : Patkai Mts. (Brit. Mus.).

Easily distinguished by the coloration of the elytra. 
242. Aspidolopha decora, Fab. (Clythra) Syst. Eleuth. ii, 1801, p. 35. Clytra amœna, Oliv. Ent. vi, 1808, p. 862, pl. 2, f. 25.

Metallic blue; elytra fulvous.

Slightly elongate and narrowed posteriorly; head rugosely punctured, with a band of grey pubescence in front of the eyes; antennæ obscure fulvous, the basal five joints testaceous. Thorax

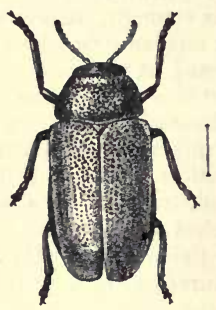

Fig. 39.

Aspidolopha decora. about one half broader than long, narrowed anteriorly, the sides nearly straight, posterior angles distinct; surface deeply and irregularly punctured, with some more or less distinct depressions at sides, median lobe short and slightly rounded. Scutellum broad, carinate at apex, base finely pubescent. Elytra very strongly and closely punctured, the punctures more or less arranged in rows, especially near the apex. Pygidium carinate in the middle. Underside clothed with grey pubescence.

Length 6-7 mm.

$H a b$. Bengal ; Nilgiris; Assam.

Except that it is smaller and the abdominal foveæ are absent, the male does not differ to any marked degree from the female. The species is without elytral markings and has the head and thorax as well as the legs and underside entirely metallic blue.

\section{Aspidolopha clavareaui, sp. $n$.}

Metallic blue; pubescent beneath; elytra fulvous.

Narrow and elongate; head rugose and longitudinally striate between the eyes, finely pubescent, the pubescence forms a silvery band in front of the eyes; anterior margin of clypeus nearly straight; labrum black; antennæ black, extending to the base of the thorax, basal three joints more or less fulvous. Thorax twice as broad as long, lateral margins feebly rounded near the base, slightly constricted anteriorly; surface irregularly and rather closely, deeply foveolate-punctate, the punctures more crowded at the sides, interstices more or less convex. Scutellum broad, pubescent, apex raised into a small tubercle. Elytra elongate, gradually narrowed towards the apex, only slightly wider at base than the thorax, shoulders prominent and shining; puncturation strong, somewhat rugose, arranged in very close irregular rows, more distinct but finer near the apex; epipleural lobes strongly produced. Body beneath covered with silvery pubescence.

Length $5 \mathrm{~mm}$.

$H a b$. India. Type in Brussels Museum. 
Closely allied to $A$. sublowicollis, Duviv., but distinguished by the strong foveolate puncturation of the thorax which also, together with its smaller size, separates the species from the preceding one.

\section{Aspidolopha ventralis, Jac. (Coptocephala) Entomologist Suppl. 1891, p. 32.}

Fulvous; head, antennæ and a spot at base of thorax black; elytra dark violaceous; breast, apex of tibiæ and the tarsi fuscous.

Head with a few fine punctures; clypeus more or less fulvous anteriorly, triangularly depressed in front; antennæ with the basal three joints fulvous, third joint extremely small, following joints transverse. Thorax twice as broad as long, narrowed anteriorly, anterior nargin concave, lateral margins straight, disc with a short transverse groove or depression near the posterior angles, impunctate, a transverse large blackish spot in the middle. Scutellum broad, black, without central ridge. Elytra strongly lobed at the base, subcylindrical, not widened posteriorly, strongly punctured in very irregular closely approximate rows that are almost obsolete near the apex; pygidium black in the middle. Body beneath pale fulvous, clothed with short yellow pubescence; last abdominal segment in the niddle and the breast darkened.

Length $4 \mathrm{~mm}$.

Hab. Assam : Patkai Mts. (Brit. Mus.).

Closely allied to $A$. carrulea, Jac., but distinguished by the strong elytral puncturation, the less transverse and longer thorax. In some specimens the breast and the pygidium are entirely fulvous. The species was previously described by me as a Coptocephala, but I find now that it cannot be placed in that genus, as the structure of the head is quite different, the elvtra distinctly lobed, and the pygidium uncovered.

245. Aspidolopha æneicollis, Jac. Ann. Soc. Ent. Bely. xlvii, 1903, p. 87.

Black; head and thorax greenish-æneous; elytra flavous, suturnl and lateral margins and a humeral spot blackish ; base of femora piceous, tarsi flavous.

Head closely and strongly rugose, opaque; clypeus shining, sparingly punctured; eyes widely separated, feebly notched at the lower margins; labrum piceous; antennæ scarcely extending to base of thorax, basal three joints more or less fulvous beneath, fourth and following joints transversely subquadrate. Thorax twice as broad as long, slightly depressed at the sides, lateral margins rounded, median lobe feebly produced, straight; angles rather obtuse, surface ringosely punctured, the punctures deep 
and sometimes confluent, interstices reticulate, a smooth more or

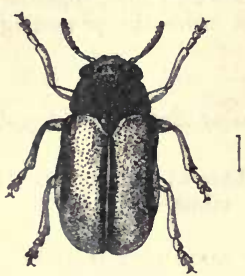

Fig. 40.

Aspidolopha aneicollis.

less distinct tubercle near the middle of the sides. Scutellum greenish, pubescent at base, very broad, apex carinate. Elytra narrow, parallel, strongly and rather closely punctured in very irregular rows, . basal lobe at shoulders strongly produced, dise flavous, sides from below base to behind the middle and the suture narrowly piceous, shoulders with a small greenish spot. Body beneath closely pubescent. First joint of the tarsi not much longer than the second joint.

Length $4 \mathrm{~mm}$.

$H a b$. Nilgiris.

This little species at first sight seems scarcely to belong to the genus, on account of its elongate narrow shape and the general shape of the thorax; on the other hand, the strongly lobed elytral epipleuræ, free pygidium and carinate scutellum agree with Aspidolopha, of which it may be considered a somewhat aberrant form.

246. Aspidolopha rugosa, Jac. Entomologist Suppl. 1891, p. 32.

Metallic dark blue; basal joints of antennæ, tibiæ and tarsi fulvous; thorax fulvous with a transverse blue band at base; elytra fulvous, a humeral spot, another at apex, and a transverse band at middle dark blue.

Head finely rugose; eyes elongate, the intermediate space with a band of fulvous pubescence at each side; antennæ fuscous,

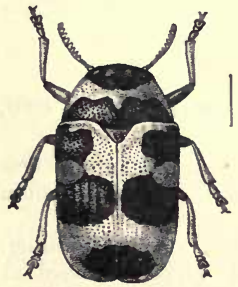

Fig. 41.

Aspidolopha rugosa. extending to base of thorax, basal four joints flavous. Thorax trausverse, sides slightly rounded, narrowed in front, surface obsoletely depressed on each side in front of scutellum, rugosely punctured throughout, anterior portion fulvous, base with a transverse blue band that has its anterior edge irregularly dentate and is partly divided in the middle, sides obliquely shaped. Scutellum broad, dark blue, pubescent, its apex carinate. Elytra strongly lobed laterally, closely and strongly punctured, interspaces transversely rugose and wrinkled, with traces of longitudinal costæ at apex, the band at middle extending nearly to either margin, the apical spot close to suture. Underside thickly clothed with yellow pubescence.

Length $6 \mathrm{~mm}$. 
Hab. Sikhim: Mungphu.

Distinguished by the rugose and feebly costate elytra, the strongly punctured thorax and its blue band; the elytral band is slightly narrowed at the sides and extends sometimes entirely across the disc to the margins.

247. Aspidolopha distincta, Duviv. Bull. Soc. Ent. Belg. xxxv, 1891, p. xxxii.

Dark blue; antennæ black, the base testaceous; thorax partly fulvous or blue; elytra fulvous, a humeral spot, a larger spot at middle and another subsutural spot

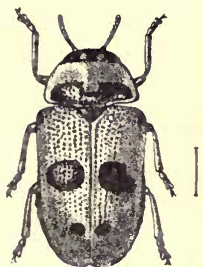

Fig. 42.

Aspidolopha distincta. near apex, blue; tibiæ more or less testaceous.

This species is so closely allied to $A$. rugosa, that it is only necessary to point out the differences. The thorax is less closely punctured and the punctures are larger and deeper, the depressions at the base are much more feeble; the elytral puncturation is much coarser and the punctures are placed in extremely closely approximate rows, the interstices are wrinkled here and there, but not transversely rugose, the markings are lighter blue in colour and instead of a transverse band there is a large spot. In other respects the two insects are similar. In the type the thorax is described as blue, but the following varieties also have been mentioned :-

Var. $a$. Thorax fulvous, with transverse blue basal bands.

Var. $b$. Like var. $a$, but without apical elytral spot.

Var. c. Elytra without discoidal and apical spots.

Var. $d$. Elytra with a discoidal spot only.

Length $4 \frac{1}{2}-6 \mathrm{~mm}$.

$H a b$. India: Konbir; Burma : 'Tharrawaddy.

248. Aspidolopha thoracica, Jac. Ann. Mus. Civ. Genova, xxxii, 1892, p. 879.

Dark blue beneath, above fulvous; thorax with a narrow transverse blue band at base; elytra with a dark blue humeral spot, another near base and a third behind the middle; tibiæ fulvous.

Posteriorly narrow in shape; head impunctate, a band of pale fulvous pubescence in front of eyes; clypeus finely punctured; labrum piceous; antennæ fuscous, scarcely extending to base of thorax, basal four joints fulvous, fourth and following joints serrate. Thorax narrowed in front, median lobe broadly rounded, 
anterior portion impunctate, the basal blue band not extending to lateral margins and interrupted in the middle by a raised smooth space of the ground-colour that terminates in a blunt protuberance, the basal portion rather strongly punctured at the sides. Scutellum broad, metallic blue, longitudinally carinate at apex. Elytra

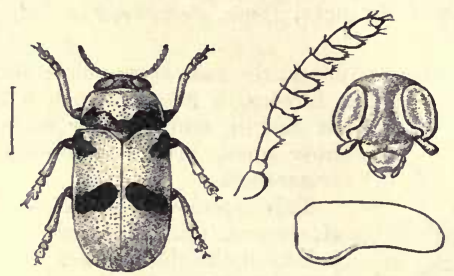

Fig. 43.-Aspidolopha thoracica.

rather strongly narrowed in $\delta^{*}$, basal lobe strongly produced at the sides; surface somewhat closely and strongly punctured, much more finely so posterior to the middle, the punctures arranged in indistinct rows at the apex. Body beneath closely covered with whitish pubescence.

Var. The basal elytral spot connected with the humeral one.

Length 4-6 $\mathrm{mm}$.

$H a b$. Burma: Rangoon, Karen Hills, Karennee.

Can be distinguished by the more or less strongly raised middle portion of thorax; the elytral pattern, however, is similar to that of several others of the genus, but there is an extra spot close to the humeral spot and the posterior spot is placed behind not at the middle. - + much more robust and larger; the markings also larger.

249. Aspidolopha trimaculata, Fab. (Clythra) Ent. Syst. Suppl.1798, p. 110; Lacord. Mon. Phytoph. ii, 1848, p. 252.

‥ Bluish-black; antennæ obscure fulvous; thorax narrowly margined with fulvous; elytra fulvous, shining, a humeral and subsutural spot before and a narrow band at the middle that consists of two united spots, blue.

"Short, parallel-sided and moderately convex, finely pubescent on the head and thorax; head short and flat, very finely punctured; clypeus not separated, feebly emarginate in front; antennæ rather stout, slightly shorter than the thorax, basal joints pale, the others darker. Thorax twice as broad as long, cylindrical, slightly narrowed anteriorly, basal and anterior margins straight; median lobe very short; posterior angles oblique, very finely punctured, 
with some feeble depressions here and there. Scutellum large, triangular, obtuse at apex. Elytra strongly lobed at the sides, strongly punctured, the punctures almost regularly placed at base and apex. The markings bright blue, the band as well as the spots obliquely placed. Legs blue, tibiæ and tarsi fuscous. Male unknown." (Lacordaire.)

\section{Length $5 \mathrm{~mm}$.}

Hab. India.

Lacordaire speaks of a finely pubescent head and thorax; no such species of the genus is known to me and it is somewhat doubtful whether the insect is a true Aspidolopha.

250. Aspidolopha interrupto-fasciata, Jac. Ann. Soc. Ent. Belg. xxxix, 1895, p. 261.

Fulvous; head and scutellum dark blue; elytra with a humeral spot, another behind the middle on the suture, lateral and sutural margins dark blue.

Head finely and closely punctured and strigose, clothed with very short pubescence; clypeus more

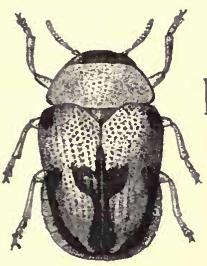

Fig. 44.

Aspidolopha interruptofasciata. strongly punctured; anterior margin nearly straight; labrum fulvous; antennæ not quite extending to the base of the thorax, basal four joints fulvous, rest fuscous. Thorax nearly three times as broad as loug, sides as well as posterior angles rounded, median lobe very broad, truncate, slightly produced; surface very closely and strongly, somewhat confluently punctured on the sides, middle remotely punctured or with a smooth central space. Scutellum broad, pointed, base finely pubescent. Elytra closely and strongly punctured anteriorly, the punctures somewhat regularly arranged in rows on the posterior portion; posterior half of suture more or less connected with a spot behind the middle, corresponding portion of lateral margins and a humeral spot dark blue; epipleuræ produced at the sides. Beneath finely pubescent, breast darker.

Length $3 \mathrm{~mm}$.

Hab. S. Bombay : Kanara.

Of short and robust shape, but of small size. Differing from its allies in the elytral markings; these in one specimen have a semicrescent blue sutural band joined to the posterior spot, neither of the lateral bands extend quite to apex of elytra.

251. Aspidolopha ceylonica, Weise, Deut, ent. Zeit. 1903, p. 25.

Rufo-testaceous; breast, a spot at sides of first abdominal segment, last segment, posterior femora and pygidium æneous or 
bluish; head æneous; antennæ fuscous from fourth joint; a band at base of thorax, a humeral spot and two transverse bands at elytra, bluish-black or æneous.

Head with a broad band near eyes of yellowish pubescence; labrum, palpi, and basal three joints of antennæ fulvous. Thorax strongly punctured, more closely on the darker than on the lighter portions, interstices very finely punctate, the posterior blue band not extending to sides and incised at middle of anterior edge. Elytra rather more strongly punctured than thorax, the punctures regularly arranged in rows except near scutellum and apex, first transverse band close to middle, directed backwards and outwards, second before apex, surrounding a flavous spot at latter place. Male organ produced into a long point of moderate width, feebly emarginate at sides, apex truncate.

o. Pygidium entire.

‥ Pygidium carinate, apex triangularly emarginate.

Length 4-6 mm.

$H a b$. Ceylon: Nalanda, Anuradhapura, Dambulla.

This species and $A$. distincta, Duv. belong to a group in which the scutellum is truncate at apex and foveolate; it is distinguished from its allies by the yellowish abdomen, that has only a smooth blue spot on the first and last serments; pygidium dark blue and metallic. From $A$. distincta the species is further distinguished by the pointed clypeus, the greater amount of metallic colour on the elytra, and the deeply emarginate pygidium of the female.

252. Aspidolopha sublævicollis, Duviv. Bull. Soc. Ent. Belg. xxxv, 1891, p. xxxi.

Metallic blue; antennæ black; elytra fulvous with a humeral spot and another near suture behind the middle, violaceous.

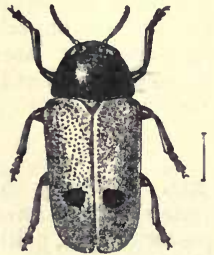

Fig. 45.

Aspidolopha sublevicollis.

Hab. India : Konbir.

Subelongate; head sparingly punctured, pubescent near the eyes; antennæ black, extending to middle of thorax, basal three joints obscure fulvous. Thorax about one half as broad again as long, narrowed anteriorly, sides nearly straight, surface sparingly punctured at base only, posterior angles obtuse. Scutellum pointed, broad, pubescent at base. Elytra narrowed posteriorly, strongly lobed at sides, puncturation strong and arranged in irregular and closely approximate rows, apex nearly impunctate.

Length $4 \frac{1}{2}-6 \mathrm{~mm}$. 
The author has only doubtfully described this species as different from $A$. trimaculata, Fabr., but it is, I think, distinct; there is no pubescence on the thorax and the latter is almost impunctate, entirely metallic bright blue and without fulvous margins, the elytra have two spots only on the shoulders and near the apex, and the legs are entirely blue; the general shape is elongate.

\section{Aspidolopha nitidicollis, sp. $\mathrm{n}$.}

Bluish black; basal joints of antennæ and anterior portion of thorax fulvous; elytra strongly and closely punctured, fulvous, a broad transverse band behind, another below the middle, also the apex metallic dark blue.

Oblong; head dark blue, impubescent, vertex impunotate, space between eyes finely longitudinally strigose and feebly depressed; clypeus finely punctured, its anterior edge

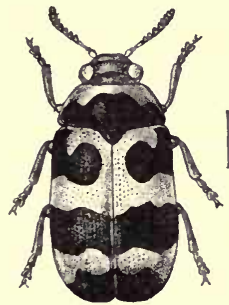

Fig. 46.

Aspidolopha nitidicollis. but slightly emarginate; antennæ short, black, basal four joints flavous, second and third very short, equal. Thorax more than twice as broad as long, strongly obliquely narrowed anteriorly, sides slightly rounded; surface extremely minutely punctured at base, nearly impunctate anteriorly, entire basal portion occupied by a broad transverse blue band that does not extend quite to lateral margins, its anterior edge deeply sinuate at sides and slightly dentate at middle. Scutellum broad, dark blue, apex rather raised. Elytra rather feebly lobed at sides, nearly parallel and subcylindrical, strongly and closely punctured, the punctures finer behind the middle, interstices slightly wrinkled; a broad transverse band, deeply constricted at middle from shoulders towards suture which latter it does not reach, another irregular shaped band behind the middle, extending to either margin and a large spot at apex, metallic blue. Beneath thickly clothed with yellow pubescence; base of femora and of tibiæ obscure fulvous. Tarsi short.

\section{Length $7 \mathrm{~mm}$.}

Hab. Khási Hills (Coll. Jacoby).

A somewhat aberrant species of which I only know the female; there is no pubescence near the eyes, the elytral lobes are less developed than usual and the abdomen is not inflated nor the pygidium exposed; the thorax and legs however, are typical and the elytral markings differ from those of any other species of the genus. 
254. Aspidolopha melanophthalma, Lacord. Mon. Phytoph. ii, 1848, p. 254.

Metallic blue; antennæ fuscous; thorax, scutellum and elytra flavous.

" $\sigma$. Very short and thickened, head more or less finely rugose,

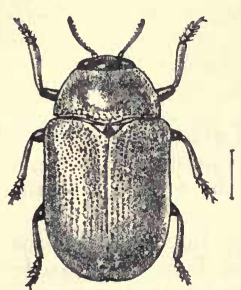

Fig. 47.

Aspidolopha melanophthalma. a band of pubescence in front of eyes antennæ extending to base of thorax, basal joints testaceous. Thorax about one and a third broader than long, cylindrical, slightly narrowed in front, median lobe very large but short and feebly rounded, surface impunctate, very shining. Scutellum large, triangular, carinate at apex. Elytra rather convex, strongly lobed at sides of epipleuræ, less shining than tborax, distinctly punctured. Legs rather feeble.

"Var. Legs and abdomen more or less testaceous." (Lacordaire.)

Length $2 \frac{1}{2} \mathrm{~mm}$.

$H a b$. Bengal ; Tenasserim.

All the Indian specimens I have seen have the thorax more or less distinctly punctured at sides, not impunctate as Lacordaire describes it. The elytral puncturation is very strong and close, but nearly absent at apex, the tibiæ and tarsi are mostly flavous.

\section{Genus EPIMELA.}

Epimela, Weise, Deut. ent. Zeit. 1903, p. 27.

Type, E. ornata, Redtenb., from Kashmir.

Range. India ; Ceylon.

Short, subcylindrical; head and thorax pubescent; antennæ slightly longer than the thorax; eyes large and distinctly emarginate. Thorax much broader than long, posterior angles rounded. Scutellum large. Elytra with large bumeral lobes; pygidiun not covered by, the elytra. Abdomen strongly inflated. Legs and tarsi rather long.

This genus has been lately established for a species from Kashmir which was placed by Lacordaire in Gynandrophthalma; the pubescent head and thorax, strongly developed elytral lobes, free pygidium etc. justify Weise's separation of the species from the last named genus.

255. Epimela ornata, Redtenb. (Coptocephala) Hügel's Reise Kaschmir, 1846, p. 560, pl. 28, fig. 5; Lacord. (Gynandrophthalma) Mon. Phytoph. ii, 1848, p. 266; Weise, Deut. ent. Zeit.1903, p. 27.

Bluish-green; apical joints of antennæ, tibiæ and tarsi black; 
elytra rufous; a humeral spot, another before the middle, a dentate broad band behind the latter and an apical spot, blue.

․ Short, parallel-sided; head nearly smooth, finely pubescent, feebly and broadly depressed at vertex; clypeus deflexed, feebly triangularly emarginate; eyes large, elongate and emarginate; antennæ brownish, slightly longer than thorax, the bases rufous, the joints obsoletely dentate. Thorax more than twice as broad as long, convex, straight at sides, posterior angles rounded, impunetate with some shallow depressions; median lobe broad but short and truncate. Scutellım large, finely rugose, carinate throughout its length. Elytra finely and irregularly somewhat confluently punctured. Legs pale, the femora and tarsi more or less dark, rather long; apical abdominal segment with a small fovea.

Length $5 \mathrm{~mm}$.

$H a b$. Kashmir.

256. Epimela viridicollis (P]. I, fig. 9), Jac. (Pantocometis) The Entomologist, xxxii, 1899, p. 69.

Metallic green; labrum, basal joints of antennæ and legs fulvous; elytra fulvous, a spot on shoulders, another before middle and a transverse band behind the latter, dark blue.

$\delta$. Head very finely longitudinally striate on the vertex, finely rugose and pubescent between the eyes; antennæ black, extending to base of elytra, basal four joints fulvous, second and third joints small, following joints strongly transverse. Thorax twice as broad as long, sides straight anteriorly, strongly rounded at base as well as at posterior angles; surface obsoletely transversely depressed anteriorly and obliquely depressed near posterior angles, very minutely punctured and pubescent. Scutellum raised, finely pubescent, apex truncate. Elytra strongly and closely punctured, a round spot before middle near suture and two spots more or less connected behind the middle dark blue. Legs robust, fulvous. Body beneath closely covered with silvery pubescence.

o. Larger, elytra much more finely punctured, spots larger, an additional spot on the shoulders.

Length $6 \mathrm{~mm}$.

Hab. Khási Hills.

257. Epimela indica, Duviv. (Lachnea) Bull. Soc. Ent. Belg. xxxv, 1891, p. xxviii.

Metallic dark blue; pubescent above and beneath; basal joints of antennæ and labrun fulvous; elytra fulvous with a narrow transverse band behind the middle.

Rather elongate and parallel-sided; head broad and elongate, rugose, clothed with dense pubescence between the eyes, the latter feebly notched; antennæ black, scarcely extending to base of

voL. I. 
thorax, basal three joints fulvous. Thorax about two and a half times broader than long, rather convex, sides straight, posterior angles rounded; surface transversely depressed near anterior margin with two small tubercles at the middle (more distinct in the male), finely punctured at the sides, clothed with dense grey

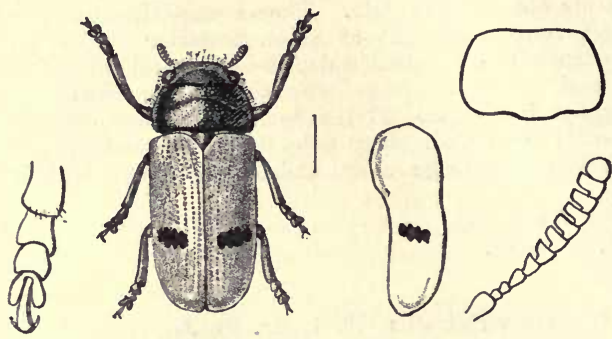

Fig. 48.-Epimela indica, $\sigma^{\star}$.

pubescence in fresh specimens. Scutellum elongately subtriangular, pubescent. Elytra rather distinctly lobed at the sides below the shoulders, strongly punctured in longitudinal rows, the interstices finely transversely wrinkled, clothed with short silvery pubescence. Pygidium finely rugose. Tarsi broad and robust.

The following varieties have been enumerated by Duvivier :-

Var. a. Head and thorax more or less black or greenish-black.

Var. $b$. Anterior margin of thorax fulvous.

Var. c. The elytral bands reduced to one or two spots, var. interrupta, Duviv.

Var. $d$. Elytra entirely fulvous, var. uniformis, Duviv.

Length $6 \frac{1}{2}-9 \mathrm{~mm}$.

$H a b$. India : Konbir-Nowatali, Tetara.

This species on account of the pubescent upper surface, produced lateral elytral epipleuræ and free pygidium, must be placed in Epimela. In Pantocometis the pubescence is long and of a different kind.

\section{Epimela insularis, Weise, Dent. ent. Zeit. 1903, p. 26.}

Blackish-blue, closely pubescent, the pubescence silvery; antennæ black, basal joints, tibiæ and tarsi ferruginous ; elytra dark fulvous, two spots before and a band behind the middle blue.

Rather smaller than $E$. ornata, Redtb., and clothed with silvery not grey pubescence, the elytra darker red, much more strongly and distinctly punctured. Head rugose, not strigose; labrum piceous, anterior edge reddish; basal four joints of the antennæ reddish, first and fourth joints sometimes stuined with piceous, the 
latter joint slightly narrower than the fifth. Thorax more than twice as broad as long, the sides rounded, finely and closely punctured, with the usual feeble impressions, the margins darker red. Scutellum pubescent and punctured. Elytra twice as strongly punctured as in E. ornata, the basal portion more closely and irregnlarly so, the rest more sparsely also in irregular rows, interstices smooth; the first blue spot on the shoulders small and round, sometimes only indicated, the second near the suture at about one-third the length of the elytra, larger, transverse; the transverse band straight, widened gradually towards the suture, not quite extended to either margin.

Length $6 \mathrm{~mm}$.

$H a b$. Ceylon: Anuradhapura.

\section{Epimela dilutipes, sp. $n$.}

Obscure dark blue; head and thorax pubescent; elytra fulvous with four dark blue spots placed transversely.

Head entirely clothed with short grey pubescence; labrum fulvous; eyes subquadrately emarginate; antennæ black, not extending to base of thorax, basal four joints fulvous, third joint extremely small, the rest strongly transverse. Thorax twice as broad as long, of equal width, sides rounded, surface pubescent like that of the head, with two small tubercles near the anterior margin. Scutellum rather pointed and elongate, pubescent. Elytra very strongly punctured in irregular rows, interstices rugose, partly enstate near suture, each elytron with two blue spots before and two behind the middle; of the former two one is placed on the shoulders and one near the suture, the latter two are transverse. Tibiæ fulvous, stained with fuscous; femora bluish, all densely pubescent like the underside.

\section{Length $5 \mathrm{~mm}$.}

Hab. Southern India : Madura. Type in Coll. H. E. Andrewes.

Separated from $E$. insularis, Weise, by the entirely pubescent head which obscures the sculpture, and by the elytral markings and the arrangement of the punctures in rows.

\section{Genus PANTOCOMETIS.}

Pantocometis, Lacord. Mon. Phytoph. ii, 1848, p. 366 ; Chapuis, Gen. Coleopt. x, 1874, p. 129.

Type, P. hirsuta, Lacord., from India.

Range. India; Ceylon.

ㅇ. Oblong; entirely clothed with long pubescence. Head short; eyes rather large; antennæ robust, second and third joints subconical, very short, equal, following joints serrate, obliquely trigonal. Thorax very short, subcylindrical, sides straight, posterior angles rounded. Scutellum rather large. Elytra feebly 
lobed at sides. Legs slender and elongate ; tarsi feeble, subcylindrical, first joint as long as the following two united, clawjoint long and slender.

Can be distinguished from any other genus by the pubescence that covers the entire upper surface. Only a few species are known.

260. Pantocometis hirsuta, Lacord. Mon. Phytoph. ii, 1848, p. 366.

Flavo-testaceous; elytra with a broad black band behind the middle, widened externally.

․ Oblong, feebly widened posteriorly. Head small, finely rugose; clypeus nearly truncate at outer edge; eyes rather large, entire; antennæ comparatively robust, slightly longer than the thorax, fuscous except at base. Thorax more than twice as broad as long, sides straight, posterior angles rounded, surface entirely impunctate. Scutellum large. Elytra feebly lobed at the sides, very finely punctured, clothed like the head and thorax with pale puhescence, mixed with longer black hairs, a black band near the apex extending to the sides where it widens. Legs moderately elongate, tarsi slender. Male unknown.

Length $5 \mathrm{~mm}$.

$H a b$. Southern India : Pondicherry.

\section{Pantocometis subfasciata, sp. n.}

Pale fulvous; terminal joints of antennæ black; elytra with a large subquadrate spot at the shoulders and a transverse band near apex, black.

Subelongate; entirely covered with long erect pubescence. Head with deep depression between the eyes, upper portion clothed with

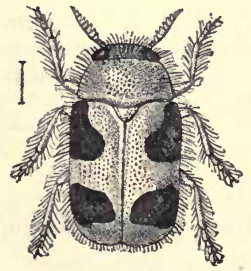

Fig. 49.

Pantocometis subfasciata. long black hairs, lower portion shining; margin of clypeus nearly straight; antennæ extending to base of thorax, basal three joints fulvous, rest black, third joint extremely small, fourth and following strongly transversely widened. Thorax twice as broad as long, sides feebly rounded, median lobe rather strongly produced, surface closely punctured. Scutellum elongate triangular. Elytra punctured, strongly lobed at the sides; the humeral spot extending downwards nearly to the iniddle, narrowed at the inner angle, not reaching to the suture; subapical spot transverse, not quite extending to either margin, both these markings bluish-black. Underside and legs pale, tarsi short.

Length $4 \frac{1}{2} \mathrm{~mm}$.

$H a b$. Southern India (Brit. Mus.). 
262. Pantocometis horni, Weise, Deut. ent. Zeit. 1903, p. 27.

Obscure yellowish-brown; elytra each with four spots (1.2.1); beneath testaceous.

Head, thorax and scutellum densely punctured; clypeus triangular, bounded at the sides by a shallow fovea and by a larger one between the eyes; antennæ rather stout, transversely serrate and darkened from the fourth joint. Elytra strongly punctured; the first black spot near the lateral margins, elongate, reaching from base to near the middle across the shoulders, second and third spots small, round, placed transversely at two-thirds the length of the elytra, fourth spot near the hind margin, transverse, sonetimes prolonged at the margin as far as the third spot.

Length 4-5 mm.

Hab. Ceylon: Anuradhapura.

The pubescence of the head and thorax is short and thin, slightly erect, whitish in colour with longer stiff black hairs intermixed.

263. Pantocometis downesi, Baly (Clythra-Pantocometis), Trans. Ent. Soc. Lond. (3) ii, 1865, p. 333.

Metallic greenish-blue; sides of thorax narrowly flavous; elytra fulvous with a transverse blue band behind the middle.

o. Head exserted; prolonged below the eyes; mandibles produced, strongly lobed within; face rugose. Thorax transverse, sides rounded, converging anteriorly, disc rather deeply transversely excavate, subremotely punctured and sparingly pubescent. Elytra distinctly subremotely punctured, clothed with erect pubescence. Anterior legs very elongate.

ㅇ. Head short, not prolonged below eyes, mandibles short, face smooth; base of thorax rounded at the sides, disc less distinctly excavate. Anterior legs not elongate.

Length, of 8, ㅇ $7 \mathrm{~mm}$.

Hab. Bombay.

\section{Genus CLYTRASOMA, nov.}

General characters of Clytra but the sexes dissimilar. Antennæ in the male very strongly transversely pectinate, as in some Lamellicornia; the clypeus not separated from the face; elytra much widened in the middle; in the male the epipleuræ entirely absent below the base.

This genus is proposed for the reception of Clytra palliata, Fabr., which it is impossible to leave in Clytra, in which the sexes are similar; the great differences in the structure of the antennæ and in the absence of elytral epipleuræ from below the shoulders justify this separation. In the female the shape of the elytra is normal, and the antennæ are less strongly pectinate or serrate.

In this genus there seems also to be an absence of stridulating organs, which are found in Clytra on the mesonotum (Gahan, Trans. Ent. Soc. 1900, p. 444). 
264. Clytrasoma palliata, Fabr. (Clythra) Syst. Eleuth. ii, 1801, p. 30 ; Lacord. Mon. Phytoph. ii. 1848, p. 191.

o. Clytra gibbosa, Vigors, Zool. Journ. ii, 1826, p. 241, pl. 9, fig. 11.

Fulvous; head, antennæ, underside and legs black; elytra with humeral, subapical spot and a transverse band at middle, black.

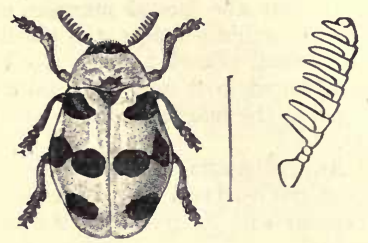

Fig. 50.-Clytrasoma palliata.

ס. Head black, closely pubescent in front of eyes, forming a pointed triangular space at each side, middle with deep groove, lower portion of face finely strigose; antennæ rather short, second and third joints fulvous, following joints shaped like transverse laminæ with an additional 12th joint. Thorax about two and a half times broader than long, opaque, sides feebly rounded, median lobe short; surface when seen under a strong lens extremely minutely punctured, with an angulate black mark on each side of the base, or the base entirely black. Scutellum black. Elytra strongly dilated, opaque, minutely and extremely closely punctured; a spot on shoulders, a more transverse spot near apex and a transverse band at middle, composed of two more or less confluent spots, black. Beneath black, closely pubescent; claw-joint partly hidden at base.

ㅇ. Elytra slightly or not at all dilated, shining.

Var. $a$. Thorax fulvous without spots.

Var. $b$. Thorax black, margined with fulvous.

Var. c. Thorax black.

Length 12-15 $\mathrm{mm}$.

$H a b$. Throughout India.

A rather common species, the sexes very dissimilar in shape, the elytral pattern subject to variation in regard to number of black markings.

265. Clytrasoma conformis, Lacord. (Clythra) Mon. Phytoph. ii, 1848, p. 194.

Black, pubescent beneath ; thorax and elytra fulvous, a spot on the shoulders, two behind the niddle, and another near apex, black. Thorax with two or three spots. 
§. Elytra only slightly dilated, opaque.

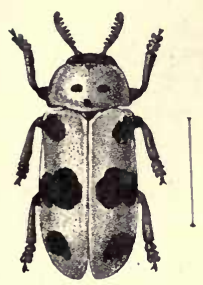

Fig. 51.

Clytrasoma conformis.

ㅇ. Elytra nearly parallel-sided, shining. Length 12-14 $\mathrm{mm}$. $H a b$. India : Kashmir ; Punjab; Bengal ; Malabar.

This species resembles in coloration C. palliata, but differs from it in the finely rugose head, the slightly dilated elytra of the male, and in the nearly free fourth joint of the tarsi. The species is subject to the same amount of variation as C. pallicata. In the thorax there is a difference in the posterior angles, which instead of being rounded are distinct and even slightly produced; the antennæ and the elytral epipleuræ agree with those of $C$. palliata.

\section{Clytrasoma ceylonensis, sp. $n$.}

ס. Beneath black, above fulvous; thorax transverse, with a black $m$-shaped band; scutellum black; elytra fulvous, a large subquadrate spot at the base, a transverse band at the middle, connected with the basal spot by a narrow stripe, and another round spot near the apex, black.

Elongate. Head black, finely rugose in front of the eyes, with a short central groove; clypeus with a trarısverse depression, finely rugose on its upper portion, the anterior border rather deeply semicircularly emarginate; antennæ with the second and third joints fulvous, the following four or five joints black, strongly transversely pectinate, the rest wanting in the type and only specimen. Thorax at least twice as broad as long, the lateral margins feebly rounded, narrowly margined, posterior angles obtuse, median lobe broadly but not strongly produced, the disc very minutely punctured. Scutellum black, triangular. Elytra of somewhat irregular rugose appearance, closely and distinctly punctured, the base with a broad subquadrate spot, not extending to either margin and connected posteriorly by a short narrow stripe with the band at the middle, this band strongly constricted at the middle portion and extended to the sutural and lateral margins; near the apex another roundish black spot; elytral epipleuræo only visible at the base. Body' beneath and legs black.

Length $12 \mathrm{~mm}$.

$H a b$. Ceylon (Coll. Jacoby).

This species does not agree either with C. palliata or C. conformis, the thorax is quite differently marked and the sculpture of the head and of the elytra is entirely different; in other respects the characters are similar to those of $C$. conformis. 


\section{Genus CLYTRA.}

Clytra, Laicharting, Verz. Tyrol. Ins. i, 1781, p. 165.

Clythra, Fabr. Suppl. Ent. Syst. 1798, p. 110 ; Lacord. Mon. Phytoph. ii, 1848 , p. 190 ; Leferre, Mon. Clyth., Ann. Soc. Ent. France, 1872, p. 139.

Type, C. 4-punctata, Laich., from Europe.

Range. Europe; Africa; Asia.

Body similar in both sexes, cylindrical ; head and underside more or less pubescent. Head perpendicular, deeply inserted; mandibles very short, robust; clypeus feebly emarginate; eyes very large, elongate, placed obliquely, very slightly notched ; antenuæ short, basal joint short and thick, succeeding two joints small, the rest strongly triangularly widened. Thorax of variable shape, generally strongly transverse and narrowed in front, posterior angies rounded. Elytra without produced lateral lobes. Legs short, anterior coxæ narrowly divided; tarsi robust, broad, first and second joints widened, equal or subequal. Last abdominal segment of male with a smooth space at middle in many species, in female with a small forea. Pygidium not exposed.

These characters apply more accurately to the European than to the exotic species, which often show such a gradual divergence from the typical forms that it is a matter of opinion as to the genera in which they should be placed, no hard and fast rule being possible for their classification.

The principal characters, viz., the absence of distinct lateral elytral lobes, covered pygidium and the short tarsi, will assist in the recognition of the genus.

The larvæ of this and other species of Clytrinae construct a light but tough cocoon which they carry about with them and only exsert the anterior portion of their body out of this covering.

267. Cytra succincta, Lacord. Mon. Phytoph. ii, 1848, p. 201.

Black. Elytra fulvous, a humeral spot and a transverse band behind the middle black.

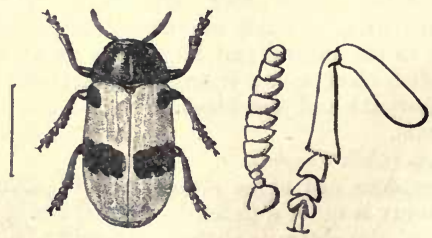

Fig. 52.-Clytra succincta.

Head very finely rugose, pubescent near the eyes; the clypeus shining, triangularly emarginate; antennæ black, slightly shorter 
than the thorax, the second and third joints small, fulvous, following joints transverse. Thorax black, often quite twice as broad as long, the posterior angles rounded, the sides slightly narrowed anteriorly, the surface extremely minutely punctured. Scutellum black, its apex slightly raised and pointed. Elytra subcylindrical, very finely and closely punctured. Body beneath and legs black, closely pubescent, tarsi broad.

Length 8-12 $\mathrm{mm}$.

Range. India: Bengal. China; Java.

A large and abundant species subject, like all the members of the family, to some amount of colour variation, but it may be distinguished by the entirely black thorax; the elytral band is sometimes partly, often entirely interrupted, but extends generally across the entire elytra.

268. Clytra chlorotica, Lefêv. Bull. Soc. Ent. Belg. xxxv, 1891, p. cel.

Elongate, parallel-sided; entirely bright fulvous, clothed with grey pubescence above; apex of the mandibles black.

"Head extremely minutely and distantly punctured, feebly depressed between the eyes; labrum, palpi and antennæ fulvous. Thorax twice as broad as long, nearly straight at the sides, the posterior angles rounded, the surface very smooth, the median lobe moderately produced, slightly punctured. Scutellum large, smooth, its apex acute. Elytra impunctate. Legs short."

"Length $10 \mathrm{~mm}$." (Lefèvre.)

$H a b$. India.

No specimen has come under my observation.

269. Clytra flavotibialis, Jac. Ann. Soc. Ent. Belg. xlvii, 1903, p. 84.

Metallic dark greenish-blue; basal joints of antennæ, tibiæ and tarsi flavous; elytra fulvous, a round spot before the middle and a transverse band behind the latter, metallic greenish.

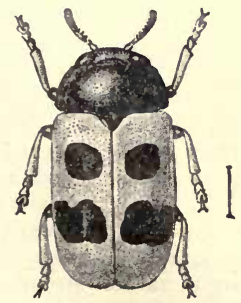

Fig. 53.

Clytra flavotibialis.

Head very finely transversely and longitudinally strigose and punctured, triangularly depressed between the eyes, these very elongate, slightly notched at the inner margin; labrum fulvous; antenuæ black, basal four joints flavous, fourth and following joints transverse and strongly widened. Thorax rather more than twice as broad as long, sides strongly rounded, with distinet reflexed narrow margins, median lobe feebly rounded, surface impunctate, very shining. Scutellum dark blue. Elytra elongate and parallel-sided, finely and irregularly punctured, a rounded spot below base between the shoulders and suture and a transverse 
band, not extending to either margin, immediately behind the middle; anterior edge deeply concave, posterior nearly straight. Beneath bluish-black, densely pubescent ; legs robust; tarsi short and broad.

Length $6 \mathrm{~mm}$.

$H a b$. India: Pondicherry.

270. Clytra dispar, Redtenb. in Hügel's Kaschm. iv, pt. 2, 1848, p. 560. Clytra trifasciata, Redtenb. $t$. $c$. pl. 28, fig. 4.

Black, clothed with grey silky pubescence beneath; the basal joints of the antennæ, the thorax and elytra flavous; the antennæ spotted with black, the elytra with three transverse macular black bands.

Head closely wrinkled, with a central groove; the antennæ dentate beyond the fourth joint, the second and third joints flavous. Thorax twice as broad as long, the angles rounded, scarcely perceptibly punctured, with an elongate black spot on each side of the base connected posteriorly with another smaller spot in the middle. Scutellum triangular, punctured at the base. Elytra extremely finely punctured, with four black transverse spots, one below the base, angulate, two in the middle sometimes joined into a band, the fourth transversely placed before the apex. In the female the elytral margins are dilated behind the middle.

Length $6 \mathrm{~mm}$.

$H a b$. Kashmir.

271. Clytra lefevrei, Jac. Ann. Soc. Ent. Belg. xxxix, 1895, p. 254.

Var. Clytra occipitalis, Jac. t. c. xli, 1897, p. 423.

Fulvous; thorax with four or five black spots. Each elytron with six sometimes connected spots (1.2.2.1); beneath and the legs spotted with black.

Of very elongate and narrow parallel-sided

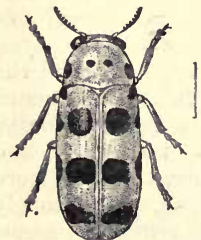

Fig. 54. Clytra lefeerei. shape; the head impunctate, fulvous or with a black spot at the sides of the vertex; anterior edge of the clypeus semicircularly emarginate; antennæ not extending to the base of the thorax, the basal four joints fulvous, the others black, the fifth and following joints strongly transversely subquadrate. Thorax scarcely twice as broad as long, slightly narrowed in front, the sides strongly deflexed, with the margins nearly straight, the posterior margin sinuate at the sides, anterior margin rather strongly produced in front, anterior angles obtuse; the surface entirely impunctate, fulvous, with four 
spots placed transversely at the middle, the outer ones much larger than the others; another small spot is sometimes placed in front of the scutellum. Scutellum triangular, strongly pointed, fulvous or black. Elytra fulvous, impunctate or with some extremely fine punctures at the base; each elytron with six black spots, one on shoulders, two larger ones, transversely shaped, before the middle (the outer one close to margin), two similar spots behind the middle, and a subapical, narrow, transverse, slightly curved spot or short band. Sides of breast and abdomen, part of femora, apex of tibiæ, and the tarsi more or less black; first joint of the tarsi slightly longer than the second.

Length 3-5 $\frac{1}{2} \mathrm{~mm}$.

$H a b$. Bengal ; S. Bombay ; Kanara ; Nilgiris ; Malabar.

An extremely variable species, narrowly elongate in shape; the head generally with a black band or spot in front of the eyes. The elytra with the spots free or connected, extending sometimes to the apex in the form of a band, preceded by another transverse band; the thorax with four spots placed transrersely, or only one spot near the posterior angles (an extra central one sometimes at base). In a single small male from Mahé the head and thorax are entirely unspotted, but the elytra bave the typical six spots; the spots are very variable and in some forms resemble those of Miochira gracilis, Lacord. It is possible that this latter specimen is only one of the many varieties of $C$. lefevrei.

\section{Clytra insularis, Lefêv. Bull. Soc. Ent. France, 1883, p. cxxi.}

Head and the underside greenish-black, densely clothed with flavous pubescence; above obscure rufo-testaceous; thorax with a large basal patch and a spot in the middle black; elytra with a broad transverse band behind the middle, a humeral and an apical spot black; femora blackish ; tibiæ and tarsi fulvous.

Head distinctly triangularly depressed between the eyes, rugose, clothed with flavous pubescence near the eyes, the vertex convex, smooth; antennæ black, the base fulvous. Thorax smooth. Elytra remotely and finely punctured, with a broad transverse band behind the middle and two black spots (one transverse below the shoulders, not extending to the suture, the other small at the apex). Tarsi more or less fulvous.

Var. Thorax and elytra without spots.

Length $6 \frac{1}{2}-7 \mathrm{~mm}$.

$H a b$. Andaman Islands.

\section{Clytra duvivieri, sp. n.}

Above flavous, beneath black. Elytra with broad transverse bluish band near apex. 
Head entirely impunctate with two feeble transverse depressions between the eyes; clypeus very broad, impunctate, its anterior margin only slightly emarginate; eyes elongate, nearly entire; antennæ with the basal four joints flavous, the rest fuscous. Thorax nearly twice as broad as long, scarcely narrowed anteriorly, the lateral margins feebly rounded, with narrowly reflexed edges; anterior angles acute, posterior obtuse, the surface entirely impunctate even when seen under a very strong lens. Scutellum broad, pointed, the basal margin black. Elytra subcylindrical, somewhat strongly lobed below the shoulders, their epipleuræ continued behind the middle; the surface finely but distinctly punctured, with a transverse, metallic, bluish-black band behind the middle, not extending to the extreme sutural or lateral margins; the edges of this band irregularly notched. Body beneath black, densely pubescent; legs fulvous. Tarsi short and broad.

Length $6 \frac{1}{2} \mathrm{~mm}$.

$H a b$. Northern India. Type in Brit. Mus.

A single $O$ specimen of this species is before me; it is rather closely allied to $C$. plagiata, Duv., but differs in the entirely impunctate head and thorax, the blue, not black, elytral band and the black underside.

\section{Clytra annamita, Lefêv. Ann. Soc. Ent. France, 1889, p. 288.}

Fulvous; head with two, thorax with one black spot; elytra with one transverse black band before and another behind the middle, the first band not extending to suture; breast and abdomen more or less black.

Elongate, subcylindrical. Head impunctate, obsoletely transversely grooved between eyes; vertex with two black spots; antennæ fnscous, basal four joints flavous, fifth and following joints strongly transversely serrate. Thorax not quite one-half broader than long, subcylindrical, sides nearly straight, surface impunctate. Elytra scarcely perceptibly punctured, a short, rather distinct row of punctures near suture, both bands of irregular shape and narrowed in the middle. Tarsi broad and equal.

Var. $a$. Elytral bands replaced by four spots, placed transrersely before and behind the middle.

Var. $b$. Head and thorax without spots.

Length $6-7 \mathrm{~mm}$.

$H a b$. Burma: Rangoon, Palon. Cochinchina: Saigon.

Larger than either $C$. occipitalis or $C$. cardoni, the elytra less spotted and the position of the bands different; in a specimen named by Lefèvre there is an additional spot at the extreme apex of the elytra which the author does not mention. 
275. Clytra orientalis, Lejèv. Bull. Soc. Ent. Bely. xxxv, 1891, p. ccl.

Black; clothed with grey pubescence, above bright fulvous; antennæ black, the basal three joints fulvous; elytra with a large triangular patch placed near the apex at the sides and the apical margins narrowly black.

Elongately oblong. Head with two confluent foveæ, the vertex punctured; the clypeus smooth; mandibles prominent, large, their apices black. Thorax slightly broader than long, the sides nearly straight, the posterior angles rounded, above convex, very smooth, with an oblique fine sulcus at the sides, strongly punctured in front of the scutellum at the base. Elytra impunctate. Legs robust and short.

Length 9-10 $\mathrm{mm}$.

Hab. Bangalore (Calcutta Mus.).

This insect might easily be mistaken for Aithiorlactyla lateralis, Lacord., with which it agrees in size and somewhat in coloration; but it is, no doubt, a true Clytra, on account of the short legs and tarsi; other differences are to be found in the short thorax, the punctured vertex of the head and base of the thorax, and in the black apical margins of the elytra.

276. Clytra cardoni, Jac. Ann. Soc. Ent. Belg. xli, 1897, p. 424.

Fulvous; head and thorax with two black spots; scutellum black; elytra with a transverse subquadrate black spot at base and a medially constricted black band behind the middle; breast and base of femora black.

Head impunctate; an elongate black spot above eyes;

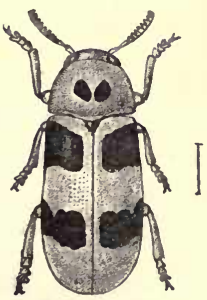

Fig. 55 .

Clytra cardoni. anterior edge of clypeus semicircularly emarginate; labrum fulvous; antennæ not extending to base of thorax, fuscous, basal three or four joints fulvous. Thorax about one-half broader than long, sides nearly straight, basal margin slightly produced at middle, angles distinct; surface impunctate, a triangular mark at middle of disc, sometimes separnted into two spots. Scutellum black, strongly pointed. Elytra narrow and elongate, a few fine punctures near suture on the basal portion, rest impunctate; an abbreviated transverse spot or band, slightly oblique, from shoulders towards suture, a second band nearly extending to either margin behind the middle. Abdomen fulvous. Length $5 \mathrm{~mm}$.

Hab. Bengal: Mandar. 
The ely tral markings differ from those of most of the other species of the genus, but are somewhat similar to those of $C$. annamita, Lefèv., from China, only the position and shape of the bands are quite different.

\section{Clytra marginicollis, sp. ฉ.}

Black and shining; lateral margins of thorax anteriorly fulvous. Elytra fulvous, with transverse black band behind the middle widened near suture.

Head transversely grooved between the eyes, the lower portion finely and irregularly punctured, anterior border subtriangularly emarginate; mandibles broad and robust, rather strongly produced; palpi fulvous ; antennæ with the basal four joints fulvous, the succeeding five joints black, the rest in the type and only specimen wanting. Thorax strongly transverse, subcylindrical, the sides strongly rounded; posterior angles distinct, the extreme lateral angles fulvous on the anterior portion, the rest of the surface black, very shining and impunctate; median lobe distinctly produced and rounded. Scutellum black, rather convex and pointed. Elytra feebly lobed at the shoulders, the black band extends right across; the puncturation arranged in very closely approximate irregular rows, which become more separated and almost obsolete near the apex. Beneath black. Tarsi robust, the first joint about as long as the second.

Length $7 \mathrm{~mm}$.

Hab. India (Coll. Jacoby).

Colouring similar to that of $C$. succincta, Lacord.; size smaller, the thorax with fulvous lateral margins anteriorly; puncturation of elytra very distinct, the band differently shaped and placed nearer the apex.

278. Clytra fasciatopunctata, Lacord. (Melitonoma) Mon. Phytoph. ii, 1848, p. 381 .

Clytra kanaraensis, Jac. Ann. Soc. Ent. Belg. xxxix, 1895, p. 256.

Head and body beneath black; labrum and thorax fulvous. Elytra fulvous, two or three spots before the middle and a curved transverse band near apex black ; legs fulvous.

Elongate and subcylindrical; the head finely rugose and pubescent; antennæ scarcely extending to the middle of the thorax, blackish, the basal four joints fulvous, fourth and following joints transversely serrate. Thorax impunctate, twice as broad as long, the posterior angles rounded, the surface impunctate. Scutellum fulvous. Elytra rather finely and irregularly punctured, with a transverse arched black band near the apex, not extending to the lateral margins; a black spot on the shoulders 
and another near the middle, close to the suture. Beneath finely pubescent.

Length 5-6 mm.

Hab. India.

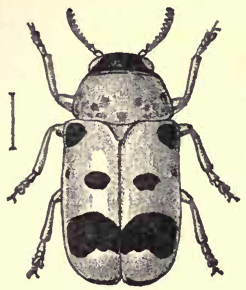

Fig. 56.-Clytra fasciatopunctata.

In a specimen from Bandra in the British Museum, which agrees in most details with Lacordaire's description, there is an additional black spot placed below the humeral and opposite the subsutural spot. In a variety mentioned by the author, the latter spot is absent and this applies probably also to one or other of the remaining markings of the elytra. In the description Lacordaire gives the head as pubescent; in the specimen before me this is only the case with the anterior portion. The variety with an additional black spot below the shoulders has been described by me as Clytra kanaraensis, but cannot be separated. I see no reason for placing this species in the African genus Melitonoma.

\section{Genus MIOCHIRA.}

Miochira, Lacord. Mon. Phytoph. ii, 1848, p. 315; Chapuis, Gen. Coleopt. x, 1874, p. 123.

Type, M. gracilis, Lacord., from India.

Runge. Africa; India.

Body very elongate and slender, smooth above. Head small, ovate, free, not deeply inserted, smooth; mandibles short; eyes rather large; antennæ somewhat robust, second and third joints short, equal, following joints transverse. Thorax with distinct posterior angles. Legs short, subequal; tarsi very short, first two joints triangularly reversed, subequal, third small, divided to base.

The narrowly elongate shape and the very short tarsi, which are even shorter than in Clytra, are the principal distinguishing characters of this genus. 
279. Miochira gracilis, Lacord. Mon. Phytoph, ii, 1848, p. 316.

Pale flavous, beneath testaceous; breast and legs spotted with black; a band in front of the eyes, two spots on the thorax and four on the elytra, black.

" $\sigma$. Elongate and cylindrical; head and thorax very shining, the former sinooth ; clypeus feebly emarginate; mandibles black;

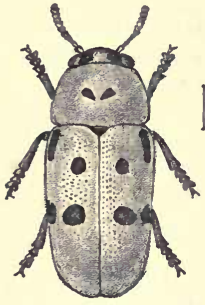

Fig. 57.

Miochira gracilis. eyes rather large, short and ovate, with a black spot near their inner margin; antennæ nearly as long as thorax, brownish, base fulvous. Thorax about one-fourth broader than long, cylindrical, narrowed in front, anterior margin slightly produced at middle; median lobe very short, posterior angles distinct; surface entirely impunctate; two triangular, rather large, closely approximate spots on the disc. Scutellum smooth, black. Elytra subcylindrical, very finely punctured, the punctures piceous and superficial, the spots placed obliquely, the first two near base, the others slightly behind the middle; humeral spot elongate, others small and round; pygidium with a large black spot. Legs slender, fulvous; base of femora, apex of tibiæ and first two joints of tarsi black; latter very short, rather robust, first two joints trigonal and equal." (Lacordcire.)

Length $5 \mathrm{~mm}$.

Hab. Sikhim; Assam; Burma.

280. Miochira montana, Jac. (Clythra) Ann. Soc. Ent. Belg. xxxix, 1895 , p. 255 .

Black. Thorax flavous, with a central black patch. Elytra fulvous, a large trigonal or subquadrate spot at base, a transverse band behind the middle and the extreme apex black.

Narrow and elongate; the head very finely and sparingly punctured, black, shining, obsoletely transversely grooved between the eyes; the clypeus also with an obsolete

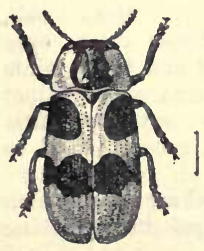

Fig. 58.

Miochira montana. depression at each side; labrum flavous; antennæ black, extending to the base of the thorax, the basal four joints flavous, fifth and following joints strongly transverse. Thorax about one-half broader than long, the sides obliquely narrowed in front, somewhat angulately widened behind the middle, the surface very minutely punctured, the middle occupied by a broad longitudinal black band from the base to the apex, slightly constricted at apex. Scutellum black, its apex pointed. Elytrn very finely punctured in 
irregular closely approximate double rows, each elytron with a subtriangular large patch on the shoulder, not extending to the suture but nearly to the middle, another transverse band behind the middle strongly narrowed at the sides, and the extreme apex black. Body beneath and the legs black, the anterior tibiæ flavous at base.

\section{Length $4 \mathrm{~mm}$.}

Hab. Himalayas : Simla, Dalhousie; Assam : Khási Hills.

The thoracic band is slightly angulate and constricted before the middle; the spot at the base of the elytra is of nearly quadrate shape, but has the inner margin slightly rounded and narrowed anteriorly, the central band is suddenly and strongly widened near the suture, and the third spot is placed at the extreme edge of the elytra, and is of narrowly transverse shape. In specimens from the Khási Hills the head has a large fulvous spot on its anterior portion, and the thoracic band is widened into a point in the iniddle; in one specimen the second elytral band is separated into two spots. The species agrees better in character with Miochira than with Clytra. It differs from $M$. nilgiviensis in the nearly black head, position and number of elytral spots and the addition of an apical spot.

\section{Miochira indica, Jac. (Melitonoma) Ann. Mus. Civ. Genova, xxix,} 1889 , p. 158.

Fulvous; apical joints of antennæ fuscous; head with a black spot at vertex; elytra with four spots subquadrately placed on each and the extreme apex black; breast and abdomen partly black.

Narrowly elongate, cylindrical. Head impunctate, a triangular black spot on the vertex; antennæ half the length of thorax, basal six joints fulvous, rest fuscous, fifth and following joints transversely dilated. Thorax about one-half broader than long (not twice as broad, as originally given), rather widened at the middle; sides and anterior margin straight; surface, when seen under a strong lens, extremely minutely punctured; median lobe feebly produced, rounded. Scutellum rather small, triangular. Elytra very minutely punctured, the punctures here and there arranged in rows; of the four spots, two, of oblong shape, are placed transversely immediately below the base, the other two behind the middle ; the outer spot of the latter two is of elongate shape and close to the lateral margin, the other near suture; there is a narrow spot also at the extreme apical margin.

Var. Scutellar elytral spot absent. Tarsi with first joint not longer than second.

Length 5-6 $\mathrm{mm}$.

Hab. Burma : Bhamo. 


\section{Genus DIAPROMORPHA.}

Diapromorpha, Lacord. Mon. Phytoph. ii, 1848, p. 227 ; Chapuis, Gen. Coléopt. x, 1874, p. 121.

Type, D. trifasciata, Oliv., from Africa.

Range. Africa and India.

Body subcylindrical, robust, often narrowed posteriorly; the head deflexed, deeply inserted; eyes large; antennæ robust. Thorax subcylindrical, strongly convex, the posterior angles more or less distinct. Scutellum small, deflexed. Elytra with very distinct lateral lobes, only partly covering the pygidium. Legs robust, tibiæ widened anteriorly ; the tarsi robust, of nearly equal length, rather short, the first joint shorter than the following two united.

These insects may be distinguished from the genus Clytra by their more cylindrical shape and the shape of the elytra ; the latter have distinct lateral lobes and not only leave the pygidium partly uncovered but often also the sides of the abdomen; the prosternum is either visible in shape of a very narrow ridge or is entirely obsolete.

\section{Secrion I. \\ Species of large size (8-12 $\mathrm{mm}$.).}

282. Diapromorpha gigantea, Jac. Ann. Mus. Civ. Genova, xxxii, 1892, p. 878.

Bluish-black; elytra with basal margin, a transverse band near middle and another near apex, flavous.

Convex, subcylindrical, narrowed posteriorly. Vertex of head swollen, impunctate, space in front of eyes finely rugose; clypens broad, flattened, bounded at sicies by a deep oblique groove, preceded by a narrow ridge; labrum and palpi black; antenn» scarcely extending to base of thorax, basal three joints dark fulvous, second and third very small, rest triangularly widened. Thorax about twice as broad as long, sides narrowed in front, posterior angles distinct, posterior margin produced in a rourded lobe at middle; surface with some obsolete depressions near the sides, shining, almost impunctate, some extremely fine punctures only on the sides. Scutellum triangular, smooth. Elytra closely and distinctly punctured, interstices very finely punctate; black, basal margin narrowly fiavous, this colour not extending to suture; the band immediately before the middle broad and of regular shape, extends to either margin, the preapical band more irregular and narrowed towards the suture. Beneath finely pubescent. Last abdominal segment with deep fovea in female.

Length 11-12 mm.

Hab. Burma : Karennee. 


\section{Diapromorpha obscuromaculata, sp. $\mathrm{n}$.}

Obscure dark fulvous; head, the basal portion of the thorax, the underside and legs black; elytra with a humeral spot and a transverse band behind the middle black.

Broad and robust. The head very minutely punctured, a band of short pubescence in front of the eyes; clypeus feebly emarginate; palpi fulvous; antennæ with the basal four joints fulvous, the succeeding five blackish, strongly transversely serrate, the rest in the type and only specimen wanting. Thorax more than twive as broad as long, narrowed anteriorly, the sides strongly deflexed, lateral margins feebly rounded, median lobe very short; surface with an oblique depression at each side, the interior of which is distinctly punctured, other punctures placed near the basal margin, the basal portion black, this colour in shape as of a transverse band, widened at each side, rest of the surface dark fulvous. Scutellum black. Elytra narrowed posteriorly, very closely and rather finely punctured; the humeral lobes very prominent; the transverse band rather broad, not quite extending to either margin. Body beneath closely pubescent.

Length $8 \mathrm{~mm}$.

Hab. Burma (Coll. Jacoby).

As in D.burmanica the obscureness of the markings and darkness of the ground-colour in the specimen before me is probably caused by discoloration.

284. Diapromorpha pinguis, Lacord. Mon. Phytoph. ii, 1848, p. 234.

Black; thorax with a subquadrate flavous patch at anterior angles; elytra flavous, a transverse band before and another behind the middle, black.

o. Short, cylindrical and robust. Head finely rugose and pubescent between the eyes, a transverse sinuate groove below vertex, the latter finely punctured and convex;

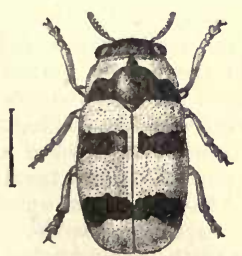

Fig. 59.-Diapromorpha pinguis. ground-colour; the first band below base interrupted by the suture 
and slightly by the lateral margins, the second near the apex, entire.

$\nabla a r$. "Elytral bands very narrow, anterior band more on less triangular, posterior band interrupted at the sides." (Lacordaire.)

Length $8 \mathrm{~mm}$.

$H a b$. India ; Assam.

285. Diapromorpha melanocephala, Jac. Ann. Mus. Civ. Genova, xxxii, 1892, p. 878.

Black; basal joints of antennæ, thorax and elytra fulvous, the latter with an obscure piceous humeral spot.

Head black, shining, impunctate, finely strigose and distinctly triangularly depressed between the eyes; antennæ black, not extending to base of thorax ( $q$ ?), basal four joints fulvous, second and third joints very small. Thorax twice as broad as long, narrowed in front, sides deflexed, lateral margins straight, medial lobe rounded, surface entirely impunctate. Scutellum broad, pointed at apex, basal portion fulvous, apex black. Elytra subcylindrical, lateral lobes feeble; disc with irregular rows of fine punctures which are double near the lateral margins; pygidium black, free, finely punctured. Body beneath clothed with yellowish pubescence. First joint of posterior tarsi as long as the following two joints united.

Length $8 \mathrm{~mm}$.

Hab. Burma: Karennee. Type in Genoa Mus.

Near D. melanopus but larger, elytral lobes not strongly produced, puncturation finer and partly geminate.

\section{Diapromorpha burmanica, sp. $n$.}

Obscure fulvous above, beneath black; thorax with indistinct bands of black at base and sides; elytra irregularly punctured, an obscure transverse band at base and the apical portion black.

Broad and subcylindrical. Head with bands of pubescence near the eyes; clypeus finely longitudinally striguse; vertex convex; antennæ dark fulvous, the fourth and following joints strongly serrate. Thorax strongly transverse, lateral margins rounded, median lobe broadly but feebly produced; the surface entirely impunctate, very shining, the greater portion of the base and sides black, the rest obscure fulvous, both colours more or less confluent and indistinct. Scutellum black. Elytra rather feebly lobed at the base, very closely finely and irregularly punctured, apex nearly impunctate; of the fuivous portion only the base, a lateral space at middle and a small sutural spot near the apex are visible, all the rest is black, very indistinctly separated from the ground-colour. Body closely pubescent. The last abdominal segment deeply triangularly ensarginate at apex (오).

Length $8 \mathrm{~mm}$.

Hab. Burma (Coll. Jacoby); Tharrawaddy, var. (Ccll. Andrevves). 
A single male specimen in Mr. Andrewes' collection is of entirely dark fulvous colour above but varies in no other way from the type, the last abdominal segment in that specimen is entire; the obscure colour of the elytra seems to point to discoloration.

\section{Section II.}

Species of smaller size $(4-7 \mathrm{~mm}$.).

287. Diapromorpha quadripunctata, Jac. P.Z.S. 1887, p. 68; Weise, Deut. ent. Zeit. 1903, p. 24.

Gynandrophthalma lacordairei, Jac. Ann. Soc. Ent. Belg. xxxix, 1895, p. 261.

Fulvous ; terminal joints of antennæ blackish ; elytra with four black spots $(2.2)$ or two transverse bands or with the posterior portion entirely black.

Head with shallow, transverse groove between the eyes; vertex convex, impunctate, intraocular space finely rugose, obsoletely
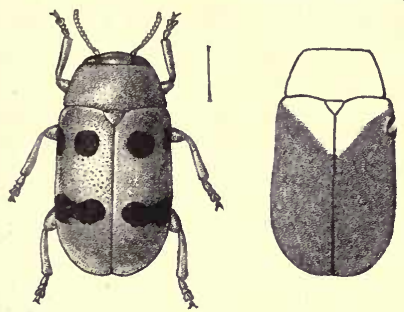

Fig. 60.-Diapromorpha quadripunctata and var. depressed at the sides; clypeus finely longitudinally strigose, anterior edge subtriangularly emarginate; eyes large, oblique, slightly notched; antennæ not extending to base of thorax, black, basal four joints fulvous, second and third short, fourth and following joints transverse. Thorax about two and a half times broader than long, sides nearly straight, slightly narrowed in front, angles distinct, anterior and posterior margins straight, latter feebly lobed at base; surface with a rather deep transverse depression near posterior angles, microscopically punctured. Scutellum broad, apex rather pointed. Elytra distinctly lobed at sides, with very feeble transverse depression before the middle, crowded with small punctures; pygidium either covered by elytra or partly free. Legs rather short, tarsi of nearly equal length, short.

Var. a. Above entirely fulvous, beneath and the legs black or fulvous : nalandensis, Weise.

Var. $b$. Elytra with a narrow black margin from behind the middle to apex, beneath fulvous.

Var.c. Elytra each with only two black spots, either the anterior or the posterior two.

Var. $d$. Elytra each with three spots (1.2.4), spot 3 absent.

Var. e. Head, thorax and underside black, elytra with four spots : dambullensis, Weise.

Var. $f$. Fulvous, posterior portion of elytra more or less black. 
Length 5-6 mm.

$H a b$. Kanara ; Nilgiris ; Travancore ; Ceylon.

The type of this species, a single specimen, was originally described from Ceylon. On account of the partly covered pygidium, the varieties from different parts of India were redescribed by me as Gynandrophthalma, in which genus I now consider the insect cannot be placed as it has pronounced epipleural elytral lobes. In the Belgian 'Annals' I have pointed out at length the differences between this and allied forms. Of these, D. dejeani, Lacord., is perhaps more nearly allied to the typical form than the others, but may be at once distinguished from it by tho strong elytral puncturation, banded thorax and differently coloured legs. D. quadripunctata is a smaller species with the sides of the thorax scarcely rounded, the latter are also less strongly transverse.

288. Diapromorpha dejeani, Lacord. Mon. Phytoph. ii, 1848, p. 235 ; Baly, Trans. Ent. Soc. (3) iv, 1865, p. 49.

Black; above fuscous; thorax with two angulate spots ( $\left.\sigma^{\circ}\right)$ or with a transverse sinuate black band near base ( $q$ ); elytra with a short transverse black band at shoulders and another longer one near apex.

ठ. Short, oblong and subcylindrical. Head shining, black, closely pubescent between the eyes, this portion depressed; verter

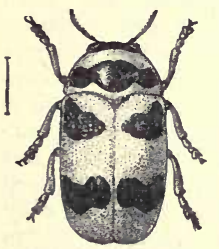

Fig. 61.

Diapromorpha dejeani and clypeus convex; antennæ nearly extending to base of thorax, basal four joints flavous, rest nearly black, fifth and following joints strongly transversely widened. Thorax about half as broad as long, widened at middle, sides feebly rounded; surface impunctate, with a subquadrate and angulate spot each side near base, its inner edge deeply concave. Scutellum small and narrow. Elytra very strongly and closely punctured, the punctures placed in very irregular rows, very fine at apex; first band short, widest at shoulders, second larger, deeply constricted at middle and irregular in outline, neither band extending to the lateral or sutural margins. Underside densely pubescent.

․ Thorax strongly transverse, twice as broad as long, with a strongly transverse black band, deeply sinuate on the anterior margin at each end, widened in the middle; elytral puncturation rather less strong and regular than in male.

Length 5-6 $\frac{1}{2} \mathrm{~mm}$.

Hab. Nepal; Sikhim; Coromandel ; recorded also from the Malay Islands.

Lacordaire evidently did not know the male of this species, which varies in the shape and markings of the thorax as pointed out above; the puncturation of the elytra in both sexes is strong. 
289. Diapromorpha sexmaculata, Jac. (Gynandrophthalma) Ann. Mus. Civ. Genova, xxix, 1889, p. 157 ; id. Ann. Soc. Ent. Belg. xxxix, 1895, p. 256.

Black; basal joints of antennæ fulvous; thorax fulvous or with two black bands; elytra fulvous, with two transverse bands.

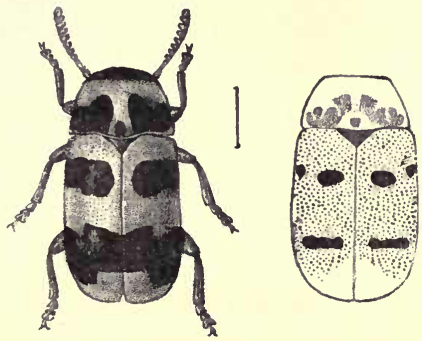

Fig. 62.-Diapromorplia sexmaculata and var.

Differs from $D$. dejeani in the bluish-black colour of the head, in being finely longitudinally strigose, not smooth, and in the clypeus and fulvous labrum. Thorax strongly transverse in both sexes; sides strongly rounded, with the black bands touching the basal margin, often connected at base. Scutellum broad and triangular, not small and narrow. Elytra extremely finely and closely punctured; the bands as in $D$. dejeani but of different shape.

Var. $a$. Thorax and elytra entirely fulvous or flavous, without spots.

Var. $b$. Thorax as in var. $a$; elytra with two small spots at base and one transverse in shape behind the middle (true D. sexmaculata, Jac.).

\section{Length 6-7 $\mathrm{mm}$.}

Hab. Burma: Bhamo, Tharrawaddy.

Neither this species nor $D$. quadripunctata, Jac. is typical of Diapromorpha, since the pygidium is exposed in the of only, not in the $\delta$, nor are the elytral lobes strongly pronounced : both insects are transitionary between the present genus and Gynandrophthalma, approaching however, more nearly to Diapromorpha.

290. Diapromorpha octomaculata, Jac. (Gynandrophthalma) Ann. Mus. Civ. Genova, xxxii, 1892, p. 884.

Beneath black, clothed with silvery pubescence, above fulvous; elytra each with four small black spots (2.2).

Subeylindrical, convex and robust. Vertex of head im- 
punctate, intraocular space very finely punctured, with an

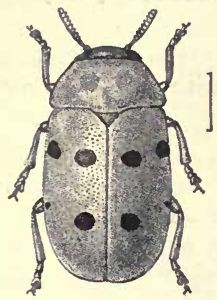

Fig. 63.

obsolete transverse groove; clypeus finely punctured, its anterior edge emarginate; labrum and palpi fulvous; antennæ fuscous, extending to base of thorax, basal four joints shining, rest triangularly widened. Thorax rather more than twice as broad as long; sides rather regularly and strongly rounded; posterior margin straight at sides, slightly produced at middle; surface with a few minute punctures. Scutellum apex acute, slightly raised. Elytra very closely and rather strongly Diapromorpha octomaculata. punctured, apex nearly impunctate, two spots transversely before the middle and two behind the latter black; outer spot of the second row very small, often indistinct, close to lateral margin. Beneath densely pubescent; legs fulvous.

Var. Thorax with four small black spots.

Length $7 \mathrm{~mm}$.

Hab. Burma : Pegu.

Differs from $D$. sexmaculata, Jac., in the fulvous, not bluishblack, head and much more strongly punctured elytra, the latter in the last-named species are nearly smooth.

291. Diapromorpha melanopus, Lacord. Mon. Phytoph. ii, 1848, p. 238. Clytra pallens, Oliv. Entom. vi, 1808, p. 836, pl. 2, fig. 27.

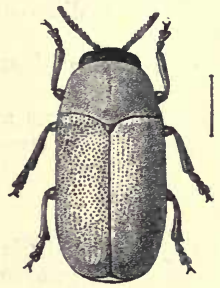

Fig. 64 .

Diapromorpha melanopus.

Black; palpi and base of antennæ testaceous; thorax and elytra pale flavous, subopaque.

$\delta$. Short, cylindrical and feebly narrowed posteriorly. Head finely rugose, pubescent between the eyes, shining and smooth on the vertex, latter slightly convex; antennæ not extending to base of thorax, dark fulvous, basal four joints testaceous. Thorax about twice as broad as long, feebly narrowed in front; median lobe obtuse; surface more or less finely punctured, sometimes indistinctly so. Scutellum fulvous or black, smooth, rather small. Elytra strongly lobed at sides, strongly punctured, the punctures rather closely placed. Legs and tarsi robust.

Var. Much smaller; upper part of head, labrum, palpi, antennæ, tibiæ and tarsi testaceous.

Length $6 \mathrm{~mm}$.

$H a b$. India; Siam.

One of the commonest species of the genus. Can be recognized by the black head and unspotted upper surface. 
The small variety described by Lacordaire is the male, in which the dense pubescence of the underside is of golden colour; that of the female is white or grey.

\section{Diapromorpha capitata, sp. $n$.}

Upper part of head and underside black; lower portion of face and thorax fulvous; elytra and legs flavous.

Elongate and subcylindrical. Head very finely pubescent near inner margin of eyes; the entire vertex crossed by a broad transverse black band that extends in a narrow stripe in front of the eyes; fulvous portion of face impressed with three deep foveæ; anterior margin of elypeus feebly emarginate; mandibles black; palpi flavous; antennæ extending to base of thorax, fulvous, second joint short, moniliform, third and fourth more elongate, the latter slightly widened, succeeding joints strongly transversely serrate. Thorax two and a half times broader than long, lateral margins moderately rounded, angles distinct, the surface impunctate, sides with two very small foveæ near the base, median lobe straight. Scutellum broader than long, apex truncate. Elytra distinctly lobed below the shoulders, subcylindrical, scarcely narrowed posteriorly, puncturation close and rather fine, interstices finely granulate. Body beneath densely clothed with silvery pubescence. Pygidium exposed. Tarsi broad and short.

\section{Length $7 \mathrm{~mm}$.}

$H a b$. Bengal (Coll. Jacoby).

I know no other species of the genus similarly coloured as regards the black band on the head added to the smooth thorax and finely punctured elytra, in which respects the species differs from $D$. melanopus, which it resembles somewhat in coloration.

293. Diapromorpha turcica, Fab. (Clythra) Syst. Eleut. ii, 1801, p. 37; Lacord. Mon. Phytoph. ii, 1848, p. 236.

Var. Diapromorpha quadrimaculata, Jac. Aun. Soc. Ent. Belg. xxxix, 1895, p. 257.

Beneath black, above fulvous or flavous. Thorax with two black spots (sometimes united). Elytra with a transverse band behind the middle, a spot below the base, and another near the apex black.
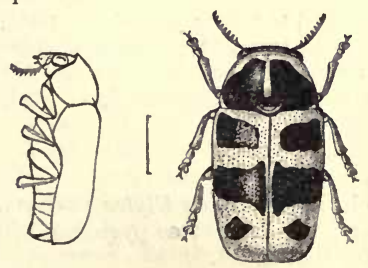

Fig. 65 .

Diapromorpha turcica, var.

Var. a. Tibiæ and tarsi more or less fulvous; subapical spot of elytra absent.

Var. b. Thorax black, the anterior and lateral margins and a median line fulvous.

Var. c. Thorax with two small spots at the base and two at the middle black.

Var. $d$. Thorax with two or four black spots or entirely fulvous. 
Var. e. Elytra with two transverse bands and a subapical spot.

Var. $f$. Elytra with a single transverse line and a subapical spot.

One of the most variable species of the genus, but fairly easy of recognition on account of the subcylindrical parallel-sided shape and the strong elytral puncturation. Head pubescent in front of the eyes, glabrous above and below the latter ; antennæ black, the basal three or four joints fulvous. Thorax rather long, about one-third broader than long, the middle somewhat widened, the posterior angles acute; the dise impunctate, shining, with two subtriangular broad and angulate black patches at the base more or less divided anteriorly, in some occupying the entire disc. Scutellum small and subelongate. Elytra moderately strongly lobed at the sides below the shoulders, very closely and strongly punctured, the interstices more or less wrinkled; in normally coloured specimens with a short transverse band at the shoulders, a larger band immediately behind the middle and a spot near the apex. Underside and legs black.

Length 4-6 mm.

$H a b$. India; Ceylon.

Diapromorpha quadrimaculata, Jac., is only a variety in which the elytral subapical spot is wanting and the tibiæ and tarsi are fulvous. A rather common and widely distributed species in India.

294. Diapromorpha balteata, Lacord. Mon. Phytoph. ii, 1848, p. 236.

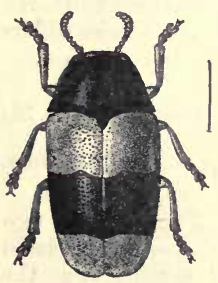

Fig. 66.

Black; elytra flavous or fulvous, a transverse black band behind the middle.

Subcylindrical, very slightly narrowed posteriorly. Head clothed (the anterior portion excepted) with fine grey pubescence; clypeus very moderately emarginate; antennæ black, extending to about the middle of the elytra, the basal four joints fulvous. Thorax scarcely twice as broad as long, narrowed anteriorly, the lateral margins nearly straight, the disc subcylindrical; the surface impunctate, black and shining. Diapromorphabalteata. Elytra finely punctured in very closely placed irregular rows, their humeral lobes very distinct; fulvous, with a transverse black band behind the middle, slightly curved and extended to either margin. Body beneath clothed with grey pubescence.

Length 6-7 mm.

$H a b$. India : Madras.

This species greatly resembles in its coloration Clytra succincta, Lacord., but the produced humeral lobes and free pygidium will prevent it from being mistaken for that insect. 
295. Diapromorpha indica, Juc. Ann. Soc. Ent. Belg. xlvii, 1903, p. 83.

Black; tibiæ and tarsi obscure fulvous; elytra fulvous, a transverse black band behind the middle.

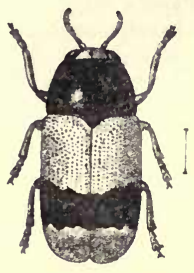

Fig. 67.

Diapromoipha indica.

Head finely and closely pubescent between the eyes; antennæ not extending to base of thorax, basal three joints fulvous, fourth and following joints transverse. Thorax subcylindrical when seen from above, strongly narrowed anteriorly; sides rounded; median lobe of basal margin very short and somewhat pointed, anterior margin rather strongly advanced at the iniddle; surface very minutely punctured. Elytral epipleuræ strongly produced at the sides, closely and strongly punctured. Body beneath densely

$H a b$. Bombay: Kanara. pubescent. Pygidium free.

\section{Length $6 \mathrm{~mm}$.}

Sinaller than $D$. balteata, Lacord. Of exactly similar coloration but separated by the strong and irregular elytral puncturation; the latter in D. balteata is arranged in rows and the transverse band is placed higher than in $D$. indica.

\section{Genus CERATOBASIS.}

Ceratobasis, Lacord. Mon. Phytoph. ii, 1818, p. 362; Chapuis, Gen. Coléopt. x, 1874, p. 129.

Type, $C$. nair, Lacord., from India.

Range. India; Ceylon.

o. Most of the characters of Coptocephala, but the head much less broad and trigonal, instead of subquadrate; the second and third joints of the antenuæ small, nearly equal. Thorax less strongly transverse, the sides only very feebly rounded. Anterior legs elongate, their tibiæ long, slightly curved ; tarsi elongate, first joint as long as the following two united.

‥ Head, antennæ and legs shorter, tarsi less elongate.

296. Ceratobasis nair, Lacord. Mon. Phytoph. ii, 1848, p. 363.

Flavous; breast, vertex and two spots on thorax black; elytra with a subquadrate spot before and another behind the middle, bluish-black.

ס. Short and cylindrical. Head smooth, with a broad transverse black band on vertex, extending as far as the eyes; clypeus triangularly emarginate; labrum piceous; eyes large, entire; antennæ slightly extending beyond thorax, fuscous, the basal 
joints fulvous, first joint subquadrate. Thorax twice as broad as long, sides straight, posterior angles distinct, basal margin feebly lobed, surface very smooth, with two large black spots placed transversely. Scutellum black, the apex sometimes fulvous. Elytra very finely punctured, the punctures only visible under a strong lens, rather regularly arranged in rows; the spots large, subquadrate, the basal spot not quite extending to basal margin, the other behind the middle sometimes slightly constricted at its inner margin. Anterior legs more elongate than the others, the first joint of their tarsi as long as the following two united.

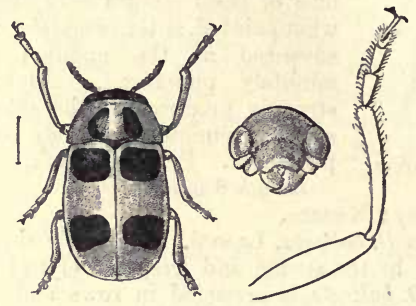

Fig. 68.-Ceratobasis nair.

ㅇ. Of more oblong-ovate shape, the head smaller, the basal joint of antennæ more slender, thorax shorter, more narrowed in front, the legs less elongate and the tarsi equal.

Var. $a$. Eyes with black orbits, thorax entirely fulvous.

Var. $b$. Head as in var. $a$. Elytra with a humeral spot, the other markings as in the type.

Var. c. Elytra black, narrowly margined with fulvous.

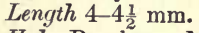

$H a b$. Bombay ; Malabar; Nilgiris.

A common and rather widely distributed Indian species; var. $c$ has been obtained on the Nilgiris and was not previously known.

297. Ceratobasis kœnigii, Fab. (Cryptocephalus) Syst. Ent. 1775, p. 111; Hübner (Cryptocephalus), Naturforscher, xxiv, 1789, p. 41, pl. 2, fig. 5; Fabr. (Clythra) Ent. Syst., Suppl. 1798, p. 114; Lacord. (Clythra-Ceratobasis) Mon. Phytoph. ii, 1848, p. 364.

Fulvous; breast, abdomen, labrum, two spots on head, and antennæ (base excepted) black. Elytra with two bluish-black spots at base, the outer one the smallest.

Rather shorter and more cylindrical than C. nair. Head very smooth, a spot near inner margin of eyes black; clypeus not separated, rather deeply emarginate; eyes ovate, nearly entire; 
antennæ slender, basal joint trigonal, strongly dilated, very slender at base. Thorax about two-thirds broader than long, regularly cylindrical, feebly narrowed in front, sides straight, posterior angles distinct, medial lobe feebly produced, surface entirely smooth. Scutellum slightly elongate. Elytra scarcely perceptibly punctured, one black spot near suture oblong, the other smaller near the margin. Legs, as well as the tarsi, rather long; anterior tarsi distinctly elongate.

Var. a. Elytral spots nearly indistinct.

Var. b. Elytra without any spots.

Length $4 \frac{1}{2} \mathrm{~mm}$.

$H a b$. India.

It is possible that specimens occur in which the elytra have four spots each, since Hübner speaks of a specimen with an additional spot at middle near margin.

\section{Ceratobasis ceylonensis, sp. n.}

Fulvous; the terminal joints of the antennæ and the breast black, the head and thorax with two

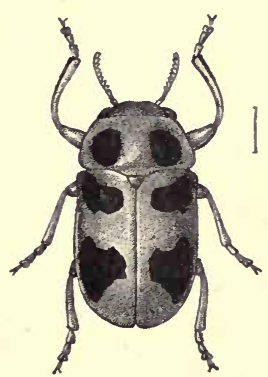

Fig. 69.

Ceratobasis ceylonensis. black spots; elytra each with a black transverse short band at the base and auother behind the middle.

๙ . Anterior tibiæ elongate, strongly curved.

Head fulvous, very broad, transversely grooved between the eyes, the latter with a black spot in front of each; clypeus with a shallow semicircular depression, triangularly emarginate at the sides and in the middle; labrum black; antennæ black, extending to the base of the thorax, the basal three joints fulvous, basal joint strongly, subquadrately widened, fourth and following joints transverse. Thorax twice as broad as long, the sides and the posterior angles rounded, the basal margin scarcely lobed at the middle; the surface convex, impunctate, fulvous, with two widely separated, black, elongate and slightly curved spots, not extending to the anterior but to the posterior margin. Scutellum triangular. Elytra fulvous, subquadrate, without basal humeral lobes, very minutely granulate and impressed with fine very obsolete punctures, the basal margin raised into a fine ridge; each elytron with a transverse, short, black band below the base and another one, slightly narrowed at its inner portion, behind the middle, neither of these bands extends to either margin. Anterior coxæ black, rest of the underside and the legs fulvous, anterior femora and their tibiæ with a narrow black upper edge. 
Length $5 \mathrm{~mm}$.

Hab. India, Ceylon, Bandra (Colls. Brit. Mus. \& Jacoby).

In the female the anterior femora and their tibiæ are of normal shape and the latter are straight instead of curved.

Very closely allied to the common $C$. nair and very similar in coloration, but I think a distinct species. The differences are as follows:- the eyes are much smaller, the third joint of the antennæ is as short as the second, not elongate and thin as in C. nair, the black thoracic spots are placed much further apart, the basal elytral band is placed less close to the basal margin, and the anterior tibiæ of the male are strongly curved.

299. Ceratobasis opacipennis, Jac. (Gynandrophthalma) Ann. Soc. Ent. Belg. xlvii, 1903, p. 86.

Fulvous above, black beneath; terminal joints of antenuæ fuscous; elytra opaque, shoulders with a small piceous spot.

Elongate; head impunctate, a very shallow fovea on each side at middle, becoming more deep and elongate at sides of clypeus; latter broad and flat, impunctate, deeply emarginate in front; labrum piceous; antennæ extending to base of thorax, basal three joints flavous. Thorax twice as broad as long, slightly narrowed anteriorly, median lobe slight, rounded; surface impunctate, shining. Scutelluin triangular. Elytra subcylindrical, microscopically punctured, punctures extremely close. Anterior legs and tarsi very elongate, first joint of latter as long as the following two united.

Length $5 \mathrm{~mm}$.

Hah. Bombay; Kanara.

The elongate legs and tarsi, distinct posterior thoracic angles and the absence of elytral lobes place this species better in Ceratobasis than in Gynandrophthalma. In the original description the length is erroneously given as five lines.

\section{Genus COPTOCEPHALA.}

Coptocephala, Lacord. Mon. Phytoph. ii, 1848, p. 345; Lefevre, Mon. Clytrina, 1871, p. 359 ; Chapuis, Gen. Coleopt. x, 1874, p. 127.

Type, C. melanocephala, Oliv., from Algiers.

Range. Europe; Asia; Africa.

б. Cylindrical; head finely pubescent; antennæ short; head very broad, subquadrate; labrum ánd clypeus broad, anterior margin of the latter more or less deeply emarginate, anterior angles rounded; eyes small. Thorax of nearly equal width, posterior angles rounded. Anterior legs elongate, the tibiæ curved, first joint of tarsi as long as following two united, lobes of the third joint prolonged into a point. 
Principally distinguished by the strong development of the head in the male, the structure of the clypeus, the short thorax and elongate legs. The female differs in the much smaller, more elongate head, the short mandibles and the anteriorly narrowed thorax.

300. Coptocephala dimidiatipennis, Baly, Cist. Ent. ii, 1880, p. 371.

Flavous; body beneath, the head and the inflexed margin of the elytra with fulvous pubescence; elytra black, the base to near the middle flavous.

Head clothed with long erect hairs, minutely punctured; clypeus not separated from face, anterior margin angulate-emarginate; apex of mandibles black; antennæ equal in length to the head and thorax, basal joint thickened, pyriform, second also thickened, short, third small, not longer than the second, fourth trigonal, scarcely longer than the third, the rest dilated, transversely trigonal, tenth and eleventh ovate. Thorax nearly three times as broad as long, sides obtusely rounded, slightly convergent in front, posterior angles rounded, anterior very obtuse, basal margin sinuate on either side of the median lobe, the latter obtusely rounded; upper surface transversely convex, remotely and very minutely punctured, a concave transverse space on and immediately in front of the basal lobe coarsely and closely punctured. Scutellum longer than broad. Elytra scarcely broader than the thorax at base, slightly dilated posteriorly, rather distantly and finely punctured. Body beneath and legs clothed with long erect fulvous hairs.

Length 6-7 mm.

Hab. India: Punjab; Jhelum Valley; Assam.

\section{Coptocephala minuta, sp. n.}

๘. Fulvous; terminal joints of antennæ fuscous, elytra and legs pale fulvous. Head broader than long, with a feeble triangular groove between eyes, the latter widely separated, rather small, surface of head with a few fine punctures; clypeus scparated by a faint transverse groove from face, its anterior margin truncate; antennæ with basal four joints flavous, rest darker. Thorax impuuctate, fulvous. Elytra flavous, rather closely and distinctly punctured, extreme apex nearly impunctate; covering the pygidium.

Length $3 \mathrm{~mm}$.

Hab. Bengal; Western India: Belgaum (Coll. II. E. Andrewes).

A very small species with a broad head and truncate anterior edge to the clypeus. The thorax is nearly three times broader than long with rounded posterior angles, the anterior legs are more elongate than the others. 


\section{Subfamily III. CRYPTOCEPHALIN E.}

Of cylindrical compact shape. Head perpendicular, flat; eyes kidney-shaped, distant or sometimes touching above; antennæ filiform, in some genera short and with dilated terminal joints. Thorax transverse, subcylindrical, sides and anterior portion strongly deflexed. Scutellum generally triangular, sometimes elongate, lanceolate, in one genus (Dioryctus) not visible from above. Elytra not wider than base of thorax, more or less strongly lobed at sides, not covering pygidium, surface punctate-striate. Legs moderately elongate ; tarsi more or less triangular, first joint sometimes longer than second, claws appendiculate or simple. Prosternum of variable shape, more frequently subquadrate, its anterior edge more or less strongly produced and hollowed for the reception of the parts of the mouth, the posterior margin generally concave with the angles produced and pointed.

Within our limits this is one of the most numerously represented subfamilies of the whole of the Chrysomelidx. It comprises an enormous number of species of neat and cylindrical shape and greatly varied colour and pattern. The species of this subfamily can as a rule be separated from the Clytrina, which they somewhat resemble, by the deeply emarginate eyes and filiform antennæ.

They inhabit all parts of the world.

\section{Key to the Genera of Cryptocephalinæ.}

A. Antennæ short, terminal joints widened.

a. Scutellum invisible from ubove ...... Dionyctus, p. 176.

b. Scutellum visible.

$\boldsymbol{a}^{\prime}$. Eyes nearly, sonietimes completely, touching above .............

$b^{\prime}$. Eyes not very closely approximate, never touching..............

B. Antennie long and filiform, joints not or Canobrus, p. 182.

Melixanthus, p. $26 \%$. scarcely widened.

a. Thorax transverse.

$a^{\prime}$. Thorax closely fitted to base of elytra, base not margined ......

$b^{\prime}$. Thorax not closely fitted to base of elytra, base narrowly margined.. PAсHyвrachys, p. 265.

b. Thorax conical, narrowed in front .... MrLinobius, p. 269.

\section{Genus DIORYCTUS.}

Dioryctus, Suffr. Linn. Ent. xiv, 1860, p. 3 ; Weise, Deut. ent. Zeit. 1903, p. 33

Atropidius, Chapuis, Gen. Coléop:'. x, 1874, p. 175.

Type, $D$. porculus, Suffr., from Ceylon.

Range. India; Japan; Malay Archipelago. 
Body strongly rounded and convex. Head broad and flat; eyes widely separated, broadly emarginate, emargination subtriangular; antennæ short, terminal six joints dilated. Thorax transverse, basal margin strongly oblique, drawn out into a point at middle, finely serrate. Scutellum invisible. Elytra with strongly produced and angulate epipleural lobes extending nearly to middle of length. Legs short and robust, tibiæ dilated at apex. Prosternum slightly transverse, subquadrate, sides strongly raised into a ridge, diverging outwards anteriorly, middle with another more blunt longitudinal elevation. First abdominal segment very broad.

A well-marked genus on account of the highly convex and rounded shape, invisible scutellum, strong elytral lobes and structure of prosternum. Atropidius, Chap. does not seem to differ from this genus, and the type species ( $A$. improbus, Chap.) is very inadequately described.

\section{Dioryctus porculus, Suffi. Linn. Ent. xiv, 1860, p. 5 .}

" $q$. Black; basal joints of antennæ flavous; breast, coxæ and knees brown; elytra reddish-brown, margins and apex black.

"Head with lower portion and area near the eyes distinctly punctured; clypeus brown, feebly and sparingly punctate; head black at base; eyes elongate, triangularly emarginate; antennæ scarcely longer than the thorax, joints three to tive each as long as the sccond but thinner, terminal joints thickened, basal five flavous, the rest black, the base of each piceous, furnished with solitary long white hairs. Thorax short and broad, basal margin produced into a point at middle, surface extremely finely and remotely punctured. Scutellum scarcely visible. Elytra only a little longer than broad, epipleural lobes strongly produced; surface very finely and remotely punctured, outer interstice slightly convex, the others flat, scarcely punctured, basal and lateral margins black, latter gradually widened towards apex. Underside strongly punctured anteriorly; abdomen finely wrinkled, black.

"Var. Entirely reddish-brown.

"Length 3-4 mm." (Suffrian.)

Hab. Ceylon.

Described from a single female specimen, that had a large but not deep forea on the middle of apieal abdominal segment.

\section{Dioryctus madurensis, sp. $n$.}

Black, with a slight greznish tint; basal joint of antennie flavous.

Head impunctate; antennæ black, basal three joints flavous; eyes subquadrately emarginate. Thorax more than twice as broad as long, medial lobe acutely pointed, surface impunctate. Ely tra ovately subquadrate, slightly narrowed at apex; epipleural

voL. I. 
lobes acutely produced, angulate; surface with a few punctures at base indicating rows, almost impunctate posteriorly, a slightly more distinct row of fine punctures near lateral margins; interstices sparingly punctured. Legs short and robust, tarsi obscurely piceous.

Length $2 \mathrm{~mm}$.

Hab. India : Madura (Coll. H. E. Andrewes).

A very small and strongly convex species, looking much like a Lamprosoma but without visible scutellum and with strongly produced lateral elytral lobes.

\section{Dioryctus glabricollis, sp. n.}

Dark blue above, black beneath; basal joints of antennæ fulvous.

Head extremely finely and sparingly punctured, dark blue; antennæ extending to base of thorax, basal four joints dark fulvous, rest black, third and fourth very small. Thorax strongly transverse, widened at middle, basal margin deeply sinuate at sides, medial lobe acutely produced, surface entirely impunctate. Elytra broadly rounded at apex, very finely but distinctly punctatestriate, the punctures nearly obsolete near apex, rows very distantly placed, interstices entirely impunctate.

Length $2 \frac{1}{4} \mathrm{~mm}$.

Hab. Nilgiris (Colls. H. E. Andrewes \& Jacoby).

Differs from $D$. madurensis in the distinct elytral punctures and the impunctate interstices.

305. Dioryctus robustus, Jac. (Atropidius) Ann. Soc. Ent. Bely. xlviii, 1904, p. 383.

Fulvous ; elytra with a transverse bilobed black band at base and one large black spot or four spots (2.2) near apex.

Broad, subquadrate, highly convex. Head very finely and closely punctured; eres broadly emarginate; labrum pale ; antennæ pale fulvous, terminal six joints widened but longer than broad. Thorax transverse, strongly widened at middle and narrowed in front, basal lobe strongly and acutely pointed, surface impunctate. Elytra finely punctate-striate, shoulders rounded, interstices flat and finely punctate, the outer two strongly convex at apex. Prosternum subquadrate, with the usual three ridges.

Length $4 \frac{1}{2} \mathrm{~mm}$.

$H a b$. Nilgiris.

The largest of the known Indian species, has variable elytral markings, the latter probably disappear entirely in some specimens. In the spotted form one spot is placed on the shoulders, another near scutellum between second and fifth row of punctures, the other two behind the middle close together between the basal spot.. 
306. Dioryctus nigroplagiatns, Jac. (Atropidius) Ann. Soc. Ent. Belg. xlvii, 1903, p. 92.

Beneath piceous; basal joints of antennæ and legs fulvous; head and thorax black; elytra flavous, a broad transverse band at base and another behind the middle, black.

Head flat, extremely minutely punctured, opaque; vertex with short central groove; clypeus fulvous;

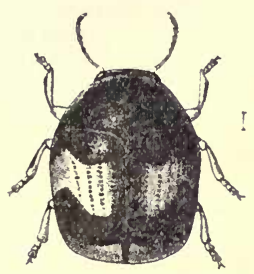

Fig. 70.-Dioryctus nigropletiatus. antennæ with basal five joints fulvous, rest black, terminal joints only slightly widened. Thorax strongly transverse, sides nearly straight, median lobe acute, entire, surface very closely and finely punctured. Elytra with lateral lobes acutely produced and angulate; finely punctate-striate, the black band at base extended along the suture, gradually narrowed near apex, the posterior band widened at the sides, placed behind the middle. Legs short, tibiæ widened at apex. Prosternum deeply concave, lateral margins strongly carinate, metasternum closely punctured.

Var. Head and thorax fulvous, elytral bands indicated only by some obscure spots.

Length 2 inm.

$H a b$. Nilgiris.

307. Dioryctus castaneus, Jac. Ann. Mus. Civ. Genova, xxxii, 1892, p. 888.

Reddish-brown; basal joints of antennæ and tarsi flavous. Beneath dark fulvous.

Robust, subeylindrical and strongly convex. Head flat, closely and finely punctured; eyes moderately deeply emarginate; antennæ not extending beyond base of thorax, basal six joints flavous, rest black. Thorax strongly transverse, sides rounded, narrowed anteriorly, basal margin sinuate at sides, median lobe strongly produced and pointed; surface extremely elosely punctured, the punctures of different sizes. Scutellum not visible. Elytra dark fulvous, with strongly produced epipleural lobes, extreme basal and lateral margins (anteriorly) black, disc regularly punctatestriate, interstices finely punctured. Prosternum with strongly raised lateral margins, broader than long.

Length $2 \frac{1}{2} \mathrm{~mm}$.

$H a b$. Burma : Karennee.

Allied to D. mouhoti, Baly, but only half the size and with the elytral interstices punctured; thoracic sculpture also different.

308. Dioryctus analis, sp. $n$.

Fulvous; breast and abdomen black, apical abdominal segment fulvous. 
Head extremely minutely and closely punctured; clypeus not separated; eyes broadly but not deeply emarginate; antennæ fulvous, second and following joints sbort, moniliform, terminal joints thickened, last joint more elongate and thinner, reaching to the base of elytra. Thorax about two and a half times broader than long, strongly widened at middle, sides nearly straight, posterior margin strongly pointed and produced at middle, finely serrate, extreme basal margin black. Scutellum invisible from above. Elytra convex and ovate, slightly narrowed towards the apex, finely punotate-striate, interstices with some very minute punctures, extreme basal margin black. Body beneath very finely punctured; legs robust; sides of abdomen fulvous. Prosternum broader than long, black.

Length $2 \frac{1}{2} \mathrm{~mm}$.

$H a b$. Nilgiris. Type in Coll. H. E. Andrewes.

Differs from $D$. castaneus in the nearly black, not fulvous, underside, absence of raised prosternal margins and uniformly coloured antennæ and legs.

\section{Dioryctus manipurensis, $\mathrm{sp} . \mathrm{n}$.}

Black; basal joints of antennæ fulvous; elytra with a kidneyshaped fulvous broad band at middle of disc that extends to the apex and sides.

Strongly rounded and convex. Head impunctate, opaque; eyes not deeply emarginate; antennæ extending to base of thorax, second and third joints very short, moniliform, following joints triangularly widened, basal three fulvous, rest black. Thorax more than twice as broad as long, narrowed in front, sides straight, posterior margin produced at middle into a pointed lobe, surface microscopically punctured, shining. Scutellum invisible from above. Elytra subglobular, epipleural lobes strongly angularly produced at sides, extremely finely punctate-striate, the first two and the outer two rows more distinctly marked; the fulvous portion commences below the shoulders, extends obliquely to the suture, and there turning outwards again occupies the entire posterior portion of sides and apex. Legs short and robust. Prosternum slightly broader than long, lateral margins highly raised and curved outwards anteriorly.

Length $2 \mathrm{~mm}$.

Hab. India: Manipur (Coll. Brit. Mus.).

Very similarly coloured to D. nigroplagiatus, Jac., but with nearly impunctate thorax and black legs, the elytral fulvous band not interrupted posteriorly.

310. Dioryctus semibrunneus, sp. n.

Fulvous; elytra black, an elongate subtriangular band at middle near suture fnlvous. 
Oblong, very convex. Head broad and rather flat, closely and distinctly punctured; clypeus not separated; eyes feebly emarginate; antennæ fulvous, not extending to base of thorax ( $q$ ), joints very short, terminal joints widened. Thorax about twice as broad as long, anterior half as wide as the posterior margin, latter produced into an acute point at middle. Elytra finely but distinctly punctate-striate, interstices flat, very finely punctured in single rows, with other more minute punctures intermixed; the fulvous band placed near suture before middle, between first and sixth rows, pointed posteriorly, not extending to apex, the latter partially fulvous.

Length $2 \frac{1}{2} \mathrm{~mm}$.

Hab. Manipur (Coll. Brit. Mus.).

Larger than $D$. manipurensis, of different coloration and strong elytral puncturation, the fulvous band consists sometimes of three nearly connected spots of elongate shape.

\section{Dioryctus abdominalis, sp. n.}

Black; basal joints of antennæ and labrum dark fulvous ; elytra reddish-brown, basal and sutural margins black; abdomen pale fulvous.

Head minutely granulate, opaque; antennæ black, extending to base of thorax, basal five joints small, more or less fulvous, rest strongly transversely widened. 'Thorax strongly transverse and widened at middle, anterior balf the width of the posterior margin, sides straight, surface with a transverse depression in front of basal lobe, latter acutely produced ; surface microscopically punctured, shining. Scutellum invisible from above. Elytra strongly rounded and convex, epipleural lobes broadly produced, subangulate; surface very finely punctate-striate, interstices sparingly punctured.

Length 211 m.

$H n b$. Burma: Ruby Mines (Coll. Brit. Mus.).

The entirely pale chestnut-coloured elytra with narrow basa margin and the fulvous abdomen distinguish this species, of which a single male specimen was obtained by Doherty.

312. Dioryctus hauseri, Weise (Atropidius), Deut. ent. Zeit. 1895, p. 327.

Rufo-testaceous; last six joints of antennæ and all the ridges on the prosternum and mesosternum piceous.

Slightly longer than broad. Head very finely and closely punctured; clypens large, semicircular, depressed; last two joints of palpi equal. Thorax strongly narrowed in front, sides but slightly rounded, posterior angles acute, margin narrowly black, tinely serrate, surface slightly more strongly punctured than head. Elytra finely punctate-striate, apex irregularly punctured. Anterior margin of thoracic episternum strongly produced into a very 
high angular ridge; mesosternum with a similar but less high ridge on each side, all the ridges piceous black.

$\delta$. Last abdominal segment evenly convex, preceding segment strongly narrowed at middle.

Length $3 \mathrm{~min}$.

$H a b$. Sikhim.

\section{Dioryctus bifasciatus, sp. $и$.}

Base of head, breast and abdomen black; thorax fulvous, middle of disc spotted with black; elytra fulvons, a sutural band strongly constricted at middle and another regular broad band near margins, black ; legs fulvous.

Rather broad and flat. Head black, finely and closely punctured; clypeus and labrum flarous; eyes widely separated, moderately

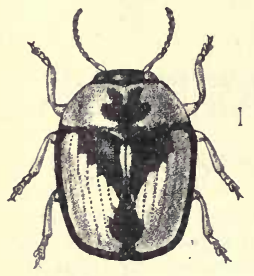

Fig. 71.-Dioryctus bifasciatus. deeply triangularly notched; antennæ black, extending to base of thorax only, the basal five joints flavous, terminal joints slightly widened but longer than broad. Thorax very short, nearly three times wider than long, strongly narrowed in front, lateral margins nearly straight; surface impunctate, very shining, the middle with an ill-defined, black, longitudinal, partly divided band, posterior margin strongly pointed and produced at middle. Scutellum invisible from above. Elytra with strongly produced lateral lobes, puncturation only visible

under a strong lens, entirely absent at sides and apex; the sutural band triangularly widened at base, but to a much less extent behind the middle, the lateral band of even width, not quite extending to the lateral margins. Prostermum subquadrate, its lateral margins raised.

Length $2 \frac{1}{2} \mathrm{~mm}$.

Hab. India. Type in Coll. Jacoby.

\section{Genus CENOBIUS.}

Coenobius, Suffr. Linn. Ent. xi, 1857, p. 61 ; Chapreis, Gen. Col. x, 1874, p. 177.

Type, C. triangulum, Suffr., from Africa.

Range. Africa and Asia.

Small species. Eyes contiguous at vertex of head, deeply emarginate ; antennæ short, the last six joints dilated. Thorax generally narrowed in front, the posterior margin formed into a ridge, often with a row of deep punctures; medial lobe short, bluntly 
pointed or rounded. Scutellum lanceolate. Elytra with strong epipleural lobes, regularly punctate-striate. Prosternum broader than long.

The most reliable character for distinguishing this genus is the structure of the eyes, which meet at the top of the head; the dilated terminal joints of the antenna and the structure of the prosternum are subject to variation, although the former organs are never long and filiform as in Cryptocephalus proper.

\section{Cœnobius insularis, Weise, Deut. ent. Zeit. 1903, p. 34.}

Black; antennæ and legs flaro-testaceous, last fonr or five joints of antenna and the intermediate and posterior femora darkened.

Thorax convex, smootl and shining, with a row of strong punctures round lateral and basal margins only. Elytra with inner rows of punctures narrow and moderately strong, outer rows much broader and deeper; sometimes only the posterior femora darkened; sides of inetasternum irregularly punctured in single rows, these are, however, doubled anteriorly and posterlorly ; projection of basal margin of thorax very small and rounded.

Length $1.5 \mathrm{~mm}$.

Hab. Ceylon : Kandy, Weligama.

315. Cœnobius lævicollis, Jac. (Bucharis) Stett. Ent. Zeit. 1899, p. 265.

Black; basal joints of antennæ, lower portion of face and legs fulvous.

Upper portion of head entirely occupied by the eyes, which meet at top; clypeus fulvous; labrum piceous; antennx extending to base of thorax, terminal six joints widened, basal five fulvous. Thorax strongly transverse, sides strongly deflexed, lateral margins nearly straight, narrowed anteriorly, anterior margin preceded by a narrow groove, posterior margin with a row of deep punctures, surface impunctate, sides with a narrow oblique groove, the middle lobe on the posterior margins pointed. Scutellum lanceolate. Flytra evenly and strongly punctate-striate, the punctures deep at base, the basal margin strongly transversely carinate, interstices broad and flat at inner disc, lateral two distinctly convex and narrower.

Length $1 \frac{1}{2}-2 \mathrm{~mm}$.

$H a b$. Tenasserim : Tavoy; Sumatra.

This little species was placed in Bucharis, but wrongly so because of the contiguous eyes. The Sumatran specimens differ in no way from those obtained by Doherty in Tenasserim. The thorax in some specimens is more or less fulvous at sides or base, while the elytra show likewise a slight fulvous tint, probably due to immaturity of the specimens examined. 


\section{Cœnobius manipurensis, sp. $n$.}

Black; basal joints of the antennæ flavous ; clypeus and legs more or less piceous or obscure fulvous.

Antennæ with the basal four or five joints fulvous or flarous. Thorax impunctate with the exception of a single row of punctures on the posterior margin and a few near the posterior angles; median lobe short and acute. Elytra with closely placed punctures, interstices convex at sides but feebly so on disc. Sides of breast rather closely punctured.

Length $1 \frac{1}{2} \mathrm{~mm}$.

Hab. Manipur (Coll. Brit. Mus.).

Evidently closely allied to $C$. insularis, Weise, from Ceylon, but the legs are black not testaceous, the knees and tarsi obscure fulvous; the thorax has some additional punctures near the posterior angles and the median lobe is pointed, not rounded; the thorax has no oblique lateral grooves. In this respect it agrees with Weise's species, but the clypeus is more or less fulvous.

\section{Cœnobius andrewesi, sp. n.}

Black ; basal joints of antennæ fulrous ; tarsi piceous.

Eyes joined at top of head, the latter finely punctured in the middle ; terminal six joints of antennæ thickened, black, basal five fulvous. Thorax very short and strongly transverse, sides evenly rounded, median lobe of posterior margin strongly produced and pointed, preceded by a transverse groove; surface very finely, evenly and rather closely impressed with elongate shallow punctures. Scutellum lanceolate. Elytra short and broad, strongly punctate-striate, interstices distinctly longitudinally convex, those at the sides costate. Prosternum one half broader than long, flat, strongly punctured, its margins not raised. Legs rather slender, tarsi short and broad. Sides of breast with several rows of punctures.

Liength $1 \frac{1}{2} \mathrm{~mm}$.

$H a b$. Nilgiris (Coll. H. E. Andrewes).

Thorax much more finely punctured than in C. chalceus; the general colour deep black.

318. Cœnobius burmanicus, Jac. Ann. Mus. Civ. Genova, xxxii, 1892, p. 889.

Piceous; head, basal joints of antennæ, thorax and legs fulvous; elytra black; prosternum fulvous.

Broad, moderately convex. Head depressed, strongly punctured at lower portion; eyes very large, contiguous or touching, broadly emarginate; antennæ black, subfiliform, extending to about half the length of elytra, basal four joints fulvous, third and fourth equal, terminal joints slightly compressed. Thorax strongly transverse, narrowed in front, sides straight, posterior median lobe 
scarcely produced; surface with a deep oblique transverse groove at sides, disc impunctate, a single row of punctures close to lateral and posterior margins, latter without denticulation. Scutellum narrow, linear, longitudinally concave at base. Elytra not broader at base than thorax, shoulders prominent, punctures deep, regular and distinct to apex, interstices at sides longitudinaliy convex, impunctate. Prosternum broad, its base slightly widened and truncate, surface transversely sulcate anteriorly and posteriorly. Abdomen nearly black.

Length $2 \mathrm{~mm}$.

Hab. Burma : Karennee. Trpe in Genoa Mus.

Principally distinguished by the strongly grooved thorax.

\section{Cœnobius chalceus, sp. n.}

Black with slight æneous gloss; labrum and tarsi beneath obscure fulvous.

Head strongly and deeply punctured; antennæ in the type and only specimen wanting. Thorax strongly convex, sides narrowly margined, feebly rounded; surface strongly and closely punctured at sides, the punctures elongate and partly confluent, middle of disc more sparingly punctate; uedian lobe short and triangularly pointed, preceded by a row of punctures which run parallel with the basal margin. Elytra with strongly tuberculate shoulders, surface strongly punctate-striate, the sides with larger punctures and costate interstices. Sides of breast with a double row of punctures, middle irregularly punctured.

\section{Length $1 \frac{1}{2} \mathrm{~mm}$.}

Hab. Nilgiris (Coll. H. E. Andrewes).

This species, of which I have seen only a single specimen, is not so deep a black as most of its allies, but has a distinct æneous gloss; the thorax and elytra are more strongly and closely punctured than in any other Indian species of the genus and the legs are entirely black.

\section{Cœnobius seminigris, sp. $\mathrm{n}$.}

Fulvous; terminal joints of antennæ piceous; elytra black.

Head with eyes that occupy the entire upper and lateral portions; clypeus pale fulvous, distinctly punctured ; antennæ extending to base of thorax, basal five joints fulvous, third and following two joints slender, rest widened, but distinctly longer than broad. Thorax subcylindrical, strongly narrowed in front, basal margin produced at middle into a very short pointed lobe; surface with a transverse sulcus behind the middle, extending across disc, entirely impunctate, posterior edge lined by a row of punctures. Scutellum lanceolate, black. Elytra about one half longer than thorax, scarcely narrowed behind, apex of each broadly rounded; surface strongly punctate-striate, each row of punctures commencing with a sinall deep forea near basal margin, the latter carinate, interstices 
very slightly convex. Body beneath and legs fulvous. Prosternum broad, anterior margin produced, ridge-shaped. Last abdominal segment of female with a deep oblong fovea that occupies the whole of the middle.

Length $1 \frac{1}{2} \mathrm{~mm}$.

Hab. Tenasserim : Tavoy (Coll. Brit. . Wus.).

Differs from $C$. burmanicus, Jac., in the sulcus of thorax, which extends across the entire disc, in the shorter antenna and the entirely fulvous underside, also in the generally smaller size of the iusect.

\section{Cœnobius nigripes, sp. n.}

․ Black; head with a few punctures, basal two or three joints of antennæ fulvous, rest black, terminal six moderately thickened. Thorax very shining, posterior margin with a deep row of elongate punctures, rest of surface entirely impunctate. Elytra with deep longitudinal striæ, the striæ studded with rather fine punctures, inner interstices feebly, outer strongly, costate. Sides of breast with a double row of punctures, middle portion and first abdominal segment more closely punctured, last segment with deep elongate fovea.

Length $2 \mathrm{~mm}$.

Hab. Travancore: Wallardi (Coll. Jacoby); Nilgiris (Coll. H. E. Andrewes).

Differs from its allies in the entirely black colour of the legs, the deep and elongate punctures at base of thorax and the absence of a groove on the latter.

322. Cœnobius dorsalis, Weise, Deut. ent. Zeit. 1903, p. 33.

Black; antennæ piceous, basal five joints and the legs testaceous, intermediate and posterior femora fuscous.

Head longitudinally strigose at vertex. Thorax distinctly punctured at middle, nearly smooth and impressed with a sinuate groove near the lateral inargins. Elytra punctate-striate, the interstices convex, nearly smooth. Sides of metasternum punctured in a single row.

Length $2 \mathrm{~mm}$.

Hab. Ceylon: Kandy.

\section{Cœnobius lateralis, Weise, Deut. ent. Zeit. 1903, p. 34.}

Black; labrum, antennæ and legs testaceous.

Thorax nearly impunctate at middle, strongly punctured at sides. Elytra punctate-striate, interstices convex, nearly sinooth.

Length $1.5 \mathrm{~mm}$.

Hab. Bengal : Manda; Nilgiris. Ceylon : Kandy, Puttalam.

'I'he lighter-coloured antennæ and legs, the want of the thoracic grooves at sides, and its different puncturation separate this 
species from the preceding. The sides of the metasternum are closely punctured and more opaque than the rest of the underside. Whether this species is specifically distinct from $C$. fulvipes is donbtful.

\section{Cœnobius aterrimus, sp. n.}

Black; labrum fulvous; head with a few punctures; antennæ entirely black, terminal six joints widened. 'Thorax very short, lateral margins straight, basal inargin acutely pointed at middle, preceded by a row of deep punctures; surface somewhat closely and strongly punctured at sides, middle very tinely and sparingly punctate. Scutellum narrowly elongate. Elytra strongly punctatestriate, sixth and seventh rows united near apex, interstices at sides longitudinally convex. Sides of breast with a double row of punctures.

Length $1 \frac{1}{2} \mathrm{~mm}$.

Mab. Madura. Type in Coll. 11. E. Andrewes.

Differs from $C$. nigripes, Jac. in the distinctly punctured thorax ; from $C$. andrewesi in the black antennæ and the different sculpture of the thorax ; from $C$. chalceus in the deep black colour, straight sides of the thorax, and the even size of the elytral puuctures which are placed in deep stria and are distinct to the apex.

\section{Cœnobius andamanensis, sp. $\mathrm{n}$.}

Head, basal joints of antenuæ and legs flavous; thorax, elytra and body beneath black.

Upper portion of head entirely occupied by the eyes; clypeus and labrum flavous, strongly punctured; basal five joints of antennæ flavous, lest black, thickened, extending to base of thorax. Thorax subcylindrical, sides strongly deflexed, median lobe not pointed, slightly produced; surface strongly but remotely punctured at middle and base, sides nearly impunctate, with a narrow oblique sulcus. Elytra deeply striate, the punctures obsolete except at sides, the interstices strongly longitudinally costate. Sides of breast with a single row of deep punctures.

\section{Length $1 \frac{1}{2} \mathrm{~mm}$.}

Hab. Andainan Islands (Coll. Brit. Mus.).

Separated by the entirely flavous lower portion of head and its strong puncturation, costate and striate elytra, and the peculiar shape of the shoulders that are raised into a subquadrate tubercle.

\section{Cœnobius discicollis, sp. n.}

Black: head and sides of thorax reddish-fulvous; legs fulvous.

Head with a few fine punctures; antenmæ in the type and only specimen wanting. Thorax strongly transverse, impunctate except the usual row of punctures on posterior margin, disc black, sides 
broadly fulvous, the separating line of the colours not well defined. Scutellum lanceolate. Elytra rather strongly punctate-striate, punctures deeper at sides, last three interstices strongly costate, others flat, all the rows commence immediately below the base, the first puncture of each row foveolate. Sides of breast with several rows of punctures.

Length $2 \mathrm{~mm}$.

Hab. Assam: Nága Hills (Coll. Brit. Mus.).

Larger than most of its congeners and with differently coloured thorax, elytral puncturation stronger and interstices at sides more strongly costate.

\section{Cœnobius fulvicornis, sp. $n$.}

Black; head, antennæ and legs fulvous.

Head with a few fine punctures on its lower portion; antennæ with terminal joints only moderately thickened, submoniliform, second joint strongly widened, third and fourth very small. Thorax short and transverse, disc entirely impunctate, sides with some distinct punctures, basal margin short and pointed but not produced at middle, with a row of deep punctures. Scutellum very narrowly elongate. Elytra very finely punctate-striate at inner disc, punctures entirely obsolete at sides, last two interstices distinctly costate, otliers flat. Sides of breast nearly impunctate.

Length $1 \frac{1}{2} \mathrm{~mm}$.

Hab. Assan : Patkai Mts. (Coll. Brit. Mus.).

Differs from its nearest allies in the entirely fulvous head and antennæ and in the sides of the thorax which are punctured near the base, but whether these differences are constant or due to variation it is impossible to say without more material for examination. I have seen only two specimens, these are alike.

328. Cœnobius fulvipes, Baly, Trans. Ent. Soc. 1877, p. 213.

Piceous; basal joints of antennæ and legs pale fulvous, face fulvo-piceous.

"Face rugulose; vertex black; labrum fulrous; basal two joints of antennæ pale fulvous, rest absent in the only specimen available for examination. Thorax rather more than twice as broad as long, sides rounded and strongly convergent from base to apex, hinder angles posteriorly produced, acute, basal margin oblique, medial lobe acute, above transversely convex; surface more coarsely and closely punctured than in $C$. chinensis, Baly, apical margin bordered with a deep transverse groove, basal margin narrowly edged with black, bordered with a single row of punctures, less defined than in C. chinensis. Elytra finely punctate-striate, striæ each impressed with a single row of fine linear punctures, narrowly and faintly sulcate on the inner disc, more strongly so on the outer, interstices plain on anterior portion of inner disc, slightly convex towards apex, more strongly convex for their whole length on outer 
dise; basal margin edged with black. Prosternum nearly twice as broad as long, lateral angles acute." (Baly.)

\section{Length $2 \mathrm{~mm}$.}

$H a b$. India.

It is very probable that this species was described from an immature specimen, as nearly all known species are black and this one only partly so.

\section{9. (?) Cœnobius basalis, sp. $n$.}

Fulvous; breast and abdomen piceous; elytra with basal and sutural margin narrowly black.

Broad and robust ; entire sides and top of head occupied by the eyes; antennæ in the type and only specimen wanting. Thorax nearly twice as broad as long at base, strongly narrowed anteriorly; disc with a transverse sulcus at middle, deep and oblique at sides, narrow and straight at middle; surface impunctate with the exception of a single row of punctures on basal margin. Scutellum black, elongate, lanceolate. Elytra broad, nearly parallel, apex of each broadly rounded; surface strongly punctate-striate, the punctures placed in striæ, first punctures at base very deep, interstices convex near suture and at sides, suture narrowly, base more broadly black. Legs robust, fulvous; claws toothed at base. Last abdominal segment fulvous. Prosternum scarcely longer than broad, transversely grooved at base.

Length $2 \frac{1}{2} \mathrm{~mm}$.

Hab. Nilgiris. Type in Coll. H. E. Andrewes.

I have only provisionally placed this species in Coenobius, from which it differs in the shape and structure of the prosternum, the latter is broad and flat, almost as broad as long and has no raised lateral margins. The thorax is not produced at middle of base into a distinct point and the elytra are strongly punctate-striate with convex interstices. The whole appearance of the insect is that of the South American genus Monachus, and it is quite possible that this is one of Motschulsky's species, perhaps his Monachus basalis. The absence of the antennæ in the only s pecimen available for examination has precluded the creation of another genus for the present insect.

\section{Cœnobius pallipes, sp. n.}

Black; antennæ and legs entirely flavous.

Head with a few fine punctures on its lower portion; palpi flavous; antennæ with strongly thickened terminal joints, that extend beyond base of thorax; the latter more than twice as broad as long, strongly narrowed anteriorly, sides feebly rounded, surface impunctate, with the exception of a single row of punctures near the basal margin; median lobe triangularly pointed, sides with a short, sometimes somewhat obsolete transverse groove. Elytra with very finely punctured strix, interstices at sides longitudinally 
costate, shoulders prominent, smooth. Prosternum strongly punctured. Sides of breast with a fine double row of punctures.

Length $1 \frac{1}{2} \mathrm{~mm}$.

Hab. Nilgiris (H. L. Andrewes).

Very nearly allied to $C$. insularis and $C$. lovicollis, but with entirely flavous antemnæ and legs, basal margins of elytra not carinate as in the last-named species.

\section{Cœnobius integris, sp. $n$.}

Head, basal joints of antennæ, thorax and legs flarous; elytra black.

Head with a few fine punctures at lower portion; eyes contiguous at top; antennæ black, not extending to middle of elytra, basal five joints fiarous, third and fourth equal, terminal joints slightly thickened. Thorax strongly transverse, the basal twice the width of the anterior margin; surface impunctate, with a transverse groove at middle that extends across the entire disc, deeper at the sides than in the middle, extreme basal margin sometimes black. Scutellum narrowly elongate, black. Elytra broadly subquadrate, slightly narrowed at apex, with closely punctured striæ, distinct to apex, interstices flat, impunctate. Prosternum broad, subquadrate. Breast sparingly, sides closely, punctured.

Length $2 \frac{1}{2} \mathrm{~mm}$.

$H a b$. Nilgiris (H. L. Andreves.)

Larger tban $C$. burmanicus, Jac., the thoracic sulcus entire: separated from $C$. seminigris, Jac. by the black underside and larger size.

\section{Cœnobius variegatus, sp. $n$.}

Thorax more or less black and flavous; basal joints of antennæ fulvons, others black; elytra testaceous, marked with black at base and suture; below black, legs ẗulvous.

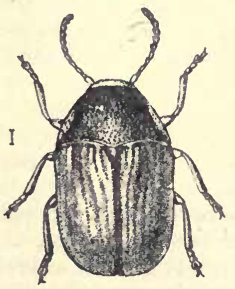

Fig. 72.-Conobius variegatus.

Head not perceptibly punctured, black ; eyes joined at the top; antennæ extending to middle of elytra, basal five joints fulvous, rest black, terminal five joints strongly triangularly thickened. Thorax nearly twice as broad as long, sides rounded, disc with a faint transverse groove at sides; black, the base more or less stained with fulvous or entirely black; surface more or less closely impressed with elongate punctures, generally more closely placed at the sides than in the niddle, basal margin with a single row of oblong punctures, median part produced into a point. Scutellum lanceolate. Elytra convex, finely punctate-striate, striæ distinct to apex. Prosternum twice as broad as long. 
Var. Entirely testaceous above.

Length $1 \frac{1}{2} \mathrm{~min}$.

Hab. Nilgiris (H. L. Andrewes).

A peculiarly marked species with a variable amount of dark and light colouring; the elytra generally with dark base and suture, the thorax sometimes entirely black. I have seen as manyspecimens of uniform testaceous colour above as of those which I consider typical.

333. Cœnobius strigicollis, sp. n.

Head blackish; basal joints of antennæ testaceous. Thorax æneous, finely strigose. Elỵtra testaceous. Legs fulvous.

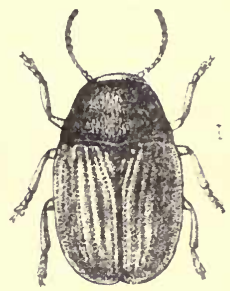

Fig. 73.-C'cenolins strigicollis.

Head deeply contracted within thorax, blackish-æneous, nearly jupunctate ; labrum fulvous; antennx black, basal five joints and base of sixth testaceous, terminal six distinctly thickened. 'Thorax nearly three times as broad as long: deeply transversely sulcate at each side, entire surface finely longitudinally strigose. Scutellum narrowly lanceolate. Elytia strongly punctatestriate, two or three of the outer interstices longitudiually convex. Underside nearly black and impunctate. Sides of thorax beneath distinctly punctured.

Length $1 \frac{1}{2} \mathrm{~mm}$.

Hab. Nilgiris. Type in Coll. H. E. Andrewes.

Differs from any other species of the genus in the colour and sculpture of the thorax.

\section{Cœnobius semilævis, sp. n.}

Black; basal joints of antennæ flavous; legs fulvous.

오. Eyes very large, connected at top, lower portions of face impunctate; labrum black; antennæ very short, basal seven joints flavous, rest black, third to fifth joints very short, nearly equal, the following joints gradually thickened. Thorax nearly twice as broad as long, sides nearly straight, median lobe triangularly pointed; surface not transversely sulcate, finely punctured, the punctures more closely placed at base and sides, middle of disc nearly smooth, basal margin not thickened, preceded by a row of sinall punctures. Elytra rather broad, apex broadly rounded, the surface with rows of shallow punctures, last two interstices convex, rest flat. Legs short and stout. Sides of breast very feebly punctured.

Length $2 \mathrm{~mm}$.

$\Pi a b$. Nilgiris. Type in Coll. H. E. Andrewes 
The short antennæ, their colour, absence of a thoracic sulcus, and the fine shallow punctures of the elytra separate this species from $C$. pallipes and several others of similar coloration.

\section{Genus CRYPTOCEPHALUS.}

Cryptocephalus, Geoffr. Ins. Par. i, 1762, p. 231 ; Suff. Linn. Ent. ii, 1847, p. 13 ; Chapuis, Gen. Coléopt. x, 1874, p. 184.

Type, C. 10-maculatus, Linn., from Europe.

Range. Nearly all parts of the globe.

Antennæ filiform; prosternum with posterior margin more or less emarginate, the angles acute or strongly pointed. Thorax closely fitted to base of elytra, with simple lateral margins.

This genus contains the bulk of the species of the subfamily. The subcylindrical shape, filiform antennæ, neat coloration, flat head, deeply inserted in the thorax, and the reniform eyes are characters by which these insects can be easily distinguished.

\section{Entirely or partly metallic species.}

\section{Cryptocephalus metallicus, sp. n.}

Metallic dark blue or greenish-æneous ; labrum, basal joints of antennæ and legs fulvous; tarsi black.

Head finely rugosely punctured with a very faint central groove; clypeus feebly separated from face, its anterior edge straight; eyes angularly emarginate, widely separated; antennæ slender, black, basal four joints fulvous, third and fourth equal, fifth and following joints more elongate and very slender. Thorax strongly transverse, very convex, narrowed anteriorly, sides narrowly margined, rather rounded, posterior angles acutely produced, preceded by a transverse depression, surface extremely minutely punctured, the punctures only seen under a very strong lens. Scutellum broad, apex pointed, base with a small fovea. Elytra subcrlindrical, narrowed posteriorly, rather finely punctate-striate, shoulders prominent and elongate, smooth; interstices flat, here and there with a few minute punctures. Body beneath darker greenish-æneous, finely punctured and pubescent. Legs very stout, tarsi black, strongly widened. Prosternum longer than broad, longitudinally excavated, posterior angles pointed.

Length $5 \frac{1}{2} \mathrm{~mm}$.

$H a b$. Malabar Coast : Mahé; Nilgiris. Type in Coll. Jacoby.

Easily distinguished by the metallic coloration of the upper and under surfaces and the fulvous legs.

336. Cryptocephalus submetallicus, sp. n.

Head and thorax metallic dark green; antennæ, breast and legs black; elytra bluish-black, with broad sutural band extending to shoulders but not to apex, sides dark flavous; abdomen flavous. 
Head flat, greenish-æneous at vertex, closely punctured, lower portion black; antennæ extending to base of elytra only, basal joint fulvons beneath, third and following nearly equal, terminal joints widened. Thorax rather long, less than twice as broad as long, strongly convex, entirely impunctate, very shining, metallic. Scutellum broad, sides rounded, bluish. Elytra broad and rather flat, somewhat widened towards apex; epipleural lobes feeble; surface strongly punctate-striate, interstices finely transversely wrinkled, flat, sides and apex broadly flavous, middle of disc and base bluish. Prosternum rugose, scarcely produced in front, posterior angles pointed.

Length $3 \mathrm{~mm}$.

Hab. India (Coll. Belg. Mus.).

Smaller than C. metallicus, the thorax metallic green and the abdomen flavous. There is only a single male specimen in the Belyian Museum without precise locality. It is probable that the elytra vary in being entirely dark blue, as the latter colour is not well defined at the margins and the flavous portion shows some darker stains.

\section{Elytia flavous or red with black lateral margins.}

337. Cryptocephalus angustomarginatus, Jac. Ann. Soc. Ent. Belg. xlvii, 1903, p. 88.

б. Flavous; two spots on thorax, margins of elytra and tarsi black.

Head distinctly and closely punctured, a small black spot at vertex and another at base of antennæ; eyes widely separated at top, acutely emarginate; antennæ rather short, basal five joints flavous, rest black, third to fifth of equal length, terminal joints slightly thickened. Thorax twice as broad as long, very convex, impunctate, extreme margins and two spots at middle of disc black. Scutellum black. Elytra rather short and broad, finely punctate-striate, the suture very narrowly, the lateral margins more broadly, black. Body beneath and legs flavous, femora stained with brown; tarsi broad, nearly black. Prosternum subquadrate, the posterior angles produced.

Length $3 \frac{1}{2} \mathrm{~mm}$.

$H a b$. Bombay; Nilgiris; Kanara.

338. Cryptocephalus circumductus, Suffr. Monogr., Linn. Ent. ix, 1854, p. 33.

Flavous; two spots on thorax, a narrow basal and a broader lateral margin to the elytra black.

Head finely and reinotely punctured; antennæ moderately robust, third and following joints gradually lengthened, fifth quite three times longer than second, sixth and following joints widened, all pale flavous. Thorax impunctate, with two small

vol. $\mathrm{I}$. 
spots at middle of disc. Scutellum raised, margined with black. Elytra with broad tuberculate shoulders; epipleural lobes strongly produced; surface very strongly punctured, outer and inner rows more deeply punctured, interstices slightly raised, more strongly so posteriorly, finely transversely wrinkled. Legs with an obsolete longitudinal spot on femora. Prosternum strongly produced anteriorly, posterior angles short and pointed.

Length $2 \frac{1}{4} \mathrm{~mm}$.

$H a b$. Ceylon.

The elytra have the base very narrowly, the lateral margins broadly, black, the latter extend to the width of two rows of punctures but in the middle to the seventh row; the epipleural lobes have only the inner edge dark but are otherwise flavous. Smaller than the preceding species, with the tarsi flavous and elytra more strongly punctured.

339. Cryptocephalus semirufulus, Suffr. Monogr., Linn. Ent. ix, 1854, p. 35.

‥ Flavous; thorax with two black spots; elytra dark red, margins blackish.

Head strongly but sparingly punctured, a transverse spot above eyes, a longitudinal stripe at middle divided anteriorly and an obsolete mark at base of antennæ, dark brown; antenuæ with third joint slightly longer than second, fourth twice as long, sixth and following joints slightly widened. Thorax short, strongly narrowed in front, posterior angles strongly pointed, margin serrate, surface scarcely perceptibly punctured, two spots before middle. Scutellum broadly triangular, raised, black. Elytra cylindrical, gradually narrowed posteriorly, transversely depressed at base, more strongly so near the scutellum and within the shoulders; epipleural lobes rather broad; puncturation strong anteriorly, gradually diminishing towards apex, interstices slightly raised at sides only, scarcely punctured, all margins (the outer ones interrupted) black. Prosternum produced anteriorly.

Length $2 \mathrm{~mm}$.

$H a b$. Nilgiris.

Suffrian described this species from a single female specimen.

340. Cryptocephalus inconstans, Jac. Ann. Soc. Ent. Bely. xxxix, 1895, p. 264.

Black; basal joints of antennæ and legs fulvous; head and thorax fulvous, the latter with two black spots; elytra fulvous, basal margin narrowly, lateral and apical margins broadly, black.

Head fulvous or flavous, sparingly and extremely finely punctured; eyes broadly and subquadrately emarginate; clypeus feebly separated from face, anterior edge strongly concave; antennæ black, basal four joints more or less fulvous, terminal joints slightly widened, not very elongate. Thorax strongly narrowed in front, 
sides slightly rounded, narrowly margined, posterior twice als broad as the anterior margin; surface impunctate, margins pale : disc fulvous, with two widely separated black spots placed rather nearer to the anterior than to the posterior margin. Scutellum flavous, margined with black. Elytra strongly and closely punctatestriate, punctures finer near apex, basal portion not depressed, interstices sparingly punctured on the anterior portion, sides and apex black, lower edge of the epipleuræ at the shoulders fulvous.

Var. $a$. Thorax without spots, elytra black.

Length 2-3 $\mathrm{mm}$.

$H a b$. Southern Bombay: Belgaum.

Differs from C.circumductus, Suffr. in the different colour of the antennæ and the absence of elytral wrinkled interstices. Black varieties of $C$. parasiticus can be distinguished by the distinctly punctured thorax and the fulvous elytral parapleuræ. C. angustomarginatus, Jac. also closely resembles the present species but is larger, the head is strongly punctured, the elytra finely punctate, the underside is flavous and the tarsi are black.

\section{Elytra black, with pale spots.}

\section{3+1. Cryptocephalus assamensis, sp. $n$.}

Fulvous; base of head and apical joints of antennæ black; thorax with two elongate black spots; elytra black, a small spot near scutellum and a large spot at middle of disc flavous.

Head strongly punctured, middle portion flavous, sides and vertex black; clypeus strongly punctured, feebly separated, anterior angles pointed; antennæ short, basal five joints fulvous, rest black, sixth and following three joints widened, rest wanting in the type and only specimen. Thorax twice as broad as long, lateral margins rounded; surface nearly impunctate, a short oblique depression at base on each side in front of scutellum; disc with two large round black spots near middle, extending to base as a narrow stripe. Scutellum broad, black. Elytra short and broad, finely punctate-striate, interstices flat and impunctate, basal spot subtriangular, discoidal spot large and round, not extending to either margin and placed at some distance from apex. Prosternum broadly produced anteriorly into a hollow projection; tarsi piceous.

Length $4 \mathrm{~mm}$.

Hab. Assam (Coll. Brit. Mus.).

342. Cryptocephalus exsulans, Suffr. Monogr., Linn. Ent. ix, 1854, p. 149 ; id.t. c. xiv, 1860, p. 56.

Black; lower part of head, lateral margins of thorax, and a middle line flavous; elytra with four flavous spots (1.2.1); legs flavous, body beneath partly so.

$\delta$. Head remotely but distinctly punctured, with deep central groove, extreme base of vertex black; clypeus distinctly separated, 
marked with a few fine punctures; mandibles black; palpi flavous ; antennse slender, basal five joints flavous, rest black, third joint distinetly shorter than fourth, fifth slightly longer. Thorax scarcely twice as broad as long, sides rounded, strongly narrowed in front; surface scarcely perceptibly punctured, the sides marked by a broad flavous deeply emarginate band at middle and a central longitudinal stripe of the same colour, the latter pointed at end, not quite extending to base. Scutellum black, apex rather broadly rounded. Elytra strongly and rather closely punctatestriate, punctures finer but distinct at apex, a transverse spot at base near scutellum, another at apex and two more rounded spots at middle, the outer one close to margin, the inner slightly lower nearer suture, all the spots flavous. Pygidium finely punctured, black, margined with flavous. Prosternum and last abdominal segment flavous, rest of underside black.

o* Elytra more strongly punctured, interstices slightly convex.

Length 4-5 mm.

Hab. Himalayas; Assam : Khási Hills.

Rather variable in regard to the markings, some specimens have some of the flavous elytral spots nearly confluent. The shape of the flavous bands of the thorax likewise varies in widtb, and the elytral puncturation is deeper in the $\sigma$ than in the $q$; the $\delta$ is also smaller in size.

\section{Elytra flavous with both spots and bands or spots only.}

343. Cryptocephalus unifasciatus, Jac. Ann. Mus. Civ. Genova, xxvii, 1889, p. 161.

Black; basal joints of antennæ fulvous; elytra flavous, a spot on shoulders, a broad transverse band at middle and sutural and lateral margins posteriorly black.

Head with a few fine punctures at middle, deeply transversely depressed between eyes; the latter broadly subtriangularly emarginate; clypeus rather closely and distinctly punctured; hasal four joints of antennæ fulvous, rest black, third joint slightly shorter than fourtb, following joints elongate and slender. Thorax nearly subcylindrical, very strongly convex, sides deeply deflexed, lateral margins nearly straight; surface entirely impunctate, deep black, very shining. Scutellum not longer than broad, sides rounded, apex rather pointed, surface impunctate. Elytra broadly subcylindrical, without depression below base, finely and regularly punctate-striate, interstices flat, with a few fine punctures here and there; basal portion to about one-third of its length flavous, followed by a broad transverse black band that extends to behind the middle, its anterior margin abruptly obliquely narrowed at sides, posterior margin straight; apex of each elytron with a transverse flavous spot. Beneath and legs black or partly fulvous.

Length $4 \mathrm{~mm}$.

Hab. Burma: Bhamo, Karennee. 
Distinguished by the entirely black thorax and the single elytral black band, abruptly constricted at the sides. In some specimens the anterior legs and sides of the abdomen are more or less flavous.

\section{Cryptocephalus simulans, sp. n.}

Head, sides of breast, legs and part of abdomen black; thorax black, anterior margin and sides fulvous; elytra fulvous, a humeral spot and a broad transverse band at middle strongly angulate anteriorly, black.

Head very finely pubescent and punctured, depressed at middle;

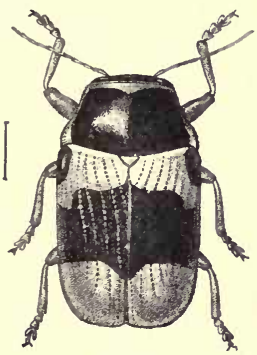

Fig. 74.

C'ryptocephalus simulans. eyes triangularly emarginate at middle; anterior edge of clypeus and labrum fulvous; antennæ slender, black, basal four joints flavous, basal joint above and the others black, terminal joints not thickened. Thorax more than twice as broad as long, sides strongly obliquely narrowed in front, nearly straight; surface impunctate, the sides rather broadly and the anterior margin very narrowly fulvous, rest of disc black, the lateral edge of this colour indented at middle. Scutellum trigonal, fulvous, margined with black. Elytra elongate, cylindrical, strongly punctate-striate, the punctures finer at base and apex; the humeral spot large, extending to the sides, the transverse black band with a slight bluish gloss, produced at the suture almost to the scutellum, abruptly and rather deeply constricted at sides, posterior edge concave. Breast at middle, first abdominal segments and extreme base of femora fulvous. Prosternum subquadrate, posterior margin deeply concave, the angles strongly produced.

Length $6 \mathrm{~mm}$.

Hab. Travancore: Wallardi. Type in Coll. Jacoby.

Very sinilar in coloration of the elytra to $C$. unifasciatus, Jac., but differs as follows: labrum fulvous, thorax much shorter and more transverse, sides and margin fulvous, black elytral band differently shaped, and humeral spot larger. The species was also obtained in a different locality.

345. Cryptocephalus posticalis, Jac. Ann. Soc. Ent. Belg. xxxix, 1895, p. 263.

Black; head fulvous at sides; thorax fulvous, with two large confluent spots; elytra fulvous, a transverse spot at base and the apical portion black. 
Head strongly punctured near eyes, but variable in that respect, an anchor-shaped band at middle black; eyes broadly subquadrately emarginate; clypeus and labrum fulvous; antennæ black, not extending to middle of elytra, basal five joints fulvous, third to fifth joints equal, succeeding joints slightly longer, slender in the male, slightly thickened in female. Thorax subcylindrical, much narrowed anteriorly, posterior angles not produced; surface entirely impunctate, the base with a large transverse black band, composed of two confluent spots, more or less separated anteriorly, sometimes entire and not extending to margins. Scutellum oblong, black, deeply foreolate at base. Elytra without basal depression, strongly punctate-striate, interstices longitudinally costate at sides, more strongly marked in the female, a transverse spot at base between second and eighth row of punctures and the apical third portion black, anterior edge of this colour rounded. Body beneath and pygidium black, closely pubescent; legs fulvous, posterior femora partly or entirely black. Prosternum very strongly produced in front, posterior margin nearly straight.

Length $4-4 \frac{1}{2} \mathrm{~mm}$.

$H a b$. Bangalore (Coll. J(acoby).

Allied to $C$. quadratus, Suffr., but the thorax impunctate and the elytral interstices not wrinkled.

346. Cryptocephalus konbirensis, Duviv. Ann. Soc. Ent. Belg. xxxv, 1891, C. Rend. p. xxxiv ; id. t. c. xxxvi, 1892, p. 402.

Fulvous; mandibles, terminal joints of antennæ, scutellum, and two spots on thorax black; elytra with a humeral and a discoidal spot and a transverse band behind the middle, black.

Oblong-ovate. Head pale, more or less strongly punctured, deeply longitudinally depressed in middle; antennæ testaceous, terminal joints black, third joint much longer than second, slightly longer than fourth, fiftl and following joints more elongate, widened and flattened. Thorax transverse, with narrow posterior edge, anterior and lateral margins flavous, surface impunctate, with slight basal depression on each side near the scutellum. Elytra moderately strongly punctate-striate, the strix indistinct near apex, interstices finely punctured and wrinkled, subcostate posteriorly ; humeral spot elongate, discoidal spot triangular, placed on anterior fourth of elytra at a little distance from suture. posterior band extending to the sides, emarginate anteriorly and posteriorly. Body beneath testaceous, finely pubescent.

Var. $a$. Thorax without spots.

Var. b. Elytra without discoidal spot.

Var. c. Elytra without humeral and discoidal spots.

In his later publication. Duvivier looks upon the following form as typical :-

“Elytra with 5 black spots (2.2.1), one on shoulders, another 
near margin slightly behind the middle, a third near apex, transverse, nearer to margin than to suture, fourth slightly below scutellum between 1st and 4th striæ, fifth slightly lower than the second, round, between 2nd and 4th striæ."

Length $3 \frac{1}{2}-4 \frac{1}{2} \mathrm{~mm}$.

$H a b$. Bengal, Konbir.

A very variable species which night easily be mistaken for one of the varieties of C. vahli, but in which the inner basal spot (when present) is always situated below the base, not at the basal margin near the scutellum. This difference too, and also the shape of the prosternum, separate this species from C. abbreviatulus, Suffr.

347. Cryptocephalus ensifer, Hope, in Gray's Zool. Misc. 1831, p. 30 ; Suffr. Monogr., Linn. Ent. xiv, 1860, p. 9.

Above flavous; two transverse spots on thorax, posterior margin and scutellum black; elytra with two spots near base, sutural margin at middle and a transverse band behind latter black; part of underside and legs entirely flavous.

Head strongly and closely punctured, longitudinally grooved in middle; antennæ with third and following joints very elongate, basal five joints flavous, rest black. Thorax strongly transverse and narrowed in front, entirely impunctate, a transverse black spot on each side at middle. Scutellum rather broad, black, base more or less flavous. Elytra broad, strongly punctate-striate, punctures distinct but finer at apex, interstices finely and sparingly puuctured, the tourth and fifth, sixth and seventh, and eighth and ninth rows of punctures joined at apex, an elongate spot on shoulders, another slightly oblique below base near suture lower than the humeral spot; the transverse band widened at sides into a round spot, joins the sutural band in a narrow stripe, is widened at junction with that band and before the middle and abbreviated at each end. Pygidium flavous at base, mesosternum and last abdominal segment likewise flavous; prosternum of same colour, scarcely produced anteriorly, posterior angles acute.

\section{Length $5 \mathrm{~mm}$.}

$H a b$. Nepal; Sikhim : Mungphu.

This is a well-marked species on account of the transverse thoracic spots and markings of the elytra; these may vary however, as in one specimen before me the posterior band is not connected with the suture, only represented by a lateral large spot, this spot is always placed nearer to margin and lower than in any of somewhat similarly marked species (herbsti, senarius, \&c.). Suffrian gives the head as remotely punctured, the puncturation is, on the contrary, close; it is also difficult to understand how this author can give the length as 5-7 nillim., since he bad only the type in the British Museum for comparison (a single ?), and Hope himself gives the correct length as $2 \frac{1}{2}$ lines. 


\section{Cryptocephalus crucipennis, Suffi. Monogr., Linn. Ent. ix, 1854,} p. 64.

Flavous; an obscure transverse band at thorax, two anterior spots and a transverse band on elytra black.

Head finely and remotely punctured; labrum and mandibles piceous, a narrow line at vertex black; eyes broadly triangularly emarginate; antennæ more than half the length of body, fifth and following joints distinctly widened, basal five joints Havous, others black. Thorax short, posterior angles produced, posterior margin straight except in front of shoulders ; surface extremely finely and remotely punctured, a very obscure elongate dark line in front of scutellum and a kidney-shaped, partly divided transverse band at middle. Scutellum broader than long, margined with black. Elytra narrowed posteriorly, puncturation fine, intermediate rows finer from middle, nearly obsolete near apex, interstices extremely finely and sparingly punctured; extreme basal margin black, two large spots at base touching basal margin, the outer spot elongate, the other transverse, not quite touching suture, the black band sinuate behind the middle, all margins below the band and the suture anteriorly black. Prosternum produced anteriorly into a short broad point.

Length $4 \frac{1}{2} \mathrm{~mm}$.

$H a b$. Bengal.

A specimen obtained by Bowring in India (precise locality nót given) agrees very nearly with Suffrian's description, but the elytral bands extend quite to suture, the thorax has a transverse short band on each side and the intermediate space is slightly darkened.

\section{Cryptocephalus monachoides, $\mathrm{sp.} \mathrm{n}$.}

Flavous; head and two large thoracic spots black; elytra with a transverse, broad, irregular band at base and a round spot at apex black.

Head strongly and closely punctured, black; clypeus flavous, equally strongly punctate, deeply concave-emarginate at apex, separated from face by a transverse groove which is joined by a central groove that extends upwards to base of head; antenuæ short, terminal six joints widened, all short. Thorax strongly transverse, posterior angles prominent, median lobe broadly truncate; surface entirely impunctate with two broad, nearly contiguous, trigonal black spots near anterior margin. Elytra rather short and broad, slightly narrowed posteriorly, very finely punctured, the punctures nearly obsolete at base and apex, the latter with a round black spot, the basal band with irregular posterior margin half the width of the flavous portion, extreme lateral margins and epipleuræ likewise black. Pygidium flavous, legs short and robust. Prosternum broad, anterior margins broadly produced, posterior margin bidentate.

Iength $3 \frac{1}{2} \mathrm{~mm}$. 
Hab. Tenasserim (Coll. Brit. Mus.).

Resembles in shape and in the short antennæ a species of Monachus.

\section{Cryptocephalus rufofemoratus, sp. $n$.}

Dark fulvous; antennæ (basal joints excepted) black; thorax with two black bands, connected at base, or with two spots at middle; elytra flavous, a small humeral spot and a transverse band (or spot) near apex black; femora fulvous; tibiæ and tarsi black.

Head longitudinally depressed at middle, with a few fine punctures near eyes; clypeus subtriangular, distinctly separated from face at sides, rugosely punctured ; eyes not very deeply emarginate ; antennæ long and slender, the first or the basal three joints fulvous, rest black, third joint shorter than fourth. Thorax moderately convex, sides very narrowly margined, feebly rounded, posterior angles not produced, surface entirely impunctate. Scutellum black, longer than broad. Elytra very slightly narrowed posteriorly, very finely punctate-striate, interstices flat. Body beneath obscurely fulvous, closely punctured and finely pubescent; last abdominal segment with deep central fovea ( + ).

Length $5 \mathrm{~mm}$.

Hab. Burma: Karen Hills (Doherty); India (Bowring). Coll. Brit. Mus.

In one specimen before me the head is deeply longitudinally sulcate at middle, the elytral band is reduced to a large spot, the extreme sutural and lateral margins at apex and the abdomen are black and the thorax has two spots placed at middle; in other respects the specimen is typical.

\section{Cryptocephalus semiflavus, sp. n.}

Black; head with a large triangular flavous patch; elytra yellowish-white, a transverse large spot at basal margiu and a transverse broad band near apex black.

Vertex of head black, the entire middle portion and clypeus flavous, the latter rather depressed with some fine punctures but not separated from face; labrum piceous; antennæ black, basal two joints flavous at apex, third and fourth joints equal, slender. Thorax subcylindrical, sides strongly deflexed, lateral margins feebly rounded, narrowed in front, posterior margin distinctly serrate; surface impunctate, very shining. Scutellum broad, triangular, black. Elytra feebly lobed at sides, distinctly punctate-striate, the basal patch widened at middle, not extending quite to either margin, the posterior band curved and narrowed near lateral margins, extending across both elytra. Prosternum subquadrate, finely punctured, posterior angles pointed, anterior margin not produced; anterior edge of metasternum flavous. Tarsi with very 
elongate first joints; last abdominal segment with deep central excavation.

Length 3-4 $\frac{1}{2} \mathrm{nIm}$.

Hab. Burma: Ruby Mines (Doherty-Coll. Brit. Mus.).

Not unlike $C$. unifasciatus, Jac., but with yellow frontal patch on head, the base of elytra black, the posterior band of different shape; the male is much smaller and the antennæ are much longer, the anterior femora are more or less flavous.

\section{Cryptocephalus dilaticornis, sp. $n$.}

Black ; basal joints of antennæ fulvous beneath ; elytra flavous, the margins, a humeral spot and a transverse band behind the middle, black; abdomen flavous.

ऽ. Head deeply excavate between eyes, vertex swollen ; clypeus strongly raised anteriorly and formed into a ridge; labrum and palpi flavous; antennæ long, intermediate joints elongately widened. Thorax strongly narrowed anteriorly, very convex, with a narrow transverse sulcus behind front margin and a short oblique depression on each side near scutellum, surface impunctate. Scutellum subquadrate, apex rather rounded, base with fovea. Elytra feebly lobed at sides, finely punctate-striate, the punctures piceous, sutural and apical margins narrowly, basal margin more broadly black; epipleuræ black only at their inner edges; posterior band broad with irregular margins, that extend upwards along suture to middle. Pygidium and abdomen flarous. Prosternum strongly produced in front, broader than long, posterior margin concave; tarsi short and broad.

Length $4 \mathrm{~mm}$.

Hab. Assam: Patkai Mts. (Coll. Brit. Mus.).

A species remarkable in more respects than one; the excavate head and highly raised clypeus are not found in any other species so far as I know, and although one of the antennæ has eleven joints (the other has the terminal two broken off) there is evidently another joint wanting, siuce the eleventh is abruptly truncate at apex. Wescribed from a single specimen obtained by Doherty.

\section{Elytra otherwise marked.}

353. Cryptocephalus fiavocinctus, Juc. Ann. Mus. Civ. Genova, xxxii, 1892, p. 892.

Black; anterior and lateral margins of thorax flavous; elytra with a broad transverse band at middle and a spot at apex flavous.

Broad and robust. Head very flat, finely punctured and sparingly pubescent; space in front of eyes below their emargination and labrum flavous; antennæ black, extending below middle of elytra, basal joint flavous beneath, third and fourth equal, rest triangularly 
widened, terminal joint with pointed appendage. Thorax strongly transverse and convex, sides widened at middle, rounded; surface impunctate, anterior margin narrowly, anterior half of lateral margins more broadly, bright flavous, this colour forms an angle with the black portion at sides. Scutellum elongate, with longitudinal groove at base. Elytra rather strongly punctate-striate, longitudinally depressed within the shoulders, puncturation nearly obsolete at apex, the flavous band narrowed at the sides but extending nearly to base at sutural portion, its upper edge oblique, lower one strongly sinuate, the apical spot narrowly edged with black. Body and legs black; upper portion of breast, prosternum and extreme base of posterior femora flavous; anterior portion of prosternum acutely produced.

Length $6 \mathrm{~mm}$.

Hab. Burma: Karennee. Type in Genoa Mus.

354. Cryptocephalus quadrillium, Suffr. Monogr., Linn. Ent. xiv, 1860 , p. 21.

Dark red; two spots on thorax and the elytra black, the latter with two large round red spots (1.1).

"Of elongate shape, narrowed posteriorly; head finely punctured, shining red, a spot below base of antennæ black; antennæ with basal joints fulvous, rest black, third joint twice, fourth, three times Jonger than second. Thorax short, posterior margin serrate, narrowly black, median lobe short, surface very shining, impunctate, the two spots placed at middle, close together. Scutellum red,triangular. Ely tra about two and a half times longer than the thorax, humeral elevations round, large, lateral lobes strongly produced; surface black, finely punctate-striate, more or less indistinct near apex, reflexed margin of epipleuræ at base, and two well-defined spots, one before, the other behind the middle, red; the first spot somewhat transverse, the suture in front of the spot with a small elongate mark, lower spot round, close to suture, only separated by a narrow black margin." (Suffrian.)

Length $4 \frac{1}{2} \mathrm{~mm}$.

Hab. Madras.

Described by Suffrian from a specimen without abdomen; no similarly marked species has come under my observation.

\section{Cryptocephalus sikhimensis, sp. n.}

Black; head and basal joints of the antennæ pale flavous, thorax and legs darker; elytra black, apex pale flavous.

Subcylindrical and parallel-sided. Head impunctate, yellowishwhite; eyes very broadly emarginate; antennæ black, extending beyond niddle of elytra, basal four joints flavous, third and fourth joints equal, shorter than fifth, terminal joints slightly thickened. Thorax twice as broad as long, sides nearly straight, 
obliquely but feebly narrowed in front, surface with a very obsolete transverse depression at sides, entirely impunctate. Scutellum black. Elytra with finely and closely approximate rows of punctures, apex broadly whitish-yellow. Prosternum not produced in front, deeply bilobed posteriorly.

Length $2 \mathrm{~mm}$.

$H a b$. Sikhim. Type in Belgian Mus.

I know of no otber similarly coloured Indian Cryptocephalus.

\section{Cryptocephalus elegans, sp. $n$.}

Black; head, antennæ, thorax and legs pale flavous; elytra with a narrow transverse flavous band behind the middle.

Head longitudinally depressed between eyes; nearly white, impunctate; antennæ long and slender, third joint shorter than fourth, terminal joints slightly widened. Thorax subconical, strongly narrowed in front, sides nearly straight, posterior angles produced; surface impunctate, sometimes with two small obscure spots at middle near anterior margin. Scutellum triangular, flavous. Elytra narrow and parallel, elongate, very finely punctatestriate, the flavous band placed bebind the middle of regular shape, leaving the apical portion to about a fourth part of the entire length black. Prosternum flavous, not produced in front, posterior angles strongly pointed.

Length $2 \mathrm{~mm}$.

Hab. Burma: Ruby Mines (Coll. Brit. Mus.).

A very small species, of narrowly subcylindrical shape and easily distinguished by its system of coloration.

\section{Cryptocephalus suffriani, sp. $\mathbf{n}$.}

Flavous; vertex of head and anterior margin of thorax with a black spot; elytra with a transverse band at base and the posterior half blood-red, two spots at base and one behind the middle near the suture black.

Head clusely and strongly punctured at vertex, an elongate black spot at middle of latter; clypeus separated from face, transverse, finely punctured, anterior edge but slightly concave; mandibles black; antennæ flavous, third and following joints very slender and elongate. Thorax subcylindrical, not strongly convex, sides nearly straight, strongly narrowed anteriorly, surface with a few minute punctures. Scutellum triangular, strongly pointed, flavous. Elytra strongly punctate-striate, interstices flat, a few fine punctures here and there. Breast slightly darker than abdomen and legs, closely punctured; prosternum deeply bilobed posteriorly.

Length $4 \mathrm{~mm}$.

Hab. Nilgiris (Coll. Brit. Mus.).

This species must not be confounded with C. carneobifasciatus, 
Motsch. as the head is strongly punctured and bears a black spot; the spot on the thorax is placed at middle of anterior margin; the thorax has nearly straight sides, and the elytral bands are broad, deep red; of the two black spots at the base of elytra one extends to the shoulders, a littlo way downwards on the sides, and is joined to the similarly coloured extreme basal margin, the second is round, placed close to scutellum and includes a small flavous spot at the base, the third spot situated between second and fourth row of punctures near suture.

358. Cryptocephalus durius, Suffi. Monogr., Linn. Ent. xiv, 1860, p. 35.

" Black; scutellum whitish, sides and a central band of thorax pale reddish; elytra with a transverse spot below base and the apex pale red.

" Head feebly convex, with deep central groove, closely punctured, opaque; clypeus shining ; lower part of labrum and sides below eyes pale red; antennæ black, with third joint shorter than following, twice as long as second, rest of the joints wanting in the only specimen I have seen. Thorax short, strongly narrowed in front, obliquely depressed at base in front of scutellum, posterior nargin sinuate, surface very finely and remotely punctured, lateral margius broadly and an interrupted middle line pale red. Scutellum triangular, margined with black. Elytra two and a quarter times longer than thorax, distinctly raised round scutellum, shoulders very prominent; surface rather strongly punctured below base, scarcely finer posteriorly and arranged in striæ on latter portion, interstices feebly raised, indistinctly wrinkled anteriorly, a transverse reddish spot at end of anterior third portion extending from the side to the second row of punctures and a narrow apical spot of the same colour. Pygidium and legs black; middle of first abdominal segment, prosternum, mesosternum, coxæ, base of femora and knees pale yellowish-red; anterior margin of prosternum hollow, produced; last segment of male depressed and shining at middle." (Suffrian.)

Length $3 \mathrm{~mm}$.

$H a \dot{b}$. Northern India.

359. Cryptocephalus depressus, Suffi. Monogr., Linn. Ent. xiv, 1860, p. 34 .

Pale flavous ; a humeral spot and an oblique band on posteriol half of elytra black.

" 3 . Elongate; head with fine central groove, scarcely punctured; autennæ of $\delta$ pale flavous, nearly as long as the body, third joint twice, fourth three times longer than the second, following two still longer, the others scarcely widened. Thorax short, strongly narrowed anteriorly, sides narrowly margined, surface deeply obliquely depressed on each side at base, surfare impuuctate, very 
shining. Scutellum strongly raised, broadly triangular, basal margin piceous. Elytra wider than thorax, slightly narrowed behind shoulders and widened again, raised round scutellum, shoulders elongate, prominent, epipleural lobes well marked; surface rather strongly punctate-striate below base, interstices distinctly raised, very finely punctured anteriorly only, very shining, the humeral spot sometimes prolonged into a band towards scutellum, posterior band triangularly emarginate at suture in front, leaving apex only narrowly flavous, extending obliquely outwards nearly as far as the humeral spot and occupying posterior half of elytra. Pygidium finely punctured, flavous, as are also the underside and legs; prosternum produced and hollow in front, posterior angles acutely pointed." (Suffrian.)

Length $2 \frac{1}{4}-2 \frac{1}{2} \mathrm{~mm}$.

$H a b$. Southern India.

Belonging to a group that has the thorax strongly narrowed in front and deeply depressed posteriorly, the antennæ very long and the elytral puncturation strongly marked.

\section{Cryptocephalus ineditus, sp. n.}

Head, thorax and legs pale flavous; antennæ and underside black; elytra black, a narrow transverse band at middle yellowishwhite.

Head impunctate, very pale, with a short groove at vertex ; eyes rather closely approximate at top, very broadly angularly emarginate; clypeus deeply depressed at middle; basal two or three joints of antennæ flavous, third joint slightly shorter than fourth, following very slender and elongate. I'horax but moderately convex, narrowed in front, sides straight, posterior margin not visibly serrate, surface impunetate. Scutellum flavous, base black, with fovea. Elytra finely and closely punctate-striate, narrow and parallel, the pale band placed at middle and slightly widened at sides. Posterior legs sometimes piceous; femora very robust and thick.

Length 2-2 $\frac{1}{2} \mathrm{~mm}$.

Hab. Burma : Ruby Mines (Coll. Brit. Mus.).

Almost identical in coloration and shape with C. elegans, but the elytral band at not behind the middle, and the abdomen black. In some specimens the anterior portion of the thorax is stained with pale fulvous, leaving the margins and two large oblique patches at base pale flavous; the antennæ in the male extend nearly to the apex of elytra.

361. Cryptocephalus feæ, Jac. Ann. Mus. Civ. Genova, xxxii, p. 891 (1892).

Beneath black; above and the tibiæ fulvous, extreme base of thorax flavous; basal margin of elytra flavous, edged with black.

Head finely and sparingly punctured, black, intraocular space 
clothed with yellow pubescence; antennæ extending to two-thirds the length of elytra, basal four joints fulvous, rest black, third and fourth joints equal. Thorax more than twice as broad as long, sides rounded and narrowed in front, narrowly margined, posterior border slightly sinuate in front, surface impunctate, extreme basal margin obscure flavous. Scutellum distinctly foveolate at base. Elytra slightly constricted at sides behind the middle, each with ten rows of piceous punctures, the sixth and seventh rows shorter than the others (subsutural row excepted), interstices very finely transversely wrinkled. Legs black, clothed with whitish pubescence, upper portion of breast, flavous.

Length 5-6 mm.

Hab. Burma : Karennee.

Distinguished from similarly coloured species by the pubescent black head.

\section{Cryptocephalus signatellus, sp. $n$.}

Black ; anterior and lateral margins of thor:ux and elytra fiavous, a broad sutural black band on the elytra, truncate before apex; legs fulrous.

Head with a few fine punctures, opaque, middle with a narrow transverse dentate pale stripe between eyes; clypeus not separated; ıabrum black, prominent; emargination of eyes round, not very deep, somewhat raised; antennæ very slender, black, basal two joints obscure fulvous, fourth and following joints very elongate and slender. Thorax scarcely twice as broad as long, strongly narrowed anteriorly, extremely finely but not very closely punctured, very shining; anterior margins very narrowly, lateral broadly, flavous. Scutellum broad, triangular. Elytra nearly parallel, strongly and deeply punctured, interstices rather convex and finely wrinkled, a broad sutural band, abbreviated at some distance from apex, and the suture below this band, black, shoulders with black spot. Prosternum longer than broad, carinate in front, the latter fulvous, posterior angles acutely produced into teeth.

Length $3 \frac{1}{2}$ mim.

Hab. Nilgiris (Coll. H. E. Andrewes).

Not unlike $C$, bombayensis, Jac., but the sutural band perfectly straight and truncate before apex.

363. Cryptocephalus heraldicus, Suffr. Monogr., Linn. Ent. ix, 1854, p. 145 .

ㅇ. "Flavous ; metasternum and abdomen black ; elytra flavous, narrowly margined with black, an elongate brownish band parallel with margins and a bilobate broad longitudinal black band at suture; pygidium black.

"Of elongate shape; head smooth; clypeus separated at sides only, rugosely punctured anteriorly ; antennæ slender, third joint 
double the length of second, following two more elongate, rest scarcely flattened, slightly darkened, basal joints flavous. Thorax entirely smooth and impunctate, posterior edge narrowly black. Scutellum also margined with black. Elytra of equal width, slightly raised round scutellum, epipleural lobes strongly marked, punctures regular, scarcely finer posteriorly, interstices flat, the outer slightly raised, impunctate, the sutural elongate mark extends at its narrowest part (before middle) to the second row of punctures, sending off a branch anteriorly to fourth row and another branch posteriorly to sixth row, nearly touching margin of lateral band, outer edge of sutural band rather obsolete." (Suffrian.)

Length $3 \mathrm{~mm}$.

$H a b$. India : Mussoorie.

Described from a single female. Unknown to me.

364. Cryptocephalus sanguinolentus, Oliv. Entom. vi, 1808, p. 829, pl. 7, fig. 106; Suffr. Monogr., Linn. Ent. ix, 185̌, p. 37.

"Black; head, thorax, outer margins of elytra and legs reddishfulvous; thorax with two black spots.

"Head finely and very remotely punctured; antennæ fulvous, terminal joint fuscous, second joint nearly as wide as third, following but slightly wider, sixth and terminal joints distinctly more widened. Thorax distinctly but finely and very remotely punctured, posterior margin serrate, black. Scutellum black, long and narrowly triangular, foveolate at base. Elytra depressed at base near scutellum, epipleural lobes short and rather obsolete; surface distinctly punctate-striate, finer posteriorly, interstices finely transversely wrinkled, rather opaque from middle downwards. Pygidium black, prosternum, mesosternum and legs fulvous; anterior margin of prosternum scarcely produced, posterior angles short and blunt." (Suffian.)

Length $3 \mathrm{~min}$.

$H a b$. Southern India.

I have not seen any species entirely answering to Suffrian's description, who says that it differs from $C$. vahli, var. in coloration and puncturation-in which way, however, is not clear. In what I take to be a variety the entire elytra with the exception of the epipleural lobes beneath are black.

365. Cryptocephalus bombayensis, Jac. Ann. Soc. Ent. Belg. xxxix, 1895, p. 266.

Black; basal joints of antennæ and legs fulvous, anterior and lateral margins of thorax flavous; elytra flavous, the base, connected with a sutural lozenge-shaped band black, abbreviated at apex. 
Head piceous or black, closely and almost rugosely punctured, a small spot at base of antennæ and on the clypeus flavous; antennæ black, extending to middle of elytra, basal five joints

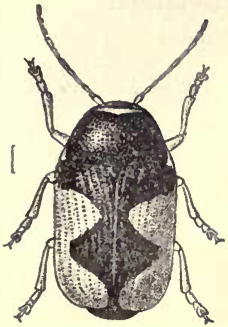

Fig. 75.-Cryptocephalus bombayensis. fulvous, rather short. Thorax with rounded sides, very strongly and closely punctured, the punctures more closely placed at sides than at middle, interstices rugose and convex, except those at middle; anterior margin narrowly, sides more broadly, flavous. Scutellnm flavous margined with piceous. Elytra without basal depression, strongly punctate-striate, punctures only slightly finer at apex, interstices minutely granulate; a broad transverse band at base, not extending to sides and joined to a sutural band, widened at middle into a lozenge-shaped spot, black, this latter not extending to apex. Pygidium black, strongly punctured. Body beneath black, finely pubescent, anterior margin of breast flavous ; posterior femora with a black spot.

Length $3 \mathrm{~mm}$.

Hab. Bombay: Belgaum.

366. Cryptocephalus belgaumensis, Jac. Ann. Soc. Ent. Bely. хxxix, 1895 , p. 265.

Beneath flavous or pale fulvous, above black; thorax with sides and anterior margin flavous; elytra with a

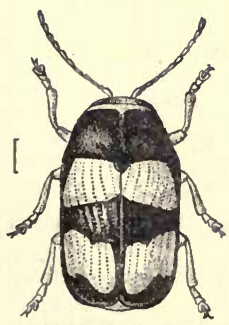

Fig. 76.-Cryptocephalus belgaumensis. broad transverse band at base, another near apex and a spot below the shoulders bright flavous.

Head closely punctured, flavous, depressed between the eyes, the latter broadly angularly notched; antennæ two-thirds the length of body, basal five joints flavous, rest black. Thorax strongly transverse and rather short, sides nearly straight, gradually narrowed anteriorly, posterior angles pointed; surface black, anterior margin very narrowly, sides more broadly, and a narrow central stripe anteriorly, flavous; a shallow fovea at each side near scutellum; sides entirely finely strigose, the strigæ changing into fine punc. tures at base. Scutellum black, not longer than broad. Elytra not depressed below base, strongly punctate-striate, apical portion very minutely punctured, interstices longitudinally costate at voL. I. 
sides. Body beneath and legs fulvous, sides of breast blackish, finely longitudinally strigose.

Length 2-2 $\frac{1}{2} \mathrm{~mm}$.

$H a b$. Bombay : Belgaum.

Can be distinguished by the fine strigæ of the thorax.

367. Cryptocephalus spengleri, Fabr. Ent. Syst. Suppl. 1798, p. 109; Suffr. Monogr., Linn. Ent. ix, 1854, p. 159.

“Thorax rufous, shining, with two black spots, elytra testaceous ; a posterior spot cyaneous." (Fabr.)

"Size of C. coloratus, C. pustulatus, and C. vahli. Antennæ black, base rufous. Head rufous, black round eyes; body obscurely coloured, legs testaceous." (Suffrian.)

Hab. "Tranquebar" (teste Fabr.).

Suffrian thinks this is a variety of $C . v a h l i$.

This and the following species cannot be recognized with any certainty without an examination of the types.

368. Cryptocephalus olivieri, Harold, Coleopt. Hefte, x, 1872, p. 254. Cryptocephalus lundi, Oliv. (nec Fabr.) Ent. vi, 1808, p. 827, pl. 6, fig. 103; Suffr. Monogr., Linn. Ent. ix, 1854, p. 159.

"Above testaceous, beneath blackish-brown, antennæ black. Small ; first joint of antennæ rufous; head testaceous. Thorax smooth. Elytra scarcely punctate-striate, shining. Body dark brown, abdomen, apex of femora and their bases, reddish." (Harold.)

Hab. India.

369. Cryptocephalus rubripes, Hope in Gray's Zool. Misc. 1831, p. 30; Suffr. Monogr., Linn. Ent. xiv, 1860, p. 49.

"Green, antennæ and femora rufous." (Hope.)

Length $4 \mathrm{~mm}$.

Hab. Assam.

Unrecognizable from the description given. Probably not a Cryptocephalus at all.

370. Cryptocephalus latimanus, Oliv. Ent. vi, 1808 , p. 825 , pl. 6, fig. 100; Suffr. Monogr., Linn. Ent. ix, 1854, p. 159.

"Testaceous, apex of antennæ fuscous; head punctured, labrum flavous. Thorax punctured, margins paler; anterior tibia widened." (Olivier.)

Hab. Bengal. 
371. Cryptocephalus lundi, Fabr. Ent. Syst. Suppl. 1798, p. 107 ; Suffr. Monogr., Linn. Ent. ix, 1854, p. 158.

"Above testaceous; head, thorax, and elytra smooth; body beneath black, partly testaceous. Size that of $C$. congestis and C. ornatus." (Suffrian.)

$H a b$. Tranquebar.

372. Cryptocephalus octavius, Thunb. Mus. Nat. Ac. Ups. iv, 1787, p. 46.

"Thorax rufous, with crescent-shaped flavous mark. Elytra black, with oblique flavous line at three-fourths of its length." (Thunberg.)

Hab. "Ind. Or."

373. Cryptocephalus decorus, Oliv. Ent. vi, 1808, p. 828, pl. 7, fig. 104.

"Dark æneous, head, thorax and legs rufous.

"Small, antennæ wanting. Thorax smooth, shining. Elytra scarcely punctate-striate, underside black." (Olivier.)

$H a b$. "India orient." (teste Olivier).

The above short description is all that Olivier gives; no opinion can therefore be formed as to the position of this species.

\section{Cryptocephalus pusaensis, sp. n.}

Testaceous; thorax with four more or less distinct black spots or bands surrounded by fulvous; elytra also with four or more small black markings placed on the punctured striæ.

Head strongly and rather remotely punctured; a central line and a small spot at base of antennæ obscure piceous; labrum testaceous; antennæ black, short, extending to base of elytra, basal four joints testaceous, apical joints slightly dilated. Thorax twice as broad as long, strongly narrowed in front, sides nearly straight ; surface strongly and subremotely punctured, middle of disc with two obscure piceous or dark fulvous longitudinal bands, more or less marked with black, sides with broader similarly coloured patch, marked with a black spot, rest of the disc pale flavous or testaceous, extreme basal margin black. Scutellum oblong, apex truncate. Elytra subcylindrical, strongly punctatestriate, punctures deep and closely placed, partly transverse in shape, nearly black; interstices sparingly punctured and finely wrinkled, the first row joined to the second near the middle, the sixth and seventh joined at apex behind the middle, interstices near lateral margins wider and raised; shoulders with an irregular black elongate spot, another near scutellum and two immediately behind the middle; these spots are often mere elongate short streaks like the widening of the punctures at those places. 
Femora and tibiæ more or less stained with pale piceous or fulvous. Prosternum subquadrate.

Length $2 \frac{1}{2} \mathrm{~mm}$.

Hab. India: Pusa (Colls. Lefroy \& Jacoby).

A peculiarly marked species which cannot be mistaken for any other.

\section{Elytra fulvous with paler spots or stripes (sometimes a small humeral spot only).}

\section{Cryptocephalus obscurc-maculatus, sp. n.}

Black; basal joints of antennæ fulvous; thorax reddish with transverse patch at base; elytra fulvous, with obscure, elongate, flavous spots; tarsi fulvous.

․ Head black, closely and strongly punctured; inner margins of eyes and labrum fulvous; basal six joints of antennæ fulvous, first basal joint black above, rest wanting in the type and only specimen. Thorax obscure flavous, strongly transverse, narrowed at sides; surface extremely minutely punctured, posterior angles with two or three distinct teeth; a central longitudinal line flavous, rest of disc reddish-fulvous, a transverse anteriorly deeply sinuate black patch or band at middle of base. Scutellum black, broadly elongate, apex truncate. Elytra with five double rows of strong and deep punctures, sixth and seventh rows the shortest, joined at apex, the other rows similarly joined ; alternate interstices marked with very pale longitudinal bands or spots of irregular shape. Pygidium and body beneath black, extreme base and apex of tibiæ fulvous. Prosternum fulvous, pointed at the posterior angles; anterior coxæ fulvous.

Length $5 \frac{1}{2} \mathrm{~mm}$.

Hab. Southern India (Coll. Brit. Mus.).

Allied to $C$. sandrocottus, Suffr. and $C$. calanus, Suffr., but distinguished by the colour of the head, thorax and legs and other details; in some specimens the flavous elytral spots are entirely obsolete. These are the only specimens with geminate punctate elytra.

376. Cryptocephalus sandrocottus, Suffr. Monogr., Linn. Ent. ix, 1854, p. 71 ; id. t. c. xiv, 1860, p. 37.

Dark fulvous above, spotted with flavous; underside and legs flavous; thorax and elytra with numerous elongate flavous spots and stripes.

Head flavous, closely and strongly punctured, with narrow central groove, a longitudinal stripe at middle dark brown; antennæ robust, basal four joints flavous, rest black, third and fourth equal, following joints widened but elongate. Thorax dark brown, rather short and transverse, extremely minutely punctured, extreme 
anterior margin, two semiconfluent spots at lateral margins, two oblique spots at base in front of scutellum and a more or less interrupted median line, flavous. Scutellum dark brown with darker margins. Elytra strongly geminate, punctate-striate, the striæ connected at apex, sixth and seventh the shortest; interstices rather convex at sides, finely transversely wrinkled, with eight more or less connected flavous spots; of these one is placed within the shoulders, one near scutellum and four transversely at middle; of these last the two inner spots are lower than the outer ones, all are elongate, two others are at the apex, each consisting of three narrow connected short stripes. Beneath finely pubescent, flavous.

Length $5 \mathrm{~mm}$.

$H a b$. Southern India ; Bombay.

An easily recognized species by reason of its coloration and elytral sculpturing.

\section{Cryptocephalus calanus, Suffr. Linn. Ent. xiv, 1860, p. 37.}

"Fulvous ; underside paler, margins of thorax and a few longitudinal spots on elytra pale flavous.

"Head broadly longitudinally depressed; clypeus feebly separated from face, surface closely and strongly punctured; antennæ half the length of body, robust, third and fourth joints equal, twice as long as the second, terminal joints widened. Thorax broad, strongly convex, sides rounded before the middle, base with a short deep depression in front of scutellum; surface when seen under a lens remotely but distinctly punctured, anterior and lateral margins and a transverse spot near base pale flavous. Scutellum short, elongately subquadrate, truncate at apex, margined with piceous. Elytra geminately and distinctly punctate-striate, outer interstices feebly convex, very finely wrinkled, base and sides slightly paler than rest of surface; on the wider interstices a yellow longitudinal, obsolete stripe." (Suffrian.)

Length 6-7 mm.

$H a b$. Southern India.

Apparently closely allied to $C$. sandrocottus, rather larger although more slender, paler and less distinctly spotted, the geminate punctured elytral striæ less marked and the markings very faint.

378. Cryptocephalus fenestratus, Suffi. Monogr., Linn. Ent. xiv, 1860, p. 45.

"Reddish-brown; sides and an obsolete median line on thorax flavous; elytra with two yellow spots on each (1.1).

"Head finely and ratber closely punctured, opaque, lower portion paler; antennæ $(q)$ half the length of body, third and fourth joints equal, twice as long as the second, terminal joints widened, 
longer, basal joints flavous, terminal darkened. Thorax short and broad, lateral margins nearly straight, narrowed anteriorly, surface finely and remotely punctured; a broad lateral margin, angulately widened at middle, and a narrow interrupted line on the middle, flavous. Scutellum transversely subquadrate, yellowish-brown, margined with black. Elytra two and a half times longer than the thorax, shoulders scarcely distinct; surface finely punctured, the punctures slightly elongate, partly connected, the outer punctures more strongly marked; interstices broad and flat, closely and finely wrinkled, of somewhat silky appearance; the yellow spots large, the first from base to middle, the second smaller, more rounded, placed on the last third of the length of the elytra but do not reach the apex, both situated about middle of disc. Anterior tibiæ curved at base." (Suffrian.)

Length 2-3 $\mathrm{mm}$.

$\mathrm{Hab}$. Ceylon.

\section{Futvous or flavous, without spots or bands.}

Thorax sometimes spotted.

379. Cryptocephalus gestroi, Jac. Ann. Mus. Civ. Genova, xxxii, 1892 , p. 890.

Pale flavous; antennæ (basal joints excepted) black, extreme basal margin of elytra black.

Head impunctate, with central longitudinal gronve at vertex; mandibles black; antennæ with basal four joints flavous, fourth joint one-half longer than the third. Thorax about one-half broader thau long, strongly narrowed anteriorly, sides straight, posterior angles produced; disc convex, impunctate, extreme posterior margin black, finely denticulate. Scutellum flavous, apex pointed, base with a narrow black margin and central fovea. Elytra punctate-striate, fourth and fifth and eighth and ninth rows connected at apex, intermediate rows much shorter, none of the striæ extending quite to the base. Legs in the male elongate, anterior first joint of tarsi dilated. Prosternum longer than broad, basal margin with angles dentiform.

Length 5-6 $\mathrm{mm}$.

Hab. Burma : Karennee.

Probably allied to $C$. cinnabarinus, Suffr., but separated by the entirely pale fulvous colour and the impunctate head and thorax; the female is of considerably larger size.

\section{Cryptocephalus pallidipennis, sp. $n$.}

Testaceous ; terminal joints of antennæ and extreme margin of thorax black.

o. Head with short but deep central furrow at vertex, impunctate; clypeus separated from face, concave-emarginate 
anteriorly; mandibles black; antennæ very long and slender, basal four joints flavous, rest black, third and fourth joints equal. Thorax about one-half broader than long, strongly narrowed anteriorly, the sides straight, median lobe short, deeply bi-emarginate; surface entirely impunctate, with a very slight depression each side near the scutellum, which is triangular, edged with black at base and with the usual forea. Elytra rather broad and robust, shoulders prominent, the sutural space round scutellum raised; the puncturation fine, not always regular but with some extra punctures here and there, the seventh and eighth rows (not counting the short subsutural one) more closely approximate and more irregular. Legs slightly darker than rest of body. Prosternum not produced in front, posterior angles pointed. Body beneath very finely punctured.

․ Larger and more robust; last abdominal segment with deep cavity at middle.

Length $4 \frac{1}{2}-5 \frac{1}{2} \mathrm{~mm}$.

Hab. Assam; Burma: Karen Hills, Ruby Mines (Coll. Brit. Mus.).

Can be distinguished from $C$. cinnabarinus, Suffr. by the generally testaceous colour and many other differences of details, and from C. gestroi by the different elytral puncturation.

\section{Cryptocephalus hampsoni, sp. n.}

Above pale fulvous ; antennæ (basal joints excepted), underside and the legs more or less black; anterior femora entirely or partly flavous.

Head sparingly but distinctly punctured at middle; clypeus transverse, subquadrate, finely punctured, separated from face by a transverse groove; eyes very broadly emarginate; mandibles black; antennæ with the basal three or four joints flavous, third and fourth equal. Thorax scarcely twice as broad as long, narrowed in front, entirely impunctate, basal margin very narrowly black, surface rather darker than elytra. Scutellum triangular, margined with black. Elytra strongly punctate-striate, the punctures piceous, distinct to apex although finer, extreme base and apex paler yellow, interstices with a few fine punctures here and there, also finely wrinkled near suture at base; fifth and sixth rows of punctures the shortest, joined at apex, ninth row placed farther from the margin than the width between the other interstices. First abdominal segment flavous at middle. Prosternum rugosely punctured, slightly produced anteriorly at middle, posterior margin obsoletely bidentate.

Length $4 \mathrm{~mm}$.

Hab. Nilgiris (Hampson-Coll. Brit. Mus.).

This species also is allied to C. oinnabarinus, Suffr. but is smaller, not red above but flarous, the elytral puncturation not fine but strong and distinct to apex, the interstices not broad and smooth 
but sparingly punctured and partly wrinkled; the tarsi entirely black but the legs variable in colour. From the preceding species the present differs in the black underside and different elytral sculpturing.

\section{Cryptocephalus cribricollis, sp. n.}

Head, basal joints of antennæ, scutellum, underside and legs flavous; above fulvous; basal margin of elytra narrowly black.

Subcylindrical and parallel. Head with a few punctures irregularly placed and an obscure central longitudinal groove, surface very shining; eyes moderately deeply and angularly emarginate; antennæ not extending to middle of elytra, basal five joints flavous, rest black, third and following two joints equal, terminal joints widened. Thorax short and transverse, not or scarcely widened at middle, posterior angles not produced but acute, entire surface covered with extremely fine longitudinal scratches or aciculations and minute punctures. Scutellum triangular, flavous. Elytra moderately strongly punctate-striate, rows distantly placed, interstices flat and finely punctured, lateral lobes very feeble. Legs and tarsi robust. Prosternum not produced in front, posterior angles finely pointed.

Length $3 \mathrm{~mm}$.

Hab. Nilgiris. Type in Coll. H. E. Andrewes.

Amongst the species with unicolorous upper surface there is none with a similarly sculptured thorax, nor can it be compared to any species of other coloration in regard to this part. The specimen before me seems to be a male.

383. Cryptocephalus hecticus, Fabr. Syst. Eleuth. ii, 1801, p. 56 ; Suffr. Monogr., Linn. Ent. ix, 1854, p. 122.

Pale flavous; base of elytra narrowly black.

"Slender and cylindrical, narrowed at base and apex; head broad, flat, entirely impunctate; antennæ moderately robust, third joint twice as long, the following two three times longer than second, rest distinctly widened. Thorax short, surface very finely, distinctly and closely punctured. Scutellum subquadrate, truncate at apex, strongly raised. Elytra raised near scutellum, shoulders rounded and strongly raised, epipleural lobes long; surface finely punctatestriate, middle rows nearly obsolete posteriorly, interstices broad, flat, finely and remotely but distinctly punctured, humeral callus brownish. Pygidium and underside yellowish-brown; legs slender, anterior tibiæ somewhat curved, very slender; posterior angles of prosternum short but pointed, anterior margin slightly produced. Last abdominal segment of female with broad aud large foveæ, edges with long grey hairs." (Suffrian.)

Length $3 \mathrm{~mm}$.

$H a b$. India: Pondicherry. 


\section{Cryptocephalus uniformis, sp. n.}

Obscure flavous; terminal joints of antennæ darkened, posterior edge of thorax and basal margin of elytra black; shoulders with a small spot; pygidium black at base only or sometimes entirely flavous.

Head closely punctured near eyes, depressed at middle; eyes very broadly emarginate; clypeus scarcely separated from face, strongly transverse, short, strongly punctured; antennæ slender; third and following joints elongate, nearly equal, terminal joints not widened. Thorax about twice as broad as long, entirely impunctate; scutellum margined with black. Elytra subcylindrical, nearly parallel, moderately strongly punctate-striate, interstices flat, impunctate; shoulders with a small black spot; prosternum broad, anterior margin produced at middle, posterior angles strongly pointed.

\section{Length $4 \mathrm{~mm}$.}

Hab. India: Trichinopoly.

Of this species I received two specimens from M. Clavareau at Brussels. These closely resemble $C$. pallidipennis, but the antennæ are shorter and without widened joints, the thorax is distinctly shorter, the elytral punctures are stronger and more regular and the shoulders have a small black spot; from $C$. cinnabarinus the species is sufficiently distinguished by the smaller size and colour of the legs, and from unicolorous varieties of $C$. vahli by the impunctate thorax, distinctly punctured apex of the elytra, and generally larger size.

\section{Cryptocephalus insignatus, sp. n.}

Reddish-fulvous; antennæ (basal joints excepted) and tarsi black.

Broad and parallel-sided; head scarcely perceptibly punctured; clypeus separated from face by a few minute punctures; labrum fulvous; antennæ black, extending beyond middle of elytra, basal three joints fulvous, first basal joint elongate, curved, slightly thickened, second short, third and following joints about as long as the first, terminal joints thickened. Thorax proportionately long, about one-half broader than long, sides feebly rounded, narrowly margined; surface entirely impunctate, very shining. Scutellum triangular, flavous, base black. Elytra parallel, broadly rounded at apex, shoulders prominent; puncturation strong and very regular, distinct and only slightly finer at apex, punctures piceous, iuterstices broad and flat, here and there finely wrinkled, fifth and sixth row of punctures shortest, joined at apex; epipleural lobes distinct but short. Breast slightly darker than rest of underside; all the tarsi black, first joint strongly widened and long; pro- 
sternum rather transverse, flavous, posterior angles strongly pointed.

Length $3 \mathrm{~mm}$.

$H a b$. Northern India (Coll. Brit. Mus.).

Allied to $C$. lovissimus, Suffr., the thorax impunctate, elytra without humeral spot, the elytral puncturation strong, not extremely fine.

386. Cryptocephalus subcostatus, Jac. Ann. Soc. Ent. Belg. xlviii, 1904, p. 382.

Flavous beneath, above fulvous; thorax with two black spots; elytra strongly punctate-striate, the interstices more or less longitudinally convex.

Head flavous or testaceous, closely semirugose, punctate throughout; labrum smooth; mandibles nearly black; antennæ entirely fulvous, the third joint longer than the

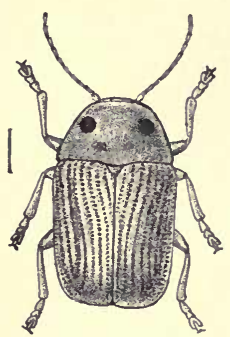

Fig. 77.-Cryptocephalus subcostatus. fourth, terminal joints widened, subtriangular, last joint with an additional pointed appendage; anterior edge of the clypeus only slightly concave. Thorax strongly deflexed at the sides, narrowed in front, the posterior angles acute but not much produced; the disc impunctate, fulvous, with two black spots, more widely separated from each other than are either of them from the lateral margins; scutellum rather broad, flavous, margined with black. Elytra not depressed below the base, fulvous, strongly punctate-striate, the punctures much finer near the apex, the interstices slightly convex, impunctate. Beneath and the legs pale flavous, the sides of the breast strongly punctured. Prosternum produced into a long projection anteriorlf, deeply bilobed posteriorly; pygidium flavous, finely rugose.

\section{Length 5-7 mm.}

$H a b$. Southern India : Anaimalai Hills.

Closely allied to several similarly coloured Indian species, notably C. fraternus, Duviv. and C. andrewesi, Jac., but distinguished from the former by the scarcely emarginate clypeus, the very closely punctured head and the structure of the prosternum; from the latter species by the rather convex elytral interstices, colour of the antennæ and the entirely flavous underside, also by the prosternum being pointed anteriorly instead of broadly rounded. C. fatuus, Suffr. has no thoracic spots, an elongate, triangular scutellum and finely punctured elytral interstices; the prosternum also is broadly not pointedly produced. The female of 
the present species is much larger, the antennæ are much shorter with the third and following joints nearly equal, and the thorax much more transverse.

387. Cryptocephalus andrewesi, Jac. Ann. Soc. Ent. Bely.xxxix, 1895, p. 267.

Fulvous, spotted with black below, terminal joints of antennæ black; thorax with two black spots, sides flavous.

Head deeply punctured; clypeus flavous, impunctate; eyes broadly emarginate; labrum piceous; an-

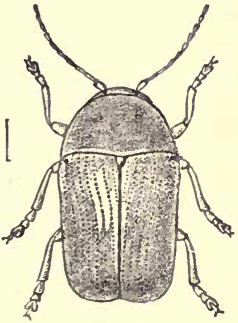

Fig. 78.

Cryptocephalus andrewesi. tennæ black, basal five joints fulvous, third and fourth equal. Thorax twice as broad as long, sides evenly rounded, strongly narrowed in front; surface en. tirely impunctate, dark fulvous, two black spots placed at middle but widely separated, sides narrowly obscure flavous, posterior margin serrate, edged with black. scutellum pale fulrous, margined with piceous. Elytra slightly narrowed posteriorly, not depressed below the base, deeply punctate-striate, punctures very fine near suture at apex, interstices impunctate, longitudinally costate at sides, shoulders scarcely prominent. Sides of breast and the abdominal segments more or less spotted with piceous, finely pubescent. Prosternum longer than broad, longitudinally concave, base bilobed; anterior margin strongly produced and concave.

Length 4-5 mm.

$H a b$. Southern Bombay : Belgaum.

Evidently allied to $C$. circumductus, Suffr. but much larger. C. fatuus, Suffr. differs in being paler, the thorax has no spots and the elytral interstices are finely punctured. Lastly, $C$. fruternus, Duv. is described as having widened terminal joints of the antennæ, an unspotted thorax, no elytral costa and differently formed prosternum.

388. Cryptocephalus fatuus, Suffi. Monogr., Linn. Ent. xiv, 1860, p. 43; Weise, Deut. ent. Zeit. 1903, p. 30.

Pale yellow; elytra with basal margin paler.

Head with a few punctures, central groove five; antennæ yellow, scarcely darker at apex, extending beyond middle of body, third and fourth joints equal, each about two and a balf times longer than the second, terminal six distinctly widened. 'Thorax 
short and globose, deeply impressed in front of scutellum, lateral margins feebly curved, distinctly margined, surface nearly impunctate. Scutellum elongate, narrow. Elytra rather flat, shoulders subtuberculate, suture near scutellum raised; epipleural lobes long; surface deeply punctate-striate, interstices slightly raised, lateral interstices more strongly so, very finely and remotely punctured. Pygidium slightly convex at middle; prosternun broadly produced at middle, posterior angles blunt and short.

Length $5 \mathrm{~mm}$.

$H a b$. India.

Much larger than C. hecticus, Fabr., with stronger elytral puncturation.

389. Cryptocephalus fraternus, Duviv. Ann. Soc. Ent. Belg. xxxvi, 1892, p. 404.

Pale fulvous; eyes, mandibles and two small spots on thorax black.

Head feebly impressed and longitudinally grooved; clypeus deeply and angularly emarginate in front; vertex strongly, lower portion more finely, punctured; antennæ with terminal joints slightly darkened, not extending beyond middle of body, third joint twice as long as second, third and fourth equal, following joints slightly longer and feebly triangularly dilated. Thorax twice as broad as long, posterior angles very short, pointed; surface impunctate, the spots placed at middle, separated by a space one and a half times wider than are the spots on the sides. Scutellum rounded at sides, smooth, extreme base dark brown. Elytra with scutellar space slightly raised, feebly impressed below shoulders, very deeply punctate-striate, interior of punctures darker, puncturation towards apex finer. Pygidium subrugose, rounded at apex, very finely pubescent. Beneath finely punctured and pubescent, except at the sides of metasternum which are deeply punctured; prosternum not prolonged in front.

o. Last abdominal segment with a deep central fovea and a sinaller fovea at each side.

Length $7 \mathrm{~mm}$.

Hab. Bengal: Maudar.

Closely allied to C. fatuus, Suffr, but differs in being more elongate and narrow, in the angularly emarginate clypeus and in the spotted thorax, the latter also more narrowed anteriorly than in $C$. fatuus. Pygidium of $C$. fatuus is more rounded at apex; the abdominal fovea of the female is less deep and the lateral foveæ are smaller.

Differs from $C$. andrewesi in the nearly unicolorous antennæ, non-costate elytra, \&c. 
390. Cryptocephalus rufnlus, Suffi. Monogr., Linn. Ent. xiv, 1860, p. 32 .

ठ. "Rufous; terminal joints of antennæ and basal edge of thorax black.

"Head distinctly but remotely punctured, mouth parts rather darker; antennæ about three-fourths the length of the body, robust, third joint three times longer than the secoad, following two still longer, rest widened, terminal joint with pointed appendage, basal four joints flavous, fifth and following black. Thorax short, sides strongly eurved towards apex, posterior angles acute, surface impunetate. Scutellum yellowish-red, with darker margins. Elytra about twice as long as broad or rather longer, shoulders produced ând elongate ; elytral epipleuræ below shoulders strongly produced; finely punctate-striate, punctures feeble at base, strongest towards middle, then finer, almost obsolete near apex, the ninth row only distinct to end, interstices flat, sparingly and finely punctured anteriorly, finely obsoletely wrinkled posteriorly, extreme basal margin black. Pygidium pale reddish, closely punctured. Beneath with middle of first abdominal segment, sides of breast and prosternum flavous, tarsi blackish.

"Length $3 \mathrm{~mm}$.

" $\mathrm{Hab}$. Madras.

"Described from a single inale specimen." (Suffrian.)

\section{Cryptocephalus madrasæ, sp. n.}

Above fulvous; terminal joints of antennæ piceons; basal margin of elytra and body beneath black.

Head strongly and rather closely punctured ; antennæ scarcely extending beyond base of elytra, basal six joints and base of seventh fulvous, rest blackish, second to fourth joints gradually lengthened, terminal joints rather short and slightly widened. Thorax rather long, somewhat strongly narrowed in front, surface crowded with shallow and small punctures. Scutellum with black basal margin. Elytra cylindrical, slightly narrowed posteriorly, distinctly punctate-striate to apex, rows more closely placed at the sides than near suture, interstices at first-named place closely and finely wrinkled, those on inner disc less distinctly so. Legs fulvous. Pygidium black, finely punctured and pubescent; prosternum not produced in front, feebly enarginate at base.

Length $5 \mathrm{~mm}$.

Hab. Madras. Type in Oxford Mus.

Elytra black.

392. Cryptocephalus mandarensis, Jac. Ann. Soc. Ent. Bely. xli, 1897, p. 421.

Flavous; thorax with two widely separated short longitudinal black stripes at base; elytra black.

Head with a few fine punctures at vertex, sometimes stained 
with fuscous; eyes broadly emarginate; antennæ flavous, third joint slightly shorter than fourth. Thorax twice as broad as long, strongly narrowed anteriorly, sides rather rounded, posterior angles acutely produced, surface impunctate, base with a short oblique depression at each side, the latter with a short perpendicular black stripe resting on the basal margin and not extending upwards to the middle. Scutellum triangular, black or fulvous. Elytra strongly punctate-striate, the puncturation distinct to the apex, first, fifth and sixth rows abbreviated, the latter two joined at apex. Elytra and the epipleuræ black. Body beneath and legs flavous; prosternum subquadrate, anterior margin scarcely produced, posterior nearly straight.

Length $3 \frac{1}{2} \mathrm{~mm}$.

Hab. Bengal : Mandar.

The widely separated black thoracic stripes and entirely black elytra principally distinguish this species, which cannot be considered one of the numerous varieties of $C$. vahli since the elytral puncturation is not obliterated posteriorly nor is the prosternum produced in front. In one specimen each elytron shows a faint fulvous patch at the middle, suggesting a probable spreading of this colour occasionally. The species is larger than C. sobrius, Suffr. or than C. sanguinolentus, Oliv., both of which it somewhat resembles in coloration.

393. Cryptocephalus subcylindricus, Suffr. Monogr., Linn. Ent. xiv, 1860 , p. 55.

" $\delta$. Pale flavous; terminal joints of antennæ, two spots on thorax and the elytra (epipleuræ excepted), black.

"Narrow and elongate; head finely and closely punctured; clypeus distinctly separated ; antennæ extending beyond middle of elytra, robust, third and fourth joints equal, each twice as long as the second, fifth and following joints widened, terminal joint with an additional pointed prolongation, basal four joints flavous, rest black, pubescent. Thorax short and broad, narrowly margined at sides, posterior angles short and pointed, surface depressed at base in front of scutellum, impunctate, extreme basal margin black, an elongate black spot at base on each side of the depression that extends nearly to the middle. Scutellum triangular, strongly raised, margined with black. Elytra raised round the scutellum, shoulders elongate, rather flat, epipleuræ at sides slight; puncturation strong anteriorly, more feeble at middle, nearly obsolete behind the latter, interstices feebly raised, transversely wrinkled; inflexed edge of epipleuræ at base yellowish. Pygidium and body beneath sparsely pubescent. Prosternum with short pointed posterior angles.

" Length $2 \frac{1}{4} \mathrm{~mm}$.

"Hab. India." (S̃uffrian.) 


\section{9-4. Cryptocephalus brahminus, sp. $n$.}

․ Head fulvous; a black transverse band at vertex; thorax fulvous, with two black spots; legs fulvous; elytra (epipleural lobes beneath excepted) and underside black.

Head somewhat convex, impunctate and shining, vertex with a shallow longitudinal groove, the black band widened at middle; eyes subangularly but not deeply emarginate; clypeus not separated, moderately concave at anterior margiu, surface impunctate; antennæ fulvous, basal joints flavous, third joint slender, twice as long as second, following nearly equally long, not thickened. Thorax short and strongly transverse, all the margins narrowly black, a large black spot on each side near the middle. Scutellum broadly triangular, black. Elytra strongly punctate-striate, the punctures replaced by striæ at the apex, interstices finely wrinkled, slightly convex at sides, shoulders highly raised and broad; epipleural lobes feeble, fulvous beneath. Legs short and stout. Prosternum deeply emarginate at middle of anterior margin; the posterior angles acutely pointed.

Length $4 \mathrm{~mm}$.

Hab. India (Coll. Brit. Mus.).

This species cannot be mistaken for one of the black varieties of $C$. vahli or $C$. senarius, as the head is entirely impunctate and has a black band. In $C$. sanguinolentus, Oliv. the head is finely punctured and entirely red, the antennæ have the joints differently fashioned and the prosternum is not emarginate anteriorly.

395. Cryptocephalus dimidiatus, Suffr. Monogr., Limn. Ent. xiv, 1860, p. 15.

"Reddish-fulvous; scutellum and elytra deep black.

"ㅇ. Head remotely but distinctly punctured; antennæ scarcely half the length of the body, robust, third and fourth joints equal, fifth and sixth longer, following broadly widened, terminal joint with very short triangular appendages, all joints except the apical red. Thorax short and broad, with two oblique depressions in front of scutellum, posterior margin narrowly black. Scutellum elongate-triangular. Elytra raised round scutellum, shoulders broad, epipleural lobes moderately produced; surface with the punctures stronger at middle than at each end, interstices broad, flat, scarcely wrinkled. Pygidium dark fulvous. Prosternum scarcely produced in front, posterior angles short and pointed.

"Length $4 \mathrm{~mm}$.

"Hab. Southern India." (Suffrian.)

Suffrian only doubtfully described this species as distinct from $C$. insubidus or its female. The apparent differences from black varieties of $C$. vahli are the impunctate elytral interstices and the finer puncturation, while the black elytra and scutellum possibly distinguish it from $C$. insubidus and the fulvous underside from C. sanguinolentus. 


\section{Elytra partly fulvous, partly black.}

396. Cryptocephalus lefevrei, Jac. Ann. Soc. Ent. Belg. xxxix, 1895, p. 268.

Black; head, basal joints of antennæ and anterior legs flavous ; elytra with the anterior portion fulvous, the posterior two-thirds and a humeral spot black.

c. Head minutely granulate-punctate; eyes widely separated, broadly emarginate; clypeus distinctly separated from face, anterior margin semicircularly emarginate; labrum flavous with the middle portion black; antennæ

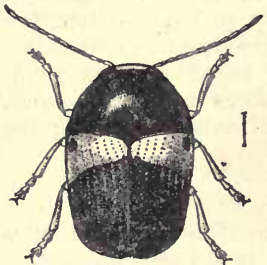

Fig. 79.

Cryptocephahus lefevrei. about two-thirds the length of body, very slender, basal five joints flavous, rest black, third to fifth joints equal, following joints longer, scarcely widened. Thorax subcylindrical, double as wide at base as anteriorly, sides nearly straight, narrowly margined, surface entirely impunctate, black. Scutellum black, not longer than broad, impunctate. Elytra finely and regularly punctate-striate, interstices smooth and impunctate, their anterior third fulvous, the rest black, extreme anterior margin also black, semicircularly rounded, shoulders with a small black spot. Anterior and sometimes the intermediate legs flavous, the others as well as the body beneath black. Prosternum strongly produced in front, posterior angles pointed.

Length 3-4 $\mathrm{mm}$.

$H a b$. Southern India: Belgaum.

397. Cryptocephalus dimidiatipennis, Jac. Ann. Soc. Ent. Belg. xxxix, 1895, p. 269.

Black; clypeus and basal joints of antennæ flavous; elytra with the anterior half flavous, the rest black.

Head finely and irregularly punctured; eyes moderately deeply and broadly emarginate; clypeus wedge-shaped, with a few fine punctures; antennæ long and slender, basal four joints flavous, rest black, third joint shorter than fourth. Thorax black, about one-half broader than long, strongly narrowed anteriorly, sides feebly rounded, surface impunctate, very shining. Scutellum black, slightly elongate, apex rather pointed, surface impuuctate. Elytra strongly and regularly punctate-striate, punctures scarcely finer at apex, fifth and sixth rows abbreviated posteriorly and joined at apex, outer interstices convex; basal halves flavous, forming a broad, laterally widened band, this colour also extends to the epipleuræ below as far as the middle. Legs and body beneath black, base of femora and anterior tibiæ sometimes 
flavous. Prosternum slightly longer than broad, scarcely produced in front.

Length $4 \mathrm{~mm}$.

$H a b$. Sikhim : Mungphu.

Similar in colour to C. lefevrei, Jac., but the elytra without a humeral spot, more strongly punctured, the outlines of the flavous and black coloured portions different, the black extends obliquely upwards at the suture towards the scutellum.

\section{Cryptocephalus manipurensis, sp. n.}

Black; basal joint of antennæ and clypeus flavous; elytra with posterior two-thirds black, anterior third flavous.

Head finely punctured and pubescent; eyes rather closely approximate; antennæ somewhat short and robust, basal joint flavous, following two piceous, remainder black, joints 2 to 4 gradually lengthened, the rest widened. Thorax very convex, about one-half broader than long, impunctate. Scutellum black and broad. Elytra twice as long as thorax, strongly punctatestriate, outer two interstices convex, others flat; inner margin of epipleural lobes strongly produced, latter very broad at base. Prosternum and mesosternum closely pubescent, the former not produced in front, posterior angles blunt.

Length $3 \mathrm{~mm}$.

Hab́. India: Manipur (Coll. Brit. Mus.).

Similar in colour to $C$. lefevrei, Jac. and $C$. deficiens, Suffr., but differs from both in the greater amount of black on the elytra, the anterior edge of which is convex, extending higher upwards along the suture than along the sides; differs also in the absence of a humeral spot and in the entirely black legs. I have only seen a single male specimen.

399. Cryptocephalus insubidus, Suffr. Monogr., Linn. Ent. ix, 1854, p. 36.

Dark fulvous; two spots on the thorax and the base of elytra black.

Head feebly convex; clypeus concave; forehead with fine longitudinal groove; antennæ pale flavous, slender ( $\sigma^{*}$ ), about balf the length of the body, third and fourth joints equal, twice as long as second, following two slightly longer, terminal joints slightly widened, last joint with a long and thin appendage. Thorax scarcely perceptibly punctured, margins slightly darker, posterior margin serrate, narrowly black, two obsolete small elongate spots at middle. Scutellum margined with piceous. Elytra short, broadly convex, shoulders broad and flat; epipleural lobes short but distinct; surface strongly punctate-striate, finer from middle but distinct to apex, interstices flat, finely punctured,

vor. I. 
shining; a broad transverse black band at base, its posterior edge somewhat obsolete but extended downwards at the sides to as far as the middle, therefore deeply concave within the humeral portion.

Length $2 \frac{1}{2} \mathrm{~mm}$.

$H a b$. Bengal.

Suffrian compares this species with $C$. vahli, from which it differs in its smaller size, the strong elytral puncturation distinct to apex and dark epipleural lobes.

400. Cryptocephalus deficiens, Suffr. Monogr., Linn. Ent. ix, 1854, p. 146.

Black; clypeus, basal joints of antennæ and legs flavous; elytra with the anterior half flavous, the rest black.

Head finely rugose between the eyes and closely pubescent; the latter rather closely approximate at the top, triangularly emarginate at middle; clypeus nearly smooth, emarginate in front; labrum and palpi flavous; antennæ slender, basal four joints flavous, rest black, third and following joints nearly equal. Thorax rather strongly narrowed anteriorly, the sides very narrowly margined; the disc entirely impunctate, very shining. Scutellum black, triangular. Elytra rather strongly punctatestriate, the punctures distinct to apex, the flavous anterior half gradually widened at the lateral margins, the edge separating it from the black portion, sinuate at the middle. Beneath and the pygidium black. Prosternum not produced in front, nearly truncate posteriorly.

Length $2 \frac{1}{2} \mathrm{~mm}$.

$H a b$. Northern India (Suffrian); Assam (Doherty).

The type of this species was described by the author from a single specimen without a head, but as every other detail given agrees with the specimens I have before me, I have no doubt about the identity of the latter with Suffrian's species. It is smaller than $C$. lefevrei and has strongly not finely punctured elytra; the same difference in size and shape of elytral markings separates the species from $C$. dimidiatipennis.

\section{Elytra fulvous or flavous with longitudinal black bands or black suture.}

401. Cryptocephalus nigrolineatus, Jac. Ann. Soc. Ent. Belg. xlvii, 1903, p. 89.

Flavous; an intraocular stripe and the apical joints of antennæ black; thorax light fulvous with pale margins; elytra with the extreme lateral margins behind the middle and a narrow lateral 
longitudinal stripe, abbreviated posteriorly, black; breast black; tarsi fuscous.

Head impunctate, a central stripe and a spot at base of autennæ black; antennæ black, not

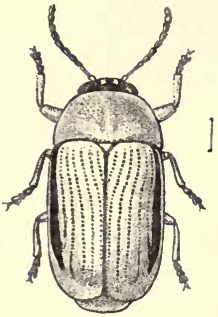

Fig. 80.-Cryptocephalus nigrolineatus. extending to middle of elytra, basal two or three joints flavous, third to fifth equal, succeeding joints longer. Thorax much narrowed anteriorly, short and transverse, sides very feebly rounded; surface impunctate, rather broadly flavous, disc fulvous. Scutellum flavous, margined with black. Elytra finely punctate-striate, the punctures nearly black, as are the extreme sutural and lateral margins, also a narrow stripe from the base that runs down the shoulders to past the middle. Prosternum and breast black; abdomen flavous.

Length $4 \mathrm{~mm}$.

$H a b$. Pondicherry (Coll. Jacoby).

This species may be distinguished from C. sehestedti, Fabr. and others that are similarly marked by the narrow elongate shape and elytral stripe, which in some specimens is only indicated at the shoulders.

402. Cryptocephalus malleatus, Suffr. Monogr., Linn. Ent. xiv, 1860, p. 50; Weise, Deut. ent. Zeit. 1903, p. 31.

" Bright flavous; terminal joints of antennæ, posterior edge of thorax, base of elytra, and a curved longitudinal band on the disc of each elytron, black or dark red.

"Head distinctly but remotely punctured, mandibles black; antennæ of male longer than half the body, third and fourth joints equal, each one-half longer than the second, tifth and following joints widened, black, basal joints flavous. Thorax entirely impunctate. Scutellum narrowly edged with black. Elytra short, scarcely narrowed posteriorly, shoulders broad and flat, scarcely prominent, without any depression within; epipleural lobes feeble. Elytral puncturation very regular, obsolete near apex, interstices flat, very finely and sparingly punctured; a broad transverse black band at base touching suture below scutellum joined by a longitudinal black stripe on the middle of disc which curves towards suture near apex. Pygidium and body beneath scarcely punctured: anterior margin of prosternum moderately produced.

"Length 2-4 mm.

"Hab. Ceylon.

"In some varieties the bands are bright red and the basal band is marked at each end with a black spot; the upper surface is yellowish-white." (Suffrian.) 
403. Cryptocephalus lutulentus, Suffr. Monogr., Linn. Ent. xiv, 1860, p. 12.

"Pale fulvous; front of head, two spots on thorax, and elytral margins broadly black.

"Head flat, distinctly grooved at middle; clypeus transversely depressed, finely and remotely punctured, sides of face paler than the rest; antennæ flavous, about half the length of body, slender and delicate, third to fifth joints gradually lengthened, rest scarcely wider. Thorax with two short but deep depressions at base; surface impunctate, two elongate spots touching posterior margin and narrowed anteriorly extend to middle of disc. Elytra raised near scutellum, only feebly depressed below, shoulders broadly raised, epipleural lobes long; surface strongly punctatestriate anteriorly, gradually finer towards apex, interstices mostly flat. Anterior margin of prosternum broadly produced, posterior angles rather blunt and short.

"Length $2 \frac{1}{2} \mathrm{~mm}$.

" $H a b$. Southern India.

"Allied to $C$. circumductus but with black forehead, two thoracic spots, and with broad black elytral margins extending to epipleural lobes." (Suffrian.)

404. Cryptocephalus sehestedti, Fabr. Ent. Syst. Suppl.1798, p. 107; Oliv. Ent. vi, p. 830, pl. 7, fig. 108; Suffr. Monogr., Linn. Ent. ix, 1854, p. 28 ; id.t. c. xiv, 1860, p. 12.

Pale fulvous; beneath black with flavous legs; elytra with a broad longitudinal black band, abbreviated posteriorly.

Short and broad; head rather strongly and closely punctured; antennæ extending to base of elytra, basal

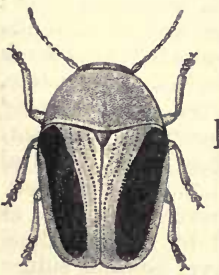

Fig. 81.-Cryptocephalus sehestedti. five joints flavous, rest dark fuscous, third and fourth joints short, nearly equal. Thorax narrowed anteriorly, extreme basal edge black, serrate, surface extremely closely aud finely punctured, lateral margins and two small spots in front of scutellum often pale. Scutellum triangular, more or less fulvous, with darker edges. Elytra moderately strongly punctured, interstices rather closely and finely punctate; the black band between second and seventh row of punctures (not counting short subsutural row) but covering the eighth row at base, slightly curved and not extending to apex. Last abdominal segment often flavous.

Length 2-3 $\mathrm{mm}$.

$H a b$. India: Bengal ; Southern Bombay; Nilgiris; Malabar. Ceylon.

Well distinguished by the elytral black band on disc. 
405. Cryptocephalus lucifer, Suffr. Monoyr., Linn. Ent. ix, 1854, p. 141.

․ Black; basal joints of antennæ, legs, anterior and lateral margins of thorax and two spots at base of latter, flavous; elytra flavous margined with black and with discoidal black band.

Head finely punctured and transversely wrinkled, mouth-parts brownish; space below eves flavous; antennæ with third joint

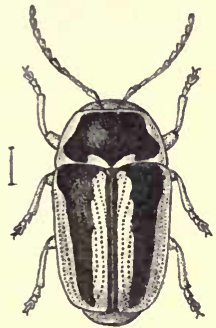

Fig. 82.

Cryptocephalus Incifer. slightly longer than second, fourth still longer and equal to following joints, basal joint flavous, black above, following three piceous, rest black. Thorax scarcely perceptibly punctured, punctures very remote, anterior margin narrowly, lateral very broadly flavous; posterior margin narrowly black, finely serrate, two oblique posteriorly connected yellow spots at base. Scutellum black. Elytra strongly punctured, the punctures distinct to apex; epipleural lobes short; base near scutellum deeply transversely depressed, interstices feebly raised; outer margins black, extending round epipleural lobes and base, sutural margins more broadly black; the discoidal stripe gradually narrowed posteriorly, not extended to apex and occupying at its narrowest portion the third to the seventh row of punctures. Pygidium yellowish with darker margin. Lastabdominal segment paler at hind margin, with an ovate posteriorly truncate cavity.

Length $5 \mathrm{~mm}$.

$H a \dot{b}$. Southern India: Pondicherry.

406. Cryptocephalus ovulum, Suffr. Monogr., Linn. Ent. ix, 1854, p. 30; id.t. c. xiv, 1860, p. 12.

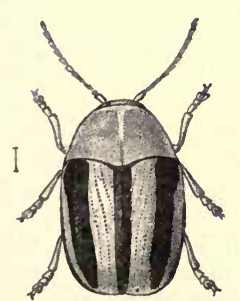

Fig. 83 .

Cryptocephalus outum.

Flavous; breast black; elytra with margins, sutureand an elongate posteriorly abbreviated stripe on disc black.

Closely resembles $C$. sehestedti, Fabr., but smaller, more rounded, puncturation of elytra finer, the impressions at base of thorax deep and the scutellum, which is triangular in sehestedti, is in this species elongate and narrow. Antennæ only flavous on the underside, brownish above; the breast less black than in C. sehestedti; abdomen scarcely darker. The elytra have the outer margins deep black and the suture is broadly of similar coloration; the bands do not extend quite to apex. Prosternum but little produced in front. 
Abdominal fovea of $q$ more elongate and narrow than in C. sehestedti, the corresponding segment in $\delta$ only slightly depressed.

Length $2 \mathrm{~mm}$.

$H a b$. "Tranquebar"; Madras.

According to Suffrian the elytra in this species may be described as having three longitudinal bands, of which the middle one is of slightly less width.

407. Cryptocephalus vittipennis, Suffr. Monogr., Linn. Ent.ix, 1854, p. 31.

Pale fulvous; two obscure spots on thorax, suture, and a broad more or less divided longitndinal band on each elytron, black.

Closely allied to $C$. ovulum, Suffr.; has the same size and shape, but the sutural band is narrower and the elytral longitudinal band bi- or trifurcate, the whole underside flavous.

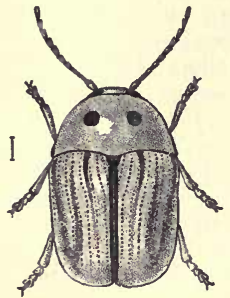

Fig. 84.-Cryptocephalus vittipennis.

Thorax more fulvous; the punctures of elytra much finer, nearly obsolete posteriorly ; interstices extremely finely transversely wrinkled. Legs pale flavous.

Length $2 \frac{1}{2} \mathrm{~mm}$.

Hab. Mussoorie ; Patna District; Calcutta.

Suffrian described this species as somewhat doubtfully different from $C$. ovulum, of which it may be a variety, but the above differences seemed to him sufficient to separate it as a distinct species. In three specimens in my collection (two from Calcutta) the extreme lateral margins of the thorax are black (not mentioned by Suffrian), but otherwise they agree with the author's description. In the third the tibiæ and tarsi are blask and the general size is larger ( $q)$. The discoidal black elytral stripe is probably subject to variation in regard to its partly divided shape, and in some specimens lately received from India the elytral stripe is trifurcate or divided into three rays as Suffrian describes it.

\section{Cryptocephalus poultoni, sp. $n$.}

Flavous; breast black; elytra with lateral margins and a broad sutiral band that is deeply constricted at the middle black.

Head impunctate; antennæ with basal four joints flavous, rest in the type and only specimen wanting, third and fourth joints equal. Thorax twice as broad as long, sides nearly straight, slightly narrowed in front; surface impunctate; extreme basal margin black. Seutellum triangular. Elytra parallel, strongly 
punctate-striate; interstices costate, strongly so at sides; the lateral black band narrow, not extending to apex, inner margin somewhat ill-defined; sutural band much broader, likewise abbreviated before apex, deeply emarginate at middle. Anterior legs flavous.

Length $3 \mathrm{~mm}$.

Hab. Nepal (Coll. Oxford Mus.).

Although the single specimen before me is very defective, without posterior legs and abdomen, it is sufficiently distinguished by the elytral pattern and the costate interstices to render recognition of the species easy. From $C$. bombayensis the different colour of head and thorax at once distinguish it, while C. signatella, Jac. has a different coloured thorax and an evenly wide sutural band.

409. Cryptocephalus uncinatus, Suffr. Monogr., Linn. Ent. xiv, 1860, p. 52 .

․ Flavous; vertex of head, two spots on thorax, scutellum, shoulders and a longitudinal band on elytra that is curved inwards, black.

Very closely allied to $C$. malleatus, Suffr., and differs only in the following details:-The head has a distinct black band on the vertex and the thorax two spots; the elytral bands are stronger, better defined, narrower, in shape linear, dilated posteriorly on the outer side; the posterior curve is placed lower down and terminates at apical angle more acutely; the apex remains very narrowly edged with flavous; the basal transverse band is wanting and is replaced by a narrow elongate spot on the humeral callus. The size is double that of $C$. malleatus; the elytral punctures are much stronger and the outer two interstices are distinctly convex, while in $C$. malleatus all interstices are flat and the punctures obsolete towards apex. Prosternum produced in front, round and hollow; posterior margin bluntly produced.

Length $4 \mathrm{~min}$.

$H a b$. Ceylon.

410. Cryptocephalus notogrammus, Suffr. Monogr., Linn. Ent. ix, 1854 , p. 143 ; id. t. c. xiv, 1860 , p. 53.

Black ; base of antennæ, two small spots on head, anterior and lateral margins of thorax and legs flavous; elytra flavous, with a broad sutural and a discoidal band.

"Head with fine central line, extremely finely and sparingly punctured, mouth-parts pale brown; sides of face and a small obsolete spot at top of eyes yellow; antennæ of about half the length of body, third and fourth joints equal, flavous, fifth and following joints blackish. Thorax extremely finely and remotely punctured, a narrow anterior wider lateral margin and anterior corners flavous. Scutellum black. Elytra narrowed posteriorly; 
epipleural lobes feeble; surface distinctly punctate-striate, interstices slightly convex; base and lateral margins narrowly, a broad sutural and a still broader discoidal band black; the last band commences at the shoulders, curves inwards and occupies the space between fourth and eighth row of punctures; all the bands are abbreviated near apex.

"Length $2 \mathrm{~mm}$.

"Hab. Himalayas : Landour." (Suffrian.)

411. Cryptocephalus virgula, Suffr. Monogr., Linn. Ent. ix, 1854, p. 32 .

Cryptocephalus sobrius, Suffr. (virgula of) t. c. ix, 1854, p. 39; Weise, Deut. ent. Zeit. 1903, p. 31 .

․ Flavous; a spot on the vertex of head, two on thorax, humeral callus, margins and an abbreviated longitudinal band on each elytron, black.

Head finely punctured, the middle with a fine groove; a transverse band on top of vertex and the labrum black; palpi flavous. Antennæ (ㅇ ) fuscous, half the length of body, slender, third and fourth joints double the length of second, the fifth and following joints slightly widened. Thorax strongly narrowed anteriorly, posterior angles strongly pointed; posterior margin deeply concave at sides, very narrowly black; two spots placed close together on the middle of the disc, and an obscure short line at middle of base. Scutellum margined with piceous. Elytra distinctly punctatestriate; interstices flat, shining; the basal margins broadly, the other margins narrowly, black; an elongate spot on shoulders, a longitudinal stripe abbreviated behind the middle on the third interstice likewise black. Pygidium and underside closely punctured, finely pubescent; breast slightly darker. Prosternum very slightly produced anteriorly, posterior angles not pointed.

Length $4 \frac{1}{2} \mathrm{~mm}$.

Hab. Ceylon.

"Much larger than $C$. vittipennis, the markings clearer and the elytral puncturation stronger." (Suffian.)

According to Weise C. sobrius is only the male of C. virgula, The o differs from the $q$ in being smaller; the oblique band of the thorax (in the banded form) is broad and parallel and unites sometimes with the opposite band, leaving only a triangular flavous spot between them in front of scutellum. The elongate stripe of the elytra unites with the humeral spot in shape of a broad band, rounded posteriorly or dilated inwards as far as the suture.

The markings of the thorax in the + (virgula) vary from two small spots to two broad bands, and the elytral markings may either consist of a single spot above the shoulders or of another second spot on the third interstice of elongate, either narrowed or posteriorly widened shape. 
412. Cryptocephalus præcox, Suffr. Monogr., Linn. Ent. xiv, 1860, p. 29.

Pale flavous; posterior margin of thorax, elytral suture and an indistinct longitudinal mark on the posterior half, blackish.

․ Head with some irregular depressions and slightly marked central line, emargination and clypeus finely and remotely punctured, other portions shining; mandibles black; antennæ more than half the length of body, robust, fourth joint slightiy longer than third, following joints rather more slender. Thorax with posterior margin serrate, black; surface inıpunctate, shining. Scutellum raised, triangular, with large fovea at base, margined with black. Elytra at base slightly wider than the thorax, still more widened behind the middle; shoulders broad and flat; epipleural lobes rather feeble; surface finely punctured, the punctures still finer on the apical third portion; interstices flat and broad, scarcely perceptibly wrinkled; extreme basal and lateral margins and the margins of epipleuræ black; this black colouring is less distinct at apex of suture but well marked at middle; the shoulders are likewise stained and an elongate obsolete streak placed behind the middle on the fourth interstice. The following variety occurs:-

Var. $a$. Entire anterior portion of ely tra with a transverse black band, broad and ill-defined, extending in part anteriorly to the epipleuræ. Pygidium feebly carinate, finely punctured, yellow; anterior margin of prosternum bluntly produced, posterior angles short and broadly pointed.

Length $7 \mathrm{~mm}$.

$H a b$. Ceylon.

Similar to $C$. indicus in size and shape but differs in the pale coloration, the black elytral margins, the very fine punctures, and the more elongate body.

\section{Cryptocephalus nigrosuturalis, sp. $n$.}

Above fulvous; antennæ, underside and legs black; thorax with two black spots, posterior portion of elytral suture narrowly black.

Short and ovate. Head sparingly but strongly punctured, more or less deeply longitudinally grooved at middle of vertex; clypeus separated from face, wedge-shaped; antennæ with terminal six joints distinctly widened, third joint one-half shorter than fourth, not much longer than the second. Thorax short and transverse, strongly narrowed in front, the sides straight, extreme margins and posterior angles flavous, rest of disc fulvous, very minutely punctured, a semicircular spot each side near anterior margin black. Scutellum narrow and pointed, margined with black. Elytra short, slightly narrowed posteriorly ; extreme basal margin, a small humeral spot, and a very narrow sutural stripe from behind the middle, black; puncturation rather strong, distinct but 
fine at apex, interstices sparingly and finely punctured. Pygidium black. Prosternum fulvous, pubescent, anterior margin broadly produced, posterior feebly emarginate. Body beneath clothed with fine yellow pubescence.

Length $4 \frac{1}{2}-5 \mathrm{~mm}$.

Hab. Burma: Ruby Mines (Coll. Brit. Mus.).

The spots on the thorax are sometimes much reduced and the humeral elytral spot may be absent. Easily distinguished by the elytral suture which is black from behind the middle, and the colour of the underside and legs.

414. Cryptocephalus suavis, Duviv. Ann. Soc. Ent. Belg. xxxvi, 1892, p. 401.

ס. "Fulvous; apex of tibiæ and the tarsi rather fuscous; metasternum, scutellum, labrum and antennæ (base excepted) black; head and thorax reddish, two spots on the latter, the basal and lateral margins black. Elytra with narrow basal and lateral margins, a sutural

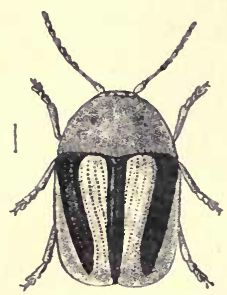

Fig. 85.

Cryptocephalus suavis. band, and a broad discoidal stripe black. Head rather closely punctured, without longitudinal groove; clypeus separated by a transverse groove. Antennæ extended to beyond middle of elytra, basal four joints fulvous, rest black; third joint slightly longer than second, last six dilated. Thorax convex at anterior twothirds of disc, narrowed in front, posterior angles pointed, sides nearly straight; median lobe bisinuate, a small depression on each side near scutellunı; surface extremely minutely and superficially punctured, two black spots placed slightly behind the middle; posterior margin finely serrate. Scutellum elongate, smooth, foreolate at base. Elytra slightly widened at base, epipleural lobes moderate; space round scutellum feebly raised; surface finely punctate-striate, more strongly so at base; interstices finely rugose; the sutural band extends sideways as far as first row of punctures; the discoidal band commences at base, is interrupted a little before apex and is placed between the third and seventh rows. Female unknown.

"Length $3 \mathrm{~mm}$.

"Hab. Sikhim: Kurseong." (Duvivier.)

\section{Cryptocephalus rectofasciatus, sp. $n$.}

Black; head flavous marked with black; thorax and femora fulvous; elytra flavous, margins narrowly and a broad discoidal longitudinal band black. 
Head with a few minute punctures, a central longitudinal stripe, a small spot at base of antennæ and the labrum black; clypeus semicircular, distinctly separated, anterior edge deeply emarginate; antennæ comparatively short, black, basal joint obscure flavous, third and fourth equal, following joints slightly widened. Thorax about one and a half times as broad as long, sides very feebly rounded; disc impunctate, fulvous, margins paler, a small black spot on middle of disc. Scutellum black. Elytra rather broad, subcylindrical, strongly punctate-striate; the discoidal black band straight, placed between fourth and ninth rows of punctures, extending to base but not quite to apex; extreme margins narrowly black. Body beneath black; sides of thorax, a transverse spot at top of breast laterally, another small spot at base of abdomen laterally, last abdominal segment and pygidiun flavous; femora fulvous ; tibiæ more or less and the tarsi black.

Length $2 \frac{1}{2} \mathrm{~mm}$.

Hab. Nilgiris. Type in Coll. H. E. Andrewes.

\section{Elytra pale with transverse black bands only.}

\section{Cryptocephalus aberrans, sp. $n$.}

Beneath black, above reddish-fulvous; thorax with two transverse large spots; elytra with a transverse black band at base and a broader similar band near apex.

Head strongly but rather sparingly punctured, with deep central groove; anterior portion of clypeus black; antennæ black, extending to base of elytra, basal two joints fulvous beneath, third and fourth equal, following joints thick and robust. Thorax short and strongly narrowed anteriorly, sides straight; surface scarcely perceptibly punctured, sides almost covered by a black subquadrate pateh that leaves the margins and middle, except at base, narrowly fulvons; at base the latter colour widens. Sct1tellum uarrow and elongate, fulvous, margined with black. Elytra about two and a half times longer than the thorax, very slightly narrowed posteriorly, subcylindrical, shoulders scarcely raised; epipleural lobes distinct; puncturation strong from base to middle, from thence to apex abruptly fine; anterior black band not touching either margin, lower edge slightly sinuate, extending to onefourth the length of elytra; posterior band wider, touching suture and extended nearly to the lateral margins, anterior edge convex; apex of elytra fulvous. Prosternum anteriorly broadly produced, rather deeply bilobed posteriorly.

Length $3 \frac{1}{2} \mathrm{~mm}$.

$H a b$. Burma : Ruby Mines (Coll. Brit. Mus.).

This Cryptocephalus differs from any similarly marked species by the rather remarkable puncturation of the elytra, which changes very suddenly from strong to fine punctures at middle; the 
markings also of the thorax are more than usually large. The specimen before me is evidently a male, without an abdominal fovea on last segment.

\section{Cryptocephalus longipes, sp. n.}

Fulvous; apical joints of antennæ, parts of breast, pygidium and last abdominal segment black; thorax with two black spots; elytra with a transverse band at base not extending to suture and another entire band near apex black.

Head distinctly but sparingly punctured, longitudinally grooved at middle; eyes deeply emarginate; clypeus separated at sides from face; antennæ long and slender, third and fourth joints equal, following rery elongate and slender, basal five fulvous, rest black. Thorax rather long but about one-half as broad again as long, strongly narrowed in front, sides straight, surface impunctate, a black spot on each side near middle, nearer to the anterior than to the posterior margin. Scutellum black, flavous at niddle. Elytra slightly narrowed posteriorly, deeply and strongly punctate-striate, punctures closely placed, interstices slightly longitudinally raised, transversely wrinkled here and there; the first band extends towards suture as far as the second row of punctures leaving basal and extreme lateral margins narrowly fulvous, second band extends across elytra quite to the margins, its edges sinuate; both bands of the same width, the apex beyond the second band appears like a round fulvous spot. Legs very elongate and slender. Prosternum not produced anteriorly, posterior angles short and pointed.

Length $3 \mathrm{~mm}$.

Hab. Manipur (Coll. Brit. Mus.).

Not unlike C. abbreviatulus, Suffr. in coloration, but the thorax with two spots, the elytra with two not one band, the pygidium and part of underside spotted with black, and the antennæ and legs elongate and slender. The type specimen obtained by Doherty seems to be a inale.

\section{Cryptocephalus obliteratus, Suffr. Monogr., Linn. Ent. ix, 1854,} p. 116.

" + . Pale flavous; metasternum black; thorax with one obsolete transverse blackish band; elytra with three similar interrupted sinuate transverse bands.

"Narrowly elongate and subcylindrical, finely pubescent above; head strongly but sparingly punctured; clypeus feebly separated, short and broad, interstices with short grey hairs; antennæ slender, third joint shorter than fourth, following joints scarcely widened, sixth and terminal joints obscure piceous. Thorax subcylindrical, very finely margined at sides, base with a transverse depression at each side in front of scutellum, surface distinctly and closely 
punctured, pubescence thin, interstices shining; the marking at middle very indistinct, only the middle line black, the lateral branches obsolete. Scutellum elongately triangular, strongly narrowed, apex shortly rounded, base with fovea. Elytra with distinct epipleural lobes, punctured, the punctures strong, finer towards apex, interstices finely punctured and transversely wrinkled, with short white pubescence. Abdomen with a black oblique spot on first segment at each side; femora with a faint black line on outer side; prosternum with hind angles broad and blunt.

"Length $4 \mathrm{~mm}$.

"Hab. Southern India." (Suffian.)

419. Cryptocephalus tricinctus, Redtenb. Hügel's Kaschm. iv, 1848, p. 562, pl. 28, fig. 6; Suffi. Monoyr., Linn. Ent. ix, 1854, p. 15; id. t. c. xiv, 1860, p. 9 .

Flavous; a transverse band at base of thorax, prolonged anteriorly from middle towards anterior margin, two transverse bands on the elytra and their apices, black.

Head closely punctured, deeply depressed at middle with longitudinal groove on vertex, vertex and

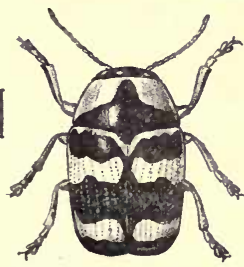

Fig. 86.-Cryptocephalus tricinctus. groove black; clypeus separated from face, broad and transverse, moderately emarginate in front; mandibles black; eyes subquadrately emarginate, sides of emargination straight with a piceous stripe within; antennæ with basal five or six joints flavous, rest black. Thorax strongly transverse, rather short, sides feebly rounded, surface extremely minutely punctured. Scutellum broad, black, apex truncate, transversely grooved. Elytra deeply punctured, the punctures not quite extended to the basal margin, interstices more or less convex; the first band not extending to base, leaving the latter narrowly flavous, its lower edge strongly dentate, its inner end not touching suture near scutellum but connected with the second band along the sutural margin; this band broader, placed behind the middle, anterior and posterior margins widened into a tooth at middle, apical black edging extended along the suture and narrowly joined on to the preceding band. Body beneath and legs flavous, sides of breast blackish.

Length 6-7 $\mathrm{mm}$.

$H a b$. Kashmir; Mussoorie, 7500 feet.

In the $\delta$ the joints of the antenno are much more elongate than in the ? 
420. Cryptocephalus maleficus, Suffr. Monogr., Linn. Ent. ix, 1854, p. 14.

" Black; elytra dark red with two black transverse bands; the anterior baud interrupted.

"Head finely punctured and wrinkled, central impressed line distinct, narrow ; labrum piceous ; antennæ about half the length of body, third and following joints nearly equal, double the length of second, basal four and basal half of fifth flavous, others black. Thorax entirely impunctate. Scutellum dark brown with darker margins. Elytra narrow posteriorly, epipleural lobes short and broad; surface strongly punctate-striate anteriorly, the punctures diminish gradually but are distinct to apex, interstices broad, feebly convex, transversely finely wrinkled posteriorly; base, posterior balf of lateral margins and apex narrowly black; the basal band extends to the shoulders, narrower than the other band that does not reach the suture nor the base, second band behind the middle extends to the outer margins, the apex beyond it appears as a light transverse spot. Pygidium black, finely punctured; underside and legs black.

"Length $5 \frac{1}{2} \mathrm{~mm}$.

“Hab. Southern India : Nilgiris." (Suffrian.)

\section{Cryptocephalus semidivisus, sp. $n$.}

Beneath black, above and the legs fulvous; head black; thorax with two black spots; elytra with two broad transverse black bands connected at the suture, divided at sides by a narrow flavous stripe, apex of elytra flavous.

ð. Head closely rugosely punctured; eyes closely approximate at top, margined narrowly within with fulvous ; clypeus narrowly triangular, fulvous; labrum flavous; antennæ black, extending to about middle of elytra, basal four joints flavous, third and fourth joints equal, following joints slightly widened. Thorax about one-half broader than long, strongly narrowed anteriorly, sides straight or nearly so, posterior angles produced; surface distinctly and rather closely punctured, the margins narrowly flavous, middle of disc with a transverse short spot on each side. Scutellum broad, black. Elytra slightly narrowed posteriorly, deeply and closely punctate-striate, the interstices costate, suture round the scutellum raised; the two transverse bands broad, not extending to lateral margins nor apex, divided partly at the sides by a narrow flavous stripe that does not extend to the suture. Abdomen narrowly fulvous at sides, finely pubescent ; prosternum very strongly produced anteriorly, the projection deeply hollowed out, fulvous; pygidium black, strongly punctured.

Length $4 \frac{1}{2} \mathrm{~mm}$.

$H a b$. India. 
Allied to $C$. crucipennis, Suffr. in coloration but quite distinct in the deep and strong elytral puncturation and the costate interstices, coloration of the head \&c.

422. Cryptocephalus angulato-fasciatus, Jac. Ann. Mus. Civ. Genova, xxxii, 1892, p. 890.

Black; clypeus, lateral and anterior margins of thorax and tibiæ flavous; elytra flavous, a humeral spot and a transverse band bebind the iniddle angularly widened at the suture, black.

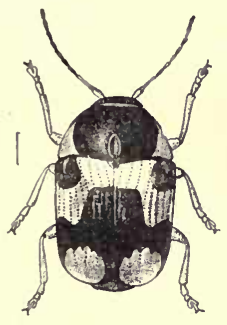

Fig. 87.-Cryptocephalus angulato-fasciatus.

Cylindrical and parallel-sided. Head finely punctured, space between upper portion of eyes and their emargination black, lower portion of face flavous ; labrum piceous; antennæ slender, extending to about the middle of elytra, basal six joints flavous, rest black. Thorax with strongly deflexed sides, posterior angles acutely produced; surface impunctate, very shining; disc black, sides broadly, anterior margin very narrowly, flavous. Scutellum black. Elytra deeply punctate-striate, the transverse band extends upwards along the suture to the middle. Pygidium black; sides of abdominal segments, anterior legs, posterior tibiæ and all the tarsi flavous.

Length $4 \mathrm{~mm}$.

Hab. Burma: Karennee.

423. Cryptocephalus dichotomus, Suffr. Monogr., Linn. Ent. ix, 1854, p. 46.

"Dark red above; two spots on thorax, a transverse band behind the middle of the elytra and the underside black.

- "Head broad and flat with deep central groove, closely and strongly punctured; emargination of eyes acutely triangular; antennæ of male half as long as the body, third joint slightly longer than fourth, twice as long as second, fifth and following joints widened, basal five pale red, rest black. Thorax short and globose, strongly narrowed in front, surface very finely and sparingly punctured; disc with two large black spots that extend to two-thirds the length and touch the hind margin; these spots are sometimes greatly enlarged, geminate and occupy the entire disc, leaving only the lateral margins narrowly red. Scutellum margined with black. Elytra slightly narrower at base than thorax, narrowed posteriorly, shoulders broad and flat; epipleural 
lobes long; disc very strongly punctate-striate, interstices scarcely perceptibly punctured, basal margin narrowly black; the posterior band of about the same width as the basal black margin, extends across both elytra. Prosternum with anterior margin broadly rounded and hollow, posterior angles short.

"Var. With another transverse band at base of elytra that consists of partly united spots and extends from the shoulder to the second row of punctures.

"Length 4-5 mm.

" $H a b$. Southern India.

"Different in shape to $C$. vahli, broadest at posterior margin of thorax, thence strongly narrowed posteriorly, the apex very shortly rounded; in $C$. vahli the greatest width lies across the shoulders and the body is much less narrowed posteriorly." (Suffian.)

424. Cryptocephalus burmanicus, Jac. Ann. Mus. Civ. Genova, xxix, 1889, p. 159.

Flavous; base of head, terminal joints of antennæ and sides of breast black. Thorax with two black spots. Elytra flavous, a transverse sinuate band at base, another

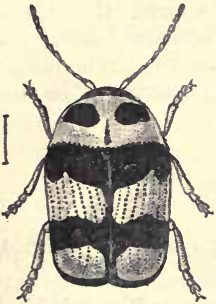

Fig. 88.- Cryptocephalus burmanicus. behind the middle and the apical margin black.

Head finely punctured, somewhat rugose, the base covered by a subquadrate spot and a narrow space in front of eyes black, the eyes themselves broadly and deeply notched; antennæ about balf the length of body, basal four joints testaceous, others black, all joints elongate (with exception of second, which is shorter) and all of nearly equal length. Thorax twice as broad as long, sides straight, narrowed in front, posterior margin finely serrate; surface extremely minutely punctured, flavous, with two black rather large transverse spots placed nearer to the anterior than to the posterior margin, the latter likewise narrowly black. Scutellum trigonal, sparingly punctured, black or pale with black margins. Elytra broad and parallel, moderately strongly and regularly punctate-striate, interstices flat throughout; the basal band occupies about one-fourth of the elytra, is notched in front of the shoulders at its hind margin and extends to the ninth row of punctures; another narrower band behind the middle extends to either margin; the sutural and apical margins of the elytra narrowly black. Legs fulvous; femora with an apical flarous spot, a small black spot on the 
flanks of the thorax beneath. Prosternum subquadrate, fulvous, posterior margin feebly bisinuate.

Length 3-4 mm.

Hab. Burma: Bhamo, Shwègu.

Allied to C. tricinctus, Redt. and C. trifasciatus, Fabr., but with two black bands only instead of three, the first of these placed at, not below the base.

425. Cryptocephalus sexsignatus, Fabr. Syst. Eleuth. ii, 1801, p. 41 ; Oliv. Ent. vi, 1808, p. 785, pl. 4, fig. 46; Suffr. Monogr., Linn. Ent. ix, 1854, p. 53; id.t.c. xiv, 1860, p. 26.

Dark red above, brownish beneath; each elytron with narrow black basal margin and three black spots $(1.2)$.

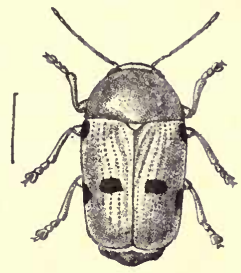

Fig. 89 .

Cryptocephalus sexsignatus.

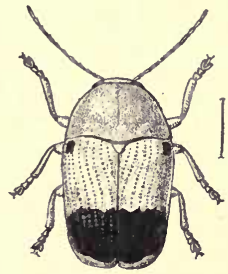

Fig. 90 .

Cryptocephalus sexsignatus, var. $c$.

Large and robust. Head distinctly but not closely punctured, front with short deep depression; labrum flavous, parts of mouth black. Antennæ of male two-thirds the length of the body, third and fourth joints each three times as long as the second, fifth to seventh strongly, terminal joints slightly, widened; basal joints flavous or red, shining, rest finely yellow pubescent. Thorax short, sides narrowly margined, narrowed in front, surface with shallow depressions at sides in front of scutellum, basal margin narrowly black, disc sometines with two black spots. Scutellum red with darker margins, sparingly punctured. Elytra with strongly developed lateral epipleuræ, the punctures coarse at base, finer towards apex, interstices rather convex at sides, finely transversely wrinkled; a black spot on shoulders, two immediately behind the middle, the inner larger one on third interstice, the other rather lower on the eighth interstice. Pygidium finely punctured, carinate; prosternum strongly produced in front, posterior angles broadly triangular.

Var. $a$. Elytral humeral spot widened into a transverse band, posterior spots greatly enlarged, more or less separated. band.

Var. $b$. Like var. $a$, but the posterior spots joined in a similar

voL. I. 
Var. c. Humeral spot as in type; posterior band very broad continued posteriorly along suture, sometimes also extending upwards.

Var. $d$. Entire posterior half of elytra black.

Length 5-8 mm.

$H a b$. Generally distributed throughout India and Ceylon.

The elytral spots vary in number but typically there are three.

426. Cryptocephalus bissexsignatus, Suffr. Monogr., Linn. Ent. ix, 1854, p. 56.

. Dark red; thorax and elytra each with four black spots (2.2).

Head finely and sparingly punctured, the interstices clothed with very short pubescence, middle of forehead and margins of clypeus darker; antennæ pale fulvous, half the length of the body, third and fourth joints equal, each about two and a half times longer than the second, following joints (the seventh especially) widened. Thorax short, narrowed in front, sides rounded at middle, depressed at base in front of scutellum, scarcely perceptibly punctured; sides pale yellowish, middle with

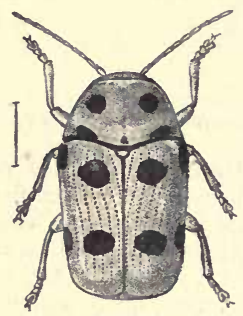

Fig. 91.-Cryptocephalus bissexsignatus.

two black spots and two others below the first spots. Scutellum fulvous margined with black. Flytra with elongate shoulders, epipleural lobes long; surface strongly punctate-striate, finer near apex, interstices flat, finely wrinkled anteriorly, very sparingly punctured; the extreme basal margin, a spot on the shoulders, an inner and slightly lower spot, and two behind the middle below the anterior spots, black, the outer spot of the latter two larger than the humeral spot. Pygidium black, broadly margined with flavous. Underside closely somewhat finely rugosely punctured, pubescent; middle of breast and of metasternum yellow, rest black; abdomen yellow, a spot on each side of first abdominal segment and a transverse band at middle of each of the following segments black. 
Length 7-8 mm.

Hab. Sikhim: Mungphu; Assam; Burma: Bhamo.

Suffrian described this species from a single female specimen. I have both sexes before me: the male is as usual smaller, and instead of four thoracic spots has only two, the elytra also have the inner spot of the second row wanting. In some specimens all the spots are present in both sexes. The form with only three spots on each elytron resembles $C$. sexsignatus, Fabr., but in this species the thoracic spots are always absent and the underside and pygidium are not marked with black. Characteristic of the present species is the finely and closely punctured and pubescent head, with its deep longitudinal depression and more or less black spots.

4.27. Cryptocephalus indicus, Suffr. Monogr., Linn. Ent. ix, 1854, p. 58 .

Fulvous; head, thorax and elytra more or less spotted, generally with three or four small spots, the spots sometimes confluent.

Closely allied to $C$. sexsignatus, Fabr. and $C$. bissexsignatus, Suffr. and as variable, but separated

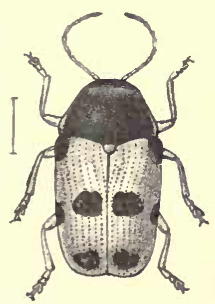

Fig. 92.

Cryptocephalus indicus. from the latter species by the difference in position of the elytral spots, and from either by the more strongly rugose, almost costate elytral interstices at the sides; the antennæ are more elongate and more slender and the posterior angles of the prosternum more strongly pointed. The elytra are strongly and regularly punctured, feebly so behind the middle of the inner disc. Body beneath either fulvous or more or less black; legs always fulvous, the posterior femora often with a black spot.

The following varieties are known :-

Var. a. Entire upper surface unicolorous fulvous.

Var. $b$. Elytra with four black marks behind the middle; thorax with two transverse ill-defined black spots at middle.

Var. c. Elytra with four black spots (1.2.1), i.e. one on shoulders and one near apex in addition to the two spots as in var. $b$.

Var. $d$. The two spots near suture joined into a transverse band; the thoracic spots likewise obliquely connected.

Var. e. Thorax and posterior half of elytra black.

Length $\overline{5}-8 \mathrm{~mm}$.

$H a b$. Southern India ; Bombay. 
428. Cryptocephalus nilgiriensis, Jac. Ann. Soc. Ent. Belg. xlvii, 1903 , p. 90.

9. Fulvous; thorax with two large central and two small lateral spots; elytra with two large black spots at base and two others behind the middle, the latter sometimes connected; beneath black and flavous.

Head black, closely and strongly punctured, subrugose; the

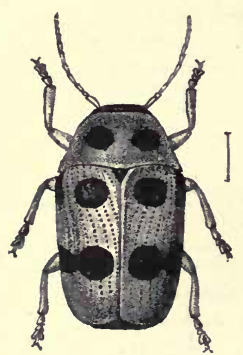

Fig. 93. area surrounding the eyes more or less flavous; clypeus fulvous; eyes broadly emarginate; antennæ rather short, fulvous, third and fourth joints equal, following joints more elongate. Thorax more than twice as broad as long, strongly narrowed anteriorly, sides nearly straight with very narrow reflexed margins; surface fulvous with some minute punctures, the margins flavous; middle of disc with two large black spots, sometimes joined anteriorly, another smaller spot on each side. Scutellum black. Elytra deeply punctate-striate, the puncturation gradually diminishing towards apex, interCryptocephalus nilgiriensis. stices strongly costate at sides, flat and impunctate on inner disc; an elongate black spot on the shoulders, a subquadrate one immediately below base near scutellum and two others behind the middle, the latter sometimes forming a transverse band. Pygidium black, margined with flavous at apex; legs fulvous; breast and abdomen more or less black; metasternum and prosternum sometimes flavous ; latter subquadrate, anterior margin moderately produced, rounded and hollow, posterior slightly emarginate.

Length $6 \mathrm{~mm}$.

$H a b$. Nilgiris.

Allied to $C$. bissexsignatus, Suffr. and more nearly to $C$. indicus, Suffr. on account of the raised lateral elytral interstices, but from both it is distinguished by the four-spotted thorax, the spots of which are placed transversely, by the position of the spots placed on the elytra and by the impubescent head.

429. Cryptocephalus leopardus, Jac. Ann. Soc. Ent. Belg. xlvii, 1903, p. 91.

Fulvous ; apical joints of antennæ, base of head and abdomen, black; thorax with two, each elytron with four black spots (1.2.1).

Head very finely and closely punctured and finely pubescent, the surroundings of the eyes, anterior edge of clypeus and labrum fulvous ; antennæ long and slender, basal four joints and part of 
fifth fulvous, rest black, all very elongate, extending beyond middle of elytra. Thorax nearly twice as broad as long, strongly narrowed anteriorly, surface entirely impunctate, fulvous; the base with two elongate

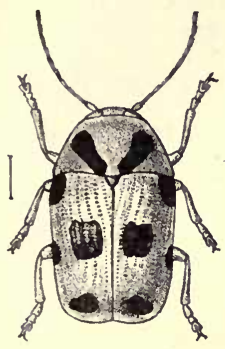

Fig. 94 .

Cryptocephalus leopardus. oblique black spots which diverge at apex. Scutellum rather narrowly triangular, fulvous margined with black. Elytra elongate subcylindrical, moderately strongly punctate - striate, the shoulders without punctures, the three or four outer interstices longitudinally costate; a black humeral spot, two others placed transversely at middle (one below the humeral spot, the other near suture). and a fourth near suture and apex, this last spot smaller than the others. Breast and legs fulvous, sides of former black; tarsi fuscous. Prosternum deeply bilobed at posterior margin, pointedly produced anteriorly.

\section{Length $5 \mathrm{~mm}$.}

Hab. Southern Bombay: Belgaum (Coll. Jacoby).

Differs from any of its congeners in the position of the elytral spots, finely pubescent and spotted head, and shape of prosternum.

430. Cryptocephalus divisus, Jac. Ann. Soc. Ent. Belg. xlvii, 1903, p. 92.

․ Testaceous ; thorax with two, elytra with four, black spots (2.2); scutellum and margins of elytra also black.

Head finely punctured, a small black spot at base of antennæ; eyes widely separated, broadly angularly notched; clypeus semicircularly divided from face; antennæ rather short, basal joint flavous, the others obscure fulvous, third and fourth equal, following joints slightly widened. Thorax twice as broad as long, strongly obliquely narrowed in front, sides feebly rounded; surface impunctate, testaceous, extreme margins black; disc with two well-separated subquadrate black spots at middle. Scutellum trigonal, impunctate. Elytra short and broad, slightly narrowed towards apex, base without depression; surface rather strongly and regularly punctate-striate, interstices slightly convex at sides; of the four black spots one is placed on the shoulders, one near the scutellum immediately below base, and the others transversely near apex, these latter are slightly oblong in shape; of the basal spots the humeral one is elongate and the inner one rounded; the elytral epipleuræ are only very feebly produced at the shoulders. Pygidium, entire underside, and legs testaceous.

Length $4 \mathrm{~mm}$.

$H a b$. Nilgiris. 
It is probable that this species is only the female of $C$. angustomarginatus, Jac., as I cannot find structural differences; but without more specimens for comparison it is impossible to be certain : the present insect, however, is larger, only the extreme elytral margins are black and the tarsi are fulvous.

431. Cryptocephalus suillus, Suffr. Monogr., Linn. Ent. xiv, 1860, p. 14.

Cryptocephalus carneobifasciatus, Motsch. Bull. Mosc. 1866, p. 411. Cryptocephalus nagpurensis, Duviv. Ann. Soc. Ent. Belg. xхxri, 1892 , p. 400.

Beneath flavous, above bright fulvous; thorax with two black spots on anterior margin and a black edging to the posterior margin. Elytra: two spots at base and one behind the middle black edged with brown, also each elytron black at base and black at base of its epipleuron.

Head rather strongly longitudinally grooved at vertex and studded with some fine punctures; clypeus more finely punctured; antennæ fulvous, extending below middle of elytra in male, third joint one and a half times longer than the second and subequal to the fourth joint. Thorax subglobular anteriorly, nearly twice as broad as long, impunctate, very shining, the spots subtriangular. Scutellum smooth, margined with black. Elytra slightly narrowed posteriorly, punctate-striate, the puncturation partly obsolete at apex, interstices with a row of very fine punctures, sides impressed; scutellar region raised, bright fulvous; the spots near scutellum and on the shoulders rounded, the posterior spot transverse in shape, placed near suture. Beneath punctured, finely pubescent; metasternum reddish; anterior margin of prosternum raised and angulate. -9 . Larger, antennæ shorter.

Length, ơ $3 \frac{1}{2}$, ㅇ $4 \frac{1}{4} \mathrm{~mm}$.

Hab. Bengal: Mandar; Konbir; Surat (Calcutta Mus.). Ceylon.

The transverse elytral bands in this species may be dark red or more or less black or black with reddish edges. The type of C. nagpurensis, Duv., which I was enabled to examine, differs in no way from the form described by Suffrian in which the thoracic spots are absent.

432. Cryptocephalus faustulus, Suffi: Monogr., Linn. Ent. ix, 1854, p. 83.

"Obscure fulvous; thorax with four obscure brownish spots; elytra with five black spots $(2.2 .1)$.

"Head with feeble central groove; clypeus not separated, closely punctured; antennæ with the third joint twice, the fourth three times as long as the second, terminal joints moderately 
widened, the last six black, basal joints flavous. Thorax strongly narrowed in front, posterior margin strongly oblique at sides, median lobe short and truncate, preceded by a curved transverse depression; surface distinctly punctured, especially at the sides, two elongate brownish spots at middle and one shorter spot on the sides, all these obscure and large. Scutelluin elongately triangular, with a few fine punctures, margins brown. Elytra strongly punctate-striate, distinct to apex, interstices broad and flat, finely transversely wrinkled and opaque, with a few solitary punctures anteriorly, an elongate spot on the shoulders and the basal margin black; each elytron with five more obscure spots, first two before, second pair behind the middle, fifth (very obsolete) near apex. Pygidium whitish pubescent, obscure flavous; breast at sides darker, finely punctured, closely so at sides; legs short and robust; femora thick, brownish at middle, as are also the tibiæ. Prosternum nearly truncate posteriorly, with short posterior angles." (Suffirian.)

Length $3 \mathrm{~mm}$.

Hab. " East India."

In the diagnosis of this species Suffrian speaks of five elytral spots only, in the description he gives six, but says that the anterior outer spot nearly joins the humeral one. No particular locality is given.

433. Cryptocephalus analis, Oliv. Ent. vi, 1808, p. 786, pl. 4, fig. 47 ; Suffr. Monogr., Linn. Ent. ix, 1854, p. 67.

Dark red; thorax with two, elytra with three, black spots (2.1), those at base often joined; middle of pygidium and of abdomen black.

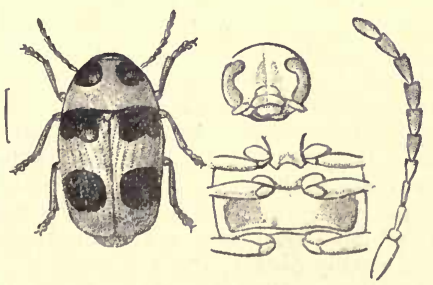

Fig. 95.-Cryptocephalus analis, var. $c$.

Head finely but distinctly punctured, depressed at bases of antennæ; these scarcely longer than half the body in both sexes, third and fourth joints equal, elongate, fifth and following joints widened, basal joints fulvous, rest black. Thorax almost impunctate, generally with two spots near middle. Scutellum 
margined with black. Elytra not deeply punctate-striate, the punctures still finer posteriorly but visible, interstices flat, transversely wrinkled at middle, opaque near apex, the markings variable in size. Pygidium generally with an obscure brown marginal spot and a central black spot at base; prosternum broadly produced at middle of anterior margin.

Var. a. Thorax without spots; elytra with three small black dots (2.1), one on shoulders, one obliquely inwards between third and fourth row of punctures and the third behind the middle, midway between first and second spot ( $C$. analis, Oliv.).

Var. $b$. Thorax with two transverse black spets, placed widely apart.

Var.c. Thorax with two large transverse kidney-shaped patches; elytra with a transverse band at base and a large transverse spot behind the middle black.

Length 5-7 mm.

$H a b$. Bengal ; Nilgiris ; Coromandel ; Tranquebar.

In well-marked specimens the sides and last segment of the abdomen are flavous, middle portion black, and the pygidium with a black spot at middle of base.

434. Cryptocephalus quadratus, Suffr. Monogr., Linn. Ent. ix, 1854, p. 66 ; id.t.c. xiv, 1860, p. 32.

" $q$. Pale fulvous; head with three, thorax and elytra with two black spots; beneath black; abdomen margined with red.

"Head with short central deep groove at vertex, closely and strongly punctured, as is also the clypeus; a broad frontal and a small round spot at base of each antenna black; the latter pale fulvous, scarcely balf the length of the body, distinctly widened terminally from beyond the fifth joint. Thorax remotely but coarsely punctured, margins and a central line pale, edge of posterior margin and two widely separated spots at middle black. Scutellum triangularly elongate, black and shiuing. Elytra raised round scutellum, epiplenral lobes short but distinct; surface regularly punctate-striate, coarse anteriorly, intermediate rows finer at middle, interstices slightly raised, finely wrinkled, less shining than thorax, basal and sutural margins narrowly black; the spots large, transverse, the basal spot near margin obliquely placed towards suture, equally distant from either margin, posterior spot behind the middle, nearly as long as broad between second and eighth rows of punctures. Pygidium black, finely silvery pubescent margined with fulvous. Prosternum, middle of first abdominal segment and margins at sides yellowish-red; anterior edge of prosternum broadly produced, hollow.

"Length $4 \frac{1}{2} \mathrm{~mm}$.

"H\&b. Southern India.

"Closely resembles $C$. cinalis, Oliv., but smaller and with entirely different elytral sculpturing." (Suffrian.) 


\section{Cryptocephalus oppositus, sp. $n$.}

Fulvous; terminal joints of antennæ darker ; thorax with two, elytra with three, black spots.

Head remotely but distinctly punctured; clypeus strongly pointed at angles; antennæ robust, basal five joints fulvous, rest fuscous, fifth and following joints somewhat triangularly widened. Thorax subglobular, narrowed anteriorly, extreme basal margin black, finely toothed, disc with two black spots rather widely separated on the middle; scutellum raised, short, base with a small fovea. Elytra slightly narrowed posteriorly, the puncturation fine and regular; a humeral spot, another near scutellum larger, a third near apex between fifth and eighth rows of punctures, of round shape, black, all these spots surrounded by a paler coloured ring. Body beneath and legs rather paler than the ground-colour above. Prosternum with posterior angles strongly pointed.

$V$ ar. Elytral basal spots nearly confluent, all of them larger; a stripe at the sides of the breast and the middle of the abdominal segments black.

Length $5 \mathrm{~mm}$.

Hab. N.W. Himalayas: Kulu (Coll. Brit. Mus.).

Allied to C.herbsti and C. pulvillatus, but without any sutural or marginal black stripes and the thorax entirely impunctate.

436. Cryptocephalus kandyensis, Weise, Deut. ent. Zeit. 1903, p. 31.

Reddish-brown ; antennæ (base excepted), two spots on thorax, three on elytra (2.1) black margined with flavous; sides of thorax and breast, abdomen and pygidium flavous; the pygidium with two black spots; first abdoninal segment at sides and last segment at middle black.

Head punctured on the middle; thorax finely and less densely punctate, interstices very minutely so; antennæ with the last seven joints widened, black. Thorax with the spots widely separated, placed transversely on the middle. Elytra moderately strongly puuctate-striate, puncturation absent towards apex; of the spots on the elytra, two are placed at the base, the inner one round, nearer to base than to suture or to outer spot, the outer one on the humeral callus, elongate subquadrate, scarcely twice as long as broad, third spot placed behind the middle, slightly larger than the others, transversely ovate.

$\delta$. Tibiæ, the intermediate especially, and the anterior tarsi strongly widened near apex; last abdominal segment with a wide shallow fovea.

Length $5 \mathrm{inm}$.

$H a b$. Ceylon: Kandy.

Allied to $C$. herbsti, Suffr., but different in coloration. 
437. Cryptocephalus laterimaculatus, Duviv. Ann. Soc. Ent. Belg. xxxvi, 1892, p. 403.

" Beneath black; prosternum, middle of meso-and metasternum, first abdominal segment and apex of ventral segment, fulvous; legs dark brown. Above ferruginous; thorax with two spots and the basal margin black. Elytra with basal margin and a subquadrate spot attached to lateral margins black.

" Head finely pubescent, densely and rather deeply punctured; sides of clypeus and the labrum testaceous; palpi fulvous; antennæ slender, black, basal four joints fulvous, apical joint extending to middle of elytra, basal joint large, third nearly as long as the first, following joints slightly longer, feebly dilated. Thorax narrowed anteriorly, moderately convex in front, very superficially punctured, punctures only visible under a very strong lens, sides with a deep groove prolonged to base, latter narrowly black, the spots placed transversely at an equal distance from anterior and posterior margins. Scutellum smooth, margined with black. Elytra slightly narrowed posteriorly, moderately convex, base scarcely raised round scutellum, very feebly depressed below the shoulders, punctate-striate, punctures obsolete near apex, interstices flat at disc, convex at sides, impressed with a single row of fine punctures; the marginal spot placed at the middle extending inwards to last row of punctures, humeral callus darker brown; epipleural lobe rather pronounced. Beneath densely punctured and pubescent. Prosternum strongly produced anteriorly and triangularly pointed. Pygidium black, densely pubescent."

"Length $4 \frac{1}{2} \mathrm{~mm}$.

"Hab. Bengal : Konbir." (Duvivier.)

\section{Cryptocephalus stigmatipennis, sp. n.}

Pale flavous; extreme basal margin of thorax and two spots on dise of latter black; elytra with two black spots at base and one close to suture.

Head with a short central groove at middle of vertex; eyes closely approximate above, intraocular space with a few fine punctures; clypeus deeply emarginate in front, the sides narrowly produced; antennæ flavous, short, extending to base of elytra, third and fourth joints equal, terminal joints slightly thickened. Thorax short and strongly transverse, entirely impunctate, the spots large and round, placed each side near niddle. Scutellum triangular, apex pointed. Elytra narrowed posteriorly, strongly punctate-striate; the basal spots elongate, one at shoulder, the other near scutellum, both extending to basal margin, the third near apex, between third and ninth row. Prosternum with anterior margin produced at the middle, posterior margin straight, not produced at the angles; base of prosternum black.

Length $3 \frac{1}{2} \mathrm{~mm}$.

Hab. Burma (Coll. Brit. Mus.). 
The closely approximate eyes at top of vertex, the pale flavous colour of upper and under sides, and the shape of the basal elytral spots and their position at the basal margin, also the position of the third spot near the apex, distinguish this species from others that have the same number of spots.

\section{Cryptocephalus bowringi, sp. n.}

Pale fulvous; terminal joints of antennæ and breast fuscous; elytra flavous, extreme basal margin and three spots placed in a triangle on each elytron black.

ㅇ․ Head sparingly but rather strongly punctured, feebly transversely depressed at middle; clypeus scarcely separated from face; antennæ only extending to base of elytra, basal five joints flavous, rest black, all very slender, third and following joints nearly equal. Thorax less subglobular than usual, strongly widened at middle, lateral margins quite straight, posterior angles pointed, only slightly produced; disc entirely impunctate. Scutellum broadly trigonal, flarous, nargined with black. Elytra broad, short aud robust, strongly punctate-striate, interstices finely and sparingly punctured; a black humeral spot, another close to margin near apex, a third between the others near suture between third and fifth row of punctures at middle or somewhat below it.

Length $6 \mathrm{~mm}$.

Hab. India (Bovring). (Coll. Brit. Mus.)

The position of the elytral spots differs from that of any other Indian species and the interstices are finely punctured; the general shape is broad and robust.

Male unknown.

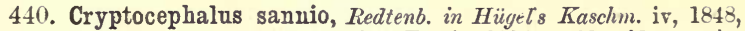
p. 561 ; Suffr. Monogr., Linn. Ent. ix, 1854, p. 63 ; id. t. c. xiv, 1860, p. 31 .

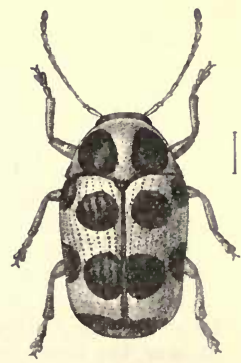

Fig. 96.

Cryptocephalus sannio.

"Flavous; two spots or bands on thorax, five on elytra (2.2.1), and the underside black.

"Head finely and remotely punctured, black; clypeus obsoletely separated from face, deflexed anteriorly; the sides and a triangular patch at middle flavous; antennæ with the basal joints flavous, rest, in the only specimen available for examination, wanting. Thorax of usual shape, impunctate, anterior and posterior margin and two large semicircular spots nearly touching base black, these spots extend nearly to the anterior margin; scutellum black. 
Elytra with strongly marked basal epipleuræ, regularly and moderately strongly punctate-striate, finer from the apical third to apex, interstices feebly convex, margins narrowly black; each elytron with five large black spots placed as in $C$. dodecaspilus but all larger, the outer spots touch the margins, the inner spots near suture are often joined to the outer ones and form a large transverse patch. Pygidium black, margins flavous. Abdomen with first segment at middle and margin of last narrowly flavous. Prosternum produced in front." (Suffrian.)

Length $4 \frac{1}{2} \mathrm{~mm}$.

$H a b$. Kashmir.

441. Cryptocephalus dodecaspilus, Suffr. Monogr., Linn. Ent. ix, 1854, p. 61.

Cryptocephalus triangularis, Hope, in Gray's Zool. Misc. 1831, p. 30.

Flavous; two spots on thorax, five on elytra (2.2.1), and the underside black; abdomen margined with flavous.

Head flat, forehead with shallow longitudinal groove, a few fine punctures near eyes only; clypeus not deflexed in front; vertex, a small spot at base of antennæ and the emargination of the eyes

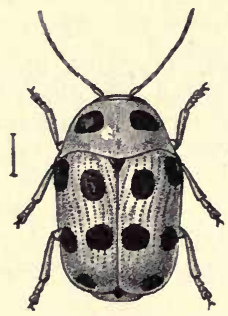

Fig. 97.-Cryptocephalus dodecaspilus.

in $q$ black; antennæ longer than half the body, third and following four joints gradually elongate, the rest distinctly widened, appendage of terminal joint long, not much pointed, basal five joints flavous, rest black. Thorax strongly convex, much narrowed in front, posterior margin serrate; surface inıpunctate, posterior edge narrowly black, two large transverse spots at middle, their posterior margins projecting outwards. Scutellum black. Elytra very slightly narrowed posteriorly, epipleural lobes indistinct; surface strongly punctate-striate, interstices feebly raised, transversely wrinkled from below scutellum, margins, except at base, black; four large black spots placed subquadrately at base, the inner spot near the scutellun placed a little below the latter, the other two 
behind the middle, fifth at the apical angle. Pygidium black at base, yellow at apex; prosternum, sides of breast, middle of first abdominal segment and the sides of the whole abdomen flavous; legs entirely flavous. Prosternum strongly produced anteriorly, hollowed out, posterior angles acutely toothed.

Length 4-41 $\mathrm{mm}$.

Hab. N.W. Himalayas : Mussoorie; Tibet.

It is very doubtful whether this species is anything else but a variety of $C$. sannio, Redt. The differences pointed out by Suffrian are not constant, as I have specimens before me which may be referred to either species; one specimen from Kashmir agrees entirely with $C$. sannio except in having entirely black underside and legs, which are supposed to be peculiar to the present species, while intermediate forms are not uncommon. In a curiously marked specimen from Chamba, in my collection, the thorax is black with the margins and a middle line yellow; the elytra are likewise black but have two narrow transverse yellow bands, indicating the limits of the spots in the normally coloured form. Hope's type in the Brit. Mus. does not differ from Suffrian's description to justify a separation, nevertheless Hope's description is useless, and that of Suffrian's together with his specific name must stand.

As I am in doubt, I have for the present accepted Suffrian's species as distinct from C. sannio, Redtenb.

\section{Cryptocephalus subgeminatus, sp. $n$.}

ㅇ. Black; basal joints of antennæ fulvous; thorax reddishfulvous, lateral margins and a central spot black; elytra coloured like the thorax, with a small humeral postmedian spot and sutural margins black.

Elongate, parallel-sided. Head black, closely punctured, irregularly impressed; a narrow flavous spot at inner margin of eyes, the latter broadly but not deeply emarginate ; antennæ extending to middle of elytra, black, basal four joints fulvous, first joint black above, third and fourth equal, following joints more elongate. Thorax more than twice as broad as long, sides rather broadly margined, rounded, the margins black; surface extremely closely and rather finely punctured, interstices still more minutelv punctured, middle with a small black spot. Scutellum black, elongate, subquadrate, broadly truncate at apex, sparingly punctured, nonfoveolate. Elytra scarcely lobed at sides, closely and irregularly geminate punctate-striate, interstices near basal portion finely wrinkled, slightly convex at apex. Beneath and legs black, latter elongate. Prosternum longer than broad, not produced anteriorly, posterior margin truncate.

Length $7 \mathrm{~mm}$.

Hab. Bengal: Konbir (Coll. Belg. Mus.). 
I know of no other similarly sculptured or coloured Cryptocephatus from our region. The second elytral spot is placed just behind the middle, nearer to the margin than to the suture and below the humeral spot, but slightly more inwards.

Male unknown.

\section{Cryptocephalus dohertyi, sp. n.}

Head and body beneath flavous; terminal joints of antennæ black; above and the legs fulvous; each elytron with a humeral and a subapical black spot.

Head strongly and closely punctured, an obscure spot at vertex and above base of antennæ fulvous ; antennæ rather robust, basal

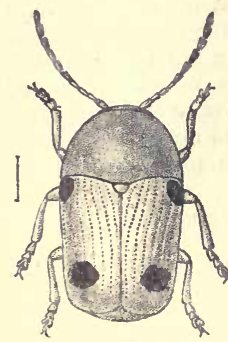

Fig. 98. five joints fulvous, rest black, second joint extremely small, third and fourth equal, intermediate joints slightly wideried, pubescent. Thorax subglobular, lateral margins nearly straight, narrowed in front, posterior angles acute; surface impunctate, extreme basal margin black. Scutellum fulvous, basal margin black, with a small fovea. Elytra very regularly and distinctly punctatestriate, the punctures only slightly finer at apex, interstices flat and impunctate; the shoulders with a black spot, another spot near apex between third and seventh rows of punctures; fifth and sixth rows of the Cryptocephalus dohertyi. punctures, not counting the subsutural row, shorter than the others and joined at the ends. Pygidium flavons, finely rugose. Prosternum subquadrate, posterior border deeply emarginate. Last abdominal segment of male with a small and round, that of female with a deep and elongate, fovea, that occupies the entire segment at middle.

Length 5-6 mm.

Hab. Burma: Ruby Mines (Coll. Brit. Mus.).

The position of the posterior spot lower down than in the allied species is a good distinction.

\section{Cryptocephalus vahli, Fabr. Ent. Syst. Suppl. 1798, p. 108.} Cryptocephalus parasiticus, Suffr. Monogr., Linn. Ent. ix, 1854, p. 42 ; id. t. c. xiv, 1860 , p. 20.

Cryptocephalus mephistopheles, Duviv. Bull. Soc. Ent. Belg. xxxv, 1891 , p. xxxvi.

Cryptocephalus piceitarsis, Jac. Ann. Soc. Ent. Belg. xlvii, 1903, p. 90 .

Cryptocephalus vahli, var. parasiticus, Weise, Deuts. ent. Zeit. 1903, p. 30.

Reddish-fulvous, elytral epipleuræ below shoulders flavous; 
thorax and elytra more or less spotted with black or without spots, or elytra black with red band near iniddle.

Head finely and remotelv punctured; a small spot at base of antennæ black; antennæ slender and short, third and following

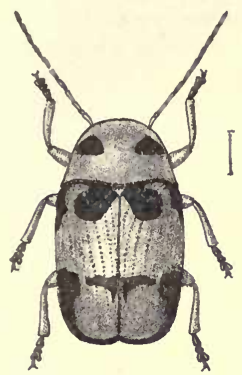

Fig. 99.-Cryptocephalus vahli, var. joints nearly equal, not much longer than the second, outer joints slightly widened, basal joints flavous, terminal joints slightly darker. Thorax about twice as broad as long, very minutely and remotely punctured, fulvous, with or without tivo black spots which sometimes assume an elongate shape and extend to the base. Scutellum pale, margined with black. Elytra rather broad, slightly narrowed posteriorly, moderately strongly punctured, the puncturation much finer posteriorly and nearly obsolete at apex, interstices finely punctured and slightly wrinkled here and there. Body beneath Havous, with more or less dark tarsi. Prosternum produced anteriorly, posterior margin with acutely produced angles.

One of the most variable of Cryptocephati, of which scarcely two specimens are the same in coloration. The following are the principal forms to be met with (the lighter coloured specimens are the females, the darker or more spotted ones the males, the latter have the apex of tibia and the tarsi black):-

Var. $a$. Above entirely fulvous; antennæ and tarsi of similar coloration.

Var. $b$. Elytra with three black spots (2.1), one on the humeral callus, the others behind the middle, the outer one double as large as inner spot; thorax unspotted.

Var. $c$. The elytral posterior spots in shape of a transverse band, and surrounding the apex, or the latter sometimes entirely covered by the band.

Var. $d$. The humeral spot similarly enlarged, but not extending to scutellum.

Var. e. Elytra black, with a narrow sinuate red transverse band before the middle, thorax with two large spots.

Var. $f$. The red transverse band only indicated near suture and margins.

Var. g. Elytra entirely black, with or without paler margins.

In all these varieties the scutellum remains red and the epipleuræa at base flavous.

Var. mephistopheles, Duviv. Fulvous; thorax with two black spots; elytra black, the sutural and lateral margins narrowly fulvous. This seems to be nothing but one of the numerous 
varieties of $C$. vahli, Fabr., and mentioned by this author in the description of the species. There is notbing in that of Duvivier which points to a specific distinction.

Var. piceitarsis, Jac. I find, on further examination, that this form also cannot be separated from $C$. vahli, Fabr., of which it forms a unicolorous variety. With the exception of the tarsi, all the upper surface is fulvous, the terminal joints of the antennæ and the tarsi alone being blackish.

Length 3-4 mm.

$H a b$. Generally distributed throughout India and Ceylon.

A common species. There are some forms in which the elytra have four spots, two at base and two at middle, others in which the elytra are black with the apex flavous only, and many other intermediate varieties. One of the latter is figured here.

445. Cryptocephalus colon, Suffr. Monogr., Linn. Ent. ix, 1854, p. 19 ; Baly, Trans. Ent. Soc. 1865̃, p. 69, pl. 2, fig. 1.

Light flavous; terminal joints of antennæ, the margins, two spots on elytra (1.1), and scutellum black.

Broad, posteriorly narrowed. Head very sparingly punctured; antennæ with basal joint elongate, third joint twice as long as second, slightly shorter than fourth,

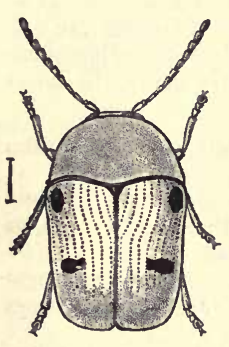

Fig. 100 .

Cryptocephalus colon. following strongly widened, basal joint flavous, following three darker, rest black. Thorax short, sides broadly rounded and narrowed anteriorly, surface very finely and remotely punctured. Elytra narrowed posteriorly, deeply depressed at base but again strorgly raised round scutellum, shoulders feebly convex; surface very finely punctate-striate, the punctures very fine near apex, interstices very finely and sparingly punctured, all margins narrowly black; an anterior black spot on shoulders slightly elongate, a second spot transverse in shape behind the middle between fourth and seventh rows, placed slightly more inwards than the anterior spot. Prosternum with anterior margin strong]y. produced.

Length 4-6 nım.

Hab. Assam; Siam.

\section{Cryptocephalus rajah, sp. $n$.}

Flavous ; antennæ (basal joints excepted) black ; posterior edge of thorax and basal margin of elytra black; the elytra with a humeral and a subapical black spot. 
Head very sparingly punctured, obsoletely longitudinally depressed at middle; clypeus

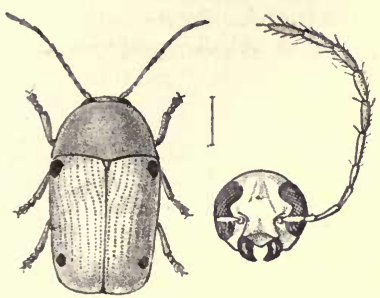

Fig. 101.-Cryptocephalus rajah. separated from face, strongly emarginate anteriorly; antennæ long and slender, basal four joints flavous, third and fourth equal, fifth and following joints slightly widened, terminal joint long and slender. Thorax strongly narrowed anteriorly, sides nearly straight, posterior margin finely serrate, disc entirely impunctate. Scutellum black at base, triangular, with the usual fovea.

Elytra narrowed posteriorly, the suture raised round scutellum; surface very finely punctate-striate, apex impunctate, interstices broad and flat, a deep black round spot on shoulders and another at apex of seventh and eighth rows of punctures. Underside very finely punctured, slightly pubescent. Prosternum with anterior margin strongly produced in front, posterior angles triangularly pointed.

\section{Length $5 \mathrm{~mm}$.} Java.

Hab. Bombay: Belgaum (Coll. Jacoby); Nilgiris (Capt.Downing);

Larger than C. colon, Suffr., the thorax entirely impunctate, the scutellum flavous, black only at base, the elytra without black lateral margins, their surface even more finely punctured and without punctures on interstices. C. tetrastigma, Suffr., seems closely allied, but has the elytra sculptured as in $C$. colon, and has the anterior margin of the prosternum slightly produced.

\section{Cryptocephalus ducalis, sp. $n$.}

Obscure dark fulvous; thorax with an obsolete black band near base. Elytra with one humeral and one subapical black sput.

‥ Large and robust. Head with two obsolete transverse depressions, strongly punctured, space in front of eyes and between antennæ stained with black; clypeus separated from the face, deeply emarginate in front, finely punctured ; antennæ short, fulvous, third and fourth joints equal, fifth and following joints strongly flattened and widened, each not longer than the preceding joint. Thorax extremely convex, almost subglobose, posterior angles produced, margins narrowly black, surface entirely impunctate, the base with a very obsolete transverse black band. Elytra very slightly narrowed posteriorly, the suture raised round scitellum; surface moderately strongly punctatestriate, punctures distinct to apex, intermediate rows shortest, each preceding and following row joined at apex ; epipleural lobes 
broad and well-marked; shoulders with a black spot, another transverse black spot between third and seventh rows of punctures. Underside rather paler, finely punctured. Prosternum strongly produced in front, triangularly so at middle, posterior angles acutely pointed.

Length $7 \mathrm{~mm}$.

Hab. Burma : Paungdé (Coll. Jacoby).

A large species, quite distinct from the preceding forms; dark fulvous in colour; the thorax very strongly convex, the posterior elytral spot placed well inwards; sculpture of head and colour of the antennæ quite different. A single female specimen only is known to me.

448. Cryptocephalus herbsti, Suffr. Monogr., Linn. Ent. ix, 1854, p. 25.

Reddish; elytra with three black spots (2.1), suture black posteriorly.

Short and ovate. Head coarsely but not closely punctured; antennæ rather short, not extending beyond thorax or only slightly so in female; antennæ with third and fourth joints not much longer than the second, six terminal joints strongly widened, black, the others flavous. Thorax closely and moderately strongly punctured. Scutellum flavous, with darker margins. Elytra strongly punctate-striate; interstices flat, finely punctured, partly wrinkled, rather opaque; basal margin and the suture posteriorly narrowly black; spots small, sometimes nearly obsolete, placed as in the allied species. Pygidium pale fulvous; abdomen sometimes brownish with paler margins; legs fulvous, tarsi short and broad. Prosternum produced in front, convex at middle in male.

Length $2 \frac{1}{2} \mathrm{~mm}$.

$H a b$. Bengal; Assam.

I have not seen any specimens like those mentioned by Suffrian; those which I refer to his species are $4 \mathrm{~mm}$. in length, and as they agree in most details $I$ have not much doubt about the correct determination.

449. Cryptocephalus pulvillatus, Suffr. Monogr., Linn. Ent. ix, 1854, p. 24.

The differences pointed out by Suffrian between this species and his $C$. herbsti are so slight that it is impossible to look upon them as more than varietal. Suffrian says that the present insect is intermediate between $C$. guttifer and $C$. herbsti; in size it agrees with the last-named species and also in most of the other characters, except that the elytral spots are rather larger and the posterior spot placed rather more forward. It is impossible to distinguish them from these slight differences, as everything else is similar, and many intermediate specimens occur that could be referred to either species.

The habitat of $C$. pulvillatus is given as the Hinalayas. 
450. Cryptocephalus floriger, Suffr. Monogr., Linu. Ent. ix, 1854, p. 27.

Another form closely related to $C$. herbsti, but, according to Suffrian, differing in the following details:-Larger than the largest specimens of last-named species but not broader, more strongly narrowed posteriorly, colour of elytra paler than that of thorax, puncturation of latter finer and more sparse. Elytra with finer punctures, interstices broader, finely transversely wrinkled anteriorly only, all intermediate punctures and those on interstices more or less obsolete from the middle posteriorly. The niarkings also differ and are as follows:-_-" A spot on shoulders, another farther down and placed obliquely inwards as in C. herbsti but connected with suture by a narrow curved line behind the middle, suture from thence to apex evenly black, at the middle a transverse band extends across suture nearly to the lateral margins; underside and legs as in C. herbsti." (Suffirian.)

Length $3 \mathrm{~mm}$.

$H a b$. India.

Described from a single female. I doubt if it is specifically distinct, possibly only a variety of $C$. herbsti.

451. Cryptocephalus guttifer, Suffr. Monogr., Linn. Ent. ix, 1854 p. 22.

Above flavous, beneath black; thorax with two, elytra with three, black spots $(2.1)$ and a sutural black band; legs flavous.

‥ Head slightly convex, front feebly depressed, sparingly but distinctly punctured; clypeus closely and rugosely punctate;

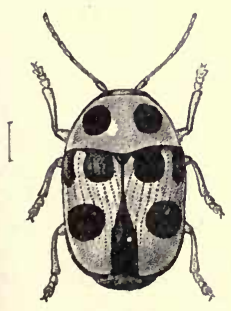

Fig. 102.

Cryptocephalus guttifer. antennæ black, rather shorter than half the length of the body, third and fourth joints scarcely longer than second, fifth and following longer and widened, basal five joints flavous. Thorax very finely and sparsely punctured, posterior margin narrowly black, two large spots at middle, close together. Scutellum pale fulvous, margined with black. Elytra broad anteriorly, narrowed posteriorly, distinctly punctured anteriorly, more finely behind the middle, but the punctures distinct to apex; posterior portion of suture and lateral margins black, that colour widened at the suture into an elliptical band; the three spots large - an elongate spot at shoulders, a round spot: between the subsutural and third rows, and a third spot, rounded or kidney-shaped, behind the middle between third and ninth rows of punctures. Pygidium black; prosternum, 
mesosternum, and middle area of first abdominal segment pale yellowish-red.

Length $5 \mathrm{~mm}$.

$H a b$. Bombay ; Central India : Raipur.

According to Suffrian this is the largest of the three or four species all similarly marked, but as he described his species from a single female the general size is probably no larger than that of the same sex of the allied forms. I have not seen specimens of his C. guttifer, or of any other species belonging to this section, which agree precisely with the descriptions, and without a large amount of material no certain conclusion can be arrived at as to the specific differences of these closely allied forms, which are all subject to great variation. Not a single specimen before me which may otherwise be referred to $C$. guttifer has the thorax sparingly punctured as Suffrian gives it; on the contrary the puncturation is fine and very close. In spite of the almost too long and detailed description, the author unfortunately makes no mention of the position of the inner elytral basal spot, whether it touches the base or is placed lower.

452. Cryptocephalus senarius, Suffr. Monogr., Linn. Ent. xiv, 1860, p. 22.

Red above; three spots on elytra, sutural margins and underside black.

Head feebly convex, impressed in front of vertex, closely and strongly rugose-punctate; antennæ half the length of body, third and fourth joints equal, fifth slightly longer, terminal joints widened, slightly darker than the others. Thorax large, strongly narrowed in front, posterior margin serrate, surface closely and strongly hut not deeply punctured, base narrowly black. Scutellum triangular, margined with piceous. Elytra narrowed posteriorly, humeral callus broad and flat; epipleural lobes well-marked ; puncturation strong, especially so at base, very feeble near apex; interstices broad, punctured anteriorly, finely wírinkled posteriorly; basal and apical nnargins warrowly black, sutural margins widened posteriorly into a longitudinal band; elytral spots placed as in $C$. herbsti and $C$. guttifer. Pygidium finely punctured, black; coxæ and legs red. Anterior margin of prosternuin feebly produced. Last abdominal segment of male simple, of female with deep fovea.

Var. $a$. Elytra with a transverse band at base instead of spots, third spot present.

Var. $b$. Posterior portion of elytra with another band.

Var. $c$. Both bands more or less connected by longitudinal stripes.

Var. $d$. Elytra black, their epipleural lobes and the suture anteriorly flavous.

Length 3-5 n:m.

$H a b$. India : Igatpuri; Surat; Kasara. 
453. Cryptocephalus obconicus, Suffr. Monogr., Linn. Ent. xiv, 1860, p. 24 .

ㅇ. "Pale flavous with paler margins; head and pygidium spotted with black; elytra with three black spots (2.1); beneath black; sides of breast, margins of abdominal segments, and legs flavous.

"Head finely and closely rugose-punctate, vertex with deep central groove; clypeus feebly separated, flavous as also an edging in front of eyes and their emargination; rest of surface black or yellow with three black spots, a central ovate spot and a spot above base of antennæ; antennæ scarcely half the length of body, third joint not longer than second, following two scarcely longer, terminal six scarcely longer than fifth, feebly widened, basal five yellowish, rest black. Thorax finely but distinctly and anteriorly more closely punctured, margins and a middle line paler, edge of posterior margin black. Scutellum margined with black. Elytra about one-half longer than broad, narrowed posteriorly; epipleural lobes feeble; puncturation moderate, finer posteriorly, the intermediate rows nearly indistinct behind the middle; interstices broad, flat, finely wrinkled; basal and sutural margins narrowly black; two spots at base, the inner the larger, the round onter spot on shoulders, more elongate, the third between third and seventh row of punctures, twice as long as broad, all the spots surrounded by a brownish margin. Pygidium black, margined with flavous. Prosternum strongly produced at middle of anterior margin, posterior angles short, pointed.

"Length $3 \mathrm{~mm}$.

"Hab. Ceylon." (Suffrian.)

Allied to C. sencrives, smaller and narrower, sculpturing much finer, colour paler especially near margins.

\section{Cryptocephalus kashmirensis, sp. n.}

Pale fulvous; breast and abdomen (last segment excepted) black; thorax with two black spots; elytra with entire sutural and posterior lateral margins and three large spots on each elytron (2.1), black.

Head strongly and somewhat sparingly punctured, a small spot at base of antennæ piceous ; antennæ not extending to middle of elytra $\left(\sigma^{*}\right)$, third joint half as long again as the second but distinctly shorter than the fourth, fifth and terminal joints black, the others flavous. Thorax very finely and closely punctured, extreme lateral and basal borders black, basal portion somewhat paler than disc; the latter with two large round black spots, widely separated. Scutellum black. Elytra about half as long again as the thorax, very slightly narrowed posteriorly, strongly punctate-striate, the punctures dark ; the suture from base to apex with a narrow black anteriorly pointed band; an elongate spot on shoulders, a round spot near scutellum immediately below base, between second and fifth row, and auother large round spot behind 
the middle between third and ninth row. Pygidium and last abdominal segment flavous. Prosternum produced at middle of anterior margin, posterior angles short, fulvous; legs fulvous.

Length $4 \mathrm{~mm}$.

Hab. Kashmir ; Punjab ; Khási Hills (Coll. Jacoby).

As this species, of which five specimens are before me of both sexes, differs from any of those described by Suffrian, I must consider it distinct. The differences consist in the black sutural elytral band extending quite to the base, in the large elytral spots, and the flavous pygidium and similarly coloured last abdominal segment; in the female the head has a small black central spot at the vertex; the thoracic spots are sometimes posteriorly pointed, the inner elytral spot near suture is always placed below base. C. obconicus, Suffr. is $3 \mathrm{~mm}$. in length, has a partly black head and pygidium, abdomen black except at sides, and different elytral puncturation, sutural margins very narrowly black, \&c.

\section{Cryptocephalus zonalis, sp. $\mathrm{n}$.}

Head and body beneath more or less black; thorax fulvous with two black spots; elytra fulvous, a transverse band at base, and another at apex, and the extreme sutural margins, black; legs fulvous.

Head rugosely punctured, dark fulvous with two large black spots and a central black band between eyes at vertex, surroundiugs

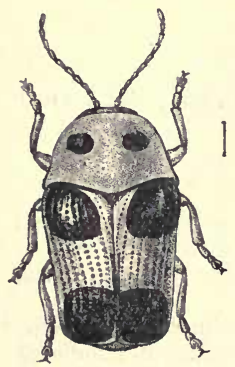

Fig. 103.

Cryptocephalus zonalis. of eyes pale; the latter closely approximate at apex, broadly but not deeply angulateemarginate; clypeus subtriangular; antennæ black, extending beyond middle of elytra, basal four joints fulvous, third and fourth equal, terminal joints gradually widened. Thorax strongly convex, rather short, impunctate, extreme margins tavous, posterior margin black, a black spot at the middle on each side. Scutellum black. Elytra narrowed posteriorly, strongly punctate-striate, the striæ closely placed but the punctures well separated, distinct and scarcely finer at apex, interstices finely wrinkled here and there, the last two convex. Prosternum flavous, longer than broad, anterior margin produced in front.

Length $3 \frac{1}{2}-4 \frac{1}{2} \mathrm{~mm}$.

Hab. Ceylon: Kandy (Colls. Belgian Mus. and Jacoby).

From other transversely banded species the present form is principally distinguished by the black apical band, if large placed at extreme apex, or if smaller not quite extending to it and never to the lateral margins, the transverse band at base touches the basal but does not reach the lateral nor the sutural margins; the suture 
near the scutellum is pale flavous, but the scutellum itself is always black; the female is larger but does not generally differ otherwise; exceptionally the head is black with a flavous border near the eyes. I know no other similarly marked species. I received four specimens from M. Clavareau trom Brussels.

\section{Cryptocephalus darjilingensis, sp. $n$.}

Pale fulvous; antennæ, the basal joints excepted, black ; elytra bright flavous, margins narrowly and three spots on each (2.1) black.

Head with narrow central longitudinal groove at vertex, impunctate, very shining; emargination of eyes shallow and broad; clypeus triangular, impunctate; antennæ with third and fourth joints slender, equal, following joints gradually widened but not shorter, basal four flavous, rest black. Thorax short and transverse, of nearly equal width, only slightly narrowed anteriorly, entirely impunctate. Scutellum triangular, small, fulvous, black at base. Elytra of equal width, subcylindrical, finely punctatestriate, the punctures piceous; interstices broad and flat, impunctate and shiuing, all margins narrowly black; two elongate spots at base touching basal margin, one at shoulders, the other near scutellum, a larger subquadrate spot near apex between third and seventh row of punctures. Prosternum subquadrate, not produced at anterior margin, posterior angles blunt.

Length $2 \mathrm{~mm}$.

Hab. Darjeeling (Coll. Belgian Mus.).

One of the smallest species and sufficiently distinct by its style of coloration, the transverse, scarcely widened thorax and impunctate head. I have only seen a single male specimen kindly sent by $\mathrm{M}$. Clavareau from Brussels.

457. Cryptocephalus decurio, Suffr. Monogr., Linn. Ent. xiv, 1860, p. 27.

Dark red; two spots on thorax and four on elytra (2.2) black, posterior spots obliquely placed.

Size, colour and pattern of elytra similar to those of C. sexsignatus; rather more robust, shorter and more strongly convex, disc of thorax more highly raised; the head with a few fine punctures only, without pubescence; the elytral punctures at middle distinctly stronger; the interstices raised, those below shoulders nearly costate, scarcely a trace of transverse wrinkles; the inner of the posterior elytral spots is placed much more forward and before the middle of the elytra, but slightly less approximate to the suture than to the corresponding spot of first row ; last abdominal segment of female with a large round fovea. Male unknown.

"From C. bissersignatus, the species differs in the markings of 
the thorax and underside and the flattened elytral interstices." (Suffian.)

Length $7 \mathrm{~mm}$.

$H a b$. Ceylon: Colombo.

Suffrian also compares this species with $C$. sexsignatus, of which no variety has been described in which the elytra have four spots instead of three, although such of course may exist.

\section{Cryptocephalus corrosicollis, $\mathrm{sp} . \mathrm{n}$.}

¿. Testaceous; terminal six joints of antennæ black; elytra with extreme sutural margins and a small bumeral spot black.

ㅇ. Head with a central black band; elytra with two spots at base and one behind the middle black.

Head deeply longitudinally grooved at vertex, very finely rugose and punctured ; clypeus triangularly emarginate, finely pubescent; eyes deeply subquadrately emarginate; antennæ rather short and robust, basal five joints testaceous, rest black, first joint thick and short, second very small, third twice as long as second, fourth and following gradually lengthened, scarcely widened. Thorax onehalf as broad again as long, strongly convex, sides rounded anteriorly, not much narrowed in front, surface minutely punctured and eutirely covered with extremely fine transverse wrinkles. Scutellum margined with black at base, the latter foveolate. Elytra narrowed posteriorly, deeply punctate-striate, interstices slightly costate, entirely covered with fine rugosities; epipleural lobes slightly angular. Body beneath very finely pubescent, testaceous, breast slightly fuscous; legs robust. Prosternum strongly produced anteriorly and hollow.

The female differs in having three elytral spots, two elongate at basal margin, closely approximate, and one transverse behind the middle between second and seventh rows of punctures.

Length $2 \frac{1}{2}-3 \mathrm{~mm}$.

$H a b$. India: Pusa.

The peculiar sculpture of the thorax will easily distinguish this species.

459. Cryptocephalus abbreviatulus, Suffr. Monogr., Linn. Ent. ix, $1854, \mathrm{p} .48$.

" $q$. Fulvous; elytra with two spots at base and an abbreviated transverse band behind the middle black.

"Head somewhat closely and distinctly punctured at middle and on lower portion, longitudinally grooved at middle of vertex ; antennæ pale flavous, slender, third and fourth joints equal, sixth and following slightly widened. Thorax strongly convex in front, two oblique depressions in front of scutellum, surface entirely impunctate. Scutellum trigonal, margin piceous. Elytra with single deep punctures at base, gradually finer posteriorly, nearly 
obsolete at apex; interstices feebly convex, finely but distinctly punctured; shoulders with an ovate spot, another larger, triangular spot touching base, near scutellum; posterior band nearly touching lateral margins and slightly curved upwards there, apparently consisting of two united spots. Pygidium finely and closely punctured ; prosternum with anterior inargin produced at middle, posterior angles produced into long points." (Suffirian.)

Lenath $3 \mathrm{~mm}$.

$H a b$. Southern India.

In colour similar to $C$. vahli, but with differently sculptured elytra and long, pointed, posterior angles to the prosternum.

\section{Genus PACHYBRACHYS.}

Pachybrachys, Suffirian, Monogr., Linn. Ent. iii, 1848, p.111; Chapuis, Gen. Coléopt. x, 1874, p. 168.

Type, $P$. hieroglyphicus, Laich., from Europe.

Range. All parts of the globe, principally developed in North and South America.

Cylindrical, only moderately convex. Antennæ filiform, terminal joints very feebly widened. Thorax transverse, sides with a subinarginal fine groove, anterior angles shortly dentate, posterior obtuse ; posterior margin with a narrow acute ridge, which is raised in front of scutellum. Scutellum divided into an anterior subquadrate and a posterior triangular portion. Elytra rather raised at base and round scutellum; epipleuræ invisible from above; surface generally partly punctured in rows, rarely irregularly, with more or less prominent elongate pale costæ or spots, the punctures dark. Prosternum not produced anteriorly for the reception of the parts of the mouth, the disc longitudinally concave, posterior margin produced into a more or less prominent lobe.

The species of this genus can be distinguished from Cryptocephalus proper by the different shape of the thorax and elytra, and the sculpture of the latter; the thorax is much more transverse and less subcylindrical, and its angles are more prominent, not closely approximate to base of elytra. Only two Indian species are known.

460. Pachybrachys rubiginosus, Suffr. Monogr., Linn. Ent. xiv, 1860, p. 64 .

"Dark brown spotted with fulvous; breast piceous; clypeus and legs flavous.

"ㅇ. Head flat, closely punctured, clothed with fine grey pubescence; vertex, central line and a spot at base of antennæ obscure fulvous; clypeus fluvous, smooth and impunctate; eyes very elongate; antennæ half the length of the body, slender, third joint shorter than fourth, fifth and following joints very slightly 
widened, flavous. Thorax nearly twice as broad as long, sides rather strongly rounded at base, from thence nearly straight and slightly obliquely narrowed towards apex; surface deeply but sparsely punctured, punctures partly confluent, forming small smooth yellow tubercles. Scutellum finely punctured, with dark margins. Elytra broad and flat, slightly wider than thorax, extreme basal margin strongly carinate near scutellum; surface closely and irregularly punctured to middle, interstices rugose, rugosities more strungly marked outwards, yellow on a dark ground-colour ; two somewhat feeble costæ between shoulders and suture, another from shoulder to apex; behind the middle more numerous and strongly raised costæ, about nine in number, all flavous. Pygidium finely punctured and pubescent, dark brown margined with flavous. Legs with dark margins to femora and tibiæ, the latter curved.

"Length $5 \mathrm{~mm}$.

“Hab. India." (Suffrian.)

461. Pachybrachys pœcilopterus, Suffr. Monogr., Linn. Ent. xiv, 1860, p. 65.

This species is probably nothing but a darker variety of the preceding one. Suffrian points out that the coloration is darker

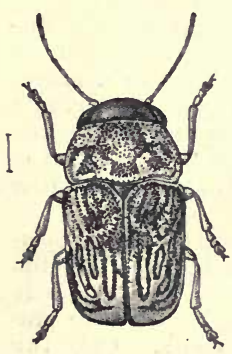

Fig. 104.-Pachybrachys pacilopterus. and that the elytra have a transverse curved flavous band at middle, in shape of a ridge. All this agrees with several specimens before me in the collection of M. Clavareau. There are, however, specimens intermediate, both in coloration and sculpture, which may be referred to either species. In one specimen the elytra are entirely dark brown with a sutural patch below scutellum. The thorax has a lateral band (not mentioned by Suffrian) and another brown spot at middle of base; and in the female (the only sex known to Suffrian) the transverse elytral ridge is very distinct in one specimen. Several smaller individuals from the same locality, which are no doubt the males, are much paler, with the elytral ridge only indicated at the sides, and with the costr at apex uniting in pairs, one costa at suture and one near the margins, long but not extending to apex, with two short costæ between the others, the inner costa is the longest. Breast and legs entirely flavous. Everything else as in $P$. rubiginosus.

Length 4-5 mm.

Hab. Konbir; Southern India (Colls. Clavareau and Jacoby). 


\section{Genus MELIXANTHUS.}

Melixanthus, Suffr. Monogr., Linn. Ent.ix, 1854, p. 8; Chapuis, Gen. Coléopt. x, 1874, p. 175 .

Type, $M$. intermedius, Suffr., from Borneo.

Range. India ; Siam; Borneo; Sumatra.

Short and ovate. Antennæ short, not extending to hind margin of thorax, basal joint slender, club-shaped, second ovate, following three short, terminal six strongly widened, triangular, as broad as long. Scutellum elongate triangular. Legs short and robust. Prosternum one-half as long again as broad, with projecting and hollowed anterior margin.

Intermediate in character between the South American genus Monachus and Cryptocephalus; distinguished from both by the shape of the prosternum and the dilated terminal joints of the antennæ.

462. Melixanthus hians, Suffr. Monogr., Linn. Ent. xiv, 1860, p. 7. Monachus luridus, Motsch. Bull. Mosc. 1866, p. 411.

"Flavous; terminal joints of antennæ black.

"ㅇ․ Head flat, finely rugosely punctured, feebly depressed at vertex; clypeus separated by a narrow groove; labrum and mandibles piceous; eyes not deeply emarginate. Antennæ extending to about base of thorax, second to fifth joints equal, but the third and fourth narrower than the second joint, terminal six strongly widened, club-shaped, the first three joints of these broader than long, last three as broad as long; basal four joints flavous, rest black, studded with single white hairs. Thorax narrowed in front, sparingly and finely but distinctly punctured, anterior and lateral margins and a middle line paler than the rest of the surface. Scutellum longer than broad, with deep fovea at base. Elytra with fine and shallow rows of punctures all surrounded by a darker ring; interstices finely and sparsely punctured, sparingly wrinkled anteriorly, more distinctly and confluently so near apex; basal margin narrowly deep black. Pygidium and body beneath rugosely punctured. Prosternum slightly longer than broad, sparingly rugosely punctured, posterior margin truncate, angles short. Last abdominal segment with a moderately deep fovea.

"Length $2 \frac{1}{2} \mathrm{~mm}$.

"Hab. Ceylon." (Suffrian.)

According to Weise (Deut. ent. Zeit. 1903, p. 29) this species is identical with Monachus luridus, Motschulsky.

463. Melixanthus assamensis, sp. $n$.

Head, part of underside and terminal joints of antennæ black ; thorax fulvous; scutellum black; elytra flavous, all the margins narrowly and a humeral spot black. 
Rather broad and short. Head distinctly punctured between

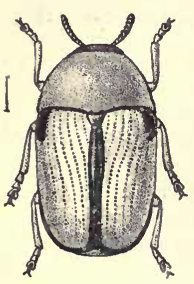

Fig. 105.-Melixanthus assamensis. eyes; clypeus, labrum and palpi flavous; anterınæ extending to middle of thorax in the female, to the base in the male, basal joint flavous, following four dark fulvous, sixth and following joints transversely widened, short. Thorax twice as broad as long, extreme basal margin black, surface extremely finely punctured. Elytra slightly narrowed posteriorly, oblong-ovate, very finely punctate-striate, the humeral spot broadly elongate, the margins narrowly black. Pygidium and last abdominal segment fulvous. Legs short and robust. Prosternum widened posteriorly, flavous, its posterior margin concave.

Length $3 \mathrm{~mm}$.

Hab. Assam: Patkai Mts. (Coll. Brit. Mus.).

\section{Melixanthus humeralis, sp. n.}

Pale flavous; head and terminal joints of antennæ nearly black; elytra with a humeral spot and the margins nearly black.

Narrow and subcylindrical. Head with a few minute punctures at vertex, lower portion more strongly punctured; eyes feebly emarginate at middle; antennæ extending to base of thorax, apical four joints piceous, basal joint elongate, third, fourth, and fifth equal, terminal joints thickened. Thorax about twice as broad as long, sides straight at base, narrowed in front; surface extremely minutely and closely punctured, the punctures only visible under a strong lens. Scutellum black. Elytra very finely punctate-striate at base only, punctures obsolete behind the middle, all the margins very narrowly black, the shoulders with a black spot. Femora robust. Prosternum longer than broad, impunctate, the lateral margins raised.

Length $2 \mathrm{~mm}$.

Hab. Nilgiris. Type in Coll. H. E. Andrewes.

\section{Melixanthus malabarensis, sp. $n$.}

Pale fulvous; head of male black : posterior edge of thorax, suture and breast obscure piceous.

Narrow and subcylindrical. Head finely granulate; antennæ flavous, second and following two joints very small, rest strongly widened. Thorax transverse, narrowed in front, sides but little deflexed; surface very closely and strongly punctured, two oblique 
spots and a central line paler than rest of disc. Scutellum small, triangular, edged with piceous. Elytra strongly punctate-striate, the punctures piceous, interstices closely and very finely punctured. Pygidium closely punctured; legs robust; prosternim elongate, narrowed in front, longitudinally sulcate. In the female the head is entirely flavous.

Length $1 \frac{1}{2} \mathrm{~mm}$.

$H a b$. Malabar.

Probably allied to $\mathrm{Cr}$. atricillus, Suffr., but scarcely typical Cryptocephalus, and better placed in Melixanthus.

\section{Genus MELINOBIUS, nov.}

Type, M. longipes, Jac., from Tenasserim.

Range. Tenasserim.

Elongate, parallel-sided and subcylindrical. Antennæ very long and slender. Thorax subconical, narrowed anteriorly, sides straight, surface with oblique depression on each side near base. Scutellum narrowly elongate. Elytra elongate, punctate-striate. Legs elongate and slender; first joint of posterior tarsi longer than

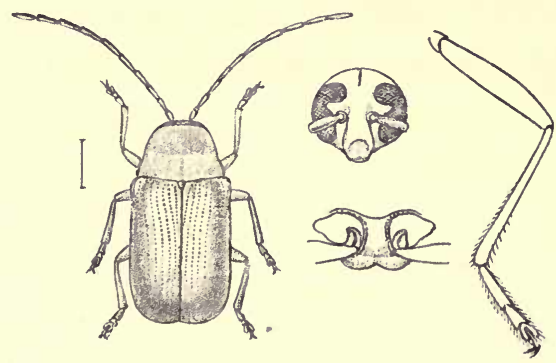

Fig. 106.-Melinobius longipes.

the following joints united, claws simple. Prosternum longer than broad, its posterior margin nearly truncate; mesosternum concaie.

This genus has an entirely different aspect from the rest of the Indian Cryptocephalince. It is more elongate and slender in shape, the legs are also longer than in any other genus, and the claws simple; the whole appearance of the insect recalls some Australian forms and cannot be mistaken for any other Indian form. The length of the metatarsus of the posterior legs is greater than in any genera of the present subfanily. 


\section{Melinobius longipes, sp. $n$.}

Pale flavous; extreme sutural margins and edge of elytral epipleuræ at base black.

Very elongate and subcylindrical. Head impunctate, with short central groove at vertex; clypeus longitudinally concave; eyes very deeply triangularly notched; apex of mandibles black; antennæ extending beyond middle of elytra, flarous, third joint distinctly shorter than fourth, following joints very elongate and slender. Thorax short and subcylindrical, narrowed in front, sides perfectly straight; surface with a distinct oblique sulcus at each side near base, entirely impunctate, posterior margin ve:y narrowly black, the angles acute but not produced. Scutellum elongate, apex pointed, base with small fovea. Elytra narrowly subcylindrical and very elongate, finely and regularly punctate-striate.

$\delta$. Elytra strongly punctate-striate; last abdominal segment with a large and broad depression, occupying the entire middle.

․ Elytra much more finely punctured; last abdominal segment with a round fovea, its margin deeply incised at middle.

Length $5 \mathrm{~mm}$.

Hab. Tenasserim (Doherty-Coll. Brit. Mus.).

\section{Subfamily IV. CHLAMYDIN Æ.}

Subquadrate or subelongate. Head deeply inserted in thorax, flat; eyes large, deeply emarginate at inner margin; antennæ short, of variable shape, inserted when in repose in deep grooves on the flanks of thorax, the basal or terninal joints dentate. Thorax always very convex, generally with a strong elevation on the posterior portion, deflexed at front of anterior angles, posterior margin sinuate at sides; median lobe pronounced, nearly always emarginate at apex. Scutellum transverse, trapezoidal, anteriorly provided with a point that fits into the aperture of the thoracic lobe. Elytra closely applied to base of thorax, lateral lobes very strongly produced, angulate, sutural margins generally serrate or denticulate, apex not covering pygidium. Legs short and robust; femora triangularly compressed with acute margins, when in repose resting in excavations on the abdomen and breast; tarsi short but variable, claws appendiculate or bifid. Prosternum generally widened anteriorly at base, compressed posteriorly into a ridge.

These insects are of rery peculiar shape, and have the upper surface almost in every case raised into tubercles and ridges. They resemble pieces of ore with metallic lustre, or bits of stone and earth; the head, as in the Cryptocephalince, is invisible from above. 


\section{Key to the Genera.}

A. Metasternum entire or emarginate, never produced anteriorly into a point.

a. Antennæ dentate, at least from fifth joint out-

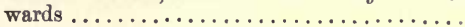

b. Antennæ dentate from sixth joint outwards ... Exema, p. 278.

B. Metasternum produced anteriorly into a triangular thickened point

Hyantes, p. 280.

\section{Genus CHLAMYS.}

Chlamys, Knoch, Neue Beit. Insektenk. 1801, p. 122 ; Lacord. Mon. Phytoph. 1848, p. 649 ; Chapuis, Gen. Coléopt. x, 1874, p. 202. Clythra, Fabr. Syst. Eleuth. ii, 1801, p. 28.

Type, C. gibbosa, Fabr., from N. America.

Range. Principally the New World; Africa ; India; China.

Characters those of the subfamily, more or less modified and varied.

\section{Chlamys coromandeliana, sp. n.}

Bluish-black; head, antennæ, the anterior and intermediate legs, fulvous.

Head rugose punctate, the vertex with a black spot. Thorax with middle portion strongly raised, the elevation bounded laterally by a deep groove, posterior portion of the elevation with a high transverse ridge which extends downwards at the sides and is preceded by another less highly raised ridge, back of the raised portion compressed and forms a ridge down the middle to the base; entire surface rugosely punctured. Scutellum twice as broad as long. Elytra constricted at middle, with the following tubercles:one at middle of base, followed by an oblique ridge from shoulders to suture, ending near latter place with a short transverse ridge, two short longitudinal ridges at sides near apex, preceded by three small tubercles on the inner disc, all more or less connected; interstices strongly punctured. Pygidium closely punctured, with a central longitudinal ridge. Beneath deeply foveolate punctate; posterior legs black, mottled with fulvous. Prosternum strongly narrowed posteriorly.

Length $3 \mathrm{~mm}$.

$H a b$. Southern India: Pondicherry (Coll. Jacoby).

Distinguished principally by the two ridges of the thorax that run down the sides, the posterior of the two are joined posteriorly and form a highly raised transverse ridge; also the general coloration is bluish-black. The antennæ are unfortunately wanting in the type and only specimen that is available for examination. 


\section{Chlamys pallifrons, Jac. P. Z. S. 1887, p. 68.}

Brownish-black ; basal joint of antennæ testaceous ; lower part of face flavous; thorax spotted with fulvous in front and at base.

Head closely granulate-punctate; antennæ with two or three basal joints testaceous, rest black. Thorax strongly raised into an undivided hump, extremely closely and finely granulate-punctate; hinder portion of elevation as well as some indistinct spots anteriorly, fulvous; a more distinct fulvous spot at each side of elevation. Scutellum transverse. Elytra slightly constricted at middle, more strongly punctured than thorax, each elytron with an indistinct ridge from middle of base to apex joined to a shorter ridge that commences at the shoulders; subsutural ridge connected with suture at middle by a short transverse tubercle that ends near apex in a more strongly raised longitudinal tubercle, three other small elevations are within the elytral constriction at sides; suture dentate throughout. Base of femora obscure fulvous.

Length $2 \mathrm{~mm}$.

$H a b$. Ceylon.

Resembles C. spilota, Baly, but is only half the size. The thorax in spilota is more finely punctured, the tubercles on the elytra are much less distinctly raised, and the interstices more finely punctured.

469. Chlamys orientalis, Jac. Ann. Soc. Ent. Belg. 1895, p. 269.

Obscure fulvous; head and thorax paler, the latter with darker spots at top and base; elevations of elytra obscure piceous; legs spotted.

Parallel-sided and subcylindrical in shape. Head deeply and closely punctured and rugose; eyes deeply notched; vertex with short longitudinal groove; antennæ flavous, extending to middle of thorax, terminal six joints strongly dilated. Thorax abruptly raised at middle, the dise canaliculate, with a tubercle at each side of the channel that extends downwards to the base ; sides of thorax with numerous more or less distinct but rounded tubercles, interstices closely punctured; median lobe of posterior margin bidentate. Elytra dark brown, furnished like the thorax with numerous tubercles: one at shoulders, one at middle of basal margin, one below scutellum near suture, two at sides behind the middle, and three large conical tubercles near apex. Pygidium deeply punctured, the punctures piceous; underside similarly punctured; femora with a small spot at middle.

Length 3-4 $\mathrm{mm}$.

$H a b$. Southern Bombay: Kanara.

Rather variable in regard to the amount of flavous and fulvous colouring, but the front portion of thorax always paler; the species is easy to distinguish on account of this coloration, and the more isolated and numerous elytral tubercles. 
470. Chlamys feæ, Jac. Ann. Mus. Civ. Genova, xxxii, 1892, p. 887.

Pale fulvous; mandibles black; surface of thorax with small longitudinal piceous stripes.

Head closely rugose-punctate; fourth and following joints of antennæ dentate, broader than long. Thorax with middle portion strongly raised, the elevation longitudinally channelled and bounded at the sides by a strongly raised ridge, sides transversely reticulate, space near lateral margins slightly raised; entire surface finely rugose, anterior portion with a small piceous stripe at each side and two small spots in the middle, cbannelled portion with another narrow transverse stripe; basal margin deeply sinuate at sides, produced into two points at the middle. Scutellum narrowly transverse, posterior angles strongly pointed. Elytra more strongly rugose than thorax, closely punctured, with an oblique strongly raised ridge (consisting of three connected tubercles) from middle of base to below shoulders, the basal tubercle of this ridge joined by a narrow longitudinal ridge to another transverse one at the sides; a broadly raised curved space from base near suture to behind the middle, space near apex convex, with three or four pale coloured tubercles, the largest of these near the suture, another smaller transverse tubercle close to the lateral margins behind the middle that sends off a ridge upwards towards shoulders. Beneath and the legs pale flavous, punctured like the elytra. Pygidium tricarinate.

Length $5 \mathrm{~mm}$.

Hab. Burma: Karennee (Mus. Genoa).

\section{Chlamys integricollis, sp. $n$.}

Black; labrum and basal joints of the antennæ fulvous.

Elongately subquadrate. Head closely rugose, slightly depressed at middle; terminal joints of antennæ fuscous. Thorax subglobularly rounded, the posterior portion gradually but strongly raised and bounded laterally by a distinct oblique groove; the entire surface finely rugosely punctured, without ridges or tubercles. Scutellum transverse, of usual shape. Elytra constricted at the middle, a minute premedial tubercle close to suture, a short transverse ridge at middle, another tubercle behind the latter, all close to the suture; an oblique rather blunt ridge near the suture starts from the transverse ridge at iniddle and runs downwards towards apex, forming an elongate tubercle near the latter place aud suture; all interstices finely rugose; suture finely serrate throughout. Pygidium with four longitudinal depressions. Underside punctured.

Length $2 \frac{1}{2} \mathrm{~min}$.

Hab. Nilgiris (Coll. H. E. Andrewes).

This species may be known by the regular, highly raised and evenly rounded posterior portion of the thorax, which is

vos. I. 
devoid of any ridges or tubercles. If the elytra are looked at sideways an obscure oblique ridge is seen from the shoulders towards the suture, another somewhat transverse tubercle is placed at the sides in a line with the transverse tubercle at middle.

\section{Chlamys tenebrosa, sp. n.}

Black; basal joints of antennæ and labrum fulvous.

Head rugose; eyes not very deeply triangularly notched; antennæ with basal four joints fulvous, basal joint black above, fifth and following joints transverse. Thorax with posterior portion highly triangularly raised, top of elevation with two rather feeble ridges that run parallel towards the anterior margin; sides of thorax with slightly raised callosities, interstices very finely and closely punctured. Scutellum strongly transverse, strongly pointed at the angles. Elytra subquadrate, narrowed posteriorly, an oblique ridge from shoulders to middle of suture, raised into three tubercles at base, middle and apex, branching from this is another high short ridge towards apex near suture; three tubercles near apex and one at middle of basal margin on each elytron; interstices more strongly punctured than those of the thorax; suture serrate throughout. Pygidium strongly carinate at middle, deeply depressed at sides. Body beneath closely reticulate; legs and tarsi black.

Length $3 \frac{1}{2} \mathrm{~mm}$.

$H a b$. Nilgiris (Coll. Jacoby).

The thorax is strongly narrowed anteriorly. The insect lias to be viewed sideways and turned about to see the real shape and position of the elevations and ridges.

\section{Chlamys semibrunnea, sp. n.}

Piceous, with flavous tubercles and ridges; legs dark fulvous, stained with flavous, tarsi flavous; beneath partly black.

Elongately subquadrate. Head piceous,

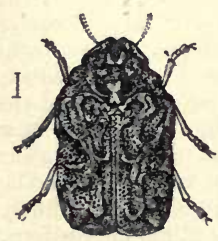

Fig. 107 .

Chlamys semibrunnea. finely rugosely punctured throughout, the vertex with two small fulvous spots; clypeus and labrum fulvous; basal joint of antennæ flavous, rest piceous, terminal five joints transversely thickened, basal joint subcylindrically elongate, second small and round, third and fourth slender, equal, more elongate than the fifth. Thorax with middle portion strongly raised, forming two ridges (when viewed from the side), each of these with three blunt fulvous tubercles, sides with shorter elevations, margins likewise thickened; all raised portions fulvous, anterior portion of thorax paler, entire surface with dark punctures. Scutellum transverse, 
smooth, black. Elytra constricted at the middle, a highly raised ridge close to suture on the posterior half that sends off two more feeble ridges towards the base and connected at the middle by a short transverse ridge with suture; apical portion of each elytron with three or four fulvous tubercles, the posterior two very strongly developed; all interstices deeply punctured; suture serrate throughout. Breast and abdomen black, sides of latter spotted with fulvous; apical abdominal segments entirely of that colour on the sides. Pygidium flavous, with piceous punctures, sides and base with depressions, middle with central ridge; prosternum broadly subtriangular, pointed at the apex.

Length $3 \mathrm{~mm}$.

$H a b$. Southern India (Coll. Brit. Mus.).

Of distinctly elongate shape. If viewed from the side the anterior portion of the thorax is seen to have higher tubercles than the posterior portion.

\section{Chlamys nilgiriensis, sp. $\mathrm{n}$.}

Subelongate; entirely black. Head finely rugose; antennæ with second and third joints short, the following joints gradually and moderately thickened. Thorax with the middle portion gradually and strongly elevated, the raised portion rounded, its middle with two longitudinal ridges that run parallel towards the anterior margin, each of these sends off two other ridges to the sides, the anterior ridge of these much longer than the other; interstices between ridges reticulate; basal margin of thorax produced into a point at middle. Scutellum transverse, short. Elytra slightly constricted at the middle, strongly rugosely punctured; each elytron with about five or six small tubercles, one of which is at the middle close to the suture, one at base near the shoulder; apical portion with four short longitudinal ridges, the first subsutural ridge has a small transverse tubercle joined to it nearly touching the suture; all interstices strongly foveolatereticulate; suture finely denticulate throughout. Pygidium bicarinate at base. Body beneath reticulate throughout. Prosternum triangularly pointed.

Length $3 \frac{1}{2} \mathrm{~mm}$.

$H a b$. Southern India: Nilgiris, Anaimalais (Coll. H. E. Andrewes).

\section{Chlamys flavitarsis, sp. $n$.}

Black; labrum, antennæ and tarsi flavous.

Head longitudinally depressed, finely rugose. Thorax with the middle portion strongly raised, a high ridge each side at the middle, that sends off two others at right angles down each side, 
back of the elevation bituberculate at top, rest of surface finely punctured and rugose. Elytra subquadrately oblong, constricted at the middle, a strong transversely shaped tubercle at middle near suture, another smaller one behind the middle, a high oblique ridge from shoulder to suture above the constriction, another narrower ridge from middle of base to the preceding ridge, three highly raised tubercles on apical portion of each elytron; interstices strongly punctured; suture dentate throughout. Pygidium with a central and a lateral ridge. Underside deeply rugose-punctate.

Length $2 \frac{1}{2} \mathrm{~mm}$.

Hab. Nilgiris (Coll. H. E. Andrewes).

The thorax differs in sculpture from other small species of the genus, and the antennæ and tarsi are entirely fulvous; when looked at from the side the thorax has four triangular pointed tubercles on the elevated portion.

\section{Chlamys kanaraensis, sp. n.}

Black ; head, antennæ, the thorax anteriorly, and the legs more or less fulvous.

Head finely rugose. Thorax black with the posterior portion highly raised, from the top of which two acute ridges run down the sides, these meet at the base and form a transverse ridge behind, two other ridges extend down the middle and are abbreviated in front, rest of the surface closely reticulate and rugose ; a transverse flavous band widened at the middle and abbreviated at the sides, close to the anterior margin. Elytra with a highly raised tubercle at middle of base continued in shape of a ridge to middle of suture, a small tubercle near scutellum, an oblique ridge from shoulders to middle of suture, raised into two transverse tubercles at its centre and termination, apical portion with five other tubercles, the terminal ones the largest; suture dentate throughout. Pygidium with faint central ridge, finely rugose. Anterior and intermediate legs and the posterior tibiæ flavous with an obscure piceous spot; posterior femora black.

Length $2 \frac{1}{2} \mathrm{~mm}$.

$H a b$. Western India : Kanara (Coll. H. E. Andrewes).

\section{Chlamys fulvipes, Baly, Journ. Linn. Soc. xiv, 1878; p. 345.}

Black; labrum, antennæ and legs fulvous; posterior femora, intermediate femora beneath and tibiæ outwardly black.

Head closely punctured, front closely pubescent with a faint longitudinal depression; sntennæ rather shorter than the thorax, six terminal joints dilated. Thorax opaque, strongly and rather abruptly raised at the middle, top of elevation canaliculate, sides with a ring-shaped ridge attached to the upper ridges which linit 
the channel, lower portion obsoletely tuberculate, finely punctured and reticulate, anterior portion clothed with grey pubescence.

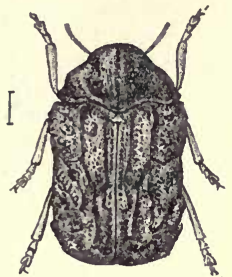

Fig. 108.

Chlamys fulvipes. Elytra constricted at the middle, a tubercle at middle of base, a transverse one near suture at middle and two or three near apex, all more or less connected by longitudinal and transverse ridges, interstices strongly punctured and reticulate. $\mathrm{Py}-$ gidium tricarinate, the ridges connected at base by a transverse costa.

Length $4 \mathrm{~min}$.

$H a b$. Northern India.

The pubescence of the head and thorax is only present in well-preserved specimens, where it is very distinct but was not noticed by Baly. That author makes no mention of any ridges connecting the tubercles of the elytra, nor of those to be seen at the sides of the thorax.

478. Chlamys indica, Jac. P. Z. S. 1901, p. 163.

Black, opaque; basal joint of antennæ, labrum, anterior femora and tarsi fulvous.

Broadly subquadrate. Head flat, variegated with fulvous, closely and finely punctured, each puncture with

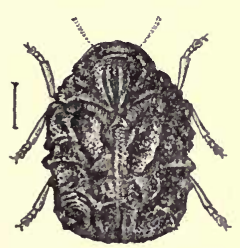

Fig. 109.

Chlamys indica. a short yellow seta ; palpi fulvous; antennæ fuscous, basal joint fulvous. Thorax very closely punctured, sides with a small callosity, middle portion very moderately and obliquely raised, narrowly sulcate at top of posterior portion, with two slight ridges that run downwards at the sides towards the anterior margin, the inner ridge forms the limit of the median sulcus above. Scutellum finely carinate. Elytra with a compressed tubercle at middle of base, a sinuate ridge parallel with suture from base ending behind the middle in a strongly-raised transverse tubercle, a similar tubercle at middle of outer dise that extends in a ridge upwards to the shoulders, a third and less strongly-marked ridge near lateral margins; apical portion occupied by another semicirenlar distinct ridge, highly raised near the suture, from whence it turns outwards and is lost near the margins; interstices strongly rugose and uneven; suture serrate. Breast closely rugose-punctate. Pygidium finely punctured, with central and lateral ridges.

Length $5 \mathrm{inm}$.

$H a b$. India. 
Allied to C. fulvipes, Baly, but larger, the head similarly pubescent, but the elytral sculpturing and the colour of the legs quite different.

479. Chlamys andrewesi, Jac. Ann. Soc. Ent. Belg. xlvii, 1903, p. 93.

Black; antennæ and legs (posterior femora excepted) fulvous*. Head flat, rugosely punctured; eyes acutely notched; labrum fulvous; antenu» with the last seven joints gradually widened. Thorax transverse, lateral margins straight, middle portion raised into a round elevation, top of the elevation bounded by a rather deep oblique groove; entire surface evenly and closely rugosepunctate, puncturation at sides stronger than within lateral grooves, top of elevation with some short oblique ridges at sides of central sulcation. Scutellum with bind angles strongly produced. Elytra much more deeply and coarsely punctured, more shining than the thorax; middle of base with longitudinal ridge to middle of disc, connected there with another ridge that runs parallel with the first ridge upwards to the shoulders, where it becomes indistinct; a strongly raised transverse tubercle near suture behind the middle, connected inwards with a short ridge which joins the basal ridges at their lower posterior connection; apical portion of elytra with another longitudinal triangular ridge close to the suture and more ridge-like tubercles near lateral margins; interstices everywhere rugosely reticulate. Pygidium finely rugose, with obsolete longitudinal grooves at the sides; the sculpture of the body beneath similar.

Length $4 \frac{1}{2} \mathrm{~mm}$.

$H a b$. Southern India : Nilgiris, Anaimalais.

\section{Genus EXEMA.}

Exema, Lacord. Mon. Phytoph. ii, 1848, p. 844.

Type, $E$. intricata, Kollar, from Brazil.

Range. North and South America; Africa; India; Malacca.

Characters similar to those of Chlamys, but the antenny are dentate from the sirth joint outwards. Thorax generally with longitudinal ridges. This is an ill-defined genus, and can scarcely be separated from Chlamys solely on the variable structure of the antennæ. I have kept it separate as a matter of convenience only.

* Through a slip of the pen these parts in the original description are given as black. 
480. Exema ceylonensis, Jac. P.Z. S. 1887, p. 69.

Black; head strigose; thorax with six longitudinal ridges; elytia with nine or ten tubercles.

Head closely covered with longitudinal strigæ; sixth and following joints of antennæ transverse. Thorax strongly raised into a pointed elevation, rather closely and distinctly punctured, each side with three longitudinal ridges, the middle pair parallel, not quite extending to anterior margin, second ridge strongly sinuate, third the shortest, only extending to the middle; interstices with some other obsolete elevations connecting the ridges at places. Elytra more deeply punctured than the thorax, each elytron with the following tubercles:-one at middle of base, one at shoulders, another near scutellum ; two transverse short ridges near suture, one at middle, the other posterior to the latter, connected by an oblique ridge from basal tubercle to near apex; another shorter oblique ridge from shoulders to the middle, joining the subsutural one; a tubercle near apex close to lateral margins; suture serrate throughout. Underside rugosely punctate.

Length $2 \mathrm{~mm}$.

$H a b$. Ceylon.

481. Exema indica, Guér. (Chlamys) Rev. Zool. 1840, p. 41; id. (Chlamys) Voy. Deless. ii, 1843, p. 63 ; Lacord. Mon. Phytoph. ii, 1848 , p. 852 .

Black; basal joint of antemuæ obscure flavous.

Subelongate, slightly constricted at middle. Head strougly rugose-punctate; antennæ black, basal joint flavous. Thorax nearly vertical, the posterior portion strongly raised, rounded, compressed posteriorly into a short perpendicular ridge; top of elevation with two parallel ridges, each connected with a ringshaped ridge, rest of surface very unevenly rugose and reticulate; median lobe of posterior margin bidentate. Flytra with a longitudinal ridge from middle of base to the middle of their length, a deep, curved, longitudinal depression from below shoulders to behind the middle of suture, a tubercle before and behind the middle at suture, three or four larger tubercles on the apical portion; interstices irregularly punctured and reticulate; suture entirely smooth. Pygidium with middle and lateral ridges. Body beneath closely rugosely punctured.

Length $2 \frac{1}{2} \mathrm{~mm}$.

Hab. Nilgiris (Coll. H. E. Andrewes).

This small species, the elytra of which have a very intricate system of sculpturing, difficult to describe, may be known by the smooth, not denticulate elytral suture. It differs in this respect from any of its allies recorded from India. I have seen only a single specimen. Lacordaire's description agrees in the main points with the specimen before me, obtained in the same locality. 


\section{Genus HYMETES.}

Hymetes, Lacord. Mon. Phytoph. ii, 1848, p. 861.

Type, H. javana, Lacord., from Java.

Range. India; Java.

Characters mostly those of Chlamys. The differences are as follows:-Antenuæ slender, distinctly dentate from the seventh joint outwards; third, fourth, and fifth joints equal, elongate, cylindrical, sixth trigonal, following joints transverse. Thorax convex, obsoletely longitudinally carinate. Scutellum large, posterior margin with two long teeth. Prosternum dilated anteriorly; metasternum produced into a small tubercle anteriorly. Tarsi robust. A single species is known from India.

482. Hymetes indica, Chapuis, Gen. Coléopt. x, 1874, p. 205, note.

"Reddish-brown, elytral tubercles obscure black.

"Subquadrately elongate. Thorax at sides rugosely punctured, elevated and gibbous, the elevation subglobose, canaliculate at middle, posteriorly bicarinate, each ridge divided anteriorly into three ridges. Elytra punctate, subcariuate and tuberculate; two tubercles at middle strongly raised, two others posteriorly, small.

"Length 6-7 mm.

" Hab. India." (Chapuis.)

The above is the brief description given by Chapuis; I have not seen any specimen of this species, nor is the exact locality of its " habitat" known.

\section{Division CYCLICA.}

\section{Key to the Subfamilies.}

A. Last joint of tarsi deeply bilobed.

$a$. Thorax as wide as elytra at base; legs compressed; abdomen grooved for reception of legs $\quad . \ldots \ldots \ldots \ldots \ldots$.

b. Thorax generally narrower than elytra at base; legs not compressed; abdonen not grooved for reception of legs.

B. Last joint of tarsi not bilobed, entire....

Lamprosomina.

Eumolpina. Chrysomelince.

\section{Subfamily I. LAMPROSOMINÆ.}

Short and very convex. Head deeply inserted in thorax; eyes well separated, feebly emarginate. Antennæ short, robust, first joint elongate, slightly curved, second half the length of the first, ovate, third to sixth joints cylindrical, seventh larger, triangular, eighth much smaller, subcylindrical, the rest transversely widened. Thorax transverse, closely fitted to elytra and nearly as broad at base, strongly narrowed towards apex, sides nearly straight, surface evenly and generally convex. Scutellum small, triangular. 
Elytra gradually narrowed posteriorly, the apex rounded, covering abdomen entirely; epipleuræ angularly produced below base, suddenly narrowed posteriorly, often provided with three foveæ. Prosternum generally subquadrate and flat but variable; inner margin of the side-pieces of breast raised, forming a groove at sides of prosternum for the reception of the antennæ; metasternum produced as far as prosternum, hollower at sides for reception of femora. Legs short, not protruding beyond elytra; tibiæ carinate; femora with sulci into which the tibiæ can be placed; tarsi short and broad, the third joint deeply divided or bilobed; claws appendiculate.

The forms in this subfamily are as a rule short and convex, often of brilliant metallic coloration. In India they are represented by species of more sombre aspect, but in tropical South Anerica, where they swarm, they inostly assume rich metallic colours. The short carinate legs which fit into abdominal grooves and the very short antennæ are good distinguishing marks of these insects.

\section{Genus LAMPROSOMA.}

Lamprosoma, Kirby, Trans. Linn. Soc. Lond. xii, 1818, p. 445.

Oomorphus, Curtis, Brit. Ent. viii, 1831, p. 347.

Type, L. bicolor, Kirby, from South America.

Range. Europe; S. America; India ; Japan.

Characters those of the subfamily. The Indian species are of sinall size and mostly of dark metallic-blue or purplish colour.

\section{Lamprosoma assamensis, sp. n.}

Black, ovate, narrowed posteriorly. Head, seen under a strong lens, extremely minutely punctured; antennæ extending to base

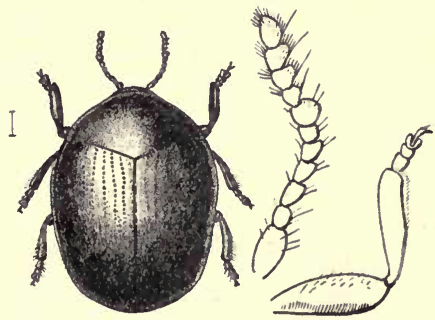

Fig. 110.-Lamprosoma assamensis.

of thorax, basal joint fulvous beneath, all following joints gradually widened, subtriangular, furnished with single stiff hairs. Thorax strongly transverse, narrowed at sides, latter straight, posterior margin oblique, medial lobe slightly prominent and pointed; surface extremely minutely and closely punctured. Scutellum small, triangular. Elytra slightly wider at the shoulders 
than at the thorax; epipleural lobes short and only slightly angulate; the puncturatiou more distinct than that on the thorax, but very fine and arranged in closely approximate rows. Entire upper surface with a very slight violaceous tint. Underside deep black. Prosternum scarcely longer than broad.

Length $2 \frac{1}{2} \mathrm{~mm}$.

Hab. Assam (Coll. Jacoby).

Much more finely and closely punctured than $L$. sumatrensis, Jac., from Sumatra.

\section{Lamprosoma rilgiriensis, sp. n.}

Bluish-black; basal joint of autennæ fulvous.

Head with a few minute punctures; antennæ extending to base of thorax, basal joint obscure fulvous, rest black, thickened. Thorax more than twice as broad as long, strongly narrowed in front, surface crowded with small punctures. Scutellum small. Elytra distinctly narrowed posteriorly, very convex, raised before the middle; surface finely punctate-striate, the rows rather distantly placed, interstices with a few minute punctures at the posterior portion. Underside deep black. Prosternum longer than broad, narrowed at middle, finely punctured.

Length. $2 \frac{1}{2} \mathrm{~mm}$.

Hab. Nilgiris. Type in Coll. Andrewes.

Narrower than $L$. assamensis, dark blue above, not violaceous, the rows of punctures on elytra more distantly placed, the thorax more strongly punctured.

\section{Lamprosoma ceylonensis, sp. n.}

Nearly black ; the head impunctate, apex of the mandibles and basal joint of antennæ beneath fulvous. Thorax nearly three times as broad as long, the sides strongly obliquely narrowed anteriorly, the median lobe only moderately and bluntly produced, the surface very closely and finely punctured throughout. Elytra with a slight violaceous gloss, nearly parallel-sided, only very slightly narrowed at apex, epipleuræ feebly angulately produced behind the shoulders; the surface comparatively strongly punctatestriate, the punctures rather closely placed, lateral margins accompanied by a narrow sulcus. Prosternum longer than broad, finely punctured.

\section{Length $2 \mathrm{~mm}$.}

$H a b$. Ceylon (Coll. Jacoby).

Swaller than $L$. assamensis, Jac., or $L$. nilgiviensis, Jac., the elytra decidedly more strongly punctured, the interstices entirely impunctate.

\section{Lamprosoma angustata, sp. $n$.}

Above blackish-blue; beneath black; basal two joints of antennæ fulvous.

Ovate, distinctly narrowed posteriorly. Head entirely impunctate, blue or greenish; antennæ extending beyond base of 
thorax, second and following joints short, terminal joints thickened, last ovately elougate. Thorax more than twice as broad as long, sides perfectly straight, posterior margin broadly rounded and scarcely produced at middle, surface microscopically punctured. Scutellum extremely minute. Elytra very finely punctured in elosely approximate rows, punctures of rather uneven size, somewhat larger near the suture. Prosternum distinctly longer than broad and constricted at the middle. Body beneath rery finely and sparingly punctured.

Length $1 \frac{3}{4}-2 \mathrm{~min}$.

$H a \dot{b}$. Nilgiris (Crupt. Downing).

Head entirely impunctate, thorax less closely punctured, elytral rows of punctures more closely placed, puncturation on both thorax and elytra finer. From $L$. assamensis, Jac., the present species differs in the inpunctate head, the slightly produced median lobe of the thorax, and the much longer prosternum; L. ceylonensis, Jac., is posteriorly less narrowed in shape and the puncturation is much stronger.

\section{Subfamily II. EUMOLPIN સ.}

Body generally oblong and convex; head more or less inserted in thorax ; antennæ widely separated at base, generally filiform or with dilated terminal joints; eyes oblong, sinuate or entire. Thorax subglobular, subconical or eylindrical, sometimes without lateral margins. Scutellum always distinct. Elytra short or oblong, generally broader than thorix with well-defined shoulders, often metallic or clothed with hairs or scales. Legs moderate or more or less robust, the femora often with tooth beneath; tarsi variable, generally with triangular joints; claws simple, appendiculate or bifid. Prosternum always distinct, sometimes narrow, sometimes broad.

This subfamily is numerously represented in India and comprises many brilliantly coloured or metallic species of moderate size; some are entirely covered with pubescence and of dull appearance. The subfamily is divided into numerous groups which again are arranged in two sections-one in which the anterior margin of the thoracic episternum is concave or straight, and the other in which this part is more or less convex; but this character bas of course to be used in connection with other structural details.

Key to the Groups of the Eumolpiuæ.

A. Anterior margin of thoracic episterna straight or concave.

a. Claws appendiculate.

$a^{\prime}$. Sides of thorax entire, not angulate. $a^{2}$. Antennæ filiform.

$a^{3}$. Intermediate and posterior tibia not emarginate at apex. IPHIMkini, p. 285. 
$b^{3}$. Intermediate and posterior tibiæ emarginate at apex.

$a^{4}$. Head not sulcate above eyes

$b^{4}$. Head sulcate above eyes ..

$b^{2}$. Antennæ with strongly widened terminal joints ............

$b^{\prime}$. Sides of thorax more or less angulate or dentate ...........

b. Claws bifid.

$a^{\prime}$. Sides of thorax with distinct mar-

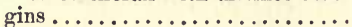

$b^{\prime}$. Sides of thorax without distinct margins.

$a^{2}$. Head with deep sulcus above eyes...................

$b^{2}$. Head without sulcus.

$a^{3}$. Intermediate and posterior tibiæ emarginate at apex ....

$b^{3}$. Intermediate and posterior tibiæ not emarginate at apex.

$a^{4}$. Thurax narrower than elytra, subcylindrical.

$a^{5}$. Antennæ filiform ......

$b^{5}$. Antennæ with widened terminal joints ........

$b^{4}$. Thorax not narrower than elytra, transverse .......

B. Anterior margin of thoracic episterna convex.

a. Elytra with more or less strong transverse rucosities at sides .........

$b$. Elytra without rugosities at sides.

$a^{\prime}$. Body above clothed with hairs or scales.

$a^{2}$. Thorax with distinct lateral mar-

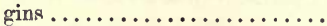

$b^{2}$. Thorax without lateral margins.

$a^{3}$. Antennæ subfiliform, terminal joints not thickened .......

$b^{3}$. Antennæ with strongly thickened terminal joints ........

$b^{\prime}$. Body above glabrous.

$a^{2}$. Intermediate and posterior tibiæ emarginate at apex .........

$b^{2}$. Intermediate and posterior tibiæ not emarginate at apex.

$a^{3}$. Head with broad sulcus above eyes..................

$b^{3}$. Head without sulcus above eyes..................
Nodostomini, p. 291.

Pagrini, p. 355.

Callisini, p. 362.

Colaspini, p. 367.

Metachromini, p. 378.

Scelodontini, p. 382.

Heteraspini, p. 387.

Leprotini, p. 395.

Eubrachini, p. 432.

Eumolpini, p. 438.

Edusini, p. 456.

Myochroixi, p. 459.

Adoxinr, p. 465.

Pseudocolaspini, p. 466.

Trpophorri, p. 468.

Corynodini, p. 491.

Endocephalini, p. 510.

The Eumolpince are distributed over both hemispheres, and form an immense complex of genera and species which has comparatively only lately been reduced to some systematic order by Baly, Chapuis, and Lefèrre; but this subfamily requires still 
furtlier investigation, since a great deal of material contained in large collections has not yet been worked out. The Eumolpinoe are numerously represented in India, and can readily be distinguished from the subfamilies in the Eupodes by the position of the antennæ, placed widely apart, and by the shape of the thorax. From the subfamilies of the Camptosomes they differ by the generally filiform and long antennæ, also by the general shape of the body. The deeply divided third tarsal joint and the round cotyloid cavities separate the Eumolpina from the true Chrysomelina.

The larræ of these insects live, so far as is kuown, free on plants or rarely within their stems, but they do not construct cocoons nor cover themselves with their own excreta, as do the larvæ of some of the forms in the preceding subfamilies.

\section{Group IPHIMEINI.}

Species of elongate or oblong-subcylindrical shape; antennæ long and filiform. Thorax transverse, with lateral margins entire. Anterior femora dilated beneath into a strong tooth. First tarsal joint as long as the following two united. Prosternum longer than broad.

Although rather numerously represented in the New World, we have only one Indian genus belonging to this group, Chrysolampra, which may be known from other Indian genera by the dentate anterior femora; ail the species are metallic.

\section{Genus CHRYSOLAMPRA.}

Chrysolampra, Baly, A. M. N. I. iv, 1859, p. 126; Chapuis, Gen. Coléopt. x, 1874, p. 237 ; Lefêv. Cat. Eumolp. 1885, p. 12.

Type, C. splendens, Baly, from China.

Range. India ; China.

Elongate. Head deeply inserted; antennæ slender and filiform, nearly as long as the whole of the body, basal joint thick, second short, third and fourth equal, fifth and following joints more elongate. Thorax transverse, convex, anterior angles deflexed. Elytra convex, partially punctate-striate, more or less rugose at the sides. Anterior femora incrassate and more or less dentate beneath; first joint of posterior tarsi elongate, as long as the following two joints united; claws appendiculate. Prosternum much longer than broad, base truncate and widened; anterior margin of thoracic episternum concave.

\section{Chrysolampra subænea, sp. n.}

Beneath piceous, with a slight greenish gloss, above obscure greenish-æneous; labrum, antennæ and legs fulvous. 
ס. Narrow, subcylindrical. Head convex, very remotely and finely punctured on the vertex; clypeus separated by an obsolete transverse groove, more strongly punctured than the head, anterior edge nearly straight; antennæ fulvous, extending nearly to apex of elytra, basal joint elongate, second very short, third and fourth elongate, equal. Thorax about half as broad again as long, of equal width, sides rounded, dise rather convex, finely and remotely punctured, punctures irregularly distributed. Scutellum ovate, smooth. Elytra with distinct basal depression, finely punctatestriate near suture, sides more strongly and irregularly punctured, interstices at same place rugose, a more or less distinct ridge close to lateral margins. Anterior femora widened into a strong tooth.

ㅇ. Larger; antennæ shorter, piceous; legs piceous. Thorax with some obsolete depressions, more transverse in shape.

Length $4 \frac{1}{2}-5 \frac{1}{2} \mathrm{~mm}$.

Hab. Burma : Ruby Mines (Coll. Brit. Mus.).

Of rather peculiar coloration, sometimes almost piceous with slight greenish lustre, at other times nore distinctly greenish; puncturation of thorax very fine, rather variable.

\section{Chrysolampra flavipes, Jac. The Entomologist, xxxii, 1899, p. 70.}

Dark æneous beneath; breast metallic greenish; antennæ, labrum and legs fulvous; above greenish-cupreous.

¿. Head very finely and rather sparsely punctured, with deep longitudinal central groove, lower portion and clypeus more strongly punctate; antennæ with basal joint strongly thickened, third and fourth joints equal, last three joints wanting in the only specimen I have seen. Thorax twice as broad as long, sides strongly rounded; surface rather strongly but not very closely punctured, the punctures somewhat irregularly distributed. Elytra elongate and pointed, not very strongly depressed below base, latter slightly raised; puncturation rather fine and geninate near suture, stronger and irregular at sides, interstices at latter place rugose; apical portion with two or three rows of deep single punctures near suture. Anterior femora dilated into a tooth beneath.

ㅇ. The sides of the elytra strongly rugose and the punctures confluent.

Length 6-8 $\mathrm{mm}$.

Hab. Assam : Khási Hills.

This species differs from $C$. thoracica, to which it is closely allied, in the shorter thorax and its more strongly and less closely punctured surface, also in the differently sculptured head, which in $C$. thoracica is extremely closely and finely punctured.

489. Curysolampra thoracica, Jac. The Entomologist, xxxii, 1899,p. 69.

Piceous beneath ; antennæ and legs fulvous; head, thorax and elytra metallic green. 
Head very finely and closely punctured, vertex with longitudinal

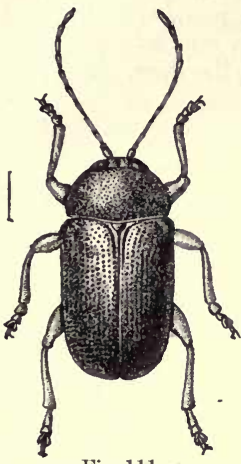

Fig. 111. groove; clypeus rugose-punctate, anterior margin slightly concave; antennæ extending nearly to apex of elytra, third joint slightly longer than fourth. Thorax twice as broad as long, of even width, sides strongly rounded at middle; surface as closely but rather more strongly punctured than the head, punctures of even size, somewhat more crowded at the sides. Elytra with slight basal depression, very closely and deeply punctured in somewhat regular rows; interstices strongly transversely rugose at sides nearly to the apex, the latter longitudinally costate.

Length $6 \mathrm{~mm}$.

$H a b$. Sylhet.

Distinguished from other allied species by the finely and closely punctured head Chrysolampra thoracica.

490. Chrysolampra minuta, Jac. Ann. Mus. Civ. Gensva, xxxii, 1892, p. 894.

Fulvous or piceous beneath, metallic green or blue above; labrum and antennæ fulvous.

$\delta$. Oblong-ovate, convex. Head sparingly and finely punctured; clypeus more strongly and closely punctate; antennæ extending to apex of elytra, third and fourth joints equal, elongate, apical joints slightly widened. Thorax transverse, more than twice as broad as long, sides rounded, very slightly subangulate behind the middle; surface finely and not very closely punctured, punctures slightly larger at the sides. Scutellum rather large. Elytra convex, scarcely depressed below base, somewhat regularly punctate-striate near suture, sides very deeply and more irregularly punctured.

‥ Blue above; antennæ shorter ; elytra longitudinally tuberculate at sides; anteriur femora only slightly dilated, armed with a small tooth.

Length $3 \frac{1}{2} \mathrm{~mm}$.

$H a b$. Burma: Karennee.

The smallest species of the genus known.

491. Chrysolampra curvipes, Jıc. Ann. Mus. Civ. Genova, xxvii, 1889, p. 161.

Metallic green or cupreous ; antenuæ, labrum and palpi fulvous.

Head partly green and aureous, closely and distinctly punctured, more strongly so at sides than on vertex, the latter with an obscure central groove and a broader smooth space above the 
clypeus; anterior margin of latter straight, surface closely punctured; antennæ extending to two-thirds the length of the body. Thorax twice as broad as long, sides slightly ronnded at the middle and narrowed towards the apex; surface remotely and finely punctured on the disc, more strongly so at the sides. Scutellum

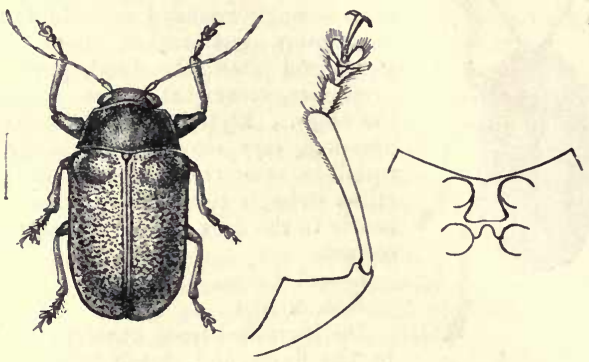

Fig. 112.-Chrysolampra curvipes, ㅇ.

impunctate. Elytra with rows of strongly raised tubercles at the sides ( $q$ ), the basal portion raised and bounded by a transverse depression ; puncturation rather fine and arranged near the suture in irregular donble rows, interstices at the sides transversely rugose and swollen. Body beneath clothed with silvery pubescence. Intermediate tibiæ curved at apex, first joint of tarsi broadly dilated.

Length 8-9 $\mathrm{mm}$.

Hab. Burma: Teinzo ; Bbamo.

Allied to $C$. splendens, Baly, but the antennæ entirely fulvous and the tibiæ curved in the male ; in the female there are generally about four rows of tubercles on the elytra; in both sexes the anterior femora are strongly dilated into a triangular tooth beneath.

4!)2. Chrysolampra varicolor, Jac. Ann. Mus. Civ. Genova, xxxii, 1892 , p. 893.

Purplish, green, or violaceous; labrum and basal joints of antennæ fulvous.

o. Head closely rugose-punctate, with a more or less deep central groove. Thorax twice as broad as long, sides rounded, with narrow reflexed margins; surface very closely impressed with larger and snaller punctures, interstices at sides finely reticulate. Scutellum smooth. Elytra with basal portion slightly raised, finely and slightly geminate-punctate near the suture, more strongly and irregularly punctured at the sides, interstices on latter transversely rugose. Tarsi blackish. 
Length 7-9 mm.

Hab. Burma : Karennee.

A very variable species in regard to colour, scarcely two specimens are alike. The sculpture of the thorax, more crowded with small and large punctures than in $C$. splendens, Baly, is the principal distinctive character. The legs are always purplish or dark blue.

493. Chrysolampra burmanica, sp. n. (Pl. I, fig. 13.)

o. Violaceous-blue; basal joints of antennæ and legs more or less fulvous.

Head closely punctured and finely wrinkled, the rugosities directed towards the centre, a deep fovea in the centre; clypeus closely punctured and transversely rugose; labrum and palpi fulvous ; antennæ nearly extending to apex of elytra, basal seven joints fulvous, rest black. Thorax of equal width, transverse, convex, sides evenly rounded with broadly reflexed margins; surface remotely and rather finely punctured. Elytra more strongly and closely punctured than the thorax, the punctures arranged in irregular rows, interstices transversely rugose at the sides; epipleuræ fulvous. Legs with violaceous gloss, tibiæ clothed with yellow pubescence.

Length $6 \mathrm{~mm}$.

Hab. Burma (Coll. Jacoby).

Only a single male specimen is before me, distinguished by the colour of the legs, sculpture of head and structure of thorax.

\section{Chrysolampra manipurensis, sp. $n$.}

‥ Violaceous; basal joints of antennæ fulrous; labrum piceous; sides of breast metallic greenish.

Head strongly but raiher remotely punctured on vertex ; clypeus strongly rugose, separated at the sides by an oblique short groove, surface rather depressed, anterior and lateral margins metallic green; antennæ with basal four joints fulvous, rest black, third and following joints very elongate and slender. Thorax scarcely twice as broad as long, widest at base, sides moderately rounded but rather strongly narrowed in front, anterior angles acute; surface very remotely and rather irregularly and finely punctured, the punctures somewhat elongate. Elytra slightly wider at base than thorax, obsoletely depressed below base, strongly and closely punctured, the punctures arranged in irregular rows, near the suture they are much finer and more regularly in lines, interstices near apex slightly costate. Breast margined with metallic green.

Length $7 . \mathrm{mm}$.

$H a b$. India: Manipur. Type in Brit. Mus.

Separated by the remotely and finely punctured thorax. Male unknown.

YOL. I. 


\section{Chrysolampra viridicollis, sp. $n$.}

o. Metallic green; antennæ and legs fulvous; elytra dark blue. Head extremely closely and rather finely rugosely punctured; clypeus not separated from the face, rather more strongly punctured ; labrum fulvous; antennæ nearly extending to apex of elytra, fifth and following joints half as long again as the third and fourth. Thorax about half as broad again as long, sides rounded, narrowly margined; surface convex, very strongly and closely punctured; interstices irregularly rugose, especially so at the sides. Scutellum metallic green. Elytra wider at base than the thorax, extremely closely and strongly punctured, interstices finely wrinkled, apical portion near suture longitudinally costate. Body beneath metallic green.

․ Above entirely metallic green; the head has a distinct central longitudinal depression, the thorax is rather less closely punctured, and the elytra have some narrow smuoth longitudinal lines; but in all other respects, except in coloration, the two. sexes agree.

Length $6 \frac{1}{2} \mathrm{~mm}$.

$H a b$. Burma : Ruby Mines. Type in Brit. Mus.

I only know a single pair, male and female, of this handsome species. The male has, as usual, the first joint of the anterior tarsi dilated.

The elytral puncturation is much stronger and closer than in C. flavipes, the coloration of the upper parts is also quite different. From $C$. indica this species differs in the finely and closely rugose head, the strongly and closely punctured elytra, general larger size and fulvous legs. C. burmanica, Jac., has a remotely and finely punctured thorax and broadly reflexed lateral thoracic margins. In $C$. thoracicu, Jac., the sculpturing of the thorax and elytra is different. Lastly, C. subonea, Jac., and C. flavipes, Jac. have finely and sparsely punctured heads.

\section{Chrysolampra bicolorata, sp. $n$.}

Violaceous; beneath metallic green; labrum fulvous; antennæ (basal joints excepted) and legs black.

Head broad, closely and strongly punctured, interstices very finely pubescent ; clypeus bounded above by a transverse ridge at the sides, and with an elongate tubercle in the middle, strongly and closely punctured like the head, anterior edge but slightly concave; mandibles robust, black; antennæ slender, basal joint beneath and the following three joints entirely pale fulvous, third and fourth joints equal, remainder longer and very slender. Thorax twice as broad as long, sides evenly rounded, anterior angles produced into an acute point; surface strongly and irregularly punctured, punctures closely placed at the sides. Scutellum impunctate. Elytra broad, wider at base than the thorax, shoulders prominent; entire surface impressed with round and closely placed deep punctures, much larger than those on the thorax; interstices more 
or less wrinkled, obsoletely costate near the suture at apex. Coxæ and extreme apex of tibiæ obscurely piceous.

Length $6 \mathrm{~mm}$.

Hab. Burma: Ruby Mines. Type in Brit. Mus.

In this species the thorax is widest at middle, the sides are strongly rounded, and the anterior angles very prominent; the elytra are much more strongly and closely punctured than in C. manipurensis.

497. Chrysolampra indica, sp. n.

Metallic greenish-cupreous; basal joínts of antennæ fulvous, rest black; legs blackish-æneous.

o. Head closely and finely punctured, vertex with longitudinal depression at middle, a smooth oblong space at base of antennæ; clypeus triangular, closely rugose-punctato; labrum dark fulvous; mandibles black; antennæ with the basal four joints fulvous, rest blackish, all the joints from the third onwards very elongate. Thorax about half as broad again as long, sides evenly rounded, narrowly margined; puncturation rather fine, distant and irregularly placed, though not more closely or strongly on the sides than in the middle. Elytra subcylindrical, twice as strongly punctured as the thorax; punctures arranged in close irregular rows near suture, larger and much more irregularly placed at sides, interstices on the sides transversely rugose. Body beneath greenish-æneous; legs nearly black with metallic gloss ; first joint of tarsi subquadrately widened.

Length 5-5 $\frac{1}{2} \mathrm{~mm}$.

Hab. Assam : Shillong, Khási Hills ; Burma : Momeit.

\section{Group NODOSTOMINI.}

Body oblong, ovate or subelongate; antennæ fliform or subfiliform. Thorax transverse or subquadrate, lateral margins rounded or angulate at base. Apex of intermediate and posterior tibiæ emarginate; claws appendiculate. Prosternum broad ; anterior margin of thoracic episternum concave.

Represented in India by a large number of closely allied species. The thorax is as a rule narrowed anteriorly and angulate at the sides near base, but also often rounded; the elytra have generally a deep depression behind the base.

\section{Key to the Genera.}

A. Body short and rounded, elytra as wide as thorax at base .................... Nodina, p. 292.

B. Body oblong or elongate.

a. Elytra not wider than thorax at base.

$a^{\prime}$. Prosternum longer than broad.

$a^{2}$. Intermediate and posterior tibiø emarginate at apex; emargination on outer side

Nodostella, p. 299.

U 2 
$b^{2}$. Posterior tibiæ only emarginate at apex; emargination on inner side.. Autolampra, p. 300.

$b^{\prime}$. Prosternum not longer than broad.

$a^{2}$. Thorax widest at base, often angulate at sides ...................

$b^{2}$. Thorax not widest at base, subquadrate ...................

b. Elytra wider than thorax ..............

Nodostoma, p. 301.

Pseudostonopa, [p. 350 .

\section{Genus NODINA.}

Nodina, Motschulsky, Étud. Ent. vii, 1858, p. 108; Chapuis, Gen. Coléopt. x, 1874, p. 262 ; Lefêv. Cat. Eumolp. 1885, p. 61.

Type, N. pusilla, Motscb., from India.

Range. India; Japan; Malayan Subregion.

Body rounded, short and convex; head deeply inserted ; antennæ scarcely extending to half the length of body, terminal joints more or less thickened. Thorax transverse, sides not angulate. Elytra not wider at base than thorax, not depressed below base, surface punctate-striate. Legs rather short and stout; femora unarmed; posterior and intermediate tibiæ more or less emarginate near apex ; tarsi equal, rather short; claws appendiculate. Prosternum transverse, subquadrate.

Small and generally metallic species, distinguished by the nearly equal width of the thorax and elytra at base, and the rather short and thickened joints of the antennæ. Both Baly and Lefèvre give the antennæ as filiform, and describe their length as more than half that of the body; this is certainly not the case, as Motschulsky, in his description of the type, $N$. pusilla, describes the terminal joints as dilated. In all species that $I$ bave examined these joints extend only up to the base of the elytra, and are certainly not filiform.

\section{a. Legs fulvous.}

498. Nodina indica, Jac. Ann. Soc. Ent. Belg. xxxix, 1895, p. 271.

Beneath black, above greenish-æneous; antennæ and legs fulvous.

o. Proportionately elongate and parallel-sided; head very finely and sparingly punctured, with narrow sulci above the eyes; mandibles black; palpi fulvous; antennæ extending to base of thorax only, terminal joints transversely widened. Thorax twice as broad as long, sides evenly rounded, scarcely narrowed in front; surface rather closely and strongly punctured, the punctures evenly distributed, posterior margin oblique at each side, median lobe short and rounded. 'Elytra strongly punctate-striate anteriorly, finely so towards apex.

‥ Head and thorax more strongly and closely punctured; elytra with three short lateral costæ, the outer costa the longest.

Length 1-2 mm.

Hab. Southeru Bombay: Belgaum. 


\section{Nodina crassipes, sp. $n$.}

Obscure æneous; legs more or less dark fulvous; underside blackish.

Head clusely and finely punctured, a short oblique groove above both eyes; clypeus not separated from the face, punctured like the head; antennæ obscure dark fulvous, with strongly thickened terminal joints. Thorax about $t w o$ and a half times broader than long, sides feebly rounded; surface very clcsely punctured, puncturation scarcely stronger than that on the head. Scutellum broad, subovate. Elytra regularly punctate-striate, the punctures distinct to apex, last row of punctures in front of the shoulders obliquely curved; interstices flat. Legs very robust; femora strongly thickened; tibiæ and tarsi fulvous, the former strongly widened at apex.

Length $23 \mathrm{~mm}$.

$H a b$. Mussoorie ( $7500 \mathrm{ft}$.) (Colls. Departm. of Agricult. India $\oint^{\circ}$ Jacoby).

Can be distinguished by the robust and thiskened legs and their coloration.

\section{Nodina rufipes, sp. $\mathrm{n}$.}

Beneath blackish, above greenish-cupreous; antennæe and legs reddish-fulvous.

Oblong, rather short. Head extremely minutely and rather distantly punctured, sides distinctly sulcate above the eyes; anterior margin of the clypeus concave; labrum fulvous; terminal joints of antennæ strongly thickened. Thorax finely and closely punctured, the punctures at the sides however well separated, nearly obsolete; lateral margins very feebly rounded. Seutellum impunctate, bluish. Elytra comparatively strongly and regularly punctate-striate. Prosternum much broader than long, with a few fine punctures.

Length $2 \mathrm{~mm}$.

Hab. Burma: Momeit (Coll. Brit. Mus.).

Differs from $N$. indica, Jac., in the finely punctured thorax, the sides of which are nearly smooth, also in the less elongated body.

\section{Nodina nigrilabrum, sp. $n$.}

Greenish-cupreous or æneous ; basal joints of antennæ and legs fulvous; labrum dark.

o. Head very finely and rather distinctly punctured, with distinct oblique sulcus in front of eyes; mandibles robust; antennæ extending to middle of elytra, basal five or six joints fulvous, rest black, third joint much slenderer and shorter than second. Thorax twice as broad as long, sides straight at base, rounded in front; surface closely and distinctly punctured, puncturation rather more dense at the sides. Elytra ovate, regularly punctate-striate, 
punctures of similar size to those on the thorax; interstices with a few minute punctures. Underside black, with slight æneous gloss; prosternum strongly punctured; rest of surface finely punctate.

․ Sides of elytra with two costæ, both very short and from below shoulders towards margin, the inner one the shorter.

Length $2 \mathrm{~mm}$.

$H a b$. Southern India: Nilgiris (H. L. Andrewes).

Differs from $N$. rufipes in the dark labrum, black terminal joints of autennæ, and the thorax distinctly punctured throughout; the female may be recognized by the very short elytral costæ that do not extend to the middle.

502. Nodina parvula, Jac. Ann. Mus. Civ. Genova, xxxii, 1892, p. 902.

Beneath blackish, above metallic greenish-æneous; basal joints of antennæ and legs dark fulvous.

Convex, rather pointed posteriorly. Head with a few minute punctures; clypeus bounded laterally by a distinct ridge extending upwards to middle of eyes, anterior edge deeply emarginate; labrum and palpi fulvous; antennæ with strongly thickened apical joints, basal five fulvous, rest black. Thorax at least twice as wide at base as at apex, rather strongly deflexed anteriorly, sides nearly straight; surface only visibly punctured when seen under a very strong lens, punctures at sides more sparse. Elytra strongly punctate-striate, punctures distinct to apex but nearly absent on the sides behind the middle. Legs short and robust.

Length $2 \mathrm{~mm}$.

Hab. Burma: Ruby Mines.

\section{Nodina ceylonensis, sp. $n$.}

Very dark æneous beneath, æneous-greenish above; antennæ and legs dark fulvous.

ㅇ. Head very closely and finely punctured; anterior edge of clypeus moderately emarginate at middle; labrum fulvous; antennæ short, terminal five joints strongly thickened. Thorax at least twice as broad as long, sides rounded anteriorly, surface punctured like the head. Elytra ovate, extremely finely punctatestriate, sides slightly more strongly punctured, an acute costa parallel with the lateral margins, shoulders also costiform. Abdomen nearly black, very finely punctured; breast smooth; prosternum strongly punctured.

Length $1 \frac{3}{4} \mathrm{mim}$.

$H a b$. Ceylon (Coll. Jacoby).

Smaller than N. parvula and separated from that species by the single elytral costa and much finer puncturation.

Male unknown. 
504. Nodina pusilla, Motsch. Étud. Ent. 1858, p. 108.

"Greenish-æneous, beneath black; mouth-parts, antennæ, and legs rufous; palpi robust, last joint elongate-ovate; antennæ half the length of body, apical joints strongly thickened, first joint incrassate, elongate, second scarcely half the length of first, ovate, third smaller than second, fourth subtriangular, following joints dilated, the last ovate. Thorax transverse, sparsely punctured, narrowed anteriorly, posteriorly marginate, median lobe produced in front of scutellum, posterior angles subacute, prominent. Scutellum subrotundate, impunctate, apex acuminate. Elytra punctate-striate, punctures obliterated posteriorly, interstices impunctate. Body beneath sparingiy pubescent; legs robust, emargination of the tibiæ pubescent.

"Length $1 \frac{1}{2} \mathrm{~mm}$.

"Hab. India." (Motschulsky.)

As Motschulsky deseribes his species as having the elytral puncturation obliterated posteriorly, it cannot be identified with N. parvula, Jac., which latter is also larger. The puncturation of the thorax is only given as sparse, but not whether the punctures are deep or shallow.

\section{b. Tarsi fulvous, legs clark.}

505. Nodina burmanica, Jac. Ann. Mus. Civ. Genova, xxxii, 1902, p. 904.

Obscure æneous; antennæ, apex of tibiæ and the tarsi fulvous.

Ovate, scarcely narrowed posteriorly. Head remotely but distinctly punctured; labrum fulvous; antennæ robust, terminal joints slightly darker, transversely thickened. Thorax with sides very feebly rounded; surface evenly, rather strongly but remotely punctured. Elytra slightly darker than the thorax, punctatestriate, punctures scarcely stronger than those on the thorax.

Length $2 \mathrm{~mm}$.

Hab. Burma; Karennee. Type in Genoa Museum.

Intermediate in size between $N$. parvula, Jac., and N. robusta, Jac., principally distinguished by the colour of the tibiæ and tarsi.

\section{Nodina subcostata, sp. n.}

Beneath black, above metallic dark blue; basal joints of antennæ fulvous; tarsi obscure piceous or dark fulvous.

. Head very finely and sparingly punctured; clypeus rather more strongly punctate, anterior edge deeply emarginate at middle; basal three or four joints of antennæ fulvous, rest black, strongly thickened, basal joint black above. Thorax twice as broad as long, sides strongly rounded; surface convex, strongly 
and closely punctured throughout. Elytra oblong with feeble depression below base, very strongly punctate-striate, punctures rather more feeble towards the apex; a strongly raised short costa from the humeral callus to the margins, preceded by another shorter costa below the shoulders. Tarsi rather elongate. Prosternum longer than broad, surface slightly concave, sparingly punctured.

Length $2 \mathrm{~mm}$.

Hab. Manipur (Coll. Brit. Mus.).

The strong puncturation of thorax and elytra and the two lateral costæ on the latter separate this species from all others.

507. Nodina tarsalis, Duriv. Amn. Soc. Ent. Bely. xxxvi, 1892, p. 409,

Underside, femora and tibiæ black; labrum, palpi, antennæ and tarsi fulvous; above bluish-black; thorax sometimes æneous or cupreous.

Head finely punctured, with groove near the posterior margin of eyes; clypeus subquadrate, emarginate anteriorly ; antennæ with slightly thickened terminal joints. Thorax transverse, sides rounded in front; surface very finely punctured, punctures placed at equal distances; a fine groove, partly punctured, parallel with basal margin. Elytra regularly rounded, narrowly margined at sides, feebly narrowed posteriorly, very convex, punctate-striate ; punctures fine, obsolete near sides and apex ; interstices very finely rugose.

Length $1 \frac{2}{3} \mathrm{~mm}$.

Hab. Bengal : Mandar; Malabar : Mahé.

The specimens I possess from the same locality have all the head and thorax obscure æneous or cupreous, but agree fairly well with the author's description of the typical form.

\section{Nodina belgaumensis, sp. $\mathrm{n}$.}

Beneath black, above obscure æneous; antennæ and tarsi fulvous.

Head entirely impunctate; clypeus not separated from the face; antennæ short, terminal joints strongly thickened, last joint oblong, ovately thickened. Thorax twice as broad as long or rather broader; sides strongly deflexed, lateral margins feebly rounded, surface entirely impunctate. Elytra finely punctate-striate; flanks of thorax impunctate. Intermediate and posterior tibiæ strongly emarginate at apex.

Length $1 \frac{3}{4} \mathrm{~mm}$.

Hab. Southern Bombay: Belgaum. Type in Coll. H. E. Andrewes.

Distinguishable from other forms by the entirely impunctate head, colour of legs, \&c. 


\section{c. Legs bicolorous.}

509. Nodina robusta, Jac. Ann. Mus. Civ. Genova, xxxii, 1892, p. 903.

Broadly rounded, convex; black beneath, bluish-black above; basal joints of antennæ and base of anterior femora fulvous.

Head remotely and finely punctured near the clypeus, vertex nearly impunctate, anterior edge of clypeus angulate-emarginate; labrum fulvous ; antennæ black, basal five joints fulvous, terminal joints short and thick. Thorax nearly two and a half times as broad as long, sides very feebly rounded; surface very finely punctured, punctures at sides elongate. (In the original description the puncturation is given as strong, this is an unfortunate error.) Elytra moderately strongly punctate-striate, rows rather distantly placed, punctures very faint at apex. Base of anterior and intermediate femora fulvous, rest black.

Length $3 \mathrm{~mm}$.

$H a b$. Burma.

\section{d. Legs clark or black.}

510. Nodina æneicollis, Jac. Ann. Soc. Ent. Bely. xxxix, 1895, p. 271.

Beneath black; thorax obscure cupreous; elytra metallic greenish.

Broadly rounded, very convex. Head finely and remotely punctured, obscure æneous; clypeus slightly more closely punctured;

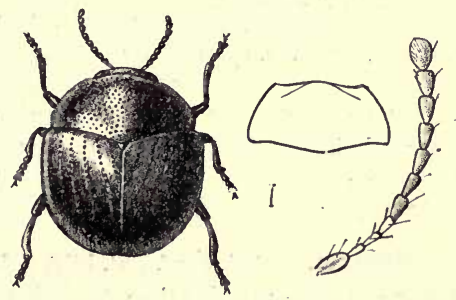

Fig. 113.-Nodina cencicollis.

labrum and mandibles piceous; antennæ black, basal four or five joints fulvous, terminal joints extending to base of thorax only, transversely widened. Thorax at least twice as broad as long, sides straight, posterior margin oblique at sides, median lobe broadly rounded, anterior portion of disc strongly deflexed; surface closely and distinctly punctured, punctures evenly distributed, rather more closely placed on the sides. Elytra as wide as thorax at base, deeply punctate-striate, punctures distinct to apex, outer row near lateral margin consisting of a few punctures only at base.

Length $2 \mathrm{~mm}$. 
Hab. Southern Bombay: Belgaum.

The obscure æneous colour, black underside and legs and strong elytral puncturation principally distinguish this species. In some specimens the tarsi are obscurely fulvous, but the sculpture and colour separate these from $N$. tarsalis, Duv.

\section{e. Above pubescent.}

\section{Nodina hirta, sp. n.}

Aneous or cupreous; finely pubescent; antennæ and legs fulvous.

đ. Oblong-ovate. Head closely and finely punctured, sparingly clothed with fine grey pubescence; clypeus semicircularly emarginate in front, not separated from face; labrum fulvous; antennæ entirely fulvous; terminal joints strongly thickened, extending nearly to the middle of the elytra. Thorax quite twice as broad as long, sides straight at base, rounded anteriorly, surface extremely closely and rather strongly punctured and sparingly pubescent. Elytra finely punctate-striate, the interstices extremely minutely punctured and granulate, finely pubescent. Legs rather long and robust. Prosternum strongly transverse, finely punctured. Underside obscurely æneous, nearly smooth.

q. Elytra 1.ith an acute costa from shoulders nearly to apex and close to lateral margins, preceded by another rather shorter costa.

Length $1 \frac{1}{2}-2 \mathrm{~mm}$.

Hab. Nilgiris (H. L. Andrewes).

A rather remarkable species on account of the finely pubescent upper suface, which, however, can only be seen in well preserved specimens; the closely punctured thorax and finely granulate and punctured elytral interstices further distinguish the species.

I give below translations of the descriptions of three species indicated by Motschulsky. It seems impossible, however, to identify them for want of details.

512. Nodina subdilatata, Motsch. Étud. Ent. 1858, p. 109.

"A little larger aud more rounded than $N$. pusilla, thorax more transversely shaped, more strongly narrowed anteriorly, the posterior angles more produced, puncturation stronger. Elytra with more strongly rounded sides, the punctures stronger and visible to apex." (Motschulsky.)

Hab. India (teste Motschulsky).

513. Nodina lævicollis, Motsch. Etud. Ent. 1858, p. 109.

"One half larger, more convex and more smooth than N. pusilla; last five joints of antennæ black. Thorax more convex, puncturation extremely fine. Elytra: the punctures obliterated on the sides and apex.

"Hab. India." (Motschulsky.) 
514. Nodina rotundata, Motsch. Étud. Ent. 1858, p. 109.

"Nearly the same size as $N$. pusilla, a little shorter and more rounded. Thorax nearly triangular, posterior angles more strongly pointed than in N. subdilatata, puncturation less deep, finer and rather obsolete. Elytra with punctures and striæ at apex more obliterated.

"Hab. India." (Motschulsky.)

\section{Genus NODOSTELLA, nov.}

Elongate; antennæ filiform, third joint twice as long as second, following joints nearly of same length. Thorax broader than long, lateral margins subangulately rounded behind the middle, surface with some irregular depressions. Scutellum broadly ovate. Elytra wider at base than thorax, elongate, punctate-striate. Legs slender ; intermediate and posterior femora strongly emarginate at apex; tarsi and claw-joint elongate, claws appendiculate. Prosternum longer than broad, widened at base, the latter straight. Anterior margin of thoracic episternum concave.

This genus, although very closely allied to Nodostoma, differs in the elongate shape of the elytra, the less transverse and slightly narrowed thorax with discoidal depressions, and in the shape of the prosternum which is longer than broad, not transverse as in Nodostoma. Several species formerly placed in the latter genus should find a place in Nodostella, which is proposed for the reception of Nodostella elongata, Jac., previously placed in Nodostoma. The sculpturing of the thorax and the elytra differs likewise from any species of Nodostoma.

515. Nodostella elongata, Jac. (Nodostoma) Ann. Soc. Ent. Belg. xlvii, 1903, p. 98.

More or less piceous; breast black; head and thorax with some obscure testaceous spots. Elytra testaceous, irregularly spotted with black.

Narrowly elongate. Head closely rugose-punctate; two spots between the eyes, clypeus and labrum testaceous, rest black; antennæ long and slender, basal two joints and apex of the others flavous, third and fourth joints nearly equal, elongate, rest of equal length. Thorax about half as broad again as long, sides angulate behind the middle; surface rather depressed, closely covered with elongate reticulations, the interstices closely punctured; disc with some obscure depressions, varied more or less with piceous and flavous. Scutellum black. Elytra wider at base than the thorax, with a short depression below base, strongly and closely punctate-striate, basal portion more irregularly punctured, with a short costa near the shoulders: the markings very irregular, in the more strongly marked specimens with an elongate spot at base between shoulders and suture, some transverse narrow bands 
or spots within depression and a broad transverse band, consisting of united elongate spots, at middle, another elongate spot near apex. Legs flarous, knees black.

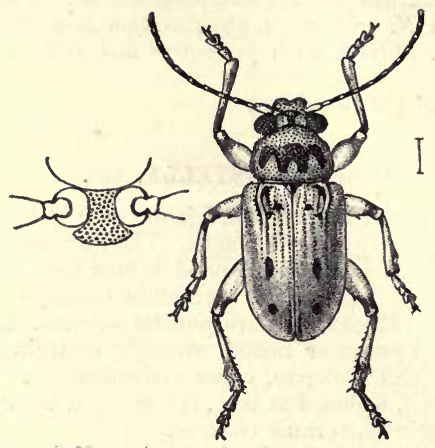

Fig. 114.-Nodostella elongata (var.).

Var. Thorax obscure dark fulvous with an irregular piceous transverse band; elytra flavous, with two piceous spots at base and two behind the middle.

Length $4 \mathrm{~mm}$.

$H a b$. Nilgiris.

Genus AUTOLAMPRA, n. nom.

Nephus, Jacoby, Ann. Mus. Civ. Genova, xxvii, 1889, p. 165.

Body oblong; antennæ filiform. Thorax transverse, sides rounded. Elytra closely and somewhat regularly punctured. Posterior tibiæ emarginate near apex; claws appendiculate. Prosternum broad, slightly longer than broad. Anterior margin of thoracic episternum concave.

$\delta$ (?). Posterior femora ciliate beneath, furnished with a long and broad appendage.

Founded on a single species, possessing most of the characters of Nodostoma, but the posterior tibiæ einarginate only, and the emargination placed on the inner, not on the outer, side; the posterior femora with a curious appendage, probably only a male character. The generic name Nephus having already been used in Coleoptera, I now change it as above.

516. Autolampra femorata, Jac. (Nephus) Ann. Mus. Civ. Genova, xxvii, 1889, p. 166.

Beneath piceous; sides of breast and femora metallic green; antennæ black, basal joints fulvous; head and thorax cupreous; elytra metallic dark blue. 
Head nearly impunctate, flat; eyes notched; clypeus separated from face by a transverse depression, cupreous like the rest of
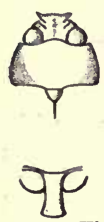

Fig. 115.

Autolampra femorata. the head ; labrum and palpi piceous ; antennæ more than half the length of the body, basal five joints fulvous, rest black, second joint extremely small, third and fourth elongate, equal, terminal joints slightly curved, inserted at the extreme base of the preceding joint. 'Thorax twice as broad as long, slightly widened at middle, sides narrowed in front, narrowly margined; surface strongly and remotely punctured, more closely so at sides. Scutellum metallic green. Elytra very strongly punctate-striate, the punctures arranged in close rather regular rows; interstices somewhat rugose and costate near apex. Femora metallic green, posterior femora with some long stiff bristles, their apices with a deep excavation; lower edge with a long blunt appendage ending in a small point piceous in colour with a bluish gloss.

Length $6 \mathrm{~mm}$.

$H a b$. Burma : Karennee. Type in the Genoa Museum.

\section{Genus NODOSTOMA.}

Nodostoma, Motsch. Reise Amur. ii, 1860, p. 176.

Basilepta (part.), Baly, Journ. Ent. i, 1860, p. 23; Chapuis, Gen. Coléopt. x, 1874, p. 261 ; Lefév. Cat. Eumolp. 1885, p. 57.

Type, $N$. fulvipes, Motsch., from China.

Kange. Most parts of India, Malay Archipelago; Tropical Asia.

Body ovate or oblong; antennæ filiform, apical joints sometimes slightly thickened. Thorax generally transverse, narrowed in front, rarely subcylindrical, more or less angulate at the sides near base, with narrow sulcus near the anterior margin. Elytra generally wider at base than the thorax, and more or less deeply depressed below base, punctate-striate, sometimes metallic, generally flavous or fulvous. Prosternum broad, subquadrate, base truncate. Legs rather long; femora incrassate, frequently with a small tocth; intermediate and posterior tibiæ emarginate at apex, claws appendiculate.

The species of this genus are very numerous, closely allied and often difficult to distinguish. They vary also frequently in the shape of the thorax and prosternum, but this is so much a matter of degree that it does not allow of subgeneric separation. As a rule, the species of Nodostoma may be known by the transverse, anteriorly strongly narrowed thorax and its more or less distinctly angulated sides; there is also a narrow sulcus close to the anterior margin, more or less strongly marked, but always distinct at the sides. 


\section{Species entively metallic.}

Sides of thorax angulate.

517. Nodostoma denticolle, Jac. Ann. Mus. Civ. Genova, xxxii, 1892, p. 900.

Metallic green or cupreous, antennæ dark fulvous.

Head extremely closely and rather finely rugose-punctate, without grooves; labrum fulvous, with a black spot or entirely black; palpi fulvous; antennæ slender and filiform. Thorax twice as broad as long, rather convex; sides very acutely dentate behind the middle, strongly obliquely narrowed in front; surface very closely and finely punctured throughout, anterior sulcus deep. Scutellum very minutely punctured. Elytra with deep transverse depression below base, the latter raised; shoulders very prominent; surface finely punctate-striate, the striæ distantly placed near suture, stronger and more closely approximate at sides; punctures very fine behind the middle. Femora with a small tooth.

Length $6 \mathrm{~mm}$.

Hab. Bengal: Mandar; Burma: Pegu District.

518. Nodostoma nobilitatum, Jac. Ann. Soc. Ent. Belg. xxxix, 1895, p. 279.

$\delta$. Black or piceous beneath; above metallic green or cupreous; basal joints of antennæ fulvous.

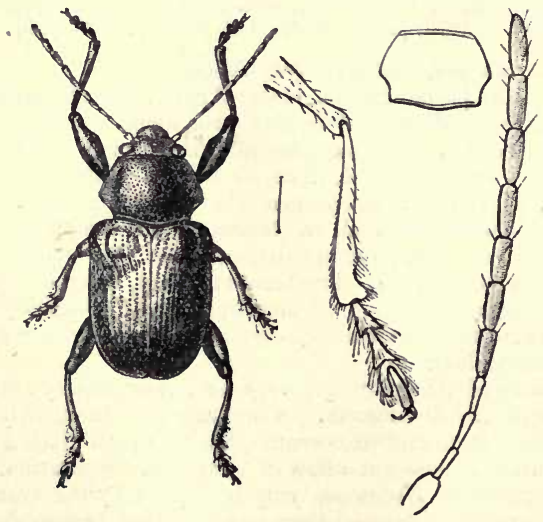

Fig. 116.-Nodostoma nobilitatum.

Head closely and strongly punctured throughout; labrum fulvous; antennæ black, extending to middle of elytra, basal 
four joints fulvous, basal joint black above. Thorax half as broad again as long, rather convex; sides strongly angulate behind the middle, greatly narrowed anteriorly ; anterior sulcus entire; surface convex, rather strongly, evenly and closely punctured. Elytra oblong, wider at base than the thorax, deeply transversely sulcate below base, strongly punctate-striate ; strix closely approximate at the sides, slightly finer at apex; interstices with some minute punctures. Legs and breast more or less æneous; flanks of thorax tinely and sparingly punctured.

ㅇ. Thorax twice as broad as long, puncturation partly substrigose at sides, very close; elytral puncturation rather finer.

Length 4-6 mm.

$H a b$. Southern Bombay : Kanara.

Differs from $N$. denticolle, Jac. in having only the basal joints of the antennæ fulvous, the rest dark ; in the much less wide thorax of the male and its puncturation, which is distinctly less closely placed. In $N$. denticolle the anteunæ are entirely fulvous and the thorax in both sexes is strongly transverse.

519. Nodostoma fulvicorne, Jac. Ann. Soc. Ent. Belg. xlviii, 1904, p. 387 .

Metallic green, blue or cupreous ; antennæ pale fulvous; tarsi piceous.

Head remotely and moderately strongly punctured, obliquely grooved at sides of clypeus, the latter strongly punctured; labrum fulvous; antennæ with the terminal joints rather short and thickened. Thorax twice as broad as long, lateral margins strongly angulate at base, anterior margin accompanied by a deep transverse groove; surface very finely and remotely punctured on the dise, sides confluently foveolate-punctate. Scutellum with a few fine punctures. Elytra with rather deep transverse depression at base, finely punctate-striate, punctures still finer at the apex. Beneath metallic greenish or bluish. All the femora armed with a very minute tooth.

Length $4 \mathrm{~mm}$.

$H a b$. Southern India : Nilgiris; Anaimalais.

Sufficiently distinguished by the pale coloured antennæ and the difference between the deep lateral punctures on the thorax and the fine punctures on the disc.

520. Nodostoma capitatum, Jac. Ann. Mu8. Civ. Genova, xxxii, 1892, p. 899 .

Metallic green ; antennæ (basal joints excepted), tibiæ, tarsi and abdomen blackish ; elytra purplish.

Head closely and strongly punctured throughout, interstices transversely rugose; clypeus continuous with the face, anterior edge deeply emarginate; labrum fulvous; antennæ black, fliform, basal four joints fulvous, apical joints in the only specimen known wanting. Thorax about half as broad again as long; 
sides oblique, strongly narrowed in front, angulated close to base ; surface strongly rugosely punctured throughout, anterior sulcus deep. Elytra wider at base than thorax, convex, subquadrate, moderately deeply depressed below base, very closely and strongly punctate-striate ; shoulders prominent, Femora bluish.

Length $2 \frac{1}{2} \mathrm{~mm}$.

Hab. Burma: Bhamo. Type in Genoa Museum.

The rugosely punctured head and thorax, closely punctured elytra and much smaller size separate this species from the preceding.

521. Nodostoma cyaneum, Lefêv. Bull. Soc. Ent. Belg. xxxv, 1891, p. celxri.

"Beneath black; breast obscure cyaneous; above dark cyaneous; labrum, palpi and antennæ fulvous, apical five joints of antennæ and the legs black ; tarsi fuscous.

"Head strongly punctured, a small fovea between the eyes. Thorax transverse, sulcate near the anterior margin; sides before the middle subspinosely angulate; surface convex, finely and densely aciculately punctured. Scutellum smooth, foveolate at middle, apex rounded. Elytra below base feebly transversely impressed, punctate-striate, punctures at - sides and within depression larger; humeral callus very prominent, smooth.

"Length $7 \mathrm{~mm}$.

Hab. "Sikhim." (Lefèvre.)

A large species, but unknown to me. Lefèvre gives the sides of thorax as angulate "before the middle"; as a rale, the angulation is behind the middle.

\section{Nodostoma pretiosum, sp. n.}

Metallic cupreous, blue or green; basal joints of antennæ and base of femora fulvous, terminal joints of antennæ and the tarsi black.

o. Broadly ovate. Head coarsely rugose-punctate, vertex at middle smooth; labrum and palpi fulvous; autennæ slender and filiform, basal four joints fulvous. Thorax strongly transverse; sides angulate behind the middle, strongly obliquely narrowed in front; anterior sulcus deep; surface very strongly punctured, on the sides the punctures partly confluent. Elytra subquadrately ovate, distinctly depressed below base at the sides; purcturation much finer than that of thorax, more strongly punctured within depression, the rows distantly placed, extremely fine at apex. Femora strongly incrassate, knees and tibiæ metallic; femoral tooth minute. Body beneath greenish.

The female searcely differs from the male, except in its larger size and more slender antennæ.

Var. Legs entirely metallic blue or green. .

Length $4 \frac{1}{2}-5 \mathrm{~mm}$.

Hab. Assam: Sylhet.

The very strong thoracic puncturation distinguisshes this species. 


\section{Nodostoma chalceum, sp. $n$.}

Dark æneous; antennæ, tibiæ and tarsi more or less flavous; abdomen fulvous.

․ Head finely and very remotely punctured; elypeus not separated in front from the face, more strongly punctured, anterior margin fulvous, thickened at the sides, semicircularly emarginate; labrum fulvous; palpi flavous; antennæ slender, pale fulvous or flavous, third and fourth joints equal, terminal two elongately thickened. Thorax twice as broad as long, sides very strongly produced into a tooth behind the middle, strongly obliquely narrowed in front and at base, anterior sulcus deep and entire, surface closely and more strongly punctured than the head. Scutellum trigonal. Elytra oblong, shoulders and basal portion strongly raised, the latter with a deep depression; surface deeply foveolate punctatestriate at base within depression, more finely and remotely so posteriorly ; sides below shoulders with two acutely raised costæ.

Length $2 \frac{1}{2} \mathrm{~mm}$.

Hab. Assam (Coll. Jucoby).

Very distiuct on account of its system of coloration, elytral sculpturing, \&e.

524. Nodostoma splendens, Hope (Eumolpus), in Gray's Zool. Misc. 1831, p. 30 ; Lefèv. (Colasposoma) Cat. Eumolp. 1885, p. 107.

Black; basal three joints of antennæ fulvous. Elytra aureocupreous.

Head strongly and rather closely punctured; labrum fulvous; antennæ with the third joint shorter than the fourth, terminal joints very elongate. Thorax transverse, subangulate near base, evenly, strongly and closely punctured. Elytra with lateral depression at sides below base, the latter rather strongly punctured, posterior portion finely puuctured. ILegs black; femora unarmed.

Length $6 \mathrm{~mm}$.

Hab. Nepal. Type in Brit. Mus.

This insect was described from a single, apparently female, specimen, and because of the useless diagnosis of the author was placed in the wrong genus by Lefèvre. It is a true Nodostoma of broadly subquadrate-ovate shape, and well distinguished by the black colour of all the parts except the elytra which are bright cupreous. The insect seems to be very rare, as I have seen oniy the type specimen; it belongs to the group containing the largest species of the genus.

525. Nodostoma semipurpureum, Jac. Ann. Mus. Civ. Genova, xxxii, 1892, p. 902.

Beneath metallic dark blue, above purplish; basal joints of antennæ fulvous.

Oblong; head distinctly but not closely punctured, space at voL. I. 
base of antennæ metallic blue, rest purplish; labrum piceous; palpi fulvous, apical joint piceous; antennæ black, half the length of body, basal four joints fulvous, third and fourth equal. Thorax twice as broad as long, sides obliquely narrowed in front, angulate behind the middle; disc rather convex, finely and not very closely punctured, sides scarcely more strongly or closely punctured. Elytra subquadrate, distinctly transversely depressed below base, extreme lateral margins blue; puncturation fine and regular near the suture, coarse and close at the sides; an obsolete short costa below shoulders. Posterior femora with a small tooth.

Length $4 \frac{1}{2} \mathrm{~mm}$.

$H a b$. Burma : Karennee. Type in Genoa Mus.

Distinguished by the purplish coloration, evenly and finely punctured thorax, and its convex shape.

\section{Nodostoma convexicolle, sp. n.}

Violaceous or metallic green; basal joints of antennæ and labrum fulvous; abdomen black.

Oblung. Head closely and strongly subpunctate-rugose, vertex longitudinally strigose; clypeus deeply concave-emarginate: antennæ black, basal three joints fulvous, basal joint black above, second to fourth gradually lengthened, terminal joints elongate. Thorax about twice as broad as long, sides distinctly angulate near base, strongly obliquely narrowed in front, anterior sulcus deep and entire; surface convex, closely and finely punctured, punctures of equal size, evenly distributed. Scutellum oblong, black. Elytra convex, narrowed at apex, deeply transversely depressed below base, strongly and regularly punctate-striate, the punctures closely placed; shoulders very prominent. Legs black, femora with a minute tooth; flanks of thorax smooth, with a few oblique strigæ.

Length $6 \frac{1}{2}-7 \frac{1}{2} \mathrm{~mm}$.

Hab. Assam (Coll. Brit. Mus.).

One of the largest species of the genus, which besides its size may be known by the rugosely punctured head and convex surface of the thorax; these seem to be males: whether two bright metallic-green female specimens of larger size, with a shorter and more transverse thorax, metallic legs and stronger femoral teeth, are the other sex of this species is doubtiul, they agree, however, in every other detail with the violaceous form; their locality is simply marked "India or."

527. Nodostoma bhamoense, Jac. Ann. Mus. Civ. Genova, xxxii, 1892, p. 896.

ð. Dark blue; basal four joints of antennæ fulvous; abdomen black; tibiæ dark piceous.

Head and clypeus strongly punctured, the punctures more sparse in the middle, the latter with a short longitudinal groove, anterior edge of clypeus deeply subtriaugularly emarginate; 
labrum fulvous; antennæ filiform, about half the length of the body, third and fourth joints equal, elongate. Thorax half as broad again as long (more transverse in $\$$ ), sides oblique, feebly angulate close to base, anterior portion strongly narrowed, the submarginal sulcus very deep and entire; surface very closely, evenly and strongly punctured, the punctures very crowded at the sides and all larger than the interstices. Elytra oblong, very feebly impressed below base, rather closely and finely punctate-striate, punctures distinct to apex. Breast dark blue. Prosternum strongly puuctured.

Length $4 \mathrm{~mm}$.

Hab. Bengal : Mandar; Burma: Bhamo.

Described originally from a single specimen, but received since in considerable numbers from Mandar. The thorax in the male insect is less transverse than in many of its allies, the lateral angle but little marked, and the puncturation very close and even, especially on the elytra.

\section{Sides of thorax rounded.}

\section{Nodostoma gracilipes, sp. n.}

Metallic dark blue; antennæ (basal joints excepted) and underside black; palpi fulvous; tibiæ and tarsi black.

o. Subelongate; head remotely and rather finely punctured; cly peus not separated, anterior margin concave; labrum piceous; basal joints of palpi fulvous, apical joint black : antennæ with the basal three joints fulvous, rest black, third joint much shorter than the fourth, terninal joints elongate and slender. Thorax subcylindrical, half as broad again as long, sides rounded, widest at middle; surface somewhat flattened, with the anterior portion rather deflexed at sides, more closely but scarcely more strongly punctured than the head, punctures evenly distributed and of equal size; sides of disc with a shallow depression (in 우), anterior margin preceded by an obsolete transverse groove at the sides only, basal margin with deep groove. Scutellum oblong-ovate, impunctate. Elytra much wider at base than thorax, rather elongate, very strongly and closely punctured, the punctures in approximate rows near suture, irregularly arranged at the sides; interstices slightly transversely rugose near shoulders. Legs slender, femora unarmed, apex of tibiæ clothed with yellow pubescence ; first joint of tarsi dilated, more slender in the female. Prosternum rather broad, strongly punctured.

․ Elytra rather more strongly and closely punctured, sides below shoulders with two short elongate ridges.

Length 4-5 mm.

Hab. Burma: Ruby Mines. Type in Brit. Mus.

The rather narrow elongate shape, close and strong puncturation of elytra, non-angulate thorax, and the elytral costæ of the female separate this species from other metallic forms. 
529. Nodostoma fabrei, Lefêv. Bull. Soc. Ent. France, 1887, p. clxxv.

Obscure cyaneous, subelongate-orate. Head strongly punctured; clypens continuous with face, apex emarginate; labrum, palpi and autennæ fulro-testaceous, the last extending to half the length of the body, terminal five joints fuscous. Thorax subcylindrical, sides evenly rounded, surface strongly and remotely punctured. Scutellum triangular, smooth. Elytra strongly impressed below shoulders, strongly punctate-striate, punctures absent near apex. Legs elongate, brownish-testaceous or piceous ; femora with minute tooth.

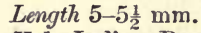

Hab. India: Ramnad; Darjeeling; Mungphu; Burma: Ruby Mines.

Specimens from the last-named localities agree so closely with Lefèvre's description of this species that I must refer them to it; the only difference is in the colour of the antennæ, which in my specimens are black with the basal three joints testaceous. The general colour of the forms also varies from dark blue to greenishæneous.

530. Nodostoma semicæruleum, Jac. Ann. Mus. Cin. Genova, xxxii, 1892, p. 897.

Black beneath; metallic dark blue above; basal joints of antennæ fulvous.

Head finely and remotely punctured; labrum fulvous; antennæ black, slender, basal four joints fulrous, third and fourth joints searcely longer than the second but more slender, following joints shorter and thicker. Thorax at least twice as broad as long, sides strongly deflexed, lateral margins subangulately rounded at the middle; disc deeply and very closely punctured, especially at the sides, punctures round. Elytra scarcely wider at base than the thorax, depressed below the base, deeply punctate-striate ; interstices longitudinally costate at sides, punctures very regular on the dise.

Length $3 \mathrm{~mm}$.

Hab. Burma.

\section{Nodostoma dubiosum, sp. $n$.}

Beneath black; above metallic dark blue; basal joints of antennæ partly flavous.

. Head remotely punctured on vertex; clypeus more closely punctate, anterior edge nearly straight; labrum piceous; antennæ black, basal two joints flavous beneath, third distinctly shorter than the fourth. Thorax half as broad again as long, scarcely narrowed in front, sides rounded, surface strongly and closely punctured. Elytra oblong, wider at base than the thorax, with 
a depression below the base, rather more strongly punctured than the thorax, puncturation arranged in closely approximate, rather irregular rows; sides with two costæ, one continued nearly to apex, the other short, both starting from the shoulders.

Length $3 \frac{1}{\frac{1}{1}} \mathrm{~mm}$.

Hai). Burma: Ruby Mines (Colls. Brit. Nus. \& Jacoby).

Smaller than $N$. blamoense, Jac., the thorax more subcylindrical and less strongly punctured, elytra narrower, with lateral costæ. The thoracic puncturation, although comparatively strong, has the punctures less deep and round than in $N$. bhamoense.

\section{Elytra pale with suture or lateral maigins black, interstices more or less costate or convex.}

\section{Nodostoma unipunctatum, sp. $n$.}

Testaceous; sutural margins and a spot near apex of each elytron black.

Head strongly and rather closely punctured; clypeus not separated from the face, distinctly emarginate in front; antennæ testaceous, nearly extending to apex of elytra, third joint scarcely longer than the second, following joints nearly equal. Thorax about half as broad again as long, sides angulate behind the middle, anterior sulcus narrow but entire; surface more finely and more closely punctured than the head. Scutellum piceous or testaceous. Elytra with short but deep basal depression, strongly punctatestriate, the punctures distinct although finer at apex, interstices at sides longitudinally costate ; shoulders tuberculiform, followed by another short costa that extends to the lateral margins; suture narrowly black, another oblong black spot belind the middle, halfway between margins and suture. Legs elongate; femora unarmed. Prosternum nearly impunctate.

Length $7 \mathrm{~mm}$.

$H a b$. Southern India: Nilgiris (Colls. H. E. Andrewes \& Jacoby).

The largest species of this division and distinguished by the black suture and subapical spots.

533. Nodostoma andrewesi, Juc. Ann. Soc. Ent. Belg. xlvii, 1903, p. 97 .

Fulvous ; sides of elytra black.

Head very strongly and rather closely punctured ; clypeus deeply emarginate in front; antennæ slender and filiform, third joint distinctly shorter than the fourth, basal four joints fulvous, rest piceous. Thorax twice as broad as long, sides rounded at base, strongly obliquely narrowed in front, anterior sulcus rather feeble; surface very finely and closely punctured, the punctures very crowded at the sides. Elytra ovate, deeply transversely depressed at 
the sides below the base, strongly punctate-striate; interstices very strongly costate, especially so at the sides, latter broadly black ; sutural and apical portions fulvous. Femora with a minute tooth.

Var. a. Entirely fulyous.

Var. $b$. Black, basal joints of antennæ fulvous.

Length $4 \mathrm{~mm}$.

$H a b$. Nilgiris.

The coloration in typical specimens and the strongly costate interstices at eides of the elytra distinguish this species from others closely allied to it.

534. Nodostoma geniculatum, Lefev. Bull. Soc. Ent. Belg. xxxv, 1891, p. cclxv.

"Body beneath, head, thorax and scutellum dark piceous; basal five joints of antennæ testaceous, rest fuscous; elytra pale fulrous, sutural and lateral margins, a small spot below base and the apex of the femora, the base and apex of the tibire and the tarsi, fuscous.

"Head strongly punctured, depressed and rugose between the eyes; labrum and palpi fulvous; antennæ scarcely so long as half the body, filiform. Thorax transverse, strongly punctate-sulcate near anterior wargin, sides areuate with reflexed narrow margins, strongly widened before the middle, closely and very finely punctured, punctures aciculate. Scutellum smooth. Elytra transversely foveolately impressed below the base, with a small piceous spot within the depression, regularly punctate-striate, punctures much finer towards apex, interstices at sides (particularly near shoulders) subcostate. Legs elongate; femora with a minute tooth.

"Length $5 \mathrm{~min}$.

"Hab. India orient." (Lefèvre). Bengal : Mandar ; Trichinopoly.

There are some specimens from the last-named localities before me which I refer to this species: one, apparently a male, is of more elongate and narrow shape, with the head testaceous at base, piceous in front, strongly but partially subrugosely punctured; everything agrees with Lefèvre's description, but it was clearly a slip of the pen on his part to say "the sides of the thorax are widened before middle," it ought to be "behind the middle" as is the case with all other species.

\section{Nodostoma longicorne, Jac. P. Z. S. 1887, p. 79.}

Fulvous; legs testaceous, knees piceous; elytra with the lateral margins anteriorly black.

0 . Head finely and rather remotely punctured; clypeus separated from the face by a few deep punctures; palpi testaceous; antennæ fulvous, as long as the body, apical joints darker, fourth ioint rather longer than the third. Thorax transverse, strongly 
narrowed in front, sides distinctly angulate near base; anterior sulcus deep and entire, impressed with punctures; surface very finely and rather remotely punctured, lateral margins obscure piceous. Elytra oblong-ovate, deeply transversely depressed below base, strongly punctate-striate anteriorly, more finely so towards apex ; interstices slightly convex, more distinctly so at the sides, the latter rather broadly piceous at base, this colour extends slightly across the elytral depression but is narrowed along the margins. Legs long and slender; femora with a small tootb.

+. Has shorter antennæ, a closely and finely punctured thorax, and the elytra scarcely perceptibly punctured below middle.

Var. Elytra entirely fulvous.

Length 4-5 $\mathrm{mm}$.

Hab. Ceylon.

In a o in my collection, the head is strongly and remotely punctured, much more so than is the thorax, the entire apical portion of the femora is black and the tooth very distinct. In coloration there is no difference.

\section{Nodostoma maculipenne, sp. n.}

Testaceous; breast obscure piceous; thorax with a transverse piceous band; elytra with one or two spots or short stripes at base, a larger spot near apex and sutural and lateral margins more or less black.

Head very sparingly and finely punctured, strongly obliquely sulcate on each side at base of clypeus; the latter transverse, with a row of punctures and a few punctures near the apex, anterior border feebly emarginate; antennæ filiform, third and fourth joints nearly equal. 'Thorax short and transverse, sides strongly angulate near base, margins narrowly reflexed, anterior sulcus entire, surface very finely and rather closely punctured, margins and a more or less distinct transverse band on disc black. Elytra oblong, with short but deep depression below base, strongly punc.tate-striate anteriorly, obsoletely so at apex, shoulders with a very deep sulcus within : the interstices slightly costate at base near the lateral margins, also a short oblique costa from shoulders. Femora unarmed.

Var. Elytra without spots.

I.ength $3 \mathrm{~mm}$.

Hab. Southern India: Nilgiris; Shembaganur (Coll. Brussels Mus.).

Of the elytral spots two or three more or less distinct are placed close to basal margin, the posterior one of more elongate shape and more plainly marked near suture at some distance from apex. These markings and those of the thorax, with the fine and close puncturation of the latter, will help to distinguish the species. In the variety, the elytra have an obscure spot within the depression and the margins piceous only, the interstices are rather 
more distinctly costate, the thorax is rather more finely and closely punctured, but markings and sculpture vary a good deal. In some specimens there is a transverse elytral piceous band behind the middle, in others this is replaced by \&pots; the thorax is also sometimes without the piceous band, and the only distinguishing characters are the short and transverse shape of the thorax and its fine and close puncturation.

537. Nodostoma cardoni, Jac. Mém. Soc. Ent. Bely. vii, 1900, p. 108.

Pale fulvous; elytra with a spot below base and the lateral margins anteriorly greenish-black.

Head remotely punctured, punctures finer on the vertex than in the middle; antennæ pale fulvous, third and fourth joints equal. Thorax short and strongly transverse, sides angulate close to base, strongly obliquely narrowed in front, anterior sulcus deep and entire; surface strongly punctured, punctures more closely placed and rather larger on the sides than on the disc. Elytra oblong, parallel-sided, deeply depressed below base, strongly punctate-striate, punctures deep and closely placed anteriorly, nearly obsolete at apex, interstices slightly convex.

Var. Entirely fulvous.

Length 4-5 mm.

$H a b$. Bengal : Mandar.

Very similar in size and colour to $N$. bipunctatum, Jac. but flavous beneath, the thorax and elytra much more strongly punctured, puncturation of latter distinct to apex, not obsolescent behind the middle, interstices raised. Differs from $N$. longicorne, Jac. in the shorter antennæ and the strongly punctured thorax.

\section{Interstices of elytia not costate, often with longitudinal bands or transverse spots.}

538. Nodostoma concinnicolle, Baly, Cistula Ent. ii, 1880, p. 373.

Pale piceous; antennæ and legs fulvous; elytra fulvous with the lateral margins and two spots black.

Head coarsely and deeply punctured, punctures on the extreme vertex closely crowded; antennæ slender, filiform, second joint three-fourths the length of the third, the latter two-thirds the length of the fourth. Thorax more than twice as broad as long; sides acutely angulate just in front of base, abruptly incurved just before apex, apical angle obtuse, hinder angle armed with a lateral tooth; disc closely corered with large, round and deep punctures, on either side are a few short suberect griseous hairs. Scutellum longer than broad. Elytra convex, transversely depressed below basilar space, strongly punctate-striate; on the transverse depression and also below the shoulders the puncturation is confused; interstices 
plain, irregularly wrinkled on the sub-basilar depression. Femora with an acute tooth.

$V a r$. Thorax piceous, elytra black.

Length $4 \mathrm{~mm}$.

Hab. Kashgar; Jhelam Valley; Bengal : Mandar.

Principally distinguished by the strong puncturation of thorax and elytra, and the comparative length of the joints of antennæ.

\section{Nodostoma duvivieri, sp. n.}

Fulvous; thorax with two black bands; elytra with a sutural black band from base to behind the middle, pointed at apex.

Oblong. Head nearly impunctate; clypeus with a few remote punctures; antennæ long and slender, fulvous. Thorax twice as broad as long, sides angulate behind the middle, obliquely narrowed to apex, anterior sulcus distinct at the sides only; surface strongly but remotely punctured on the sides, dise more sparingly punctured, a broad black patch from base to apex occupies almost the entire sides. Elytra oblong, with distinct depression below the base, rather strongly punctate-striate on the anterior two-thirds, apex nearly impunctate. Femora only moderately thickened, unarmed.

Var. Thorax without bands.

Length $3-3 \frac{1}{4} \mathrm{~mm}$.

Hab. Burma: Momeit; Ruby Mines. Type in Brit. Mus.

Although very closely allied and of very similar coloration to $N$. bengalensis, Duviv., the present insect differs in the comparatively strong puncturation of the thorax and elytra, these parts being nearly impunctate in $N$. bengalensis. The specimens I take to be females are of broader and more subquadrate shape and have no markings on the thorax; in other respects they are identical with the males.

\section{Nodostoma bistrigatum, sp. n.}

Testaceous; thorax with central black spot; elytra with sutural and lateral margins and a longitudinal short stripe at middle, black.

Head strougly but remotely punctured on the vertex; very closely punctured on the clypeus; basal four joints of antennæ testaceous, following two black, rest wanting in the type and only specimen. Thorax about half as broad again as long, sides angulate near base, anterior sulcus obsolete except at the sides, surface remotely and strongly punctured. Elytra oblong, subcylindrical, deeply depressed below the base, strongly punctatestriate anteriorly, more finely punctured behind the middle, interstices sparingly punctured, the black streak placed below depression between third and fifth rows of punctures. Femora unarmed.

Length $3 \frac{1}{2} \mathrm{~mm}$.

Hab. Ceylou (Coll. Jacoby). 
The single, apparently female, specimen before me resembles very closely $N$. lewisi, Jac., but is larger, with a much more remotely and less strongly punctured thorax, punctured elytral interstices, and different markings on the latter.

\section{Nodostoma violaceo-fasciatum, Jac. Ann. Mus. Civ. Genova,} xxxii, 1892, p. 901.

Dark fulvous; apical joints of antennæ black; elytra with broad, longitudinal violaceous band, not extending to apex.

Head rather convex, strongly punctured, the punctures sparse on the vertex, more closely placed anteriorly, three small tubercles between the eyes; antennæ black, basal four joints fulvous. Thorax transverse, convex, about half as broad again as long, sides strongly dentate behind the middle, surface very strongly and closely punctured, anterior sulcus deep. Elytra broader at base than the thorax, deeply depressed below the base, latter convex; surface strongly punctate-striate, striæ distantly placed, punctures very fine towards apex; ground-colour paler than that of the thorax, the greater part of the disc occupied by a violaceous band which ends in a point before the apex.

Length $6 \mathrm{mim}$.

Hab. Burma : Palon.

Can be distinguished by the elytral violaceons band.

\section{Nodostoma quadrifasciatum, sp. $\mathrm{n}$.}

Fulvous; terminal joints of antennæ and the tarsi piceous; elytra with a broad longitudinal band on the dise and a narrow band near the lateral margins bluish-black.

‥ Subquadrate-ovate. Head strongly but not closely punctured; labrum fulvous; antennæ long and slender, third and fourth joints very elongate, basal four flavous, rest blackish. Thorax strongly transverse, sides angulate near the base, anterior margin not preceded by a sulcus; surface strongly, closely and evenly punctured, more sparingly so near the anterior margin. Elytra with a short but deep basal depression, finely punctatestriate, punctures stronger on the sides and within the depression, extremely fine near the apex; the discoidal band broad at base, gradually narrowed and pointed posteriorly, extending to apex; the marginal band only one half the width of the discoidal band, joined at apex to it.

$V u r$. The bands extend from base barely to the middle of the elytra.

Length $5 \mathrm{~mm}$.

Hab. Sikhim : Mungphu.

A plainly marked species of which two specimens are contained in the Brit. Mus. collection. In the variety the thorax and elytra are rather more strongly punctured, but I think it may be referred to this species on account of its shape and elytral markings. 
543. Nodostoma plagiosum, Baly, Cist. Ent. ii, 1880, p. 373.

"Piceous; antennæ and legs piceo-fulvous; elytra obscure fulvous, the sutural and lateral margins very narrowly and an irregular transverse patch from below the base to the middle or beyond it, piceous.

"Oblong; vertex and front subremotely punctured; clypeus

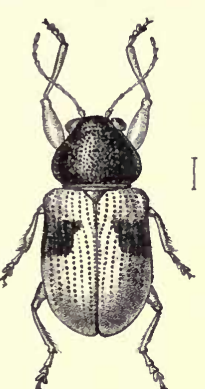

Fig. 118.

Nodostoma plagiosum. strongly and closely punctured, anterior border deeply excavate - emarginate, the emargination produced at sides into a tooth; antennæ slender, second and third joints nearly equal in length, fourth very slightly longer than the third. Thorax nearly twice as broad as long, sides diverging at the base, obtusely angulate behind the middle, thence obliquely convergent and very slightly rounded to apex; disc transversely convex, very coarsely and deeply punctured. Elytra convex, strongly punctate-striate, the punctures nearly obsolete near apex; interstices plain, impunctate; the piceous patch covers the outer disc (shoulders excepted)." (Baly.)

\section{Length $3 \mathrm{~mm}$.}

Hab. "Kashgar" (Baly.) India: Murree; Assam : Khási Hills.

A well-marked species, with the elytral patch of variable length; the antennæ have the basal joints more or less flavous, and in the specimens from the Khási Hills before me the legs are entirely of that colour. The thorax in the male is only half as broad again as long; in botll sexes the extreme anterior margin is flavous, rest of the disc piceous and very strongly punctured.

\section{Nodostoma nigrocinctum, sp. n.}

Testaceous; head and thorax obscure fulvous; elytra with sutural and lateral margins narrowly and a spot below base, black.

Head very strongly and subremotely punctured throughout; clypeus not separated from the face, feebly semicircularly emarginate at the middle of the anterior border ; antennæ slender, flavous, third joint only a little longer than the second and scarcely more than half the length of the fourth. Thorax very short, rather more than twice as broad as long, sides angulate near base; surface strongly and very closely punctured, more so at the sides than in the middle; anterior sulcus narrow and entire. Scutellun with some extremely fine punctures. Elytra oblong, a round black fovea below the base; surface strongly punctate-striate nuteriorly, finely so behind the middle, the black colour of the margins not extending to apex. Legs testaceous.

Length $3 \mathrm{~mm}$. 
Hab. Burma: Paungdé (Coll. H. E. Andrewes).

Similar in coloration to $N$. bipunctatum, Jac., smaller, the thorax much more strongly punctured; elytra with rows of coarse punctures, continued and becoming finer posteriorly; femora unarmed.

545. Nodostoma nigrofasciatum, Jac. Ann. Mus. Civ. Genova, xxvii, 1889, p. 163.

․ Fulvous or testaceous; apical joints of antennæ black; elytra with sutural and lateral black margins.

Head with a few extremely fine punctures; clypeus very obsoletely separated from the face, deeply semicircularly emarginate in front, bidentate at the sides; antennæ long and slender, third joint much shorter than the fourth. Thorax twice as broad as long, sides very prominently angulate behind the middle, the tooth slightly flattened, anterior sulcus deep at sides, obsolete at middle ; surface finely and remotely but more distinctly punctured than the head. Scutellum rather elongate and pointed. Elytra distinctly wider at base than the thorax, broadly ovate, basal portion and shoulders highly raised, a short oblique costa from the shoulders to the margin, raised portion of base with deep depression below, studded with a few deep punctures, rest of the surface very finely and irregularly punctured.

Var. Elytra black.

Length $4 \mathrm{~mm}$.

Hab. Bengal: Mandar. Burma: Bhamo, Teinzo.

$N$. nigrofasciatum may be distinguished by the acutely produced sides of the thorax and the sparse and fine puncturation of this part, also by the irregularly arranged elytral punctures on the posterior half, a rare character in these insects; the coloration is, however, very variable. Another mark of distinction is the short third joint of the antennæ as compared with the fourth.

\section{Elytra partly or almost entively impunctate.}

\section{Nodostoma dharwarense, sp. $\mathbf{n}$.}

Fulvous; terninal joints of antennæ black; elytra with a short longitudinal stripe at base, a narrow sutural and broader lateral band, black.

Head distinctly punctured at vertex, rest of surface sparingly punctate; clypeus not separated from the face; autennæ with the second joint nearly as long as the first, third slightly longer than the second but shorter than the fourth joint. Thorax twice as broad as long, sides distinctly angulate below middle, anterior sulcus narrow, deep and entire; disc irregularly but somewhat closely impressed with siallow punctures, not extending to the sides. Elytra ovate, with a short depression below base, the latter only distinctly punctured, rest of surface very obsoletely so, a short black stripe from 
middle of base to the depression; sutural band slightly widened at the middle, lateral band close to margin, nearly extending to apex.

Length $4 \mathrm{~mm}$.

Hab. Southern India: Dharwar (Coll. Jacoby).

\section{Nodostoma bipunctatum, Jac. P. Z. S. 1887, p. 76 .}

Testaceous; elytra with sutural and lateral margins and a spot below base on each elytron, black.

Head with a few fine punctures below the eyes; clypeus not separated from the face ; antennæ filiform, apical joints not thickened, testaceous, fourth joint distinetly longer than the third. Thorax short, narrowly transverse, sides subangulate near base, anterior portion strongly uarrowed, anterior sulcus distinct, closely and finely punctured. Elytra with deep depression below the base, distinctly punctured in the depression only, rest of surface obsoletely punctate, interstices very slightly raised, lateral margins accompanied by a row of deep punctures. Legs testaceous; all femora armed with a small tooth.

$V$ ar. Elytra black.

Length $4 \mathrm{~mm}$.

Hab. Ceylon: Dikoya, Kandy.

I have lately received a specimen from Kandy which I refer to this species, in which the thorax has a black patch at each side, and the elytral spot extends within the shoulders upwards to the base. The species is easily distinguished by the very short thorax and the nearly impunctate posterior elytral parts.

\section{Nodostoma wallardiense, $\mathrm{sp.}$.}

Testaceous or piceous with shoulders and apex pale; basal joints of antennæ and legs flavous or testaceous; thorax with black spot; external and lateral margins of elytra black.

Head remotely but distinctly punctured; clypeus not separated from the face, more strongly punctate; antennæ very slender, four or five basal joints pale, rest black. Thorax twice as broad as long, sides strongly angulate behind the middle, anterior portion strongly obliquely uarrowed in front, anterior sulcus obsolete at middle; surface strongly and closely, sides rather more remotely punctured. Elytra oblong, with deep transverse basal groove, the latter with a few punctures arranged in rows, another short row within shoulders extends to the base, and two others near suture at anterior portion, suture also accompanied by a single row of close punctures, rest of surface entirely impunctate. Femora with a ininute tooth.

Var. a. Above testaceous; thorax as in type; elytra narrowly margined with black.

Var. $b$. Nearly black; elytra with humeral and apical portions flavous ; thorax black. 
Length $3-3 \frac{1}{2} \mathrm{~mm}$.

Hab. Travancore: Wallardi (Coll. Jacoby).

A variable species in regard to colour, the head either entirely or partly pale and black, thorax sometimes entirely black, strongly punctured. The puncturation on the elytra in the depression separates this species from some of the similarly coloured varieties of $N$. variabile, Duv. (mandarense, Jac.). $\dot{N}$. geniculatum, Lefèv., in some of its varieties resembles the present insect in coloration, but may be distinguished by the extremely finely and closely punctured thorax.

\section{Nodostoma lewisi, Jac. P. Z. S. 1887, p. 77.}

Fulvous; elytra testaceous; terminal joints of antennæ and sutural and lateral margins of elytra narrowly black.

Head shining, fulvous, with a few punctures at base and between the eyes; antennæ long and slender, basal four joints flavous, rest black, third and fourth equal, rest not thicker. Thorax about half as broad again as long, sides distinctly angulate near base, strongly obliquely narrowed anteriorly, sulcus distinct at sides only, surface very strongly and rather closely punctured, interstices more or less convex. Elytra oblong, distinctly transversely depressed below the base, the latter only distiuctly punctured, rest of surface nearly impunctate.

Length 2-2 $\frac{1}{2} \mathrm{~mm}$.

Hab. Ceylon: Dikoya.

In some specimens the thorax has the disc more or less piceous, and the black sutural stripe varies somewhat in width.

550. Nodostoma bengalense, Duviv. Bull. Soc. Ent. Belg. xxxv, 1891, p. xxxviii.

Fulvous; elytra with the suture broadly and apical portion of lateral margins more or less black.

Head with a few fine punctures; clypeus separated at the sides by a fovea, surface with a few punctures; antennæ filiform, fifth and following joints more or less darkened, third joint shorter than the fourth. Thorax about twice as broad as long, distinctly angulate at sides near base, anterior sulcus well marked and strongly punctured; surface with a few very fine, widely separated punctures. Elytra with strongly raised base, deeply depressed below that, bearing some deep punctures within the depression, rest of the surface nearly impunctate, sutural portion with some rows of fine punctures.

Var. Elytra entirely fulvous or flavous.

Length $3 \frac{1}{2}-4 \frac{1}{2} \mathrm{~mm}$.

Hab. Bengal: Konbir-Nowatoli ; Burma: Toungoo.

The nearly impunctate thorax and only partly punctured elytra are the principal characters that separate this species from $N$. nigro- 
fasciatum, Jac. In one specimen from Toungoo, the thorax is entirely impunctate and of more transverse shape than in another from the same locality, which in addition has the thoracic sulcus interrupted at the middle; these differences are probably sexual distinctions.

\section{Nodostoma nigro-bimarginatum, sp. $n$.}

Above fulvous: beneath black; scutellum, and sutural and lateral margins of elytra narrowly black.

Oblong. Head sparingly and finely punctured; clypeus not separated from the face, rather more strongly punctured, lateral margins raised; eyes large and prominent; antennæ moderately long, fulvous, sixth and following joints distinetly shorter than the preceding joints and very slightly thickened. Thorax scarcely twice as broad as long, sides obtusely angulate behind the middle, obliquely narrowed in front, anterior sulcus distinct at sides only; surface strongly but not very closely punctured at sides, more finely punctured on disc. Elytra rather pointed at apex, somewhat deeply transversely depressed at base, strongly punctate-striate on anterior half, smooth posteriorly, a single row of deep punctures near suture; black margins of latter and of sides not quite extending to apex. Femora unarined.

Length $2 \frac{1}{2} \mathrm{~mm}$.

$H a b$. Southern India: Nilgiris. Tenasserim: Mergui. Type in Brit. Mus.

\section{Nodostoma hampsoni, sp. n.}

Beneath black; head and thorax obscurely fulvous, the latter more or less with a greenish-æneous tint; elytra pale fulvous, sutural and lateral margins black.

Head with a few extremely minute punctures; clypeus more strongly punctate; antennæ slender, black, basal two joints flavous. Thorax strongly transverse, subangulate near base, anterior sulcus distinct at the sides only, surface rather strongly but not very closely punctured. Elytra with deep transverse depression below base, distinctly punctured within the depression only, rest of surface nearly impunctate; a short, oblique row of punctures from shoulders to lateral margins, the latter narrowly black on the middle portion only, sutural margins narrowly black or piceous from base to apex.

Length $2 \frac{1}{4} \mathrm{~mm}$.

Hab. Southern India: Nilgiris (Hampson). Type in Brit. Mus.

Differs from $N$. lewisi, Jac., as follows : the basal two joints of the antennæ only flavous, a row of punctures from shoulders to margins and the underside black.

553. Nodostoma latefasciatum, sp. $n$.

Fulvous; antennæ (basal joints excepted) and a broad sutural band on elstra black. 
Head entirely impunctate; clypeus distinctly separated from the face, its margins raised, anterior edge semicircularly emarginate, surface entirely smooth; antennæ with the basal four joints and part of the fifth pale fulvous, rest blackish, third and fourth joints equal. Thorax half as broad again as long, scarcely narrowed in front, sides rounded, anterior sulcus entire, surface not perceptibly punctured. Elytra ovate, very feebly depressed below the base, with two or three rows of fine punctures near the suture, rest of surface impunctate, very shining; a broad sutural band, black, extending from base to apex and widened at the apex.

Length $3 \mathrm{~mm}$.

Hab. Bengal (Coll. Jacoby).

\section{Nodostoma andamanense, sp. $\mathrm{n}$.}

Fulvous; sutural and lateral margins of elytra narrowly black.

Head with two or three fine punctures only; clypeus strongly punctured at base, deeply emarginate, angles strongly pointed; mandibles black; antennæ flavous or fulvous, very slender, third joint slightly shorter than the fourth. Thorax twice as broad as long, of even width, sides strongly rounded, anterior sulcus distinct, surface very remotely and finely punctured at the sides. Elytra elongate, pointed at apex, very deeply transversely sulcate below the base and within the shoulders, distinctly punctured within depression and with two or three rows of punctures near the suture, apical portion strongly deflexed and nearly impunctate, a short oblique costa below the shoulders, sutural margins strongly raised.

$\nabla a r$. Elytra entirely fulvous.

Length $3 \mathrm{~mm}$.

Hab. Andaman Islands (Colls. Brit. Mus. \& Jacoby).

The strong deflexion of the posterior portion of the elytra can best be seen when the insect is viewed sideways. The puncturation of the thorax is distinct only at the sides, where it is arranged in somewhat regular longitudinal rows : this character and the strongly rounded sides and shape of the elytra will help to distinguish this species. The specimens before me are apparently females.

Above fulvous; sides of thorax generally angulate.

555. Nodostoma obliteratum, Jac. P. Z. S. 1887, p. 80.

Pale fulvous, subelongate. Head and clypeus with a few fine punctures, the anterior border of the latter semicircularly emarginate; antennæ flavous, extending very nearly to apex of elytra, third joint much shorter than fourth, terminal joints more or less fuscous. Thorax twice as broad as long (not three times, as originally given), sides angulate near the base, strongly obliquely narrowed in front, anterior sulcus deep and entire, surface very sparingly and finely punctured. Elytra slightly broader than the thorax, with rather shallow basal, short depression, sparsely 
punctate-striate, puncturation much finer near apex; femora with a minute teoth.

\section{Length 3-4 mim.}

Hab. Ceylon: Dikoya.

The depression of the elytra is much less marked than in most other species, the antennæ are very long, and the general shape is elongate.

556. Nodostoma puncticolle, Lefêv. Ann. Soc. Ent. France, 1889, p. 295.

Var. Nodostoma birmanicum, Jac. Ann. Mus. Civ. Genova, xxxii, 1892, p. 898.

Obscure fulvous ; labrum and palpi darker; basal four joints of anternnæ fulvous, rest fuscous.

Head sparsely punctured, punctures large and deep on clypeus. Thorax transverse, sides abruptly angulate before base, from thence to apex oblique, anterior sulcus punctate; disc strongly and rather closely, sides as strongly and confluently, punctured. Elytra much broader at base than the thorax, transversely impressed below base, strongly punctate-striate anteriorly, finely punctured towards apex. Femora with small tooth; apex of tibiæ and the tarsi fuscous.

Var. Head and thorax fulvous, elytra bluish-black.

Length $4-4 \frac{1}{3} \mathrm{~mm}$.

Hab. India: Punjab; Burma (Coll. Jacoby). Tonkin.

Of this species, principally distinguished by the strong and partly confluent puncturation of the thorax, I possess two specimens, both named by Lefèvre-one from Tonkin, the other from India. I am unable to find any structural differences between them. The puncturation of the thorax is close but not so close as on the sides. On more careful examination I am disposed to think that $N$. birmanicum, Jac. is a variety of this species.

\section{Nodostoma sylhetense, sp. n.} black.

o. Dark fulvous; antennæ (basal joints excepted) and legs

Oblong-ovate. Head very sparingly and finely punctured; clypeus not separated from the face, studded with a few fine punctures, anterior margin nearly straight; inandibles broad, black; antennæ long, terminal joints rather widened, very elongate, basal three and base of fourth flavous, third and fourth joints equal. Thorax scarcely twice as broad as long at base, sides obtusely angulate near base, strongly obliquely narrowed in front, anterior sulcus deep and entire, surface entirely impunctate. Elytra broadly ovate, with short and deep transverse depression below the base impressed with a few punctures, rest of surface nearly impunctate,

ror, I. 
shoulders with a short row of punctures on the inner sides. Femora with a minute but distinct tooth.

Length $4 \frac{1}{4} \mathrm{~mm}$.

Hab. Assam : Sylhet (Coll. Brit. Mus.).

Amongst the larger species the present form may be known by the nearly impunctate thorax, sparingly punctured elytra and black legs.

\section{Nodostoma inconspicuum, sp. n.}

Obscure fulvous; apical joints of antennæ black; knees and bases of tibiæ obscure fuscous.

‥ Head remotely and finely punctured on vertex, very strongly punctured on the clypeus, the latter not separated from the face; apex of mandibles black; antennæ long and slender, third and fourth joints equal, basal four testaceous, rest progressively darkening to black. Thorax scarcely twice as broad as long, sides distinctly angulate near base; anterior sulcus entire, strongly punctured; surface very strongly but subremotely punctured, punctures rather stronger at the sides. Elytra with deep basal depression and prominent shoulders, very strongly punctate-striate, punctures finer but distinct to apex, sides at shoulders with short oblique costa. Femora with short tooth. Prosternum subquadrate, strongly and remotely punctured.

Length $3 \mathrm{~mm}$.

Hab. Assam : Patkai Mts. (Coll. Brit. Mus.).

This form bears a close resemblance to $N$. duvivieri, but is rather smaller, the elytra are without the sutural black stripe and are more distinctly punctured. The species may possibly be a local form of $N$. duvivieri.

\section{Nodostoma subdepressum, sp. n.}

Fulvous; terminal joints of antennæ black.

ㅇ. Ovate, subdepressed. Head extremely finely and sparingly punctured at base; clypeus more strongly but remotely punctate, scarcely separated from the face; mandibles black; antennæ long and slender, basal four joints flavous, rest black. Thorax strongly transverse, sides angulate near base, strongly obliquely narrowed in front, anterior sulcus distinct and punctured at the sides only, rest of surface strongly and remotely punctured, punctures extending to all the margins. Elytra deeply depressed below base, shoulders very prominent, deeply sulcate within, followed by short oblique costæ running to lateral margins; surface closely and somewhat irregularly punctate-striate, punctures stronger within depression and at the sides, two more regular and deeper rows of punctures near suture, latter deeply sulcate near the margins, interstiees at the same place with some minute punctures. Femora with a small tooth.

Length $\pm \mathrm{mm}$. 
Hab. Burma: Momeit. Type in Brit. Mus.

In this species the elytral puncturation is more closely placed and less regular than is generally the case, and the surfaces of the thorax and elytra are but slightly convex. Two female specimens were obtained by Doherty.

\section{Nodostoma semilævam, sp. n.}

o. Fulvous. Head and clypeus with a few fine irregularlyplaced punctures only; antennæ long and filiform, third and fourth joints equal, very elongate, terminal three shorter than the preceding joints. Thorax scarcely twice as broad as long, sides angularly rounded near base; surface very remotely and finely punctured, with a few deeper punctures at the sides, anterior sulcus indistinct at the middle. Elytra oblong, moderately strongly depressed below base, strongly punctate-striate, more finely punctured near apex, a short oblique costa at the sides near the shoulders. Femora unarmed.- $q$ more broadly ovate, less parallel-sided; elytral costa at sides more strongly inarked.

Length $3 \mathrm{~mm}$.

Hab. Burma: Ruby Mines (Coll. Brit. Mrts.).

Rather closely allied to $N$. subdepressum, but the antennæ are entirely fulvous, thorax finely and sparingly punctured, the size smaller.

\section{Nodostoma oblongo-punctatum, sp. n.}

9. Pale fulvous; terminal joints of antennæ black.

Head very sparingly and finely punctured, a short oblong fovea at middle; clypeus not separated from the face, with a few fine punctures; mandibles piceous; antennæ with the basal three joints flavous, rest black, third and fourth elongate, equal, terminal joint thickened but elongate. Thorax rather more than twice as broad as long, sides strongly angulate behind the middle, anterior sulcus entire; surface very finely, rather sparingly and evenly punctured, the punctures more or less oblong. Scutellum not longer than broad. Elytra with deep foveolate depression below base, strongly punctured anteriorly and within depression, finely punctured towards the apex, the apex impunctate, a short oblique costa from shoulders to margins. Flanks of thorax impunctate; sides of breast strongly and closely punctured. Femora unarmed. Prosternum nearly impunctate.

Length $3 \mathrm{~mm}$.

$H a b$. Southern India: Nilgiris (Coll. Jacoby).

Larger than $N$. weisei, Jac., darker in colour, the thorax still more transversely shaped, more finely punctured, the punctures less closely placed and oblong in shape, the elytral depression deeper and foveolate; this latter character also separates this species from $N$. semilaevum, as does the different thoracic sculpture. The strongly pnnctured clypeus and finely punctured thorax will distinguish the insect from $N$. inconspicurm. 


\section{Nodostoma separatum, sp. $n$.}

ㅇ. Fulvous. Head with a few punctures placed obliquely below the eyes, rest of surface impunctate; clypeus distinctly separated from face, punctured on the line of separation; antennæ long and slender, pale fulvous, terminal two joints fuscous, thickened, third slightly shorter than the fourth. Thorax twice as broad as long, sides distinctly angulate near base, anterior sulcus distinct throughout; surface very finely punctured, anterior portion near the margin nearly impunctate. Elytra oblong, deeply depressed below base, strongly puncate-striate anteriorly, more finely punctured towards apex, a short oblique costa from the shoulders to margins. Femora with a minute tooth.

Length $2 \frac{1}{2} \mathrm{~mm}$.

Hab. Assam (Coll. Jacoby).

Sides of thorax rounded.

563. Nodostoma fulvotibiale, sp. $n$.

Fulvous; terminal joints of antennæ, apex of femora and base of tibiæ black.

Head impunctate; clypeus with the lateral margins raised, impunctate ; antennæ comparatively short, basal four joints fulvous, fifth and following joints black, gradually thickened. Thorax abont twice as broad as long, convex, sides rounded, anterior angles rather strongly deflexed, sulcus absent; surface entirely impunctate. Elytra oblong, subcylindrical, feebly transversely depressed below the base, shoulders moderately prominent; surface very finely and remotely punctate-striate, the punctures widely separated, scarcely perceptible at apex. Femora, extreme base excepted, black, tibiæ more or less and the tarsi pale fulvous.

Length $2 \frac{1}{2} \mathrm{~mm}$.

Hab. Tenasserim: Mergui, Tavoy. Type in Brit. Mus.

Easily distinguished on account of the rather short antennæ, impunctate thorax and its rounded sides, also by the colour of the legs.

\section{Nodostoma intactum, sp. $n$.}

‥ Fulvous; terminal joints of artennæ black.

Head impunctate; clypeus with an elongate, triangular, deep depression at sides, finely punctured anteriorly, anterior margin very feebly emarginate; antennæ rather short, basal four joints fulvous, rest black, terminal four joints thickened. Thorax scarcely twice as broad as long, sides rounded, anterior sulcus only distinct near the angles; surface very finely and remotely, sides slightly more strongly punctured, posterior angles strongly dentiform. Elytra oblong-ovate, very feebly depressed below base, finely and regularly 
punctate-striate throughout, interstices minutely and sparingly punctured.

Length $3 \mathrm{~mm}$.

$H a b$. Assam: Patkai Mts. (Colls. Brit. Mus. \& Jacoby).

Separated by the colour of the antennæ in connection with the rounded sides of thorax, the feeble elytral depression and the regular rows of punctures over their entire surface, also by the finels punctured elytral interstices.

Above testaceous. Sides of thorax angulate.

565. Nodostoma thoracicum, sp. $n$.

Entirely testaceous. Head with a few widely distributed punctures; clypeus similarly sculptured, its sides cariniform, anterior margin deeply semicircularly emarginate; antennæ long and slender, testaceous, apical joint fuscous, third and fourth joints very
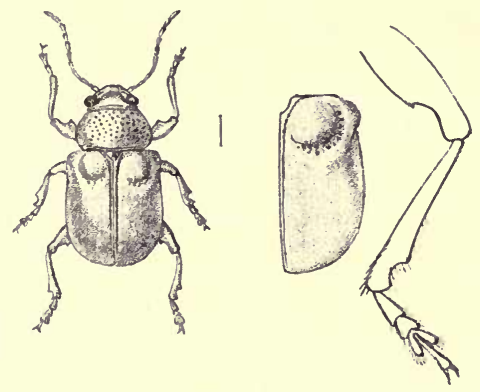

Fig. 118.-Nodostoma thoracicum.

elongate, equal. Thorax half as broad again as long, sides angularly rounded near base, anterior sulcus distinct at the sides only; surface very deeply but not very closely punctured, the punctures round. Elytra elongate, pale testaceous, with deep basal depression, the latter with a few punctures, another short row of punctures within the shoulders that extends to base, rest of surface impunctate. Anterior femora strongly thickened and with a minute tooth.

Length $3 \frac{1}{2} \mathrm{~mm}$.

$H a b$. Southern India: Nilgiris; Southern Bombay: Belgaum (Colls. H. E. Andrewes \& Jacoby).

Separated by the exceptionally strongly punctured thorax and the nearly impunctate elytra. 


\section{Nodostoma binghami, sp. n.}

Pale lestaceous; head and thorax slightly darker.

$\sigma^{*}$. Head and clypeus very strongly and closely punctured, the latter ueeply emarginate ; antennæ slender, testaceous, third and fourth joints equal. Thorax half as broad again as long, sides strongly angulate behind the middle, anterior sulcus somewhat obsolete in the middle, surface very strongly and subremotely punctured. Elytra subelongate, basal portion raised, smooth; shoulders very prominent, bounded within by a sulcus that extends round the basal elevation to suture, this sulcus strongly impressed with a few short rows of punctures, rest of disc impunctate. Femora with a minute tooth, anterior femora strongly thickened.

Length $3 \mathrm{~mm}$.

$H a b$. Southern India: Nilgiris (Coll. Brit. Mus.).

More nearly allied to $N$. thoracicum than to any other form, but easily separated from that species by the strongly and closely punctured head and the much more strongly angulate sides of the thorax.

\section{6\%. Nodostoma semistriatum, sp. n.}

T'estaceous; terminal joints of antennæ stained with piceous or blackish.

Head impunctate; clypeus with a few punctures at base only, not separated from the face; antenpæ long and slender, second to fourth joints gradually lengtbened. Thorax twice as broad as long, sides angulate near base, obliquely narrowed in front, anterior sulcus narrow but deep; surface impunctate. Elytra elongate, subcylindrical, deeply depressed below the base, the latter convex, anterior portion rather strongly punctate-striate, posterior nearly impunctate. 'Legs unarmed.

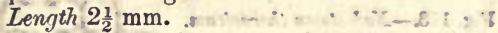

Hab. Burma : Toungoo (Coll. H. E. Andrewes). Tenasserim:

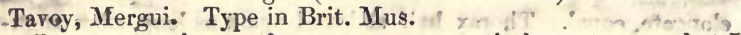
: In some specimens the antennæ are entirely testaceous, but I can find no other differences.

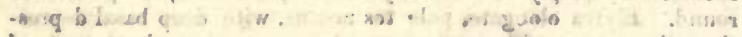
5.68. Nodostoma fairmairei, Jac P. Z. S. $1887_{p} \mathrm{p}_{\mathrm{h}} 80$.

- Pale testaceous ; antennæ (basal joints excepted) black ; apex of tibia and the tarsi more or less piceous.

$\delta$. Head remotely but strongly punctured; clypeus not separated from face, antennm two-thirds the length of the body, third and fourth joints equal, rest slightly thickened. . Thorax about half as broad again"as long, sides subangulate behind the middle, narrowed in front; surface strongly punctured at the sides and 
anteriorly, interstices slightly rugose. Elytra subcylindrical, parallel-sided, with a distinct basal depression, puncturation rather strong anteriorly, finer towards apex. Legs rather long, femora with a small tooth.

Length 3-4 mm.

Hab. Ceylon: Dikoya.

This species, in addition to its pale colour, differs from $N$. obliteratum Jac. in the much more strongly punctured head and thorax, angulate sides of latter, shorter and nearly black antennæ, and colour of tibie and tarsi.

569. Nodostoma bimaculicolle, Jac. Ann. Mus. Civ. Genova, xxxii, 1892 , p. 899 .

Light testaceous; thorax with two small black spots.

Head with a few punctures between the eyes; clypeus separated by deep lateral sulci that extend upwards to the eyes, surface rather strongly but very sparingly punctured, anterior border deeply emarginate; antennæ filiform, testaceous, terminal joints stained with piceous, third joint slightly shorter than the fourth. Thorax very short, rather more than twice as broad as long, sides obtusely angulate just behind the middle, anterior sulcus deep and entire; surface with some strong punctures in the middle only, a small black spot at each side. Elytra with deep depression below the base, the latter raised; a short row of deep punctures near suture at base, another within shoulders and a few punctures within the depression, the latter sometimes with a small black spot, sutural margins more or less piceous; rest of surface impunctate, punctures replaced by closely approximate rows of fuscous spots.

Length $\dot{3} \frac{1}{2} \mathrm{~mm}$.

Hab. Burma: Karennee. Sumatra.

This form has a very short thorax, angulated close behind the middle, the spots often obsolete. The Sumatran specimens agree so closely with those from Burma that I am unable to separate them specifically.

570. Nodostoma clypeatum, Jac. P. Z. S. 1887, p. 79.

Pale testaceous; apical joints of antennæ fuscous.

Head nearly impunctate on the vertex; clypeus strongly but very remotely punctured, not separated from the face, space above insertion of antennæ obliquely grooved; antennæ slender, nearly as long as the body, terminal three or four joints fuscous or black. Thorax twice' as broad as long, strongly narrowed in front, sides distinctly angulate near base, anterior groove absent; surface strongly punctured at the sides only, middle of disc with a few fine punctures. Elytra with rery distinct subbasal depression, the 
base itself with a few remotely placed punctures arranged in rows which extend more or less distinctly as far as the middle, behind the middle the punctures are more or less obsolete. Femora with minute tooth.

Length $2 \mathrm{~mm}$.

Hab. Ceylon: Galle.

The nearly impunctate vertex, the strongly punctured clypeus and sides of thorax, joined to its small size and absence of an anterior thoracic sulcus, clearly distinguish this species.

\section{Nodostoma montanum, sp. $n$.}

ס. Testaceous. Head entirely impunctate; sides with oblique groove at base of the antennx; clypeus not separated from face but with a small fovea on each side; antennæ testaceous, third joint shorter than the fourth, terminal joints slightly thickened. Thorax twice as broad as long, sides angulate near base, moderately oblique towards apex, no anterior suleus ; surface with a few strong punctures on the sides only, dise with a few fine punctures. Elytrnoblong, narrowed at apex, with very feeble depression at base, shoulders only slightly prominent; surface very regularly and somewhat finely punctate-striate, apex very obsoletely punctured. Legs unarmed. - $q$. Similar but with much shorter antennæ, a more transverse thorax and a short feeble elytral costa below shoulders.

Length $2 \mathrm{~mm}$.

Hab. Burma : Karen Hills. Type in Brit. Mus.

Nearly allied to $N$. clypeatum, Jac., from Ceylon; but the clypeus impunctate, the antenur entirely testaceous, elytral depression nearly absent.

572. Nodostoma weisei, Jac. Mém. Soc. Ent. Belg. vii, 1900, p. 105.

Testaceous. Head and the clypeus also very sparingly punctured; antennw long and filiform, third joint longer than second and more slender. Thorax rather more than twice as broad as long, ides angulate near base; surface finely and closely punctured, anterior sulcus entire, punctures at sides of thorax slightly larger than those ou the middle but not more closely placed. Elytra oblong-orate, with deep basal depression, strongly punctured anteriorly, much more finely so behind the iniddle, a short oblique costa at the shoulders.

Length 2-2 $\frac{1}{2} \mathrm{~mm}$.

Hah. Bengal: Barway, Mandar. Southern India: Nilgiris, Anaimalais.

Principally distinguished from most of the similarly coloured species by the sparingly punctured head, short and very strongly transverse thorax and its fine and rather close puncturation, the very long antennæ, \&c. 


\section{Nodostoma congregatum, sp. n.}

ऽ. Testaceous. Head finely and sparingly punctured at vertex; clypeus slightly nore strongly punctate, not separated from the face, anterior border deeply emarginate; antennze extending to half the length of the body, all the joints elongate, third and fourth equal. Thorax half as broad again as long, sides strongly angulate behind the middle, anterior sulcus obsolete at middle; surface closely and strongly punctured at middle of anterior portion, more remotely and strongly punctured at the sides. Elytra oblong, with a short but distinct transverse depression below base, a few punctures within depression only; base and rest of surface entirely inpunctate except on the sides ontside the shoulders where there are three short rows of punctures, suture likewise accompanied by a single row of punctures as far as the middle. Femora with a small tooth.

Length 3 inm.

Hab. Travancore: Wallardi (C'oll. Jacoby).

Very nearly allied to $N$. impressipenne, Jac., but differs in the much more strongly angulated sides of thorax and in its puncturation. The puncturation being dense on the anterior portion of the thorax, instead of on the sides, is the reverse of what obtains in the allied forms.

\section{Nodostoma aggregatum, sp. n.}

ठ. Testaceous, elongate and subcylindrical. Head rather strongly and sparsely punctured; clypeus more strongly punctate; mandibles robust, piceous; cyes very large; antenna long and slender, testaceous, terminal two joints piceous, third and following joints elongate, apical joints shorter and stouter. Thorax twice as broad as long, sides obtusely angulate near base, anterior sulcus entire; surface extremely closely and rather finely punctured, the punctures crowded on the middle of the disc. Elytra scarcely wider at base than the thorax, with a rather deep depression belowbase, closely and strongly punctured at base, less so posteriorly, apex nearly impunctate. Feinora very stout, with minute tooth. Prosternum broad, strongly and remotely punctured; rest of underside nearly impunctate.

Length $3 \mathrm{~mm}$.

$H a b$. Southern India: Nilgiris (Cupt. Downing).

Differs from $N$. weisei in its much more elongate and subcylindrical shape, stronger puncturation of head and the more crowded punctures on thorax; the elytra bave also the punctured rows much more closely placed at base than in $N$. weisei; lastly, the prosternum in that species is shorter and more transverse in shape. 
575. Nodostoma bituberculatum, Jac. P. Z. S. 1887 , p. 76.

Testaceous; terminal joints of antennæ black ; beneath obscure fulvous.

Head very strongly and remotely punctured; clypeus not separated from the face; antennæe nearly as long as the body, second joint nearly as long as the first, fourth slightly longer than the third. Thorax twice as broad as long, narrowed in front, sides angulate near base; surface strongly and closely rugose-punctate, without an anterior sulcus. Elytra very slightly depressed below base, puncturation nearly obsolete near apex; bumeral callus in shape of an elongate tubercle, followed immediately below by anotber smaller tubercle, space between these latter and the lateral margin deeply depressed. Underside darker fulvous, Femora with minute tooth.

Length $2 \mathrm{~mm}$.

Hab. Ceylon: Dikoya. Type in Coll. G. Lewis.

The small size, strongly rugose thorax and the lateral elytral tubercles suffice to separate this species from its congeners.

\section{Sides of thorax rounded.}

576. Nodostoma maheense, sp. n.

c. Testaceous. Head with a few deep punctures at middle; clypeus deeply emarginate in front with the sides highly raised; antennæ filiform, third and following joints very elongate, - last three wanting in the only specimen $I$ have seen. Thorax about half as broad again; as long, sides rounded and widened at the middle, anterior sulcus deep and entire; surfáce very deeply and rather remotely punctured, punctures irregularly placed; diso somewhat strongly convex. Elytra oblong, basal portion raised; transversely impressed, posteriorly punctured within the depression and in front of the shoulders, rest of surface extremely minutely punctate, external and lateral margins narrowly fuscous.

- 9 . Thorax less çnvex and widened at the sides.

Length $3 \frac{1}{2} \mathrm{~mm}$.

Hab. Malabar: Mabé (Coll. Jacoby).

The thorax is more convex and more strongly punctured than in $N$. andamanense, the elytra are nearly impunctate and bave no black margins as in $N$. nigrobimarginatim, in which species the thorax is likewise, more finely punctured and the elytra distinctly so. i

577. Nodostoma orientale, sp. n.

Testaceous. Head and clypeus remotely but rather strongly punctured; antennæ with the third and fourth joints equal, each about half as long again as the second, terminal two thickened, 
the last joint piceous. Thorax nearly twice as broad as long, sides rounded; anterior sulcus very narrow, distinct at the sides only; surface closely and deeply foveolate-punctate, interstices at the sides reticulate and confluently raised, punctures near anterior margin, at middle, fine. Elytra feebly depressed below base, paler in coloration than the thorax, margins obscure fulvous, anterior portion distinctly, apical portion very finely punctured. Femora unarmed.

Length $21 \mathrm{~mm}$.

$H a b$. Southern India; Nilgiri and Anaimalai Hills (Coll. H. E. Andrewes).

Amongst the smaller Indian species with rounded sides, there is none with an equally deeply punctured thorax. This will help in the recognition of the insect.

Elytra only generally metallic; other parts mostly reddish, exceptionally black.

578. Nodostoma haroldi, Jac., nom. nov.

Nodostoma æneipenne, Baly (nec Motschulsky), Trans. Ent. Soc. 1867 , p. 235 .

Var. apicipes, Jac. Entomologist 'Suppl. 1892, p. 87.

Rufous; antennæ (basal joints excepted) black; knees, tibiæ and tarsi dark piceous; elytra æneous or'metallic green.

Head with large deep scattered punctures; clypeus not separated from face, anterior border deeply angulate-emarginate ; mandibles black, middle portion rufo-piceous; antennæ filiform, rather more than half the length of the body, basal four joints obscure fulvous, third nearly twice the length of the second. Thorax at base more than tivice as broad as long, sides with lateral border very narrowly dilated, abruptly angulated just in front of the base, obliquel'y divergent to apex, anterior and posterior angles tuberculate; surface with large deep punctures, irregularly scattered over the disc; anterior sulcus with oblong punctures. Scutellum longer than broad, subpentagonal. Elytra excarated below basilar space and within humeral callus, deeply and strongly punctured, striæ entire, punctures smaller on basilar space and behind the middle. Femora with a tooth.

\section{Length $4 \mathrm{~mm}$.}

Hab. Assam; Burma: Teinzo, Karennee; Tenasserim. Ḿalacca (Baly).

3. The Indian specinens agree so closely with Baly's type in the British Museum that I cannot separate them satisfactorily.

Var. apicipes, Jac. has the apex of the tibia and the tarsi more or less piceous.

579. Nodostóma dormeri, Baly, Trans, Lnt. Soc. 1877, p. 39.

: Rufous; antennæ (base excepted), unandibles, tibiæ and tarsi - black; elytra bright metallic green.

2. Oblong-ovate, Head coarsely, and closely punctured, rugose, 
punctate on clypeus, the latter not separated from the face; basal four joints of antennæ rufous, rest black. Thorax nearly twice as broad as long, sides very obtusely angulate behind the middle; surface coarsely punctured, a narrow space along middle of apical border slightly thickened, impunctate, smooth and shining. Scutellum bluish-black. Elytra broadly oblong, transversely excavated below base, shoulders strongly raised; surface distinctly punctate-striate, puncturation much finer behind the middle, nearly obsolete at apex; a strong longitudinal costa near outer border, from humeral callus to commencement of apical third of elytron, anterior half of costa flexuose. Hinder pair of femora armed with a small tooth; extreme bases of all tibiæ piceous.

\section{Length $6 \mathrm{~mm}$.}

$H a b$. Southern India : Nilgiris; Travancore.

In some specimens only the basal three joints of the antennx are fulvous. Differs from $N$. haroldi, Jac. in the black tibiæ and tarsi and larger size.

580. Nodostoma sikhimense, Jac. Mém. Soc. Ent. Belg. vii, 1900, p. 102.

Beneath black; head, thorax and part of legs fulvous; elytra metallic green; tarsi black.

Head remotely but strongly punctured at middle; anterior border of clypeus triangularly emarginate; antennæ black, basal two joints fulvous, terminal joints stout, elongate. Thorax twice as broad as long, sides obsoletely angulate behind the middle, strongly narrowed in front, anterior sulcus distinct only at sides; surface very sparingly punctured, slightly more closely and strongly at the sides. Scutellum black. Elytra subquadrate-ovate, deeply depressed below base, strongly, rather closely and somewhat irregularly punctate-striate, apex nearly impunctate.

Var. The knees, tibiæ and tarsi of the anterior and intermediate legs and the whole of the posterior legs black.

Length $6 \mathrm{~mm}$.

$H a b$. Sikhim.

Can be separated from $N$. dormeri by the black underside and the much more sparingly punctured thorax; the puncturation of the head and thorax is, however, subject to some variation, some specimeus being much more sparingly punctured than others, but none so closely and strongly punctured as $N$. clormeri.

581. Nodostoma indicum, Jac. Entomologist Suppl. 1892, p. 86.

Metallic green; basal joints of antennæ, head and thorax fulvous.

Subquadrate-orate. Head coarsely and remotely punctured; clypeus deeply triangularly emarginate in front, bidentate at the sides anteriorly; antennæ black, long and slender, basal four joints 
fulvous. Thorax twice as broad as long, sides obsoletely angulate near base, anterior sulcus deep at the sides, obsolete in front; surface strongly and remotely punctured, punctures similar to those on the head. Scutellum metallic green. Elytra with a deep basal depression, closely and strongly punctate-striate, distinct to apex, but the punctures finer. Legs metallic green; abdomen bluish-black.

Length $4 \mathrm{~mm}$.

Hab. Burma.

Smaller than $N$. dormeri and $N$. sikhimense, with metallic-green breast and legs, thorax and elytra differently punctured; the metallic underside and legs distinguish the species also from N. haroldi, Jac.

\section{Nodostoma femoratum, sp. n.}

Metallic green; head, basal joints of antennæ, thorax and bases of anterior and intermediate femora rufo-fulvous.

Broadly ovate. Head deeply and somewhat sparsely punctured at middle, more sparingly so on the vertex; clypeus emarginate at apex; antennæ black, filiform, basal four joints fulvous, third and fourth equal, last three joints wanting in the type and only specimen. Thorax scarcely more than half as broad again as long, sides obtusely angulate behind the middle, moderately narrowed anteriorly, with narrow reflexed border; anterior sulcus deeply punctured, shallow in the middle; surface strongly and sparsely punctured on the disc, area near margins nearly impunctate. Scutellum metallic green. Elytra moderately depressed below base, strongly punctate-striate, the rows of punctures more closely approximate at the sides, apex finely punctured. Femora unarmed.

Length $5 \mathrm{~mm}$.

Hab. Sikhim: Kurseong (Coll. Jacoby). Assam (Coll. Brit. Mus.).

Differs from $N$. haroldi, Jac. and $N$. indicum, Jac. in the shape and puncturation of the thorax, which is much less transverse and not at all strongly angulated at the sides; the puncturation is deep and slightly scattered, not stronger or closer on the sides than on the disc; the anterior femora alone are fulvous at base, the rest of the fore and the whole of the intermediate and posterior legs metallic green. Two exactly similar specimens are before me.

583. Nodostoma variabile, Duviv. Ann. Soc. Ent. Belg. xxxvi, 1892, p. 406.

Var. abbreviatum, Jac. Mém. Soc. Ent. Belg. vii, 1900, p. 106.

Var. mandarense, Juc. l. c. p. 107.

Body beneath, legs, part of head and thorax piceous, often with a greenish tint; basal joints of antemus testaceous; elytra blackish or greenish-black. 
خ. Head finely and remotely punctured; clypeus not separated from the face, with some widely placed strong punctures; antennæ nearly extending to apex of elytra, basal four joints and base of fifth flavous, rest black, third distinctly shorter than fourth, terminal joints very elongate and slender. Thorax at base tivice as broad as long, sides strongly angulated near base, anterior sulcus deep and entire; surface convex, very finely and remotely punctured. Scutellum piceous or fulvous. Ėlytra broadly ovate, with a short not very deep depression below base, rather finely and closely punctate-striate, tne depression somewhat more strongly and irregularly punctured. Femora with a small tooth.

$V(a)$. Head, thorax, underside and legs flavous or the whole insect flavous.

Length 4-5 mm.

Hab. Sikhim: Kurseong; Bengal: Mandar.

Very variable in colour, some specimens have the upper portion of the head flavous and the lower piceous or entirely of either colour. The species differs from $N$. fulvipes, Mots., and its varieties in the remote puncturation of the head and thorax, although in the female it is rather more close. The colour of the elytra and of the underside separates this from the preceding species.

584. Nodostoma subcostatum, Jac. Ann. Mus. Civ. Genova, xxrii, 1889, p. 164.

Fulvous or piceous; head, thorax and legs rufous; elytra metallic green or blue.

Head strongly but remotely punctured, puncturation stronger on the clypeus, anterior edge of latter deeply emarginate; antennæ fliform, flavous, terminal joints stained witl fuscous, third and fourth very elongate, equal. Thorax rather more than twice as broad as long, strongly narrowed anteriorly, sides distinctly angulated near base; anterior sulcus entire, deep and strongly punctured; surface strongly and closely punctured at the sides, more remotely so on the disc. Scutellum fulvous. Elytra rather broadly oblong, basal portion raised, with a depression below; surface strongly punctate-striate, the punctures distinct but rather finer near apex; shoulders costiform, a ridge below them running parallel with the lateral margins to about the middle; interstices somewhat raised, more distinctly so at sides. Femora with a very small tooth.

Var. a. Head fulvous, thorax and elytra blue.

Var. $b$. Entirely fulvous.

Length $3 \mathrm{~mm}$.

Hab. Assam; Burma: Tharawaddy, Teinzo, Bhamo.

No other species of this section is known to me in which the elytral lateral costa is continued to or behind the middle; this seems the same in both sexes but to a greater extent in the female. 
585. Nodostoma irrègulare, Jac. Mém. Soc. Ent. Bely. vii, 1900, p. 105 .

Fulvous; terminal joints of antennæ black; elytra metallicgreen or æneous.

Head closely punctured, rugose between the eyes; clypeus not separated from the face, anterior edge deeply concave; antenna long and slender, basal three or four joints fulvous, third twice as long as secoud. Thorax strongly transverse, strongly narrowed anteriorly, sides strongly angulate behind the middle, anterior sulcus distinctly punctured; surface closely and strongly punctured at the sides, more remotely so in the middle. Scutellum broad, smooth. Elytra distinctly depressed below base, very strongly and closely punctate-striate, with four raised narrow spaces or costæ. Femora with small tuoth.

Length $6 \mathrm{~mm}$.

Hab. Burma (Colls. H. E. Andrewes \& Jacoby).

Quite distinct on account of the close elytral puncturation and smooth interstices; at the sides the puncturation may almost be called irregular, the punctures are so close; those on the thorax vary, however, in strength.

\section{Nodostoma waterhousei, sp. n.}

Fulvous; elytra metallic greenish-æneous.

Head and clypeus rugosely punctured; antennæ rather short, extending to base of elytra, stout, third joint but little longer than second, terminal joints shorter and thicker than the preceding joints. Thorax half as broad again as long, sides angulate immediately behind the middle, anterior sulcus narrow and entire; surface fulvous, with slight metallic lustre, crowded with strong pnnctures. Elytra strongly punctate-striate, very feebly depressed below base; interstices longitudinally convex at sides. Legs fulrous.

Length $4 \frac{1}{2} \mathrm{~mm}$.

Hab. India (Coll. Brit. Mus.).

The rugosely punctured head and thorax and the close puncturation, with costate elytral interstices, distinguish this species from any other of similar coloration.

\section{Nodostoma occipitale, sp. $n$.}

Subquadrately ovate; black; base of head and basal joints of antennæ more or less fulvous; elytra metallic green or blue; abdomen flavous.

ᄋ. Head very finely and remotsly punctured, upper portion obscure fulvous; clypeus not separated from the face, anterior edge strongly triangularly emarginate, sides angulate, surface with a few punctures, stronger than those on the head; labrum fulvous; antennæ with the first three or four basal joints flavous, first basal joint piceous above, terminal joints slightly widened 
but elongate, extending to middle of elytra. Thorax transverse, strongly narrowed in front, sides strongly angulate near base, anterior transverse sulcus very deep; surface very sparingly and finely punctured on the disc, elosely punctured on the sides. Scutellum black. Elytra with a distinct depression at base, strongly punctate-striate near the base and sides, more finely punctured posteriorly, the punctures very distinct to apex. Anterior femora dilated, with a distinct tooth beneath.

Length $3 \mathrm{~mm}$.

Hab. Tenasserim : Tavoy, Mergui. Type in Brit. Mus.

Elytra black or nearly so.

\section{Nodostoma semiglabratum, sp. n.}

Fulvous; elytra black.

Head impunctate; clypeus with a few fine punctures; basal five joints of anteunæ fulvous, rest in the type and only known specimen wanting. Thorax transrerse, sides angulated some distance from base, the base twice as broad as at apex, anterior sulcus distinct at the sides only, surface scarcely perceptibly and very sparsely punctured. Scutellum fulvous. Elytra oblong, base strongly convex, shoulders very prominent, sulcate within; puncturation only distinct within the depression, rest of surface nearly impunctate; some very fine punctures arranged in a row are visible near the suture. Legs and underside fulvous.

Length $4 \mathrm{~mm}$.

$H a b$. Burma; Toungoo.

There is a single specimen of this species in the collection of Mr. H. E. Andrewes, which differs from $N$. variabilis, Duv. in the nearly impunctate elytra and in the angle on the thoracic sides being placed further from the base.

\section{Nodostoma glabricolle, sp. n.}

Fulvous; elytra bluish-black.

Head with the clypens very sparsely punctured; the latter deeply emarginate anteriorly ; antennæ with the basal five joints testaceous (rest wanting in the type and only specimen recorded), third and fourth joints equal, very elongate. Thorax about half as broad again as long, sides angulated near base, anterior sulcus deep, entire; surface entirely impunctate. Scutellum fulvous. Elytra oblong, parallel-sided, feebly depressed below base, finely and rather closely punctate-striate, the punctures, as usual, finer towards the apex. Flanks of thorax nearly smooth. Femora unarmed, fulvous.

Length $3 \frac{1}{2} \mathrm{~mm}$.

$H a b$. Southern India: Trichinopoly (Coll. Jacoby).

Amongst the species with blue or black elytra and fulvous thorax, there is none in which the thorar is entirely impunctate as in the present species. 
590. Nodostoma abdominalis, sp. $n$.

Fulvous; apical joints of antennæ, knees and abdomen partly piceous; elytra metallic bluish-black.

Head strongly and very remotely punctured; clypeus wedgeshaped, separated from the face by some deep punctures, anterior border strongly triangularly emarginate; antennæ very slender, basal six joints fulvous, rest dark piceous, third and fourth joints very elongate, equal, terminal joints shorter. Thorax twice as broad as long, sides strongly angulated near base, anterior sulcus deep and entire, surface very closely and strongly punctured throughout. Scutellum dark fulvous. Elytra with deep depression below base, puncturation very deep and strong, less so at apex, rows more closely approximate at the sides than on the disc. Legs and last abdominal segment fulvous, rest of abdomen and the breast piceous. Auterior femora with a very small tooth.

Length $2 \frac{1}{2} \mathrm{~mm}$.

Hab. Assam (Coll. Jacoby).

\section{Nodostoma sublævipenne, sp. n.}

Fulvous; elytra, breast, abdomen and the posterior legs black.

Head impunctate; clypeus not separated from the face; antennæ with the basal four joints flavous, rest black, terminal joints slender and elongate. Thorax about half as broad again as lung, sides obliquely narrowed anteriorly, rounded near the base, no anterior sulcus, surface entirely impunctate. Scutellum black. Elytra wider at base than the thorax, subquadrately ovate, base with deep transverse depression, the latter with the commencement of three rows of punctures, another short row within shoulders extending to base, rest of the surface entirely impunctate; suture accompanied by a deep striga. Anterior legs fulvous, apex of the intermediate femora, their tibiæ and tarsi and the entire posterior legs black.

Length $3 \frac{1}{2} \mathrm{~mm}$.

Hab. Burma: Momeit. Type in Brit. Mus.

A very distinct species on account of the rounded sides of the thorax at base, the black and almost impunctate elytra and the colour of the legs. I have seen only a singlo specimen, which is apparently a female.

\section{Upper surface piceous or black (sometimes with aeneous lustre).}

\section{Elytra tuberculate or costate.}

592. Nodostoma tuberosum, Jac. P. \%. S. 1887, p. 78, pl. x, fig. 4.

Dark brown. Head closely and distinctly, vertex more remotely, punctured; clypeus not separated from the face, anterior margin perfectly straight, surface clothed with a little silvery pubescence; antennæ with the basal three joints fulvous, rest in the type

VOL. I. 
and only specimen wanting. Thorax transverse, narrowed in front, sides distinctly angulated near base, surface entirely covered with deep round punctures, interstices sparingly clothed with short hairs. Elytra closely covered with strongly raised tubercles. placed irregularly along the sides, arranged in longitudinal rows on the disc; interstices with some deep punctures; shoulders prominent, each in shape like an oblique, smooth, strongly raised. tubercle.

Lenyth $6 \mathrm{~mm}$.

Hai. Ceylon.

\section{Nodostoma lefevrei, Jac. P. Z. S. 1887, p. 78.}

Dark fulvo-piceous; base of femora fulvous.

Head closely punctured on the vertex and sides; clypeus separated from the face on each side by a deep fovea, anterior edge tridentate, surface scarcely perceptibly punctured; labrum fulvous; antennæ slender, third and following joints elongate. Thorax nearly three times as broad as long, sides strongly angulated near base, posterior angles produced into an acute tooth, anterior sulcus distinct; surface very closely punctured, with some smooth raised spaces, irregularly distributed. Scutellum nearly black. Elytra with deep basal depression, very strongly longitudinally costate on the inner dise, interstices regularly punctate-striate, sides transversely rugose and wrinkled, darker in colour than the sutural portion. Femora with a minute tooth, base pale fulvous.

Length $5 \mathrm{~mm}$.

$H a b$. Ceylon.

Allied to $N$. tuberosum, but the thorax much more transverse and more finely punctured, the elytra costate and differently coloured.

\section{Nodostoma obscurum, sp. $\mathrm{n}$.}

Piceous ; bases of the antennæ and of the femora obscure fulvous. o. Narrowly oblong. Head broad, convex at base, latter remotely and finely punctured, lower portion more closely and strongly punctate; anterior edge of clypeus semicircularly emarginate; labrum piceous; antennæe extending beyond the middle of the elytra, basal three joints fulvous, rest black. Thorax about half as broad again as long, sides strongly angulated behind the middle, surface very clusely and finely punctured, anterior margin not preceded by a sulcus, posterior angles produced into a straight tooth. Seutellum smooth, apex subtruncate. Elytra oblong, strongly depressed at base, the latter raised; dise strongly punctatestriate; shoulders very prominent, followed by two or three longitudinal costre, their interstices much more strongly punctured than the others. Femora strongly incrassate, with a small tooth; intermediate tibiæ strongly, posterior feebly, emarginate at apex. Prosternum much broader than long. 
오. Thorax more transverse, elytra very strongly costate at sides. Length $3 \frac{1}{2} \mathrm{~mm}$.

Hab. Assam: Patkai Mts. Type in Brit. Mus.

Differs from $\boldsymbol{N}$. lefevrei, Jac. in the sparsely punctured head, the much less transversely shaped thorax, non-rugose sides of the elytra and the smaller general size.

\section{Elytra not costate or tuberculate.}

\section{Nodostoma picimane, sp. n.}

Beneatl dark piceous, above black; labrum and the basal and apical joints of antennæ fulvous.

Oblong. Head strongly and remotely punctured; clypeus with the inargins obscure fulvous, surface punctured like the head; antennæ slender, basal three and apical two joints fulvous. Thorax transverse, acutely angulated behind the middle; anterior sulcus entire, deep at sides; surface very strongly and somewhat sparsely punctured, interstices at the sides somewhat convex. Scutellum broad, smooth. Elytra subeylindrical, parallel-sided, deeply depressed below base and within shoulders, strongly punctate-striate, puncturation gradually diminishing posteriorly. Legs black, knees obscure piceous or fulvous.

Length $4 \mathrm{~mm}$.

Hab. India (Coll. Jaroby).

\section{Nodostoma imitans, sp. $\mathrm{n}$.}

Piceous or black; basal joints of antennæ and head more or less fulvous.

$0^{*}$. Head rather strongly and closely punctured; anterior border of clypeus strongly emarginate; antennæ with the basal four joints fulvous, rest black, third and fourth equal. Thorax half as broad again as long, sides very strongly angulated just behind the middle, strongly obliquely narrowed in front and at base, anterior sulcus entire, surface strongly and closely punctured. Elytra with deep basal depression, shoulders very prominent ; surface strongly punctate-striate anteriorly, finely punctured towards apex, the punctures widely separated. Femora unarmed.

Length $2 \frac{1}{2} \mathrm{~mm}$.

Hab. Manipur (Coll. Brit. Mus.).

Closely allied to $N$. obscurum, Jac., but constantly smaller, the thorax less closely punctured, the elytral interstices not costate in either sex and the punctures much inore widely separated; there is also a slight greenish tint on the surface of the elytra.

597. Nodostoma angulicolle, Duviv. Anu. Soc. Ent. Belg. xxxvi, 1892, p. 408.

"Body beneath, legs, head (anterior portion excepted) and thorax piceous; scutellum fulvous; antennæ black, base paler; elytra greenish-black. 
"Head moderately strongly punctured; clypeus and labrum fulvous; antennæ black, base fulvous. Thorax about twice as broad as long at base, strongly angulated at sides near the base, surface very strongly and densely punctured except near anterior margin. Elytra oblong-ovate, distinctly depressed below the base, the anterior portion moderately strongly, posterior more finely punctate-striate. Femora with a small tooth; flanks of thorax strongly punctured.

" Length $4 \frac{2}{3}$ min.

"Hab. Sikhim : Kurseong." (Duvivier.)

It is very probable that this species is only a variety of N. puncticolle, Lefèv., from which, according to the description, it does not seem to differ structurally.

598. Nodostoma feæ, Jac. Ann. Mus. Civ. Genova, xxxii, 1892, p. 897.

Piceous; head fulvous; antennæ partly and the legs flavous.

Head very remotely and rather strongly punctured; clypeus not separated from the face, punctured like the bead; antennæ with the apical joints darker, slightly thickened. Thorax half as broad again as long, distinctly angulated at the middle, very deeply and coarsely but not very closely punctured. Elytra wider at base than the thorax, basal portion strongly raised, bounded by a deep depression, the latter deeply punctured, rest of surface impunctate with the exception of a single row of punctures near the suture.

Var. $a$. Apex of elytra flavous, other parts piceous.

Var. $b$. Fulvous, elytra paler.

Length $3 \mathrm{~mm}$.

Hab. Burma: Karennee.

The strongly punctured thorax and impunctate posterior portion of the elytra separate this species from others that are similar in coloration.

Var. $a$ must not be confounded with $N$. flavolimbatum, Jac., which is similar in coloration, as that species has an impunctate head and the sides of the thorax angulated near the base, not at the middle.

\section{Elytra clark, apex pale.}

599. Nodostoma nilgiriense, Jac. Ann. Soc. Ent. Belg. xlvii, 1903, p. 96.

Flavous; apical joints of antennæ black; elytra black, the apex flavous.

Head finely and sparingly punctured, with a short but deep depression in front of eyes, indicating the limit of the clypeus at the sides, anterior margin of latter nearly straight; antennæ black, basal four joints flavous, third and fourth equal, terminal joint slender. Thorax more than twice as broad as long, very short, sides subangulate near base, anterior sulcus entire, surface 
rather finely but not closely punctured. Scutellum flavous. Elytra with deep but short depression below base, shoulders prominent, followed by a short costa, surface strongly punctatestriate anteriorly. Femora with a minute tooth.

Var. $a$. Body beneath black.

Var. $b$. Above and beneath entirely flavous.

Length $3 \mathrm{~mm}$.

$H a b$. Southern India: Nilgiris.

A small species which has also been obtained by Mr. H. L. Andrewes lately; in some of these specimens the head is entirely impunctate. The angle at the sides of the thorax is placed close to the base, and the flavous apex of the elytra appears like a narrow band extending upwards a little way along the lateral margins. I have but little doubt that the entirely unicolorous pale specimens represent the same species, since there are absolutely no structural differences. The species is characterized by the nearly or entirely inpunctate head and very finely but not very closely punctured and short thorax.

\section{Nodostoma flavolimbatum, sp. n.}

Fulvous; elytra black, extreme apex fulvous; sides of breast black.

Oblong, convex, subcylindrical. Head impunctate; clypeus with a few punctures at base, sides with a forea indicating separation from face; antennæ slender, fulvous, terminal joints scarcely thicker than the basal. Thorax more than twice as broad as long, sides angulated near base; anterior sulcus deep at sides, obsolete in the niddle, the sulcus with a few fine punctures; dise impunctate or with a few punctures, widely scattered. Scutellum black. Elytra with distinct basal depression, strongly punctate-striate anteriorly, posterior portion nearly impunctate, a single row of punctures near suture distinct to apex. Breast black; legs fulvous; femora unarmed.

Length $2 \frac{1}{2} \mathrm{~mm}$.

Hab. Southern India: Nilgiris; Burma: Ruby Mines. Type in Brit. Mus.

The small size and black elytra with the apical margins narrowly fulvous, separate this species from its allies. The specimens from the Nilgiris only differ in having the legs more or less stained with piceous and some slight variations in puncturation.

\section{Nodostoma terminatum, sp. n.}

Oblong; nearly black; basal joints of antennx and femora more or less fulvous; apex of elytra flavous.

Head sparingly and very remotely punctured; antennæ black, basal three joints obscure fulvous beneath, third joint but little longer than second, following joints of similar length. Thorax half as broad again as long, sides strongly angulated directly behind the iniddle, anterior sulcus only distinct at the sides; 
surface with a transverse depression at each side, strongly and closely punctured. Scutellum broadly ovate. Elytra with very deep depression below base, base strongly convex; surface strongly punctate-striate, more finely so towards the apex, apex entirely impunctate, flavous to a short extent. Femora unarmed, base fulvous.

Length $3 \frac{1}{2} \mathrm{~mm}$.

Hab. Manipur (Coll. Brit. Mus.).

\section{Thorax or elytra pubescent; colour variable.}

602. Nodostoma pubicolle, Jac. Ann. Soc. Ent. Belg. xxxix, 1895, p. 277.

Nodostoma anchoralis, Jac. Mém. Soc. Ent. Belg. vii, 1900, p. 103.

Testaceous ; apical joints of antennæ, a central spot on head (sometimes absent), another on thorax, elytral suture at middle and a spot behind the latter, black.

Head closely and strongly punctured; clypeus not separated from the face, semicircularly emarginate in front; antennæ extending to middle of elytra in male, shorter in female, basal four or five

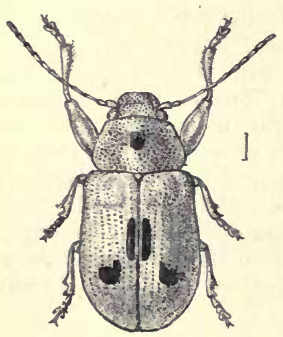

Fig. 119.-Nodostoma pubicalle, var. joints fulvous, rest black, third joint rather smaller than the fourth. Thorax half as broad again as long, sides more or less distinetly angulated near base; anterior sulcus indistinct at middle; surface strongly and closely rugose-punctate, interstices finely and sparingly pubescent, a more or less dereloped black spot at middle. Elytra with shallow depression below base, orate, rather convex, strongly punctate-striate, base irregularly punctured, punctures nearly as strong at apex; interstices more or less costate anteriorly; shoulders tuberculiform, followed by another small tubercle posteriorly. Sides of hreast sometimes piceous. Femora unarmed.

Var. a. Elytral sutural stripe and spot connected at apex. anchor-shaped ( $N$. anchoralis, Jac.).

Var. $b$. Thorax and elytra without black markings.

Length $3 \mathrm{~mm}$.

Hab. Madras Presidency: Madura; Pondicherry ; Mysore (var. $a)$.

A variable species in regard to markings: these sometimes occupy the greater part of the head and thorax, while the inarkings on the elytra may consist of two small streaks in the middle and the suture more or less black; the species can, howerer, always be recognized by the rugose and pubescent thorax. 
603. Nodostoma hirsutum, sp. n.

Piceous, strongly pubescent; base of femora and the elytra dark fulvous.

Oblong. Head dark fulvous, strongly and elosely punctured and rugose, sparingly pubescent; eyes entire; clypeus not separated trom the face; antennæe searcely extending to middle of elytra, basal four joints fulvous, rest nearly black, second joint eurved, elongate and as long as the third, fourth longer than the third, following joints slightly thickened. Thorax about lialf as broad again as long, sides distinetly angulated behind the middle, obliquely narrowed anteriorly, surface finely and elosely rugose and pubescent, interstices subtuberculate anteriorly. Scutellum piceous, punctured and pubescent, rather large, subpentagonal. Elytra wider at base than the thorax, parallel-sided, subcylindrical ; entire surface strongly and closely rugose, irregularly punctured and clothed with long yellow pubescence. Femoria incrassate, minutely toothed beneath. Prosternum very broad, finely rugose and pubescent.

Length $4 \mathrm{~mm}$.

Hab. Assam : Patkai Mts. Type in Brit. Mus.

A very aberrant species, which, although it possesses nearly all the structural characters of the genus, differs in the long second joint of the antennæ, the entirely rugose upper surface and the long although rather sparingly distributed pubescence above. Notwithstanding these structural differences, I prefer at present to locate it in this genus.

\section{Nodostoma cribricolle, sp. n.}

Flavous. Head finely granulate, sparingly punctured, opaque; clypeus semicircularly emargiuate; antennæ black, basal three joints flavous, second joint as thick as the basal joint but shorter, terminal joints scarcely thickened. Thorax half as broad again as long, sides angulated just behind the middle, apex and base strongly obliquely narrowed, anterior sulcus feeble but distinct; surface closely and finely punctured and wrinkled, clothed with a little extremely short pubescence. Elytra oblong, with distinct basal depression, strongly and elosely punctate-striate, puncturation nearly as strong at apex, an obscure fuscous elongate mark behind the middle.

Length $3 \mathrm{~mm}$.

$H a b$. Southern India: Nilgiris. Type in Brit. Mus.

Allied to N. pubicolle, Jac., dise without markings, elytra more regularly punctate, not irregularly puuctured at base near suture as in the allied species.

\section{Nodostoma antiquum, sp. n.}

Head and thorax fulvous; apical joints of antennæ black; elytra testaceons; femora more or less piceous.

Head closely rugose and sparingly pubescent ; basal four joints 
of antennæ testaceous, rest piceous or blackish, third and fourth equal. Thorax twice as broad as long, sides acutely angulate near base; anterior sulcus nearly entire, very narrow; surface sculptured and pubescent like the head. Scutellum trigonal, smooth. Elytra with deep basal depression, strongly punctatestriate, punctures very closely placed, interstices strongly costate at the sides and to a less degree on the disc. Legs testaceous; femora more or less piceous at apex, with a small tooth beneath. Prosternum twice as broad as long, punctured.

Length $3 \mathrm{~mm}$.

Hab. Southern India: Nilgiris (Coll. H. E. Andrewes).

\section{Nodostoma maculiceps, sp. $\mathrm{n}$.}

Piceous or black beneath; terminal joints of antennæ black, basal joints flavous; head and thorax fulvous, each with a black spot; elytra testaceous, sutural and lateral margins anteriorly, a spot below base and two behind the middle, black ; femora more or less spotted.

Head dark fulrous, closely and strongly rugose and punctured; clypeus rugose like the rest of the head, its anterior border slightly emarginate; antennw black, slender, basal four joints flavous, third slightly shorter than the fourth, terminal joint elongate, thickened. Thorax scarcely twice as broad as long, convex, sides obsoletely angulate near base, gradually narrowed at apex; surface very strongly rugose and punctured, sparingly clothed with short pubescence; anterior sulcus faintly marked. Scutellum nearly black. Elytra oblong, transversely depressed below base, each with ten strongly raised longitudinal costæ, the interstices strongly punctured, the suture and an elongate spot or short stripe behind the middle on the fonrth costa obscure piceous. Anterior femora strongly thickened, with a large black spot below near apex.

Var. Elytral and femoral markings obsolete.

Length $2 \frac{1}{2}-3 \mathrm{~mm}$.

$H a b$. Southem India: Madura; Anaimalais (Coll. H. E. Andrewes); Trichinopoly; Pondicherry (Colls. Brussels Mus. \& Jacoby).

A very variable species in regard to size and markings, but well distinguished by the closely rugose head and thorax, central spot of latter, and the elytral costæ. In well marked specimens the elytral spots are black, in others only fuscous or absent altogether.

\section{Nodostoma instabile, sp. n.}

ऽ. Testaceous. Head strongly and closely punctured; clypeus not separated from the face; antennæ entirely testaceous, second joint proportionately long, but slightly shorter than the first and third joints, terminal joints rather thickened, extending beyond middle of elytra. Thorax transverse, strongly narrowed in front, sides with a blunt angle near base, anterior sulcus entire; surface closely rugosely punctured, interstices sparingly pubescent. Elytra rather long, with distinct depression below base; puncturation 
neariy as strong as that on the thorax, arranged in closely approximate rows; interstices feebly longitudinally costate at sides only. Legs robust, unarmed, tarsi broad.

․ Thorax less strongly punctured; elytra with a short row of tubercles below shoulders; tarsi less robust.

Length $3 \mathrm{~mm}$.

$H a b$. Southern India: Trichinopoly. Type in Coll. Jacoby.

Very like $N$. maculiceps, but the thorax longer and less transverse in shape, the elytra only feebly costate at the sides, punctures less closely placed.

\section{Nodostoma dimidiatipes, sp. $n$.}

Head and thorax dark fulvous, finely pubescent; elytra testaceous, sutural and lateral margins anteriorly, spot behind the middle and underside black; basal joints of antennæ, base of femora, apices of tibiæ and the tarsi pale fulvous.

Closely allied to $N$. antiquum, sinaller, rather broad and oblong; head and thorax similarly sculptured and pubescent; elytra very strongly punctate-striate, interstices feebly convex at sides; anterior legs elongate, femora strougly thickened, unarmed.

Length $2 \frac{1}{2} \mathrm{~nm}$.

$H a b$. Southern India: Nilgiris. Type in Coll. H. E. Andrewes.

Differs in the markings of the elytra and colour of underside from other pubescent species.

\section{Elytra otherwise mar\%ed, non-pubescent.}

\section{Nodostoma fulvofasciatum, sp. n.}

Fulvous ; thorax and sides of breast black ; elytra black, a broad transverse band behind the middle fulvous.

․ Subquadrately ovate. Head fulvous, impunctate, with a narrow central groove; clypeus not separated from the face, studded with a few punctures on the sides and middle, anterior margin subtriangularly emarginate; antennæ flavous, long and slender, apical tliree joints thickened, piceous. Thorax very short, more than twice as broad as long, sides strongly angulated behind the middle, obliquely narrowed in front; anterior margin fulvous, followed by a distinct sulcus; surface minutely and remotely punctured. Elytra with deep transverse basal depression, strongly punctate-striate within shoulders and in the depression, rest of the surface very finely, nearly obsoletely punctured, punctures near suture more distinct; a short, oblique, strongly raised costa runs from the shoulders to the lateral margin at the basal portion. Legs pale fulvous; femora with a minute tooth beneath. Length $3 \frac{1}{2} \mathrm{~mm}$.

Hab. Assam Valley (Doherty). 'Type in Brit. Mus.

\section{Nodostoma momeitense, sp. n.}

Fulvous; elytra with a black spot on each below base; the apex of the posterior or of all the femora black.

c. Subquadrate-ovate. Head nearly impunctate, only a single 
row of punctures at extreme base, middle with short groove; clypeus separated at the sides by an elongate fovea, semicircularly emarginate in front; mandibles black; antennæ long and slender, pale fulvous, apex of terminal joint thickened, piceous. Thorax very short, strongly transverse, sides obtusely angulated near the base, strongly obliquely narrowed anteriorly, anterior sulcus deep and narrow ; surface very sparingly and finely punctured at the sides only. Scutellum broad, impunctate. Elytra with a deep fovea below base, the interior of which is black; surface rather strongly punctate-striate, punctures at the sides very strong, closely placed; a short oblique costa from shoulders to margins, interstices slightly convex. Posterior femora with a distinct tooth beneath.

Var. Elytra, the extreme base excepted, black.

Length $3 \frac{1}{2}-4 \mathrm{~mm}$.

Hab. Burma : Momeit. Type in Brit. Mus.

Differs from $N$. cardoni, Jac. in the impunctate head and nearly impunctate thorax, the black apex of the femora and the want of the black sutural and lateral margins. In the female the punctures at the sides of the thorax are rather more distinct (in some males the entire thorax is nearly impunctate). Some specimens have the elytral spots scarcely indicated, some entirely absent, but the black apex of the femora seems constant. In one instance the elytra are black, with the extreme basal margin only fulvous; whether this is the norinal form or a variety of the one described above I cannot say, the specimen agrees in every other respect with the type.

611. Nodostoma discicolle, Jac. Mém. Soc. Ent. Belg. xxxix, 1895, p. 278.

Fulvous; thorax with two large nearly connected discoidal black spots; elytra with a small piceous spot within depression.

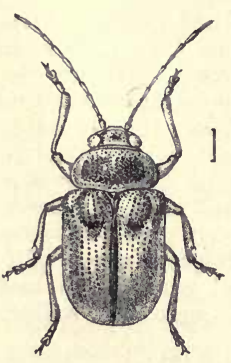

Fig. 120.

Nodostoma discicolle.

Head strongly and closely punctured; clypeus not separated from the face, closely punctured like the head; anteunæ slender, fulvous, terminal joints stained with piceous, third joint half the length of the fourth; vertex of head sometimes with a small piceous spot. Thorax rather more than twice as broad as long, sides rather strongly rounded, very obsoletely angulate near base, anterior sulcus entire; surface very finely and closely punctured on the disc, sides more strongly punctured, middle with a narrow longitudinal smooth line; disc with two large black patches, the margins around them only, of the ground-colour. Scutellum with apex broadly rounded. Elytra deeply and closely punctate-striate at sides, more finely punctured near the suture; a deep transverse 
depression below base, marked with black; interstices at sides rather costate; shoulders very prominent, followed by a short oblique costa. Knees and breast sometimes uarked with piceous.

Length $3 \mathrm{~mm}$.

$H a b$. Southern Bombay : Kanara.

Allied to $N$. geniculatum, Lefèv. in coloration but with differently coloured head, thorax, scutellum, and underside.

\section{Nodostoma impressipenne, Jac. P. \%. S. 1887, p. 77.}

Testaceous; last seven joints of antenuæ black; sutural and lateral margins of elytra obscure fulvous.

Head strongly but very remotely punctured; clypeus not separated from the face; antennæ slender and long, third and fourth joints equal. Thorax scarcely twice as broad as long, sides angulated near the base, strongly narrowed anteriorly, anterior sulcus distinct; surface punctured as on the head. Elytra narrowed and pointed at apex, with a deep basal depression, the latter deeply punctured, rest of surface punctate-striate; within the shoulders and near the suture, a short row of deeper punctures extends to base and two other short rows from below shoulders to margins. Legs comparatively very elongate; all the femora with a small tooth beneath.

Length $3 \mathrm{~mm}$.

$H a b$. Ceylon: Galle.

Differs from $N$. fairmairei in the sculpture and comparative greater length of the thorax and of the legs.

\section{Nodostoma nigrolineatum, sp. n.}

Beneath black, above testaceous; head black on vertex; disc of thorax nearly black; elytra with three or four short dark stripes from base to middle, a transverse medial spot and a sutural spot black.

Head remotely and finely punctured, base black, the black

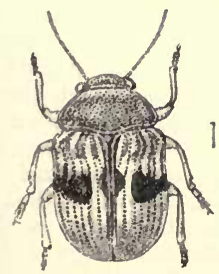

Fig. 121.-Norlostoma nigrolincatum.

Length $2 \frac{1}{2} \mathrm{~mm}$. disposed as a transverse band; clypeus rather more strongly punctured, somewhat feebly emarginate in front; basal six joints of the antennæe testaceous, rest in the type and only specimen wanting, third and fourth joints equal. Thorax short and strongly transverse, angulated near the base, the angle not strongly marked, anterior sulcus entire; surface extremely closely and finely punctured; entire disc black, margins and sides narrowly flavous. Elytra with a short and deep basal depression, strongly punctate from base to middle, posterior half nearly impunctate. Legs testaceous.

Hab. Travancore: Wallardi (Coll. Jacoby). 
A very short and rather broad species sufficiently distinguished by the elytral markings.

\section{Nodostoma obscuro-maculatum, sp. n.}

Obscure pale fulvous ; terminal joints of antennæ black ; elytra testaceous, some small elongate spots at base and another spot near the apex piceous.

Head closely and strongly punctured, shining ; antennæ slender, basal four joints testaceous, rest black, third joint slightly shorter than the fourth. Thorax about half as broad again as long, obtusely angulated behind the middle, strongly narrowed in front, anterior sulcus narrow but distinct, surface finely and closely rugosepunctate. Elytra elongate, with deep basal depression, strongly punctate-striate; interstices closely and strongly longitudinally costate; two short piceous spots at base of outer two rows of punctures within shoulders, another spot on third costa near suture and apex.

Length $2 \frac{1}{2} \mathrm{~mm}$.

$H a b$. Southern India : Nilgiris. Type in Brit. Mus.

Although closely allied and of nearly similar sculpture to $N$. corrosicollis, evidently distinct on account of the non-rugosely punctured and shining head, less strongly rugosely-punctured thorax, and the elytral spots, on which the punctures are also less regularly placed.

\section{Nodostoma ornatum, sp. $n$.}

Greenish-æneous; antennæ and legs fulvous; elytra with a round spot at base and an elongate spot at middle near suture, fulvous.

Oblong-ovate. Head strongly rugose-punctate, obscure fulvous on the vertex ; clypeus not separated from the face, semicircularly emarginate in front; labrum æneous; palpi fulvous; basal seven joints of the antennæ fulvous, rest wanting in the type and only specimen, second joint as long as the first, more slender, third slightly longer. Thorax transversely subcylindrical, sides deflexed, lateral margins feebly rounded, anterior sulcus distinct only near the angles; surface extremely closely punctured, the puncturès crowded at the sides and partly confluent. Scutellum subquadrate, impunctate. Elytra broadly ovate, with a feeble depression below the base, strongly punctate-striate, apex very finely punctured; first four interstices fulvous behind the middle, thus forming an elongate patch. Femora strongly thickened, with distinct tooth beneath.

Length $4 \frac{1}{2} \mathrm{~mm}$.

$H a b$. Southern Bombay: Kanara (Coll. H. E. Andrewes).

A peculiarly marked species that differs somewhat structurally from other species in the genus in the proportionately long second joint of the antennæ and in the shape of the thorax, which is not 
more than half as broad agnin as long, with rounded sides, the sides more deflexed than usual.

\section{Nodostoma tavoyense, sp. $n$.}

ऊ. Fulrous; elytra, legs, and antennæ testaceous; suture of elytra fuscous.

Head very finely and sparingly punctured, extreme vertex of head more closely punctured, the punctures elongate; clypeus with a few deep punctures, sides with a short elongate groove, anterior edge nearly straight; antennæ long and slender, third, fourth, and fifth joints very elongate and slender. Thorax twice as broad as long, sides angulated near the base, anterior sulcus distinct, surface rather strongly but not very closely punctured except at the sides. Elytra elongate, strongly transversely depressed below the base, anterior portion rather strongly punctate-striate, apical area nearly impunctate, two rows of punctures only near the suture.

Length $3 \mathrm{~mm}$.

Hab. Burma: Ruby Mines; Tenasserim: Tavoy. Type in Brit. Mus.

This species belongs to the group that has an elongate not ovate shape, and a distinctly punctured thorax; in the Burma specimen the thoracic sulcus is obsolete at the middle. I cannot find other differences of importance.

617. Nodostoma suturale, Motsch. Bull. Mosc. 1866, p. 410.

"Rufo-testaceous. Thorax remotely punctured; elytra distinctly punctate-striate.

"Length $2 \frac{1}{2} \mathrm{~mm}$.

"Hab. Ceylon." (Motschulsky.)

This and the following four species cannot be identified with any degree of certainty.

618. Nodostoma viridipenne, Motsch. in Schrenck, Reise Amur. 1860, p. 177.

"Resembles greatly $N$. aneipenne in shape, form and colour; and only differs in the rather shorter elytra, a more trapezoidal thorax, less closely punctured, more shining, and by the feebly dentate femora.

"Hab. India." (Motschulsky.)

619. Nodostoma pusillum, Gyllenh. (Colaspis) in Schönh. Syn. Insect i, 2, 1808, p. 233.

"Greenish-æneous; beneath bluish-black; labrum, base of antennæ and legs rufo-testaceous.

"Subglobose. Head finely and remotely punctured. Thorax broadly transverse, scarcely narrowed in front, angles strongly deflexed and pointed; sides scarcely rounded, narrowly margined, posterior angles produced; above strongly convex, finely 
punctured. Elytra widened below base, apex rounded, finely punctate-striate. Below finely pubescent femora strongly widened at middle.

"Length $2 \mathrm{~mm}$.

"Hab. India orient." (Gyllenhal.)

Doubtful whether it belongs to this genus.

620. Nodostoma sculpturatum, Motsch. in Schrenck, Reise Amur. 1860, p. 177 ; Lefèv. Cat. Eumolp. 1885, p. 60.

"Resembles much $N$. cribricolle, Motsch. The thorax is similarly opaque, on account of the deep puncturation; the general size is, however, larger, humeral angles more prominent; the femora and the epipleuræe are blue like the upper surface, and the femora are feebly dentate.

"Hab. India orient." (Motschulsky.)

621. Nodostoma picturatum, Motsch. Bull. Mosc. 1866, p. 409; Lefèv. Cat. Eumolp. 1885, p. 60.

"Testaceous, shining; head in front and thorax distantly punctured and impressed; body beneath, the knees, tibiæ and tarsi fuscous; antennæ (base excepted), four spots on each elytron, and the suture black, finely punctate-striate.

"Length $3 \mathrm{~mm}$.

"Hab. Ceylon." (Motschulsky.)

\section{Genus PSEUdOSTONOPA.}

Pseudostonopa, Jac. Ann. Soc. Ent. Belg. xlvii, p. 98 (1903).

Type, P. bicolor, Jac., from India.

Range. India.

Subquadrately-ovate; eyes entire; clypeus not separated from the face, anteriorly triangularly emarginate: palpi very slender: antennæ filiform, second joint as long as or longer than the third. Thorax transversely subquadrate, subcylindrical, lateral margins rounded or obtusely biangulate. Scutellum broadly subovate. Elytra slightly wider at base than the thorax, subeylindrical, punctate-striate. Legs robust; femora thickened, unarmed; tibiæ sulcate, intermediate and posterior tibiæ emarginate at apex, the emargination closely pubescent; claws appendiculate. Prosternum subquadrate; anterior margin of thoracic episternum concave.

The affinities of this genus are nearer to Nodostoma than to any other, but the whole appearance of the insects is different, very contex and subcylindrical; the elytra are but slightly wider at base than the thorax and have only a very slight depression below the base. The principal difference, however, is in the equal width of the thorax, which is not narrowed in front nor angulate at sides near base as in most of the forms of Nodostoma. 
622. Pseudostonopa bicolor, Jac. Ann. Soc. Ent. Belg. xlrii, 1903, p. 99.

Dark fulrous, nore or less marked with black; thorax with broad black band; legs spotted, apex of tibire and the tarsi fulvous.

o. Head closely punctured anteriorly ; clypeus longitudinally striate at the anterior edge, the latter triangularly emarginate;

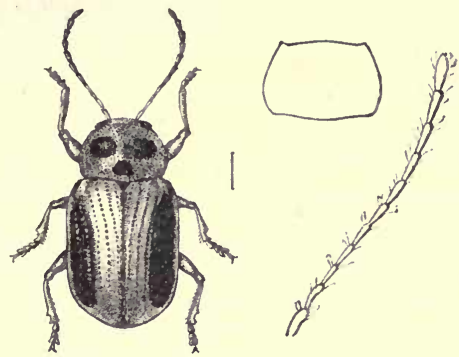

Fig. 122.-1'seudostonopa bicolor.

anteunæ fulvous, terminal joints more or less piceous. Thorax with disc more or less piceous, closely punctured at middle, sides with a more or less distinct trausverse sulcus. Elytra feebly depressed below base, with short rows of tine punctures, distinct only below the base; the base and the apex fulvous, disc more or less black. Legs fulvous. Beneath more or less piceous. Tibiæ widened at apex, first joint of anterior tarsi dilated.

․ Thorax without sulcus; anterior tarsi less widened than in the $\delta$. Otherwise similar.

Var. Nearly black; apex of elytra flarous.

Length $4 \mathrm{~mm}$.

Hah. Southern India : Nilgiris.

The amount of black on the elytra is variable, and sometimes assumes the shape of a longitudinal band; the knees also are more or less piceous in some specimens, in one specimen they are nearly black; a small humeral spot, the anterior margin of the thorax and apex of elytra alone are pale fulvous.

623. Pseudostonopa biplagiata, Jac. (Nodostoma) Ann. Mus. Civ. Genora, xxvii, 1889, p. 162.

Piceous; basal joints of antennx, head, anterior inargin of thorax, legs and abdomen fulvous; elytra fulvous, each with a discoidal oval black spot.

q. Oblong and subcylindrical; upper portion of head impunctate; clypeus strongly and remotely punctured, anterior margin feebly emarginate; antennæe with the basal three joints flavous, rest more or less fuscous, joints rather short and stout, third joint shorter than the second and fourth, apical joint scarcely 
extending to the middle of the elytra. Thorax not more than half as broad again as long, sides biangulate, only slightly narrowed at base and apex; surface convex, without anterior sulcus but with a short row of punctures at the sides of the anterior margin; surface finely and irregularly punctured on the basal portion and sides, anteriorly sparingly punctured. Elytra oblong-ovate, convex, without any basal depression, strongly punctate-striate, the punctures remotely placed, nearly absent on the black spots but continued near suture. Legs unarmed.

Length 3-31 $\mathrm{mm}$.

Hab. Burma: Bhamo, Teinzo.

\section{Psendostonopa castanea, sp. n.}

Reddish-fulvous; antennæ and legs black, basal joints of antennæ fulvous.

Head strongly but not very closely punctured; clypeus separated from the face by a distinct transverse grouve, surface with a few fine punctures, anterior margin very moderately concave-emarginate; antennæ rather robust, basal two joints fulvous, third joint not longer than second, fourth shorter than the fifth, terminal joints elongate. Thorax only a little broader than long, sides nearly straight, obtusely biangulate; anterior sulcus deep at the sides, obsolete in the middle; surface strongly and remotely punctured. Scutellum longer than broad, smooth. Elytra wider at base than the thorax, transversely sulcate below base, convex and subcylindrical, finely punctate-striate, punctures stronger at base and within depression; shoulders prominent, followed inwardly by a short costa that is divided anteriorly. Flanks of thorax and the breast impunctate. Femora unarmed. Prosteruum subquadrate, posterior margin feebly rounded.

Length $4 \mathrm{~mm}$.

Hab. Darjeeling (Coll. Jacoby).

The coloration at once separates this species from the preceding.

\section{Pseudostonopa picea, sp. n.}

Above inore or less piceous; beneath black; antennæ and apex of elytra pale fulvous.

Of obloug shape. Head broad, strongly rugosely punctured; clypeus and labrum fulvous, upper portion darker; antennæ slender, extending to the middle of the elvtra, basal joint short and thick, second very elongate, as long as third, fourth and following joints longer. Thorax scarcely half as broad again as long, sides strongly rounded at the middle, narrowed at base and apex, lateral margins subangulate behind the niiddle, surface closely impressed with large round punctures, all the angles inucronate. Elytra oblung, not wider at the base than the thorax, very strongly and deeply 
punctate-striate, punctures below shoulders deeply foveolate; humeral callus tuberculate. Legs robust; femora fulvous at base, black at apex. Prosternum subquadrate, deeply punctured.

\section{Length $4 \mathrm{~mm}$.}

Hab. Sikhim : Mungphu. Type in Brit. Mus.

A species of peculiar shape on account of the oblong elytra narrowed at base; also distinguished by the strong puncturation, very long second joint of antennæ, \&c.

\section{Genus CHRYSONOPA, nov.}

Type, C. viridis, Jac.

Range. India.

Body elongate, metallic; antennæ filiform; clypeus not separated from the face. Thorax subquadrate, sides rounded at the middle, surface convex, without depressions. Elytra wider at base than the thorax, elongate, with a basal depression, punctate-striate. Legs slender; femora widened at the middle furnished with a small tooth beneath, slender at base ; intermediate and posterior tibiæ emarginate at apex, tarsi with the first joint distinctly longer than the second; claws appendiculate. Prosternum subquadrate, scarcely longer than broad; anterior margin of thoracic episternum concave.

Most of the characters similar to those of the genus Nodostella, Jac., but the coloration metallic, thorax convex, subquadrate, without depressions, legs much more elongate and slender, femora furnished with a small tooth beneath.

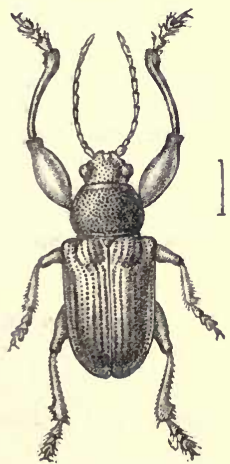

Fig. 123.

Chrysonopa rotundicollis.
626. Chrysonopa rotundicollis, Jac. (Nodostoma) Mém. Soc. Ent. Belg. vii, 1900, p. 104.

Black beneath, dark fulvous above; elytra with black lateral stripe; knees and apex of tibiæ piceous.

c. Elongate. Head strongly rugosepunctate; clypeus not separated from the tace, anterior margin deeply concave-emarginate; mandibles black, robust; antennæ filiform, fulvous, seventh to ninth joints black, terminal joints in the type and ouly specimen wanting, basal joint short and broad, second curved and slender, nearly as long as the first, third slightly longer than the second, fourth much longer. Thorax half as broad again as long, of equal width, sides strongly rounded, surface strongly rugose-punctate, anterior sulcus deep. Elytra wider at base than the thorax, elongate, rather flattened, deeply depressed below the base; vor. I. 
surface stronglv punctured in closely approximate rows, less regular within depression and below shoulders where the interstices are transversely rugose; interstices on disc longitudinally costate. Legs very elongate; anterior femora more than usually incrassate, armed with a small tooth; anterior tibiæ rather curved, deeply sulcate, apex abruptly thickened and angulate. Flanks of thorax finely strigose. Prosternum deeply punctured posteriorly.

Length $7 \mathrm{~mm}$.

Hab. Assam : Khási Hills (Coll. Jacoby).

This species, although not metallic in coloration, agrees in structural characters with the type, except that the anterior femora in the only specimen available for examination are enormously incrassate, which is probably a sexual distinction.

\section{Chrysonopa viridis, sp. $\mathrm{n}$.}

Metallic green or blue; antennæ and legs fulvous or piceous.

Very elongate. Head very closely and

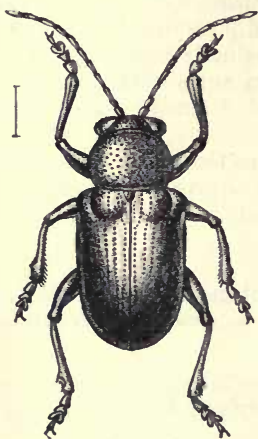

Fig. 124.

Chrysonopa viridis. strongly punctured; punctures on the clypeus almost confluent; the clypeus not separated from the face, anterior edge deeply concavely emarginate; labrum fulvous; palpi flavous; antennæ slender, extending below middle of elytra, third and fourth joints elongate, equal, nearly twice as long as the second, following joints shorter and stouter. Thorax scarcely broader than long, sides rounded at the middle, angles mucronate, surface punctured like the head. Elytra wider at base than the thorax, very elongate, deeply transversely depressed below base, shoulders acute, terminating in short costro; surface deeply punctate-striate except at base and apex where the punctures are finer. Legs elongate, femora thickened at middle, intermediate and posterior tibiæ emarginate at apex; claws appendiculate. Prosternum subquadrate.

Length $6 \mathrm{~mm}$.

Hab. Southern India: Pondicherry, Trichinopoly (Cotls. Brussels Mus. \& Jacoby).

628. Chrysonopa longipes, Jac. (Dermorhytis) Norit. Zool. i, 1894, p. 275 .

Beneath black with slight greenish tint, or piceous; above metallic dark green; labrum and basal joints of antennæ fulvous.

Head strongly and remotely punctured; clypeus not separated 
from the face, punctured like the head, anterior border concaveemarginate; palpi flavous, slender, terminal joint pointed ; antennæ extending to about middle of elytra, third and fourth joints very elongate, equal, more than twice as long as second, following very slightly thickened and shorter, basal three or four joints fulvous, rest black. Thorax about half as broad again as long (not twice as broad, as originally given), convex, surface punctured like the head, the punctures distant. Elytra about half as long again as broad, deeply depressed below the base, the latter raised, shoulders very prominent; surface strongly and deeply punctate-striate, punctures below shoulders more irregular and larger, those near apex smaller; interstices smooth. Legs elongate, femora robust, intermediate tibiæ emarginate at apex.

Length $4 \mathrm{~mm}$.

Hab. Burma: Ruby Mines.

There does not seem to be much difference between the sexes, if I have rightly paired the specimens; the tarsi in the male are slightly more dilated and the antennæ rather longer, the femora in both are distinctly thickened at middle.

\section{Chrysonopa brunnea, sp. $n$.}

Fulvous; antennæ, apices of tibiæ and the tarsi paler.

Elongate. Head strongly and remotely punctured; clypeus not separated from the face, anterior edge feebly concave; palpi flavous; antennæ with the basal five joints flavous, rest wanting in the type and only specimen, basal joint elongate and thickened, second about half the length, more slender, the others longer. Thorax but little broader than long, sides rounded, sulcate behind anterior margin, entire surface impressed with deep and strong punctures that are partly confluent at the sides. Elytra much wider at base than the thorax, basal portion raised, dise finely punctate-striate, apex nearly impunctate. Legs elongate; femora unarmed. Prosternum slightly longer than broad, narrowed anteriorly.

Length $4 \mathrm{~mm}$.

$H a b$. Southern India : Nilgiris. Type in Coll. H. E. Andrewes.

Smaller than C. rotundicollis, Jac., with the elytra finely punctured and smooth interstices.

\section{Group PAGRINI.}

Body short, ovate, convex, smooth; eyes entire, deeply and broadly sulcate above; antennæ filiform, scarcely longer than half the body, basal two joints incrassate. Thorax with sides angulated at the middle. Legs rather elongate; the femora of all the legs armed with a small tooth beneath; intermediate and posterior tibiæ emarginate at apex; claws appendiculate. Prosternum subquadrate; anterior margin of thoracic episternum concave.

Small species resembling Nodostoma, but with a broad sulcus 
above the eyes*. The Indian species at present placed in this genus seem to differ in the non-angulate sides of the thorax, but agree in all other respects with Lefèvre's description. The group is represented in India by a single genus only.

\section{Genus PAGRIA.}

Pagria, Lejèv. Bull. Soc. Ent. France, 1884, p. Ixvii; id. Cat. Eumolp. 1885, p. 62.

Type, $P$. suturalis, Lefèv., from Africa.

Range. Africa; India; Sumatra; Java.

Characters those of the group.

630. Pagria flavo-pustulata, Baly (Nodostoma), Trans. Ent. Soe. 1874, p. 169.

Black; antennæ flavous, terminal joints darker; labrum and legs flavous. Elytra nearly black, a small spot at base within shoulders flavous.

\section{Length $2 \mathrm{~mm}$.}

$H a b$. India : Belgaum; Japan; Sumatra (Coll. Jacoby).

This species seems to differ from $P$. signata, Motsch. in coloration only. It is quite possible that $P$. sumatrensis, Lefèv., and $P$. coneicollis, Lefèv., both from Sumatra, are varieties of the present species, which in turn may be another variety of $P$. signata, but I have not seen at present any intermediate forms.

631. Pagria signata, Motsch. (Metachroma) Étud. Ent. 1858, p. 110. Nodostoma consimile, Baly, Trans. Ent. Soc. 1874, p. 168.

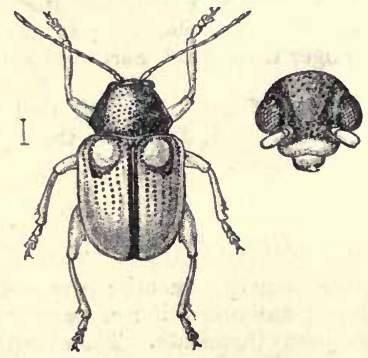

Fig. 125.-Pagria signata.

"Testaceous; beneath more or less fuscous; base of head, thorax, suture of elytra and two spots below base, black.

* Pagria bipunctata, Lefèv. excepted. 
"Head subdepressed. Thorax strongly and sparingly punctured, convex, anteriorly triangularly narrowed, posteriorly less narrow, sides dentate. Scutellum triangular, testaceous or black. Elytra strongly punctate-striate, subsutural stria very short, fifth entire, rest obliterated at base, the latter gibbous. Posterior tibiæ excavate (emarginate) near apex. Antennæ extending to base of thorax, basal joint large, ovate, second short, thickened, third very narrow, scarcely as long as second, fourth and following as long as third, terminal joints slightly thickened, more or less darkened." (Motschulsky.)

Var. a. Thorax more or less æneous.

Var. $b$. Elytra with lateral and sutural margins black.

Var. $c$. Above fulvous.

Length $2 \mathrm{~mm}$.

$H a b$. Southern India: Nilgiris; Burma; Ceylon; China; Japan.

Baly has described his $P$. consimile as a Nodostoma, although he points out the sulcus near the eyes which places the insect in Pagria; he further compares it with Nodostoma 4-signatum of Motschulsky, but probably means " signatum," as Motschulsky has not, to my knowledge, described any species of Nodostoma under the former name. Baly also separates his consimile from Motschulsky's insect by the strongly punctured thorax, but Motschulsky described his species likewise as "grosse punctata." All the Nilgiri specimens have pale testaceous elytra with the typical piceous spot below the base.

632. Pagria bipunctata, Lefèv. Bull. Soc. Ent. Bely. xxxv, 1891, p. cclxri.

"Beneath piceous, above fulvous; sutural and lateral margins of elytra and a small spot below base brownish-piceous.

"Head strongly punctured; labrum, palpi and antennæ fulvous, terminal six joints of the antennæ fuscous. Thorax much broader than long, sides angulated at middle, very convex, somewhat sparsely punctured on the middle of disc, sides strongly and subconfluently punctured. Scutellum smooth, subcordiforin. Elytra with rounded fovea below base, remotely punctured in rows, punctures at base and sides large, nearly obsolete at apex, humeral callus prolonged into a short oblique costa. Legs fulvous, tarsi fuscous.

"Length 4 min.

"Hab. Hindustan." (Lefèvre.)

633. Pagria ceylonensis, sp. $n$.

Beneath black, above metallic green or æneous; basal joints of antennæ flavous.

Head deeply and rather closely punctured; eyes with narrow 
sulcus on their inner margins ; clypeus closely punctured ; antennæ rather long, black, basal four joints flavous, third and fourth subequal, second rather long and stout, terminal joints slightly subtriangularly widened. Thorax subcylindrical, sides rounded, surface with anterior sulcus near margin, convex, closely and strongly punctured, the punctures round and deep. Elytra with deep transverse depression below base, closely and strongly punctate-striate, interstices costate at sides and apex. Legs rather long ; femora thickened at middle, with a minute tooth beneath; tarsi obscure fulvous.

Length 2-3 mm.

Hab. Ceylon (Colls. Oxford Mus. \& Jacoby).

In the P. Z. S. 1887 I have given a description of this species under the name of Nodina subdilatata, Motsch., to which at that time I referred the insect, on the authority of Baly in whose collection the species bore that name. It is, however, very evident that Motschulsky's description, short and insufficient as it is, could not refer to this insect, as no indication is given of the characteristic sculpture of the upper surface, nor has the species the slightest resemblance to a Nodinc.

634. Pagria costatipennis, Jac. P. Z. S. 1887 , p. 73, pl. x, fig. 2 (February).

Pagria strigicollis, Lefêv. Bull. Soc. Ent. France, 1887, p. clxviii (October).

Bronze-coloured; basal joints of antennæ, apices of tibiæ and the tarsi fulvous.

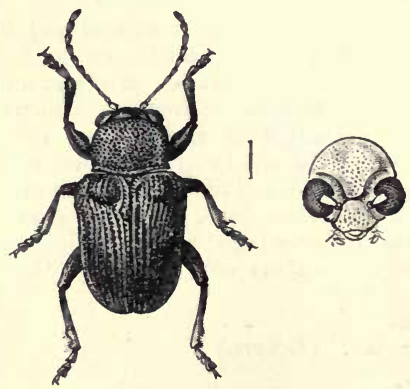

Fig. 126.-Pagria costatipennis.

Subquadrate-orate. Head coarsely rugose-punctate, sulcate above the eyes, anterior border of clypeus concave-emarginate; labrum and palpi fulvous; antennæ more than balf the length of 
body, shorter in the female, basal four or five joints fulvous, rest black, second and third nearly equal, slightly shorter than the fourth. Thorax subcylindrical, about half as broad again as long, sides rounded; disc strongly convex, strongly longitudinally strigose and reticulate. Scutellum pentagonal, with a few punctures. Elytra wider at base than the thorax, distinctly depressed below the base, closely iongitudinally costate, interstices strongly punctured. Legs piceous, apex of tibia and the tarsi (generally) fulvous; femora with distinct tooth beneath.

Length 3-4 mm.

$H a b$. Southern India: Malabar; Belgaum; Nilgiris; Pondicherry; Ceylon.

Easily recognizable by the dark bronze-coloured upper surface and the rugose and costate thorax and elytra; the species is not entirely typical of the genus and the ocular sulei are not always well marked. Lefèvre's description of his $P$. strigicollis published some months later than that of $P$. costatipennis, mihi, closely agrees with it, except that the antennæ of $P$. strigicollis are given as scarcely reaching to the end of the thorax, which is not the case in any specimen before me.

635. Pagria restituens, Walker (Rhynchites), A. M. N. H. (3) iii, 1859, p. 263.

Dark æneous; labrum and basal joints of antennæ fulvous.

Head closely rugose-punctate; antennæ black, basal four joints fulvous, third and fourth elongate. Thorax subcylindrical, sides rounded, closely rugose-punctate. Elytra much wider at base than the thorax, deeply transversely depressed below base, surface strongly costate, interstices strongly punctate-striate, sides irregularly punctured, without costæ. Legs slender, piceous; femora with a small tooth beneath.

Length $4 \mathrm{~mm}$.

Hab. Ceylon (Coll. Brit. Mus.).

This insect was described by Walker as one of the Curcutionidce, to which it has some slight outward resemblance. It is so closely aliied to $P$. costatipennis, Jac. that it is doubtful whether it is specifically distinct, but the elytra are more irregularly punctured at the sides and the legs seem more slender and are with piceous in colour.

\section{Pagria lævifrons, sp. n.}

Black; labrum, antennæ, tibiæ and tarsi fulvous.

Head entirely impunctate, deeply sulcate above the eyes; clypeus subquadrate, separated from the face by a deep groove; antennæ entirely fulvous, terminal joints thickened. Thorax subcylindrical, posterior nearly twice the width of the anterior margin, sides not angulated, nearly straight, surface rather closely and finely 
punctured, the punctures shallow, sides near margins nearly smooth. Elytra gradually widened towards the middle, subcylindrical, with a shallow depression below base, moderately strongly punctate-striate, punctures finer towards apex, shoulders. rather prominent.

Length $2 \frac{1}{2} \mathrm{~mm}$.

Hab. Burma: Momeit (Coll. Brit. Mus.).

Differs from any of its allies in the impunctate head and system of coloration.

637. Pagria kanaraensis (Pl. I. fig. 14), Jac. (Nodostoma) Ann. Soc. Ent. Belg. xxxix, 1895, p. 279.

Blackish ; antennæ, legs and elytra flavous, sutural and lateral margins and a small spot below base piceous.

Head strongly and closely punctured, blackish, generally with two obscure fulvons spots between the eyes, latter with a sulcus above, bounded by a distinct ridge; clypeus not separated from the face, punctured like the head, anterior margin fulvous; antennæ pale flavous, extending to middle of elytra. Thorax half as broad again as long, subcylindrical, sides angulated near the base, obliquely narrowed in front; surface obscure blackish-æneous, deeply and closely punctured, anterior margin narrowly fulvous. Scutellum piceous. Elytra wider at base than the thorax, with a shallow depression below base, deeply punctate-striate, the punctures piceous, sutural margins very narrowly, lateral margins more broadly piceous or greenish-black, a piceous spot within basal depression.

\section{Length $2 \mathrm{~mm}$.}

Hab. Southern India : Belgaum; South Kanara.

This small species is closely allied to $P$. signata, Motsch., but differs in the thorax which has a distinct æneous gloss and an anterior fulvous margin; the elytra, instead of having the basal portion swollen and impunctate, are in this species scarcely raised and distinctly punctured, the humeral callus alone has no punctures: the four specimens before me show no differences in these respects.

\section{Pagria burmanica, sp. n.}

Fulvous; breast and abdomen black; elytra with sutural and lateral margins and a spot at the middle, piceous.

Head impunctate; clypeus separated from the face by a transverse groove, surface with a few punctures; antennæ pale fulvous, terminal joints thickened; supraocular sulci very deep. Thorax about half as broad again as long, surface rather obsoletely punctured in the middle only, margins impunctate. Elytra feebly depressed below base, some short rows of punctures within depression, 
one or two rows of finer punctures near suture, rest of surface impunctate.

Length $2 \frac{1}{2} \mathrm{~mm}$.

Hab. Burma : Momeit (Coll. Brit. Mus.).

In one specimen the anterior portion of breast only is fulvous. Differs from the preceding species in the impunctate bead and differently punctured thorax and elytra.

\section{Pagria ænescens, sp. n.}

đ. Subelongate; obscure fulvous with more or less æneous gloss.

Head closely rugose, the vertex raised, bilobed in front; clypeus separated from the face by a deep transverse groove; antennæextending to middle of elytra, terminal joints distinctly thickened, third elongate, longer than the fourth; eyes with a deep and broad sulcus above. Thorax about balf as broad again as long, sides nearly straight,'anterior margin produced at the middle; surface finely and somewhat sparsely punctured at the middle, strongly and closely so at the sides, punctures somewhat elongate. Scutellum subovate, smooth. Elytra feebly depressed below the base, strongly punctate-striate within the depression, finely so on the rest of the disc, punctures rather distantly placed, distinct to apex. Body beneath fulvous and glabrous. Femora with a very minute tooth beneath; posterior two pairs of tibiæ deeply emarginate near apex; claws appendiculate.

Length $3 \mathrm{~min}$.

Hab. Burma: Tharawaddy.

Can be distinguished by the rugose head and structure of the vertex, deep ocular sulci and obscure æneous colour.

\section{Pagria conglomerata, sp. $n$.}

Black; vertex of head fulvous; antennæ and legs flavous.

Head deeply inserted, closely rugose, with deep sulcus above eyes, lower portion piceous, upper fulvous; antennæ slender, not extending to middle of elytra, second and following joints elongate, nearly equal, terminal joints scarcely thicker. Thorax about half as broad again as long, sides rounded, narrowed in front, dise rather convex; entire surface crowded with strong round punctures, rather stronger, larger and partly confluent at the sides, extreme anterior margin fulvous. Scutellum broadly ovate, smooth. Elytra oblong, convex, wider at base than the thorax, feebly depressed before the middle, strungly punctate-striate at base, finely so near the apex, latter obscure flavous. Femora with a minute tooth beneath and the extreme base black. Prosternum. transverse, subquadrate, strongly punctured.

Lenath $4 \frac{1}{2} \mathrm{~mm}$.

$H a b$. Southern India: Nilgiris. Type in Coll. H.E. Andrewes. 


\section{Group CALLISINI.}

Head oblong, partly exserted; antennæ with terminal joints more or less strongly dilated or inoniliform. Thorax transverse, subquadrate, of equal width, sides angulated at the middle. Elytra short, oblong, basal portion rather strongly raised. Tibiæ of the intermediate and posterior legs emarginate at apex ; claws appendiculate.

Principally distinguished by the structure of the antennæ and tibiæ, the angulate sides of thorax and equal width of latter.

\section{Key to the Genera of Callisini.}

a. Antennæ with terminal joints broadly dilated; femora toothed beneath ............... b. Antennæ without dilated terminal joints, moniliform; femora not toothed beneath.......... Edistus, p. 365.

\section{Genus CALLISINA.}

Callisina, Baly, Juurn. Ent. i, 1860, p. 30; id. Trans. Ent. Soc. (3) iv, 1867, p. 153; Chapuis, Gen. Colêopt. x, 1874, p. 264; Lefèv. Cat. Eumolp. 1885, p. 63.

Type, C. fasciata, Baly, from Malacca.

Range. India ; Cambodia; Malayan Subregion.

Oblong, convex. Head exserted; eyes prominent, sinuate below; apical joints of antennæ strongly dilated and flattened, terminal three as broad as long. Thorax transverse, convex, margined at the sides. Scutellum subtrigonal, apex rounded. Elytra oblong, wider than the thorax. Legs robust; femora incrassate with acute tooth beneath ; first joint of tarsi shorter than the following two united; claws appendiculate.

This genus is not closely allied to any other and certainly not to Corynodes as Baly states, to which it has only a superficial resemblance in shape; the head is without ocular sulci and the thoracic episternum is concave instead of convex.

\section{Callisina brunnea, sp. n.}

Dark brown; antennæ (basal joints excepted) and legs black.

Head rather strongly and closely punctured, with central groove on the vertex; clypeus punctured at base, sides with a deeply punctured short groove; space above eyes sulcate, longitudinally strigose; antennæ extending to middle of elytra, basal three joints fulvous, third and fourth equal, terminal joints elongate, very moderately thickened. Thorax subquadrate, transverse, not narrowed anteriorly, sides feebly rounded, strongly angulate at the middle, a deep medially interrupted sulcus near anterior margin, disc rather strongly but unevenly punctured. Elytra wider at base than the thorax, oblong, subcylindrical, transversely 
impressed below the base, shoulders prominent, followed by a short oblique costa, disc finely punctate-striate, punctures within depression rather stronger. Prosternum broader than long, remotely punctured.

Length $4 \frac{1}{2} \mathrm{~mm}$.

Hab. Sikhim: Kursenng, Darjeeling (Colls. Brussels Mus. \& Jacoby).

Smaller than the other species of the genus, differently coloured, and with less strongly dilated antennæ, although in other structural characters it does not differ from the type of the genus.

\section{Callisina indica, Baly, Trans. Ent. Soc. 1881, p. 503.}

"Obscure rufo-piceous; thorax nigro-piceous; elytra with a large subquadrate patch at base and another behind the middle, rufo-testaceous.

"Head rugosely punctured, inner and upper orbits of eyes nigro-piceous. Thorax one-fourth as broad again as long, sides straight and parallel from base to beyond the middle, thence rounded and convergent towards the apex, anterior angles submucronate, disc distinctly but not closely punctured. Elytra subquadrate-ovate, rather strongly punctate-striate ; basal rufo-testaceous patch extending from outer margin nearly to suture, the other similarly coloured patch subovate, placed between middle and apex.

"Length $6 \mathrm{~mm}$.

"Hab. India." (Baly.)

\section{Callisina prominula, sp. $n$.}

Black, shining; elytra with a humeral subquadrate spot, not extending to base, and an oblique subtransverse spot near apex, fulvous.

Head impunctate at middle, obliquely strigose above the eyes, an oblong fovea between the eyes; clypeus scarcely separated from the face, nearly impunctate, anterior cdge feebly concave; antennæ with the basal three joints fulvous, rest black, terminal joints moderately widened. Thorax half as broad again as long, sides with a short but acute angle at the middle; surface rather convex, without depressions, somewhat sparingly punctured, punctures stronger and more closely placed at the sides, a narrow sulcus near anterior margin. Elytra withvvery prominent and swollen shoulders, finely punctate-striate on the black portion, sides more irregularly punctate, a short oblique costa below the shoulders, these with a subquadrate fulvous patch scarcely extending to the middle of base of ely tra and not reaching basal margin ; posterior spot oblique, wider than long, between second row of punctures and margin. Femora strongly incrassate, with an acute tooth beneath; extreme apex of anterior tibix fulvous.

Length $4 \frac{1}{2} \mathrm{~mm}$. 
Hab. Bombay : Belgaum (Coll. Brit. Mus.).

This species seems to be distinct from its allies on account of the outwardly prominent basal portion of the elytra; the fulvous spot is much smaller and does not extend so far inwards, and the head is differently punctured.

\section{Callisina assamensis, sp. $n$.}

Black; elytra with a humeral and a subapical flavous spot; head with a central fulvous patch.

Head strongly but somewhat sparsely punctured; an elongate stripe between the eyes fulvous; clypeus deeply separated from face, sparingly and finely punctured, anterior edge feebly emarginate; antennæ black, nearly extending to middle of elytra, basal three joints more or less stained with fulvous, terminal five moderately dilated. Thorax half as broad again as long, sides acutely angulate at middle, oblique in front and below the angle; surface rather closely and strongly punctured with some obsolete depressions at the sides and near the lateral margins. Scutellum impunctate. Elytra finely and regularly punctate-striate, only, however on the black area, flavous patches and apex impunctate; humeral flarous patch swollen, extending to the second row of puncturesnear the suture; subapical patch transversely subquadrate, not quite extending to either margin. Femora with a small tooth beneath.

Length $4 \mathrm{~mm}$.

Hab. Assam: Patkai Mts. (Coll. Brit. Mus.).

Closely allied to C. 4-pustulatus, Baly, from Java, but I think distinct. In $C .4$-pustulatus, the last joints of the antennæ are more broadly dilated, the posterior flavous elytral patch is much larger and rounded, not transverse, the puncturation is more close and irregular, and the insect is much larger.

\section{Callisina balyi, Jac. Ann. Soc. Ent. Belg. xxxix, 1895, p. 276.}

ऽ. Black; antennæ and femora partly fulvous; elytra with a transverse patch at base and another near apex fulvous.

Head more or less piceous, finely and subremotely punctured at the sides, middle with a few fine punctures only ; clypeus wedgeshaped, finely punctured; palpi fulvous; antennæ black, terminal joints moderately incrassate, third and fourth equal, basal two joints fulvous beneath. Thorax about half as broad again as long, sides very feebly rounded and obsoletely angulated at middle; dise very finely, remotely and irregularly punctured, sides rather more closely punctate. Scutellum oblong, smooth. Elytra with the humeral area strongly raised, bounded posteriorly by a transverse groove, the black area very finely punctate-striate, fulrous patches smooth; of these the basal patch is subquadrate, leaving the upper portion of the shoulders black and extending laterally to the middle and posteriorly for one-fourth the length of the elytra; 
posterior spot transverse, smaller, slightly curved. Femora with a small tooth beneath.

Length $4 \mathrm{~mm}$.

$H a b$. Southern Bombay: Belgaum, Kanara.

Differs from $C$. indica in the angulated thorax, smaller elytral fulvous patches and their fine puncturation; also in the deep black general colour.

646. Callisina burmanica, Jac. Ann. Soc. Ent. Belg. xxxix, 1895, p. 277.

Black; basal four joints of antennæ fulvous; elytra with a transverse narrowly divided spot at base and another near apex fulvous.

Head strongly and closely punctured, longitudinally strigose on the vertex; eyes with a sunken

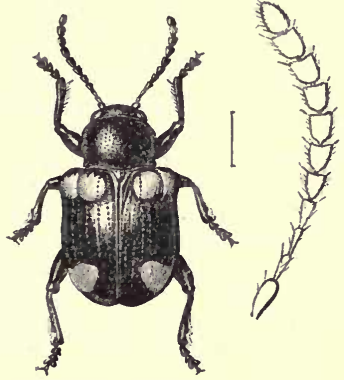

Fig. 127.-Callisina burmanica. orbit; palpi pale fulvous; antennæ black on the terminal joints, which are gradually and broadly dilated. Thorax half as broad again as long, sides with reflexed margins, strongly dentate in the middle, disc strongly and closely punctured. Elytra much wider at base than the thorax, subquadrate-ovate, basal portion swollen, rest of surface strongly punctate-striate, punctures at the sides rather more confused; the fulvous basal patch subdivided within the shoulders by a single row of punctures, otherwise impunctate, the patch does not extend to the basal margin but laterally to as far as the second row of punctures, and longitudinally for about one-fifth the length of elytra; posterior spot subquadrate, rather small, placed near the apex. Femora strongly incrassate and dentate.

Length $6 \mathrm{~mm}$.

$H a b$. Burma.

Much more strongly punctured than $C$. balyi, the fulvous elytral spots of different shape and the anterior one subdivided, the thorax strongly dentate.

\section{Genus EDISTUS.}

Edistus, Lefèv. Bull. Soc. Ent. Belg. xxvii, 1884, p. ccii.

Type, E. fulgidus, Lefèv., from Bintang Isl.

Range. Africa: India; Malayan Subregion.

Short and ovate; glabrous; head exserted, deflexed, vertex 
swollen; eyes globular, entire; antennæ scarcely longer than half the body, basal two joints thickened, third and fourth short, equal, rest moniliform. Thorax transverse, convex, sides angulate at middle. Femora fusiform, unarmed ; tibiæ straight, intermediate and posterior tibiæ strongly emarginate at apex, the emargination densely pubescent; claws appendiculate. Prosternum subquadrate, base truncate.

Difters from Callisina in the structure of the antennæ and in the unarmed femora. Except in the angulate sides of the thorax this genus does not seem to differ from Nodina.

\section{Edistus cæruleus, sp. n.}

Dark blue; basal joints of antennæ fulrous; apical joints, underside and legs black.

Ovately rounded. Head closely and finely punctured; clypeus not separated from the face, more strongly punctured than the head, anterior margin concave; eyes with distinct sulcus above; antennæ very short, basal three joints fulvous, basal joint above and the others black, first joint strongly incrassate, second rather longer than the third, fourth and fifth equal, following joints triangularly thickened, scarcely longer than broad, last elongate-ovate. Thorax more than half as broad again as long, sides nearly straight, anterior portion of dise deflexed, median lobe of posterior margin broadly rounded and produced; surface crowded with large, deep punctures, evenly distributed. Scutellum ovate, black. Elytra convex, not depressed below base, very strongly punctatestriate, shoulders prominent. Posterior tibiæ feebly emarginate at apex; claws appendiculate. Prosternum quadrate, strongly punctured; anterior margin of thoracic episternum nearly straight.

Length $2 \mathrm{~mm}$.

Hab. Manipur (Doherty, Coll. Brit. Mus.).

648. Edistus indicus, Jac. Ann. Soc. Ent. Bely. xlvii, 1903, p. 99.

Beneath black, above metallic blue or æneous; base of antennæ, apex of tibiæ and the tarsi fulvous.

Rounded and convex. Head distinctly but remotely punctured on its anterior portion; clypeus not separated from the face; labrum obscure fulvous; antennæ short, black, basal five joints fulvous, terminal seven short, thick and moniliform, second to fourth nearly equal. Thorax strongly transverse, sides rounded, anterior portion deflexed, basal margin produced at the middle into a short, broadly rounded lobe; surface evenly but not closely punctured, the puncturation somewhat finer and closer at the sides. Scutellum subovate, impunctate. Elytra convex, not depressed below base, 
rather strongly punctate-striate; interstices flat, with a few

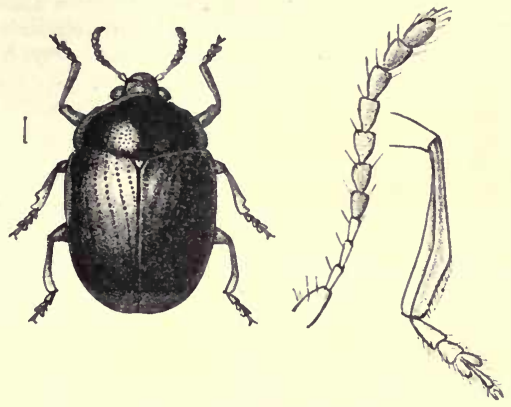

Fig. 128.-Edistus indicus.

scattered minute punctures. Legs piceous; anterior margin of thoracic episternum concave.

Length $2 \mathrm{~mm}$.

$H a b$. Southern India: Nilgiris.

\section{Group COLASPINI.}

More or less oblong or elongate; head prominent; antennæ slender, filiform. Thorax transverse, sides more or less dentate or distinctly angulate. Prosternum oblong, base truncate; anterior margin of thoracic episternum concave. Legs slender, femora unarmed, tibiæ entire; claws appendiculate.

Metallic species often brilliantly coloured and ornamented with purplish markings; principally distinguished by the dentate or angulate sides of the thorax, but resembling in shape Chrysolampra, from which they can be readily separated by the non-incrassate anterior femora.

\section{Genus DERMORHYTIS.}

Dermorhytis, Baly, Journ. Ent. i, 1861, p. 282; Chapuis, Gen. Coléopt. x, 1874, p. 252; Lefêv. Cat. Eumolp. 1885, p. 48.

Type, D. igneo-fasciata, Baly, from Ceylon.

Range. India; Ceylon; Borneo.

Elongate, subcyclindrical. Eyes feebly emarginate; antennæ slender, filiform, third joint more than double as long as the second. Thorax transverse, sides more or less angulate. Scutellum somewhat ovate. Elytra oblong, parallel-sided, sides generally transversely rugose. Legs rather robust, femora unarmed, tibiæ 
deeply longitudinally sulcate, widened at the apex, first joint of tarsi shorter than the following two united; claws appendiculate. Prosternum oblong, narrowed in the middle and obsoletely dentate at the sides.-Highly metallic species, often very handsomely marked with purplish or golden bands or spots.

\section{A. Thorax remotely punctured.}

a. Elytra with cupreous or metallic purplish spots or bands.

649. Dermorhytis ornatissima (Pl. I, fig. 11), Baly, Descr. gen. \&. spec. Phytoph. 1864, p. 8 ; Jac. P.Z. S. 1887, p. 82, pl. x, fig. 6. Dermorhytis fasciato-rutilans, Lefev. Rev. et Mag. Zool. 1875, p. 123.

Metallic green; antennæ blackish; thorax with a transverse purplish-cupreous band; elytra with a similarly coloured band at base, a spot near the lateral margins and an elongate broad stripe at the suture that extends to the apex.

o. Head closely and strongly punctured, cupreous; antennæ with the basal four joints more or less fulvous, rest nearly black, third and fourth equal, terminal joints very elongate and pointed. Thorax scarcely half as broad again as long, convex, lateral margins very faintly angulate, surface deeply and remotely punctured. Elytra with prominent shoulders, deeply and strongly punctatestriate on the inner disc, transversely rugose at the sides. Body beneath and legs cupreous.- + . The thorax is, as usual, more transverse in shape.

Length 5-7 mm.

Hab. Ceylon.

One of the handsomest species of the genus; the thoracic band extends generally across the entire disc and is deeply emarginate on each side at its lower edge; the elytra have the marginal spot sometimes united with the sutural stripe forming an acute angle, the transverse rugæ do not extend to the inner disc.

\section{Dermorhytis variabilis, Jas. P. Z. S. 1887 , p. 82.}

Greenish-æneous beneath, metallic green above; shonlders, sides and apex of elytra reddish-cupreous; basal joints of antennæ and legs fulvous or piceous.

Head finely and rather closely punctured, interstices slightly rugose; clypeus not separated from the face, more closely and finely punctured than the head; labrum fulvous ; antennæ slender, basal five or six joints fulvous, rest piceous, third and fourth joints equal, fifth longer. Thorax scarcely twice as broad as long, lateral margins obsoletely angulate at middle, surface remotely and strongly punctured, rather convex. Elytra subcylindrical, rather convex, somewhat finely punctate-striate near the suture, trans- 
versely rugose at the sides, the rugosities not quite extending to apex.

Lenyth 4-5 mm.

$H a b$. Ceylon: Galle, Kandy.

A species that is sometimes entirely metallic green or obscure cupreous, but always of small size.

\section{Dermorhytis kandyensis, sp. n.}

Metallic green; antennæ blackish; elytra with a spot near scutellum, a transverse cupreous band at middle not reaching the suture and an elongate cupreous spot near margin and apex.

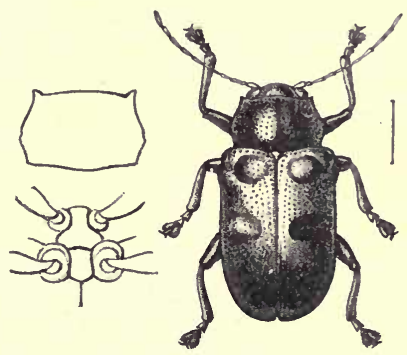

Fig. 129.-Dermorhytis kandyensis.

Head strongly and rather closely punctured. Thorax remotely and very strongly punctured, halt as broad again as long, convex, sides obsoletely biangulate in the middle. Elytra finely punctatestriate near the suture, apex nearly impunctate, sides strongly transversely rugose below the shoulders and in the middle. Legs more or less cupreous.

Var. The lateral subapical elytral spot absent.

Length 6-7 $\frac{1}{2} \mathrm{~mm}$.

$H a b$. Ceylon : Kandy.

Although closely allied to $D$. ornatissima evidently distinct. I have many specimens but no specimen intermediate between the two species. The thorax in the present insect has never any purplish markings and the markings on the elytra are different in shape, the transverse band does not extend to the suture nor downwards along the suture to the apex as in D. ornatissima; the elytra in the last named insect are more strongly punctured and rugose, the punctures distinct to the apex. The species was formerly considered by me as a variety of $D$. ornatissima (P. Z. S. 1887, p. 82.)

voL. I. 
652. Dermorhytis igneo-fasciata (Pl. I, fig. 12), Baly, Journ. Ent. i, 1861, p. 283 ; Jacoby, P. Z. S. 1887, p. 83, pl. x, fig. 5.

Colaspis aureofasciata, Motsch. Bull. Mosc. 1863, p. 520.

Dark purplish; margins of thorax, two transverse bands on elytra and their suture posteriorly greenish-golden.

․ Head rugose; sides and lower portion of face dull igneous. Thorax twice as broad as long, sides rounded, obsoletely biangulate in the middle, anterior angles produced; surface closely impressed with large, round, deep punctures. Elytra narrowed at the apex, the latter acutely rounded; surface as closely but more strongly punctured than on the thorax; interstices everywhere reticulate, costate at the sides and suture; extreme basal and lateral borders and two bands igneous, first band just before the middle, second wider and near the apex. Body beneath cupreous, finely pubescent. In the male the thorax is not more than half as broad again as long.

Length 8-9 mm.

$H a b$. Ceylon.

\section{Dermorhytis atkinsoni, sp. n.}

․ Metallic green; labrum, antennæ, apices of tibiæ and the tarsi fulvous; elytra with three purplish-violaceous blue bands.

Head remotely and finely punctured, with a central fovea on the vertex; clypeus distinctly separated at the sides, anterior border angularly emarginate; palpi fulvous ; antennæ not extending to the middle of the elytra, third and fourth joints equal, seventh to ninth joints very elongate, the terminal two wanting in the type and only specimen. Thorax about half as broad again as long, sides with a strong tooth at and a smaller tooth below the middle; anterior portion strongly obliquely narrowed in front, anterior angles very prominent; surface strongly convex, remotely and finely punctured on the disc, more strongly so at the sides. Scutellum with deep fovea. Elytra wider at the base than the thorax, broadly oblong, finely punctured in two or three double rows near the suture, rest deeply punctured and strongly transversely rugose; a purplish short band near the scutellum that does not extend to the base nor to the margins, a straight broader band at the middle and a transverse spot near the apex, the latter finely punctured without rugosities. Beneath metallic green, finely punctured and pubescent.

Length $6 \frac{1}{2} \mathrm{~mm}$.

Hab. India : Kulaur (Atkinson Coll., Brit. Mus.).

Can be distinguished by the colour of the antennæ, legs and tarsi and by the purple elytral bands. 
b. Elytra without spots or bands.

\section{Dermorhytis viridinitens, sp. $\mathrm{n}$.}

ㅇ. Metallic bright green; palpi and antennæ flavous.

Head moderately closely and strongly punctured ; clypeus transverse, not separated from the face; basal joint of antennæ blackishæneous above, third and fourth joints equal. Thorax about half as broad again as long, sides straight at base, slightly rounded before the middle, angles produced; surface with strong, very sparse and irregularly placed punctures, basal margin with a deep transverse groove. Elytra wider at base than the thorax, very finely punctured in double rows near the suture; strongly transversely rugose at the sides.

Length $5 \mathrm{~mm}$.

Hab. Southern India: Travancore (Coll. Brit. Mus.).

In this species the thorax is more sparsely punctured than in any other species of the genus, and the antennæ are fulvous.

\section{Dermorhytis imitans, sp. $n$.}

‥ Metallic greenish-blue, beneath green; labrum and antennæ nearly black.

Head finely and remotely punctured; clypeus separated from the face, sparsely punctured, anterior border blackish ; antennæ with the basal joint metallic green, second and following two joints with their apices fulvous, rest black (apical three joints wanting in the type and only known specimen), third and fourth joints equal, shorter than the fifth. Thorax half as broad again as long, sides rounded, entire, anterior angles prominent, surface finely and remotely punctured. Elytra finely punctate-striate near the suture, more strongly so at the sides; some few rugosities below the shoulders.

Length $6 \mathrm{~mm}$.

Hab. Southern India : Nilgiris (Hampson, Brit. Mus.).

Larger than the preceding species, the antennæ dark and the basal joints different in length, the thorax rather more transverse and although remotely punctured more closely so than in the other species; the elytral rugosities few and feeble. Described from a single female.

\section{B. Thorax closely punctured; elytra without transverse bands or spots.}

656. Dermorhytis ceylonensis, Jac. P. Z. S. 1887, p. 81, pl. x, fig. 7 .

Beneath fulvo-piceous with æneous gloss, above greenishæneous; antennæ aud legs fulvous.

Head rather finely and very closely rugose-punctate, with a small central tubercle; labrum fulvous ; antennx long and slender, 
all the joints from the third outwards of equal length. Thorax obsoletely biangulate at the middle, sculptured like the head, interstices irregularly convex and reticulate, the punctures scarcely larger than those on the heat. Elytra more remotely and strongly punctured than the thorax, interstices transversely reticulate over the entire surface, the lateral margins as well as those of the thorax narrowly cupreous.

Length 5-6 mm.

$H a b$. Ceylon.

657. Dermorhytis lewisi, Jac. P. Z. S. 1887, p. 82.

Greenish or brownish-cupreous ; labrum, basal joints of antennæ and legs obscure fulvous.

Head closely rugose-punctate; clypeus not separated from the face; apical joints of antennæ very slightly thickened, third and fourth joints equal, basal five or six joints fulvous, rest fuscous. Thorax transverse, sides nearly straight, surface closely and strongly punctured, interstices everywhere transversely rugose. Elytra subcylindrical, slightly narrowed posteriorly, punctured like the thorax, but the interstices transversely raised over the entire surface. Body beneath clothed with fine silky pubescence.

Length 5-6 $\mathrm{mm}$.

Hab. Ceylon: Dikoya.

Distinguished by the straight sides of the thorax and the transversely rugose interstices.

\section{Dermorhytis cuprea, Jac. P. Z. S. 1887, p. 81.}

Bronze-coloured; legs nearly black; antennæ piceous; thorax and elytra with more or less of a greenish-cupreous gloss.

Head strongly rugosely punctured on the vertex; clypeus separated from the face, much more finely and closely punctured; antennæ two-thirds the length of the body, third and following three joints piceous, equal, the rest nearly black, slightly thickened. Thorax half as broad again as long, sides angulate before the middle, straight from thence to base, anterior portion obliquely narrowed; surface strongly and moderately closely punctured on the disc, sides more strongiy punctate and transversely rugose. Elytra wider at base than the thorax, surface more or less punctate-striate near suture, strongly and irregularly punctured on the sides, the interstices at that place transversely rugose.

Var. Metallic green; antennæ and legs fulvous.

Length 6-7 mm.

Hab. Ceylon.

Since describing this species in $1887 \mathrm{I}$ have seen other specimens which, although in colour and puncturation they vary greatly, I refer to the present form. In none of them are the punctures 
of the thorax so closely placed and of such depth and regularity as in $D$. mugosa and $D$. ceylonensis, while the sides of the same parts are much straighter than in either of the above-named species. All the specimens I have seen seem to be females.

\section{Dermorhytis biangulata, sp. $n$.}

Metallic green or cupreous; labrum, basal joints of antennæ and base of the femora fulvous; margins of elytra and scutellum purplish-blue or green; tarsi black.

o. Head strongly and closely punctured; clypeus separated from the face by a shallow transverse depressiou; antennæ black, second, third and fourth joints fulvous, terminal five joints widened. Thorax about half as broad again as long, sides nearly straight, middle with two closely approximate small teeth, disc closely and rather more strongly punctured than the head. Scutellum smooth. Elytra narrow and elongate, punctured like the thorax, the punctures arranged in close and irregular rows near the suture, irregularly scattered and larger at the sides, interstices at the sides transversely rugose. Legs finely pubescent, fulvous with metallic purplish gloss; tarsi black.

Length $5-5 \frac{1}{2} \mathrm{~mm}$.

Hab. Southern India: Nilgiris (Colls. H. E. Andrewes and Jacoby).

In this species, which may possibly be a local variety of $D$. speciosa, the thorax has two small teeth at the middle of the lateral margins, in the last-named species this portion is only angulate and the general size is larger ; but these scem to be the only differences between the two insects.

\section{Dermorhytis rugosa, sp. $n$.}

Dark greenish-æneous; basal joints of antennæ fulvous, margins of elytra more or less cupreous.

$\sigma^{*}$. Elongate, narrowed at apex. Head closely and finely rugose and wrinkled, the rugosities directed towards the centre; labrum fulvous; antennæ extending beyond the base of the elytra, basal five or six joints fulvous, rest black, first joint black above, third and following joints very slender. Thorax less than twice as broad as long, sides obsoletely angulated before the middle, straight from thence to base, disc strongly and closely punctured, interstices closely longitudinally reticulate. Scutellum small, cupreous. Elytra closely transversely rugose; interstices punctured like the thorax; epipleural lobes rather strongly produced. Beneath finely pubescent. Legs robust, femora incrassate.

‥ Much larger; thorax twice as broad as long; first joint of tarsi much smaller.

Length $5 \frac{1}{2}-7 \mathrm{~mm}$.

Hab. Ceylon (Coll. Jacoby). 
$D$. rugosa differs from $D$. ceylonensis in the evenly rugosely punctured thorax, the latter in the last-named species has the interstices irregularly reticulate.

\section{Dermorhytis violacea, sp. $n$.}

Violaceous; labrum, palpi and basal joints of antennæ fulvous.

Head very closely punctured, punctures at the sides confluent, studded each with a short grey hair; clypeus not separated from the face, very closely punctured ; antennæ with the basal five joints piceous, apex of each fulvous, rest wanting in the type and only known specimen. Thorax scarcely twice as broad as long, sides rounded, angles pointed, surface punctured like the head, the punctures crowded and confluent at the sides and rather larger, interstices with some minute punctures, an obsolete depression on each side near base, basal margin preceded by a deep transverse groove. Scutellum shining, greenish, pointed. Elytra nearly parallel, bluntly pointed at the apex, wider at base than the thorax; surface with a few fine rows of punctures near the suture, rest of dise entirely covered with strong transverse rugæ which assume the shape of tubercles near apex. Body beneath clothed with fine short pubescence, tibiæ and tarsi more or less piceous.In the of the thorax is more transverse in shape.

Var. Entirely dark æneous.

Length $7 \mathrm{~mm}$.

Hab. Cerlon (Coll. Brit. Mus.).

Distinguished by its entirely violaceous colour, the rounded sides of the thorax and sculpture of the elytra.

662. Dermorhytis punctatissima, Jac. (Chrysolampra) P. Z. S. 1887 , p. 73.

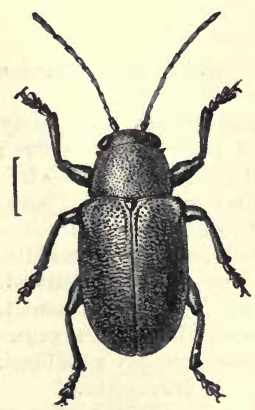

Fig. 130.

Dermorhytis punctatissima.

which near the apex boved with strong transverse rugosities,

Aneous or dark purplish ; labrum and the basal joints of antennæe more or less fulvous.

Head extremely closely and rather finely rugose-punctate, each interstice studded with a short grey hair; anterior border of the clypeus semicircularly emarginate : antennæ slender, terminal five joints slightly widened. Thorax nearly twice as broad as long, sides rounded at the middle, anterior angles prominent; surface sculptured like the head, the punctures rather larger; interstices minutely punctured, rugose at sides, furnished with short hairs as on the head. Scutellum subovate, shining, metallic green. Elytra entirely covered with strong transverse rugosities, which near the apex become tuberculate; area near base and 
suture remotely and finely punctured, the latter accompanied by one or two longitudinal costæ. Anterior femora dilated at the middle and furnished with a more or less distinct tooth.

Length 6-8 $\mathrm{mm}$.

$H a b$. Ceylon.

In spite of the obsoletely toothed anterior femora in the male, this species, I think, is better placed in Dermorhytis than in Chrysolampra where I located it originally, since the metatarsus of the posterior legs is much shorter than in Chrysolampra and the femoral tooth is very small.

663. Dermorhytis fulvipes, Jac. Ann. Soc. Ent. Belg. xlvii, 1903, p. 102.

Cupreous or green ; antennæ and legs fulvous, femora sometimes more or less æneous ; elytra, if green, with rather broad cupreous margins.

Elongate and parallel-sided. Head very closely rugose-punctate; clypeus not separated from the face, sculptured like the head; labrum fulvous; antennæ with the third and fourth joints equal. Thorax subcylindrical, of the same shape as in $D$. speciosa; sides straight, more strongly but not so closely punctured than the head, interstices rugose only at the sides. Elytra very elongate and pointed, very closely and moderately strongly punctatestriate near the suture, interstices closely transversely rugose along the lateral areas; apex furnished with very short grey hairs.

Length $7 \mathrm{~mm}$.

$H a b$. Southern India: Pondicherry, Nilgiris.

Of the same shape and length as D. speciosa and difficult to distinguish from that species, but the head more closely and evenly punctured, the antennæ and legs fulvous, the thorax not angulate at sides and more finely and closely punctured, the elytral puncturation likewise arranged in closely approximate rows near the suture.

664. Dermorhytis andrewesi, Jac. Ann. Soc. Ent. Belg. xxxix, 1895, p. 274.

Greenish-æneous; antennæ and legs piceous; thoracic and elytral lateral margins cupreous.

Narrowly elongate. Head strongly and closely punctured near the eyes, less closely so on the middle; cly peus not separated from the face, closely rugose-punctate, anterior margin cupreous or metallic green, nearly straight; labrum fulvous; mandibles black. Antennæ fulvous, long and slender, third joint slightly longer than the fourth, following joints very elongate and slender; second and following two joints fulvous, rest piceous, basal joint æneous above, fulvous beneath. Thorax scarcely more than half as broad again as long, sides feebly angulate at middle; surface evenly, extremely closely and rather strongly punctured; interstices narrower than 
the large punctures and also sparingly and very minutely punctate. Scutellum more or less cupreous. Elytra gradually narrowed posteriorly, more finely punctured than the thorax; puncturation arranged in very closely approximate, partially regular rows, those near the suture rather more distantly placed. Body beneath sparingly clothed with grey pubescence and more or less cupreous; femora thickened.

\section{Length 5-6 mm.}

$H a b$. Southern Bombay : Kanara.

The thorax in this species is of equal width, the sides are only slightly narrowed at base and apex, and the general appearance and sculpturing resembles a species of Abirus, but the concave anterior margin of the thoracic episternum separates it at once from any form in that genus.

665. Dermorhytis speciosa, Jac. Ann. Soc. Ent. Belg. xxxix, 1895, p. 275 .

Metallic greenish or æneous beneath, bright cupreous above; basal joints of antennæ fulvous, rest black ; margins of thorax and elytra greenish golden.

Rather narrow and elongate. Head strongly and somewhat

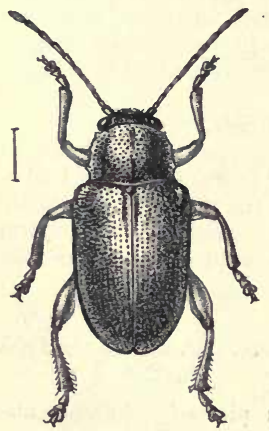

Fig. 131.

Dermorhytis spsciosa. remotely punctured; clypeus separated from face at the sides, surface with a few punctures, anterior portion nearly smooth; labrum fulvous; antennæ with the basal four joints fulvous, third joiut longer than the fourth. Thorax subcylindrical, half as broad again as long; sides straight, biangulate at middle; surface with an obsolete transverse depression at the sides, closely and strongly impressed with round punctures; interstices broader than the punctures, not rugose or wrinkled. Scutellum metallic green. Elytra pointed at apex, closely geminate punctate-striate near the suture, strongly and irregularly punctured at the sides; interstices at the latter place strongly transversely rugose and raised into small more or less numerous tubercles. Legs fulvous, with somewhat of an æneous gloss.

Var. Violaceous blue; legs fulvous.

Length $6 \mathrm{~mm}$.

Hab. Southern Bombay : Kanara.

Of the same shape as D.andrewesi but the elytra more elongate and pointed, the thorax distinctly biangulate at the sides, head 
more remotely punctured, elytral rugosities stronger and partly tuberculate.

\section{Dermorhytis costata, sp. n.}

Narrowly elongate; fulvous; knees, tibiæ and tarsi black.

Head very closely and rather finely punctured; clypens not separated from the face, a smooth space at the base of the antennæ; antenuæ elongate, filiform, third and fourth joints equal, the following joints more elongate. Thorax transversely subquadrate, sides obsoletely angulate before the middle, with narrow reflexed margin, surface strongly and closely punctured. Elytra with double rows of closely placed deep punctures, interstices strongly longitudinally costate. Femora fulvous, their apices as well as the tibiæ and tarsi black, the last joint of the latter more or less fulvous.

Length $5 \mathrm{~mm}$.

Hab. Burma : Karen Hills (Coll. Brit. Mus.).

Of totally different coloration and sculpturing from the other species of the genus but possessing all its structural characters.

\section{Thorax and elytra pubescent.}

667. Dermorhytis hirsutus, Jac. (Chrysochus) Mém. Soc. Ent. Bely. vii, 1900, p. 117.

Dark violaceous-blue, clothed with short silvery pubescence; the antennæ black.

Head closely and irregularly punctured, greenish, finely pubescent; the clypeus not separated from the face, punctured like the head, its anterior margin moderately concave; labrum piceous; antennæ black, extending nearly to the middle of the elytra, the terminal six joints dilated. Thorax about half as broad again as long, the sides nearly straight, slightly rounded at the middle, the surface convex, closely rugose-punctate, the interstices sparingly clothed with very short silvery hairs. Scutellum with a depression. Elytra wider at the base than the thorax, depressed below the base near the suture, much more strongly but less closely punctured than the thorax, the punctures round and deep, with a very short white hair in each puncture. The underside and the legs likewise covered with short pubescence; claws appendiculate. Prosternum and mesosternum elongate, narrowed between the coxæ; anterior margin of thoracic episternum concave.

Length $9 \mathrm{~mm}$.

Hab. Burma.

This species 1 find on close examination is a Dermorhytis and not a Chrysochus. From most species of Dermorhytis it is distinguished by the pubescence on the upper surface. This species is an aberrant one and seems transitionary between the Iphimeini and Colaspini. 


\section{Group METACHROMINI.}

Body non-pubescent above. Head exserted. Antennæ elongate, filiform. Thorax with distinct lateral margins. Intermediate and posterior tibiæ emarginate at apex; claws bifid. Anterior margin of thoracic episternum concave.

Represented by a single Indian genus which is similar to Nodostoma in general appearance, but has bifid not appendiculate claws.

\section{Genus RHYPARIDA.}

Rhyparida, Baly, Journ. Ent. i, 1861, p. 286 ; id. Trans. Ent. Soc. (3) iv, 1867, p. 163; Lefêv. Cat. Eumolp. 1885, p. 94.

Marsous, Clark, Journ. Ent. ii, 1864, p. 252.

Type, $R$. dimidiasa, Baly, from Australia.

Range. India; Malayan Subregion; Australia.

Body subquadrate-ovate, oblong or' subelongate, glabrous; palpi and antennæ filiform; eyes sinuate on their inner margins. Thorax transverse, more or less convex, lateral margins entire, angles distinct. Elytra puuctate-striate. Legs rather robust; femora often with a tooth on the lower margin; tibiæ emarginate at apex; claws bifid. Prosternum oblong or elongate.

668. Rhyparida khasianensis, Jac. Entomologist, 1899, p. 80.

Fulvous; terminal joints of antennæ black; tarsi piceous.

Head impunctate; clypeus very broad, subquadrate, distinctly separated from the face, impunctate, anterior margin concavo-emarginate. Antennæ extending nearly to the apex of the elytra, second joint short, third nearly three times as long, last seven joints black. Thorax twice as broad as long, only slightly widened at the middle, sides nearly straight, anterior angles slightly thickened, surface rery sparingly and finely punctured. Scutellum broad, smooth. Elytra wider at base than the thorax, not depressed below the former, shoulders prominent; surface rather strongly punctatestriate, punctures closely placed; interstices slightly convex, impunctate. Prosternum broad, punctured.

Length $6 \mathrm{~mm}$.

Hab. Assam : Khási Hills.

669. Rhyparida bengalensis, sp. $n$.

Head and thorax fulvous; terminal joints of antennæ black; elytra flavous.

Head with a few minute punctures; clypeus transverse, finely punctured, obsoletely separated from the face ; eyes large, slightly notched; antennæ long and slender, basal five joints pale, rest black, second as long as the third but thicker. Thorax half as broad again as long, of equal width, sides rounded, basal margin very feebly produced at the middle, surface very finely and obsoletely punctured, dark fulvous. Scutellum oblong, smooth, 
flavous. Elytra scarcely wider at base than the thorax, with a very shallow depression below the base, strongly punctate-striate anteriorly, and still more at apex, the latter paler in colour than the rest of the disc ; first row of punctures short, not extending to the middle, eighth row only visible at the middle, interstices flat and impunctate. Body beneath and legs flavons; intermediate and posterior tibix strongly emarginate at the apex; claws bifid. Prosternum subquadrate, anterior margin strongly produced.

Length $2 \frac{1}{2} \mathrm{~mm}$.

$H a b$. Bengal : Mandar (Coll. Jacoby).

Much smaller than $R$. khasianensis, legs entirely fulvous, secund joint of the antennæ much longer, elytra with a depression and not wider at base than thorax.

\section{Rhyparida immaculata, sp. n.}

Pale fulvous; apical joints of antennæ black.

Head entirely impunctate, vertex above eyes with a deep short groove on each side that nearly meet in front; clypeus broadly subquadrate, separated from the face by a shallow transverse groove, surface scarcely perceptibly punctured, anterior margin concave-emarginate; antennæ with the basal five joints flavous, rest black, second joint short, third and following joints very elongate. Thorax twice as broad as long, sides rounded, base with a submarginal deeply impressed line, anterior margin with a similar but less deep line, surface only slightly convex, impunctate. Scutellum oblong, impunctate. Elytra slightly wider at base than the thorax, oblong, scarcely perceptibly depressed below the base, moderately strongly and regularly punctatestriate, the punctures very closely placed, scarcely finer at the apex than anteriorly, interstices sparingly and minutely punctured; seventh and eighth rows of punctures abbreviated, the outer two rows rather deeply impressed below the shoulders. Prosternum broadly subquadrate. Tibiæ strongly emarginate at apex; claws bifid. Anterior margin of thoracic episternum concave.

Length $4 \mathrm{~mm}$.

$H a b$. India (Coll. Jacoby).

Larger than $R$. bengalensis, the clypeus of different shape and impunctate,the thorax more stronglytransverse, less subcylindrical, second joint of the antennæ short, elytra wider at base.

671. Rhyparida aterrima, Juc. Ann. Mus. Civ. Genova, xxxii, 1892, p. 911.

Black, the basal joints of the antennæ fulvous.

Of an entirely deep black colour. Head obsoletely punctured and with a more or less distinct oblique ridge at the sides of the vertex; the clypeus separated from the face by a transverse groove, transversely subquadrate, with a few fine punctures, the anterior edge dentate at the middle; labrum and palpi fulvous; antennæ black, not extending to half the length of the elytra, the 
basal six joints fulvous, the third and the following three joints slender, of nearly equal lengtli. Thorax about twice as broad as long, less broad in the male, the sides straight, the angles acute, the dise irregularly inpressed with large and small punctures, the sides nearly impunctate, the base with a narrow impressed margin. Elytra convex, scarcely broader at the base than the thorax, without basal depression, the sides with a narrow reflexed margin, the surface rather strongly punctate-striate, the punctures fine towards the apex. Prosternum nuch broader than long, with a few fine punctures. Underside of the tarsi fulvous; femora with a distinct tooth beneath and dilated at the middle.

Length $2 \frac{1}{2}-3 \mathrm{~mm}$.

Hab. Burma : Bhamo (June); Karennee.

672. Rhyparida bimaculata, Jac. Ann. Mus. Civ. Genova, xxrii, 1889, p. 174.

Fulvous; apices of femora, the tibiæ and tarsi black. Elytra with longitudinal black band.

Head entirely impunctate; the clypeus nearly square, separated

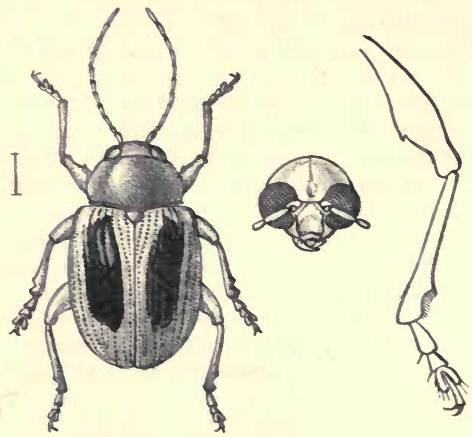

Fig. 132-Rhyparida bimaculata.

from the face by a narrow transverse groove, its anterior edge sinuate at the sides and middle; labrum and palpi fulvous; mandibles black; antennæ nearly as long as the body, filiform, fulvous, the terminal joint slightly darker, the third and following joints slender, equal. Thorax more than twice as broad as long, the sides strongly rounded near the base, narrowed towards the front, the anterior angles with a small tubercle, the surface with a few scarcely visible punctures or impunctate, fulvous. Scutellum fulvous, broader than long. Elytra nearly parallel-sided, impressed with regular but not very deep striæ in which the punctures are scarcely risible, except at the sides where they become more distinct, the sixth and following stria are interrupted by the humeral callus, the eighth and ninth being only half the length of 
the others; the interstices are flat and impunctate; placed near the suture is a black longitudinal band which, although of variable length, does not extend to the base or apex on each elytron. The femora are armed with a very small tooth and like the underside are fulvous, their apices and the tibix and tarsi black; claws bifid.

Var. Entirely fulvous.

Length $4 \mathrm{~mm}$.

Hab. Burma: Teinzo; Bhamo.

$R$. bimaculata may be known by the finely punctured strix of the elytra and the nearly impunctate thorax.

\section{Rhyparida assamensis, sp. n.}

Beneath piceous; head and basal joints of antennæ fulvous; thorax black. Ely tra black, a broad longitudinal band at the middle, widened near the apex, fulvous.

Broadly ovate, rather flattened. Head elongate, nearly impunctate, a small central fovea on the vertex; clypeus separated from the face by a shallow groove, widened in front, its anterior edge tri-emarginate; palpi slender, Hlavous; antennæ filiform, basal three or four joints fulvous, rest piceous, apex of each joint paler. Thorax twice as broad as long, narrowed anteriorly, sides strongly rounded at the middle, surface with a small forea at sides, impunctate, extreme anterior margin fulvous, rest black. Elytrit closely punctured in longitudinal striæ, the interstices slightly convex. Intermediate and posterior pair of tibiæ emarginate at apex ; claws bifid.

Length $5 \mathrm{~mm}$.

Hab. Assam: Patkai Mts. Type in Brit. Mus.

674. Rhyparida quinquemaculata, Jac. P. Z. S. 1887 , p. 75, pl. x, fig.3.

Rufous; the last eight joints of the antennæ and the legs black ; thorax sparingly and finely punctured; elytra regularly punctatestriate, a sutural spot at the middle, another at the shoulder, and a third near the apex of each elytron, black; femora toothed.

Head with a deep fovea at the vertex, not visibly punctured; the clypeus separated from the face by a slight transverse depression. Antennæ half the length of the body, black, the basal three joints fulvous, the third and fourth joints slender, of equal length, the following joints slightly depressed and shorter. Thorax transversely convex, about three times as broad as long, the sides rounded; the surface rufous, very finely and sparingly punctured, with a small obscure piceous spot at the sides. Elytra with a distinct transverse depression below the base, the punctured stria very distinct anteriorly, less so posteriorly; each elytron with a square-shaped spot at the shoulder, a triangular spot near the apex, and a common sutural elongate spot near the middle, black. Sides of the breast and the legs black; all the femora with a small tooth; claws bifid.

Length $4 \mathrm{~mm}$.

Hab. Ceylon. 


\section{Group SCELODONTINI.}

Body short, oblong; head with deep supraocular sulei; antennæ short and robust, terminal joints thickened. Thorax short, subglobular, much narrower than the elytra ; lateral margins obsolete. Elytra short. Legs robust, femora dentate; tibiæ entire or very slightly emarginate at apex; claws bifid. Prosternum transverse; thoracic episternum colicave.

The species are more or less metallic and pubescent; the thorax is frequently transversely strigose; elytra generally with rows of punctures and fine hairs, the interstices more or less finely wrinkled. Very similar in appearanee to Pseudocolaspis, but can be readily distinguished by the supraocular grooves.

\section{Genus SCELODONTA.}

Scelodonta, Westw. P. Z. S. 1837, p. 129.

Heteraspis, Leconte (nec Blanchard), Col. of Kansas, 1859, p. 23.

Odontionopa, Motsch. (nec Erichs. \& nec Lefêre) Bull. Mosc. 1866, p. 408.

Graphops, Leconte, Trans. Am. Ent. Soc. xii, 1885, p. 26.

Type, S. curculionoides, Westw., from Manilla.

Range. Africa; India; China; Malayan Islands.

Characters those of the group. Fenora dentate; antennæ with basal joint thickened, second very short, terminal joints short and thick.

675. Scelodonta vittata (Pl. II, fig. 5), Oliv. (Eumolpus) Ent. vi, 1808, p. 907, pl. i, fig. 18; Lefêv. Rev. et Mag. Zool. 1875, p. 128 .

Metallic cupreous; antennæ black; elytra with four longitudinal stripes of pale golden pubescence.

Broad and robust. Head elosely punctured with short yellow pubescence, deeply longitudinally sulcate in the middle and above the eyes. Antennæ extending to base of thorax, basal six joints cupreous, rest black. Thorax transverse, closely transversely strigose, with three bands of pale yellow pubescence at the middle and on sides. Scutellum pentagonal, pubescent. Elytra very wide at base, convex, pointed at apex, with rows of strong transverse punctures, interstices alternately purplish and pale golden. Sides of breast densely pubescent; abdomen and legs less pubescent, bright metallic cupreous; femora toothed.

Length $8 \frac{1}{2} \mathrm{~mm}$.

$H a b$. India: Pusa; Bombay. Cochinchina.

The largest and handsomest species of the genus. Not uncommon in India. 
676. Scelodonta ænea, Motsch. (Odontionopa) Bull. Mosc. ii, 1866, p. 408.

"Short, subquadrate, shining, cupreo-æneous; base of antennæ and legs rufo-testaceous. Thorax strongly punctured, sides arcuate. Elytra half as broad again as the thorax, transversely impressed anteriorly, deeply crenulate-striate, interstices carinate.

"Length $3 \mathrm{~mm}$.

"Hab. Ceylon." (Motschulsky.)

Lefèvre has placed this species, which is unknown to me, in the present genus. There is no described species of true Scelodonta known to me which has the basal joints of the antennro and the legs pale in colour.

\section{Scelodonta alternata, sp. n.}

Cupreous; terminal joints of antennæ black; elytra greenishæneous, interstices cupreous, forming narrow longitudinal lines.

Head irregularly rugose throughout,

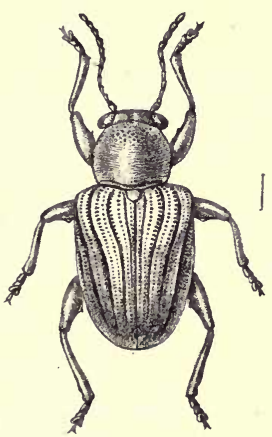

Fig. 133.

Scelodonta alternata. reddish-cupreous, deeply sulcate in the middle and above the eyes; palpi flavous, terminal joint piceous ; antennæ piceous, basal four joints cupreous, terminal joints elongate. Thorax of usual shape, transversely strigose and sparingly punctured. Scutellum subquadrate, strongly punctured. Elytra oblong, convex, without any depressions, finely punctate-striate near the suture, more strongly so at the sides, the suture and about six narrow, smooth, longitudinal lines cupreous, other interstices finely pubescent. Flanks of thorax and sides of breast densely coated with white matter; abdomen finely punctured; legs cupreous; femora dentite.

\section{Length $4 \mathrm{~mm}$.}

Hab. Andaman Islands (Colls. Brit. Mus. \& Jacoby).

Quite distinct in sculpture and coloration from any other species, the elytral punctured spaces with some very fine pubescence.

678. Scelodonta indica, Duviv. Bull. Soc. Ent. Belg. xxxv, 1891, p. xxxix.

Bronze-coloured; labrun, mandibles and terminal joinis of antennæ black; palpi fulvous; elytra with three smooth purplish spots. 
Oblong, clothed with fine white pubescence. Head very deeply punctured, strigose at sides of vertex, an oblong fovea in the middle; antennæ slightly extending below the base, the basal two joints æneous, rest black and thickened. Thorax slightly broader than long, feebly impressed on the disc and sides; surface strongly transversely strigose except near the anterior margin. Scutellum

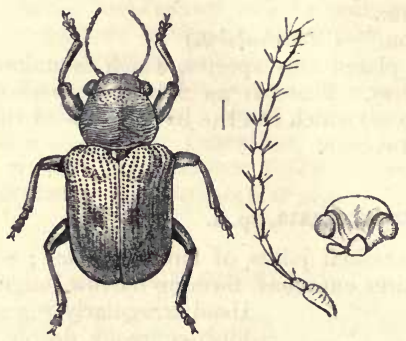

Fig. 134.-Scelodonta indica.

with a few punctures. Elytra with a depression below the shoulders and at the sides on its anterior third, another short depression below the first spot; disc scarcely convex, deeply punctate-striate and finely transversely wrinkled; interstices slightly convex anteriorly, costate posteriorly ; each elytron with three bluish-black spots, one below base, one larger, subtriangular, near the middle and placed nearer the suture, the third spot narrow, between the suture and the posterior margin. Beneath deeply and closely punctured.

Length $4 \frac{1}{2} \mathrm{~mm}$.

$H a b$. Bengal : Konbir.

679. Scelodonta areolata, Lefêr. Bull. Soc. Ent. Belg. xxxv, 1891, p. cclxvii.

" Aneous, subcupreous, sparingly pubescent; sides of metathorax densely clothed with white pubescence.

"Head remotely punctured, finely granulate if seen under a strong lens, faintly impressed between the eyes. Antennæ with the basal six joints greenish-æneous, the rest cyaneous. Thorax anteriorly rather deeply and irregularly transversely strigose, in the middle distinctly punctured, with shining subelevated spaces here and there. Scutellun smooth. Elytra rather deeply transversely depressed below the base, regularly punctured in rows, punctures stronger at the sides and in the basal depression; humeral callus smooth."

"Length $4 \frac{1}{2}-5 \mathrm{~mm}$.

"Hab. Hindustan." (Lejèvre.) 
680. Scelodonta dillwyni, Stephens (Eumolpus), Illustr. Brit. Entom. iv, 1831, p. 364, pl. 23, fig. 3.

Scelodonta nitidula, Baly, Descript. new gen. \& spec. Phytoph. 1864, p. 2; id. Trans. Ent. Soc. (3) iv, 1867, p. 157.

Greenish-cupreous ; terminal joints of antennæ and tarsi black ; elytra with suture anteriorly and three spots (2.1) purplishcupreous.

Head strongly punctured, with central longitudinal groove antennæ rather slender, extending to base of elytra, terminal joints scarcely thickened. Thorax transversely convex, surface entirely covered with transverse strigæ, anterior portion bebind the margin with some fine punctures, very sparingly pubescent. Elytra with closely approximate rows of transverse punctures, strong at base, fine near apex, interstices at the apex and on the sides finely costate and pubescent; a spot immediately below base close to suture, an elongate spot at shoulders, and a third at middle below the basal spot, purplish-cupreous ; suture likewise more or less cupreous anteriorly. Sides of breast densely clothed with white pubescence.

Length $3 \frac{1}{2} \mathrm{~mm}$.

Hab. Tenasserim (Doherty); Borneo; Singapore.

Mr. G. C. Champion has pointed out in the Ent. Month. Mag. that a specimen of this species, no doubt accidentally introduced, was taken in England and described by Stephens under the above name, which has priority of Baly's name by noore than twenty year's.

The Indian specimens agree very closely with Baly's specimens from Borneo, but have the basal six joints of the antennæ metallic greenish, not black as Baly gives in the description of his insect.

\section{Scelodonta nilgiriensis, sp. $\mathrm{n}$.}

ㅇ. Brownish-cupreous; terminal joints of antennæ black; elytra with suture and a lateral narrow stripe pale cupreous.

Broad and robust. Head coarsely rugose, with narrow central groove; clypeus deeply separated from face, subquadrate, strongly punctured, supraocular grooves very deep; antennæ with the basal six joints cupreous, terminal joints blue-black, strongly thickened, third and fourth elongate, equal. Thorax nearly twice as broad as long, sides strongly deflexed, rounded, middle rather widened, surface closely transversely rugose. Scutellum strongly punctured. Elytra feebly depressed below the base, strongly punctate-striate, the row s more distinctly placed near the suture than at the sides; the punctures transverse, confluent at the sides; interstices finely punctate, rather strongly costate except on the outer disc; a pale golden stripe from the shoulders to near the apex, suture of similar colour. Beneath strongly punctured, scarcely perceptibly pubescent.

Lenyth $5 \mathrm{mim}$.

Hab. Southern India: Nilgiris (G. Hampson). voL. I. 
682. Scelodonta? strigicollis, Motsch. (Odontionopa) Bull. Mosc. xxxix, 1866, p. 409 ; Lefèv. Cat. Eumolp. 1885, p. 69.

Motschulsky's description only gives " colour greenish-æneous, thorax strigose, and elytra marked with four violet spots, suture of similar colour.

Hab. "India."

In the absence of any further details the species is unrecognizable.

\section{Scelodonta subcostata, sp. n.}

Dark cupreous. Head and clypeus strongly rugose; basal four joints of antennæ cupreous, terminal joints black, slightly widened. Thorax of the same shape and sculpturing as in S. nilgiriensis. Elytra deeply punctate-striate, interstices with distinct grey pubescence, placed in rows, also finely punctured and costate throughout, strongly so at the sides, more feebly on the disc; an obscure purplish spot at the middle. Femora strongly dentate.

Length $4 \frac{1}{2} \mathrm{~mm}$.

Hab. Andamans (Coll. Brit. Mus.).

Smaller than S. nilgiriensis, and separated from it by the regularly costate elytra and their distinct pubescence.

684. Scelodonta granulosa, Baly, Trans. Ent. Soc. (3) iv, 1867, p. 158.

Dark cupreous ; antennæ (base excepted) and tarsi black ; elytra with some dark purplish spots.

Head closely rugose-punctate, interstices between punctures granulate; basal tive or six joints of antennæ metallic cupreous. Thorax broader than long, sides rounded, surface closely transversely strigose. Scutellum pentagonal, punctured. Elytra granulose over the whole surface, coarsely punctate-striate; interstices transversely punctate so as to render the striæ themselves rather indistinct; two short ridges at base between shoulders and suture, a long and more distinct ridge near lateral margins and another near apex short and feeble; at the middle some of these ridges and also those at the base are marked with dark purplish narrow spots, some ill-defined longitudinal depressions are also visible below base and at the sides. Breast closely pubescent on the sides.

Length $3 \frac{1}{2}-4 \mathrm{~mm}$.

Hab. Madras ; Assam; Andamans; Borneo; Celebes.

The Indian specimens do not seem to differ from Baly's type with which I have compared them, and although the species is closely allied to several others, it may be known generally by the two short costæ at the base of the elytra, the granulose surface and feeble longitudinal depressions; in some specimens the purplish spots are absent. 
685. Scelodonta immaculata, sp. n.

Dark æneous. Head deeply and closely punctured, sulci very deep, forehead with a central longitudinal groove; clypeus distinctly bidentate in front; antennæ nearly black, with the basal two joints æneous, third elongate, terminal joints strongly thickened. Thorax transversely subcylindrical, sides rounded, surface closely transversely strigose. Scutellum transverse, punctured. Elytra strongly convex, faintly transversely depressed below base, closely punctate-striate, punctures transverse, interstices finely punctured, longitudinally costate at the sides. Femora strongly dentate. Prosternum much broader than long, remotely punctured. Abdomen finely, breast strongly, punctured.

Length $4 \mathrm{~mm}$.

Hab. Travancore: Wallardi (Coll. Jacoby).

\section{Scelodonta longicollis, sp. n.}

Dark bronze-coloured. Head finely granulate, closely pnnctured and longitudinally strigose, interstices with some very short grey hairs; antennæ with the terminal joints black and gradually thickened, basal joint æueous, third and fourth equal. Thorax scarcely broader than long, sides strongly rounded and widened; surface depressed on the disc, transversely strigose throughout, studded with scattered hairs. Scutellum transverse, distinctly punctured. Elytra longer than broad, depressed below base and longitudinally depressed at the sides near the middle, closely and strongly punctured in rows; interstices within depressions and at the sides feebly costiform, furnished with single short hairs like those on the thorax; an obscure spot on the middle of disc. Legs rather elongate; anterior femora unarmed, the others with a small tooth. Sides of breast closely covered with white pubescence.

Length $4 \mathrm{~mm}$.

Hab. Kashmir. Type in Coll. H. E. Andrewes.

The thorax in this species is longer than in that of any other form known to me from India or the East.

\section{Group HETERASPINI.}

Body above more or less strongly pubescent. Thorax with distinct lateral margins. Elytra broader at base than the thorax, Intermediate tibiæ emarginate at apex; claws bifid. Anterior margin of thoracic episternum concave.

Metallic species distinguished by the long silky pubescence of the upper parts. A single genus only is known from India.

\section{Genus TRICHOCHRYSEA.}

Trichochrysea, Baly, Journ. of Ent. i, 1860, p. 195.

Type, $T$. mouhoti, Baly, from Cambodia.

Range. India; China; Malayan Subregion. 
Characters those of the group; clypeus toothed; thorax subquadrate, often with a tubercle near the anterior angles, closely pubescent like the rest of the surface.

\section{Trichochrysea bhamoensis, sp. n.}

q. Dark violaceous; second, third and fourth joints of antennæ fulvous, rest black.

Broad, subquadrate, clothed with grev pubescence. Head strongly and closely punctured, a small tubercle at the middle; clypeus with the anterior border semicircularly emarginate; labrutn black; antennæ extending only to base of elytra, third joint half as long again as the second, nearly as long as the fourth, terminal joints longer than broad. Thorax about half as broad again as long, sides slightly constricted at base, lateral margins feebly rounded anteriorly; surface very closely but more strongly punctured than the head; pubescence long, grey and black. Scutellum subquadrate, covered with long hairs. Elytra with distinct depression below base, very closely punctured ; punctures uneven in size, gradually finer towards apex; disc with two or three obsolete longitndinal smooth lines; shoulders very prominent; pubescence similar to that of thorax. Breast more distinctly, abdomen very finely, punctured; legs clothed with long pubescence; intermediate tibiæ strongly emarginate at apex.

\section{Length $9 \mathrm{~mm}$.}

Hab. Burma: Bhamo (Coll. Jacoby).

Distinguished from its congeners by the dark purplish colour, the long grey pubescence and the sculpturing of the elytra.

\section{Trichochrysea rufofemoralis, $\mathrm{sp} . \mathbf{n}$.}

ð. Obscure dark æneous, clothed with white pubescence; base of femora fulvous; antennæ and tarsi black.

Oblong. Head closely punctured, clothed with long white and black pubescence; clypeus derply emarginate, sides produced into a long point; lahrum fulvous; antennæ extending nearly to apex of elytra, basal four joints more or less fulvous, rest black, second and third joints equal, furth and following more elongate, terminal joint long and slender. Thorax twice as broad as long, of equal width, lateral margins rounded, surface finely and extremely closely punctured, covered with long white pubescence. Seutellum subquadrate, greenish. Elytra subcrlindrical, oblong, with a very feeble depression beluw base, punctured and pubescent like the thorax, apex obsoletely punctured. Upper portion of hreast, prosternum and coxæ pale, base of femora darker fulvous. Prosternum subquadrate, strongly puuctured. Lower portion of breast metallic greenish; abdomen fuscous.

Length $4 \mathrm{~mm}$.

Hab. Burma : Toungoo. Type in Coll. H. E. Andrewes.

Easily distinguished by the colour of the underside, the femora and tarsi. 
689. Trichochrysea antennata, sp. n.

Violaceous ; antennæ black, basal joints fulvous ; labrum metallic green.

Closely covered with long grey pubescence. Head strigose on vertex, rather closely punctured on the front; palpi fulvous; antennæ short, not extending much beyond base of elytra, basal three joints fulvous, basal joint piceous above, terminal five strongly widened, scarcely longer than broad. Thorax nearly twice as broad as long, lateral margins very feebly rounded, anterior angles prominent, surface finely and closely punctured, but the interstices wider than the punctures. Scutellum broader than long, finely punctured. Elytra broadly subquadrately ovate, very feebly transversely depressed below base, more strongly, but not more closely punctured than the thorax. Prosternum subquadrate, closely punctured.

Length $6-7 \frac{1}{2} \mathrm{~mm}$.

Hab. Sikhim : Mungphu; Burma.

Very closely allied to T. hirta, Fabr., but more shining in appearance and less closely pubescent. The principal distinction, however, is that the antennæ have their terminal joints dilated, while they are filiform and elongate in T. hirta.

690. Trichochrysea vestita, Baly, Journ. Ent. i, 1861, p. 196; id. (Bromius) Journ. Ent. ii, 1865, p. 440.

Dark cupreo-æneous ; base of antennæ fulvous ; the whole body clothed with long, suberect, silvery-grey hairs.

Head extremely closely punctured, furnished with a small central tubercle; clypeus of male produced at either side into a strong tooth; labrum metallic green or æneous; antennæ rather slender, basal joint æneous, following three or four joints fulvous, rest black. Thorax subglobose or subcylindrical, surface rather strongly rugose-punctate, interstices at the sides confluent. Scutellum closely punctured, greenish. Elytra feebly depressed below base, more finely punctured than the thorax, puncturation arranged in very irregular rows, interstices everywhere finely punctured.

Length $6-7 \mathrm{~mm}$.

Hab. Northern India; Assam: Khási Hills; Burma: Bhamo; Tenasserim.

691. Trichochrysea severini, Jac. Mém. Soc. Ent. Belg. vii, 1900, p. 109.

Cupreous or dark æneous; basal joints of antennæ and the tibiæ more or less fulvous.

Head finely and rather closely punctured; clypeus semicircularly emarginate in front; labrum flavous, stained with æneous; antennæ with the basal five or six joints fulvous, rest fuscous. Thorax strongly subcylindrical, sides straight (not rounded as originally given), puncturation rather close and somewhat stronger than that on the head, interstices clothed with long stiff black 
hairs and shorter white pubescence. Elytra oblong, a sballow depression below base, puncturation much finer than that on the thorax, especially behind the middle but similarly pubescent.

Length $5 \mathrm{~mm}$.

$H a b$. Bengal : Mandar.

Smaller than $T$. vestita, Baly, the head and thorax more remotely and finely punctured, but otherwise similar; perhaps only a local form of T, vestita.

692. Trichochrysea hirta, Fabr. (Eumolpus) Syst. Eleuth. i, 1801, p. 420 ; Baly (Bromius), Trans. Ent. Soc. (3) iv, 1867, p. 96.

"Metallic blue or green, densely pubescent; bead coarsely punctured, basal four or five joints of antennæ rufo-piceous

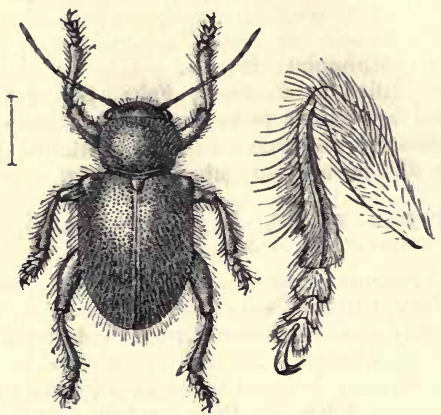

Fig. 135.-Trichochrysea hirta.

beneath, second and third sometimes entirely so, basal joint cupreo-aureous. Thorax subcylindrical, sides slightly rounded, scarcely convergent in front, anterior angles armed with a short tooth. Elytra much broader than the thorax, sides parallel, apex broadly rounded, surface very coarsely and closely punctured.

" Length 6-11 mm.

"Hab. Sylhet; Malayan Islands." (Baly.)

It is somewhat doubtful whether Baly had the true $T$. hirta of Fabricius before him, and whether the Indian species is identical with that from Java and Sumatra. In the specimens before me there is considerable variation in the amount of the pubscence, which is short and silky, nearly white in some, and much longer and more rigid in others.

693. Trichochrysea quadrifasciata, Jac. (Heteraspis) Ann. Mus. Civ. Genova, xx vii, 1889, p. 171.

Obscure picenus beneath, metallic green above ; antennæ black, basal joints fulvous; elytra with a narrow subsutural and a sublateral cupreous band. 
Head rather finely and closely punctured; clypeus not separated from face; mandibles and palpi piceous; antennæ two-thirds the length of the body, terminal joints scarcely thickened, basal three or four joints fulvous, rest black. Thorax twice as broad as long, sides straight, slightly convergent in front; surface strongly and closely punctured, clothed with long black and white hairs. Scutellum sparingly punctured. Elytra scarcely depressed below base, shoulders prominent, dise strongly and rather closely punctured; punctures arranged in somewhat regular rows, greatly diminishing towards the apex; interstices with long black and white hairs; the cupreous sutural band greatly narrowed posteriorly, not quite extending to apex, the lateral band broade:. Legs piceo-æneous.

Length $5 \cdot \mathrm{mm}$.

Hab. Burma: Bhamo. Type in Genoa Mus.

694. Trichochrysea clypeata, Jac. (Heteraspis) Ann. Mus. Civ. Genora, xxvii, 1889, p. 172.

Obscure æneous beneath, purplish above, closely pubescent; basal five joints of antennæ fulvous, rest black, basal joint æneous ; labrum, scutellum and legs metallic green.

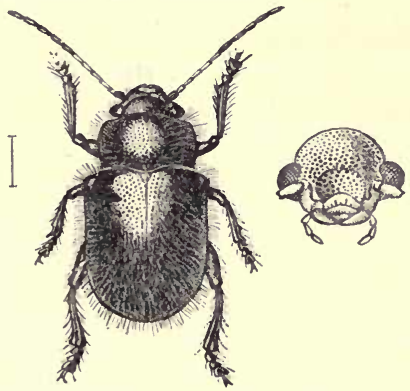

Fig. 136.-Trichochrysea clypeata.

\$. Head closely and very finely punctured on vertex, pubescent; clypeus with a broad tooth at the sides; antennæ about half the length of the body, much shorter in the female, terminal joints scarcely widened. 'Thorax twice as broad as long, sides feebly rounded, not narrowed anteriorly, surface extremely closely and more strongly punctured than the head, clothed with short white and long erect black hairs, puncturation nearly confluent on the sides. Elytra with a shallow depression below the base, puncturation slightly stronger than that on the thorax and urranged in very close irregular rows, interstices pubescent like those on the thorax.

Length 6-7 mm.

Hab. Burma : Bhamo. 
Although closely allied to $T$. vestita, Baly, the present species differs in the much more transversely shaped thorax and its closer and finer puncturation and in the structure of the clypeus.

\section{Trichochrysea viridis (Plate II, fig. 4), Jac. (Heteraspis) Entomologist, Suppl. 1892, p. 86.}

Bright metallic green, with dense white pubescence.

Subquadrate-orate. Head strongly and rather closely punctured; clypeus not separated from face; labrum metallic green, anterior edge trisinuate; basal joint of palpi fulvous; antennæ extending to about one-third the length of the elytra, basal five or six joints metallic green, rest black, slightly thickened, basal joints more or less fulvous beneath. Thorax subcylindrical, sides straight, slightly widened at the apex, anterior angles preceded by a tubercle, surface densely rugose-punctate and pubescent. Scutellum closely punctured. Elytra much wider and more strongly rugose than the thorax, interstices closely punctured and densely pubescent.

Length $8 \mathrm{~mm}$.

$H a b$. Burma.

Although closely allied to $T$. hirta, Fabr., the soft metallic green colour, the very fine and dense white pubescenue which gives the species the appearance of being covered with mould, and the densely rugose upper surface distinguish the present insect.

I have seen only females.

696. Trichochrysea parvula, Jac. (Heteraspis) Ann. Mus. Civ. Genova, xxxii, 1892, p. 909.

Bluish-black, pubescent;; elytra violaceous or æneous; basal joints of antennæ fulvous.

Head without depressions, very finely punctured; labrum and palpi fulvous; antennæ black, slender, extending to middle of elytra, basal five joints fulvous, terminal joints scarcely thickened. Thorax strongly transverse, more than twice as broad as long, sides nearly straight, anterior angles acute but not produced; surface extremely finely and closely punctured throughout, clothed with greyish pubescence. Elytra scarcely wider at base than the thorax, puncturation slightly stronger anteriorly than on the thorax, finer towards the apex; surface with greyish not very long pubescence, intermixed with longer stiff black hairs.

Length $4 \frac{1}{2} \mathrm{~mm}$.

Hab. Burma : Karennee. Type in Genoa Mus.

$T$. parvula is smaller than most of its congeners, and differs in the scarcely thickened antennæ, the strongly transverse thorax and its fine puncturation. In one specimen the legs are dark fulvous.

697. Trichochrysea variegata, Jac. (Heteraspis) Ann. Mus. Civ. Genova, xxvii, 1889, p. 172.

Blue or purplish ; antennæ black ; thorax greenish with a dark purplish semicircular band; elstra greenish, pubescent; each elytron with two purplish oblique bands from shoulder to suture. 
Head deeply and remotely punctured ; vertex convex, purplish, middle depressed, greenish ; anterior border of clypeus broadly emarginate, sides angulate; labrum and palpi black. Antennæ with basal joint metallic green above, terminal five compressed and widened, opaque. Thorax subcylindrical, sides strongly deflexed, lateral margins straight, posterior margin rounded, produced at the middle; dise deeply and rather remotely punctured, clothed with short pubescence, a space near the anterior margin more finely and closely punctured; a broad purplish band extends across the disc near base and to the sides. Scutellum violaceous. Elytra more deeply but scarcely more closely punctured ; interstices near base slightly transversely rugose, impressed with a few smaller punctures; shoulders prominent; surface greenish; suture narrowly purplish, a similarly coloured band from within shoulders to suture; another band from below shoulders runs parallel with the first, not extending to apex of elytra; posterior portion of lateral margins similarly coloured. Below dark blue, parapleuræ of breast clothed with thick yellow pubescence. Legs metallic green.

Length $8 \mathrm{~mm}$.

$H a b$. Burma: Shwègu. Type in Genoa Mus.

All the purplish bands although visible are obscure, the pubescence is short and not close.

698. Trichochrysea hebe, Baly (Bromius), Journ. of Entom. ii, 1864, p. 220.

Purplish; elytra metallic bright cupreous, a transverse band below base, angulate at middle and extending downwards and a sntural and a lateral band purplish.

Short and ovate. Head closely and strongly punctured; antennæ black, second joint obscure fulvous, terminal joints thickened, not extending to middle of elytra. Thorax subquadrate, not much broader than long, closely and strongly but not confluently punctured, clothed with erect black pubescence. Scutellum purplish. Elytra much wider than the thorax, with a shallow transverse basal depression, scarcely more strongly punctured than the thorax, punctures extremely closely placed in irregular rows ; surface pubescent like that of the thorax; a transverse band at hase greenish-cupreous, followed by a purplish band which sends off a short branch at the middle downwards; a narrow sutural and a marginal band likewise purplish ; posterior portion of elytra metallic cupreous like the base. Beneath and the legs purplish. Femora with a small tooth; tibix slightly curved, anterior tibiæ thickened at apex.

Length 6-7 $\mathrm{mm}$.

Hab. Burma; Siam.

The above description is taken from a specimen in my collcction named by Baly himself. The species is one easily recognized by its system of coloration. 
699. Trichochrysea nitida, Jac. (Heteraspis) Ann. Mus. Civ. Genova, xxxii, 1892, p. 909.

Metallic green; antennæ (the basal joints excepted) and the tarsi black; elytra clothed with white pubescence.

Head very finely and closely punctured, covered with short white and longer black hairs; palpi fulvous; antennæ rather slender, basal five joints fulvous, basal joint metallic green above, fourth joint twice as long as the third. Thorax about half as broad again as long, broader in the female, lateral margins quite straight; surface extremely closely and rather finely punctured throughout, all the punctures of the same size, interstices pubescent like the head. Scutellum finely punctured. Elytra distinctly wider at base than the thorax, more distantly punctured than the latter and with similar pubescence. Beneath metallic green, covered with white pubescence; intermediate tibiæ deeply emarginate at apex.

length $5 \mathrm{~mm}$.

Hab. Burma: Karennee.

700. Trichochrysea purpureomaculata, Jac. Ann. Soc. Ent. Beig. xlii, 1898, p. 187.

Metallic purplish-blue; elytra with two spots below base and another near a pex dark purplish.

Broad and robust, subquadrate-ovate. Head closely rugosepunctate, sides and anterior edge of clypeus metallic green. Antennæ black, basal four joints dark fulvous, terminal three joints strongly flattened and widened. 'Thorax very strongly transverse, subcylindrical, lateral margins nearly straight, somewhat sinuate, anterior margin narrowly thickened; surface strongly punctured, but the punctures well separated; interstices clothed with short silvery pubescence, anterior margin narrowly metallic green. Scutellum broad, strongly punctured. Elytra punctured like the thorax anteriorly, the punctures becoming finer towards the apex; interstices more finely punctate, slightly wrinkled at the sides; whole surface pubescent like that of the thorax, a shallow transverse depression below the shoulders; two united purplish spots placed within this depression, another spot near apex. Body beneath clothed with long grey hairs.

Length $10 \mathrm{~mm}$.

$H a b$. India; Burma : Tharawaddy.

Allied to $T$. mouthoti, Baly, from Siam.

Species recorded as Indian descriptions of which are omitted.

Eumolpus setulosus, Motsch. Bull. Mosc. xxxix, 1866, p. 406.

Eumolpus picipes, Motsch. t. c. p. 407.

Eumolpus rugicollis, Motsch. t. c. p. 407.

Eumolpus fascicularis, Motsch. t. c. p. 407.

Eumolpus albostriatus, Motsch. t. c. p. 407. 
Eumolpus incanus, Motsch. $t$. c. p. 408.

Eumolpus rufulus, Motsch. t. c. p. 408.

Eunolpus fusculus, Motsch. t. c. p. 408.

All these species have been placed by Motschulsky in Bromius, but are quite unrecognizable from his descriptions. The habitat of all as given by him is Ceylon: Newarra Ellia.

\section{Group LEPROTINI.}

Body above and beneath pubescent or clothed with scales and single rigid bairs; thorax subcylindrical, scarcely marginate at sides. Legs long and slender, tibiæ nearly always entire; claws bifid. Prosternum narrow ; anterior margin of thoracic episternum concave.

This division contains the greatest number of the genera of the Eumolpina. The species in all the genera are mostly of sombre coloration, never metallic, and are characterized by the close pubescence or scale-like covering of the upper parts. The species require a very laborious and careful study for their determination as many of them are small and of intricate sculpture and structure.

\section{Key to the Generc of the Leprotini.}

A. Body clothed with hairs or hair-like scales above.

a. Eyes entire or with inner margins obsoletely sinuate.

$a^{\prime}$. Mesosternum transverse, bifurcate. $a^{2}$. Body above closely pubescent... $b^{2}$. Body above very sparingly pibescent ..................

$b^{\prime}$. Mesosternum subquadrate, entire, or slightly notched.

$a^{2}$. Femora strongly thickened.

$a^{3}$. Anterior more strongly thickened than posterior femora and strongly toothed ...........

$b^{3}$. Anterior less strongly thickened than posterior femora, both toothed ..................

$b^{2}$. Femora normal, scarcely thickened.

Aonra, p. 396.

Pseudaoria, p. 399.

Trichotheca, p. 400.

Pseudolomera, p. 403.

$a^{3}$. Thorax transverse, depressed or more or less sulcate.

$a^{4}$. Sides of thorax simple ......

$b^{4}$. Sides of thorax with two or three teeth ............

$b^{3}$. Thorax cylindrical above.

$a^{4}$. Femora toothed beneath.

$a^{5}$. Body elongate, furnished with a white excrescence .

$b^{5}$. Body oblong, clothed with scale-like hairs.........

$b^{4}$. Femora not toothed beneath.

$a^{5}$. Antennæe moniliform ....

$b^{5}$. Antennæ not moniliform, terminal joints widened..

b. Eyes reniform .................
Xanthophords, p. 404.

Aulnxis, p. 410.

Lypksthes, p. 412.

Neculla, p. 413.

DEMOTINELLA, p. 414.

LEPROTELLA, p. 415.

Nephrella, p. 416. 
B. Body clothed with regular scales above.

a. Prosternum not separated from episternum by a sutural groove.

$a^{\prime}$. Anterior and posterior femora thickened, intermediate femora more slender.

$a^{2}$. Sides of thorax serrate .........

$b^{2}$. Sides of thorax not serrate ......

$b^{\prime}$. Anterior and posterior femora not more thick than the intermediate femora.

$a^{2}$. Tibiæ simple ..............

$b^{2}$. Tibiæ of intermediate and posterior

legs emarginate at apex ........

b. Prosternum separated from episternum

by a deep groove.............. Aulacolexis, p. 431.

Pshedometaxis, p. 424.

Hyperaxis, p. 417

LEPROTES, p. 425.

Demotina, p. 427.

\section{Genus AORIA.}

Aoria, Baly, Journ. Ent. ii, 1863, p. 149; Chapuis, Gen. Coléopt. x 1874, p. 270 ; Lefêv. Cat. Eumolp. 1885, p. 71.

Type, A. nigripes, Baly, from China.

Range. India; China; Malayan Subregion.

Oblong, subcylindrical; closely covered above and beneath with adpressed silky hairs. Head perpendicular; antennæ subfiliform, moderately robust, first joint incrassate, second about half as long as first, third longer than second, shorter than fourth; eyes entire ; terminal joints of palpi ovate, acuminate at apex. Thorax subcylindrical, lateral border entirely obsolete. Elytra much broader than thorax, surface closely punctured, sometimes impressed with longitudinal striæ. Legs moderately robust, femora unarmed, basal joint of tarsi nearly equal in length to the following two united; claws bifid. Prosternum transverse, its anterior margin continuous with that of the episternum; mesosternum transverse, its apex bifurcate.

701. Aoria nigripes, Baly (Adoxus), Journ. Ent. i, 1860, p. 28; Jac. Notes Mus. Leyd. vi, 1884, p. 203.

Fuscous or obscure fulvous; antennæ (basal four joints excepted) and legs black.

Very convex, pubescence paler than the ground colour. Head and thorax very closely, somewhat rugosely punctured; antennæ two-thirds the length of body, third and following joints elongate and slender. Thorax rounded and convex. Elytra broadly ovate, punctured like the thorax and with some obsolete longitudinal grooves, entire upper-surface covered with long and soft grey pubescence that partly obscures the sculpture.

Length $5 \mathrm{~mm}$.

Hab. India: Malabar; Assam; Burma ; China; Sumatra. 
702. Aoria nigrita, Jac. Ann. Mus. Civ. Genova, xxxii, 1892, p. 904.

Black, clothed with white pubescence; femora rufous.

Head closely and finely punctured, pubescent; antennæ rather more than half the length of the body, basal three joints fulvous beneath, fourth the longest. Thorax very closely and rather more strongly punctured than in $A$. nigripes, but of similar shape. Elytra with deep punctures arranged in rows; pructuration transverse, wrinkled, interstices finely punctured and pubescent.

Var. Legs entirely black.

Length $5 \frac{1}{2} \mathrm{~mm}$.

Hab. Burma : Ruby Mines.

703. Aoria bowringi, Baly (Adoxus), Journ. of Ent. i, 1860, p. 27 ; id. Trans. Ent. Soc. (3) iv, 1867, p. 79, pl. iv, fig. 1.

Dark fulvous, with five or six spots on the elytra, a patch at apex of each pleuron and the metacoxæ black.

Ovate, very convex; body covered with obscure fulvous hairs. Head closely punctured; clypens triangular, separated from the face by an acutely angulate grooved line; surface more strongly

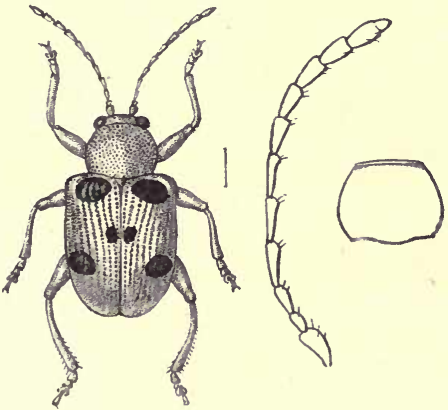

Fig. 137.-Aoria bowringi, var.

and remotely punctured, shining; on either side above the insertion of the antennæ is a slightly raised sinooth tubrrcle. Thorax subglobose above, covered with fulvous hairs which are shorter than those on any other part of the body, sides regularly rounded, surface deeply punctured; puncturation crowded and often rugose at sides, rither more scattered on the disc, centre of latter covered by a large black patch sometimes absent. Flytra oblong. convex; each elytron with eleven sulcate striæ, the first abbreviated, each stria impressed with a single ro: $v$ of irregular punctures; interstices raised and subcostate towards the lateral margin, all distinctly but finely punctured; a large spot at middle 
of base, a common sutural spot below the latter, another oblongovate on the sides behind the middle and a small spot external to the humeral callus, black and shining.

Var. Thoracic patch and several of the spots on the elytra absent.

\section{Length 5-6 mm.}

Hab. Nepal; Assam: Khási Hills; Burma; Andamans; Sumatra; Northern China.

This species seems to vary a good deal in regard to the black markings ; in some specimens the sides of the breast and abdomen bave black spots, in others these are absent; the sides of the thorax have likewise sometimes black markings. A specimen from the Andamans in my collection is of more elongate shape and the markings are opaque, but I cannot find any other differences.

704. Aoria semicostata, Jac. Ann. Mus. Civ. Genova, xxxii, 1892, p. 906.

Reddish-fulvous, clothed with white pubescence.

Head strongly and closely punctured, with central groove ; mandibles black, apex fulvous; antennæ fulvous, apical joints slightly thickened. Thorax about half as broad again as long, very closely and much more strongly punctured than the head, interstices slightly rugose, pubescent. Elytra with the shoulders prominent and angulate, a depression below the base ; puncturation very close, much finer than that on the thorax; interstices longitudinally costate at base, the costæ disappearing towards the middle, pubescence long. Body beneath more shining.

Length $6 \mathrm{~mm}$.

$H a b$. Burma : Karennee.

Separable by the angulate shoulders and costate base of the elytra.

705. Aoria fulvifrons, Jac. Ann. Mus. Civ. Genova, xxxii, 1892, p. 905.

Black, clothed with fine white pubescence; head, basal jointe of antennæ and labrum fulvous.

Head very finely punctured; antennæ slender, black, the basal four joints fulvous, the fourth joint longer than the third. Thorax of usual shape, widened towards the middle, very closely punctured and closely covered with whitish hairs. Elytra wider at the base than the thorax, the shoulders rather angulate but not very prominent, the puncturation fine and very close, the interstices finely transversely wrinkled, very closely covered with rather long white pubescence. Underside and legs black, clothed with white pubescence.

\section{Length $4 \mathrm{~mm}$.}

$H a b$. Burma : Karennee.

Smaller than $A$. nigrita, and distinguished by the colour of the head and the wrinkled surface of the elytra. 


\section{Genus PSEUDAORIA, nox.}

Type, $P$. burmanica, Jac., from Burma.

Kange. Manipur; Burma.

Narrowly oblong, finely pubescent; eyes entire; antennæ filiform, very long and slender, third and following joints very elongate. Thorax subcylindrical, narrowed at base and apex, lateral margins absent. Elytra much wider at base than the thorax, pointed at apex, surface rugose. Legs elongate and slender; femora thickened; first joint of tarsi as long as the following two united; claws bifid. Prosternum subquadrate; mesosternum strongly emarginate at base; anterior margin of thoracic episternum concave.

This genus is closely allied to Aoria, Baly; the species for which it is proposed are, however, of more narrow and elongate shape, and with the surface of the thorax and elytra not closely covered with hairs but shining and rugose, only very sparingly pubescent; the legs generally and the metatarsi are inuch more slender and elongate; the prosternum is not transverse but nearly quadrate.

\section{Pseudaoria burmanica, sp. $n$.}

Black. Head finely rugose; clypeus separated from face by an obsolete groove, wedge-shaped,

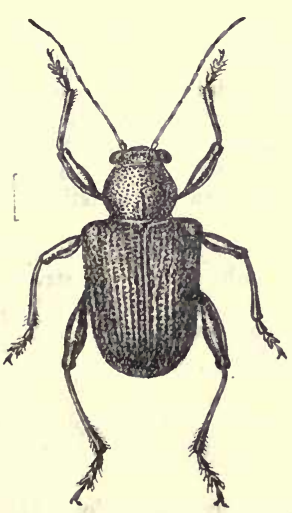

Fig. 138.-Pseudaoria burmanica. anterior border without teeth; palpi slender; antennæ black, basal three joints more or less fulvous beneath, fourth joint nearly twice as long as the third, terminal joint extending to apex of elytra. Thorax widened at the middle, subcylindrical, surface very strongly and closely punctured, interstices rugose throughout, sparingly clothed with grey pubescence. Scutellum longer than broad, apex truncate, strongly punctured. Elytra with a transverse depression below base, longitudinally costate and irregularly rugose at the sides, the costæ frequently interrupted; sparingly clothed with stiff grey pubescence. Body beneath and legs similarly pubescent. The female is of more robust and broader shape, with shorter antennæ and shorter metatarsi to anterior legs.

Length 5-6 mm.

Hab. Manipur; Burma: Ruby Mines (Coll. Brit. Mus.). 
707. Pseudaoria cærulea, sp. $n$.

Metallic blue or violaceous; antennæ, tibiæ and tarsi black; basal joints of antennæ fulvous; breast and abdomen black.

Head rather closely and strongly punctured; labrum black; antennæ nearly as long as the body, third joint scarcely longer than the second, both short, fourth and following joints elongate. Thorax similar to that of $P$. burmanica, and punctured like the head. Elytra scarcely perceptibly depressed below the base near the suture, closely and strongly punctured in rows, interstices only transversely rugose at the sides, very sparingly pubescent. Legs very elongate and slender.

\section{Length $5 \mathrm{~mm}$.}

Hab. Manipur (Coll. Brit. Mus.).

Distinguished from the preceding species by the metallic blue colour and the short third joint of the antennæ, also by the entirely different sculpturing.

\section{Genus TRICHOTHECA.}

'Trichotheca, Baly, Journ. Ent. i, 1860, p. 26 ; Chapuis, Gen. Coléopt. x, 1874, p. 272; Lefèv. Cat. Eumolp. 1885, p. 75.

Type, T. hirta, Baly, from India.

Range. India.

Body elongate, subcrlindrical, pubescent; antennæ. filiform, nearly as long as the body, third joint shorter than the fourth. Thorax subcylindrical, lateral margins absent. Scutellum trigonal. Elytra much wider than the thorax at base. Legs rather elongate, slender; anterior femora incrassate, strongly toothed beneath ; intermediate femora with small tooth; tarsi slender, first joint as long as the following two united ; claws with distinct tooth at base.

Trichotheca, although placed near Aoria by Baly, has very little in common with that genus; shape, pubescence and structural characters are quite distinct, and instead of being ovate and convex, the species are elongate and narrow. They form with several other genera a group by themselves.

708. Trichotheca hirta, Baly, Journ. Ent. i, 1860, p. 26, pl. i, fig. 5.

Pale fulvo-fuscous; a short vitta on the disc of the thorax and three patches on each elytron, black.

Elongate; whole body clothed with suberect, concolorous hairs. Head shining, remotely punctured, sparingly pubescent; clypeus transverse, separated from face by a deep groove which runs across between the insertion of the antennæ; maudibles black; antennæ nearly equal in length to the body, third joint two-thirds the length of the fourth. Thorax slightly broader than long, subcylindrical, slightly flattened above, sides rounded, sinuate behind the middle, posterior angles produced into an obtuse tooth, surface covered with large deep punctures Scutellum trigonal, sides slightly 
excavated, apex truncate. Elvtra broader than the thorax, sides parallel, above convex, each elytron with eleven rows of deep punctures, the first abbreviated, outer striæ indistinctly sulcate; interstices smooth and shining; two parallel patches immediately below the base, the first within shoulders narrowly oblong, second on outer margin still more narrow and elongate, and a large subovate patch behind the middle, shining black. Beneath shining, more sparingly pubescent.
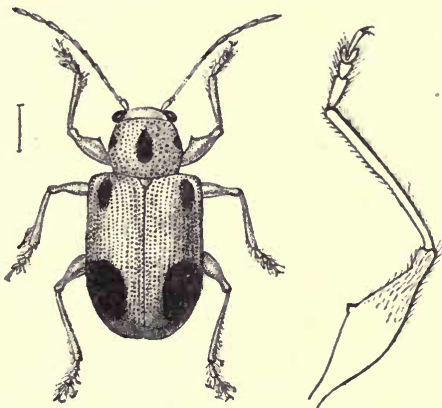

Fig. 139.-Trichotheca hirta.

$V$ ar. Elytra entirely black or fulvous.

Length $4 \frac{1}{2} \mathrm{~mm}$.

$H a b$. Northern India; Sikhim: Kurseong; Manipur.

Baly described the black variety only, but I cannot distinguish from the type specimens that are entirely fulvous.

709. Trichotheca basifemorata, Duviv. Ann. Soc. Ent. Belg. xxxvi, 1892 , p. 410.

"Sides of vertex, thorax and scutellum fulvous; elytra blackishæneous; metasternum and abdomen piceous; pro- and mesosternum, base of femora, a spot on the tibiæ and base of antennæ, fulvous.

"Head pubescent, middle of vertex piceous, deeply impressed, space at base of antennæ raised, a transverse groove ketween the eyes; antennæ three-fourths the length of the body, basal joint very thick, second short, third more than double as long as second, fourth as long as the preceding two joints united, terminal joints shorter and rather more robust, basal three fulvous, rest black. Thorax subcylindrical, scarcely broader than long, sides subangulate a little behind the middle; surface slightly convex, very strongly punctured, interstices smooth, pubescence sparse, short and fulvous. Elytra much wider at base than the thorax, oblong, rather short, transversely depressed below the base near the scutellum; surface very deeply punctured in rows, punctures finer vol. $\mathrm{I}$. 
towards apex, interstices smooth with some very fine punctures and a thin fulvous pubescence. Prosternum broad, slightly dilated posteriorly, pun tured like the thorax. Legs rather long, anterior femora strongly, the others moderately dentate; claws bifid, inner portion small.

"Length $5 \mathrm{~mm}$.

"Hab. Sikhim : Kurseong." (Duvivier.)

Whether this species is distinct or a variety of $T$. hirta, Baly, is doubtful.

710. Trichotheca duvivieri, Jac. Ann. Soc. Ent. Belg. xlviii, 1904, p. 386.

Obscure dark fulvous, clothed with white scale-like hairs; antennæ flavous; legs pale fulvous.

Oblong and rather narrow. Head entirely pubescent; anterior border of the clypeus emarginate; labrum and palpi flavous; eyes nearly entire; antennæ slender and filiform, nearly as long as the body, third to sixth joints nearly equal, terminal joints shorter. Thorax not longer than broad, lateral margins obsolete, sides very slightly widened at the middle; surface like that of the head, pubescent, finely rugose. Scutellum rather broad. Elytra wider at the base than the thorax, more distinctly punctured than the latter, clothed with very closely placed rows of white hairs, interstices here and there furnished with stiff black hairs. Anterior femora more strongly thickened than the others and with distinct tooth; intermediate and posterior femora each with a very small tooth; claws bifid.

Length $3 \mathrm{~mm}$.

Hab. Southern India: Nilgiris; Anaimalais.

\section{Trichotheca fusca, sp. $\mathrm{n}$.}

Entirely dark fuscous, clothed with grey pubescence; basal ioints of antennæ and palpi pale.

Elongate, slightly widened posteriorly. Head closely and somewhat rugosely punctured, finely pubescent; anterior portion of clypeus, labrum and palpi pale flavous, last joint of latter thickened; eyes entire; antennæ not extending to middle of elytra, basal three and terminal joints paler than the others, third to fifth elongate, equal, following joints slightly shorter. Thorax not wider than long, sides slightly narrowed at base and apex, surface with a very faint transverse depression anteriorly, similarly punctured and pubescent as the head. Scutellum subquadrate. Elytra much wider at base than the thorax, distinctly widened towards apex, rather strongly punctured in very closely approximate rows, interstices finely rugose at base and closely covered with rather long lubescence. Legs slender and elongate; anterior femora moderately dilated and toothed beneath; tarsi slender and elongate; claws slightly bifid.

Length $5 \frac{1}{2} \mathrm{~mm}$.

$\bar{H} a b$. N.W. Himalayas. Type in Brit. Mus. 


\section{Genus PSEUDOPIOMERA.}

Pseudopiomera, Jac. Ann. Mus. Civ. Genova, xxxii, 1892, p. 907.

Type, $P$. pallidicornis, Jac., from India.

Range. India ; Ceylon; Burma.

Subcylindrical, pubescent; eyes entire; antennæ filiform, long, third and fourth joints elongate. Thorax broader than long, lateral margins obsolete anteriorly. Elytra closely punctate-striate, clothed with scale-like pubescence. Legs elongate; femora dentate, posterior femora very strongly widened into a triangular tooth; interınediate tibiæ emarginate at apex; claws bifid. Prosternum broadly subquadrate, its base truncate; anterior margin of thoracic episternum concave.

Differs from the allied genera in the very elongate third and fourth joints of the antennæ in connection with the strongly dilated posterior femora.

712. Pseudopiomera pallidicornis, Jac. Ann. Mus. Civ. Genova, xxxii, 1892, p. 908.

Obscure fulvous, clothed with yellowish pubescence. Head closely pubescent; clypeus transverse, fulvous, glabrous; mandibles piceous; palpi slender; antennæ pale fulvous, nearly extending to apex of elytra, terminal joints slightly darker, shorter and slightly thickened. Thorax nearly twice as broad as long,

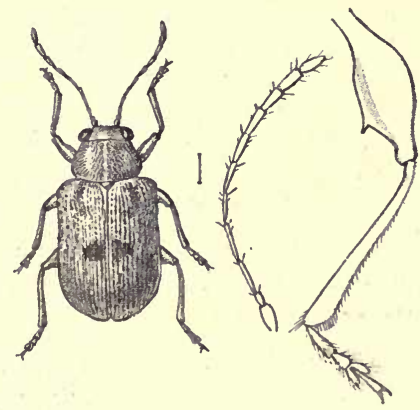

Fig. 140.-Pseudopiomera pallidicornis.

widened and rounded at the sides in the middle, a shallow transverse sulcus near the anterior margin, lateral margins indicated at base only; surface clothed with adpressed yellowish hairs that form an indistinct band at the sides. Scutellum subquadrate. Elytra distinctly punctured in closely approxımate rows; pubescence of mottled appearance, intermixed with erect short black hairs; 
an obscure spot at base and another near the suture below the middle fuscons.

Length $3-3 \frac{1}{2} \mathrm{~mm}$.

Hab. Burma : Karennee.

\section{Pseudopiomera ceylonensis, sp. $n$.}

Piceous, irregularly clothed with grey scales.

Head nearly black with some grey scales above the eyes; clypeus rugose, anterior portion fulvous, middle of anterior edge concaveemarginate; antennæ dark fulvous, extending beyond base of elytra, terminal joints stained with fuscous. Thorax half as broad again as long, lateral margins forming strong ridges at base; surface with transverse depression near the anterior margin followed by two strong tubercles, one at each side; middle of disc piceous, sides grey, that colour forming a broad band. Scutellum oblong, apex rounded, surface finely pubescent. Elytra much wider at base than the thorax, convex, subcylindrical, sligbtly widened at the apex; surface irregularly dotted with small black patches, also with several spots of greyish-white arranged in longitudinal rows, rest of disc clothed with grey pubescence; a very obsolete fulvous oblique band is also visible behind the middle across the snture. Base of femora and apex of tibix pale fulvous.

Length $3 \frac{1}{2} \mathrm{~mm}$.

Hab. Ceylon (Coll. Jacoby).

\section{Pseudopiomera andrewesi, sp. n.}

Piceous; covered above with spots of yellowish and black scales. Elongate. Head entirely covered with yellowish scales; labrum piceous ; eyes slightly notched; antennæ filiform, third and fourth joints elongate, terminal joints shorter. Thorax subquadrate, slightly broader than long, lateral margins distinct, disc rather flattened, clothed with scales that forn indistinct longitudinal bands. Scutellum covered with pale pubescence. Elytra wider at base than the thorax, rather deeply punctate-striate; interstices clothed with pale yellowish scales, variegated with black and whitish spots, also furnished with short black bristles. Femora all strongly dentate; claws bifid. Body beneath closely covered with yellowish scales.

Length $6 \mathrm{~mm}$.

$H a b$. Southern India : Nilgiris. Type in Coll. H. E. Andrewes.

Larger than $P$. ceylonensis, Jac., the elytra variegated with spots, some pale yellow, some black, that form a kind of network towards apex.

\section{Genus XANTHOPHORUS, nov.}

Type, $X$. flavopilosus, Jac., from Ceylon.

Range. India; Ceylon.

Body elongate, clothed with silky pubescence. Head perpendicular; eyes round, entire; antennæ filiform, long in the 
male, shorter in the female, terminal joints not thickened, third shorter than the fourth. Thorax transverse, widened at the middle, surface with or without a shallow transverse sulcus. Elytra finely granulate-punctate. Legs slender ; femora unarmed; first joint of tarsi as long as the following two united; claws bifid. Prosternum elougate, strongly narrowed and angulate at the middle; mesosternum elongate, in shape similar to the prosternum.

This genus is proposed for Xanthonia flavopilosa, Jac., from Ceylon and several other Indian species, which differ much in character from typical Xanthonia ; the shape is much more elongate, the thorax more transverse with transverse shallow sulcus at the middle, and the elytral sculpture is quite different ; there are also other minor differences. Allied also to Nephrella, but in that genus the eyes are kidney-shaped and the thorax lias no sulcus.

715. Xanthophorus flavopilosus, Jac. (Xanthonia) P. Z. S. 1887, p. 72 .

Pale fulvous; clothed with yellow pubescence; terminal joints of antennx sometimes dusky.

Head extremely finely punctured, clotlied with yellowish hairs; clypeus not separated from the face, anterior margin nearly straight; labrum flavous; antennæ nearly as long as the body in the male, third and fourth joints nearly equal. Thorax half as broad again as

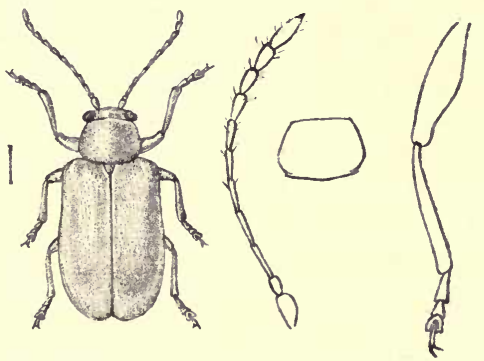

Fig. 141.--_Yanthophorus flavopilosus.

long, obsoletely transversely depressed near the base, sides strongly rounded, surface granulately punctate, closely pubescent. Elytra with similar sculpture, the whole upper surface clothed with fine silken yellow pubescence.

\section{Length 3-4 mm.}

Hab. Ceylon.

Larger than $X$. Zemoides, Walk., pubescence longer and thicker. Neither in this species nor in that of Walker's does the thorax show a distinct sulcus, but the eyes are ovate and entire, not elongate and kidney-shaped. 
716. Xanthophorus andrewesi, Jac. (Nephrella) Ann. Soc. Ent. Beig. xlvii, 1903, p. 100.

Beneath blackish; head, basal joints of antennæ, thorax and legs flavous; elytra fuscous.

Head finely and sparingly punctured and pubescent, vertex sometimes obscure piceous; clypeus not separated from the face, anterior portion deflexed, margin concave at middle; penultimate jo:nt of maxillary palpi incrassate; antennæ black, nearly as long as the body, basal four joints flavous, third and following joints elongate, equal. Thorax subquadrate, disc obliquely sulcate near the base at each side, finely and sparingly punctured, ciothed with pale flavous hairs; near the anterior margin there is another transverse obsolete depression. Elytra much wider at base than the thorax, very finely and closely punctured, clothed with longish pale hairs. Legs slender, unarmed. Prosternum very narrow.

Length $3 \mathrm{~mm}$.

$H a b$. Southern India: Nilgiris.

717. Xanthophorus balyi, Jac. (Nephrella) Am. Soc. Ent. Belg. xlvii, 1903, p. 101.

Obscure fulvous or fuscous; apical joints of antennæ black ; elytra with long grey pubescence.

Oblong, rather broad. Head rather strongly and remotely punctured; clypeus subquadrate; eyes oblong, slightly sinuate; antennæ slender, black, basal four joints fulvous, third slightly shorter than the fourth, apical two shorter than all the preceding joints. Thorax about half as broad again as long, surface very finely and closely punctured and finely pubescent, a transverse sulcus near the base almost extending across the disc. Scutellum finely punctured. Elytra punctured like the thorax, clothed with rather long grey pubescence.

Length $5 \mathrm{~mm}$.

$H a b$. Sonthern India: Nilgiris; Anaimalais.

718. Xanthophorus pallidus, Jac. (Nephrella) Ann. Soc. Ent. Belg. xlvii, 1903, p. 101.

Pale fulvous; apical joints of antennæ piceous; elytra closely pubescent.

Head not perceptibly punctured, sparingly pubescent; antennæ long, pale fulrous, third joint only slightly longer than second, shorter than fourth, terminal four rather thickened and shorter than the intermediate joints. Thorax subquadrate, finely and remotely punctured, disc obsoletely depressed anteriorly and posteriorly at the sides. Elytra pale fulvous, more strongly punctured than in most other species of the genus.

Length $4 \mathrm{~mm}$.

$H a b$. Sonthern India : Nilgiris.

The thorax in this species has no regular sulcus as usual, but has obsolete depressions as in $X$. nigricollis. 


\section{Xanthophorus lævicollis, sp. n.} fulvous.

Black, finely pubescent; basal joints of antennæ and legs

Head not perceptibly punctured, finely pubescent; clypeus rather narrow, sides carinate, surface wiih a few punctures, anterior portion narrowly fulvous; antennæ extending beyond middle of elytra, basal three joints fulvous, rest black, third and fourth equal, terminal joints elongate. Thorax subquadrate, sides not widened, surface transversely sulcate at the middle, sulcus interrupted in the centre, disc entirely impunctate, sparingly pubescent. Elytra narrowly parallel-sided, very finely and closely punctured, pubescence silvery.

Length $3 \mathrm{~mm}$.

$H a b$. Southern India: Trichinopoly (Coll. Jacoby).

This cannot be considered a variety of $X$. nigricollis, since the thorax has a distinct broad sulcus and shows no trace of punctures, even when seen under the strongest lens; the entirely black colour of the upper and under sides also distinguishes this species. I only know of a single specimen, but it is possible that a specimen of larger size and fulvous colour from the same locality, which is contained in the Museum at Brussels, represents the female of the present species; in this specimen the antennæ are shorter and the thorax shows some traces of punctures.

\section{Xanthophorus fuscipennis, sp. $n$.}

Fulvous; upper surface with fine yellowish pubescence; antennæ (basal joints excepted), tibiæ and tarsi black; elytra fuscous or flavous, with a lateral fuscous stripe.

Head broad, scarcely perceptibly punctured, shining, vertex rather convex; base of clypeus with some deep punctures, anterior margin nearly straight; palpi slender, flavous ; antennæ extending beyond middle of elytra, basal three or four joints flavous, rest black, third joint half the length of the fourth, terminal joints filiform. Thorax half as broad again as long, sides rounded and widened at the middle, surface with shallow transverse sulcus at the sides, punctured like the head, clothed with very fine silky yellowish pubescence. Elytra wider at the base than the thorax, similarly punctured and pubescent, but the pubescence thicker, the base and a lateral stripe more or less fuscous.

Var. Entirely fulrous.

Length 3-5 mm.

$H a b$. Ceylon (Coll. Jacoby).

A very variable species in colour and size; in some specimens the antennæ, elytra and legs are entirely fulvous, but there are no structural characters to separate these; the clypeus is sometimes more elosely punctured, but always more strongly 80 than in $X$. flavopilosus, and the third joint of the antennæ is 
shorter than in that species. $X$. balyi, Jac., has the head strongly punctured. All the specimens before me seem to be females.

\section{Xanthophorus carinatus, sp. $n$.}

Fulvous; apical joints of antennæ and thorax piceous; above clothed with yellowish pubescence.

Elongate. Head more or less closely and strongly punctured, with a rather high central ridge on the vertex; clypeus more or less strongly punctured; basal four joints of antennæ fulvous, rest black, third and fourth joints equal, following joints elongate, pubescent. Thorax half as broad again as long, sides not widened; surface transversely sulcate, very finely but distinctly punctured, finely pubescent. Elytra with similar puncturation and pubescence.

Length $3 \frac{1}{2}-4 \frac{1}{2} \mathrm{~mm}$.

$H a b$. Southern India : Ni!giris (Coll. Brit. Mus.); Travancore: Wallardi (Coll. Jacoby).

Easily distinguished by the strongly raised ridge on the vertex. The Nilgiri specimens, probably females, are larger and more convex and robust. Specimens obtained by Mr. Andrewes on the Nilgiris have the base and sides of the elytra more or less black, these are all females. There is scarcely a trace of any pubescence except in one specimen, which has the elytra clothed with short hairs.

\section{Xanthophorus nigricollis, sp. $n$.}

Black; basal joints of antennæ, elytra and legs fulvous; surface above closely pubescent.

Head black and shining, nearly impunctate and sparingly pubescent; clypeus very finely punctured; labrum fulvous; antennæ long and filiform, basal three joints fulvous, rest black, second to fourth gradually lengthened, terminal joints elongate, pubescent. Thorax black, rather shining, subquadrate, sides scarcely rounded; surface with several transverse obsolete depressions near the anterior and posterior margins, finely punctured and sparingly pubescent. Scutellum black. Elytra wider at base than the thorax, minutely punctured, clothed with yellowish hairs, posterior portion sometimes obscure fuscous.

Length 3-31 $\mathrm{mm}$.

$H a b$. India: Shembaganur (Colls. Belgian Mus. \& Jacoby).

A very distinct species.

723. Xanthophorus lemoides, Walker (Ptinus) A. M. N. H. (3) ii, p. 283.

Obscure fulvous above; basal joints of antennæ and the legs flavous. 
Head minutely punctured, elothed with flavous pubescence; clypeus slightly emarginate in front; labrum flavous; eyes scarcely sinuate; antennæ slender, basal five joints flavous, rest fuscous, third joint half as long as the fourth, terminal two slightly shorter than the preceding joints. Thorax half as broad again as long, sides strongly widened, surface obsoletely depressed. Elytral puncturation scarcely perceptible, surface clothed with fine yellow puhescence.

Length $3 \frac{1}{2} \mathrm{~mm}$.

Hab. Ceylon.

Smaller than $X$. flavopilosus, of different colour, pubescence much shorter and stouter, antennæ with the joints of different lengths.

724. Xanthophorus nigripennis, Jac. (Xanthonia) Mém. Soc. Ent. Belg. vii, 1900, p. 100.

Head, basal joints of antennæ, thorax and legs fulvous ; elytra and body beneath black.

Head very strongly and closely punctured, shining, a slightly vaised narrow central ridge on the vertex; clypeus similarly punctured, transverse, anterior border emarginate in the middle, sides acutely carinate; antennæ black, rather short and stout, basal three joints fulvous, third and following two joints equal, terminal joints shorter and thicker. Thorax half as broad again as long, sides scarcely widened at the middle; surface shining, obsoletely sulcate below the middle, finely and subremotely punctured and very sparingly pubescent. Scutellum fulvous. Elytra with basal portion slightly raised, finely rugosely punctured, clothed with fine grey pubescence.

Length $3 \frac{1}{2}-5 \mathrm{~mm}$.

$H a b$. Bengal : Mandar.

Most nearly allied to $X$. balyi, Jac., and $X$. carinatus, Jac., but distinguished from both by the short and thick terminal joints of the antennæ; the head also is more closely punctured and the elytra are black.

\section{Xanthophorus montanus, sp. n.}

Beweath black; basal joints of autennæ and upper surface fulvous, clothed with yellow pubescence.

Head finely and rather closely punctured, sparingly pubescent; anterior border of clypeus straight ; labrum piceous ; last joint of palpi robust; antennæ black, extending to about middle of elytra, basal four joints fulvous, third and fourth equal. Thorax not broader than long, sides nearly straight, surface more finely and closely punctured than the head, sides with a rather deep transverse depression not extending to the middle. Scutellum twice as long as broad. Elytra nuch wider at base than the thorax, sculptured 
like the latter, closely covered with yellow pubescence. Legs fulvous. Body beneath black, clothed with silvery pubescence. '

Length $3 \frac{1}{2}-4 \mathrm{~mm}$.

$H a b$. Southern India; Nilgiris (H. L. Andrewes).

Closely allied to $X$. pallidus, but distinguished by the very finely and closely punctured thorax, longer antennæ, and the entirely black underside; these differences are constant in all the specimens obtained by Mr. Andrewes.

\section{Genus AULEXIS.}

Aulexis, Baly, Journ. Ent. ii, 1863, p. 153 ; id. Trans. Ent. Soc. (3) iv, 1867, p. 81 ; Chapuis, Gen. Coléopt. x, 1874, p. 276 ; Lefèv. Cat. Eumolp. 1885, p. 76.

Type, A. nigricollis, Baly, from Borneo.

Range. India; China; Malayan Subregion.

Elongate, subcylindrical; clothed above and beneath with suberect hairs.

Head exserted, perpendicular; anterior margin of clypeus with two acute flattened teeth, which partly cover the upper surface of the labrum; antennæ subfiliform, clothed with coarse hairs, basal joint incrassate, second half the length of the first, subincrassate, third shorter than the fourth, following joints rather shorter; eyes with their inner margins slightly sinuate;

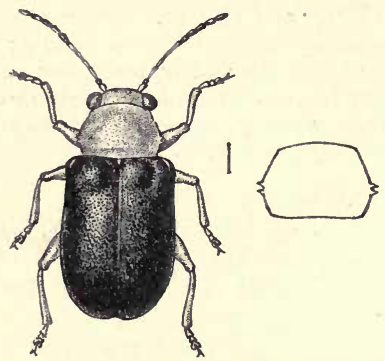

Fig. 142.-Aulexis nigripennis.

terminal joint of palpi slender, orate. Thorax subcylindrical in front, flattened, more or less excavated on the hinder half of the dise, lateral border obsolete, rarely visible at the base, its place supplied in the middle by two or more teeth. Elytra rather broader than the thorax, parallel-sided. Legs moderate, stout; femora unarmed; basal joint of tarsi as long as the following two united; claws more or less bifid. Prosternum greatly narrowed between the coxæ.

A well-marked genus on account of the toothed clypeus and similarly armed sides of the thorax. 


\section{Aulexis nigripennis, sp. $n$.}

Fulvous ; terminal joints of antennæ black ; above clothed with short grey pubescence; elytra black.

Head almost impereeptibly punctured; terminal five joints of antennæ black, third joint as long as the second and rather shorter than the fourth. Thorax half as broad again as long, sides produced at the middle into two small teeth; surface with transverse sulcus behind the middle, extremely minutely punctured, sparingly pubescent. Scutellum fulvous. Elytra very elosely and more strongly punctured than the thorax, clothed with silvery-gres pubescence; shoulders prominent.

Length $2 \frac{1}{2}-3 \mathrm{~mm}$.

Hab. Tenasserim: Thandaung (Coll. Jacoly).

Closely allied to $A$. varians, Baly, from Borneo, but more elongate and parallel, the thorax extremely minutely punctured. the sulcus placed at the sides only; elytral basilar area not thickened.

727. Aulexis tibialis, Jac. Ann. Mus. Civ. Genova, xxvii, 1889, p. 167.

Fulvous; finely clothed with whitish pubescence; antennæ fuscous or fulvous, basal joints flavous; tibiæ pieeous or black.

Head with a few obsenre punetures, sparingly pubescent; mandibles very long and stout, apex bidentate; palpi flavous, long and slender; antennæ extending to two-thirds the length of the elytra, basal four joints fulvous. Thorax half as broad again as long, sides strongly widened at the middle, furnisbed with three acute teeth ; surface dark fulvous, finely punctured and pubescent, obsoletely transversely depressed near the anterior margin. Elytra paler, extremely closely and finely punctured. Tibiæ and tarsi piceous.

Var. Legs entirely fulvous.

Length $5 \mathrm{~mm}$.

Hab. Assam: Manipur (Coll. Brit. Mus.); Burma: Teinzo. Type in Genoa Mus.

Allied to A. elonyata, Jac., from Java, but with filiform, not thickened antennæ, and differently coloured legs; in some of the specimens the head and thorax are obscure piceous and the legs fulvous, but there are no specific differences.

728. Aulexis assamensis, Jac. Amn. Soc. Ent. Belg. xlvii, 1903, p. 102.

Fulvous; head and thorax nearly black; elytra clothed with flavous pubescence.

Head very finely punctured on the vertex; clypeus more strongly punctured, bidentate; labrum and base of mandibles fulvous; antennæ fulvous (last three joints in the only known specimen wanting), third joint at least twice as long as the second. 
Thorax half as broad again as long, nearly black, anterior margin obscure fulvous; surface with a very obsolete sulcus, punctured like the head, thickly clothed with yellowish hairs; sides with two small teeth. Elytra with similar sculpture, pubescence yellow.

Length $5 \mathrm{~mm}$.

Hab. Assam (Coll. Jacoby).

\section{Genus LYPESTHES.}

Lypesthes, Baly, Journ. Ent. ii, 1863, p. 152 ; Chapuis, Gen. Coléopt. x, 1874, p. 273 ; Lefev. Cat. Eumolp. 1885, p. 74.

Type, L. ater, Motsch., from Japan.

Range. India ; China; Japan.

Subelougate, subcylindrical; clothed above and beneath with fine suberect hairs.

Head perpendicular; antennæ slender, filiform, first joint incrassate, second shorter than the third, terminal five slightly thicker than the preceding joints except the first; eyes prominent, entire; apical joint of palpi orate. Thorax subcylindrical, lateral margins obsolete. Elytra broader than the thorax, parallelsided, upper side coarsely punctured. Legs slender, elongate; femora moderately incrassate, toothed; claws bifid. Prosternum and mesosternum oblong.

\section{Lypesthes indica, sp. $\mathrm{n}$.}

Black, finely pubescent; basal joints of antenuæ fulvous.

Oblong, subcylindrical. Head

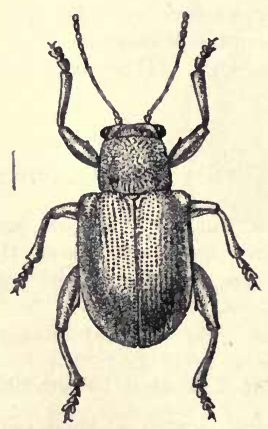

Fig. 143.-Lypesthes indica. finely rugose and pubescent; clypeus transversely depressed; labrum fulvous ; anteunæ filiform, basal joint short and thick, second more slender but nearly as long, following joints elongate, terminal two slorter, basal three fulvous, rest black. Thorax subcylindrical, not longer than broad, sculpture and pubescence similar to those on the head. Elytra much wider than the thorax at base, extremely closely punctured; the punctures somewhat regularly arranged in rows, of transverse shape; the interstices finely transversely wrinkled at base, slightly costate at apex and furnished with rows of short grey hairs. Legs elongate, femora with a small tooth; claws bifid. Prosternum oblong.

Length $4 \frac{1}{2} \mathrm{~mm}$.

Hab. Burma: Ruby Mines (Coll. Brit. Mus.). 
Smaller than $L$. ater, Motsch., from Japan, with the elytral punctures more regularly arranced, forming rows like the hairs on the interstices.

\section{Genus NECULLA.}

Neculla, Baly, Journ. Ent. ii, 1863, p. 152; Chapuis, Gen. Coléopt. x, 1874, p. 274 ; Lefêv. Cat. Eumolp). 1885, p. 75.

Type, N. pollinaria, Baly.

Range. India.

Body oblong, subcylindrical, clothed above and beneath with subdepressed scale-like hairs; antennæ moderately robust, subfiliform, first joint incrassate, second subovate, as long as the third, latter shorter than the fourth; eyes prominent, entire. Thorax subcylindrical, lateral margins obsolete in front, indicated on the posterior half by a faint ridge. Elytra much broader than the thorax, coarsely punctured. Legs stout; femora moderately incrassate, armed beneath with a stout tooth; basal joint of tarsi much shorter than the following two united; claws bifid. Prosternum subelongate, gradually widened posteriorly ; mesosternum quadrate, oblong, apex obtusely angulate.

The species resemble in shape the forms of Aoria, but can be separated by the toothed femora and oblong mesosternum.

730. Neculla pollinaria, Baly (Adoxus), Journ. Lint. i, 1860, p. 28.

Black, clothed with grey and white hairs, the latter cover a broad space along the outer margin of each elytron and form an interrupted vitta on the inner dise.

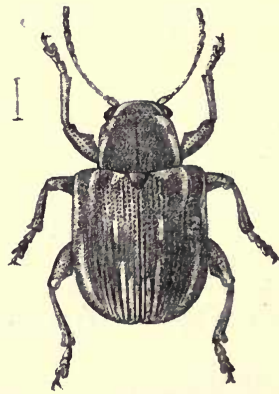

Fig. 144.-Nicullu pollinaria.

Head rugose-punctate; basal joints of antennx obscure fulvous. Thorax rugose-punctate, centre of disc with a 
slightly elevated ridge. Elytra coarsely punctured, puncturation irregularly arranged in striæ. Anterior and intermediate femora with a minute tooth; tibiæ and tarsi rufo-piceous.

Length $5 \mathrm{~mm}$.

Hab. Bombay.

\section{Neculla obscurata, sp. n.}

Black, entirely covered with white scale-like matter; basal joints of antennæ, palpi and labrum fulvous.

Broad and robust, upper surface sparingly furnished with white erect hairs. Head finely punctured; basal three joints of the antennæ fulvous, rest black, basal joint thickened, third and fourth equal, terminal joints shorter, not extending much further than to the base of the elytra. Thorax half as broad again as long, subcylindrical, finely rugose, middle portion somewhat raised. Elytra wider at the base than the thorax, strongly convex, strongly rugose and punctured. Legs elongate; femora armed with a tooth; tarsi short; claws bifid. Prosternum subquadrate, widened at base.

Length $6 \mathrm{~mm}$.

Hab. Manipur (Coll. Brit. Mus.).

On account of the white matter that entirely covers the upper and under sides of the specimens, the sculpturition is not visible except in some small denuded spaces. The species is larger than $N$. pollinaria, Baly, and the legs are entirely black, the general shape is broader and more robust.

\section{Genus DEMOTINELLA, nov.}

Type, D. pectoralis, Jac.

Range. Tenasserim.

Oblong, subcylindrical, pubescent; antennæ short and moniliform, terminal joints thickened and widened; eyes oblong, entire. Thorax transverse, subcylindrical, lateral margins obsolete. Elytra wider at base than the thorax, punctured in rows. Legs short and robust ; femora moderate, unarmed; tibiæ widened at the apex, entire; claws bifid. Prosternum broadly subquadrate. Anterior margin of thoracic episternum concave.

Separated from any other genus of this group by the moniliform antennæ, unarmed femora and non-emarginate tibiæ.

\section{Demotinella pectoralis, sp. n.}

Obscure dark fulvous, clothed with yellowish-grey pubescence; posterior portion of elytra paler; antennæ flavous; breast piceous. 
Head deeply inserted in thorax, rugose; clypeus wedge-shaped, separated by distinct grooves from the

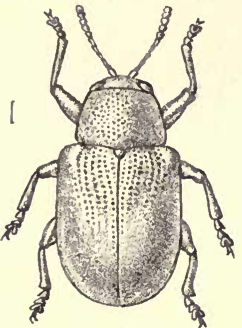

Fig. 145.

Demotinella pectoralis. face; antennæ only extending to base of thorax, basal joint thickened, subelongate, following four joints short, nearly equal, rest strongly widened, moniliform. Thorax transversely subquadrate, finely punctured, pubescence rather long, yellowish-grey. Elytra rather more strongly punctured than the thorax, puncturation arranged in closely approximate rows, pubescence similar to that of the thorax. Abdomen and legs fulvous, breast nearly black.

Length $2 \mathrm{~mm}$.

Hab. Tenasserim: Tavoy. Type in Brit. Mus.

The pubescence in this small species is distinctly longer than in any Demotina or Hyperaxis.

\section{Genus LEPROTELLA.}

Leprotella, Jac. Mém. Soc. Ent. Belg. vii, 1900, p. 100.

Type, L. cashmirensis, Jac.

Range. Kashmir.

Oblong, subcylindrical, densely covered with fine scales. Head broad, partly exserted; eyes rather small, entire; antennæ short, second to sixth joints small, nearly equal, terminal joints subtriangularly widened. Thorax subcylindrical, lateral margins only indicated near base, anterior and posterior margins straight. Scutellum subquadrate. Elytra wider at base than the thorax, convex, parallel-sided, apex of each elytron rounded. Femora moderately incrassate, unarmed; tibiæ stout; tarsi short and broad, first joint slightly longer than the second; claws bifid. Prosternum broadly subquadrate; anterior margin of thoracic episternum concave.

Closely allied to Neculla, Baly, but the antennæ different in structure, the femora unarmed and the prosternum broad.

733. Leprotella cashmirensis, Jac. Mem. Soc. Ent. Belg. vii, 1900, p. 101.

Fuscous or blackish, densely covered with grey scales ; antenna and legs fulvous.

Sculpturation of upper surface entirely hidden by pale grey scales. Head not longer than broad; clypeus not separated from the face, anterior margin nearly straight; labrum and palpi 
fulvous; antennæ extending to base of elytra only, basal joint subquadrately thickened, rest of the joints as given in the generic
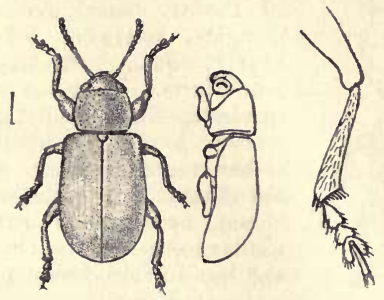

Fig. 146.-Leprotella kashmirensis.

diagnosis. Thorax snbquadrate, subcylindrical, middle of disc with some slightly raised spaces. Elytra about twice as long as broad.

Length $2 \frac{1}{2} \mathrm{~mm}$.

$H a b$. Kashmir.

In this insect the upper surface shows no erect pubescence mixed with the scales as is the case with so many allied forms.

\section{Genus NEPHRELLA.}

Nephrella, Baly, Journ. Ent. ii, 1863, p. 155; Chapuis, Gen. Coleopt. x, 1874, p. 277; Lefèv. Cat. Eumolp. 188ঠ, p. 77.

Type, $N$. elongata, Baly, from Ceylon.

Range. Ceylon.

Elongate, subcylindrical, corered with coarse adpressed hairs; antennæ moderately robust, subfiliform, third joint half as long again as the second, fourth and following two each longer than the third, equal; eyes large, reniform. Thorax subcylindrical, lateral border obsolete. Elytra broader than the thorax, closely punctured. Legs short, moderately robust; femora unarmed beneath; basal joint of tarsi rather shorter than the following two joints united; claws bifid. Prosternum narrow, elongate; mesosternum subelongate, apical half dilated, apex itself truncate.

734. Nephrella elongata, Baly, Joum. Ent. ii, 1863, p. 155; Lefêv. Cat. Eumolp. 1885, p. 77.

Dark fuscous, clothed with bright fulvous hairs; abdomen and legs fulvous; tibiæ piceous; antennæ black, base fulvous; breast and base of abdomen pale piceous.

Head and thorax closely covered with coarse adpressed hairs. 
Thorax rather broader than long, sides nearly straight, surface not

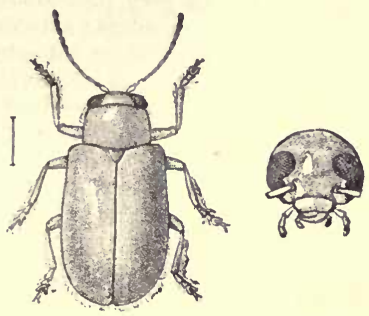

Fig. 147.-Nephrella clongata.

very deeply punctured. Elytra finely punctured, surface indistinctly wrinkled, pubescent like the head and thorax. Abdomen more sparingly pubescent.

Length $5 \frac{1}{2} \mathrm{~mm}$.

$H a b$. Ceylon.

\section{Genus HYPERAXIS.}

Hyperaxis, Lefèv. Cat. Eumolp. 1885, p. 79.

Metaxis, Baly (nec de Chaudoir), Journ. Ent. ii, 1863, p. 157.

Type, H. sellata, Baly, from Borneo.

Range. India ; Burma; Andamans; China; Borneo.

Oblong, subcylindrical, clothed with scales above, intermixed with short, rigid, erect hairs. Head moderately exserted, perpendicular; antennæ slender, filiform, nearly equal to the body in length, first joint incrassate, second very short, moderately thickened, third slender, equal in length to the preceding two united, the rest each nearly as long as the third, terminal joints slightly shorter and thicker; eyes entire; terminal joint of maxillary palpi narrow, ovate. Thorax subcylindrical, lateral border obsolete (in some species with finely serrate margins). Elytra much broader than the thorax, deeply punctate-striate. Legs moderate; femora toothed beneath, anterior and posterior femora strongly incrassate, intermediate femora more slender, the latter emarginate or notched at apex ; claws bifid. Prosternum elongate, broad, somewhat wedge-shaped ; mesosternum oblong.

Dull-looking insects with close, adpressed pubescence that forms sometimes obscure bands or spots. In the typical forms the anterior and posterior femora are much thicker than the femora of the intermediate legs, but certain species occur in which this is much less marked and these can scarcely be distinguished from Demotina. 


\section{Hyperaxis quadraticollis, sp. $n$.}

Piceous; closely covered with grey pubescence; antennæ and legs dark fulvous. Head rugose-punctate; anterior edge of clypeus nearly straight; labrum fulvous; antennæ not extending to middle of elytra, third and fourth joints equal, terminal five rather strongly triangularly widened, last joint ovately thickened. Thorax subcylindrical, not broader than long, sides not widened, surface closely covered with rather long yellowish bairs, middle with a narrow impressed line. Elytra closely punctured and like the thorax pubescent. Anterior and posterior only slightly thicker than the intermediate femora; tibiæ of latter not perceptibly enarginate at apex; all the femora with a small tooth.

Length $4 \mathrm{~mm}$.

Hab. Andaman Islands (Coll. Brit. Mus.).

The shape of the thorax and the rather long pubescence will help to discriminate this species.

736. Hyperaxis duvivieri, Jac. (Trichotheca) Ann. Soc. Ent. Belg. xlviii, 1904, p. 386.

Obscure dark fulvous, clothed with whitish scales; antennæ and legs pale fulvous.

Oblong, narrowly subcylindrical. Head entirely covered with scales; labrum and palpi flavous; antennæ sleuder and filiform, extending beyond the middle of the elytra, intermediate joints elongate, terminal joints shorter but not thicker. Thorax scarcely broader than long, sides feebly ronnded and but little widened at the middle, surface finely rugose-punctate and pubescent. Scutellum clothed with similar hairs or scales. Elytra obscure dark fulvous, more strongly rugose than the thorax and punctured in very closely approximate rows, also clothed with pale grey scales and single erect black hairs. Legs pale; femora only moderately thickened, the intermediate fenora less so than the others, all armed with a small toutb.

Lenyth $3 \mathrm{~mm}$.

$H a b$. Southern India: Nilgiri and Anaimalai Hills.

A small species which cerlainly is better placed in the present genus than in Trichotheca; the scarcely widened sides of the thorax and uniformly coloured upper surface will assist in its - recognition.

737. Hyperaxis fulvohirsuta, Jac. (Demotina) Ann. Soc. Ent. Belg. xiviii, 1904, p. 384.

Piceous, clothed with short pale fulvous pubescence; elytra with a smooth spot at base, a transverse band behind the middle and a shorter band near the apex, black.

Head entirely clothed with pale fulvous scale-like pubescence; anterior portion of clypeus and the labrum fulvous; palpi slender, fulvous; antennæ very slender, three or four basal joints pale fulvous, other joints darker, third to seventb joints elongate, equal, 
terminal joints shorter. Thorax half as broad again as long, lateral margins obsolete anteriorly, surface sculptured like the head and similarly pubescent. Scutellum subpentagonal, pubescent. Elytra with a depression below the base, rather pointed at the apex, strongly and closely punctate-striate, clothed with fulvous pubescence like the rest of the body but the pabescence interrupted by a black spot near the scutellum; an oblique transverse band behind the middle and a slıorter band near the apex that is joined by a longitudinal stripe near the suture. Legs with the femora more or less piceous, armed with a distinct tooth. Prosternum subquadrate, broad.

\section{Length 4-5 mm.}

Hab. Malabar: Belgaum, Mahé; Nilgiris.

The thickened anterior and posterior femora in this species place it with more right in Hyperaxis than in Demotina. The dark bands and spots of the elytra are often more or less obscure, but the latter are of a more shining appearance on account of the denuded bands and the puncturation is stronger than in the allied species; great variability, however, obtains in this respect, also in regard to size, scarcely two specimens are alike; only well-preserved specimens can be distinguished by the regular shape and position of the elytral dark bands.

\section{Hyperaxis foveolatus, sp. $n$.}

Beneath nearly black, above closelv covered with brownish-grey scales; elytra with numerous smail black foveæ; labrum and antennæ fulvons.

Oblong. Head densely covered with thick scales; clypeus dark brown, closely punctate, anterior margin black, nearly straight; eyes round; antennæ filiform, third and fourth joints elongate, equal (terminal three joints wanting in the type and only known specimen), eighth shorter than the preceding joints. Thorax nearly as long as broad, narrowed anteriorly, sides rounded, surface entirely covered with scales. Elytra wider at base than the thorax, about twice as long as broad, surface with small black fover arranged partly in rows, interstices with short stiff black hairs. Body beneath with short grey pubescence. Anterior and posterior femoru strongly incrassate, each with distinct tooth; intermediate femora more slender though similarly toothed, their tibiæ emarginate at apex. Prosternum broad, widened at apex.

Length $5 \frac{1}{2} \mathrm{~mm}$.

Hab. Southern India: Nilgiris (Coll. H. E. Andrewes).

The elytra in this species ar $\leftrightarrow$ of peculiar structure and the black, shining impressions form a kind of network.

739. Hyperaxis distincta, Duviv. Ann. Soc. Ent. Belg. xxxvi, 1892, p. 411.

Brownish-fulvous, varied with grey above; antennæ and labrum fulvous. 
Head closely rugose-punctate, entirely clothed with yellowish scales; clypeus strongly transverse, closely punctured; labrum and palpi pale fulvous; antennæ about two-thirds the length of the body, third and fourth joints very elongate and equal, terminal joints rather shorter. Thorax about half as broad again as long (?), sides rounded and widened at the middle, anterior portion slightly narrowed, lateral margins absent, surface sculptured and furnished with scales like the head, two obscure darkish bands at the middle. Scutellum clothed with whitish hairs. Elytra much wider at base than the thorax, extremely closely punctate-striate, punctures rather deep; the interstices forming very narrow, slightly convex lines, covered with scales and furnished with short erect darker hairs. Anterior and posterior femora strongly toothed.

Length $4 \frac{1}{2}-5 \mathrm{~mm}$.

$H a b$. Bengal : Mandar.

In the original description the thorax is given as half as long again as broad, but the reverse is the case in the specimen I received from Durivier and named by him.

740. Hyperaxis semifasciata, Jac. (Demotina) P. Z. S. 1887, p. 70, pl. $x$, fig. 1 .

Obscure fulvous or piceous; antennæ and legs dark fulvous : scutellum white; elytra with obscure darkish band and four or five white spots behind the middle, a small white spot at base.

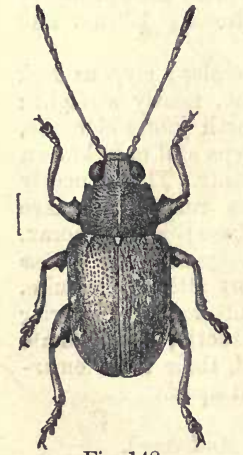

Fig. 148.

Hyperaxis semifasciata.

Head with yellowish pubescence, on the vertex, hiding any sculpture; clypeus closely punctured, glabrous, fulvous ; eyes entire; antennæ filiform, third and fourth joints slender, nearly equal, terminal joints slightly thickened. Thorax scarcely twice as broad as long, lateral margins indicated at base only, sides rounded, very slightly narrowed in front, anterior angles dentiform; surface convex, closely covered with yellowish slightly curved scales or scalelike hairs, flanks beneath densely corered with white pubescence; a very slender, medial, longitudinal white stripe on the disc. Elytra strongly and for the most part irregularly punctured, pubescent like the, thorax; a small white pubescent spot at the middle of the basal margin, three spots transversely across the middle and two behind the middle, one near margin, the other near suture. All femora strongly dentate; intermediate tibiæ emarginate at base.

Length 4-6 mm.

Hab. Ceylon. 
Subject to considerable variation in size, the elytral spots sometimes quite obsolete or just visible without a lens, and only in well-preserved specimens.

\section{Hyperaxis feæ, Jac., nom. nov.}

Demotina semifasciata, Jac. Ann. Mus. Civ. Genova, xxxii, 1892, p. 906: id. Ann. Soc. Ent. Belg. xlviii, 1904, p. 384.

Closely covered with grey hairs; antennæ, labrum and legs fulvous; two transverse bands behind the middle on the elytra and some spots, denuded of hairs, fuscous.

Head closely covered with grey adpressed pubescence; clypeus fulvous, shining, transverse, separated from the face by a deep groove, anterior border deeply emarginate in the middle; antennæ long and filiform, apical three or four joints piceous, third and fourth elongate, equal, terminal joints much shorter. Thorax transver'se, twice as broad as long, sides slightly rounded, margined at the base only, surface pubescent like the head, a faint whitish stripe in the middle. Scutellnın with similar pubescence. Elytra wider at the base than the thorax, subcylindrical, punctures in closely approximate rows; the smooth spaces form two transverse macular bands, between which on each elytron a fuscous spot of irregular shape is apparent. Posterior femora very strongly incrassate, with a large tooth, the other femora less strongly thickened and more feebly dentate.

Length $3 \frac{1}{2}-4 \mathrm{~min}$.

$H a b$. Burma : Karennee.

I find it necessary to change both the generic and specific names of this species on account of the original name having been used by me previously for another species.

742. Hyperaxis variegata, Juc. Ann. Soc. Ent. Belg. xlviii, 1904, p. 385.

Obscure fuscous, clothed with grey scales; basal joints of antennæ and base of tibiæ fulvous; thorax with indistinct grey bands; elytra piceous, shoulders within and the sides obscure fulvous.

Head covered with grey scales, sides obscure fulvous, middle piceous, or the head entirely of this colour; clypeus fulvous, not separated from the face, transverse, finely and closely punctured; labrum also fulvous; antennæ extending to middle of elytra, second joint small, third and fourth equal, terminal joints shorter. Thorax about half as broad again as long, lateral margins obsolete, surface closely covered with grey scales which form sometimes more or less distinct longitudinal stripes, puncturation very fine and close. Scutellum closely pubescent. Elytra rather more distinctly punctured than the thorax, punctures arranged in extremely close rows, a sutural patch at base and the 
sides more or less piceous, scales more prominent on the basal margin in front of the shoulders. Legs fulvous; femora with a small tooth, anterior and posterior femora strongly thickened.

Length $4 \mathrm{~mm}$.

$H a b$. Southern India: Nilgiris; Pondicherry.

This species appears to be closely allied to H. harmandi, Lefèr. (Ann. Soc. Ent. France, 1893), but in that insect the elytra as described are strongly punctured, with grey and white scales and round denuded patches intermixed, while the intermediate tibiæ are emarginate at apex.

The present species seems somewhat interinediate between Demotina and Hyperaxis, as the anterior and posterior femora are less incrassate than is generally the case in the last-named genus, but more thickened than in Demotina.

\section{Hyperaxis penicillata, sp. $n$.}

Fuscous; basal joints of antennæ fulvous; elytra with small whitish pubescent and bare fuscous spots near the suture and margins.

Head closely covered with fulvous scales; antennæ with the basal seven joints fulrous, rest wanting in the type and only specimen. Thorax subquadrate, scarcely broader than long, not widened at the sides, disc with an obsolete transverse depression in the middle, clothed with scales like the head. Elytra oblong, subcylindrical, finely punctured in rather distantly placed rows, which are visible only at base; pubescence partly white and fulvous, forming irregular spots, five or six more conspicuous fuscous spots are apparent near the suture and can be best seen when looked at sideways; interstices with single stiff short black hairs. Anterior and posterior femora incrassate, armed each with a stout tooth ; intermediate tibiæ distinctly notched at the apex.

Length $3 \frac{1}{2} \mathrm{~mm}$.

$H a \dot{b}$. Southern India : Travancore, Wallardi (Coll. Jacoby).

The mottled appearance given by the grey and fuscous spots on the elytra, and the shape of the thorax with its obscure sulcus will help to discriminate this insect.

\section{Hyperaxis mandarensis, sp. $\mathrm{n}$.}

Obscure piceous, clothed with yellow pubescence; labrum, antennæ and legs fulvous; elytra with an indistinct transverse band at the middle, a spot near lateral margins, another at the suture near apex and the apex itself, white.

Head clothed with the usual fulvous scales; clypeus strongly transverse, pubescent, anterior margin nearly straight; labrum fulvous; antennæ fulvous, third and following joints elongate, terminal three joints shorter and thicker. Thorax scarcely half 
as broad again as long, sides slightly widened near base, surface. pubescent like the head with two very obscure fuscous bands at the middle. Scutellum clothed with whitish pubescence. Elytra extreinely closely rugose-punctate, the arrangement of punctures in rows very indistinct, scales fulvous; a very indistinct narrow transverse band at the middle and another more distinct and broader band, consisting of two spots, and the apex whitish, pubescent. Femora of typical shape and dentate; the emargination of the intermediate tibiæ distinct, latter widened at apex and strongly pubescent.

Length $5 \mathrm{~mm}$.

Hab. Bengal: Mandar (Coll. Jacoby).

\section{Hyperaxis malabarica, sp. n.}

Pale fulvous, clothed with fine yellow pubescence; apical joints of antennæ fuscous; elytra with some very obscure fuscous spots at base and behind the middle.

Head finely rugose-punctate, clothed with scale-like fulvous pubescence; clypeus transverse, more shining, closely punctured, anterior border deeply emarginate in the middle; antennæ long and slender, pale flavous, apical two joints more or less stained with fuscous, third and following joints very elongate. Thorax. half as broad again as long, sides rather strongly widened in the. middle, surface sculptured and pubescent like the head. Elytra oblong, subcylindrical, parallel-sided, shoulders acute, surface strongly and extremely closely punctate-striate; interstices not. larger than the punctures themselves, slightly wrinkled, furnished with single, short, stiff black hairs and very sparse yellow pubescence; an obscure spot at the base, one near the suture behind the middle and two transverse spots near apex fuscous. Anterior and posterior femora strongly incrassate, each furnished with a large. tooth.

Length $4 \mathrm{~mm}$.

Hab. Malabar: Mahé (Coll. Jacoby).

In one specimen the elytral pubescence is rather thicker, but the spots, although rather obscure, are the same in number and position in the two specimens before me.

\section{Hyperaxis dubia, sp. n.}

Obscure fulvous or piceous, clothed with grey pubescence or scales; thorax with a fine pale central stripe; sides of elytra mottled with small spots and greyish-white pubescence.

Shape and sculpture as in the preceding species, but a larger form and distinguished by the reticulate or mottled sides of the elytra, which mottling forms a broad band that consists of small spots of the ground-colour and whitish pubescence; in some 
specimens a broad fuscous subsutural band extends along each elytron near to apex, in others this is absent.

Length $4-4 \frac{1}{2} \mathrm{~mm}$.

Hab. Malabar: Mahé (Coll. Jacoby).

Whether this species is really specifically distinct from the preceding or only a form of it is doubtful, but the elytra are quite differently marked. It is also uncertain whether the subsutural fuscous band of regular shape, present in the two specimens before me, is due to the absence of hairs caused accidentally or is normal.

\section{Hyperaxis grisea, sp. $n$.}

Blackish, covered with grey scale-like pubescence; antennæ, base of femora and the tibiæ more or less fulvous.

Head closely covered with grey scales; clypeus not separated from the face, transverse, anterior margin dark fulvous, concaveemarginate: labrum fulvous ; antennæ extending to the middle of the elytra, basal joints slender, fulvous, terminal joints shorter and thicker, slightly darkened, third joint very slightly longer than the fourth, terminal four rather strongly thickened. Thorax nearly twice as broad as long, lateral margins strongly rounded and widened at the middle, strongly obliquely narrowed anteriorly, entire surface covered with short grey scales. Scutellum similarly clothed, broad, sides rounded. Elytra wider at the base than the thorax, oblong, parallel-sided, finely punctured in extremely close rows, clothed with scales like the thorax and single bristle-like short fulvous hairs (only seen when the specimen is held sideways). Femora thickened, the middle femora each with a very short tooth; apex of the intermediate and posterior tibir emarginate, the emargination very slight; claws bifid. Prosternum elongate; anterior margin of thoracic episternum concave, not separated from the prosternum by grooves.

\section{Length $3 \mathrm{~mm}$.}

Hab. Southern India: Trichinopoly (Coll. Jacoby).

Smaller that $H$. variegatus, Jac., the anterior and posterior femora although distinctly thicker than the intermediate, are much less so than in the allied species and their dental armature is smaller.

\section{Genus PSEUdometaxis.}

Pseudometaxis, Jac. Mém. Soc. Ent. Belg. vii, 1900, p. 101.

Type, P. serraticollis, Jac., from Burna.

Rangc. Burma.

Subquadrate-ovate; densely clothed with short scales and sparingly with short erect hairs; antennæ filiform. Thorax broader than long, distinctly serrately margined. Legs rather long; 
anterior and posterior femora rery strongly dilated into a broad tooth, intermediate femora less strongly thickened, their tibiø emarginate at apex; claws bifid. Prosternum constricted between the coxæ, strongly widened posteriorly.

Most of the characters of Hyperaxis, but the thorax with serrate margins and the prosternum of different shape.

748. Pseudometaxis serraticollis, Jac. Mém Soc. Ent. Belg. vii, 1900 , p. 10:2.

Obscure piceous or fulvous, densely clothed with grey scales.

Head closely covered with grey scales; clypeus concave on the anterior margin; labrum and palpi fulvoris; antennæ fulvous,

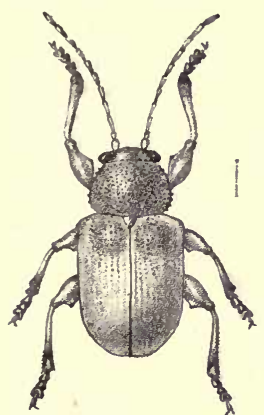

Fig. 149.-Pseudometaxis serraticollis. extending to middle of elytra, third and following two joints equal, terminal joints shorter. Thorax about half as broad again as long, sides rounded and gradually widened near the base, margins with a row of teeth. Elytra wider at base than the thorax, subcylindrical, very finely and closely punctured, clothed with very short grey scales and rows of erect black hairs, sutural portion near base obscure fuscous; sides of more fulvous colour. Legs and body beneath Iul:ous.

Length $4 \mathrm{~mm}$.

Hab. Burma.

This species must not be confounded with Demotina serraticollis, Baly, which is a smaller insect of different colour and with differently shaped thorax; the anterior and posterior femora in the present species are very strongly dilated and agree in this respect with Hyperaxis, but it is not convenient to include in one genus insects with no thoracic nargins and others in which the latter are present. The prosternum also in Hyperaxis is broadly subquadrate, not widened at the base.

\section{Genus LEPROTES.}

Leprotes, Baly, Journ. Ent. ii, 1863, p. 158 ; Lệ̀v. Cat. Eumolp. 1885 , p. 80.

Type, L. gracilicornis, Baly. from Hongkong.

Range. Tartary; India; China; Japan.

Body elongate, subcylindrical, clothed above and beneath with adpressed scales. Head exserted; antennæ filiform, scarcely thickened at apices, basal joint incrassate, second shorter than the 
first, third and following four joints each nearly twice the length. of the second, rest shorter; eyes prominent, entire. Thorax subcylindrical, lateral borders obsolete. Elytra much broader than the thorax, surface deeply punctured, covered with adpressed. scales, mixed sparingly with some rigid erect hairs. Legs subelongate; femora with a stout tooth; claws bifid. Prosternum. narrowly oblong or subquadrate.

This genus scarcely differs from Neculla, Baly; the only difference seems to be the more elongate legs, although Baly gives the sides of the thorax entirely without the trace of a margin; a distinct indication of a ridge is present in a specimen in my collection named by Baly himself.

749. Leprotes kanarænsis, Jac. Ann. Ent. Soc. Belg. xxxix, 1895, p. 270.

Black, finely pubescent. Head rugose-punctate, with medial longitudinal groove; clypeus separated from face by a shallow transverse groove, sculptured like the head but the punctures finer, anterior border feebly emarginate; labrum fulvous; antennæ black, not extending much further than the base of the elytra, basal three joints more or less fulvous, third joint but slightly longer than the second, terminal joints shorter and thicker.

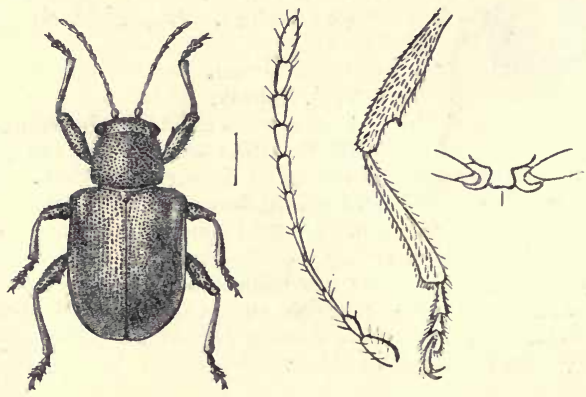

Fig. 150.-Leprotes kanaransis.

Thorax subcylindrical, scarcely broader than long, lateral margins obsolete except near the base, surface finely rugose-punctate, sometimes with a fine medial smooth line, interstices more or less finely pubescent (rubbed specimens are entirely smooth). Elytra much wider than the thorax, convex, subquadrately obloug, twice as strongly punctured as the thorax, shoulders very acute; surface clothed with very short yellowish pubescence. Legs rather long. 
and slender, femora with a distinct tooth; tibiæ simple; claws bifid. Prosternum broadly subquadrate; mesosternum not longer than broad, covered with long hairs.

Length $6 \mathrm{~mm}$.

Hab. Bengal: Mandar; Southern Bombay: Kanara; Malabar Coast: Mahé.

This species closely resembles Neculla obscurata, Jac., but all the specimens I have seen of $L$. Kanaransis are black with a fine yellowish pubescence, while $N$. obscuratı is entirely white on account of the white excrescence and is furnished with long erect white hairs which are absent in L. kanaronsis, the legs in the last-named insect are also more slender and elongate.

\section{Genus DEMOTINA.}

Demotina, Baly, Journ. Ent. ii, 186\%, p. 158; id. Trans. Ent. Soc. 1864, p. 84 ; Chapuis, Gen. C'oléopt. x, 18i4, p. 281 ; Lefêv. Cat. Eumolp. 1885, p. 80.

Type, D. bouringi, Baly, from China.

Range. India ; Ceylon; Burma; China; Japan; Malayan Subregion.

Body oblong, subcylindrical, covered above and beneath with small adpressed scales. Head perpendicular; antennæ either slender and filiform or rather more robust, subfiliform, basal joint ovate, incrassate, second shorter than the first, the rest somewhat variable, four or five terminal joints rather shorter and often slightly thickened; eyes prominent, entire. Thorax transversely convex, lateral margins either obsolete or finely serrate. Elytra oblong, closely punctured. Legs moderately long; femora moderately thickened, armed each with a tooth beneath; intermediate or posterior tibiæ or both notched at their apices; claws bifid. Prosternum oblong or oblong-quadrate, its anterior margin continuous with that of the episternum. Mesosternum oblongquadrate.

The notched tibiæ separate this genus from Leprotes, the scales instead of hairs from Lypesthes, and the equal thickness of the femora from Hyperaxis.

\section{Demotina modesta, Baly, Trans. Lint. Soc. 1873, p. 161.}

Pale flavous; thorax slightly darker, entirely clothed with flavous adpressed scales.

Head with the clypeus very narrowly transverse, finely punctured; antennxe pale, extending to base of elytra only, third jount scareeiy longer than the second, terminal joints short and thickened. Thorax about half as broad again as long, lateral margins very finely serrate. Elytra with very shallow depression at the base, more strongly punctured than the thorax, punctures 
extremely closely arranged in irregular rows; entire surface clothed with short flavous scales. Femora very slightly toothed; tibis not perceptibly notched.

Length $2 \frac{1}{2} \mathrm{~mm}$.

Hab. Assam: Patkai Mts. (Coll. Brit. Muss); Japan (Coll. Jacoby).

Originally described from Japan. Except that they are smaller in size and paler in coloration, I am unable to separate the Indian specimens obtained by Doherty from the Japanese form.

751. Demotina andrewesi, Jac. Ann. Soc. Ent. Belg. xlviii, 1904, p. 383.

Obscure piceous, clothed with grey scales.

Head not longer than broad, densely elothed with grey scales;

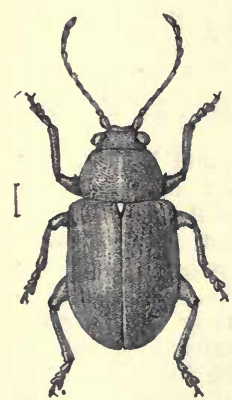

Fig. 151. clypeus and labrum fulvous; antennæ fulvous, slender, terminal joints widened, third and fourth joints very elongate, equal. Thorax about half as broad again as long, sides rounded and widened at the middle, lateral margins obsolete, disc clothed with scales like the head. Scutellum triangularly elongate. Elytra strongly punctured in very closely approximate rows, the scales also arranged in rows, interstices with single stiff black hairs. Body beneath densely covered with white scales. Femora with a small tooth; claws bifid.

Length $3 \frac{1}{2} \mathrm{~mm}$.

Hab. Southern India: Nilgiris, Anaimalais.

The densely placed white scales on the Demotina andrewesi. head and thorax which obscure the sculpture separate this species from its allies; the piceous ground-colour of the elytra can just be seen under the covering of scales.

\section{Demotina minuta, sp. n.}

Obscure piceous clothed with whitish scales; antennæ and legs fulvous; a small fuscous spot on the middle of the elytra.

Head covered with grey scales; clypeus narrowly transverse, smooth, strongly punctured; antennæ rather short, not extending much beyond base of elytra, basal joints short, sixth and following two joints widened, terminal joints wanting in the type and only known specimen. Thorax about half as broad again as long, sides very slightly widened in the middle, margins obsolete except at base, surface clothed with scales like the head. Elytra oblong, nearly parallel, puncturation fine and very close; 
scales not very dense, more close above the smull fuscous spot near the middle. Intermediate tibiæ slightly emarginate at apex.

Length $2 \frac{1}{2} \mathrm{~mm}$.

Hab. Assam: Patkai Mts. (Coll. Brit. Mres.).

The smallest of the Indian species; the elytral fuscous spot is very obsolete, but similar on both elytra and marked above by a slightly more dense accumulation of scales.

\section{Demotina serraticollis, Baly, Trans. Ent. Soc. 186\%, p. 85.}

Piceous, subopaque; antennæ and legs rufo-piceous; elytra fuscous, clothed with fine grey pubescence and erect hairs.

Head closely corered with adpressed dingy white scales; clypeus transverse, not distinctly separated from the face, surface glabrous, rugose, rufo-piceous ; antennæe slender, nearly filiform. Thorax transverse, sides rounded, convergent in front, lateral margins armed with a single row of short teeth: surface transversely convex, finely ("coarsely," Baly) punctured, rugose at the sides. Elytra coarsely striate-punctate, clothed with dingy white, intermixed with other dark fuscous scales that form irregular patches.

Length $4 \mathrm{~mm}$.

Hab. Burma: Ruby Mines; Penang.

I caunot find sufficient differences between the Indian specimen and the type to justify a separation; the only rariation seems to be in colour. In the Indian form the ground-colour is fuscous instead of piceous. I cannot call the puncturation of the thorax or elytra "coarse," but, on the contrary, would describe it as rather fine, even under a strong lens.

754. Demotina balyi, Jac. Ann. Mus. Civ. Genova, xxxvii, 1889, p. 168.

Obscure fuscous, covered with short greyish seales and erect hairs; clypeus fulvous; antennæ flavous; thorax with narrow whitish bands; scutellum and some spots at the base of the elytra whitish, the latter strongly punctate-striate, with an obscure fulvous transverse band.

Head dark fulvous, clothed with pale yellowish scales; clypeus fulvous, broader than long, without scales, strongly punctured, its lower edge slightly emarginate; apex of mandibles black; antennæ filiform, two-thirds the length of the body, the apical joint fuscous, the third and fourth joints very elongate, equal, following joints gradually shortened and slightly thickened. Thorax more than twice as broad as long, the sides margined, slightly widened at the middle and rounded; the surface rugose, dark fulvous, clothed with pale yellowish-white short adpressed scales which form a narrow longitudinal vitta on the dise and a broader stripe on each side, all the vittæ are, however, indistinct. Scutellum thickly pubescent. Elytra very closely and deeply 
punctate-striate, dark fuscous or fulyous, closely covered with scales and short single erect black hairs; behind the middle a transverse obscure band is visible, caused by the absence of scales. Femora with a stout triangular tooth; intermediate tibiæ feebly notched near the apex; claws bifid.

Length $4 \frac{1}{2} \mathrm{~min}$.

Hab. Upper Burma: Thagatà.

\section{Demotina ceylonensis, Jac. P. Z. S. 1887, p. 72.}

Broadly ovate, robust; fuscous, clothed with fulvous pubescence; the basal three or four joints of the antennæ fulvous; elytra with a transverse whitish band at the middle, the apical portion spotted.

Broader and more robust than $D$. thoracica, with the pubescence fulvous instead of whitish. The elytra, instead of being finely and distantly punctate-striate, are bere strongly and closely punctured, and a transverse band, composed of thick white pubescence, is placed at the middle; this band is narrowed towards the suture and is, in one specimen, followed by a hroad black denuded space, while the apical portion is variegated by white and fulvous pubescence; in another specimen, which I refer to the same species, the transverse band is only indicated, and the space below it shows some small fuscous spots, alternated by white and fulvous pubescence.

Length $4 \mathrm{~mm}$.

Hab. Ceylon: Galle.

756. Demotina lewisi, Jac. P. Z. S. 1887, p. 71.

Fuscous or dark piceous, covered with yellowish scale-like pubescence; basal joints of the antennæ fulvous; scutellum whitish; elytra closely punctate-striate, each elytron with two more or less distinct rows of white spots.

Antennæ more than two-thirds the length of the body, the third and fourth joints equal, the terminal five joints slightly thickened. Thorax tuice as broad as long, the sides strongly rounded, the surface closely and finely rugose-punctate like the head. S'utellum thickly clothed with whitish pubescence. Elytra closely covered with yellowish scale-like pubescence, the puncturation distinct, close and arranged in rows; each elytron with two stripes of whitish pubescent spots, of which one is placed at a little distance and close to the suture, the other at the middle of the disc and extends from the shoulder to the apex; besides the pubescence, single short stiff black bristles are visible on the surface of the elytra. Legs dark fulvous; the femora with a distinct tooth.

Length $4 \mathrm{~mm}$.

Hab. Ceylon: Galle. 
757. Demotina thoracica, Jac. P. Z. S. 1887, p. 70.

Greyish-fuscous, closely pubescent; the apices of the tibiæ fulvous ; thorax strongly rounded at the middle, obscurely marked with brownish bands; elytra covered with light grey pubescence, a spot at the base and two rows of similar spots placed transversely behind the middle, fuscous.

Head closely punctured, covered with light grey pubescence, which is interrupted on the vertex by two more or less distinct longitudinal brownish bands; the anterior margin of the clypeus and the labrum fulvous, glabrous; antennæ half the length of the body, slender, the terminal joints slightly thickened, the third and fourth joints equal, all the joints piceous or dark fuscous. Thorax transverse, strongly rounded and widened in the middle; the entire surface covered with whitish-grey pubescence, which assumes the shape of a longitudinal band at the sides; the latter with a round depression. Scutellum greyish-pubescent. Elytra finely punctate-striate, clothed with greyish pubescence like the thorax; at the basal margin are two more or less distinct fuscous or dark brown spots, bounded at the sides by whitish bands; behind the middle are placed two transverse rows of similar spots. All the femora are armed each with a strong tooth; the sides of the elytra are furnished with short and stiff bristles.

Length 3-4 min.

Hab. Ceylon: Dikoya.

The thorax in the present species is much narrowed in front and at the base, giving more prominence to the middle; the pubescence of the upper surface is generally whitish-grey, but sometimes of a more fulvous tint, and the fuscous spots are more or less distinct ; in well-marked specimens they are often preceded by whitish spots, caused by the thickening of the pubescence in those places; in some specimens there are three oblique rows of obscure spots on each elytron besides those at the base, which latter are generally present.

\section{Genus AULACOLEPIS.}

Aulacolepis, Baly, Journ. Ent. ii, 1863, p. 162 ; id. Trans. Ent. Soc. 1867, p. 93; Chapuis, Gen. Coleopt. x, 1874, p. 327 ; Lefêv. Cat. Eumolp. 1885, p. 127.

Type, A. mouhoti, Baly, from Siam.

Range. Burma; Siam; Sumatra.

Body oblong, subcylindrical, clothed with large, broad, rigid, adpressed or suberect curved scales, surface of the scales longitudinally concave. Head short, perpendicular, very deeply immersed in the thorax; antennæ scarcely longer than the head and thorax, their terminal portion moderately incrassate, basal joint thickened, second moderately so, third and following three 
joints each about equal in length to the first, each slightly decreasing in length, slightly thickened at their apices, following four moderately thickened, nearly equal, submoniliform, eleventh rather longer; eyes entire. Thorax transverse, subcylindrical in front, gibbous, strongly tubereulate on dise, lateral margins distinct, strongly produced, their outer edges sometimes minutely toothed. Elytra much broader than the thorax; surface rugosepunctate, covered with adpressed curved scales, intermixed with tufts of suberect similar scales. Legs robust; femora beneath with a short stout tooth; tibiæ curved; claws bifid. Prosternum transverse, quadrate, separated from episternum by a deep groove. Mesosternum short, transverse, apex concave.

Can be distinguished by the produced lateral border of the thorax. In the typical species, $A$. mouhoti, Baly, the thorax is dilated at the sides; in the other known species the lateral margins are finely serrate.

\section{Aulacolepis mouhoti, Baly, Journ. Ent. ii, 1863, p. 163.}

Black, subnitidous, closely covered with large, curved, concave,

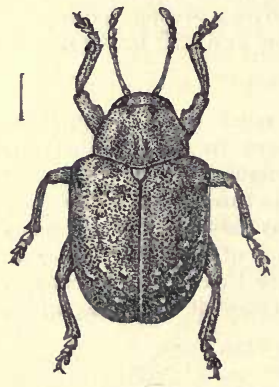

Fig. 152.

Aulacolepis mouhoti. fulvo-fuscous scales. Head short, subglobose; antennæ fusco-fulvous, scarcely longer than the thorax. Thorax onethird as broad again as long, the posterior four-fifths of the lateral border strongly produced, the anterior fifth ill-defined, the outer edge armed with minute teeth; surface of disc deeply punctured, elevated into two large parallel conical tubercles, two small patches of scales on the anterior border together with a somewhat longer patch immediately behind each of the conical protuberances on the disc, black. Elytra deeply punctured, clothed with fulvo-fuscous intermixed with similar black and white scales; each elytron is also furnished with about seven tufts of rigid, erect, black scales.

Length $6 \mathrm{~mm}$.

Hab. Burma : Momeit; Siam.

\section{Group EUBRACHINI.}

Characters of Pseudocolaspini, but with the anterior margin of thoracic episternum concave. It is on this character that Baly has separated the Eubrachini from the Pseudocolaspini. The group contains two genera which can be tabulated as follows :- 


\section{Key to the Genera.}

A. Lateral margins of thorax obsolete....... Eurbrachis, p. 433.

B. Lateral margins of thorax distinct, serrate . Mrsocolaspis, p. 437.

\section{Genus EUBRACHIS.}

Eubrachis, Baly, Journ. Linn. Soc. xiv, 1877, p. 248.

Pseudocolrspis, Chapuis, Gen. Coléopt. x, 1874, p. 288 ; Lefêv. Cat. Eumolp. 1885, p. 85.

Type, E. spinipes, Baly, from Africa.

Range. Europe; Africa ; India.

Characters those of the group.

\section{Eubrachis indica, Baly, Journ. Linn. Soc. xiv, 1877, p. 249.}

Metallic green or æneous; base of the femora, the antennæ and labrum rufous or piceous, terminal joints of the antennæ black.

o. Head coarsely punctured, vertex swollen, front with illdefined longitudinal groove: auterior margin of clypeus deeply notched, the notch subangulate; antennæ extending to base of elytra, either entirely fulvous or with basal joints only of that colour. Thorax a little broader than long, strongly widened and swollen at the middle on the sides, transversely depressed and narrowed at apex and to a less extent at the base; surface very closely and rather finely punctured, clothed with short grey pubescence, somew hat sparingly distributed. Scutellum broadly subquadrate, finely punctured and pubescent at base. Elytra very faintly depressed below the base, punctured like the thorax, shoulders tuberculate; surface clothed with short, erect, silvery hairs. Legs æneous, base of femora and apices of tibiæ more or less fulvo-rufous or sometimes piceous.

Var. Dark blue.

Length 3-4 mm.

Hab. Kashmir; Himalayas ; Northern India ; Punjab ; Mussoorie.

\section{Eubrachis rufotibialis, sp. $\mathrm{n}$.}

Obscure cupreous or æneous, basal joints of the antennæ, the labrum and palpi fulrous; upper surface finely pubescent; base of femora and the tibiæ more or less dark fulvous.

ð. Head broad, finely semirugosely punctured; clypeus not separated from the face, its base finely longitudinally strigose, anterior border deeply triangularly emarginate; antennæ black, not extending to middle of elytra, basal six joints light fulvous, basal joint thick and short, second elongate and slender, last five joints strongly transversely thickened. Thorax about balf as VOL. I. 
broad again as long, sides rounded and widened at the middle, with shallow but distinct transverse depression anteriorly; surface rather convex, punctured and pubescent like the head. Scutellum subquadrate, pun ti.red and pubescent. Elytra oblong, narrowed at the apex, shoulders prominent and acute; surface finely and closely rugose-punctate, clothed with silvery pubescence. Underside greenish-æneous, very sparingly punctured and pubescent; femora rather elongate with an acute tooth.

Length $3 \frac{1}{2} \mathrm{~mm}$.

Hab. Khási Hills (Coll. Jacoby).

The amount of fulvous on the tibiæ is variable; sometimes this colour is bright and well distributed, at other times it is confined more to the sides or beneath. The species differs from $E$. orientalis, Jac. in the much less strongly widened and convex thorax and shorter shape of the latter.

\section{Eubrachis andamanensis, sp. $n$.}

Dark æneous, finely pubescent; basal six joints of the antennæ fulvous.

Head finely longitudinally strigose and sparingly punctured; clypeus deeply subtriangularly emarginate; labrum fulvous; antennæ scarcely extending to base of thorax, basal joint thick and short, second scarcely shorter but less thick, following two joints short and more slender, terminal five strongly thickened. Thorax scarcely half as broad again as long, sides rounded but scarcely widened; surface with obsolete transverse sulcus near the anterior margin, very closely and evenly punctured; interstices not wrinkled, finely pubescent. Scutellum broadly subquadrate, nearly smooth. Elytra about twice as long as the thorax, slightly depressed below the base; puncturation stronger than that on the thorax, very close, finer and more remote towards the apex ; interstices finely wrinkled at base; pubescence short and erect, silvery in colour. Femora dark æneous, robust, with a strong tooth beneath.

Length $4 \mathrm{~mm}$.

$H a b$. Andamans (Coll. Jacoby).

- Differs from $E$. rufotibialis, Jac. in the finely strigose head, the strigæ directed towards the centre, in the entirely dark æneous legs and finely rugose basal portion of the elytra. The type specimen seems to be a female.

762. Eubrachis orientalis, Jac. (Preudocolaspis) Ann. Soc. Ent. Belg. xxxix, 1895, p. 280.

Very dark æneous; antennæ, labrum and legs dark fulvous.

0 . Head very closely and rather strongly punctured; clypeus triangularly but not deeply emarginate; antennæ extending to 
base of thorax, terminal five joints strongly transversely dilated. Thorax almost as long as broad, subcylindrical, rounded and widened at the middle, entire surface extremely closely punctured and finely strigose, sparingly clothed with grey pubescence. Scutellum much broader than long, closely punctured. Elytra much wider at base but only slightly longer than the thorax, of similar sculpture and pubescence arranged in rows, shoulders ridge-shaped. Legs fulrous with æneous gloss.

q. Thorax not so long or wide, more narrowed in front.

Length $3 \mathrm{~mm}$.

Hab. Bombay: Belgaum; Burma: Tharawaddy (Colls. H. E. Andrewes \& Jacoby).

763. Eubrachis discoidalis, Jac. (Pseudocolaspis), Ann. Soc. Ent. Belg. xl, 1896, p. 304.

Metallic greenish-æneous, pubescent; the basal joints of the

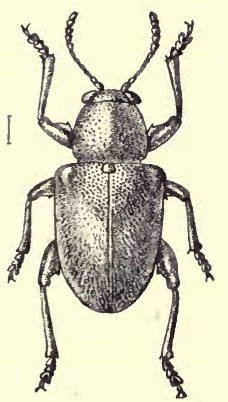

Fig. 153.

Eubrachis discoidalis. antennæ and the legs more or less fulvous; thorax finely and closely punctured; elytra more strongly punctured, the sides and apex pale fulvous, the base and suture metallic greenish.

Head closely punctured and slightly rugose, æneous; the clypeus not separated from the face, bounded laterally by a narrow ridge; antennæ fulvous, extending to the base of the thorax, the first and second joints thickened, nearly equal, terminal joints distinctly dilated, not longer than broad. Thorax about as long as broad, gradually widened at the middle, the surface finely and not very closely punctured, cupreous or æneous, clothed with grey pubescence. Scutellum subquadrate, its apex truncate. Elytra wider at the base than the thorax, more closely and rather more strongly punctured, the punctures arranged in very closely approximate irregular rows, rather sparingly pubescent like the thorax, the sides and apex fulvous; the disc has a greenish æneous triangular patch gradually narrowed and pointed along the suture. Underside also metallic greenish ; legs fulvous, the tarsi piceous. Prosternum broadly subquadrate, sparingly punctured. Femora with a very small tooth.

Length $3 \mathrm{~mm}$.

Hab. Nortl-West Provinces ; Bengal : Mandar.

I am not acquainted with any species of this genus that possesses similarly coloured elytra; there are several specimens before me which show no difference in this respect. In all, the 
metallic discoidal patch commences broadly at the base and gets gradually narrowed towards the apex which it does not quite reach, the pubescence of the elytra is stiff and arranged more regularly near the apex; in some specimens the apical joints of the antennæ are nearly black.

764. Eubrachis himalayensis, Jac. (Pseuducolaspis), Mêm. Soc. Ent. Belg. vii, 1900, p. 111.

Metallic green; the apical joints of the antennæ and the tarsi blackish; legs fulvous.

Head very closely and finely punctured, the interstices minutely granulate, the vertex swollen, the middle with a longitudinal groove, the anterior edge of the clypeus deeply concave emarginate; labrum fulvous; antennæ fulvous, extending to the base of the elytra, the apical four or five joints black. Thorax transverse, the middle distinctly swollen, the basal and apical portions constricted, the surface transrersely depressed near the anterior margin, very closely and rather distinctly punctured. Scutelluin broad, transverse, its apex truncate, distinctly punctured at the base. Elytra wider at the base than the thorax, the shoulders prominent, the punctures arranged in ill-defined rows; the interstices finely transversely rugose and furnished with single white hairs, arranged in rows. Legs fulvous; the femora robust, with a small tooth beneath, the posterior femora greenish-æneous at the apex, tarsi more or less black. Underside metallic green, clothed with very short silvery pubescence. In the female the thorax is, as usual, much less swollen and constricted at the base and apex.

Length $5 \mathrm{~mm}$.

$H a b$. Himalayas: Chamba.

Closely allied to E. (Pseudocolaspis) indica, Baly, but differs in the puncturation, in the longer thorax and in the entirely fulvous legs.

765. Eubrachis bengalensis, Duviv. (Pseudocolaspis), Ann. Soc. Ent. Belg. xxxvi, 1892, p. 412.

Dark bronze or cupreous; palpi, tibiæ, tarsi and the bases of antennæ reddish-brown.

Head densely and strongly, iu part confluently punctured; labrum piceous; clypeus rather more distantly punctured; antennæ not extending to base of thorax, last five joints black. Thorax scarcely broader than long, appearing narrowed anteriorly if seen from above; surface densely reticulate and punctured. Scutellum broad, subpentagonal, finely punctured. Ely tra wider at base than the thorax, narrowed towards the apex; surface rather depressed, more finely punctured than the thorax, punc- 
turation extremely close, interstices very finely wrinkled and sparingly pubescent.

Length $4-4 \frac{1}{2} \mathrm{~mm}$.

Hab. Bengal: Mandar, Konbir.

A dark and sombre-looking species which may be known by the fine reticulations of the thorax and elytra; the thorax is less elongate and widened at the middle than in E. lonyicollis, Baly, and the anterior margin of its episternum is concave.

\section{Genus MESOCOLASPIS, nov.}

Oblong-ovate, finely pubescent. Head without sulci or grooves; antennæ short, with dilated terminal joints. Thorax slightly broader than long, with distinct serrate lateral margins, surface with short hairs. Elytra wider at base than the thorax, punctatestriate, with rows of hairs. Legs robust; femora thickened, with tooth beneath; tibiæ entire; tarsi short; claws bifirl. Prosternum broad, widened posteriorly; anterior margin of thoracic episternum concave.

The species are similar in shape to the species of Pseuclocolaspis, but have distinct and serrate lateral margins to the thorax; the prosternum is less broad generally, more narrowed in front.

The genus somewhat resembles the African genus Cheiriclella, Jac., but differs in the short and thickened terminal joints of the antennæ. This genus is proposed for a species that was previously placed in the genus Apolepis, Baly, from the species of which it differs however in the concave thoracic episternum.

766. Mesocolaspis indica, Jac. (Apolepis), Ann. Soc. Ent. Belg. xlviii, 1904 , p. 385.

Fulvous, above pubescent; antennæ and legs flavous; elytra with sutural triangular patch, a lateral stripe and two spots obscure fuscous.

Upper surface furnished with short curved silvery hairs. Head closely rugose, fulvous; clypeus separated at the sides by narrow grooves; palpi flavous; antennæ short, flavous, terminal five joints strongly thickened, second longer and more slender than the basal joint. Thorax fulvous, subquadrate, sculptnred like the head, with finely serrate lateral margins. Elytra flavous, very closely and strongly punctured, with raised interstices at base and sides, pubescence arranged in rows; a posteriorly pointed fuscous patch across the suture at base nearly extending to the middle, a fuscous stripe close to lateral margins not extending to apex, and two fuscous spots on the disc, one at, the other behind the middle. Prosternum strongly punctured.

Length $2 \mathrm{~mm}$.

Hab. Nilgiris (Colls. H. E. Andrewes \& Jacoby). 


\section{Mesocolaspis nigrita, sp. n.}

Black; basal joints of antennæ fulrous.

Head finely rugosely punctured and pubescent, very broad; clypeus not separated from the face, anterior margin nearly straight; eyes entire, rather small. Antennæ extending to base of elytra, basal two joints short and thick, following four joints slender and more elongate, terminal five transversely thickened. Thorax about half as broad again as long, sides rounded and moderately narrowed in front, the lateral margins with a row of fine teeth, surface rugose, with short and stiff pubescence. Scutellum ovate, not longer than broad. Elytra closely and strongly punctured, basal portion more irregularly punctured, posterior

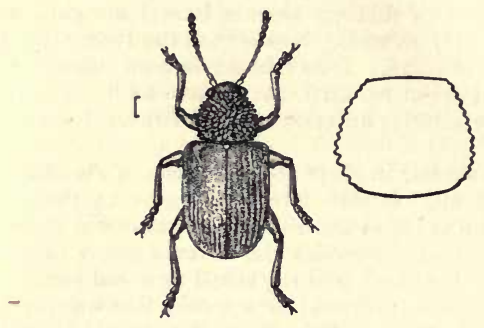

Fig. 154.-Mesocolaspis nigrita.

portion with rows of regular punctures, interstices with rows of short, strongly-curved grey hairs. Femora each with an acute tooth beneath. Underside and legs black, shining. Prosternum strongly punctured.

\section{Length $2 \mathrm{~mm}$.}

$H a b$. Southern India: Nilgiris (Andrewes).

This species agrees in all structural details with the type, but differe totally in colour and markings.

\section{Group EUMOLPINI.}

Subavadrate-ovate. Head broad, deeply inserted in thorax; eyes globulär, obsoletely sinuate; antennæ filiform. Thorax transverse, sides rounded, narrowly margined. Elytra generally irregularly punctured, sides more or less rugose at base, as a rule more so in the female than in the male. Legs robust; femora thickened at the middle, generally unarmed; apex of tibiæ in male mostly thickened and curved inwards, in female straight; tarsi rather short and broad; claws bifid. Prosternum subquadrate, often densely pubescent.

Metallic species very rarely pubescent above, with a strongly transverse thorax and of rather broad shape, more or less resembling true species of Chrysomela. The thorax is as wide as the elytra at the base, the head very flat and perpendicular. 


\section{Genus COLASPOSOMA.}

Colasposoma, de Laporte, Silberm. Rev. Entom. i, 1833, p. 22.

Acis, Chevrol. Cat. Dej. ed. 3, 1837, p. 435.

Thysbe, Dej. l. c. p. 435.

Type, $C$. senegalense, Dej., from Africa.

Range. Africa; India; Malayan Subregion; Australia.

Short, oblong and convex, metallic, rarely pubescent above. Head deeply inserted in thorax, flat; antennæ filiform, terminal joints more or less widened. Thorax transverse, sides more or less rounded, not narrowed in front. Elytra slightly punctatestriate, generally rugose at the sides in the female. Legs robust; femora thickened, sometimes armed with a tooth beneath; tibiæ sulcate, dilated and curved at apex in the male, simple in the female. Prosternum nearly quadrate, frequently pubescent; anterior margin of thoracic episternum concave.

The insects which constitute this genus are of very variable sculpture, closely allied and difficult to separate, and the specific distinction of many is often a case of conjecture only. The examination of the male organs is a useful guide to the identification of the species.

\section{Species more or less pubescent above.}

768. Colasposoma albovillosum, Duviv. Bull. Soc. Ent. Belg. xxxv, 1891, p. xl.

б. Bronze, cupreous or blue, finely pubescent; labrum fulvous. Head strongly and very closely punctured; clypeus rugosely

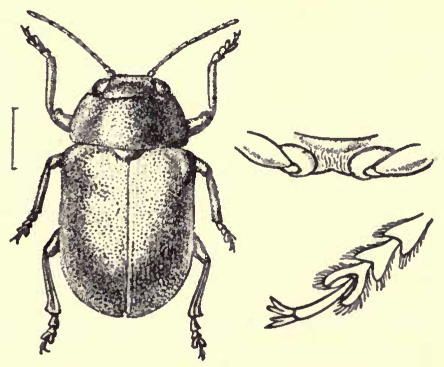

Fig. 155.-Colasposoma albovillosum.

punctate; antennæ fulvous, last five joints slightly widened. Thorax about three times as broad as long, narrowed in front, 
finely margined, sides subangulate near base, sculptured and punctate like the head. Scutellum large, strongly punctured. Elytra large, oblong, closely punctured, the punctures slightly larger than those on the thorax; sides finely transversely strigose, base obsoletely depressed; surface like that of the head and thorax clothed with very short white pubescence, rather longer at the sides; some narrow elongate smooth lines are present or indicated only on the disc. Body beneath metallic greenish or æneous, with short but rather dense pubescence.

Length 5-7 mm.

$H a b$. Bengal: Konbir, Tetara.

Resembles C. villosulum, Lefèv., but more oblong in shape and less closely wrinkled at sides of elytra, the coloration quite different.

769. Colasposoma villosulum, Lefev. Cat. Eumolp. 1885, p. 107, note 2.

Eneous or metallic green; surface above finely pubescent; labrum, antennæ and legs fulvous.

$\checkmark$. Head extremely finely and closely punctured and pubescent, sometimes with a small central cupreous spot; antennæ long and slender, third and fourth joints equal, terminal joints elongate, very slightly thickened. Thorax twice as broad as long, sides rounded, surface sculptured and pubescent like the head. Elytra similarly elothed with hairs, finely transversely strigose, very feebly depressed below shoulders, a few rows of punctures near suture. gloss.

Var. $a$. Above and below dark bronze; legs piceous with æneous

Var. $b$. Above metallic greeu; elytra with a reddish cupreous band near the suture.

Length $4 \frac{1}{2}-4 \frac{3}{4} \mathrm{~mm}$.

$H a b$. Coromandel; Madras.

The original description of Lefèvre is short and unsatisfactory, the sex of the specimen described is not mentioned and the antennæ and legs are described as "testaceous," fulvous probably being meant. The above description is from specimens in my collection which I cannot refer to any other pubescent species. Lefèvre's type was of metallic green coloration, with narrow thoracic and elytral cupreous margins.

Species without pubescence; legs generally fulvous or flavous.

770. Colasposoma lividipes, Jac. Ann. Soc. Ent. Belg. xlvii, 1903, p. 95.

Metallic green, sometimes bluish; antennæ and labrum fuscous; legs flavous, knees æneous, tarsi obscure fuscous. 
$\delta$. Head finely and rather remotely punctured, depressed between the eyes; clypeus separated by a transverse groove, finely punctured ; antennæ fuscous, terminal joints slightly darker, third and fourth elongate, equal, fifth and sixth much shorter, the following joints more elongate aud slightly thickened. Thorax twice as broad as long, sides rounded, narrowed anteriorly ; surface convex, slightly depressed near the anterior margin, punctured like the head, the punctures evenly distributed. Scutellum with a few fine punctures. Elytra rather elongate and somewhat narrower than the thorax, sutural portion remotely and finely punetured in rows, sides transversely wrinkled from base to behind the middle, with a rather distinet depression below the shoulders.

‥ Antenna longer, third, fourth and fifth joints elongate, following joints shorter. Thorax less convex, more transverse and more distinetly narrowed in front, sides with some fine grey pubescence.

\section{Length 5-6 min.}

Hab. Southern India: Nilgiris; Ceylon.

Prineipally distinguished by the pale legs with metallic knees. The male organ is very slender, strongly curved and pointed, upper surface very deeply longitudinally sulcate, bounded at base by the truneate edge of the non-sulcate portion. C. geniculatum, Jac. has strongly punctured thorax and elytra, the male organ is quite different. $C$. versicolor, Lefèv. has dark terminal joints of antennæ, acieulate punctures and black tarsi. A little pubescence at sides of thorax is present in well-preserved specimens.

771. Colasposoma laticolle, Jac. Mém. Soc. Ent. Belg. vii, 1900, p. 115.

Dark cupreous; antennæ and legs fulvous or with æneous gloss; beneath piceous with a metallie appearance.

o. Head elosely and strongly punetured throughout; the clypeus separated from the face by an obsolete triangular depression, its surface punctured like the head but the interstices Jongitudinally strigose; labrum piceous ; antennæ pale fulvous, extending to the middle of the elytra. Thorax nearly three times as broad as long, very convex, its sides strongly rounded, the angles distinct but not produced; the surface very closely and strongly punctured, the punctures evenly distributed, not stronger at the sides than in the midale, the latter with a narrow short smooth raised line, the space belind the anterior margin transversely depressed. Scutellum distinctly and rather closely punctured. Elytra not widened posteriorly, the shoulders prominent, the puneturation rather stronger than that of the thorax and arranged in somewhat regular closely approximate rows ; a very narrow and not strongly raised costa extends from the shoulders to behind the middle, the sides with a rather strongly deflexed lateral margin. Legs robust, obscure fulvous, with a more or less metallic green gloss; the anterior tibix slightly curved, strongly 
tricarinate at the sides, the underside clothed with fine grey pubescence.

Length 5-6 mm.

$H a b$. Bengal : Mandar.

The thorax of this species is more convex in the male than in any other of its Indian congeners, and resembles that of some African species of the geuus; the sides are very strongly rounded at the middle; the elytral depression is very feeble in both sexes, but in the female (if rightly referred to this species) the thorax is less convex and the sides are less rounded, the puncturation also of the elytra is closer and finer. Rubbed female specimens of C. albovillosum can be distinguished from this species by the shorter and much nore strongly transverse thorax.

772. Colasposoma downesi (Pl. II, fig. 7), Baly, A. M. N. H. (3), x, 1862 , p. 19.

Metallic green; labrum, base of antennæ and legs rufo-fulvous, knees greenish-æneous, tarsi fuscous; elytra cupreous, margined with greenish-æneous.

ㅇ. Narrowly oblong, convex. Head and thorax deeply but not coarsely punctured; antennæ black, slender, filiform, two-thirds the length of the body, basal five joints rufous or fulvous. Thorax more than twice as broad as long, sides rounded, roundly narrowed in front. Elytra oblong, sides parallel, more coarsely punctured than the thorax, slightly broader than the latter; disc transversely impressed below basilar space, strongly rugose and tuberculate at the sides.

o. Elytra with the sides closely transversely rugose, without tubercles.

Length $6 \mathrm{~mm}$.

Hab. Sikhim: Kurseong; Nilgiris; Burma.

Elytra and legs variable in coloration; some specimens have the elytra metallic green with a lateral cupreous stripe, in others the stripe is wanting; the legs are either coloured as given above or metallic green.

773. Colasposoma rufipes, Jac. Mém. Soc. Ent. Belg. vii, 1900, p. 114.

Greenish-cupreous ; antennæ, legs and abdomen fulvous.

ㅇ. Head finely and rather closely punctured; the clypeus similarly punctured, indistinctly separated from the face; labrum and antennæ fulvous. Thorax very short, nearly three times as broad as long, the sides very strongly rounded, slightly narrowed in front, the surface coarsely and not very closely punctured, the sides more closely so. Scutellum broader than long, with a few punctures. Elytra rather finely and regularly punctured on the inner disc, the outer half entirely covered with strongly raised 
transverse rugosities which diminish gradually towards the apex. Breast metallic green; rest of the underside and the legs fulvous.

Length $7 \mathrm{~mm}$.

$H a b$. India.

Although I have only seen a single female specimen of this species, the differences in the sculpturing and coloration are so marked that it cannot easily be confounded with any other of its allies; the short and very strongly punctured thorax and the rugosities of the elytra, which resemble those of the genera Edusia and $A b i r u s$, instead of the usual irregular rough appearance, will at once distinguish this species.

\section{7t. Colasposoma semicostatum, sp. n.}

Metallic green; basal joints of antennæ and legs (knees excepted) fulvous.

$\sigma^{\circ}$. Head strongly and closely punctured; clypeus separnted at the sides by deep punctures; labrum fulvous; antennæ extending beyond middle of elytra, basal six or seven joints fulvous, rest black, third and following joints very elongate, nearly equal. Thorax strongly transverse, more than twice as broad as long, sides narrowed towards apex, lateral margins rounded, the surface as strongly and closely punctured as the head. Scutellum very finely punctured. Elytra slightly depressed below base, closely punctured in rows near the suture, more strongly and irregularly so at the sides, interstices on the latter area transversely rugose. Body beneath greenish-æneous, finely pubescent; anterior legs elongate, their femora strongly thickened, unarmed, knees of all the legs metallic green.

․ . Elytra with a short acute costa at the shoulders and another near the apex at the sides.

Var. a. Above reddish-cupreous.

Var. $b$. Thorax violaceous, elytra green.

Length $4 \frac{1}{2}-5 \mathrm{~mm}$.

Hab. Sikhim: Mungphu; Cachar. Type in Brit. Mus.

Elytra obsoletely depressed below base, legs metallic.

775. Colasposoma bicallosum, Lefêv. Bull. Soc. Ent. Bely. xxxr, 1891, p. celxviii.

"Cupreous, with greenish-golden gloss; labrum, palpi and antennæ black, basal three joints of the last æneous.

"Head closely punctured, finely strigose between the eyes, a small fovea in the middle. Thorax transverse, moderately convex, subremotely punctured, punctures aciculate. Scutellum broad, apex rounded, base punctate. Elytra obsoletely transversely depressed below base, minutely punctured, the puncturation arranged in rows near the suture, more strongly impressed within 
depressions, interstices below shoulders subelevate, transversely strigose; humeral callus smooth, very prominent; each elytron with an oblong tubercle near apex and suture.

"Length $9 \mathrm{~mm}$.

"Hab. Bengal." (Lefêre.)

Unknown tu me.

\section{Colasposoma clavareani, sp. n.}

Metallic green; antennæ and tarsi black or piceous; beneath dark æneous.

3 . Head closeiy punctured and obliquely strigose throughout; a small tubercle at the base of the clypeus; labrum piceous; antennæ with the basal six joints purplish-blue, rest black, terminal tive strongly thickened, third and following two elongate, equal. Thorax twice as broad as long, sides moderately rounded, puncturation deep, punctures subremotely placed on the middle, more closely so at the sides, interstices at latter place slightly rugose. Scutellum finely punctured. Elytra very convex; punctures not larger than those on the thorax, arranged in closely approxinate rows on the inner disc, more irregularly so at the sides, interstices below shoulders slightly transversely rugose. Femora and breast more or less metallic green.

Length $4 \mathrm{~mm}$.

Hab. Pondicherry (Colls. Brit. IIus. \& Jacoby).

Principally distinguished by the entirely strigose interstices of the head, the punctures visible on the vertex only, and the strongly and closely punctured thorax, colour of the antennæ, \&c. Female unknown.

\section{Colasposoma coromandeliana, sp. n.}

Metallic blue or green; terminal joints of antennæ and the tarsi black.

$0^{\circ}$. Head closely punctured on the vertex, longitudinately strigose above the eyes; clypeus rugose; labrum piceous; antennæ with basal joint metallic green or blue, following three or four joints purplish or piceous, rest black, short and stout, third and fourth equal. Thorax transversely convex, lateral margins rather strongly rounded in the middle; surface closely and tinely punctured, slightly more strongly so at the sides; interstices smooth, impunctate, larger than the punctures themselves. Scutellum broad, metallic green, with a few punctures. Elytra scarcely more strongly punctured than the thorax. punctures arranged in irregular rows, a very feeble depression below the base slightly more strongly punctured. Breast and legs metallic greenish or bluish, abdomen nearly black. Anterior tibiæ widened and curved at apex.

9. Besides the usual non-dilated and straight tibiæ differs from the $\delta$ in the deeper elytral depression, which is strongly rugose, 
but the rugosities are confined to the depression and do not extend lower down; in nearly all suecimens the basal joints of the antennæ are purplish.

\section{Length $5 \frac{1}{2}-7 \mathrm{~mm}$.}

$H a b$. Southern India: Nilgiris: Pondicherry; Travancore.

Differs from $C$. robustum, Jac. in its smaller size, stronger and more close puncturation of the head, the short, thick, terminal joints of the antennæ, and the larger non-aciculate punctures of the elytra and thorax. Male organ strongly curved, somewhat suddenly narrowed anteriorly, apex acute, upper cavity orate, bounded in front by a narrow smooth space.

778. Colasposoma serratulum, Lef'er. Cat. Eumolp. 1885, p. 106, note 3 .

Colasposoma planifrons, Jac. Mém. Soc. Ent. Belg. vii, 1900, p. 116.

Greenish-cupreous; antenne and labrum fulvous; abdomen black.

$\delta$. Head remotely and rather finely punctured; clypeus scarcely separated from the face; untenna with the terminal joints distinctly thickened, the latter black or fulvons, basal joints always fulvous. Thorax rather more than twice as broad as long, not narrowed anteriorly, lateral margins narrowly reflexed, punctures like those on the head and similarly arranged except at the sides, where the puncturation is closer. Scutellum finely punctured. Elytra rather more strongly punctured than the thorax, puncturation arranged in close rather regular rows, basal depression generally obsolete. Breast metallic greenish; legs more or less æneous ; femora sometimes fulvous at base.

ㅇ. Elytra with feeble basal depression, lateral interstices only slightly rugose, extending beyond the middle, more strongly marked near the margins.

\section{Length 4-5 mm.}

Hab. Bengal ; Malacca.

A female specimen, kindly sent me by $\mathbf{M}$. Clavareau and named by Lefèvre, proves his species to be identical with my $C$.planifrons. The author's description applies equally well to many other's, as no details of distinction are given. The present species is characterized by the remote puncturation of the head, the comparative strong punctures of the thorax, which have the interstices much wider than the punctures and the all but complete absence in the male of an elytral depression.

The species is extremely close to $C$. asperatum, Lefèv., and can scarcely be distinguished from it, although the author describes the head of the last-named species as "densely punctured" and of $C$. serratulum as finely and remotely so, but there is scarcely any difference in this respect in the specimens determined by Lefèvre and contained in my collection. 
779. Colasposoma metallicum, Clark, A. M. N. H. (3) xv, 1865, p. 142.

Colasposoma capitatum, Jxc. Ann. Mus. Civ. Genova, xxvii, 1889, p. 178.

Bronze, metallic blue or green.

ס. Head closely and strongly punctured, strigose above the eyes between which there is a small tubercle; clypeus transverse, closely punctured; labrum, mandibles and base of palpi nearly black ; antennæ piceous, basal joints bluish, apex of each fulvous, second to fourth joints gradually elongate, terminal fire widened. Thorax twice as broad as long, sides rounded, angles dentiform but not produced, disc convex, closely and finely punctured at the sides, more remotely so in the middle. Scutellum broad, sparingly punctured. Elytra wider at base than the thorax, with a very feeble depression below the shoulders, not more strongly punctured than the thorax; punctures arranged in irregular rows near the suture, distinct to apex ; sides below shoulders more strongly punctured within the depression and with slightly rugose interstices. Body beneath and legs æneous, finely pubescent. Prosternum broad, subquadrate. Anterior tibiæ widened at the apex, slightly curved; first joint of tarsi dilated. Generative organ moderately curved, rather suddenly contracted near the apex, the latter terminating broadly and rounded not pointed.

․ Elytral interstices at the sides strongly transversely rugose and partially tuberculate, a single longitudinal costa near the lateral margins, the rugosities not extending to the apex.

Length 6-7 mm.

$H a \dot{b}$. India: Southern Bombay; Burma: Bhamo; Andaman Islands; Penang.

A very variable species and difficult to define accurately. Clark's type was described from Penang with the underside and legs as black, which is not the ease, as the type in the British Museum proves. These parts are bronze-coloured like the upperside. All the specimens from the other localities given above are so closely allied in sculpture that it is impossible to separate them. The male was unknown to Clark.

C. capitatum, Jac., on remamination, does not seem to differ sufficiently to justify its separation.

\section{Colasposoma subopacum, sp. n.}

Dark æneous or blue, moderately metallic; labrum, antennæ and tarsi black.

3. Oblong. Head deeply rugosely punctured, strongly strigose above the eyes; a distinct tubercle at base of clypeus, the latter extremely closely rugose-punctate, angulate-emarginate in front, sides obliquely truncate; antennæ with the basal four joints 
æneous, obscure fulvous beneath, the rest black, terminal joints widened. Thorax more than twice as broad as long, sides rounded; surface extremely closely and slightly more strongly punctured than the head, punctures confluent and the interstices rugose at the sides; an obsolete short depression near the middle at sides. Scutellum subquadrate, punctured. Elytra not more strongly punctured than the thorax, punctures arranged in rows on the inner disc; base with shallow transverse depression below the shoulders, the depression more strongly punctured with transversely rugose interstices; extreme lateral margins metallic green. Body beneath and legs greenish, tibiæ obscure cupreous. Prosternum closely pubescent.

ㅇ. Elytra with strong transverse rugosities at the sides, which extend to the apex.

Length $4 \frac{1}{2}-5 \mathrm{~mm}$.

Hab. India: Ranchi; Burma: Momeit (Coll. Brit. Mus.).

\section{Colasposoma cœruleatum, Baly, Cist. Ent. ii, 1879, p. 440.}

o. Entirely dark blue. Head closely subrugose-punctate, sides strigose, middle with a small forea, a small tubercle at base of clypeus; antennæ black, not extending to middle of elytra, terminal five joints strongly dilated and compressed, basal joints dark blue. Thorax more than twice as broad as long, sides rounded, anterior angles acutely produced; disc closely and rather strongly punctured, obsoletely transversely depressed near the anterior margin, basal portion transversely convex. Scutellum subquadrate, smooth or with a few punctures. Elytra subquadrately oblong, wider at the base than the thorax, very obsuletely depressed below the base, punctured like the thorax, puncturation arranged behind the middle in very close irregular lines; anterior tibiæ strongly widened and curved at base. Male organ short and curved, upper surface with a deep ovate cavity near apex, the latter obtusely but narrowly pointed.

․ Elytra strongly rugose at the sides, two short obsolete costæ near the lateral margins below shoulders; puncturation at sides of thorax very close, that on the elytra more regularly arranged in rows on the inner disc.

Length 7-8 $\mathrm{mm}$.

Hab. Southern Bombay; Ceylon; Assam; Burma; China.

Principally distinguished by its entirely dark blue or violaceous colour, large size (though I have not seen specimens $10 \mathrm{~mm}$. in length that Baly speaks of), and close and uniform puncturation. Baly's description refers to the female only. The terminal joints of the antennæ are more than usually dilated in this species. 
782. Colasposoma transversicolle, Jac. Amn. Mus. Civ. Genova, xxrii, 1889, p. 176.

Metallic green or blue; basal joints of antennæ (first excepted) fulvous, rest black.

$0^{*}$. Head longitudinally strigose at the vertex, strongly and moderately closely punctured on the lower portion, the space between the eyes with a small depression; the anterior margins of the clypeus deeply concave-emarginate; labrum fulvo-piceous; mandibles metallic green; antennæ filiform, slender, piceous or black, the basal joint metallic green, the following three joints fulvous. Thorax strongly transverse, the lateral margins strongly widened at the base, from there to the apex greatly and rather suddenly narrowed; the surface punctured like the head, more finely and very closely near the anterior margin along which are placed one or several rows of smaller punctures; the dise rather swollen. Scutellum not longer than broad, punctured at the base. Elytra with a shallow transverse depression below the base, rather closely and regularly punctured near the suture where the punctures are arranged in rows, the rest of the surface near the sides deeply and irregularly punctate, the interstices strongly transversely rugose, the apex finely punctured and without rugosities. Beneath and the legs metallic dark green; abdomen and the tarsi nearly black.

Length 5-5 $\frac{1}{2} \mathrm{~mm}$.

Hab. Burma: Bhamo ; Tenasserim : Thagatà, Meetan, Moulmein, Haungtharaw Valley.

The anterior tibiæ of the male are straight, not curved or much thickened at apex as is generally the case, the tarsi scarcely more widened than those of the female.

783. Colasposoma multipunctatum, Jac. Ann. Mus. Civ. Genova, xxvii, 1889, p, 177 .

Metallic greenish or purplish; basal joints of antennæ and labrum fulvous.

Head closely, finely and evenly punctured, the vertex with a more or less distinct longitudinal groove; the clypeus not separated from the face; labrum fulvous; mandibles cupreous; antennæ fulvous, with the terminal joints slightly dilated, the apical four or five joints fuscous. Thorax twice as broad as long ( $\sigma^{\circ}$, nearly three times as broad as long ( $q$ ), the lateral margin rounded at the base, rather suddenly narrowed towards the apex, the surface transversely convex, with a very obscure anterior transverse depression; the disc light cupreous, the extreme lateral margins metallic green, crowded with small punctures which are still more closely placed at the sides, the middle of the dise with a very narrow longitudinal smooth line. Scutellum as broad as long, impunctate. Elytra slightly transversely depressed below the base, more strongly and not quite 
so closely punctured as the thorax, the punctures arranged in irregular rows; the interstices also very minutely punctured, transversely rugose at the sides, the rugosities assuming the shape of tubercles behind the middle near the lateral margin ( 9 ). Underside and legs piceous, with a slight metallic gloss.

Length 4-5 mm.

Hab. Burma: Teinzo, Bhamo.

Very closely allied in sculpture to $C$. albovillosum, Duv., but without any pubescence and the punctures on the thorax and elytra still more numerous, finer and more evenly distributed; the colour of the antenne also differs; the scutellum is nuch smaller and scrrcely punctured. The difference in the width of the thorax in the sexes is very great: in both this part has a distinct reflexed lateral margin, the latter is also subangulate behind the middle.

As regards the male, the species is very difficult to distinguish from $C$. asperatum, Lefèv., and may possibly be identical with it, but Lefère's description is too general for a more certain identification.

\section{Elytra strongly depressed below base.}

\section{Colasposoma bicoloratum, sp. n.}

Dark violaceous; elytra cupreous.

Head closely punctured and strigose above the eyes; base of clypeus rugose, with the usual tubercle; labrum black; antenuæ long and slender, basal six joints purplish, rest black, terminal joints elongate, only slightly thickened. Thorax more than twice as broad as long, sides very strongly rounded, puuctures finer than those on the head, very closely placed aud evenly distributed, not deeper and more distantly arranged at the sides. Scutellum purplish-blue, with a few punctures. Elytra wider at base than the thorax, punctures as fine as those on the thorax, arranged in rows; sides below shoulders with a distinct transverse depression, more deeply punctured and rugose. Legs violaceous blue; anterior tibiæ of male strongly widened at the apex.

Length $8 \mathrm{~mm}$.

Hab. Bombay (Coll. Jacoby).

Closely allied in coloration to $C$. pretiosum, Baly, but the sculpture quite different, that of the thorax less closely placed, of the elytra arranged in rows, much finer; the interstices not finely rugose.

785. Colasposoma pretiosum (Pl. II, fig. 7), Baly, Journ. Ent. i, 1860 , p. 36.

Colasposoma thibettanum, Jac. Entomologist Suppl. 1891, p. 35.

Metallic blue or violaceous; antennæ and tarsi black; elytra reddish-cupreous.

3. Broadly subquadrate-oblong. Head closely punctured, vertex strigose at the sides; three small smooth metallic green tubercles

voL. I. 
placed in a triangle at base of clypeus, this portion slightly rugose ; antennæ with the terminal joints widened, basal five metallic blue or greenish, third and fourth equal. Thorax nearly three times as broad as long, sides strongly rounded, surface convex, punctured like the bead. Scutellum violaceous, sparingly punctured. Elytra with deep transverse depression below the base, scarcely more strongly punctured than the thorax, punctures mostly arranged in irregular rows, interstices finely wrinkled in places and aciculate.

ㅇ. Elytra transversely rugose at sides near base, with a longitudinal costa near the lateral margins.

Length $6 \frac{1}{2}-8 \mathrm{~mm}$.

$H a \dot{b}$. Darjeeling; Nilgiris; Assam : Khási Hills; Tibet.

$A$ large and bandsome species, with dark blue thorax and bright cupreous elytra; there seems to be no difference between the Indian specimens and those from Tibet described and previously considered distinct by me. Lefèvre gives $C$. auripenne, Motsch., as a synonym of this species, but neitber the size nor the coloration of the elytra as given by that author agrees with Baly's insect.

\section{Colasposoma robustum, Jac. P. Z. S. 1881, p. 446.}

Metallic green; elytra with the margins narrowly and a transverse band below the base purplish, entirely dark blue or copper on the upper surface.

б. Broad and robust. Head not very strongly or closely punctured, without strigæ; clypeus separated by a triangular, subrugose depression from the face; antennæ bluish-black, last five joints black, moderately widened, basal three or four joints metallic blue, third and fourth equal. Thorax more than twice as broad as long, sides rounded, surface moderately strongly and closely punctured. Scutellum subquadrate. Elytra with a short transverse depression below the base, rather more finely punctured than the thorax, interstices finely aciculate here and there. Tibiæ strongly curved and dilated at apex.

ㅇ. Elytra with basal depression more strongly marked and punctured, also strongly transversely wrinkled; tibiæ straight.

Length $8-10 \mathrm{~mm}$.

$H a b$. Southern India: Malabar coast; Nilgiris ; Ceylon.

Very variable in coloration, sometimes metallic cupreous above and beneath. Can be separated by the fine puncturation of the head, thorax and elytra and the want of rugosities on the head. Both sexes have an elytral depression, but in the male this is feeble and has only a few deeper punctures; the purplish band on the elytra is generally found in the female only.

7o i. Colasposoma uigriventre, Baly, Trans. Ent. Soc. (3) iv, 1867, p. $2 \% 3$.

Metaliic green, cupreous or blue; abdomen black; labrum and basal joints of antennæ fulvous; tarsi piceous. 
0. Head closely and rather strongly punctured; clypeus strongly rugose at base, with an elongate tubercle at the middle of the latter; surface strongly rugosely punctured ; antennæ with distinctly thickened terminal joints, basal joint metallic, following four or five joints dark fulvous, rest blackish, terminal joint elongate, third rather longer than the fourth. Thorax more than twice as broad as long, scarcely narrowed anteriorly, sides rounded; surface finely and closely punctured, punctures slightly larger and partly confluent at the sides, those on the disc finer than the punctures on the head. Scutellum very broad, half as broad again as long. Elytra about two and a half times longer than the thorax, with a distinct but short depression below the base, interior of depression strongly punctured, rest of surface very finely punctured in irregular rows, these rather distantly placed at base but closer and irregular towards apex. The male organ is strongly curved, very gradually narrowed anteriorly, the upper cavity is elongate and bounded by an acute ridge or edge.

․ The elytra more closely and strongly punctured although comparatively finely so, but the punctures are larger than those on the thorax; the rugosities at the sides of the elytra are scarcely more strongly developed than those in the male.

Length $4 \frac{1}{2} \mathrm{~mm}$.

Hab. Bengal; Pondicherry; Bangalore; Assam; Burma; Ceylon; Sumatra.

Specimens from Ceylon are generally metallic cupreous in colour. The species seems closely allied to C. splendidum, Fabr., which is a doubtful species, but according to Baly an insect of $7 \mathrm{~mm}$. in length. This author in his description of Fabricius's supposed species makes no mention of the sex he had before him, without which no recognition of a species in this genus is certain. One of the principal characters of distinction is the black abdomen. I cannot find sufficient differences between the type from Sumatra and the Indian specimens to warrant their separation.

788. Colasposoma splendidum, Fabr. (Chrysomela) Ent. Syst. i, 1792, p. 324; Baly, Trans. Ent. Soc. (3) iv, 1867, p. 275.

Metallic green or blue; antennæ, palpi and tarsi black.

$\delta$. Head finely and remotely punctured, finely strigose above the eves ; clypeus with a deep fovea at base; basal joint of antennæ metallic blue or green, terminal five joints slightly thickened, longer than broad, third and fourth equal. Thorax more than twice as broad as long, sides strongly rounded, disc evenly and finely punctured. Elytra with short depression below base, rugose within the depression, rest of disc punctured like the thorax, the punctures irregularly placed. Body and legs metallic green. The male organ is short, only moderately curved, with high lateral ridges, the apical portion is strongly deflexed and gradually terminates in a point.

$$
\text { Length 6-7 mm. }
$$


$H a b$. "India or."; also Java and other Malayan islands.

In this species the puncturation of the elytra is very fine and not very closely arranged, but it is somewhat doubtful whether the description above would apply to the specimen on which Fabricius founded his type more accurately than to one or other of the elosely allied species belonging to this puzzling group.

789. Colasposoma asperatum *, Lejèv. Cat. Eumolp. 1885, p. 104, note 2 .

"Metallic green, æneous or bluish-black; labrum and antennæ fulvous, terminal joints of

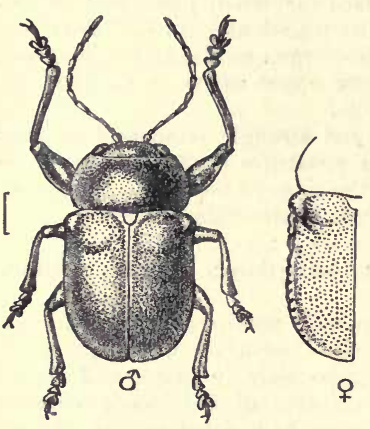

Fig. 156.-Colasposoma asperatum. latter often dark; legs sometimes fulvous.

" $\sigma$. Head and thorax densely punctured, the latter transversely depressed behind the anterior margin, sides rounded and margined; tarsi fuscous. Elytra transversely depressed below the shoulders, densely punctured, sides finely substrigose ; anterior tibiæ dilated at apex.

“ $\%$. Elytra more strongly depressed below shoulders, sides strongly strigose, a row of tubercles placed near the margins extending from shoulders nearly to apex." (Lefevre.)

$$
\text { Length } 4_{4}^{3}-6 \mathrm{~mm} \text {. }
$$

Hab. Bengal ; Burma; extending to China.

The above description as given by Lefèvre is scarcely detailed enough for certain recognition of the male, while the female is better distinguished on account of the rows or row of tubercles at the sides of the elytra. In the male of the Indian specimens which I refer to this species the thorax is proportionately wide,

* Colasposonia prostermale, Jac. Ann. Soc. Ent. Belg. xl, 1896, p. 303.

It is somewhat doubtful whether this species is specifically distinct from C. asperatum as far as the male is concerned, as I have not seen the type of the latter and the description is too vague to be certain. The female, however (if this is rightly referred to the same species, $C$. prosternale), certainly differs from that of $C$. asperatum in having the sides of the elytra simply rugose not tuberculate. In all other respects the two species are identical. In C. prosternale the male organ seems also to differ from that of the allied species, instead of its being strongly curved it is more slender and straight, the apex is widely opened and contains a kind of hardened tubercle: this is the same in the two specimens dissected.

The species has been obtained at Tharawaddy in Burma, and Mandar in Bengal, also in the Andaman Islands ( $q$ q). 
with very strongly rounded sides and a deeper transverse depression near the middle behind the anterior margin than is generally found in other species.

The male organ is strongly curved, terminating in an acute point preceded by an elongate shallow cavity.

790. Colasposoma andrewesi, Juc. Ann. Soc. Ent. Bely. xxxix, 1895, p. 272.

Dark violaceous blue or cupreous ; basal joints of antennæ and the labrum fulvous.

ㅇ. Head finely aud noderately closely punctured, the punctures well separated; clypeus very obsoletely separated from the face; latter without tubercle or groove; antennæ with the basal six joints fulvous, rest black or entirely fulrous, third and following two joints equal, terminal joints elongate, scarcely widened. Thorax twice as broad as long, sides rounded; surface strongly, closely and evenly punctured, but the intervals between the punctures much wider than the punctures, sides rather more closely punctate. Scutellum broader than long, distinctly punctured. Elytra with some rows of strong punctures near the suture only, rest of the disc occupied by two or three rows of acute tubercles, extending but decreasing in number towards the apex. Breast and legs metallic æneous, abdomen dark; femora sometimes dark fulvous, unarmed.

Length 4-5 mm.

Hab. Burma: Paungdé, Moulmein.

Very closely allied to C. asperatum, but differs in the much more numerous elytral tubercles which in the present insect form several rows. It is possible, however, that this form may be only a local race. The male is unknown.

Species with cupreous or purplish bands, glabirous above.

791. Colasposoma ornatum, Jac. P. Z. S. 1881, p. 445.

Var. obscurofasciatum, Jac. Ann. Soc. Ent. Bely. xxxix, 1895, p. 273.

Beneath blackish, above aureo-cupreons; margins of ely tra and an angulate longitudinal band on the disc of latter, blue or purplish.

o. Head very closely and rather strongly punctured, strigose abore the eyes; clypeus punctured like the head; antennæ black, basal joint metallic, third joint longer than the fourth, terminal joint widened. Thorax twice as broad as long, sides round; surface cupreons, punctured like the head, the margins more or less purplish-blue. Scutellum subquadrate, with a few punctures. Elytra very tinely and irregularly punctured near the suture, more strongly and less closely so at the sides, scarcely perceptibly depressed below base. Breast and legs dark cupreous; abdomen nearly black.

+ . Larger ; sides of elytra more strongly punctured, more distinctly depressed and with rugose interstices below the shoulders. 
Var. Above metallic dark green or blue; thorax with purplish margins; elytra with purplish band as in typical form.

Length 5-7 $\mathrm{mm}$.

$H a b$. Southern Bombay: Belgaum; Sangir.

Not unlike some forms of $C$. pulcherrimum, but with longer and more pronounced purplish elytral band, which extends angularly nearly to the suture at the base. C. aureo-vittatum, Baly, has differently sculptured upper surface. In the variety, which I formerly considered a distinct species, the elytra are entirely blue with a darker purplish band, but there is no structural difference of importance.

792. Colasposoma auripenne (Pl. II. fig. 9), Motsch. in Schrenck, Reise Amur. ii, p. 179 (1860).

Colasposoma pulcherrimum, Baly, Descript. new gen.\&s sp. Phytoph. 1864 , p. 15.

Colasposoma mutabile, Baly, Trans. Ent. Soc. (3) iv, 1867, p. 273.

Metallic green, æueous or purplish; antennæ (base excepted) black; elytra aureous, trigonal patch below base and the suture and margins purplish-blue.

$\delta$. Head strongly and rather closely punctured, with raised strigæ on the sides above the eyes; clypeus strongly punctured, a distinct tubercle placed at the middle of its base; antennæ with the apical five joints distinctly widened. Thorax twice as broad as long, sides rounded, surface strongly and closely punctured, more conspicuously at sides than at middle. Scutellum subquadrate, sides oblique and pointed at apex. Elytra scarcely perceptibly depressed below base, more strongly punctured than the thorax; punctures very closely placed in irregular rows, larger on the side below the shoulders, the interstices at the latter place slightly rugose.

$q$. Head strongly rugosely-punctured and strigose, puncturation of thorax and elytra more closely placed than in the male, sides of elytra strongly rugose and wrinkled.

Var. Above metallic green, elytral purplish spot obscure.

Length $4 \frac{1}{2}-5 \mathrm{mim}$.

Hab. Amur; India ; Burma ; Andaman Islands ; Malayan Subregion; China.

I identify this as C. auripenne of Motsch. It is comparatively easy to distinguish in the typical form, which has the elytra blue, the sutural and lateral margins and transverse spot below base purplish. The species must not be confounded with C. ornatum, Jac. nor C. aureovittatum, Baly, in both of which the sculpture is quite different. C. mutabile, Baly, does not seem to differ, and as the type of $C$. pulcherrimum, but not of $C$. mutabile, is in this author's collection, the insect has evidently been described in error under two different names.

The specimens from the abore different localities show no marked differences, nor can I find any in the male genitalia. 
793. Colasposoma aureovittatum, Baly, Descript. new gen. \& sp. Phytoph. 1864, p. 14.

Metallic green; basal joints of antennæ fulvous; thorax with a transverse cupreous band; elytra with a broad longitudinal band near suture and another near margins, aureo-cupreous.

$\delta$. Head closely and rather strongly punctured; labrum fulvous; antennæ filiform, terminal joints not thickened, basal joint metallic green, third and fourth equal. Thorax quite twice as broad as long, sides rounded, surface strongly convex, crowded with oblong deep punctures evenly distributed. Elytra oblong, very closely and rather irregularly punctured, punctures fine near suture, strong and more regularly arranged in rows at the sides, base with a very feeble depression below shoulders.

ㅇ. Thorax more narrowed in front; elytra with deep transverse lateral depressions at base, sides strongly transversely rugose to behind the middle.

Length $5 \frac{1}{2}-6 \mathrm{~mm}$.

$H a b$. India ; Assam,

Closely allied in coloration to C. ornatum, Jac., but the elytra are more strongly punctured and rugose, and the longitudinal bands are cupreous instead of purplish.

794. Colasposoma versicolor, Lefêv. Bull. Soc. Ent. France, 1887, p. clxxiv.

Colasposoma bifasciatum, Jac. Mém. Soc. Ent. Belg. vii, 1900, p. 116.

A bove metallic green, elytra with a narrow reddish-cupreous longitudinal band; beneath obscure greenish-æneous; antennæ and legs fulvous, knees metallic æneous.

ठ. Head closely and finely punctured, without strigæ ; clypeus obsoletely separated from face, punctured like the head; labrum fulvous ; antennæ slender, third and following joints very elongate, nearly equal, basal five fulvons, rest black. Thorax twice as broad as long, convex, sides rather strongly rounded near base, slightly narrowed towards apex, surface with similar puncturation to that on the head, but with a narrow central smooth line. Elytra not wider at base than the thorax, strongly and closely punctured, base with a scarcely perceptible depression, interstices closely transversely rugose at the sides extending across disc nearly to the middle, punctures arranged in somewhat regular rows near the suture; a cupreous longitudinal band extends from base to within a short distance of the apex, this band gradually narrows and approaches towards the suture near the apex. Abdomen obscure cupreous; tarsi fuscous.

$\$$. Thorax less strongly transverse, only feebly convex, sides more distinctly narrowed in front; tibiæ not dilated at apex; legs more or less æneous.

Length 5-6 mm.

$H a b$. Southern India: Madura; Nilgiris. 
Closely allied in coloration to banded forms of $C$. villosulum, Lefèv., but without any pubescence, the thorax perceptibly more strongly punctured and the punctures more widely separated; also much like $C$. downesi, Baly, but in that species the elytra] rugosities do not extend so far inwards nor downwards and the puncturation is finer and closer, also the, elytra are without the narrow cupreous bands.

\section{Group EDUSINI.}

Elongate, head immersed in thorax. Thorax subconical with distinct lateral margins. Elytra generally transversely rugose at sides. Tibiæ not emarginate at apex, claws appendiculate. Prosternum oblong. Anterior margin of thoracic episternum convex.

\section{Genus ABIRUS.}

Abirus, Chapuis, Gen. Coléopt. x, 1874, p. 310; Lefèv. Cat. Eumolp. 1885, p. 113.

Type, $A$. coneus, Wiedem., from Java.

Range. India, China, and Malayon Subregion.

Characters those of the group. Body elongate and subcylindrical, with strongly developed elytral rugosities, sometimes pubescent above. Antennæ with terminal joints more or less widened. Thorax broader than long, with rather straight sides and pointed anterior angles. Legs somewhat robust; tibiæ gradually but slightly widened towards apex; first joint of tarsi triangular, shorter than the following two united; claws appendiculate.

The forms in this genus are very similar in shape and appearance to those belonging to the genus Dermorhytis, but differ in that the sides of thorax are not angulate and the anterior margin of the episternum is convex not concave.

795. Abirus angustatus, Lefev. Bull. Soc. Ent. France, 1887, p. clxxv.

"Body beneath brownish-æneous, above finely pubescent, greenish or cupreous; labrum, palpi and anternn brownishtestaceous, tarsi blackish.

" Oblong-elongate, parallel-sided. Head densely substrigosely punctured. Thorax nearly twice as long as broad, densely punctured, punctures uneven in size. Elytra below base scarcely perceptibly impressed, regularly punctate-striate near suture, outer disc densely transversely substrigose, very minutely pubescent towards apex.

“ Length $5 \frac{1}{2}-6 \mathrm{~mm}$.

"Hab. Hindustan : Rbamnad." (Lefèvre.) 
I know no species of Abirus with a thorax nearly twice as long as broad, and I am unable to refer any Eastern form known to me to Lefèvre's species.

\section{Abirus elongatus, sp. n. (Pl. II, fig. 10).}

Obscure cupreous or greenish; antennæ and legs fulvous; beneath obscure æneous, finely pubescent.

ऽ. Very narrow and elongate. Head densely punctate and rugose throughout; labrum fulvous; antennæ scarcely extending to middle of elytra, third to fifth joints rather elongate, nearly equal, sixth much shorter, apical joints more or less stained with fuscous. Thorax subcylindrical, half as broad again as long, sides straight; surface densely punctured, punctures not larger than those on the head; interstices very minutely and sparingly punctate, transversely rugose at the sides. Scutellum broader than long, impunctate. Elytra closely and finely punctate-striate near the suture, transversely rugose at the sides from base to apex. Legs fulvous or obscure æneous.

\section{Length $5 \frac{1}{2}-6 \frac{1}{2} \mathrm{~min}$.}

Hab. Siknim : Kurseong (Colls. Brussels Mus. \& Jacoby).

Very closely allied to $A$. angustatus, Lefèv., but the thorax broader than long, the tarsi not black; more narrowly elongate than any of the allied Indian species, sometimes æneous above or green with cupreous lateral margins or entirely cupreous.

\section{A birus rubripes, Lejèv. Cat. Eumolp. 1885, p. 114, note 1 .}

"Beneath subcupreous-æneous, above bright metallic green, sometimes golden cupreous; labrum, palpi, antennæ and legs rufofulvous. Thorax closely punctured, finely strigose at the sides. Elytra somewhat regularly punctate-striate on the inner dise, sides more strongly and irregularly so, interstices transversely rugose.

"Length $4 \frac{1}{2}-5 \mathrm{~mm}$.

"Hab. Ceylon." (Lefèvre.)

The above description is not detailer enough for certain identification of the species.

799. A birus andamansis, Lefìv. Bull. Soc. Ent. Belg. xxxv, 1891, p. celxix.

"Greenish-æneous or æneous; labrum, palpi and antenuæ fulvotestaceous, terminal five joints of the last fuscous ; body beneath and legs piceous.

"Oblong-elongate, subcylindrical. Head strongly punctured, substrigose behind the eyes, a smooth narrowly elongate space on the middle of the front. Thorax much wider than long, sides nearly straight, surface convex, strongly punctured. Scutellum 
smooth. Elytra scarcely perceptibly depressed below base, very strongly punctured, at sides finely transversely strigose, sparingly longitudinally costate; shoulders prominent, densely punctured. Head and thorax with short golden hairs, elytra with rows of erect golden pubescence.

"Length 7-8 mm.

"Hab. Andaman Islands." (Lefèrre.)

799. Abirus igneicollis, sp. $n$.

Dark blue or violaceous; antennæ and legs nearly black; head, thorax and scutellum golden cupreous.

․ Head closely semirugosely punctured; clypeus distinctly separated from the face, punctured

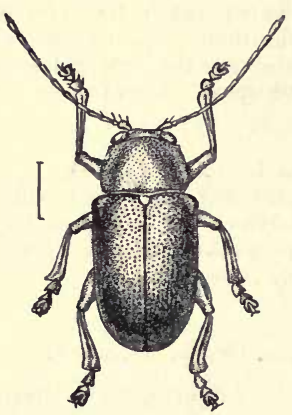

Fig. 157.-Abirus igneicollis. like the head; labrum, palpi and mandibles piceous; antennæ with the terminal five joints very elongate and slightly dilated, third and fourth equal, slender, last joint reaching beyond the middle of the elytra. Thorax subcylindrical, strongly transverse, the lateral margins rather strongly rounded at the middle, anterior angles produced into an acute point; the surface extremely closely and evenly punctured, the punctures more crowded at the sides, the interstices at the latter place wrinkled, those on the disc impressed with some very minute punctures. Scutellum bright cupreous, smooth. Elytra wider at the base than the thorax, subcylindrical, the shoulders prominent, deeply impressed within; the puncturation very similar to that of the thorax, the interstices below the shoulders transversely rugose as far as the middle; the suture near the apex accompanied by a deep, short, elongate sulcus. Posterior tibiæ strongly widened at the apex; claws appendiculate. Prosternum subquadrate; anterior margin of thoracic episternum convex.

6. Antennæ with the terminal five joints broadly dilated.

Var. Above entirely dark blue or cupreous.

Length $7-7 \frac{1}{2} \mathrm{~mm}$.

Hab. Burma (Coll. Brit. Mus.).

This is a species in which the sexes differ greatly in the structure of the antennæ, a rare occurrence in this genus. The male is as usual further distinguished from the female by the dilated first joint of the anterior tarsi. 


\section{Abirus ceylonicus, sp. $n$.}

Piceous, head and thorax with slight æneous gloss; legs fulvous.

- Head extremely closely and rather finely punctured; clypeus not separated from the face, its anterior margin slightly concave; labrum fulvous; antennæ slender, scarcely extended to the middle of the elytra, piceous. Thorax about twice as broad as long, sides only slightly deflexed, lateral margins feebly rounded, the surface punctured like the head. Elytra subcylindrical, the shoulders tuberculate, the surface strongly transversely rugose, without punctures, the sides with three or four longitudinal rows of tubercles. Legs dark fulvous. Body beneath with greenish gloss, finely pubescent and punctured.

Length $6 \frac{1}{2} \mathrm{~mm}$.

Hab. Ceylon (Coll. Jacoby).

Well distinguished from any of its allies by the sculpturing of the elytra.

\section{Group MYOCHROINI.}

Body clothed with scales or hairs, subcylindrical or oblong in shape. Antennæ subfiliform or with strongly thickened terminal joints. Thorax with distinct lateral margins. Prosternum often provided with grooves at the sides for lodging the antennæ. Tibiæ often emarginate at apex, claws appendiculate.

This group contains a number of genera which possess most varied structural characters, although all have in common a convex shape of the anterior thoracic episternum and a pubescent or scaly upper surface. The Indian genera, however, are but few and not difficult to separate.

Key to the Gener of Myochroini.

A. Intermediate and posterior tibiæ emarginate at apex..$\ldots \ldots \ldots \ldots \ldots$

B. Intermediate and posterior tibiæ not emarginate at apex.

a. Colours metallic.

$a^{\prime}$. Scutellum transverse

$b^{\prime}$. Scutellum oblong.

$a^{2}$. Last joint of antennæ longer than broad ...................

$b^{2}$. Last joint of antennæ broader than long $\ldots \ldots \ldots \ldots \ldots \ldots \ldots . . .$.

b. Colours non-metallic ................ Le LopheA, p. 462.

Eurypeita, p. 464.

PachNerhole ts, p. 460.

Acrothinium, p. 461.

Heter otrichus, p. 463. 


\section{Genus PACHNEPHORUS.}

Pachnephorus, Redtenb. Fauna Austr. i, 1848, p. 569 ; Baly, Journ. Ent. ii, 1865, p. 436; Chapuis, Gen. Coléopt. x, 1874, p. 323 Weise, Ins. Deutschl. 1893, p. 282.

Type, $P$. pilosus, Rossi, from Europe.

Range. All parts of the world, except Australia.

Elongate, nearly cylindrical, sparingly or moderately pubescent. Head deeply inserted in thorax; eyes small; antennæ about half as long as the body, terminal joints strongly thickened, as broad as long. Thorax subcylindrical, nearly as long as broad, narrower than the elytra, with distinct lateral margins, the anterior margin rather strongly produced in the middle. Elytra generally punctatestriate, the surface often clothed with scale-like pubescence or true hairs. Prosternum oblong with deep grooves at the sides for the reception of the antennæ. Mesosternum short and transverse. First abdominal segment as long as the rest of the segments united. Legs moderately stout, pubescent or clothed with scales; intermediate and posterior tibiæ more or less distinctly emarginate at their apices; claws appendiculate (in some European species simple).

801. Pachnephorus bretinghami, Baly, Jou'n. Linn. Soc., Zool. xiv, 1878, p. 256.

Pachnephorus plagiata, Jac. Ann. Mus. Civ. Genova, xxxii, 1892, p. 913.

Piceous with æneous gloss, clothed with whitish scales; antennæ and legs obscure rufo-piceous.

Head strongly punctured; excavated between eyes; clypeus transverse, thickened at the base. Antennæ about a third the length of the body, terminal five joints fuscous. Thorax scarcely broader than long, sides straight and diverging from base to far beyond the middle, thence rather abruptly rounded and converging to the apex, above convex, subcylindrical, deeply punctured; clothed with deeply bifid, narrowly oblong, adpressed scales. Elytra broader than the thorax, convex, deeply excavated below basilar area, deeply and coarsely punctate-striate, puncturation rather finer towards the apex; surface clothed with similar scales to those on the thorax, forming here and there illdefined patches.

Length $2 \frac{1}{2} \mathrm{~mm}$.

Hab. Bengal: Pusa ; Calcutta; Burma: Bhamo; Sumatra.

The general ground-colour is piceous (not black as given by Baly) with more or less æneous gloss. In well preserved specimens the elytra have a number of small whitish pubescent spots. The 
species is of somewhat broad, flattened shape. On more carefully comparing my $P$. plagiata with Baly's type $I$ find that it cannot be separated.

802. Pachnephorus impressus, Rosenh. There Andal. 1856, p. 310.

Pachnephorus convexicollis, Baly, Trans. Ent. Soc. Lond. (3) iv, 1867 , p. 95 .

Dark æneous or cupreous. Head coarsely and closely punctured ;

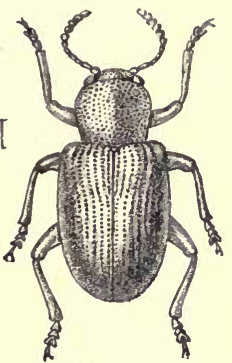

Fig. 158.

Pachnephorus impressus. anterior border of clypeus distinctly angulate-emarginate, hinder margin not thickened, surface coarsely punctured. Thorax broader than long, very convex above, coarsely and closely punctured, clothed with bifid scales; sides obliquely divergent from base to beyond the middle, thence sharply rounded and convergent to apex; middle of disc glabrous. Elytra oblong-orate, subcylindrical, strongly and closely punctate-striate, interstices clothed with white scales that form small spots. Antennæ, tibiæ and tarsi more or less fulvous.

Length $2 \frac{1}{2} \mathrm{~mm}$.

Hab. Europe; Africa; India: Bengal ; Philippines; Macassar.

Much more elongate and narrowly subcylindrical than $P$. bretinghami, the thorax strongly constricted at base, sides distinctly angulate before middle. The species seems to have a wide geographical distribution if indeed all really represent the same form, but I am quite unable to separate Baly's type in the Brit. Mus. from the European species; this latter has also been recorded as occurring in Ashanti (Weise, Ins. Deutschl.).

\section{Genus ACROTHINIUM.}

Acrothinium, Marshall, Journ. Linn. Soc., Zool. viii, 1864, p. 47; Baly, Jour'n. Ent. ii, 1865, p. 441; Chapuis, Gén. Coleopt. 1874, p. 315; Lefêv. Cat. Eumolp. 1885, p. 11\%.

Ty pe, A. gaschkevitchi, Motsch., from China.

Range. India; Japan; China.

Body subquadrately ovate, sparingly pubescent, hairs suberect. Head broad, deeply inserted; eyes round, feebly sinuate. Antennæe scarcely extending to middle of body, terminal joints distinctly dilated. Thorax transversely subquadrate. Elytra wider at base than the thorax. Tibix not emarginate at apex but abruptly widened; tarsi short, triangular; claws appendiculate. Prosternum broad, scarcely longer than broad, widened at the base. 
803. Acrothinium violaceum (Pl. II, fig. 1), Jac. Ann. Mus. Civ. Genova, xxvii, 1889, p. 180.

Dark violaceous blue; clothed with thin whitish pubescence; antennæ and tarsi black.

Head very closely and deeply punctured, with a short longitudinal groove between the eyes; the clypeus separated from the face by a deep transverse groove, strongly punctured; labrum black. Antennæ black, with the last six joints dilated and compressed. Thorax subcylindrical, about half as broad again as long, the sides nearly straight, the anterior angles strongly produced forwards, the surface deeply and rather closely punctured, sparingly clothed with whitish pubesence. Scutellum finely punctured at the base, its apex broadly rounded. Elytra convex, narrowed near the apex, the base slightly raised and bounded below by a shallow transverse depression; the disc deeply impressed with round punctures arranged in very close longitudinal rows, the interstices also very minutely punctate and clothed with rather long whitish hairs. Femora with a very sbort tooth; tibiæ entire; claws appendiculate. Anterior margin of the thoracic episternum convex. Underside sparingly pubescent.

Length 5-6 mm.

Hab. Tenasserim : Thagatà.

The uniform dark metallic violaceous colour separates the present species from the other two forms now known of this genus; the thorax is of a more blackish-blue than the elytra.

\section{Genus LOPHEA.}

Lophea, Baly, Journ. Ent. ii, 1865, p. 441; Chapuis, Gcn. Colépt. x, 1874, p. 316 ; Lefêv. Cat. Eunolp. 1885, p. 117.

Type, L. melancholica, Baly.

Range. Burma.

Body subelongate, parallel-sided, subcylindrical, non-metallic, clothed with coarse, suberect hairs. Head deeply buried in the thorax; eyes entire; antennæ subfiliform, terminal five joints slightly thickened and compressed, first joint incrassate, second short, third to sixth slender, equal, each rather longer than the first. Thorax transversely convex, subglobose on disc, lateral border distinct, entire. Elytra broader than thorax, subcylindrical, coarsely punctured. Legs robust, femora simple, intermediate tibiæ entire at apex, not notched; basal joint of tarsus narrower than the second joint, the latter triangular, the third broad at base, transverse; claws appendiculate. Prosternum united with the episternum in a single piece, the latter wedge-shaped.

Differs from Acrothinium in the non-metallic coloration and more elongate shape, by the different lengths of the basal joints of the antennæ, and by the difference in shape of the tarsal joints. In Lophea the third joint is distinctly broader than the first, the 
second closely articulated with the third, the two conjointly being heart-shaped; in Acrothinium the three joints are of equal width, the second is less closely articulated with the third.

\section{Lophea melancholica, Baly, Journ. Ent. ii, 1865, p. 442.}

Black or bluish-black, subnitidous.

Head rugose, front impressed with a longitudinal groove; clypeus

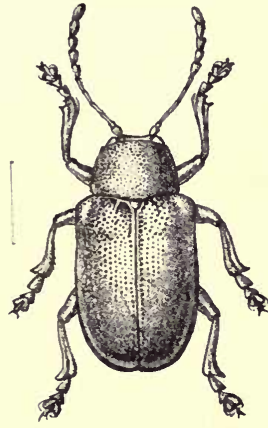

Fig. 159.

Lophea melancholica. transverse, anterior margin slightly concave; antennæ two-thirds the length of the body, terminal five joints compressed, slightly dilated forming a elub. Thorax about onethird as broad again as long, very convex, sides parallel, sinuate posteriorly, convergent in front, angles acute; surface coarsely punctured, sometimes with a smooth longitudinal middle line. Scutellum somewhat ovate, smooth, concare. Elytra parallelsided, apex broadly rounded, surface obsoletely impressed below basilar area, coarsely punctured, clothed like the rest of the body with coarse griseous hairs. Legs robust, all the tibiæ dilated externally at apex. Breast and abdomen more finely punctured than the upper surface, clothed with silvery pubescence. Length $10 \mathrm{~mm}$.

Hab. Burma (Coll. Brit. Mus.).

\section{Genus HETEROTRICHUS.}

Heterotrichus, Chapuis, Gen. Colépt. x, 1874, p. 316 ; Lefêv. Cat. Eumolp. 1885, p. 118.

Type, $H$. balyi, Chapuis, from Siam.

Range. Burma; Siam.

Subquadrate, pubescent. Head and eyes partly inserted in thorax, clypeus not separated from the face. Antennæ scarcely extending to the middle of the elytra, basal joint globular, third to the sixth more elongate and slender, following joints broadly dilated and flattened, broader than long. Thorax transverse, convex, subquadrate, sides feebly rounded. Scutellum subovate. Elytra much wider at base than the thorax, very convex. Legs moderately long; femora fusiform, with a small tooth beneath ; tibiæ dilated at apex, entire, longitudinally sulcate; tarsi broadly subtriangular, equal; claws appendiculate. Prosternum subquadrate, with gruove at the sides for reception of part of the antennæ. 
This genus differs from Acrothinium and Lophea in the very broadly dilated apical joints of the antennæ, the more dense pubescence which consists of short and long hairs, the dentate femora and prosternal grooves.

805. Heterotrichus balyi (Pl. II, fig. 2), Chapuis, Gen. Colépt. x, 1874, p. 317 , note 1 .

Black; elytra golden cupreous; the suture and a broad angulate band placed near base and sides bluish-black.

Head closely rugosely punctured and finely pubescent. Thorax closely but not rugosely punctate and pubescent. Elytra punctured like the thorax and with silvery short and longer suberect black pubescence; the bluish band placed below base, very broad and extending at right-angles downwards to behind the middle, rest of surface cupreous. Body beneath closely and finely punctured.

Length $6 \mathrm{~mm}$.

Hab. Tenasserim (Coll. Jacoby); Siam (Chapuis).

\section{Genus EURYPELTA.}

Euraspis, Chapuis (nec Blanchard), Gen. Coléopt. x, 1874, p. 317. Eurypelta, Lejèv. Cat. Eumolp. 1885, p. 118.

Type, E. modesta, Fabr.

Range. India.

Subquadrate-ovate. Antennæ subfiliform, about half the length of the body, basal joint thickened, second half as long as the third, the latter slightly longer than the fourth, terminal joints slightly widened, much longer than broad. Thorax transverse, wider at middle than at the sides, latter nearly straight, angles acute. Scutellum broader than long. Elytra much broader at base than the thorax, irregularly punctured, each puncture with a minute hair. Prosternum narrowed between the coxæ. Legs unarmed, tibiæ entire, first joint of tarsi slightly or not longer than the second; claws appendiculate.

The pubescence of the upper surface in this genus is so sbort as to be easily overlooked. The scutellum and the prosternum are of a different shape to those in the preceding genera, to which Eurypelta is, however, closely related.

806. Eurypelta modesta (Pl. II, fig. 3), Fabr. (Chrysomela) Ent. Syst. i, 1792, p. 323.

Eurypelta vittata, Chapuis (Euraspis) Gen. Coléopt. x, 1874, p. 318, note 1.

ð. Beneath greenish-æneous or piceous; thorax with four purple and three golden bands; elytra with alternate golden and purplish longitudinal bands.

Head closely and strongly punctured, sides purplish, the middle 
golden cupreous; antennæ black, basal joints more or less fulvous. Thorax verv deeply and closely punctured, banded alternately with purple and gold. Elytra sculptured like the thorax, punctures somewhat more regularly placed, but similar in pattern to those on the thorax.

․ Less bright in colour; elytral interstices longitudinally costate, intervals geminate punctate; pubescence rather more marked.

Length 6-8 $\mathrm{mm}$.

$H a b$. Bengal ; Mysore.

A handsome species and apparently not an uncommon one. Chapuis only knew the male it seems, and his diaguosis scarcely gives sufficient clue to its determination.

\section{Group ADOXINI.}

Body subcylindrical, subelongate, clothed with fine hairs or scales; head deeply inserted; eyes entire; antennæ subfiliform, terminal joints gradually widened. Thorax without lateral margins. Elytra wider at base than the thorax. Legs moderitely long; tibiæ not emarginate near the apex; claws bifid. Prosternum broader than long; anterior margin of thoracic episternum strongly convex. Two genera are placed in the group, only one of which is found in India.

\section{Genus BROMIODES.}

Bromiodes, Jac. Ann. Soc. Ent. Belg. xxxix, 1895, p. 286.

Type, $B$. indicus, Jac.

Range. India.

Subcylindrical, non-metallic, closely covered with adpressed scales; antennæ short, apical joints thickened. Thorax subcylindrical without distinct lateral margins. Femora not dentate; tibiæ entire; claws bifid. Prosternum subquadrate, broader than long ; anterior margin of thoracic episternum strongly convex.

Differs from the genus Adoxus of Furope as follows:- Shape subcylindrical; scales which cover the whole upper surface, obscuring any puncturation, much more dense.

807. Bromiodes indicus, Jac. Ann. Soc. Ent. Bely. xxxix, 1895, p. 287.

Entirely covered with greyish scales; antennæ and legs dark fulvous; thorax with whitish central line; elytra variegated with whitish spots or entirely greyish-white.

Head convex, very broad, with more or less distinct central groove; eyes widely separated; anterior maryin of clypeus nearly straight; labrum fulvous; antennæ fulvous, scarcely extending beyond base of thorax, terminal five joints thickened, slightly longer than broad. Thorax about half as broad again as long,

vOL. I. 
subcylindrical, covered with grey and brownish scales, the former prevailing more on the disc, the latter on the sides. Scutellum subquadrate, apex broadly truncate. Elytra clothed with scales like the thorax, these form sometimes pale spots and patches,

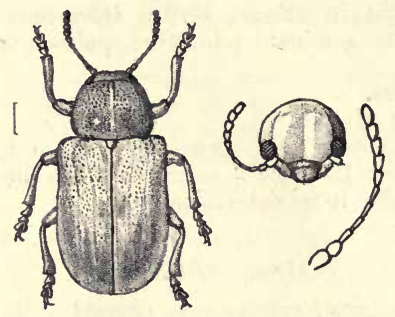

Fig. 160.-Bromiodes indicus.

two before and two behind the middle near the suture; sides and apex of elytra also more or less clothed with whitish scales. First joint of posterior tarsi not longer than the second.

Length $2 \frac{1}{2}-3 \mathrm{~mm}$.

Hab. The Himalayas: Dalhousie, Chamba.

If the scales are removed, the ground-colour is seen to be black and finely punctured.

\section{Group PSEUDOCOLASPINI.}

General shape rather short; colour metallic, upper surface more or less pubescent. Head rather produced; antennæ short and robust with thickened terminal joints. Thorax subglobular or conical, lateral margins obsolete or entirely absent. Elytra short, often flattened, with more or less distinct pubescence, often arranged in rows. Legs elongate, femora dentate; tibiæ not emarginate at apex; claws bifid. Prosternum broad, transverse, unterior margin of thoracic episternum convex.

\section{Genus PSEUDOCOLASPIS.}

Pseudocolaspis, Laporte, Silberm. Rev. Ent. i, 1853, p. 23 ; Chapuis, pt., Gen. Coléopt. x, 1874, p. 288 ; Baly, Journ. Linn. Soc., Zool. xiv, 1877, p. 248.

Type, $P$. cylindrica, Küst, from Algiers.

Range. Europe; Africa; India.

Generally metallic, more or less pubescent species of small size. Head exserted; eyes entire, globose; clypeus dentate in front; antennæ short and robust with strongly thickened terminal joints. 
Thorax subglobose, often depressed anteriorly, without distinct lateral margins. Scutellum subquadrate with a more or less pointed apex. Elytra with prominent shoulders, often depressed, pubescence frequently arranged in rows. Prosternum oblong, dilated posteriorly, base truncate ; anterior margin of thoracic episternum convex. Legs robust, femora thickened, furnished with an acute tooth beneath; tibiæ not emarginate at apex, channelled; claws bifid.

808. Pseudocolaspis longicollis, Baly, Journ. Linn. Soc., Zool. xiv, 1877, p. 259 ; Lefeve. Cut. Eumolp. 1885, p. 86.

Cupreous or metallic green; tibiæ, tarsi and antennæ piceous.

Head coarsely punctured, vertex rugulose-strigose, front with longitudinal groove; anterior margin of clypeus concave; antennæ as long as the thorax, terminal six joints pale rufo-piceous, forming an elongate club, seventh obconic and slightly compressed. Thorax about a quarter as long again as broad, sides rounded, widened at the middle; surface convex at base, thence subconic to apex, clothed with adpressed griseous hairs, deeply impressed with large

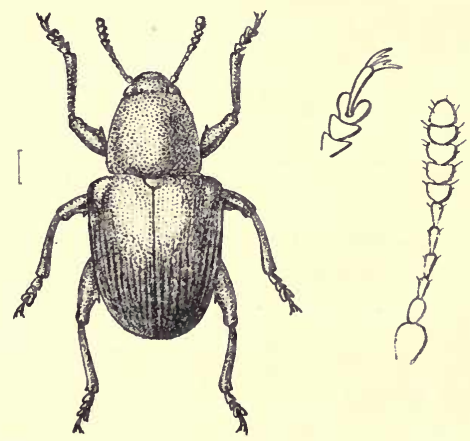

Fig. 161.-Pseudocolaspis longicollis.

round punctures. Scutellum not longer than broad, coarsely punctured. Elytra narrowed from base to apex, above convex, transversely excavated below basilar area; humeral callus strongly elevated, compressed; surface clothed with stout, suberect, griseous hairs, rather strongly punctured, punctures finer towards apex, arranged in ill-defined longitudinal rows, interstices just below base rugulose. Femora with a stout spine.

Length 3-4 mm.

$H a b$. Bengal : Mandar; Southern India 


\section{Group TYPOPHORINI.}

Body oblong or ovate, glabrous above; eyes often with a broad sulcus above; antennæ subfiliform. 'Thorax narrower than the elytra, with distinct lateral margins. Posterior and intermediate tibiæ emarginate at apex; claws bifid or appendiculate. Anterior margin of thoracic episternum convex.

This group is more strongly represented in Africa than in India, from whence only a few genera are known. The emarginate, intermediate and posterior tibiæ in connection with the shape of the thoracic episternum form the best marks of distinction for this group.

\section{Key to the Genera of the Typophorini.}

A. Claws bifid.

a. Prosternum constricted at middle ..... PARIA, p. 468.

b. Prosternum not constricted, brosd.

$a^{\prime}$. Anterior femora with a strong tooth beneath .................... Trichiona, p. 469.

$b^{\prime}$. Femora unarmed $\ldots \ldots \ldots \ldots \ldots \ldots$ Cl. Copores, p. 479.

B. Claws appendiculate.

a. Body rounded ................... Clemorina, p. 482.

b. Body oblong, subcylindrical ........... Novнotina, p. 490.

\section{Genus PARIA.}

Paria, Leconte, Proc. Acad. Nat. Sci. Phtad. ix, 1858, p. 80 ; Chamis, Gen. Coléopt. x, 1874, p. 331 ; Lefèv. Cat. Eumolp. 1885, p. 132.

Type, $P$. quadri-guttatu, from N. America.

Range. North and South America; Japan; Tibet; India.

Short and ovate; elytra punctate-striate; femora dentate beneath, all other characters those of the group. The genus differs from Mouhotina in the constricted shape of the prosternum and the bifid, not appendiculate, claws.

809. Paria leferrei, Jac. Ann. Soc. Ent. Belg. xxxix, 1895, p. 282.

Fulvous; the terminal joints
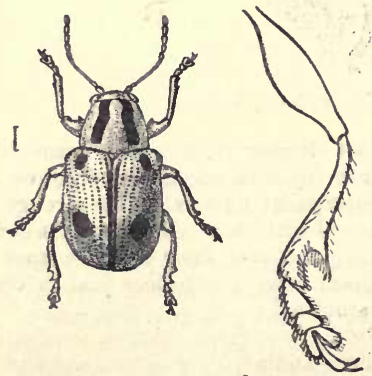
of the antennæ and the breast black. Thorax finely and sparingly punctured, with two black vittæ. Elytra distinctīy punctate-striate, fulvous, the suture anteriorly, the lateral margins a spot at the base and another behind the middle, black.

Head entirely impunctate, with a deep sulcus above the eyes; clypeus broader than long, separated from the face by an obsolete transverse groove, impunctate; antennæ Fig. 162.-Paria leferrei. with the terminal joints slightly thickened. Thorax 
fulvous, about half as broad again as long, subcrlindrical, the sides very slightly rounded, the disc sparingly punctured in the middle, the sides nearly impunctate, marked with two narrow longitudinal short black stripes from the middle of the anterior margin not extending to the base; the stripes have a slight outward direction and vary in width and length, being sometimes reduced to two small spots. Elytra subcylindrical, scarcely depressed below the base, strongly punctate-striate anteriorly, very finely so towards the middle, the apex entirely impunctate; the sutural and lateral margins, an elongate spot at the middle of the basal margin extending to one-fourth the length of the elytra and a roundish spot immediately behind the middle, placed in a line with the first, black. Underside fulvous, the breast black; femora with a small tooth; the posterior four tibiæ strongly emarginate at the apex; claws bifid. Anterior margin of the thoracic episternum strongly convex.

Var. $a$. Beneath entirely fulvous.

Var. $b$. Thorax with two small spots; elytra with basal spots only.

Var. $c$. Entirely fulvous without spots.

Var. $l$. Thorax and elytra black or only the former fulvous.

Length $2-2 \frac{1}{2} \mathrm{~mm}$.

$H a b$. Southern Bombay: Kanara; Sumatra.

This species greatly resembles P. binotata, Jac., from Mexico, and cannot easily be distinguished from that species, but the posterior spot on the elytra in the present insect is placed lower down than in the Mexican form; the general size of the latter is also larger. Mogdiliani also obtained this species in Sumatra. It is subject to a great deal of variation; the black colour of the lateral margin of the elytra is often widened at the middle, the antennæe and the entire upper surface are sometimes entirely fulvous. Again, pale fiavons specimens without spots occur, as well as those in which the entire upper surface is black or the black colour may be confined to the elytra. It is one of the most variable insects imaginable in regard to colour.

\section{Genus TRICLIONA.}

Tricliona, Lefèv. Bull. Soc. Ent. France, 1885, p. clxvii ; id. Cat. Eumolp. 1885, p. 141.

Type, T. bifasciata, Lefèv., from Sumatra.

Range. India; Ceylon; Sumatra.

Oblong-ovate; head inserted; eyes large, rather closely approximate, sinuate along the inner margins; antennæ slender, third joint twice as long as the second, terminal seven joints thicker. Thorax transverse, sides rounded, anterior and posterior angles acute. Legs moderately robust; anterior femora with a strong tooth beneath, the anterior and intermediate femora with much smaller teeth; claws bifid. Principally distinguished by the strongly dentate anterior femora. 
810. Tricliona semivittata, Baly (Nodostoma) Descr. new gen. \& sp. Phytoph. 1864, p. 13.

Fulvous; apical joints of antennæ, posterior femora and body beneath more or less piceous; elytra with a piceous longitudinal band from base to behind the middle.

Elongate. Head impunctate, with a short, central, longitudinal groove; clypeus distinctly separated from the face, broad, wedgeshaped, with rounded sides, finely punctured and granulate; antennæ with the basal four joints pale fulvous, rest piceous, slender, second joint nearly as long as the third. Thorax about half as broad again as long, slightly narrowed in front, sides

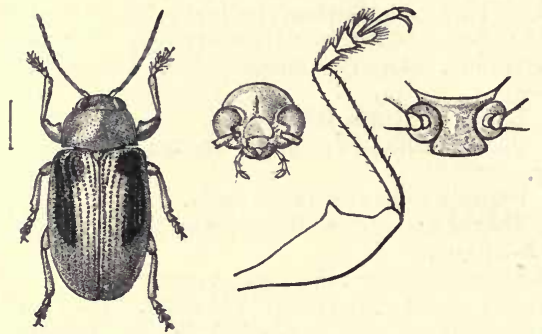

Fig. 163.-Tricliona semivittata.

feebly rounded, surface finely and rather closely punctured, punctures somewhat elongate. Elytra deeply and closely punctatestriate, sides below the shoulders irregularly punctured; the piceous band on each elytron placed between the third and seventh rows of punctures.

Length $5 \mathrm{~mm}$.

$H a b$. Southern India.

More elongate than 'T. bifasciata, Lefèv., the elytra much more strongly punctured, the stripe less elongate, the thorax without a black spot. Baly has placed this species iu Nodostoma, from which genus it is clearly separated by the convex anterior margin of the thoracic episternum and strongly dentate anterior femora.

\section{Tricliona puncticeps, Duviv. Ann. Soc. Ent. Belg. xxxv, 1891 p. xli.}

Fulvous; antennæ paler, thorax darker, reddish-brown.

Head rugosely punctured, longitudinally grooved in front; palpi testaceous; eyes large, deeply emarginate, rather closely approximate; antennæ filiform, extending to slightly below the base of the thorax, basal joint thickened, third half as long again as the second, following joints slightly thickened. Thorax transverse, sides regularly rounded, very deeply and densely punctured throughout, anterior and posterior angles pointed, the latter somewhat dentate. Elytra subparallel, narrowed towards the 
apex, deeply punctate-striate, interior of punctures dark, interstices smooth. Femora dentate, the anterior femora strongly so.

Length $4-4 \frac{1}{2} \mathrm{~mm}$.

Hab. Bengal: Konbir; Bombay ; Belgaum, Kanara; Malabar Coast.

Principally distinguished by the close and strong puncturation of the thorax. The latter is frequently stained with piceous at the sides.

\section{Tricliona lævicollis, Jac. (Rhyparida) P. Z. S. 1887, ค. 75.}

Obscure fulvous.

Head impunctate; eyes very large, the space dividing them narrower than their diameter, their inner margins deeply notched clypeus separated from the face by only a few punctures antennæ fulvous, nearly as long as the body, the fourth joint longer than the third, the third joint longer than the second, the following joints slightly thickened, their apices stained with fuscous. Thorax transverse, the sides rounded, the angles distinct, the surface entirely impunctate or with a few microscopically fine punctures. Elytra with a distinct depression below the base, the latter somewhat swollen, the surface deeply punctate-striate on the anterior portion, more finely punctured towards the apices. The anterior and posterior femora dilated into a strong triangular tooth, the intermediate femora minutely dentate; claws bifid.

Length $4 \mathrm{~min}$.

$H_{a b}$. Ceylon: Galle.

$T$. levicollis may be recognized by the large and closely approximate eyes and the impunctate thorax, in connection with the strongly dentate anterior and posterior femoria ; the elytra have the basal portion more distantly punctured than the rest of the surface, and the shoulders are entirely devoid of puncturation, but bounded within by a deep line of closely approximate punctures, the punctures being more widely placed below the elytral depression; the general colour varies from pale to dark fulvous, the sides and the suture are sometimes stained with piceous.

This species, on account of the strong femoral tooth, is most probably a Tricliona, although I have not now the type before me to verify this; in Rhyparida the fenora are either unarmed or have but a minute tooth.

\section{Tricliona glabricollis, nom. nov.}

Tricliona lævicollis, Jac. (nec Jac. suprì) Mém. Soc. Ent. Belg. vii, 1900 , p. 110.

Fulvous; thorax nearly impunctate; elytra closely punctatestriate, the interstices sligbtly wrinkled at the sides.

ס. Head with a few fine punctures, longitudinally grooved between the eyes; the clypeus indistinctly separated from the face, punctured like the head; antennæ fulvous, the 
third and following joints elongate and slender, the apical joints in the type wanting. Thorax twice as broad as long, the sides rounded, the surface impunctate or with a few very minute punctures, the extreme basal margin impressed with a row of deeper punctures. Scutellum broader than long. Elytra not depressed below the base, strongly punctured, the punctures arranged in closely approximate rows which form divided striæ near the apex, the puncturation at the sides below the shoulders more irregularly placed. Anterior femora with a strong tooth, the others less strongly dentate.

ㅇ. Third to the terminal joints of the antennæ nearly equal, the last two joints piceous. Head and the thorax entirely impunctate.

Length $5 \mathrm{~mm}$.

$H a b$. Bengal: Barway, Mandar; Southern India : Nilgiris.

The general colour of this species is pale fulvous in all the specimens before me; the nearly impunctate thorax and the elytral puncturation differ entirely from any of its congeners from the same region.

\section{Tricliona inconspicua, sp. n.}

Testaceous. Head impunctate, with a short central groove; eyes with a very narrow sulcus near their inner margins; clypeus transverse, feebly separated from the face, surface with some fine punctures; antennæ long and slender, second joint nearly as long as the third, apex of terminal joints stained with fuscous. Thorax twice as broad as long, sides rounded, surface entirely impunctate. Elytra slightly wider at base than the thorax and with a shallow transverse depression below the base, very strongly punctatestriate, punctures very fine at the apex, last interstice at shoulders slightly costate. Body beneath inpunctate. Prosternum narrowed anteriorly. Anterior femora armed with a strong tooth.

Length $2 \frac{1}{2} \mathrm{~mm}$.

$H a b$. Southern India : Nilgiris.

Differs from $T$. variabilis in the entirely impunctate head and thorax.

815. Tricliona inåica, Jac. Mém. Soc. Ent. Belg. vii, 1900, p. 110.

Dark fulvous or piceous; apical joints of the antennæe black.

Head finely and sparingly punctured; the clypeus broad, distinctly separated from the face, punctured like the head: labrum fulvous; eyes very lis ge; antennæ black, the basal four joints flavous or fulvous, the second and third joints thickened, equal, the fourth more elongate and slender. Thorax twice as broad as long, the sides rounded, the angles distinct, the surface finely and subremotely punctured. Elytra strongly and regularly punctate-striate, feebly depressed below the base, the punctures stronger at the sides and within the depression than near the suture, the apex more finely punctured, the interstices at the 
sides slightly costate. Femora robust, the anterior strongly, the posterior femora more finely toothed.

Length 3-4 mm.

$H a b$. Bengal: Mandar.

Closely allied to $T$. puncticeps, Duviv., the thorax much more finely punctured. T. melanura, Lefèr. is black above with æneous gloss, the clypeus is rugose and the interstices are flat. The present insect varies much in size, the larger specimens are probably females. $T$. picca, Jac., likewise from Bengal, is also closely allied, but the thorax is broader, the sides are still more rounded, and the puncturation of the same part is much stronger.

816. Tricliona variabilis, Jac. Ann. Soc. Ent. Bely. xxxix, 189.5, p. 286.

Subquadrate-ovate, black; the antennæ flavous; head, thorax and legs fulvous; elytra black, distinctly punctate-striate, an oblique stripe near the suture and the apex broadly fulvous.

Head entirely impunctate; the eyes surrounded by a narrow sulcus; clypeus impunctate, fulvous like the rest of the surface. separated from the face by a semicircular groove; palpi and antennæ flavous, the latter rather long and slender, the third and fourth joints equal, the terminal joint stained with piceous. Thorax transverse, more than twice as broad as long, the sides rather strongly rounded, narrowed in front and with a narrow margin, the angles not produced but distinct, the anterior margin concave behind the eyes, the surface fulvous, sparingly and finely punctured on the disc, the sides finely longitudinally strigose. Scutellum black, as broad as long. Elytra black, strongly punctate-striate, convex, scarcely perceptibly depressed below the base, with an oblique short band near the suture at the middle and the apex broadly triangularly fulvous, this colour also extends upwards a little way at the suture. Breast and abdomen black; legs flavous or fulvous; the anterior femora dilated into a broad triangular tooth, the other femora less strongly dentate; claws bifid.

Var. $a$. Fulvous, a spot at the base and a stripe at the middle of the elytra black.

Var. $b$. Entirely fulvous without markings.

Length 2-2 $\frac{1}{2} \mathrm{~mm}$.

Hab. Southern Bombay: Kanara; Belgaum.

Smaller and of more subquadrate shape than T. bifasciata and in addition to the system of coloration differs by the differently sculptured thorax. The species is probably subject to a good deal of variation, the specimens before me show already three different variations: in one of the dark fulvous varieties, the thorax is more closely punctured than in the others and the sides are scarcely so strigose as in the type; on the other hand, more pale coloured and somewhat smaller specimens have a more sparingly punctured thorax, but I believe that all these forms represent only one species. Taken from February to July. 
817. Tricliona apicata, Jac. Ann. Soc. Ent. Belg. xxxix, 1895, p. 285.

Piceous; anteunæ and legs flavous; elytra piceous, the apex nearly impunctate, obscure flavous.

Narrow and elongate in shape. Head densely and finely rugose throughout; the lateral margins of the clypeus raised; antennæ flavous, the apical joints slightly stained with piceous, second and following joints nearly equal ; mandibles robust. Thorax with strongly rounded sides, the anterior margin slightly produced at the middle, the sides extremely closely and strongly punctured, the punctures partly confluent, the disc more remotely punctate. Scutellum slightly broader than long. Elytra with a shallow depression below the base, deeply punctate-striate, the punctures nearly obsolete at the apex, the apex flarous gradually shading into the nearly black colour of the rest of the surface, the interstices with some few and very minute punctures. Legs entirely flavous, the anterior and posterior femora dilated each into a strong tooth.

Length 3-4 mm.

$H a b$. Southern Bombay: Belgaum.

Can be distinguished by the rugose head, extremely closely punctured thorax and flavous apex of the elytra.

818. Tricliona bifasciata, Jac. Ann. Soc. Ent. Belg. xxxix, 1895, p. 284.

Subquadrate-ovate; beneath black, abore and the legs fulrous; thorax with two small lateral and a large central black spot.

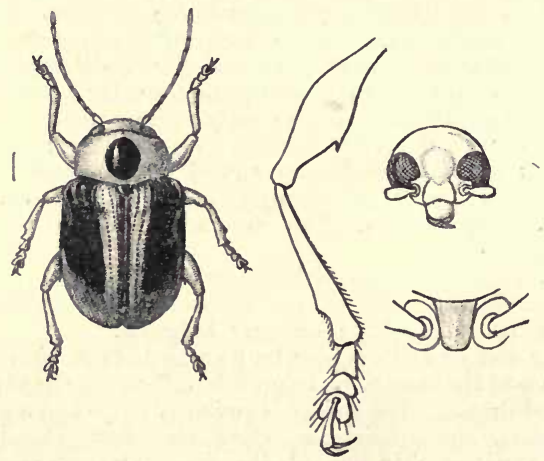

Fig. 164.-Tricliona bifasciata.

Elytra with the sutural and lateral margins and a broad band from the shoulder to behind the middle, black; femora toothed. 
Head impunctate, fulvous; eyes notched at their inner margins; clypeus broader than long, separated from the face by a shallow transverse groove; antennæ pale fulvous, extending to the middle of the elytra, third and fourth joints equal, terminal joints scarcely thickened. Thorax fulvous, more than twice as broad as long, slightly widened at the middle, the sides nearly straight, the surface scarcely perceptibly punctured, rather convex. Scutellum black. Elytra slightly wider than the thorax, very slightly depressed below the base, regularly and distinctly punctate-striate anteriorly, the punctures nearly obliterated behind the middle. Femora fulvous, the posterior femora strongly dilated into a tooth, the anterior pair dentate to a less degree; the posterior four tibiæ emarginate at the apex; claws bifid.

Var. a. Head and thorax fulvous without spots; elytra black, the apex flavous.

Var. $b$. Thorax and elytra black.

Var. c. Entirely fulvous.

Length $3 \mathrm{~mm}$.

Hab. Southern Bombay: Kanara; Belgaum.

This is a most variable species in regard to coloration, varying from flavous to black, with or without black markings. In some specimens the thorax is fulvous with the black spots confluent, in others the head and thorax are fulvous and the elytra black with a pale flavous apex, but all these forms show by their shape and sculpture that they represent the same species. They can be recognized by their short subquadrate, not narrowly elongate shape and by the transverse exceedingly finely punctured thorax and its equal width ; the typical banded form is of course easily known.

\section{Tricliona picea, Jac. Ann. Soc. Ent. Bely. xxxix, 1895, p. 284.}

Piceous; basal joints of the antennæ flavous; the anterior femora with a broad triangular tooth.

Head extremely finely punctured with a more or less distinct central ridge; clypeus distinctly separated from the face, wedgeshaped, its surface finely rugose; antennæ extending to the middle of the elytra, the basal five joints flavous, the rest black or entirely fulvous, third joint slightly shorter thau the fourth. Thorix rather broad, of equal width, the sides straight at the base, rounded and slightly narrowed in front; the disc rather sparingly but distinctly punctured at the sides leaving the small middle portion nearly impunctate, posterior margin straight at the sides, slightly but broadly produced at the middle. Scutellum as broad as long. Elytra very shallowly depressed below the base, deeply punctate-striate anteriorly, the punctures much finer posteriorly and closely approximate. Anterior femora strongly dilated into a triangular tooth, the other femora less strongly dentate. 
Length 3-4 mm.

Hab. Southern Bombay: Kanara.

$T$. picea differs from $T$. melanura, Lefèv. in its entirely piceous colour and the nearly impunctate head, also in the absence of the æneous gloss of the elytra; T. puncticeps, Duviv. is narrower, the head is rugosely punctured and the thorax of different shape and sculpture.

820. Tricliona bicolor (Pl. II, fig. 6), Jac. Ann. Soc. Ent. Belg. xxxix, 1895, p. 283.

Fulvous ; terminal joints of the antennæ black; elytra widened at the middle, black, finely punctate-striate, the apex nearly impunctate; abdomen piceous.

Of medially widened shape. Head fulvous, broad, nearly impunctate; the clypeus with a few very minute punctures, not separated from the face, its anterior border emarginate at the middle, its sides oblique with a distinctly raised margin; antennæ black, extending to the middle of the elytra, the basal four joints fulvous, second and third joints nearly equal, fourth and following joints elongate. Thorax more than twice as broad as long, of equal width, the sides strongly rounded, the posterior angles obsolete, the anterior margin not produced, the surface reddish-fulvous, microscopically punctured. Scutellum fulvous, broader than long, impunctate, its apex acute. Elytra greenish-black, ovate, widened towards the middle, rather opaque, finely punctate-striate, the punctures nearly absent at the apex, the shoulders produced into a narrow short ridge. Underside and legs fulvous; the anterior femora dilated into a moderately strong tooth, posterior femora less strongly toothed; abdomen more or less piceous.

Length $3 \mathrm{~mm}$.

$H a b$. Southern Bombay: Belgaum.

The shape of this species is different from that of most'of its allies, being much more ovate in regard to the elytra, this and the nearly impunctate head and thorax as well as the coloration will at once distinguish the species. Taken during the rains.

\section{Tricliona ceylonensis, sp. $n$.}

Fulvous or piceous; apical joints of antennæ black; legs dark, apex of tibiæ and the tarsi fulvous.

Short and broad. Head finely and sparingly punctured, with a short central groove; eyes with a narrow sulcus above; clypeus separated from the face by a shallow transverse groove, finely punctured ; antennæ with the basal four joints fulvous, rest black, third and fourth joints equal, following joints rather shorter and distinctly thickened. Thorax twice as broad as long, sides rounded, with narrow reflexed margins; surface with very shallow puncturation, irregularly distributed. Scutellum impunctate. Elytra 
with distinct transverse depression below the base, strongly punctate-striate within depression only, very finely so over the rest of the surface, the interstices below the shoulders slightly costate, punctures on the same area deep. Femora strongly thickened, armed with a distinct tooth beneatl. Prosternum subquadrate, punctate.

$V a r$. A bove nearly black, apex of elytra paler.

Length $2 \frac{1}{2} \mathrm{~mm}$.

$H a b$. Ceylon: Kandy.

In shape this species agrees nearly with $T$. variabilis, Jac., but the thorax is more closely punctured (in the variety inore strongly so) and the elytra have the lateral interstices below the shoulders costate; the legs are dark with the exception of the apex of the tibiæ and the tarsi.

\section{Tricliona nigra, sp. $\mathrm{n}$.}

Black, shining; basal joints of antennæ flavous.

Oblong-ovate. Head impunctate, black; eyes extremely large, the diameter of each wider than the intermediate space; clypeus subquadrate, nearly smooth, separated from the face by a transverse sulcus; antennæ extending nearly to the apex of the elytra, slender, black, basal four joints flavous, second and third joints nearly equal in length, fourth longer, following joints slightly shorter and thicker. Thorax twice as broad as long, sides rounded, surface finely and rather obsoletely punctured. Elytra wider at the base than the thorax, distinctly depressed and punctate-striate below the base, more finely punctured towards apex, interstices feebly longitudinally convex. Femora with a minute tooth. Body beneath smooth and impunctate. Prosternum transverse, strongly punctured.

Var. Above obscure fulvous, sides more or less black.

Length $3 \mathrm{~mm}$.

$H a b$. Southern India: Nilgiris (H. L. Andrewes).

Differs from $T$. indica, Jac. in its constantly smaller size and less elongate shape; the eyes are larger and more closely approximate in both sexes, the colour deep black in most specimens.

823. Tricliona sulcipennis, Jac. Ann. Soc. Ent. Belg. xlviii, 1904, p. 388.

Obscure fulvous; dise of thorax, sides of breast, knees, and apex of tibiæ black.

Head stained with piceous, entirely impunctate; clypeus distinctly separated from the face, wedge-shaped; eyes broadly emarginate; antennæ extending beyond the middle of the elytra, basal three joints fulvous, rest piceous. Thorax transverse, lateral margins strougly rounded, constricted anteriorly, hasal margin 
broadly rounded, disc impunctate, nearly covered by two large piceous patches. Elytra pale fulvous, longitudinally sulcate, sulci with some fine punctures below the base, ninth and tenth sulci abbreviated at each end and united, two outer and two inner sulci curved at the base. Legs spotted with black; anterior femora with a short tooth.

Length $5 \mathrm{~mm}$.

$H a b$. India.

Distinguished by the piceous patches on the thorax and the sculpture of the elytra.

\section{Tricliona marginata, sp. $\mathrm{n}$.}

Flavous; terminal joiuts of antennæ and margins of elytra narrowly black.

Head entirely impunctate, with a short central groove; clypeus transverse, separated at the sides by very shallow grooves, impunctate, anterior margin feebly concave; labrum testaceous; mandibles black; antennæ slender, black, extending to about the middle of the elytra, basal three joints flavous, third and fourth equal, fifth much longer ; the following joints of nearly similar length. Thorax nearly twice as broad as long, sides rounded, angles acute; surface ratber strongly and closely but irregularly punctured, the punctures arranged in patches. Elytra flavous, with the extreme margins deep black; slightly wider than the thorax, distinctly punctate-striate, the punctures very closely placed in striæ. Anterior femora dilated into a moderate tooth; first joint of tarsi rather long; claws deeply bifid. Anterior margin of the thoracic episternuin strongly convex.

Length $4 \frac{1}{2} \mathrm{~mm}$.

$H a b$. Bombay : Belgaum.

Belongs to those forms that have the elytral punctures placed very close together in striæ.

\section{Tricliona subdepressa, sp. $\mathrm{n}$.}

0. Testaceous. Head with a few very minute punctures; clypeus broadly subquadrate, very finely punctured; mandibles broad and robust; antennæ reaching to the middle of the elytra, third and following joints slender and elongate, equal or nearly so. Thorax twice as broad as long, of equal width, sides evenly rounded, surface rather flattened, sides but slightly deflexed; surface sparingly and very finely punctured, the punctures very superficial. Elytra elongate, rather depressed, finely punctatestriate; punctures closely placed in striæ, the punctures obsolete towards the apex. Anterior femora rather strongly thickened, armed beneath with a strong tooth.

Length $4 \frac{1}{2} \mathrm{~mm}$.

Hab. Southern India: Trichinopoly. Type in Coll. Jacoby. 


\section{Tricliona longicornis, sp. $\mathrm{n}$.}

Fulvous; terminal joints of the antennæ black.

Oblong. Head entirely impunctate; eyes very large, closely approximate at the middle; clypeus impunctate, separated from the face by deep grooves; antennæextending to the apex of the elytra, basal four joints fulvous, rest black, third and following joints nearly equal, elongate. Thorax nearly twice as broad as long, of equal width, sides evenly rounded, surface impunctate. Elytra wider at base than the thorax, deeply and strongly punstatestriate, interstices longitudinally costate throughout. Anterior femora strongly thickened, dilated into a small tooth beneath; claws bifid.

Length $2 \frac{1}{2} \mathrm{~mm}$.

Hab. Ceylon (Coll. Jacoby).

Very distinct by the more than ustally large eyes, long antennæ, costate elytra and small size.

\section{Genus CLEOPORUS.}

Cleoporus, Lefív. Bull. Soc. Ent. France, 1884, p. Ixxvi.

Type, C. cruciatus, Lefèv., from the Philippine Islands.

Range. India; China; Malayan Subregion.

Body oblong, smooth. Head deflexed, inımersed in thorax up to the eyes, these distant, globular, feebly emarginate, deeply sulcate above; clypeus transverse, slightly or not separated from the face; antennæ filiform, half the length of the body, basal two joints thickened, third more than twice as long as the second. Thorax much broader than long, convex, sides nearly straight. Prosternum broad, subquadrate. Legs robust; femora unarmed, moderately thickened ; intermediate strongly, posterior tibiæ feebly emarginate at apex; claws bifid.

Differs from Tricliona in the unarmed femora and deep supraocular sulci.

827. Cleoporus maculicollis, Jac. Ann. Soc. Ent. Belg. xlviii, 1904, p. 388.

Fulvous; thorax with two black patches; elytra obscure piceous, margins more or less flavous; legs testaceous; abdomen piceous.

Head almost confluently punctured; clypeus not separated from the face, pale fulvous; eyes with narrow sulcus above; antennæ testaceous, extending to about the middle of the elytra; second joint thickened, slightly longer than the third, terminal joints slightly thickened. Thorax half as broad again as long, sides rounded; surface rather closely and strongly punctured at the sides, less so in the middle, sides with a large black patch 
that occupies nearly the whole of the surface. Elytra slightly wider than the thorax at base, feebly depressed below the latter, regularly punctate-striate, punctures distinct to apex. Femora unarmed. Bbreast fulvous.

Length $3 \mathrm{~mm}$.

Hab. Western India: Khandesh.

828. Cleoporus variegatus, Jac. Ann. Soc. Ent. Belg. xlviii, 1904, p. 387.

Flavous; thorax with a transverse black band; elytra with a small spot at base and an elongate sutural spot in the middle, piceous; body beneath more or less piceous.

Head finely punctured, base of vertex more or less black or with a central black spot; clypeus broadly transverse, scarcely separated from the face, strongly punctured; antennæ black, basal four joints flavous, third shorter than the fourth, rest slender. Thorax nearly twice as broad as long, sides rounded; surface very finely and rather closely punctured, a narrow transverse piceous band in the middle, strongly constricted at each end. Elytra flavous, elongate, with a shallow basal depression; surface punctate-striate, punctures finer towards the apex, base with a piceous spot in the middle, suture with another spot of variable size, often very narrow. Beneath piceous; legs flavous.

Var. Thorax and elytra without spots.

Length 3-5 $\mathrm{mm}$.

$H a b$. Southern India: Pondicherry.

\section{Cleoporus inornatus, sp. $n$.}

Pale fulvons or testaceous ; terminal joints of antennæ piceous.

Head entirely impunctate; clypeus more or less distinetly separated from the face; antennæ with the five or six basal joints pale, rest piceous, basal joint short and thick, second smaller but thickened, third slightly longer, following joints of nearly similar length. Thorax scarcely half as broad again as long, sides nearly straight, angles acute, posterior margin feebly produced at the middle. Scutellum ovate. Elytra wider at the base than the thorax, with a very feeble depression below the base, extremely finely punctate-striate, apex nearly impunctate, sutural and lateral margins sometimes obseure piceous.

Length $2 \frac{1}{2} \mathrm{~mm}$.

Hab. Bombay: Kanara; Assam: Patkai Mts.; Burma : Momeit.

In several specimens before me, the thorax has some few shallow punctures, in others these are entirely absent; in the latter specimens the antennm are rather louger and the thorax is less transverse. These are probably the males. 
830. Cleoporus leferrei, Duviv. Ann. Soc. Ent. Belg. xxxvi, 1892, p. 414.

Black with slight æneous gloss beneath; head, antennæ and legs fulvous; thorax and elytra greenish-æneous.

Head impunctate, vertex darker; supraocular sulci broad and deep; clypeus separated from the face by a transverse groove, emarginate anteriorly; palpi fulvous; antennæ with the apical joints fuscous. Thorax scarcely twice as broad as long, narrowed in front, anterior angles deflexed, posterior angles acute, sides feebly rounded; surface moderately convex, obsoletely punctured. Scutellum smooth. Elytra wider at the base than the thorax, moderately convex, narrowly margined at the sides, regularly punctate-striate; interstices flat, very finely punctured anteriorly.

Length $3 \frac{1}{2} \mathrm{~mm}$.

Hab. Bengal: Mandar.

Easily distinguished by the bronze-coloured upper surface and fulvous legs.

831. Cleoporus plagiatus, Jac. Ann. Mus. Civ. Genova, xxxii, 1892, p. 915.

Above fulvous; thorax with two black spots; elytra strongly punctate-striate, the suture, a spot at the base and two spots placed transversely behind the middle, black.

Head impunctate, with the exception of the broadly sulcate space in front of the eyes which is finely impressed with elongate punctures, the vertex with a central longitudinal ridge, colour dark brown, shining; clypeus separated from the face by a deep transverse groove, its surface impunctate; antennæ fulvous, extending to about half the length of the elytra, filiform, the terminal joints slightly thickened, stained with fuscous at the apex, the third and following two joints slender, equal. Thorax half as broad again as long, convex, the sides straight, the anterior angles prominent and acute, the surface sparingly punctured on the disc, the sides nearly impunctate; dark fulvous with two obscure piceous spots in the middle. Scutellum fulvous. Elytra fulvous, slightly wider at the base than the thorax, subcylindrical, without basal depression, strongly and regularly punctate-striate; the sutural and lateral margins, a round spot at the base and two more elongate spots, placed transversely behind the middle, piceous; all the punctures also surrounded by piceous spots. Underside black, shining. Prosternum subquadrate, punctate. The anterior margin of the thoracic episternum convex. Femora with a very small tooth; the posterior four tibiæ emarginate at their apices; claws bifid.

Length $3 \mathrm{~mm}$.

Hab. Burma: Pegu. 
832. Cleoporus burmanicus, Jac. Ann. Mus. Civ. Genova, xxxii, 189-2, p. 914.

Obscure fulvous or piceous beneath, pale fulvous above; head impunctate; elytra punctate-striate, the suture and a broad discoidal band not extending to the suture or apex obscure piceous, or the band separated into two spots one at base and one at middle.

Subcylindrical in shape. Head pale fuivous, deeply and broadly sulcate above the eyes, the inner margin of the sulcus piceous;

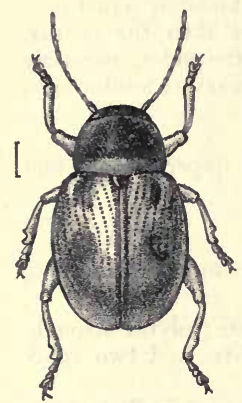

Fig. 165.

Cleoporus burmanicus, var. clypeus transversely subquadrate, separated from the face by a deep transverse groove; labrum fulvous ; antennæ fulvous, scarcely extending to half the length of the elytra, the terminal joints slightly darker and thickened, third and fourth joints equal. Thorax fulvous, transversely convex, the surface sparingly and finely punctured, the margins narrowly piceous. Scutellum fulvous, margined with piceous. Elytra subcylindrical, slightly depressed below the base, rather deeply punctured within the depression, much more finely punctatestriate posteriorly; pale fulvous or flavous, the margins and an irregular-shaped broad band at the sides piceous or dark fuscous : this Dand when entire is deeply concave at its lower edge and includes a pale-coloured spot of the ground-colour below the shoulder, it is sometimes interrupted at some distance from the apex and the suture. Femora with a small tooth; the posterior four tibiæ. emarginate near the apex; claws bifid. The anterior margin of the thoracic episternum strongly convex.

Var. The elytral band obliterated at the sides.

Length $3 \mathrm{~mm}$.

Hab. Burma: Bhamo.

The figure represents the form with elytral spots.

\section{Genus CLEORINA.}

Cleorina, Lefêr. Cat. Eumolp. 1885, p. 143.

Type, C. aulica, Lefèv., from Java.

Range. India; China; Malayan Subregion.

Body very round and convex, generally highly metallic. Head deeply inserted; eyes rather large, oblong, feebly emarginate on their inner orbits; clypeus not separated from the face; antennæ filiform, short, third joint scarcely twice as long as the second, terminal joints widened. Thorax transverse, convex, narrower at base and apex, deeply transversely sulcate near the anterior margin, sides often straight. Elytra wider at base than 
the thorax, more or less strongly excavated below the base, punctate-striate, near the lateral margins longitudinally sulcate; epipleuræ rounded, prominent. Legs moderately robust; femora unarmed; claws appendiculate. Prosternum very broad, flat, the base truncate. Anterior margin of thoracic episternum convex.

Can be separated from Nodostoma (in which several of the species belonging to this genus were formerly placed) by the form of the thoracic episternum and general rounded and convex shape of the body, also by the more or less thickened terminal joints of the antennæ.

\section{Metallic species with very finely and remotely punctured thorax.}

833. Cleorina nigroviridis, $\mathrm{sp} . \mathrm{n}$.

Nearly black beneath, greenish-black above; labrum, palpi and basal joints of the antennæ fulvous.

Head impunctate, nearly black; antennæ black, long and filiform, basal four joints fulvous, third and fourth very elongate, equal, terminal joints slightly thickened. Thorax barely twice as broad as long, sides straight, anterior sulcus entire; surface rather convex, rather finely and very remotely punctured, sides near the margins impunctate. Elytra oblong, very convex, basal portion strongly raised, deeply depressed below as well as within the shoulders; surface strongly punctate-striate, punctures finer towards the apex, basal portion very finely punctured; below the shoulders is a costiform tubercle.

Length $3 \mathrm{~mm}$.

Hab. Assam (Coll. Brit. Mus.).

A very dark metallic species with comparatively slender antennæ and a more than usually remotely punctured thorax, but possessing all the other characters of the genus.

\section{Cleorina modesta, sp. n.}

Metallic dark green; abdomen blackish; basal joints of antennæ fulvous ; tarsi black.

Head extremely finely and remotely punctured; labrum piceous; antennæ black, basal four joints fulvous, basal joint æneous above, third and fourth elongate, equal, terminal joints strongly thickened but twice as long as broad. Thorax rather more than half as broad again as long, sides straight, anterior sulcus obsolete at the middle, surface brassy green, subremotely but much more strongly punctured than the head. Elytra with very shallow subbasal depression, rather strongly punctate-striate anteriorly, punctures very fine but distinct to apex.

Length $3 \mathrm{~mm}$.

Hab. Assam: Nága Hills (Coll. Brit. Mus.).

The extremely fine and remote puncturation of the head and the feeble elytral depression are distinctive of this species. 
835. Cleorma leferrei, Jac. Entomologist, 1890, p. 116.

Metallic dark blue; basal three joiuts of the antennæ fulvous, basal joint metallic blue or green above; abdomen bluish-black.

Broadly rounded. Head remotely but rather strongly punctured; anterior edge of clypeus deeply emarginate; antennæ rather long, terminal joints black. Thorax about half as broad again as long, sides nearly straight, narrowed anteriorly, finely and subremotely punctured. Elytra slightly wider at the base than the thorax, with a short but deep depression below the base, finely punctate-striate except within the depression where the punctures are stronger, apex nearly obsoletely punctured. Legs metallic green; flanks of thorax strongly punctured.

Length $3 \mathrm{~mm}$.

$H a b$. Burma: Ruby Mines; China.

Originally described from China; the Burma specimens are rather smaller, but there seem to be no differences of sufficient importance to justify specific separation. The species may be known by the rather fine puncturation of the head and thorax and the somewhat less transverse shape of the latter as compared with its congeners.

\section{Thorax strongly, often confluently, punctured.}

\section{Cleorina nobilis, Lefêv. Cat. Eumolp. 1885, p. 144, note 6.}

Greenish-æneous beneath, metallic green above with a golden cupreous tint; labrum piceous; palpi and the basal joints of the antennæ fulvous; apex black.

Head distantly punctured, feebly strigose behind the eyes, faintly impressed on middle of front. Thorax closely and strongly punctured, subarcuate at the sides. Scutellum smooth. Elytra round, moderately excavate below the base, punctate-striate, punctures stronger within the depression, nearly obsolete at apex; humeral callus very prominent. Prosternum very broad. Legs greenish ; tarsi bluish-black.

Length $5 \frac{1}{2}-6 \mathrm{~mm}$.

Hab. India ; Burma : Palon.

In a specimen from Burma before me, which I refer to this species, the head and thorax are reddish-cupreous, the elytra metallic green.

837. Cleorina bevani, Baly (Nodostoma), Trans. Ent. Soc. 1877, p. 40.

Obscure greenish-æneous; above aureous ; antennæ black, basal four joints flavous; elytra narrowly margined with metallic green.

Short and ovate, very convex; clypeus not separated from the face, its anterior border angulate-emarginate; front impressed with a shallow fovea. Thorax nearly twice as broad as long, 
sides rounded and convergent from base to apex, all the angles acute; surface rather more coarsely punctured than the head. Scutellum broader than long, metallic green. Elytra broader at base than the thorax, apex broadly rounded, surface faintly impressed below the base; humeral callus prominent; the punctured striæ distinct for their whole length, less deeply impressed towards the apex. Posterior femora with a minute tooth.

Length $5 \mathrm{~mm}$.

$H a b$. Southern India.

838. Cleorina jacobyi, Duviv. Ann. Soc, Ent. Belg. xxxvi, 1892, p. 415 .

Head, thorax and elytra metallic green; palpi testaceous; antennæ black, third and part of fourth joint fulvous; breast and femora blackish-æneous; labrum, knees, tibiæ and tarsi fulvous; abdomen black.

Head moderately strongly and remotely punctured; antennæ extending to two-thirds the length of the body, basal three joints and part of fourth fulvous, first and second joints thickened, latter short, third and fourth slender, subequal, half as long again as the second, the following joints gradually widened and thickened. Thorax about half as broad again as loug, narrowed anteriorly, sides rugose and regularly rounded, deeply rugosely punctured, interstices convex. Scutellum smooth. Elytra wider than the thorax at base, subparallel, sulcate near the margins, with a short depression below base; surface distinctly punctate-striate within the depression, the punctures larger towards the sides, finer and nearly obsolete towards the apex, interstices flat and smooth, sides with some transverse wrinkles.

Var. Thorax green, elytra violaceous.

Length $3-3 \frac{1}{2} \mathrm{~mm}$.

Hab. Sikhim : Kurseong.

\section{Cleorina indica, sp. $n$.}

Purplish or dark violaceous; basal joints of the antennæ fulvous.

Head extremely finely and sparing,y punctured; clypeus strongly emarginate, not separated from the face; antennæ black, basal four joints fulvous, fifth and following joints gradually widened. Thorax nearly twice as broad as long, sides nearly straight, anterior margin with a narrow groove, surface strongly and rather closely punctured througbont. Scutellum broader than long, metallic green. Elytra with a distinct depression below the base, strongly punctate-striate, punctures obsolete at the apex, shoulders prominent, followed by a short costa. Beneath metallic green, impunctate; abdomen and legs darker.

Length $2 \frac{1}{2} \mathrm{~mm}$.

Hab. Tenasserim. Type in Brit. Mus.

Sometimes cupreous above, or the thorax of that colour only, and the elytra violaceous. 


\section{Cleorina assamensis, sp. $\mathrm{n}$.}

Violaceous blue; margins of the elytra, breast and legs more or less metallic green.

Head remotely but rather strongly punctured; edge of clypeus metallic green; labrum nearly black; antennæ black, basal two or three joints fulvous beneath, basal joint metallic green above. Thorax twice as broad as long, widened at the middle, sides rounded and strongly punctured; surface strongly and elosely

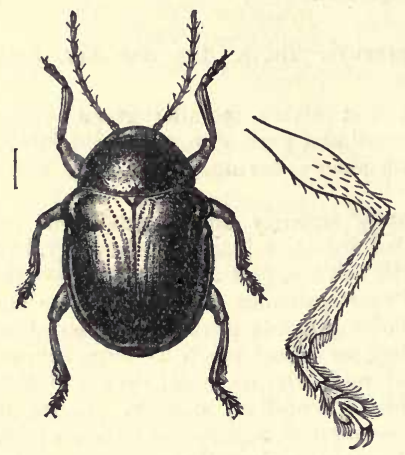

Fig. 166.-Cleorina assamensis.

punctured, the puncturation evenly distributed. Elytra broadly rounded, deeply transversely depressed below the base, shoulders very prominent, followed by a curved ridge as far as the middle, strongly angulate below humeral callus; surface strongly punctured within depression, finely so towards the apex, extreme lateral margins rather broadly reflexed. Prosternum transversely raised at its anterior portion.

Length $4 \mathrm{~mm}$.

Hab. Assam (Coll.Jacoby); Patkai Mts. (Coll. Brit. Mus.).

\section{Cleorina manipurensis, sp. $n$.}

Metallic green; basal.joints of antennæ fulvous, first joint green above, the terminal joints black.

Head remotely and strongly punctured; clypeus rather more sparingly and finely punctate; antennæ with the terminal joints moderately thickened, each joint longer than broad. Thorax half as broad again as long, sides straight, anterior suleus distinct; surface closely and strongly punctured, sides more closely punctate, punctures round and deep, spaces dividing the punctures larger than the punctures themselves. Elytra with rather shallow basal depressions, strongly punctate-striate, punctures distinct 
but somewhat finer at apex. Abdomen blackish; emargination of tibiæ clothed with rather long pubescence.

Length $2 \frac{1}{2} \mathrm{~mm}$.

$H a b$. Manipur.

\section{Cleorina andamanensis, sp. $\mathrm{n}$.}

Metallic green; antennæe black, basal joints fulvous; thorax cupreous ; elytra dark violaceous.

Head very remotely punctured, metallic green; labrum and palpi piceous; antentio with the basal four joints fulvous, basal joints black above, terminal joints slightly widened. Thorax about twice as broad as long, sides straight, disc very strongly and rather closely punctured, punctures somewhat more closely placed at the sides. Elytra broadly rounded, with a shallow basal depression, rather strongly punctate-striate, punctures finer towards the apex. Breast metallic green; abdomen black.

Length $2 \frac{1}{2}-3 \mathrm{~mm}$.

Hab. Andaman Islands (Coll. Brit. Mus.).

In all the specimens before me, the puncturation of the thorax is strong without being confluent.

\section{Cleorina oblonga, sp. n.}

Metallic greenish-cupreous ; antennæ black, basal joints fulvous.

Head remotely and inoderately strongly punctured; antennæ with the terminal joints thickened, the joints but slightly longer than broad, basal joint æneous above, following two fulvous. Thorax rather convex, sides somewhat rounded, anterior sulcus deep at the sides, obsolete at middle; surface strongly and closely punctured, punctures round and deep, more closely placed at the sides. Scutellum subpentagonal, cupreous, impunctate. Elytra oblong, somewhat pointed at apex, deeply transversely depressed below the base, shoulders promiuent, gradually narrowed into a blunt costa that extends to the middle; surface strongly punctate-striate, punctures distinct to apex, extreme lateral margins cupreous. Underside and abdomen æneous or greenish-cupreous; apices of tibir and the tarsi black.

Length $2 \frac{3}{4} \mathrm{~mm}$.

Hab. Burma : Karen Hills (Coll. Brit. Mus.).

More oblong and posteriorly more pointed in shape than most species of the genus.

\section{Cleorina dohertyi, sp. n.}

Metallic blue or greeuish; head remotely and rather finely punctured; antennæ black, rather long, basal three joints fulvous, third joint elongate, as long as the fourth, following joints triangularly widened but longer than broad. Thorax nearly twice 
as broad as long at base, sides very feebly rounded, anterior sulcus entire; surface strongly and very closely punctured, punctures confluent at sides. Elytra rounded, deeply depressed below the base, strongly punctate-striate, distinct to apex, punctures closely placed, interstices at the sides slightly convex. Legs and abdomen bluish-black.

Length $2 \frac{1}{2} \mathrm{~mm}$.

Hab. Tenasserim : Tavoy (Doherty, Coll. Brit. Mus.).

Distinguished by the strong and confluent thoracic puncturation, The species is extremely closely allied to $C$. autica, Lefèv., and differs constantly only in its smaller size and in the coloration of the legs and abdomen.

845. Cleorina aulica, Lefèvre, Cat. Eumolp. 1885, p. 144.

Metallic green beneath, cupreous-violaceous above; abdomen black ; antennæ with the basal joints fulvous, apical joints black; legs metallic green; apices of tibiæ and the tarsi black.

Length $2 \frac{3}{4}-3 \mathrm{~mm}$.

Hab. Java: Batavia. Burma: Momeit.

I cannot separate Burmese specimens from one from Batavia in the collection named by Lefèvre; the former are slightly smaller, and either dark blue or violaceous, but differ in no other important way.

\section{Cleorina longicornis, sp. $n$.}

Black; basal joints of antennæ, tibix and tarsi fulvous.

Head purplish-black with a few fine punctures only; antennæ very long and slender, basal four joints fulvous, rest black, third and fourth elongate, terminal joints slightly thickened. Thorax nearly twice as broad as long, sides straight, anterior sulcus entire, surface strongly, confluently punctured at the sides, remotely and finely so in the middle. Elytra broadly rounded, deeply depressed below the base, very strongly punctate-striate, punctures closely placed, distinct to apex, interstices strongly longitudinally costate at the sides.

Length $2 \frac{1}{4} \mathrm{~mm}$.

Hab. Tenasserim : Tavoy (Coll. Brit. Mus.).

C. nigrita, Jac., from Borneo, is closely allied to this, but has a much more coarsely punctured thorax, although it agrees with it in other respects.

\section{Cleorina bicolor, sp. $n$.}

Black; elytra, breast and abdomen fulrous.

Broadly oblong-ovate. Head with a few punctures near the eyes only, base rather convex; clypeus separated from the face by a shallow groove, deeply emarginate in front; labrum obscure fulvous; antennæ black, long and filiform, extending to the middle 
of the elytra, basal three joints fulvous beneath, fifth and following joints subtriangularly widened. Thorax barely twice as broad as long, sides straight or nearly so, anterior sulcus entire; surface very remotely and finely punctured, in the middle of the disc the punctures shallow. Scutellum oblong, obscure piceous. Elytra wider at base than the thorax, convex, with a short but deep depression below the base, finely punctured within the depression and near the suture only, rest impunctate, very shining. Legs black; femora strongly thickened; intermediate and posterior tibiæ deeply emarginate near the apex; claws appendiculate.

Length $3 \frac{1}{2} \mathrm{~mm}$.

Hab. Tenasserim (Coll. Brit. Mus.).

\section{Cleorina fulva, sp. n.}

Fulvous; apical joints of antennæ black.

Subquadrate-ovate. Head impunctate on the vertex, middle with a short groove and a few fine punctures; a deep semicircular groove from above the eyes to the sides of the clypens, anterior margin of the latter concave ; antennæ with the basal three joints flavous, rest black, terminal five joints widened but not wider than long. Thorax more than twice as broad as long, sides strongly rounded, surface convex, with some minute shallow punctures. Elytra with a shallow depression below the base, finely punctatestriate, punctures obsolete at the apex.

Length $3 \mathrm{~mm}$.

$H a b$. Southern India: Nilgiris (Coll. Jacoby).

Differs from any of its allies in the uniform non-metallic coloration, also in the more than usually thickened terminal joints of the antennæ.

849. Cleorina saturata, Jac. Ann. Soc. Ent. Belg. xliv, 1900, p. 111.

Beneath piceous, above and the legs fulvous. Elytra fulvous, with a sutural band, narrowed and shortened posteriorly, and the extreme lateral margins black.

Ovate, rounded iu shape; the head impunctate; the eyes large; the clypeus not separated from the face; antennæ flavous, long and rather slender, second joint thickened, scarcely shorter than the basal joint, third and fourth joints slender, equal, terminal joints stained with fuscous, elongate and slightly thickened. Thorax more than twice as broad as long, sides feebly rounded, the angles distinct, the surface minutely and not very closely punctured, the sides and the space near the anterior angles impunctate, posterior margin feebly produced at the middle. Scutellum fulvous. Elytra not depressed below the base, convex, regularly punctate-striate, the punctures larger at the sides than over the rest of the surface, those near the suture nearly confluent, forming strix; each elytron with a broad sutural band, from the base to behind the middle, where it is narrowed and terminated 
suddenly, the lateral margins also more or less black or unicolorous. Beneath piceous. Prosternuın very broad. Legs fulvous, the anterior femora with a strong tooth.

\section{Length $2 \frac{1}{2} \mathrm{~mm}$.}

$H a b$. Bengal : Mandar.

Cleorina seens to me to be the only suitable place for the reception of this species, in spite of its strongly toothed anterior femora. Cleoporus has the eyes surrounded by a broad sulcus, and Morthotina has the thorax and elytra subcylindrical in shape; the present insect has the ovately rounded shape, the long, filiform antennæ and broad prosternum peculiar to Cleorina.

\section{Genus MOUHOTINA.}

Mouhotia Baly (nec Casteln.), Journ. Linn. Soc., Zool. xiv, 1878, p. 262 .

Mouhotina, Lefère, Cat. Eumolp. 1885, p. 130.

Type, M. femoratc, from Cambodia.

Range. Burma; Chira; Solomon Islands.

Short, ovate, very convex, glabrous above.

Head perpendicular, immersed in thorax; eyes narrowly ovate, sinuate within; clypeus distinctly separated from the face, anterior border concave-enarginate; antennæ half the length of the body, basal four joints cylindrical, following joints compressed, feebly dilated. Thorax transverse, sides margined. Scutellum subovate. Eiytra much wider than the thorax, subquadrate-ovate, very convex, regularly punctate-striate, shoulders prominent. Legs robust; femora incrassate, anterior and posterior femora dentate; intermediate and posterior tibia emarginate at their apices; claws appendiculate. Prosternum transverse, subquadrate; anterior margin of thoracic episternum convex. Mesosternum short, transverse.

The transverse prosternum and appendiculate claws characterize this genus; the shape of the thoracic episternum distinguishes it from Pagria.

850. Mouhotina burmanica, Jac. Ann. Mus. Civ. Genova, xxxii, 1892, p. 913.

Piceous beneath; above obscure fulvo-æneous.

Head sparingly punctured on the vertex, the lower portion strongly strigose or covered with highly raised oblique rugosities, the space in front of the eyes bounded by an oblique ridge, another less distinctly marked ridge is placed on the middle of the vertex; clypeus separated from the face by a transverse groove, from the middle of which another deep longitudinal groove extends upwards for some distance, dividing the rugose space between the eyes; antennæ dark fulvous or with the apical joints darker, the latter distinctly thickened, the third joint a little longer than the fourth. Thorax about half as broad again as long, the sides very slightly 
rounded, the angles distinct; the surface deeply subfoveolatepunctate at the sides, the punctures rather elongate, the middle of the disc nearly as strongly but much more remotely punctured. Elytra convex, subcylindrical, witl a slight depression below the base, dark fulvous with a slight æneous gloss, deeply and regularly punctate-striate, the sides with a deep longitudinal sulcation posteriorly near the lateral margin. Femora dilated at the middle, all the femora armed with a tooth. Prosternum longer than broad, rather rugose, the middle portion raised; anterior margin of the thoracic episternum very strongly convex.

Length $3-4 \mathrm{~mm}$.

Hab. Burma : Palon.

\section{Mouhotina rugifrons, sp. $\mathrm{n}$.}

Piceous; antennæ and legs pale fulvous.

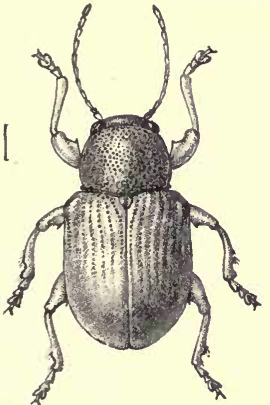

Fig. 167 .

Head closely and strongly rugosely punctured; narrowly sulcate above the eyes; clypeus not separated from the face, punctured like the head; labrum fulvous; antennæ filiform, reaching to about the middle of the elytra, basal four joints very nearly equal in length, terminal three more elongate and slender. Thorax subcylindrical, about half as broad again as long, sides feebly rounded, very closely, finely but distinctly punctured, punctures finer than those on the head, evenly distributed. Elytra wider at the base than the thorax, subcylindrical, without a basal depression, rather strongly punctate-striate, punctures obsolete near the

Mouhotina rugifrons.

apex ; claws appendiculate.

apex. Legs robust; femora with a small tooth; tibiæ strongly emarginate at

Length $4 \mathrm{~mm}$.

$H a b$. Southern India : Nilgiris. Type in Coll. H. E. Andrewes.

\section{Group CORYNODINI.}

More or less oblong-elongate, glabrous above. Head with deep, posteriorly widened sulci above the eyes. Antennæ robust, terminal joints widened and claviform or subfiliform. 'Thorax narrower at base than the elytra, subconical or globose, lateral margins distinct and entire. Elytra convex, subcylindrical. Legs robust; tibiæ simple, longitudinally sulcate; tarsi broad; claws appendiculate or bifid, divaricate.

Insects mostly of comparatively large size, metallic blue or 
green, sometimes ornamented with purple spots or bands. Can be distinguished by the deep supraocular sulci and the broadly widened terminal joints of the antennæ.

\section{Key to the Genera of Corynodini.}

a. Head with a broad excavation above eyes .. Conynodes, p, 492.

b. Head with a narrow sulcus above eyes ...... Chrysochus, p. 508.

\section{Genus CORYNODES.}

Corynodes, Hope, Coleopt. Man, iii, 1840, p. 162 ; Marshahl, Journ. Linn. Soc., Zool. viii, 1865, p. 24; Baly, Trans. Ent. Soc. (3) iv, 1867, p. 99 ; Chapuis, Gen. Coléopt. x, 1874, p. 337 ; Lefêv. Cat. Eumolp. 1885, p. 146.

Type, C. compressicornis, Fabr., from Africa.

Range. Africa; India; Malayan Subregion.

Characters those of the group.

852. Corynodes pyrophorus, Parry (Eumolpus), Proc. Ent. Soc. 1843, p. 87 ; id. (id.) Trans. Ent. Soc. 1845 , p. 86.

Corynodes gloriosus, Baly, A. M. N. H. iv, 1859, p. 125.

Dark violaceous or purplish; elytra cupreous, a humeral spot and the apex purplish.

Head strongly rugose and punctured with a shallow central groove; antenn: with the terminal five joints strongly flattened. Thorax subcylindrical, sides nearly straight, very slightly narrowed near the apex; surface very deeply, strongly but sparingly punctured, although variable in this respect. Elytra with very close rows of punctures, the latter finer than those on the thorax, somewhat more irregular near the sides; the humeral patch of triangular shape; the apical patch also triangular but very much longer. Claws bifid.

Length 10-12 mm.

Hab. Himalayas ; Nepal ; Assam ; Burma ; China.

The species is not an uncommon one.

\section{Corynodes decemnotatus (Pl. II, fig. 11), Baly, Journ. Ent. i,} 1860 , p. 31.

Metallic blue; prosternum and pleuræ bright metallic green. Each elytron with five large subcupreous spots.

Subelongate, very convex. Head distinctly punctured; antennæ deep metallic blue. Thorax subglobose above, deeply but remotely punctured. Elytra irregularly punctate-striate, the punctures aciculate, less deep towards the apex, the spots placed as follows :the first subrotundate at base, two before the middle parallel and oblong, the inner one somewhat larger, the fourth rotundate, placed just bebind the middle, and the fifth elongate and subapical, parallel with the suture. Body beneath deep metallic 
blue. Prosternum and pleuræ bright metallic green. Legs deeply punctured, anterior pair of tibiæ slightly curved near their apices, intermediate pair strongly curved heyond the middle; claws bifid.

Length $10 \mathrm{~mm}$.

$H a b$. Bombay; Kanara.

854. Corynodes undatus (Pl. II, fig. 12), Oliv. (Cryptocephalus) Encycl. Méth. vi, 1791, p. 614.

Eumolpus bifasciatus, Oliv. Ent. vi, 1808, p. 900, pl. 1, fig. 5 ; Baly (Corynodes), Trans. Ent. Soc. (3) iv, 1867, p. 130.

Eumolpus gröndalii, Swartz in Schönh. Syn. Ins. i, pt. 2, 1808, p. $23 \pi$, note 1 .

Corynodes flosculus, Marshall, Journ. Linn. Soc., Zool. viii, 1865, p. 37 .

Purplish-violaceous; elytra cupreous, the lateral margins, a broad transverse band before the middle and a trigonal sutural patch at apex, purplish.

Head coarsely and closely punctured, longitudinally impressed on the front which is continuous in the middle with the clypeus, excavated on either side of the latter, surface of clypeus more finely and closely punctured; antennæ purplish-blue with gradually but broadly dilated terminal joints. Thorax subconical, sides straight at the base, slightly rounded anteriorly, surface very deeply and irregularly punctured. Elytra without basal depression, punctured in very closely approximate rows, rather more finely so posteriorly, more irregularly at the sides in the female than in the male; the transverse purplish band is widest at the sides, where it extends downwards for a short distance, the anterior margin is also slightly prolonged upwards in front of the shoulders; the apical patch occupies about one-third of the length of the elytra. Claws bifid.

Var. a. Elytra greenish-æneous, marked as in the type.

Var. $b$. The anterior band not produced posteriorly, its hinder border straight but anteriorly extending upwards to the base, entirely covering the shoulders.

Var. $c$. The elytral band smaller and irregularly cruciform.

Length 10-11 mm.

Hab. India ; Burma; Siam; China; Malacca; Pulo-Penang.

855. Corynodes peregrinus, Fuessly (Cryptocephalus), Arch. Ins. 1783, p. 63, tab. 23, fig. 25; Baly, Trans. Ent. Soc. (3) iv, 1867, p. 132 .

Eumolpus cyaneus, Oliv. Ent. vi, 1808, p. 899, pl. 1, fig. 4.

Var. C. chapuisi, Lefèv. Cat. Eumolp. 1885, p. 147, note 1.

o. Metallic blue. Head very coarsely and deeply punctured, front rugose and irregularly excavated at lower border, latter continuous with apex of clypeus; clypeus wedge-shaped, more closely and finely punctured than the front; antennæ dark blue, 
reaching to the base of the elytra or slightly beyond, fifth and following joints gradually widened, terminal joints very broadly dilated. Thorax nearly twice as wide at base as anteriorly, lateral margins feebly rounded, surface very coarsely and irregularly punctured. Elytra subcylindrical, the base barely transversely

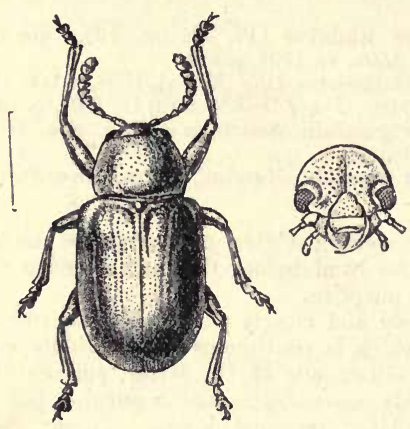

Fig. 168.-Corynodes peregrimus.

depressed, the punctures crowded but more regularly arranged in rows near the suture and nearly as large as those of the thorax. Claws bifid.

․ Has rather shorter antennæ and a more conical-shaped thorax as a rule, and the puncturation on the latter varies a good deal, although it is always deep.

Length 9-12 $\mathrm{mm}$.

Hab. India; Ceylon; Burma ; Siam; Malacea.

An abundant species; distinguished by the strong puncturation of the thorax and elytra, and very similar to C.mouhoti, Baly, but with bifid not appendiculate claws.

856. Corynodes amethystinus, Marshall, Journ. Linn. Soc., Zool. viii, 1865, p. 35.

Corynodes andrewesi, Jac. Ann. Soc. Ent. Belg. xxxi, 1895, p. 281.

Violaceous-blue. Head not swollen at vertex, coarsely but not very closely punctured; the clypeus slightly rugose, slightly separated from the face by three small smooth tubercles; supraocular sulci narrower and less deep than in the majority of species; anteunæ purplish, with a broad six-jointed club, the basal joints nearly black, shining, basal joint bluish. Thorax about half as broad again as long, subquadrate, the sides rounded and widened at the middle, the disc sparingly and deeply punctured, the punctures nearly absent at the base and at the sides, the angles not 
prominent. Scutellum not longer than broad, impunctate. Elytra scarcely perceptibly depressed below the base, finely and evenly punctured in rows, not very closely approximate. Underside very sparingly pubescent. Anterior tibix of of curred; claws bifid.

Length $7-8$ mim.

Hab. Sonthern Bombay: Kanara; Nilgiris; Travancore : Wallardi ; Igatpuri.

The distinctive characters of the present species are the sculpture of the liead with the shallow ocular sulei and the shape of the thorax, which closely resembles that of a Chrysochus, the sixjointed club of the antenna and the distinctly bifid claws.

Marshall gave no "habitat" for his species, but in comparing the type in the Brit. Mus. I find that my $C$. andrewesi is identical.

857. Corynodes curvipes, Duiv. Bull. Soc. Ent. Bely. xxxv, 1891, p. xlii.

"Purplish-cupreous above, violaceous blue beneath; labrum, palpi and antennæ (basal joints excepted) black.

"Head strongly rugose, obsoletely tuberculate between the anteunæ and bifoveolate; antennæ reaching to the middle of the elytra, third and fourtl joints subequal, the following joints gradually widened, terminal five joints broad. Thorax subglobular, scarcely broader than long, anterior angles strongly produced, lateral margins regularly rounded, base sinuate at each side, posterior angles acutely produced, surface finely punctured and impressed also with large and deep punctures. Scutellum violaceous. Elytra biimpressed behind the shoulders, surface strongly punctured, the punctures rather regularly placed, interstices finely punctured and wrinkled, giving a leather-like appearance to the surface. Beneath punctured and pubescent; a tuft of fulvous hairs on the pro- and mesosternum and on the basal halves of the anterior and intermediate femora beneatl. Legs rather elongate, tibiæ widened at their apices, the anterior and intermediate pair strongly curved from their apical third portion; claws deeply bifid.

"Length $12 \frac{1}{2} \mathrm{~mm}$.

"Hab. Bengal : Konbir." (Duvivier.)

85S. Corynodes pyrospilotus (Pl. II, tig. 13), Baly, Journ. Ent. i, 1860 , p. 32 .

Metallic blue with purple reflections; the pleuræ, two patches on the forehead, four others placed trarisversely on the thorax and three on the elytra in addition to a curved transverse band on each elytron, metallic green.

Oblong or elongate. Head with lower portion of face finely rugose-punctate, forehead deeply punctate, two trigonal patches on its surface bright metallic green. Thorax slightly broader than long, apex sinuate on eitber side, above moderately subglobose, deeply and subremotely punctured, four patches placed transversely 
metallic green, these are placed one on either side of the centre of the disc, the two others larger and lateral, extend from the apical nearly to the basal margin. Scutellum minutely punctured. Elytra much broader than the thorax, very convex, transversely grooved below the basilar area; surface somewhat closely impressed with deep punctures arranged in irregular striæ; each elytron with three metallic green patches-the first oblong near the suture, the second on the shoulder covering the humeral callus, the third placed obliquely immediately before the apex; a broad, sinuate, transverse band, commencing just behind the middle and extending across the elytron nearly to the suture, its apex curved suddenly backwards; all these markings narrowly edged with æneous. Claws appendiculate.

\section{Length 7-9 $\mathrm{mm}$.}

$H a b$. Tenasserim ; Siam.

859. Corynodes mouhoti, Baly, Desc. new gen. \& spec. Phytoph. 1864, p. 7 .

Violaceous-blue; broad and robust. Head strongly and rather closely punctured with a deep longitudinal central groove, middle of front produced into a short lobe; clypeus separated by a deep fovea on each side, finely rugosely punctured; antennæ with the terminal five joints very broadly dilated. Thorax subconical, broader than long, coarsely and rather closely punctured, flanks smooth. Elytra very faintly depressed below the base, the puncturation similar to that of $C$. peregrinus, punctures subgeminate near the suture. Claws appendiculate.

Length 10-12 $\mathrm{mm}$.

$H a b$. Sikhim: Mungphu: Burma: Rangoon; Siam; Cambodia.

This species can only be separated from $C$. peregrinus by the appendiculate claws.

\section{Corynodes ceylonensis, sp. $n$.}

Metallic blue; head, underside and legs green.

$\sigma^{*}$. Head rather finely and remotely punctured, with a shallow central longitudinal groove; clypeus wedge-shaped, separated by very deep oblique grooves; antennæ extend to about the middle of the elytra, basal six joints metallic blue, rest purplish, broadly flattened, broader than loug. Thorax half as broad again as long, subcylindrical, sides nearly straight, surface remotely and finely punctured. Elytra parallel-sided, with a very shallow depression below the base, punctured like the thorax, punctures arranged in close, rather regular rows. Flanks of thorax strigose on their lower areas. Claws appendiculate.

Length $6 \frac{1}{2}-7 \mathrm{~mm}$.

$H a b$. Ceylon: Kandy.

Differs from C. asphodelus in the bright blue colour and green legs and underside, in the nearly straight sides of the thorax and 
the more cylindrical not medially widened shape. C. travancorensis, Jac. is larger, has much shorter antennæ and elytra deeply depressed below the base.

861. Corynodes sheppardi, Baly, Descript. nero gen.\& spec. Phytoph. 1864, p. 7.

Corynodes clypeatus, Jac. Ann. Soc. Ent. Belg. xlviii, 1904, p. 389

Metallic green; antennæ purplish, basal joints partly fulvous.

$\delta$. Head very finely punctured, more or less strongly longitudinally depressed at the middle; clypeus separated from the face by a narrow transverse groove, much broader than long, very finely and closely punctured; labrum metallic green; antennæ extending to the middle of the elytra, basal joint subquadrate, metallic green, following two more or less fulvous, apical joints purplish, gradually dilated. Thorax nearly twice as broad as long, of nearly equal width, sides feebly rounded in the middle, surface very sparingly and finely punctured. Scutellum obsoletely depressed at the middle. Elytra with a short basal depression, very finely punctured in irregular, rather closely approximate rows, interstices often aciculate. Prosternum rather strongly punctured, longer than broad, slightly convex. Claws appendiculate.

‥ Antennæ shorter.

Length 10-12 $\mathrm{mm}$.

Hab. Southern India: Mercara, Coorg; Nilgiris; Bombay : Kanara.

862. Corynodes speciosus, Lefêv. Bull. Soc. Ent. Belg. xxxv, 1891, p. cclxxvi.

Blackish-blue; elytra reddish-cupreous, on the sides greenishcupreous.

Head strongly and remotely punctured, irregularly impressed between the eyes; labrum piceous; palpi and antennæ bluishblack, terminal five joints dilated. Thorax globular, very shining, remotely and deeply punctured. Scutellum smooth, apex rounded. Elytra obsoletely depressed below the base, densely and strongly punctured, punctures (especially near the suture) subgeminately arranged. Legs short; claws appendiculate.

Lenith $8 \mathrm{~mm}$.

$H a b$. Sikhim.

Allied to C. parryi, Baly, but differently coloured, and separated by the strong and remotely placed punctures on the thorax.

863. Corynodes burmanicus, Jac. Ann. Mus. Civ. Genova, xxxii, 1892 , p. 917.

Dark violaceous-blue.

Head strongly swollen at the vertex, the latter very strongly vol. I. 
but not very closely punctured, the front divided by a deep longitudinal groove; clypeus separated from the face by a transverse groove; antennæ metallic blue, extending rather beyond half the length of the elytra, the terminal five joints dilated but longer than broad. 'Thorax nearly twice as broad as long, the anterior margin straight, the sides only slightly rounded, the surface rather sparingly punctured on the disc, the sides nearly impunctate. Elytra subcylindrical, not impressed below the base or with a scarcely perceptible depression, strongly and very closely punctate-striate. Claws appendiculate.

Length $6 \mathrm{~mm}$.

Hab. Burma: Karennee.

Amongst the smaller species of this genus C. burmanicus may be known by the rather long antennæ, the want of an elytral depression, the close and strong puncturation and appendiculate claws.

\section{Corynodes cavifrons, sp. $\mathrm{n}$.}

o. Dark violaceous; second and third joints of the antennæ fulvous; labrum blue.

Head purplish, with deep longitudinal cavity on the front, remotely and rather finely punctured; clypeus separated from the face by a transverse straight sulcus, very closely and finely rugose and sparingly pubescent ; antennæ purplisb, basal joint dark blue, second and third more or less fulvous, terminal five joints dilated but longer than broad. Thorax twice as broad as long, lateral margins evenly rounded, narrowly reflexed, posterior angles not produced, anterior dentiform; surface finely, very irregularly and remotely punctured, with a depression near the posterior angles. Scutellum smooth, base with a fovea. Elytra parallel-sided, a shallow depression below the base and a very short one within the shoulders, the shoulders not very prominent; entire surface very finely punctured, with partly aciculate interstices. Flanks of the thorax distinctly punctured. Claws appendiculate.

Length $9 \mathrm{~mm}$.

Hab. Southern India : Nilgiris (Coll. H. E. Andrevees).

865. Corynodes gratiosus, Baly (Platycorinus), Descript. nero gen. \&. spec. Phytoph. 1864, p. 7 ; Marshall (Corynodes), Journ. Linn. Soc., Zool. viii, 1865, p. 41; Baly, Trans. Ent. Soc. (3) iv, 1867, p. 127.

Narrowly oblong or subelongate, metallic greenish-blue.

Head with the front swollen, obliquely depressed and excavate anteriorly ; face with its anterior border rounded, slightly depressed and excavated, surface coarsely punctured; clypeus broader than long, not separated at base from the face, sides obliquely convergent posteriorly, apex broadly truncate, surface closely punctured; antennæ nearly two-thirds the length of body 
in $\delta^{*}$, rather shorter in $q$, terminal five joints broadly dilated. Thorax at base rather broader than long, sides rounded, narrowed towards the apex, posterior angles dentate, abore subconic in front, irregularly punctured. Elytra convex, slightly excavated below basilar area, surface coarsely and somewhat closely punctured, punctures arranged in irregular longitudinal striæ.

Length 10-12 $\mathrm{mm}$.

Hab. Burma; Malay Peninsula: Tringanee; Cambodia.

Differs from $C$. mouhoti, Baly, in the shorter, more finely punctured thorax with the interstices very minutely punctate. Male genitalia broad, strongly curved, apex with two oblique ridges meeting in front.

\section{Corynodes impressicollis, sp. n.}

б. Violaceous. Head strongly and subremotely punctured, with deep longitudinal central excavation; clypeus with two deep forese at base, wedge-shaped, closely and finely punctured; antenuæ purplish, extending beyond middle of elytra, terminal joints broadly subtriangularly widened but distinctly longer than broad. Thorax about half as broad again as long, lateral margins nearly straight, slightly rounded anteriorly, surface strongiy and rather closely punctured, punctures irregularly distributed, sides smooth, with a more or less deep fovea of irregular shape near the base. Scutellum impunctate. Elytra elongate, parallel-sided, subcylindrical, with a shallow depression below base; punctures of similar size to those on the thorax, arranged in close, irregular rows. Body beneath impunctate. Claws appendiculate.

ㅇ. The antennæ shorter than in the $\delta$.

Length $10 \mathrm{~mm}$.

Hab. Sikhim: Darjeeling (Colls. Brit. Mus. \& Jacoby).

867. Corynodes (?) fulvicollis, Jac. Ann. Mus. Civ. Genova, xxvii, 1889, p. 183.

Elongate, subcyliudrical, fulvous; antennæ filiform, apical joints black; elytra metallic blue, the disc finely punctured near the suture, strongly at the sides, the latter subrugose.

Head very finely punctured, flattened; clypeus continuous with the front, fulvous, its lateral limits indicated by a short oblique groove; antennæ half the length of the body, the basal six joints fulvous, the rest black, terminal five joints only slightly thickened. Thorax subcylindrical, about half as broad again as long, the sides strongly deflexed, the lateral margins slightly rouuded, the anterior angles produced into short teeth, the surface remotely impressed with rather large punctures, the base with a narrow margin. Scutellum impunctate. Elytra dark metallic blue, slightly depressed below the base, deeply punctured at the sides, more finely near the suture, where the punctures are arranged in irregular 
double rows with two distinct longitudinal costæ that extend from the shoulders downwards to near the apex. Underside and legs fulvous. Claws appendiculate.

Length $6 \mathrm{~mm}$.

$H a b$. Burma: Teinzo.

This small species, which differs much from most other species of Corynodes by its peculiar colour, also varies greatly from the typical forms in the apparent absence of the deep sulcation at the sides of the vertex, which is present in all its congeners; the head is however, in the type contracted within the thorax up to the margins of the eyes, hiding therefore the vertex, which may possibly be found to be sulcate, if exposed to view; the flat lower portion of the face also differs from most other forms placed in the genus. On account, however, of the general typical shape and the other structural characters which are present, I have retained this insect in Corynodes.

868. Corynodes chrysis, Oliv. (Eumolpus) Ent. vi, 1808, p. 901, pl. 1, fig. 8; Marshall, Journ. Linn. Soc., Zool. viii, 1865, p. 36.

Metallic blue, green or cupreous; basal joints of antennæ black.

c. Head coarsely and closely punctured, with a more or less distinct central groove; a small tubercle at base of clypeus, the latter closely and finely punctured, finely pubescent; labrum black; antennæ extending to about the middle of the elytra, terminal five joints broadly dilated, second joint sometimes obscure fulvous. Thorax when seen from above subconical, about half as broad again as long, lateral margins nearly straight, surface very sparingly but deeply punctured. Elytra rather strongly punctured in closely approximate rows which are occasionally in pairs, last interspace near the lateral margins thickened; area below the base rather feebly depressed. Claws appendiculate.

Length 10-11 $\mathrm{mm}$.

$H a b$. Bengal : Calcutia.

The strongly and remotely punctured thorax, subconical shape of the latter, the strongly punctured elytra and bright metallic coloration distinguish this species.

869. Corynodes malachiticus, Marshall, Journ. Linn. Soc., Zool. riii, 1865, p. 42.

"Dark bluish-green. Head dark blue, impunctate, with a faint medial longitudinal impression; antennæ very long, rufo-fuscous, apical five joints broadly dilated. Thorax narrowed in front, very finely and sparingly punctate. Scutellum impunctate. Elytra robust, with a transverse depression on either side behind the shoulders, surface finely punctate-striate. Abdomen and underside 
dark bluish-green, apical segments and the tarsi clothed with fusco-flavous pubescence.

"Length 10 nim.

"Hab. India." (Marshall.)

I have not been able to find the type of this species, nor do I know of one with an impunctate head and colour of the antennæ as given by the autbor. The structure of the claws is not mentioned.

\section{Corynodes pretiosus, Baly (Platycorynus), Descript. new gen. \&} spec. Phytoph. 1864, p. 4

Vertex of head cupreous, anterior portion blue or green ; antennæ, legs and underside purplish; thorax blue or partly cupreons ; elytra cupreous, the suture narrowly, a broad transverse band at the middle and a trigonal patch near the apex dark blue margined with green.

Head with deep central groove, remotely punctured; supraocular cavities blue, deep and smooth; clypeus separated from the face by a deep transverse groove, closely punctured; labrum and mandibles black; antennæ with the terminal five joints broadly widened, basal joints more or less stained with dark fulvous, first joint blue. Thorax about half as broad again as long, sides straight at the base, rounded and narrowed anteriorly, anterior angles acutely produced, surface rather strongly but remotely punctured. Scutellum blue. Elytra very convex, without any basal depression, punctured in rather closely approximate and regular rows, the punctures like those on the thorax or somewhat finer. Claws appendiculate.

Length 8-10 inm.

$H a b$. India ; Burma.

One of the bandsomest species of the genus. The elytral transverse band does not extend to either margin and is considerably narrowed at its inner portion near the suture; the subapical patch is likewise transverse and extends across the suture. The head, antennæ and legs are wrongly described as black by Baly.

871. Corynodes lateralis, Hope (Eumolpus), in Gray's Zool. Misc. 1831 , p. 30.

Eumolpus nitens, Hope, $t$. $c$.

․ Flongate, metallic greeu. Head subremotely and finely punctured; clypeus separated by a deep groove. Thorax transverse, rather flat, angles prominent, sides widened from base to apex, rounded anteriorly, puncturation rather fine and remote. Elytra strongly punctured in closely approximate rows, sides with two acute longitudiual costæ. Claws appendiculate. 
ऽ. Thorax less transverse ; antennæ long and slender, terminal joints only slightly thickened, angles of thorax very prominent. Elytra with a deep depression, closely and strongly punctured, with indications of ridges at the sides. Tarsi purplish.

\section{Length $11 \mathrm{~mm}$.}

Hab. Nepal.

The thorax less convex than in most other species. C. nitens does not differ from $C$. lateralis, the types of both of which are contained in the British Museum Collection.

\section{Corynodes obesus, sp. $n$.}

․ Metallic cupreous or green, nnderside and legs dark blue.

Short and robust. Head finely and closely punctured, with a deep central depression; clypeus transverse, separated from the face by a deep transverse groove;

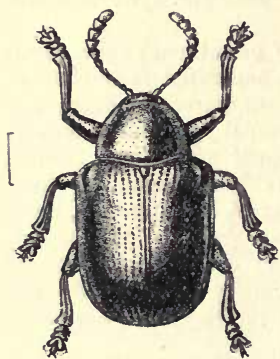

Fig. 169.-Corynodes obesus. antennæ dark blue, scarcely extending beyond the thorax, basal six joints shining, terminal five purplish, broadly dilated and flattened. Thorax half as broad again as long, widened at the middle, sides rounded, surface very minutely and closely punctured. Elytra much wider than the thorax at base, much more strongly punctured than the latter, punctnres arranged in double rows, interstices longitudinally costate, more strongly so at the sides; a distinct depression below the base, within which the interstices are rugose. Claws appendiculate.

\section{Length $5 \frac{1}{2}-6 \mathrm{~mm}$.}

Hab. Burma; Borneo (Colls. Brit. Mus. \& Jacoby).

There is a single specimen labelled "Burma" in the British Museum Collection; all other specimens known to me have come from Borneo, and the Indian locality seems somewhat doubtful. C. multicostatus, Jac., from Borneo differs by the remote and coarsely punctured thorax.

873. Corynodes dilaticollis, Jac. Ann. Mus. Civ. Genova, xxxii, 1892, p. 916.

Dark violaceous-blue. Head strongly but not closely punctured, with an obscure triangular depression; clypeus separated from the face by a deep transverse groove, very finely and closely punctured, the space at the base of the antennæ shining, impunctate: labrum greenish, edged with fulvous; antennæ violaceousblue, the second joint fulvous, the terminal five joints broadly 
dilated. Thorax about lialf as broad again as long, the anterior portion deflexed, the sides strongly rounded and widened towards the base, the surface subremotely impressed with smaller and finer punctures, the sides nearly impunctate. Scutellum broader than long, impunctate. Elytra subcylindrical, the base convex with a deep transverse depression; the entire surface very closely punctured, the punctures arranged in somewhat regular close rows; shoulders very prominent. Legs rugosely punctured ; claws appendiculate.

\section{Length $8 \mathrm{~mm}$.}

Hab. Burma : Karennee.

Principally distinguished by the shape of the thorax, which appears strongly narrowed in front when viewed from above, and by the close puncturation of the elytra, which is closer than in most species; the punctures are of about the same size as the larger ones on the thorax.

874. Corynodes andamanensis, Lefév. Bull. Suc. Ent. Belg. xxxv, 1891, p. cclxxvi.

Metallic green beneath; greenish-golden or coppery above clothed with short grey pubescence.

Head densely subrugosely punctured, vertex feebly raised, with a medial longitudinal sulcus; labrum and palpi piceous ; mandibles robust; basal six joints of the antennæ fulvous, rest blue-black, dilated. Thorax subconical, very convex, closely aciculate-punctate. Scutellum smooth. Elytra strongly depressed below the base, rather densely subgeminate-punctate; punctures aciculate, stronger at the sides and within the depression. Legs short and robust; claws with a short appendage at base.

Length $7-7 \frac{1}{2} \mathrm{~mm}$.

$H a b$. Andaman Islands.

Easily known by the short pubescence that elothes the upper side. The punctures of the elytra are similar in size to those on the thorax.

\section{S75. Corynodes travancorensis, sp. n.}

Bright metallic blue; antennæ purplish; legs bright green.

$\checkmark$. Head finely and remotely punctured, triangularly depressed at the lower portion, deeply transversely sulcate between the eves, the median lobe of the front produced into a blunt point; clypens metallic green, subquadrate, coarsely punctured, depressed, anterior margin with a fringe of grey pubescence; labrum green; mandibles and palpi nearly black; antennro extending just beyond the base of the thorax, basal five joints metallic green, rest purplish, terminal five broadly dilated, not longer than broad. Thorax scarcely half as broad again as long, very moderately convex, lateral margins feebly rounded, anterior angles pointed; surface 
irregularly, rather remotely and not deeply punctured. Scutellum slightly broader than long, impunctate. Elytra parallel-sided, deeply depressed below the base, shoulders prominent, surface finely and closely punctured in rows. Breast and abdomen very finely and sparingly punctured, metallic green like the legs. Legs strongly punctured; claws appendiculate.

Length 8-9 mm.

$H a b$. Southern India: Travancore, Wallardi ; Pondicherry (Coll. Jacoby).

876. Corynodes asphodelus, Marshall, Journ. Linn. Soc., Zool. viii, $1865, \mathrm{p} .43$.

ऽ. Violaceous or blue. Head rather closely and finely punctured, with deep subtriangularly elongate central cavity at anterior portion; clypeus separated from face by a very deep transverse groove, widened anteriorly, closely rugose-punctate ; supraocular cavities very deep, sparingly pubescent ; antennæ purplish, second joint fulvous, last five joints broadly dilated, slightly longer than broad. Thorax strongly subcylindrical, scarcely broader than long, anterior portion strongly deflexed, sides rounded and slightly widened at the middle, strongly transversely strigose and with a few punctures; surface subremotely impressed with punctures like those on the head. Scutellum subtriangular. Elytra narrow and parallel-sided, with deep semicircular depression at the base, punctured in irregular rather close rows, punctures of the same size as those on the thorax except within the depression where they are larger; shoulders very prominent and elongate; a somewhat blunt longitudinal costa near lateral margins at posterior portion of elytra. Lugs and breast greenish; claws appendiculate. Length 5-6 $\frac{1}{2} \mathrm{~mm}$.

Hab. Nepal; Assam: Sylhet; Kachar.

\section{Corynodes modestus, sp. $n$.}

Dark violaceous; posteriorly rather narrowed.

Head strongly but not closely punctured, anteriorly longitudinally depressed, produced in the middle into an acute tooth, sides likewise narrowly prolonged and smooth; supraocular cavities distinctly punctured; clypeus closely rugosepunctate; antennæ with the apical joints purplish, last five joints broadly flattened, nearly extended to the middle of the elytra. Thorax transverse, rather short, sides feebly rounded at the middle, anterior portion strongly deflexed, surface strongly and subremotely punctured, area near the margins nearly smooth. Scutellum oblong, smooth. Elytra with a deep transverse depression below the base, finely, closely and regularly punctured in rows, interstices finely aciculate here and there. Claws appendiculate.

Length $10 \mathrm{~mm}$.

Hab. Burma (Coll. Jacoly). 
More nearly allied to $C$. dohrni, Baly, than to any other species, but more narrowed posteriorly, the head different in structure, the thorax shorter, and the general colour very dark violaceous.

\section{Corynodes tridentatus, sp. n.}

․ Metallic dark blue. Head with deep central groove on the vertex, remotely but distinctly punctured, apex of anterior portion produced into three acute teeth ; clypeus separated from the face by a deep transverse sulcus, broader than long, very closely and finely punctured; labrum black; antennæ entirely black, not extending to the middle of the elytra, terminal five joints strongly widened, broader than long. Thorax conical, gradually narrowed towards apex, lateral margins straight; surface finely and irregularly punctured, very sparingly so and strigose at the sides, more closely in the middle, but leaving a small central space nearly smooth. Scutellum rather longer than broad. Elytra parallelsided, rather deeply transversely depressed below the base, very closely and somewhat regularly punctured, punctures not larger than those on the thorax, extreme lateral margins purplish. Breast impunctate; abdomen finely punctured. Claws appendiculate.

Length $10 \mathrm{~mm}$.

$H a b$. India. Type in Brit. Mus.

Can be distinguished by the black antennæ and tridentate margin to the face.

879. Corynodes dohrni, Baly, Descript. new gen. \& spec. Phytoph. 1864, p. 4 ; Marshall, Journ. Linn. Soc., Zool. viii, 1865, p. 39.

Violaceous-blue; basal joints of antennæ (first excepted) fulrous.

đ. Vertex strongly convex, puncturation variable, generally subremote, a more or less strongly marked central groove; clypeus extremely closely and finely punctured, strongly separated from the face, the base marked with a tubercle; antennæ with the basal joint blue, following five joints light fulvous, rest purplish-black, broadly dilated. Thorax slightly narrowed in front, conical when looked at from above, lateral margins nearly straight, punctures deep and remotely placed. Elytra with prominent shoulders, a short and deep depression below the base, not extending to the sides; surface punctured like the thorax, punctures placed in irregular rows, lateral margins preceded by a strong costa. Claws appendiculate.

Var. (?). Metallic green; sides of elytra purplish, apex pubescent; body beneath and legs aureous or cupreous.

Length 8-10 mm.

$H a b$. Ceylon.

Differs from $C$. peregrinus in the much more finely punctured 
thorax and elytra, the distinct costa on the latter near the margins, and the appendiculate not bifid claws; the elytral punctures are not invisible near apex as Marshall states, but on the contrary quite distinct. The sexes differ but little.

Whether the metallic-green form with pubescence at the apex of the elytra and the reddish-cupreous underside is really a variety or a distinct species I cannot say. I cannot find any structural differences.

880. Corynodes nitidus, Fabr. (Chrysomela) Ent. Syst. i, 1792, p. 325. Corynodes approximans, Buly (Platycorynus), Descript. new gen.\& spec. Phytoph. 1864, p. 6.

Corynodes hyacinthinus, Marshall, Journ. Linn. Soc., Zool. viii, 1865, p. 42 .

Corynodes amœnus, Lefèv. Bull. Soc. Ent. Bely. xxxv, 1891, p. cclxxvii.

ऽ. Dark blue or violaceous. Head rather remotely and strongly punctured, generally with a deep triangular cavity on the forehead; clypeus separated by a deep transverse sulcus, finely and closely punctured, transverse ; antennæ bluish-black, reaching nearly to the middle of the elytra, basal six joints shining, the rest broadly dilated, opaque, third and fourth joints equal. Thorax about half as broad again as long, subquadrate, lateral margins very feebly rounded and very slightly narrowed anteriorly; surface very remotely and sparingly punctured, the punctures shallow, sides of thorax when seen from above rather strongly deflexed anteriorly. Scutellum smooth. Elytra parallel-sided and cylindrical with a deep transverse depression below the base, joined to another equally deep depression in front of the shoulders that extends to the basal margin; surface rather finely, closely and regularly punctate-striate, punctures within the basal depressions stronger, the others much more distinctly marked than those on the thorax. Intermediate femora slightly dilated into a small tooth beneath. Claws appendiculate.

ㅇ. Elytra with an acute costa at the sides from before the middle to apex and a more obsolete and shorter costa near the lateral margins.

Length 9-10 $\mathrm{mm}$.

Hab. Bombay : Kanara ; Penang; Sumatra; Java.

The above description is drawn up from the type of Fabricius in the Banksian Collection in the British Museum. Marshall's types of the synonyms as given above are likewise contained in the Museum collection and cannot be separated specifically; but C. sheppardi, Baly, which is united by Marshall and Lefèvre with C. nitidus, is in every respect a totally different species, while so far as the description of $C$. amœenus goes it agrees in every detail with Fabricius's type. 
881. Corynodes assamensis, Baly, Cist. Ent. ii, 1879, p. 439.

Metallic purplish. Head strongly but not very closely punctured on the vertex, front with a longitudinal groove which terminates just above the apex of clypeus in a large ill-defined forea ; clypeus rather broader than long, semi-ovate, separated from the face by a deep groove on either side, its extreme apex transverely depressed; surface closely punctured, clothed with fulvous hairs. Antennæ nearly three-fourths the length of body in the $\sigma^{*}$, terminal six joints only slightly dilated; scarcely more than half the length of the body in the $o$, terminal six joints more broadly dilated. Thorax rather more than half as broad again as long, sides straight and slightly convergent from base to middle, thence rounded and convergent, to apex ; dise convex, subcylindrical, sparingly punctured, impressed at the sides just behind the middle with an ill-defined fovea. Elytra narrowly oblong, convex, with a deep transverse depression or sulcus below the base; just within the lateral margins in both sexes is a broad ill-defined longitudinal groove, within this in the $ᄋ$ is a narrow longitudinal costa that extends from the shoulders nearly to the apex of the elytra. Claws appendiculate.

Length 8-11 mm.

Hab. Assam.

\section{Genus CHRYSOCHUS.}

Chrysochua, Redtenb. Fanna Austr. 1848, p. 558; Moravitz, Hor'e Soc. Ent. Ross. i. 1861, p. 159 ; Marshall, Journ. Linn. Soc. viii, 1865, p. 48 ; Baly, Trans. Ent. Soc. (3) xiv, 1867, p. 133 ; Chapuis, Gien. Coléopt. x, 1874, p. 341.

Type, $C$. pretiosus, Fabr., European.

Range. Europe; N. America; India ; China; Japan.

Head inserted as far as the eyes in the thorax; eyes surrounded by a narrow sulcus; clypeus feebly separated from the face; antennæ subfiliform, the terminal joints only slightly thickened. Thorax narrower than the elytra, similar in shape to that of Corynodes but as a rule less conical. Claws appendiculate (in the type) or bifid.

The absence of the deep supraocular cavities separates this genus from Corynodes, with which it otherwise agrees in metallic coloration and proportionately large size; the antennæ never have broadly dilated but only slightly thickened terminal joints.

\section{Chrysochus sikhima, sp. n.}

Violaceous-blue; second and third joints of the antennæobscure piceous.

Elongate, nearly parallel-sided. Head sparingly and finely punctured; clypeus feebly separated at the sides, very finely and closely punctured, finely pubescent on the anterior margin; labrum and palpi black; antennæ bluish-black or with the second and third joints more or less piceous, the terminal joints gradually but 
slightly thickened, extended only a little beyond the thorax in the + . Thorax subquadrate, about half as broad again as long, sides straight or slightly concave at the base, rounded in front, anterior angles dentiform, surface rather strongly but irregularly

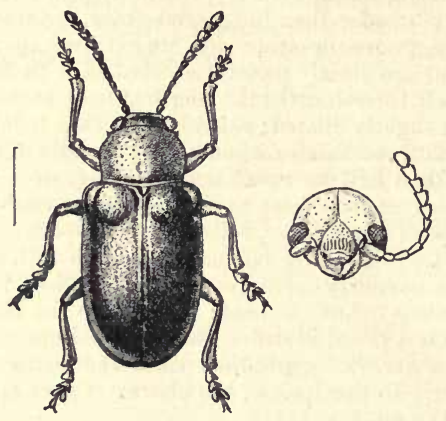

Fig. 170.-Chrysochus sikhima.

and subremotely punctured. Scutellum smooth, ovately rounded. Elytra much wider at the base than the thorax, perceptibly depressed behind the base, very finely punctured, the interstices everywhere finely aciculate or scratched. Legs rather elongate; claws bifid, the inner portion short.

Length $10 \mathrm{~mm}$.

Hab. Sikhim (Coll. Jacoby).

May be known by the sparsely punctured head, short joints of the antennæ, and the finely punctured and aciculate elytra. The two specimens before me seem to be females.

\section{Chrysochus nilgiriensis, $\mathrm{sp} . \mathrm{n}$.}

Metallic green; labrum and basal joints of antennæ fulvous.

Head remotely and rather finely punctured, deeply longitudinally sulcate at the middle; clypeus not separated from the face, strongly punctured; antennæ not extending to the middle of the elytra, basal joint greenish, the following three fulvous, rest black, third joint half as long again as the fourth, terminal joints equal, slightly thickened. Thorax transverse, nearly twice as broad as long, very slightly widened at the middle, lateral margins feebly rounded and finely strigose, angles acute, surface rather strongly and subremotely punctured, interstices somewhat unevenly raised here and there. Scutellum metallic blue, rather broad, with two small foveæ. Elytra much wider than the thorax, with a shallow transverse depression below the base, closely punctured in rows; punctures stronger within the depression and anteriorly than posteriorly 
where the puncturation is very fine and less regularly arranged; interstices at sides below the shoulders and within the depression transversely wrinkled, more or less aciculate over the rest of the surface. Body beneath and legs metallic green, abdomen bluish. Prosternum broad, strongly punctured. Claws bifid. Length $9 \frac{1}{2} \mathrm{~mm}$. Mus.

Hab. Southern India : Nilgiris (G. Hampson). Type in Brit.

884. Chrysochus siamensis, Jac. Stett. ent. Zeit. v, 56, 1895, p. 67.

Metallic green; base of the head purplish; thorax with a round purplish spot on disc; elytra, the suture posteriorly, the lateral margins and a broad transverse band before the middle, purplish.

Head rather strongly and closely punctured, with a deep central depression, the upper half purplish, the lower metallic green; clypeus sparingly punctured; labrum fulvous; antennæ black, basal joint purplish, the following three fulvous, terminal joints slightly thickened. Thorax transversely subquadrate, scarcely twice as broad as long, lateral margins feebly rounded anteriorly; the disc convex with a subquadrate, elongate purplish patch, not extending to the anterior but extending to the posterior margin where it is greatly narrowed, the surface punctured like the head. Scutellum purplish. Elytra metallic green with a slight cupreous tint, the suture posteriorly, the lateral margins more broadly and a transverse band before the middle, purplish; this band greatly widened below the shoulders and extended in a short branch upwards in front of them and to a less extent near the suture; the puncturation rather fine, slightly stronger on the purplish portion, arranged in closely approximate rows. Underside and legs metallic green, the femora inore or less and the abdomen purplish-blue. Claws bifid.

\section{Length 7-9 mm.}

Hab. Burma (Coll. Brit. Mus.); Siam (Coll. Jacoby).

The sutural purplish band is slightly widened posteriorly in some specimens.

885. Chrysochus pulcher, Buly, Desc. new gen. \& spec. Phytoph. 1864, p. 1 ; id. Trans. Ent. Soc. (3) iv, 1867, p. 134, pl. 5, f. 4.

Purplish-blue; subbasal joints of antennæ fulvous; thorax golden-cupreous.

Subquadrate-ovate, broad. Head rather finely and remotely punctured, with deep longitudinal central excavation; labrum black; antennæ extending beyond the base of the thorax, the basal joint blue or green, its apex together with the second and following two joints fulvous, the remaining joints black, slightly compressed. 'Thorax transverse, sides moderately rounded, nearly straight at the base, above subcylindrical, punctured like the head but the puncturing rather more closely placed. Elytra wider at 
the base than the thorax, not deeply but distinctly transversely depressed below the base, punctured in very closely approximate rows, the punctures rather stronger than those on the thorax.

Length 7-8 $\mathrm{mm}$.

Hab. Burma; Malay Peninsula.

A handsome and easily recognized species closely resembling in coloration Colasposoma pretiosum, Baly, from which the much more subcylindrical thorax and the structural characters of Chrysochus at once separate it.

\section{Chrysochus mouhoti, Baly, Journ. Ent. ii, 1864, p. 223.}

Violaceous or green; a trigonal patch before the middle of the elytra and the lateral margins purplish; labrum and basal joints of antennæ fulvous.

Subquadrate-ovate. Head rather closely and strongly punctured, strigose above the eyes, a deep central elongate cavity between the eyes; antennæ extending below the base of the elytra, basal joint metallic blue or green, following three joints fulvous, the rest black, slightly widened, longer than broad, third joint longer than the second. Thorax twice as broad as long, transversely subquadrate, lateral margins straight at base, feebly rounded in front, the surface closely punctured like the head. Scutellum subquadrate, sparingly punctured. Elytra with a very shallow depression below the base, very closely punctured in somewhat regular rows, punctures of the same size as those on the thorax, sometimes finer on the posterior portions of the elytra, the interior of the depression slightly more strongly punctured and with a purplish transverse, trigonal patch, not quite extending to the suture. Underside and legs blue or green. Prosternum very broad. Claws bifid.

Length 9-9 $\frac{1}{2} \mathrm{~mm}$.

Hab. Burma: Tharawaddy ; Siam : Tonkin.

The purplish elytral patch can only be distinctly seen in the green specimens; in those of violaceous tint is is only just indicated by a slightly darker colour of the corresponding part of the elytra. In spite of some slight differences in the puncturation I cannot separate the Burmese specimens from those from Siam.

\section{Group ENDOCEPHALINI.}

Oblong or subovate, glabrous above; antennæ filiform or with widened terminal joints; eyes not surrounded by sulci. Thorax transverse with distinct lateral margins; tibiæ not emarginate at apex. Claws appendiculate. Prosternum oblong; anterior margin of thoracic episternum convex.

Three genera of this group occur in India, to which, though widely divergent in general appearance, the above structural details apply. 
Key, to the Genera of Endocephalini.

A. Prosternum produced anteriorly into a cupshaped projection ...................

B. Prosternum not produced anteriorly.

a. Antennæ with terminal joints broadly flat-

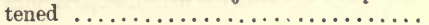

b. Antennæ filiform, terminal joints not flat-

tened $\ldots \ldots \ldots \ldots \ldots \ldots \ldots \ldots \ldots \ldots \ldots \ldots \ldots \ldots \ldots \ldots \ldots \ldots$ Colaspoides, p. 514.

Aemestes, p. 511.

Heminodes, p. 512.

\section{Genus AEMnestus, nor.}

Type, A. fulvitarsis, Jac.

Range. Assam.

Body oblong, convex, subcylindrical, glabrous. Eyes oblong; antennæ filiform; mandibles of male very prominent and robust. Thorax strongly transverse, anterior portion deflexed, sides rounded. Scutellum transversely ovate. Elytra not wider at base than the thorax, oblong, subcylindrical, lateral lobes not indicated. Femora unarmed, tibiæ entire, tarsi short; claws appendiculate. Prosternum distinctly longer than broad, widened anteriorly and produced into a round cup-shaped projection, deeply hollowed within; anterior margin of the thoracic episternum slightly convex.

Allied to Colaspoides, but distinguished by the shape of the prosternum and the strongly developed mandibles of the male, also by the different shape of the thorax.

\section{Aemnestus fulvitarsis, sp. $n$.}

Cupreous or greenish-æneous; antennæ and tarsi fulvous; body beneath piceous.

$\delta$. Head closely rugose and punctured, a central short groove

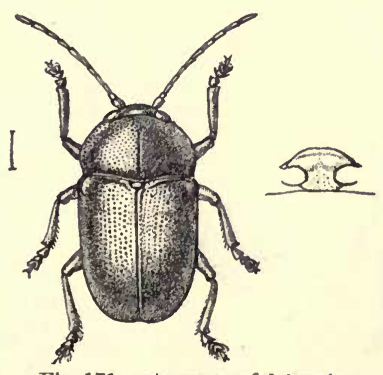

Fig. 171.-Acmnestus fulvitarsis.

closely and finely punctured. narrowed at apex, surface rather at middle of vertex, three smooth small spaces between the eyes; clypeus not separated from the face, anterior edge perfectly straight; labrum piceous; mandibles very prominent, broad at base, curved at apex; palpi slender, fulvous; antennæ extending to two-thirds the length of the elytra, basal joint thickened, second small, third and following joints nearly equal, terminal joints scarcely thicker. Thorax transversely convex, sides strongly rounded, narrowed in front, surface very Elytra subcylindrical, slightly more strongly punctured than 
the thorax, punctures arranged somewhat in rows, except at the sides, interstices on the latter slightly rugose, apex more finely and regularly punctate-striate, shoulders prominent. First joint of anterior tarsi widened.

‥ Only differs in having rather shorter antennæ, normal mandibles, and tarsi of equal width.

Length $4 \mathrm{~mm}$.

Hab. Assam: Patkai Mts. Type in Brit. Mus.

\section{Genus HEMINODES.}

Heminodes, Jac. Ann. Soc. Ent. Belg. xxxix, 1895, p. 287.

Type, $H$. indicus, Jac.

Range. India; Burma.

Body shaped like that of Corynodes, the eyes without sulci; the terminal joints of the antennæ broadly compressed and dilated; the claws appendiculate; the anterior margin of the thoracic episternum convex. Prosternum elongate, narrowed at the middle.

The species for which this genus was proposed resembles those belonging to the genus Corynodes. I have placed it, however, in the Endocephalini, as the head shows no trace of a sulcus round the eyes and the claws are broadly appendiculate.

From Chrysochus the genus differs in the want of a supraocular sulcus and in the structure of the antennæ.

888. Heminodes indicus, Jac. Ann. Soc. Ent. Belg. xxxix, 1895, p. 288.

Metallic dark blue or green. Head broad, very closely and rather finely punctured, the vertex at the sides strigose, the surface

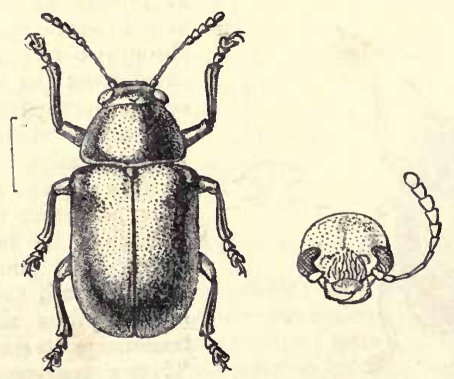

Fig. 172.-Heminodes indicus.

clothed with short grey pubescence; eyes slightly emarginate; clypeus not separated from the face, its anterior margin deeply 
concave-emarginate ; mandilles robust, black ; palpi rather slender; antennæ scarcely extending to the middle of the elytra, the first joint more or less metallic, the following three joints fulvous, slender, the terminal five joints purplish, forming a broad club, the joints broader than long. dilated and flattened, pubescent. Thorax more than twice as broad as long, the sides strongly deflexed, narrowly margined, the lateral margins rounded, the angles distinct; the surface closely and rather strongly punctured at the sides, more remotely so on the disc, and one or two shallow depressions on the sides. Scutellum broader than long. Elytra broader at the base than the thorax, transversely depressed bilow the base, slightly more strongly punctured than the thorax, especially within the depression, with slight traces of longitudinal smooth lines, the shoulders very prominent and with a short oblique costa running towards the outer margin, elytral epipleuræ narrow, continued behind the middle. Underside clothed with short white pubescence. Femora unarmed, tibiæ longitudinally sulcate, the first joint of the posterior tarsi double the length of the second; claws broadly appendiculate. Prosternum narrowed between the coxæ, strongly punctured, much longer than broad.

Length 6-10 $\mathrm{mm}$.

Hab. Burma : Tharawaddy, Taungdé.

889. Heminodes unicolor, Duviv. (Dermorhytis) Ann. Soc. Ent. Belg. xxxv, 1891, p. 38.

Bright metallic green or blue; antennæ, palpi, labrum and tarsi nearly black, basal four or five joints of antennæ fulvous.

Head rugose, especially on the front, clothed with very short pubescence, a fovea between the eyes and a narrow central groove on the front; eyes large, rounded ; antennæ piceous, reaching to two-thirds the length of the body, third joint slightly longer than the fourth, following joints slightly longer than the third, terminal joints slightly dilated and compressed. Thorax about twice as broad as long, transversely convex, sides subangulate before the middle, anterior border deeply emarginate near the sides, surface strongly and closely punctured. Elytra wider at base than the thorax, extreme basal margin carinate; surface as strongly and closely punctured as the thorax, puncturation slightly finer towards the apex, interstices here and there with traces of longitudinal ridges. Prosternum rather broad and subquadrately oblong. Legs robust, femora strongly thickened, tarsi broad.

Length $7 \frac{1}{2}-9 \mathrm{~mm}$.

$H a b$. Bengal : Konbir; Bombay: Kanara, Belgaum; Burma.

The want of the dilated prosternum posteriorly as in Dermorhytis and the convex anterior margin of the thoracic episternum place this species more appropriately in Heminodes.

vOL. I. 
890. Heminodes antennatus, Jac. (Abirus) Ann. Soc. Ent. Belg. xxxvi, 1892, p. 912.

Beneath metallic greenish or bluish, above obscure æneous; anteunæ with the apical joints dilated; the head and thorax cupreous.

Head strongly and rather closely punctured, the vertex more sparingly punctate, the middle of the front with a small, more or less distinct tubercle; the anterior margin of the clypeus, the labrum and the mandibles black; antennæ black, the second and third joints more or less fulvous, the last five joints broadly dilated. Thorax twice as broad as long, the sides strongly rounded at the margin, the anterior angles pointed; the surface strongly, closely and rather evenly punctured, the punctures more crowded at the sides but all of equal size, a very obsolete oblique depression at each side. Scutellum broader than long, smooth. Elytra convex, subcylindrical, very closely and much more strongly pnnctured than the thorax, the punctures arranged in very closely approximate semiregular rows, in the female interrupted by longitudinal narrow sunooth spaces, the interstices at the sides moderately transversely rugose. Underside and legs bluish or greenish, not very shining and clothed with short whitish pubescence.

Var. A bove entirely dark æneous.

Length 6-10 $\mathrm{mm}$.

Hab. Burma : Karennee.

More appropriately placed in Heminodes than in Abirus.

\section{Genus COLASPoIdes.}

Colaspoides, Laporte, Silberm. Rev. Ent. i, 1833, p. 20; Baly, Trans. Ent. Soc. (3) iv, 1867, p. 134; Chapuis, Gén.Coléopt.x, 1874, p. 346.

Type, C. limbata, Fab., from Cayenne.

Range. Generally distributed, except in Europe and North America.

Somewhat short and oblong in shape, rather convex. Head deeply inserted; eyes rather large, oblong, more or less sinuate within ; antennæ filiform or subfiliform, generally lonis and slender, terminal joints very slightly thickened, second joint half the length of first, third to sixth joints elongate. Thorax transverse, nearly as wide at base as the elytra, narrowed anteriorly, lateral margins more or less rounded. Elytra ovate or oblong, more or less regularly punctured, the punclures sometimes in rows. Legs variable; femora slightly thickened, sometimes with a tooth beneath; first tarsal joint rather elongate, but as a rule shorter than the following two united; claws appendiculate. Prosternum rather large, of variable shape, generally longer than broad, posterior margin truncate; anterior margin of thoracic episternum convex.-Dpecies mostly of metallic coloration, ovate and convex, with the tibiæ not emarginate. 


\section{Colaspoides subrugosa, sp. n. (Pl. II, fig. 14).}

ㅇ. Dark æneous, with slight cupreous gloss; antennæ and legs more or less piceous.

Head cupreous or greenish, vertex remotely, anterior portion closely and strongly punctured; antennæ slender, basal five joints fulvous, rest piceous, third and following joints very elongate, not thickened. Thorax twice as broad as long, sides rounded, surface extremely closely and rather strongly punctured, the punctures nearly confluent at the sides, extreme margins metallic green. Elytra oblong, very strongly subgeminately punctured, the interstices longitudinally costate near the apex, transversely rugose anteriorly at the sides. Legs unarmed.

Length 6 min.

$H a b$. Himalayas (Coll. Jacoby).

Can be recognized by the strong elytral puncturation, the costate and rugose interstices and the very closely punctured thorax. Male unknown.

\section{Colaspoides melanocephala, sp. n.}

Head, thorax and underside black; elytra metallic green; basal joints of antennæ flavous.

Head impunctate, the clypeus not separated from the face except at the sides by vèry feeble grooves; labrum piceous ; palpi fulvous; antennæ extending nearly to the middle of the elytra in $q$, basal four joints flavous, the rest black. Thorax at base twice as broad as long, the sides rounded at the middle and narrowed in front, surface entirely impunctate, black and shining. Scutellum black. Elytra very closely and rather strongly punctured, the punctures irregularly placed at the sides, with the interstices transversely rugose anteriorly $\left(\sigma^{*}\right)$ or geminate punctate-striate with the interstices longitudinally costate ( $q$ ). Legs, especially the first joint of the posterior tarsi, elongate.

Length $5 \mathrm{~mm}$.

$H a b$. Southern India: Nilgiris; Travancore: Wallardi (Colls. Andrewes \& Jacoby).

('an be easily known by the black, entirely impunctate head and thorax and the green elytra. The antennæ in the male specimen before me are imperfect, but the terminal joints extend probably a good deal further than in the female; the sculpture of the elytra is very different in the sexes.

893. Colaspoides montana, Jac. Mém. Soc. Ent. Belg. vii, 1900, p. 114.

Black beneath, metallic green above; the labrum, antennæ and legs fulvous.

Head strongly and remotely punctured with a central longitudinal groove; clypeus similarly sculptured; labrum fulvous; 
antennæ pale fulvous, extending below the middle of the elytra, the last two joints stained with fuscous at the apex, third and fourth joints equal, following joints more elongate. Thorax about twice as broad as long, the sides rounded at the base and somewhat suddenly narrowed towards the apex; the disc convex, remotely and finely punctured with some still more minute punctures on the interstices, the sides with a distinct reflexed margin. Scutellum triangular, inpunctate. Elytra very convex, closely impressed with strong punctures which are arranged regularly close to the suture and near the apex, but much more irregularly so over the rest of the disc, they are much larger on the sides; the interstices nearly throughout transversely rugose, especially on the sides. Legs fulvous; the femora unarmed.

Length $5 \frac{1}{2} \mathrm{~mm}$.

Hab. Assam: Khási Hills (Coll. Jacoby).

Principally distinguished by the nearly black underside and the close and deep puncturation of the elytra and their rugose interstices.

894. Colaspoides semipicea, Jac. Ann. Soc. Ent. Belg. xxxix, 1895, p. 280.

Beneath fulvous, above æneous.

đ. Head obscure fulrous, with a few very minute punctures near the eyes; clypeus not separated from the face, nearly sinooth; antennæ pale fulvous, extending beyond the middle of the elytra, with a short twelfth joint, third and following joints slender, equal, terminal joints slightly shorter. Thorax rather more than twice as broad as long, strongly narrowed in front, the sides slightly rounded, the angles acute but not produced; the surface smooth, piceous, shining, very sparingly impressed with a few minute punctures, the disc with a slight metallic greenish gloss (sometimes absent). Elytra strongly punctured in c'osely approximate rather regular rows which are doubled near the suture but become single towards the apex where three or four of the rows are distinct; at the sides the puncturation is more irregular. Underside and legs fulvous; the anterior femora dilated into a strong tooth, the posterior femora armed with a smaller tooth.

ㅇ. The tooth on the anterior femora beneath much smaller.

Var. Above violaceous-blue.

Length $5 \mathrm{~mm}$.

$H a b$. Southern Bombay: Kanara.

895. Colaspoides pallidula, Jac. Ann. Mus. Civ. Genova, xxvii, 1889, p. 187.

Fulvous; the apical joints of the antennæ black; elytra testaceous.

Head rather swollen, with a few fine punctures on the sides at 
base; clypeus separated from the face by an obsolete transverse groove, remotely punctured, its anterior margin straight; labrum testaceous; antennæ filiform, more than half the length of the body, the basal four joints testaceous, the others black. Thorax at least twice as broad as long, the sides rounded in the middle, narrowed in front, the anterior angles acute, slightly produced; the surface dark fulvous, remotely impressed with rather deep punctures and with a shallow transverse impression on each side. Scutellum obscure fulvous. Elytra convex, parallel-sided, subcylindrical, pale testaceous, the suture narrowly black, the surface not depressed below the base, deeply and very closely punctured, the punctures arranged in somewhat regular rows. Underside and legs dark fulvous.

Length $5 \mathrm{~mm}$.

$H a b$. Tenasserim: Meetan.

The pale colour of the elytra and their deep and close puncturation distinguish $C$. pallidula from most of its allies.

896. Colaspoides glabricollis, nom. nov.

Colaspoides lævicollis, Jac. Ann. Mus. Civ. Genova, xxvii, 1889, p. 186 (name preocc.).

Beneath black or piceous, above metallic green; antennæ and legs flavous.

Head extremely finely gramulate, entirely impunctate, the vertex with a more or less distinct central depression or groove; clypeus wedge-shaped, separated at the sides only from the face, its surface with a few small punctures, its anterior border only slightly emarginate at the middle; labrum and palpi fulvous; antennæ nearly as long as the body, entirely flavous, the third joint scarcely shorter than the fourth. Thorax three times as broad as long, the sides nearly straight, strongly narrowed in front, the anterior margin deeply concave behind the eyes, the posterior angles strongly pointed, the surface entirely impunctate, metallic bright green. Scutellum broad, impunctate. Elytra convex, not depressed below the base, the shoulders slightly prominent, the puncturation fine and arranged in rather regular but not very close rows. Legs flavous; the anterior femora with a sniall tooth.

$V a r$. Elytra purplish.

Length 3-4 inm.

Hab. Burma: Bhamo.

The entirely impunctate thorax, in connection with the flavous antennæ and legs, separates $C$. glabricollis from any of its allies.

897. Colaspoides feæ, Jac. Ann. Mus. Civ. Genova, xxvii, 1889, p. 185.

Obscure piceous ; abore greenish-cupreous ; labrum and antennæ fulvous.

Head remotely but distinctly punctured, the vertex with a 
longitudinal impressed groove; clypeus separated from the face, strongly punctured; labrum fulvous ; antennæ fulvous, nearly as long as the body, the apical three joints black. Thorax twice as broad as long, strongly narrowed in front, the sides very slightly rounded, the surface rather closely and finely punctured, the punctures at the sides rather more closely placed and of elongate shape. Elytra strongly convex, without basal depression, æneous or pale cupreous; the punctures strong and arranged in numerous and close longitudinal rows, those a.t the sides larger, the interstices transversely wrinkled, those near the apex longitudinally costate. Legs piceous; femora unarmed; the tarsi fulvous.

\section{Length 4-5 $\mathrm{mm}$.}

Hab. Burma: Bhamo, Teinzo.

Closely allied to $C$. rafflesi, Baly, but the puncturation in the present species much finer and more closely placed, the interstices less swollen.

\section{Colaspoides cupreicollis, nom. nov.}

Colaspoides igneicollis, Jac. (nec Lefèvre) Ann. Mus. Civ. Genova, xxvii, 1889, p. 185.

Obscure piceous, stained with metallic blue beneath; bright reddish-cupreous above; labrum and antennæ fulvous.

Head metallic green, finely and very remotely punctured, the vertex with a deep longitudinal central groove; clypeus separated from the face, more coarsely punctured; labrum fulvous; antennæ nearly as long as the body, entirely fulvous, the third and following joints very elongate and slender. Thorax twice as broad as long, the sides nearly straight, narrowed towards the front, the anterior angles acute; the surface remotely and finely punctured, golden cupreous, the lateral margin narrowly metallic blue. Scutellum metallic blue, broader than long. Elytra reddish-cupreous, convex, nearly parallel-sided, with a rather distinct but short transverse depression below the base, coarsely and closely punctured, the punctures arranged in striæ near the suture, the interstices transversely rugose at the sides, the lateral margin narrowly metallic blue. Underside fulvo-piceous; the legs violaceous, tarsi nearly black.

Length $5 \mathrm{~mm}$.

$H a b$. Tenasserim: Haungtharaw Valley.

This species is closely allied to C. speciosa, Lefèv. (Notes Leyd. Mus. ix.), but is much smaller and the thorax instead of being three times as broad as long is only twice as broad; the femora are without teeth; in C. speciosa they are dentate.

899. Colaspoides falcata, Harold (Amasia), Coleopt. Hefte, xvi, 1879, p. 230.

"Greenish-cupreous; epipleuræ posteriorly violaceous; antennæ, underside and legs testaceous. 
"Thorax narrowed anteriorly, rather densely punctured on the sides. Elytra strongly and anteriorly irregularly punctured, subsulcate posteriorly, apices nearly smooth. Anterior femora with a short, acute tooth, intermediate femora unarmed, posterior femora with a large curved tooth, acute at apex. Third joint of antennæ slightly shorter than fourth.

"Length $4 \mathrm{~mm}$.

"Hab. Burma." (Harold.)

Whether this species, of which the above description is all that the author has given, is rightly placed in Colaspoides where Lefèvre placed it, can only be settled by an examination of the type.

\section{Colaspoides dohertyi, sp. n.}

Beneath piceous; antennæ and legs fulvous; above fulvous with a strong, metallic, æneous gloss.

$\delta$. Elongate. Head finely and rather remotely punctured on the vertex ; clypeus not separated from the face, rather more strongly punctured; eyes large; labrum fulvous; antennæ reaching to some little distance from apex, third and following joints elongate, nearly equal, last two joints slightly widened. Thorax half as broad again as long, of equal width, not narrowed anteriorly, lateral margins feebly rounded, surface rather closely and finely punctured, punctures shallow. Elytra parallel-sided, elongate, pointed at apex, much more strongly punctured than the thorax, punctures arranged in very close, rather regular rows ; interstices finely transversely wrinkled except near the suture, slightly longitudinally costate near the apex. Legs and tarsi rather elongate; anterior femora dilated into a small tooth beneath.

‥ With a more transverse thorax and shorter antennæ, but otherwise similar.

Length $3 \frac{1}{2} \mathrm{~mm}$.

Hab. Assam: Patkai Mts. Type in Brit. Mus.

Principally distinguished by the partly fulvous and partly metallic coloration, the dentate anterior femora and generally small size.

\section{Colaspoides fulvimana, sp. n.}

Beneath black, above metallic blue; labrum, basal joints of antennæ and tarsi fulvous.

Oblong-ovate. Head finely and very remotely punctured, with a deep central longitudinal groove; clypeus rugosely punctured, depressed, sides of face deeply obliquely grooved; antennæ long and slender, extending beyond middle of elytra, basal three or four joints fulvous, rest black, third and following joints very elongate and nearly equal. Thorax twice as broad as long, narrowed in front, lateral margins slightly rounded, somewhat deeply punctured: 
surface rather closely punctured, the punctures shallow in the middle, stronger at the sides. Scutellum oblong, smooth. Elytra convex, not depressed below base, much more strongly punctured than the thorax; punctures arranged in irregular rows on the disc, but very regular near apex and suture, interstices at sides below the shoulders slightly rugose. Prosternum broader than long, finely punctured. Legs rather elongate.

Length $2 \frac{3}{4 m}$.

Hab. Manipur. Type in Brit. Mus.

The following two species are unknown to me:-

902. Colaspoides sublævicollis, Duviv. Ann. Soc. Ent. Belg. xxxvi, 1892, p. 417.

"Entirely obscure fulvous, shining; palpi, antennæ and legs pale fulvous; elytra with slight bronze reflection.

"Head nearly smooth, some superficial punctures between the eyes as well as a fine longitudinal groove; clypeus slightly longer than broad, separated by lateral grooves which unite in front; mandibles robust, black; antennæ reaching to four-fifths the length of the elytra, terminal joints slightly thickened. Thorax twice as broad as long, lateral margins straight at base, rounded in front; surface feebly convex, extremely finely and remotely punctured, a row of stronger punctures near the basal margin. Scutellum somewhat rounded, smooth. Elytra rounded at their apices, very feebly depressed within the shoulders, basal portion without a depression, puncturation rather strong and regular, arranged on the anterior half in double rows, interstices on the anterior half flat, posterior half punctured in single rows with the interstices convex, the two rows of punctures nearest the suture more strongly marked than the others. Anterior rather strongly, posterior femora more feebly, dentate ; intermediate femora unarmed.

"Length 6 mm.

"Hab. Sikhim : Kurseong." (Duvivier.)

The author says that this species is very closely allied to C. inornata, Baly, from Penang, from which it differs in the nearly smooth thorax, the nearly impunctate head, the entirely fulvous antennæ, and in the thorax being darker in colour than the elytra.

903. Colaspoides bengalensis, Duviv. Ann. Soc. Ent. Belg. xxxvi, 1892 , p. 418.

"Reddish-fulvous; sides of the pro- and metasternum and the middle of the abdomen greenish-æneous; legs reddish-fulvous with æneous gloss, apices of the tibiæ and of the tarsi blackish; underside greenish-bronze. 
Vertex of head with deep fovea, less strongly punctured than the front portion; clypeus deeply punctured at base, not separated from the face, reddish anteriorly, with two obtuse teeth on the anterior edge ; antennæ slender, as long as the body, the fifth and seventh joints slightly darker, the last five elongate. Thorax about two and a half times as broad as long, narrowed in front, sides straight at base, surface densely punctured. Scutellum smooth. Elytra wider at base than the thorax, scarcely depressed near the scutellum, strongly punctate-striate; interstices impunctate, flat anteriorly, subcostate posteriorly; sides with some transverse rugæ, more strongly and very irregularly punctured. Anterior femora with a very minute tooth beneath.

" Length 5-6 $\frac{1}{2} \mathrm{~mm}$.

“Hab. Sikhim : Kurseong." (Duvivier.) 



\section{ALPHABETICAL INDEX.}

abbreviatulus (Cryptocephalus), 264.

abbreviatum (Nodostoma), 333.

abdominalis (Dioryctus), 181.

abdominalis (Nodostoma), $33 \overline{7}$.

aberrans (Cryptocephalus), 235.

Abirus, 456.

Acis, 439.

Acrothinium, 461.

admirabilis (Lema), 59. adonis (Crioceris), 78 .

Adoxini, 465.

Aemnestus, 511. ænea (Scelodonta), 383. æneicollis (Aspidolopha), 137.

æneicollis (Nodina), 297.

æneipenue (Nodostoma), 331.

ænescens (Pagria), 361. æneus (Abirus), 456. araria (Donacia), 10. Etheodactyla, 100. Etheomorpha, 123. affine (Gynandrophthalma), 109.

aggregatum (Nodostoma), 329.

albostriatus (Eumolpus), 394.

albovillosum (Colasposoma), 439.

alternata (Scelodonta), 383.

ametbystina (Lema), 24.

amethystinus (Corynodes), 494. amœna (Clytra), 136. amœnus (Corynodes), 506.

analis (Cryptocephalus), 247.

analis (Dioryctus), 179.

Anchenia, 71 .

anchorale (Nodostoma), 342.

andamanense (Nodostoma), 320 .

anciamanensis (Cleorina), 487.

andamanensis (Cœnobius), 187.

andamanensis (Corynodes), 503.

andamanensis (Eubrachis), 434 .

andamanensis (Lema), 24.

andamansis (Abirus), 457.

andrewesi (Chlanys), 278.

andrewesi (Cœuobius), 184.

andrewesi(Colasposona), 453.

andrewesi (Corynodes), 494.

andrewesi (Cryptocephalus), ¿219.

andrewesi (Demotina), 428.

andrewesi (Wermorlyytis), 375.

andrewesi (Leina), 68. andrewesi (Nodostoina), 309.

andrewesi (Psendoclytra), 101. andrewesi (Psendopiomera), 404.

andrewesi (Xanthophorus), 406.

andrewesi (Zengophora), 14.

angulato-fasciatus (Orsptoceplualus), 239.

angulicolle (Nodostoma), 339.

angustata (Lamprosoma), 282.

angustatus (Abirus), 456. angustomarginatus(Cryptocephalus), 193.

annamita (Clytra), 156. antenuata (T'richochrysea), 389.

antennatus (Heminodes), 514.

antiquum (Nodostoma), 343.

antonii (Lema), 38.

Aoria, 396.

apicalis (Aspidolopha). 135.

apicalis (Zeugophora), 13.

apicata (Tricliona), 474.

apicipennis (Gynandrophthalıua), 105.

apicipes (Nodostoma), 331.

approximans (Coryvodes), 506.

areolata (Scelodonta), 384.

arrogans (Lema), 60.

asperatum (Oolasposoina), $45^{\circ} 2$.

asphodelus (Corynodes), 504. 
Aspidolopha, 134.

assamensis (Ftheo-

morpha), 131.

assamensis (Aulexis), 411.

assamensis (Callisina), 364.

assamensis (Cleorina), 486.

assamensis (Corynodes), 507.

assamensis (Cryptocephalus), 195.

assamensis (Gynandrophthalma), 111

sssamensis (Lamprosoma), 281.

assamensis (Lema), 40. assamensis (Melixanthus), 267.

assamensis (Rhyparida), 381 .

assamensis (Temnaspis), 91.

ater (Lypestbes), 412.

aterrima (Rhyparida), 379.

aterrimus (Conobius), 187.

atkinsoni (Dermorhytis), 370.

atkinsoni (Lema), 28.

atro-cærulea (Lema), 66.

Atropidius, 176.

Aulacolepis, 431.

Aulexis, 410.

aulica (Cleorina), 488.

aureofasciata (Colaspis), 370 .

aureovittatum (Colasposoma), 455.

auripenne (Colasposoma), 454.

Autolampra, 300 .

balteata (Diapromorpha), 170.

balyana (Lema), 20.

balyi (Callisina), 364.

balyi (Demotina), 429.

balyi (Heterotrichus), 464.

balyi (Xanthophorus), 406.

basalis (Cœnobius), 189. basifemorata (Trichotheca), 401.

Basilepta, 301.

belgaumensis (Cryptocephalus), 209.

belgaumensis (Iema), 70. belgaumensis (Nodina), 296.

bengalense (Nodostoma), 318.

bengalensis (Colaspoides), 520.

bengalensis (Eubrachis), 436.

bengalensis (Lema), 21.

bengalensis (Rhyparida), 378.

bengalensis (Temnaspis), 87.

bevani (Cleorina), 484 .

bhamocnse (Nodostoma), 306.

bhamoensis (Trichochrysea), 388

biangulata (Dermorhytis), 373 .

bicallosum (Colasposoma), 443.

bicolor (Cleorina), 488 .

bicolor (Lamprosoma), 281.

bicolor (Lema), 71 .

bicolor (Pseudostonopa), 351.

bicolor (Tricliona), 476 .

bicolorata (Chrysolampra), 290.

bicoloratum (Colasposoma), 449.

bifasciata (Triclioua), 474.

bifasciatum (Colasposoma), 455.

bifasciatus (Dioryctus), 182.

bifasciatus (Eumolpus), 493.

bimaculata (Lema), 54 .

bimaculata (Miopristis), 99.

bimaculata (Rhyparida), 380.

bimaculicolle (Nodostoma), 327.

binghami (Lema), 61.

binghami (Nodostoma), 326.

biplagiata (Pseudostonopa), 351.

bipunctata (Pagria), 357.

bipunctatum (Nodostoma), 317 .

birmanica (Gynandrophthalma), 111.

birmanica (Lema), 17.

birmanicum (Nodostonia), 321. bissexsignatus (Cryptoceplalus), 242.

bistrigatum (Nodostoma), 313.

bituberculatum (Nodostoms), 330.

bohemani (Gynandrophthalma), 107.

bombayensis (Cryptocephalus), 208.

bowringi (Aoria), 397.

bowringi (Cryptocephalus), 251.

bowringi (Demotina), 427.

brahminus (Cryptocephalus), 223.

bretinghami (Lema), 45.

bretinghami (Pachnephorus), 460.

brevipes (Sagra), 6 .

Bromiodes, 465.

brunnea (Callisina), 362.

brunnea (Chrysonopa), 355.

burmaensis (Lema), 54.

burnanica (Callisina), 365.

burmanica (Chrysolampra), 289.

burmanica (Diapromorpha), 164.

burmanica (Mouhotina), 490.

burmanica (Nodina), 205.

burmanica (Pagria), 360.

burmanica (Pseudaoria), 399.

burmanicus (Cleoporus), 482.

burmanicus (Cœnobius), 184.

burmanicus (Corynodes), 497.

burmanicus (Cryptocephålus), 240.

cærulea (Aspidolopha), 134.

cærulea (Gynandrophthalma), 106.

cærulea (Pseudaoria), 399.

crruleus (Edistus), 366.

calanus(Cryptocephalus), 213.

Callisina, 362.

Callisini, 362.

Camptosomes, 86. 
capitata (Diapromorpha), 169.

capitatum(Colasposoma), 446.

capitatum (Nodostoma), 303.

carbunculus (Sagra), 7. cardoni (Clytra), 157. cardoni (Crioceris), 82. cardoni (Lema), 53.

cardoni (Nodostoma), 312.

carinata (Lema), 33.

carinatus (Xantho-

phorus), 408.

carneobifasciatus(Cryptocephalus), 246.

cashmirensis (Leprotella), 415 .

castanea (Orioceris), 72.

castanea (Lema), 37.

castanea(Pseudostonopa), 352.

castaneus (Dioryctus), 179.

cavifrons (Corynodes), 498.

cerasi (Orsodacna), 15.

Ceratobasis, 171.

cerea (Lema), 37.

ceylonensis (Ceratobasis), 173.

ceylonensis (Clytrasoma), 151.

ceylonensis (Oorynodes), 496.

ceylonensis (Demotina), 430.

ceylonensis (Dermorhytis), 371.

ceylonensis (Exema), 279. ceylonensis (Lamprosoma), 282.

ceylonensis (Lema), 22.

ceylonensis (Nodina),

294.

ceylonensis (Pagria), 357. ceylonensis (Pseudopiomera), 404.

ceylonensis (Tricliona), 476.

ceylonica (Aspidolopha), 141.

ceylonica (Gynandrophthalma), 113.

ceylonicus (Abirus), 459.

chalceum (Nodostoma), 305.

chalceus (Cœnobius), 185. chalybeo-notrta (Lema), 59. chapuisi (Coryuodes), 493.

Chlamydinx, 270.

Chlamys, 271.

chlorotica (Clytra), 153.

chrysis (Corynodes), 500.

Ohrysochus, 507 .

Chrysolampra, 285.

Chrysomelidæ, 1.

chrysomeloides (Gynandrophthalma), 113.

Chrysonopa, 353.

cincta (Atheomorpha), 124.

circuinductus (Cryptocephnlus), 193.

citrinella (Gynandrophthalma), 115.

clavareaui (Aspidolopha), 136.

clavareani(Colasposoma), 444.

clavarenui (Temnaspis), 90.

Cleoporus, 479.

Cleorina, 482.

clypeata (Lema), 41.

clypeata (Trichochrysea), 391.

clypeatum (Nodostoma), 327.

clypcatus (Corynodes), 497.

Clythra, 152, 271.

Clytra, 152.

Clytrasoma, 149.

Clytrinæ, 94.

cochinchinensis (Gynandrophthalma), 111.

Conobius, 182.

coruleatum (Colasposorua), 447.

Colaspini, 367.

Colaspoides, 514.

Colasposoma, 439.

Oolobaspis, 91 .

colon (Cryptocephalus), 256.

compressicornis (Corynodes), 492.

concinnicolle (Nodostoma), 312.

conformis (Clytrasoma), 150.

conglomerata (Pagria), 361 .

congregatum (Nodostoma), 329 .

consimile (Nodostoma), 356.

constricto-fasciata

(Lema), 46.
convexicolle(Nodostonia), 306.

convexicollis (Pachnephorus), 461.

Coptocephala, 174. cornuta (Gynandrophthalma), 108.

coromandeliana

(Chlamys), 271.

coromandeliana (Colasposoma), 444.

coromandeliana (Leına), 25.

corrosicollis (Cryptocephalus), 264.

Corynodes, 492.

Corynodini, 491.

costata (Aspidoloplia), 135.

costata (Dermorhytis), 377.

costatipennis (Pagria), 358.

crassicollis (Lema), 70. crassicornis (Crioceris), 72.

crassipalpis (Lema), 53. crassipes (Gynandrophthalma), 112. crassipes (Nodina), 293. crebrepunctata (Lema), 66.

cribellata (Etheomorpha), 127.

cribricolle (Nodostoma), 343.

cribricollis (Cryptocephalus), 216.

cribricollis (Lema), 65.

Criocerinæ, 12.

criocerioides (Lema), 31.

Crioceris, 71 .

cruciata (Crioceris), 80. cruciatus (Cleoporus), 479.

crucipennis (Cryptocephalus), 200.

crucipenuis (Gyna11drophthalma), 118.

Cryptocephalinæ, 176.

Cryptovephalus, 192.

cummingi(Labidostomis), 97.

cuprea (Dermorhytis), 372.

cupreicollis(Colaspoides), 518.

curculionoides (Scelodonta), 382.

curvipes (Chrysolampra), 287. 
curvipes (Corynodes), 495.

cyanea (Lema), 64 .

cyanella (Lema), 15.

cyaneum (Nodostoma), 304.

cyaneus (Eumolpus), 493. cyanipennis (Lema), 23.

Cyclica, 280.

cylindrica (Pseudocolaspis), 466.

darjilingensis (Cryptocephalus), 263.

decemnotata (Etheomorpha), 132.

decemnotatus (Corynodes), 492.

decolorata (Lema), 42.

decora (Aspidolopha), 136.

decorus(Cryptocephalus), 211.

decurio(Cryptocephulus), 263.

deficiens (Cryptocephalus), 226.

dehaani (Lema), 73.

dejeani (Diapromorpha), 166.

delesserti (Donacia), 10.

delesserti (Gynandrophthalma), 104.

Demotina, 427.

Demotinella, 414.

denticolle (Nodostoma), 302.

depressus (Cryptocephalus), 205.

Dermorhytis, 367.

dharwarense (Nodostoma), 316 .

Diapromorpha, 162.

dichotomus (Cryptocephalus), 239.

difficilis (Lema), 47 .

dilaticollis (Corynodes), 502.

dilaticornis (Cryptocephalus), 202.

dillwyni (Scelodonta), 385.

dilutipes (Epimela), 147.

dimidiata (Rhyparida), 378.

dimidiatipennis (Coptocephala), 175.

dimidiatipennis (Cryptocephalus), 224.

dimidiatipennis (Lema), 57. dimidiatipes (Nodostoma), 345.

dimidiatus (Cryptocephalus), 223.

Dioryctus, 176.

discicolle (Nodostoma), 346.

discicollis (Cœnobius), 187.

discoidalis (Eubrachis), 435.

dispar (Clytra), 154.

distincta (Aspidolopha), 139.

distincta (Hyperaxis), 419.

divisa (Gynandrophthalma), $11 \%$.

divisus(Cryptocephalus), 245.

dodecaspilus (Cryptoce- phalus), 252.

dohertyi (Cleorina), 487.

dohertyi (Colaspoides), 519.

dohertyi (Crioceris), 79.

dohertyi (Cryptocephalus), 254.

dobertyi (Gynandraphthalma), 107.

dohertyi (Manipuria), 84.

dohrni (Corynodes), 505.

Donacia, 10.

Donaciinæ, 9.

dormeri (Nodostoma), 331.

dorsalis (Conobius), 186.

downesi (Colasposoma), 442.

downcsi (Lema), 43.

downesi (Pantocometis), 149.

downesi (Temnaspis), 88.

druryi (Sagra), 4.

dubia (Hyperaxis), 423.

dubiosum (Nodostoma), 308.

ducalis (Cryptocephalus), 257.

durius (Cryptocephalus), 205.

duvivieri (Clytra), 155.

duvivieri (Hyperaxis), 418.

duvivieri (Lema), 38.

durivieri (Nodostoma), 313. duvivieri (Trichotheca), 402.

Edistus, 365.

Edusini, 456.

elegans(Cryptocephalus), 204.

elongata (Nephrella), 416.

elongata (Nodostella), 299.

elongatus (Abirus), 457.

empyrea (Sagra), 5.

Endocephalini, 510 .

ensifer (Cryptocephalus), 199.

Epimela, 144.

epipleuralis (Lema), 21.

Eubrachini, 432.

Eubrachis, 433.

Eumolpinæ, 283.

Eumolpini, 438.

Eupodes, 3.

Euraspis, 464.

Eurypelta, 464.

Exema, 278.

exsulans (Cryptocephalus), 195.

fabrei (Gynandrophthal$\mathrm{ma}), 122$.

fabrei (Nodostoma), 308.

fairmairei (Nodostoma), 326.

falcata (Colaspoides), 518.

fallax (Ftheomorpha), 123.

fasciata (Callisina), 362.

fasciatipennis(Crioceris), 80.

faciato-punctata(Clytra), 158.

fasciato-rutilans (Dermorhytis), 368.

fascicularis (Eumolpus), 394.

fatuus (Cryptocephalus), 219.

faustulus (Cryptocephalus), 246.

feæ (Chlamy's), 273.

fex (Colaspoides), 517 .

feæ (Cryptocephalus), 206.

fer (Hyperaxis), 421.

feæ (Lema), 40.

feæ (Nodostoma), 340.

femorata (Autolampra), 300.

femorata (Lema), 56. 
femorata (Mouhotina), 490.

femorata (Sagra), 4.

femoratum (Nodostoma), 333.

fenestratus (Cryptocephalus), 213.

flavicornis (Temnaspis), 89.

flavimana (Lema), 27.

flavipannis (Orioceris), 76.

flavipes (Chrysolampra), 286.

flavipes (Pedrillia), 14.

flavitarsis (Chlamys), 275.

flavobasalis (Gynandrophthalına), 121.

flavocinctus (Cryptocephalus), 202.

flavolimbatum (Nodostoma), 341.

flavonigra (Colobaspis), 91.

flavopilosus (Xanthophorus), 405.

flavopustulata (Pagria), 356.

flavotibialis (Clytra), 153.

floriger(Cryptocephalus), 259.

flosculus (Corynodes), 493.

foveolata (Hyperaxis), 419.

fraternus (Cryptocephalus), 220.

frontalis (Gynandrophthalma), 104.

fulgidus (Edistus), 365.

fulva (Cleorina), 489.

fulvicollis (Corynodes), 499.

fulvicorne (Nodostoma), 303.

fulvicornis (Cœnobius), 188.

fulvicornis (Lema), 16.

fulvifrons (Aoria), 398.

fulvimana (Colaspoides), 519.

fulvimana (Lema), 62.

fulvipes (Chlamys), 276.

fulvipes (Cœnobius), 188.

fulvipes (Dermorhytis), 375.

fulvipes (Nodostoura), 301. fulvitarsis (Aemnestus), 511.

fulvofasciatum (Nodostoma), 345.

fulvofrontalis (Lema), 61.

fulvohirsuta (Hyperaxis), 418.

fulvotibiale(Nodostoma), 324.

fulvula (Lema), 35.

funerea (Labidostomis), 97.

funerea (Leına), 69.

fusca (Trichotheca), 402.

fuscicornis (Gynandrophthalma), 114.

fuscipennis (Xanthophorus), 407.

fuscitarsis (Gynandrophthalma), 114.

fusculus (Eumolpus), 395.

gahani (Lema), 63.

gangetica (Lema), 25.

gaschkevitchi (Acrothinium), 461.

geniculatum (Nodostoma), 310.

gestroi (Cryptocephalus), 214.

gibbosa (Chlanys), 271.

gibbosa (Clytra), 150 .

gigantea(Diapromorpha), 162.

glabricolle (Nodostoma), 336.

glabricollis (Colaspoides), 517.

glabricollis (Dioryctus), 178.

glabricollis (Tricliona), 471.

globicollis (Lema), 21.

gloriosus (Corynodes), 492.

gracilicornis (Leprotes), 425.

gracilipes (Nodostoma), 307.

gracilis (Miochira), 160.

granulosa (Scelodonta), 386.

Graphops, 382.

gratiosus (Corynodes), 498.

greeni (Lema), 31.

grisea (Hyperaxis), 424.

gröndalii (Eumolpus), 493.
guttifer(Cryptocephalus), 259.

Gynandrophthalma, 103.

hampsoni (Crioceris), 81.

hampsoni (Cryptocepha$\ln 8), 215$.

hampsoni (Nodostoma), 319.

baroldi (Nodostoma), 331.

hauseri (Dioryctus), 181.

hebe (Trichochrysea), 393.

hecticus (Cryptocephalus), 216.

Heminodes, 512.

heraldicus (Cryptocephalins), 207 .

berbsti (Cryptocephalus), 258.

Heteraspini, 387.

Heteraspis, 382.

Heterotrichus, 463 .

hians (Melixanthus), 267.

hieroglyphicus (Pacloybrachys), 265.

himalayensis(Eubrachis), 436.

hirsuta (Pantocometis), 148.

hirsutum (Nodostoma), $3+3$.

hirsutus (Dermorhytis), 377.

hirta (Nodina), 298.

hirta (Trichochrysea), 390.

hirta (Trichotheca), 400.

histrio (Lema), 52.

hopei (Lema), 19.

horni (Lema), 20.

horni (Pantocometis), 149.

humeralis (Crioceris), 79.

bumeralis (Melixanthus), 268.

hyacinthinus (Oorynodes), 506.

Hymetes, 280.

Hyperaxis, 417.

igneicollis (Abirus), 458. igneicollis (Colaspoides), 518.

igneo-fasciata (Dermorhytis), 367, 370. 
imitans (Dermorbytis), 371.

imitans(Gynandrophthalma), 120.

imitans (Nodostoma), 339.

immaculata (Rhyparida), 379.

immaculata (Scelodonta), 387.

impotens (Lema), 36.

impressa (Crioceris), 72.

impressicollis (Corynodes), 499.

impressipenne (Nodostoma), 347.

impressus (Pachnephorus), 461.

incanus (Eumolpus), 395.

inconspicua (Crioceris), 75 .

inconspicua (Tricliona), 472.

inconspicuum (Nodostoma), 322.

inconstans (Oryptocephalus), 194.

indica (Callisina), 363.

indica (Chlamys), 277.

indica (Chrysolampra), 291.

indica (Cleorina), 485.

indica (Diapromorpha), 171.

indica (Donacia), 11.

indica "Epimela), 145.

indica (Eubrachis), 433.

indica (Exema), 279.

indica (Gynandrophthalma), 117.

indica (Hymetes), 280.

indica (Labidostomis), 96.

indica (Lema), 30.

indica (Lypesthes), 412.

indica (Mesocolaspis), 437.

indica (Miochira), 161.

indica (Nodina), 292.

indica (Orsodacna), 15.

indica (Scelodonta), 383.

indica (Tricliona), 472.

indica (Zeugopbora), 14.

indicum (Nodostoma), 332.

indicus (Bromiodes), 465.

indicus(Cryptocephalus), 243. indicus (Edistus), 366.

indicus (Heminodes), 512.

ineditus (Cryptocephalus), 206.

inornata(Ftheomorpha), 126.

inornatus (Cleoporus), 480.

insignatus (Cryptocepholus), 217.

insignis (Colobaspis), 92. instabile (Nodostoma), 344.

insubidus (Cryptocephalus), 225.

insularis (Clytra), 155.

insularis (Cœnobius), 183.

insularis (Epimela), 146.

intacta (Lema), 22.

intactum (Nodostoma), $3: 24$.

integricollis (Chlamys), 273.

integris (Cœnobius), 190.

intermedius (Melixanthus), 267.

interrupto-fasciata (Aspidolopha), 141.

intricata (Exema), 278.

Iphimeini, 285.

irregulare (Nodostoma), 335.

jacobyi (Cleorina), 485.

jansoni (Lema), 52 .

jansoni (Sagra), 6.

javana (Hymetes), 280.

javana (Temnaspis), 87.

juvenilis (Lema), 43.

kauaraensis (Chlamys), 276.

kanaraensis (Clytra), 158.

kanaraensis (Leprotes), 426.

kanarsensis (Pagria), 360.

kandyensis(Cryptocephalus), 249.

kandyeusis (Dermorbytis), 369 .

kandyensis (Lema), 26.

kashmirensis (Cryptocephalus), 261.

khasianensis (Rhyparida), 378. kœnigii (Ceratobasis), 172.

konbirensis (Cryptocophalus), 198.

Labidostounis, 96.

lacertosa (Lema), 35.

lacordairei (Gynandrophthalma) 165.

lacordairei (Lema), 23.

lævicollis (Cœnobius), 183.

lævicollis (Colaspoides), 517.

lævicollis (Nodina), 298.

lævicollis (Tricliona), 471.

lævicollis (Xanthophorus), 407.

lævifrons (Pagria), 359.

lævipennis (Gynandrophthalma), 122 .

Lamprosonıa, 281.

Lamprosoninæ, 280.

latefasciatum (Nodostoma), 319.

lateralis (Atheodactyla), 100.

lateralis (Cœnobius), 186.

lateralis (Corynodes), 501.

lateralis (Lema), 48.

laterimaculatus (Cryptocepbalus), 250.

laticolle (Colasposomn), 441.

laticollis (Gynandrophtbalına), 105.

latimanus (Cryptocephalus), 210.

lefevrei (Cleoporus), 481.

lefevrei (Cleorina), 484.

lefevrei (Clytra), 154.

lefevrei (Cryptocephalus), 224 .

lefevrei (Nodostoma), 338.

leferrei (Paria), 468.

Lema, 15, 71 .

lemoides(Xanthophorus), 408.

leopardus (Cryptocephalus), 244.

lepida (Miopristis), 99.

Leprotella, 415.

Leprotes, 425.

Ieprotini, 395.

lewisi (Demotina), 430.

lewisi (Dermorhytis),

372 . 
lewisi (Nodostoma), 318.

limbata (Colaspoides), 514.

lividipes (Colseposoma), 440.

locuples (Crioceris), 74.

longefemorata (Lema), 38.

longicollis (Preudocolaspis), 467.

longicollis (Sagra), 4.

longicollis (Scelodonta), 387.

longicorne (Nodostoma), 310.

longicornis (Cleorina), 488.

longicornis (Gynandrophtbalma), 103.

longicornis (Pedrillia), 13.

longicornis (Tricliona), 479.

longipes (Chrysonopa), 354 .

longipes (Cryptocephalus), 236.

longipes (Melinobius), 270.

longipes (Sagra), 6.

Lophea, 462.

lucifer (Cryptocephalus), $2 * 29$.

lundi (Cryptocephalus), 210.

lunulata (Merilia), 98.

luridus (Monacbus), 267.

lut ulentus (Cryptocephalus), 228.

lycaon (Lema), 44.

Lypesthes, 412.

macei (Lema), 71.

10-maculatus (Cryptocephalus), 192.

maculiceps (Nodostoma), 344.

maculicollia (Cleoporua), 479.

maculipenne (Nodosto$\mathrm{ma}), 311$.

madrasæ (Cryptocephalins), 221 .

maduraensis (Etheomorpha), 133.

madurensis (Dioryctus), 177.

VOI, I. mabéense (Nodostoma), 330.

mahéensis (Lema), 39 .

nıindroni (Lema), 56.

malabarensis (Melixanthus), 268.

malabarica (Crioceris), 72.

malabarica (Hyperaxis), 423.

malabarica (Lema), 18.

malachiticus(Corynodes), 500.

maleficus (Cryptocephalus), 238.

malleatus (Cryptocephalus), 227.

mandarense(Nodostoma), 333.

mandarensis (Cryptocephalus), 221.

mandarensis(Hyperaxis), 422.

nuandarensis (Lema), 69.

mandibularis (Lem $\Omega), 32$.

manipurensis (Chryso-

lanipra), 289.

manipureasis (Cleorina), 486.

manipurensis(Cœnobius), 184.

manipurensis (Cryptocephalus), 225.

manipurensis (Dioryctus), 180.

Manipuria, 84.

marginata (Tricliona), 478.

marginicollis (Clytra), 153.

Marsœus, 378.

medio-lineata (Lema), 49.

Megalopinæ, 86.

melancholica (Lophea), 463.

melanocephala (Colaspoides), 515 .

melunocephala (Ooptocephala), 174.

melauocephala (Diapromorpha), 164.

melanophthalnı (Aspidolopha), 144.

melanopus (Diaproniorpha), 168.

Melinobius, 269.

Melixanthus, 267.

mephistopheles (Cryptocephalus), 254.
Merilia, 98.

Mesocolaspis, 437.

Metachromini, 378.

nietallicum (Colasposoma), 446.

metallicus (Cryptocephalus), 192.

Metaxis, 417.

minor (Pseudoclytra), 102.

minuta (Chrysolampra), 287.

minuta (Coptocephala), 175.

minuts (Demotina), 428.

minuta (Gynandrothalma), 115.

Miochira, 159.

Miopristis, 99.

modesta (Oleorina), 483.

modesta (Demotina), 427.

modesta (Eurypelta), 464.

modestus (Corynodes), 504.

momeitense (Nodostoma), 345.

momeitensis (Lema), 60.

monachoides (Cryptocephalus), 200.

montana (Colaspoides), 515.

montana (Miochira), 160.

montanum (Nodostoma), 328.

montanus (Xanthophorus), 409.

mouhoti (Aulacolepis), 432.

mouhoti (Chrysochus), 510.

mouhoti (Corynodes), 496.

mouboti (Sagra), 7.

mouboti (Trichochrysea), 387.

Mouhotia, 490.

Mouhotina, 490.

multimaculata (Crioceris), 82.

multiplagiata (Etheomorphs), 124.

multipunctata (Sagra), 8.

multipunetatum (Colasposoma), 448.

$2 \mathrm{x}$ 
uu ungphuensis (Gynandrophthalma), 109. suurrayi (Pedrillia), 13. mutabile (Colasposoma), 454.

Myochroini, 459.

nagaensis (Gynandropbthalma), 112.

nagpurensis (Cryptocephalus), 246.

nair (Ceratobasis), 1:1.

Neculia, 413.

nematoides (Etheomorpha), 123.

Nephrella, 416 .

Nephus, 300.

rigra ('Tricliona). 47\%.

nigriceps (Colobaspis), 91.

nigricullis (Aulexis), $\$ 10$.

nigricollis (Lema), 69.

nigricollis (Xanthophorus), 408.

nigrilabrum (Nodina), 293.

nigripennis (Aulexis), 411.

nigripennis (Temnaspis), 87.

nigripennis (Xanthophorus), 409.

nigripes (Aoria), 396.

nigripes (Coenobius), 186.

nigrita (Aoria), 397.

nigrita (Mesorolaspis), 438.

nigrita (Sagra), 5.

nigriventre (Colasposoma), 450.

nigro-bimarginatum (Nodostoma), 319.

nigrocinctum (Nodoatoma), 316.

nigrofasciatum (Nodostoma), 316.

nigrofrontalis (Lema), 17.

nigrolinentum (Nodostoma), 347.

nigrolineatus (Crypto('epbalus), 226.

nigromarginata (Etheomorpha), 125.

nigro-urnata (Crioceris), 81.

nigropicta (Etheoinorpha), 1:2t. nigropicta (Crioceris), 81.

nigroplaginta (Temnaspis), 88.

nigroplagiatus (Dioryctus), 179.

nigropunctata (Gynandrophthalma), 103.

nigrosuturalis (Oryptocephalus), 233.

nigrosuturalis (Gynandrophthalma), 118.

nigrosuturalis (Lema), 43.

nigrotibialis (Gynandrophthalma), 116.

nigroviolacea (Lema), 68.

nigroviridis (Cleorina), 483.

nilgiriense (Nodostoma), 340.

nilgiriensis (Chlamys), 275.

nilgiriensis (Chrysochus), 508.

nilgiriensis (Cryptocephalus), 244.

nilgiriensis (Gynandrophthalma), 119.

nilgiriensis (Lamprosoma), 282.

nılgiriensis (Lema), 67.

nilgiriensis (Scelodonta), 385.

nitens (Eumolpus), 501.

nitida (Trichochrysea), 394.

vitidicollis (Aspidolopha), 143.

nitidissima (Lema), 6\%.

nitidula (Scelodonta), 385.

nitidus (Corynodes), 506.

nobilis (Cleorina), 484 .

nubilitatum (Nodostoma), 302.

Nodina, 292.

Nodostella, 299.

Nodostomn, 301.

Nodostomini, 291.

notogramnus (Cryptocephalus), 231.

obennicus (Cryptocephalus), 261 .

obertlıuri (Teunaspis), (). obesus (Corynodes),

502.

obliterata (Lema), 16.

obliteratum (Nodostoma), 320.

obliteratus (Cryptocephalus), 236.

oblonga (Cleorina), 487.

oblongo-punctatum (Nodostoma), 323.

obscurata (Neculla), 414.

obscurifrons (Lema), 51. obscuritarsis (Lema),

19.

obscuro-fasciatum(Colasposoma), 453.

obscuro-maculata (Diapromorpha), 163.

obsciro-nıaculatum (Nodostoma), 348.

obscuro - maculatus

(Cryptocephalus), 212.

obscurum (Nodostoma), 338.

occipitale (Nodostoma), 335.

occipitalis (Clytra), 154. occipitalis (Lema), 52. octavius (Cryptocephalus), 211.

octomaculata (Diapromorpha), 167.

Odontionopa, 382.

olivieri(Cryptocephalus), 210.

omophloides (Crioceris), 72.

Oomorphus. 281.

opncipennis(Ceratobasis), 174.

oppositus (Cryptocephalus), 249.

orientale (Nodostoma), 330.

orientalis (Chlamps), 27 .

orientalis (Clvtra), 157. orientalis (Eubrachis), 434.

orientalis (Gynandrophthalina), 105.

nrnata (Epimela). 14. ornaticollis (Lena), 50. ornatipennis (Lema), 46.

ornatissima (Dermorhytis), 368.

oruatum (Colasposoma), 453. 
ornatum (Nodostoma), 348.

Orsodacna, 15.

ovulum (Cryptocephalus), 229 .

Pachnephorus, 460.

Pachybrachys, 265.

Pagria, 356.

Pagrini, 355.

pallens (Clytra), 168.

palliata (Clytrasoma), 150.

pallide-testacea (Lema). 41.

pallidicornis (Pseudopiomera), 403.

pallidipennis (Cryptocephalus), 214.

pallidula (Colaspoides), 516.

pallidus (Xanthophorus), 4116.

pullifrons (Chlamys), 272.

pallipes (Ccenobius), 189.

palonensis (Lema), 34.

palpalis (Leina). 29.

Pantocometis, 147.

paradoxa (Lema), 63.

parasiticus (Cryptocephalıs), 254.

Puria, 468.

parvula (Etheomorpha), 132.

parvula (Nodina), 294.

parvula ('Trichochrysea), 392.

pectoralis (Demotinella), 414.

pedestris (Lema), 66 .

Pedrillia, 12.

peguensis (Lema), 28.

penicillata (Hyperaxis), 4:2.2.

peregrivus (Corynodes), 493.

petelii (Sagra), 8.

picea (Pseudostonopa), 352.

picea (Tricliona), 475.

piceitarsis (Cryptocephalus), 254 .

picimane (Nodostoma), 339.

picipes (Eumolpus), 394.

pictipennis (Elheomorpha), 128. picturatum (Nodostoma), 350.

pilosus (Pachnephorus), 460.

pinguis (Diapromorpha), 163 ,

plagiata (Pashnephorus), 460.

plagiata (Pseudoclytra), 102.

plagiatus (Cleoporus), 481.

plagiosum (Nodostoma), 315.

planitrons(Colasposoma), 445.

planifrons (Gynandrophthalma), 113.

Focilomorulia, 91.

poecilopterus (Pachybrachys), 266 .

pollivaria (Neculla), 413.

Polyphaga, 1.

porculus (Dioryetus), 177.

posticalis (Cryptocephalus), 197.

poultoni (Cryptocephalus), 230.

proclara (Leina), 23.

præclarior (Lema), 23.

pracox (Cryptocephalus), 233.

præusta (Lema), 58.

pretiosum(Colasposuma), 449.

pretiosum (Nudostoma), 304.

pretiosus (Chrysochus), 5017.

pretiosus (Curynodes), 501.

prominula (Callisina), 363.

prosternale (Colasposoma), 452.

Pseudoaria, 599.

Pseudoclytra, 101.

Pseudocolaspini, 466.

Pseudocolaspis, 433, 466.

Pseudolema, 83.

Psendometaxis, 124.

Pseudopiomera, 40:3.

Pseudostonopa, 3:0.

psyche (Lema), 63.

pubicolle (Nodostoma), 342.

pulchella (Crioceris), 77.

pulcher (Chrysochus), 509. pulcherrimum (Colasposoina), 454.

pulvillatus(Oryptocephalus), 258.

14-punctata (Etheomorpha), 130.

punctatissina (Dermorhytio), 374.

7-punctatus (Megelopus), 93.

puncticeps (Tricliona), 470.

puncticolle (Nodostoma), 321.

purpurea (Lema), 68.

purpureomaculata (Trichochrysea), 394.

pusaensis (Cryptocephalus), 211.

pusilla (Crioceris), 73.

pusilla (Nodina), 295.

pusilluin (Nodostoma), 349.

pyrophorus (Corynodes), 492.

pyrospilotus (Corynodes), 495.

quadraticollis (Hyperaxis), 418.

quadratus (Cryptocephalus), $2+8$.

quadrifasciata (Trichochrysea), 390.

quadirfasciatum (Nodostuma), 314.

quadriguttata (Paria), 468.

quadrilliun (Cryptocephalus), 203.

quadrimaculata (Diapromorpha), 169.

quadripunctata (Clytra), . 152.

quadripunetata (Diapromorpha), 165.

quadripunctata (Lema), 55.

quadripustulata (Crioceris), 78.

quinquemaculata (Rliyparida), 381 .

quinquenaculatus (Colobaspis), 93.

mjinh (Cryptocephalus), 256.

recticullis (Donaoia), 11. 
rectofasciatus (Cryptocephalus), 2.4.

restituens (Pagria), 359.

Rhyparida, 378.

robusta (Lema), 31.

robusta (Nodina), 297.

robustum (Colasposoma), 450.

robustus (Dioryctus), 178.

rotundata (Nodina), 299. rotundicollis (Chrysonopa), 353.

rotundicollis (Lema), 21. rubiginea (Lema), 38.

rubiginosus (Pachybrachys), 265.

rubripes (Abirus), 457.

rubripes (Cryptocephalus), 210.

rufipes (Colasposoma), 442.

rufipes (Nodina). 293.

rulobrunnea (Lema), 28.

rufofemoralis (Trichochrysea), 388.

rufofemoratus (Cryptocephalus), 201.

rufofrontalis (Lema), 6.2.

rufo-ornata (Lema), 45.

rufo-testarea (Lema), 36.

rufo-tibialis (Eubrachis), 433.

rufo-tibialis (Lema), 48.

rufulus(Cryptocephalus), 221.

rufulus (Eumolpus), 395. rugicollis (Eumolpus), 394.

rugifrons (Lema), 40.

rugifrons (Mouhotina), 491.

rugosa (Aspidolopha), 138.

rugosa (Dermorhytis), 373.

\section{Sagra, 4.}

Sagrinæ, 3.

sandrocottus (Cryptocephalus), 212.

sanguinolentus (Cryptocephalus), 208.

sannio (Cryptocephalus), 251.

saturata (Cleorina), 489.

Scelodonta, 382.

Scelodontini, 382 sculpturatum (Nodostoma), 350.

sehestedti phalus), 228.

sellata (Hyperaxis), 417.

semibrunnea (Chlamys), 27 t.

عemibrunneus (Dioryctıs), 180.

setuicæruleum (Nodostoma), 308.

semicosta (Aoria), 398.

semicostata (Crioceri3), 77.

semicostatum (Colasposoma), 443.

semidivisus (Cryptocephalus), 238.

semifasciata (Demotina), 421.

semifasciata (Hyperaxis), 420.

semiflarus (Cryptoosphalus), 201.

semifoveolatr (Crioceris), 76.

semifulva (Lema), 51.

semiglabritum (Nodostoma), 33 t.

senihirsuta (Crioceris), 75.

semilnevis (Cœuobius),

191.

semilævum (Nodostoma), 323.

seminigra (Crioceris), 74.

seminigris (Coenobius), 185.

semipicea (Colaspoides), 516.

semipunctata (Crioceris), 73.

semipunctata (Gynandroptualma), 110.

semipurpureum (Nodostoma), 305.

semiregularis (Leina), 18.

semirufulus (Cryptocepbalus), 194.

semistriatum (Nodostoma), 326.

gemivittata (Lema). 48.

semivittata (Tricliona), 470.

sensrins (Cryptocepbalus), 260.

senegalense soma), 439. separatum (Nodostoma),

$3: 4$.

serraticollis (Demotinn), 429.

serraticollis (Pseudometaxis). 425 .

serratulum (Colasposoma), 445.

setulosus (Eumolpus), 394.

severini (Trichochrysea), 389.

sexmaculata (Diapromorpha), 167.

sexsignatus (Cryptocephalus), 241.

sbeppardi (Corynodes), 497.

siameusis (Chrysochus), 509.

signata (Pagria), 356.

signatellus (Crytocephalus), 207.

signaticollis (Gynandrophthalma), 109.

signatipennis (Lema), 57.

sikhima (Chrysochus), 507.

sikbiua (Gynandrophthalma), 117.

siklimense (Nodostoma), 332.

sikhimensis (Cryptocephalus), 203.

simillima (Lema), 33.

simulans (Cryptocephalus), 197.

singularis (Irema), 32.

sinuato-vittata (Lema), 45.

sobrius (Cryptocephalus), 232.

sodalis (Etheomorpha), 127.

solani (Lema), 71.

speciosa (Attelabus), 78.

speciosa (Dermorhytis), 376.

speciosus (Colobsspis), 9:.

speciosus (Corynodes), 497.

spengleri (Cryptocephalus), 210.

spinipes (Eubrachis), 433.

splenderis (Chrysolampra), 285.

splendens (Nudostoma), 305. 
splendidum soma ), 451.

spoliata (Leina), 50.

stigmatipennis (Cryptocephalus), 250.

striatipennis (Gynandrophthalma), 119.

strigicollis (Conobius), 191.

strigicollis (Pagria), 358.

strigicollis (Scelodonta), 386.

suavis (Cryptocephalus), 234.

subænea (Chrysolampra), 285.

subcostata (Nodina), 295.

subcostata (Scelodonta), 386.

subcostatum (Nodostoma), 334.

subcostatus (Cryptocephalus), 218.

subcylindricus (Cryptocephalus), 222.

subdepressa (Tricliona), 478 .

subdepressum (Nodostoma), 322.

subdilatata (Nodina), 298.

subdivisa (Gynandrophthalnia), 121.

subfasciata (Pantocometis), 148.

subgeminatus (Cryptocephalus), 253.

subiridea (Lema), 34.

sublævicollis (Aspidolopha), 142.

sublævicollis (Colaspoides), 520.

sublævipenne (Nodostoma), 337.

submetallicus (Cryptocephalus), 192.

subopacum (Colasposoma), 446.

subrugosa (Etheomorpha), 130.

subrugosa (Colaspoides), 515 .

subspinosa (Zeugophora), 14.

subtuberculata (Lema), 29.

succincta (Clytra), 152.

suffriani (Cryptocephalus), 204. suillus (Cryptocephalus), 246.

sulcipennis (Tricliona), 477.

suturale (Nodostoma), 349.

suturalis (Pagria), 356.

suturalis (Pseudolema),

83.

suturata (Etheomorpha), 124.

guturella (Lema), 42.

sylhetense (Nodostoma), 321 .

tarsalis (Nodina), 296.

tavoyense (Nodostoma), 319.

Temnaspis, 87 .

tenebrosa (Chlamys), 274 .

terminalis (Gynandrophtbalma), 120 .

terminata (Lema), 59.

terminatum(Nodostoma), 341 .

tharawaddyensis (Lema), 39.

thibettanum (Colasposoma), 449.

thoracica (Aspidolopha), 139.

thoracier (Chrysolampra), 286

thoracica (Demotina), 431.

thoracicnm(Nodostoma), $3 \cdot 25$.

Thysbe, 439.

tibialis (Aulexis), 411.

tibiella (Lema), 26.

toxicornis (Labidostomis), 96.

tranquebarica (Lema), 27.

transversicolle (Colasposoma), 447.

travancorensis (Corynodes), 503.

triangularis (Cryptocephalus), 252.

triangulum (Coenobius), 182.

Trichochrysea, 387.

Trichotheca, 400.

tricinctus (Cryptocephalus), 237.

Tricliona, 469.

tridentata (Sagra), 4. tridentatus (Corynodes), 505.

trifasciata (Clytra), 154.

trifasciata (Diapromorpha), 162.

trifasciata (Lema), 44.

triusaculata (Aspidclopha), 134, 140.

tripunctata (Ætheomorpha), 131.

tuberosum (Nodostoma), 337.

tureica (Diapromorpha), 169.

Typophorini, 468.

uncinatus (Cryptocephalus), 231.

undatus (Corynodes), 493.

unicolor (Heminodes), 513.

unifasciata (Etheomorpha), 129.

unifasciatus (Cryptocephalus), 217.

uniformis (Cryptocephalus), 217.

unipunctatum (Nodostowa), 309.

vahli (Cryptocephalus), 254.

vahli, var. parasiticus

(Cryptocephalus), 254.

variabile (Nodostoma), 333.

variabilis (Dermorbytis), 368.

variabilis (Tricliona), 473.

varicolor(Chrysolampra), 288.

variegata (Hyperaxis), 421.

variegata (Trichochrysea), 392.

variegatus (Cleoporus), 480.

variegatus (Conobius), 190.

ventralis (Aspidulopha), 137.

versicolor(Colasposoma), 455.

restita (Trichochrysea), 389. 
villosulum (Colasposoma), 440 .

vinula (Etheomorpha), 126.

violacea (Dermorhytis), 374.

violaceo-fasciatum (Nodostoma), 314.

violaceum(Acrothinium), 462.

virgula (Etheomorpha), 128.

virgula(Cryptocephalus), 232.

viridicollis (Chrysolampra), 290.

viridicollis (Epimela), 145.

viridinitens (Dermorhytis), $3 i 1$. viridipenne (Nodostoma), 349.

viridi-suturata (Lema), 43.

viridis (Chrysonopa), 354.

viridis (Trichochrysea), 392.

vittata (Eurypelta), 464. vittrata (Scelodonta), 382.

vittipennis (Cryptocephalus), 230.

wallacei (Lema), 64. wallardiense (Nodostoma), 317.

wallardiensis (Gynandrophthalma), 116. wallardiensis (Lema), 33.

waterhousei (Nodostoma), 335 .

weberi (Lema), 71.

weisei (Nodostoma), 328.

westwoodi (Lema), 64 .

Xanthophorus, 404.

yerburyi (Lema), 30 .

Zeugophora, 14. zonalis (Cryptocephalus), 262. 



\section{PLATE J.}

Fig. 1. Sagra femorata, Drury . . . . . . p. 4.

"2. Lema lacordairei, Baly . . . . . . . . p. 23.

" 3. Crioceris flavipennis, Baly . . . . . . . p. 76.

"4. Crioceris adonis, Baly . . . . . . . p. 78 .

" 5. Temnaspis nigroplayiata, Jac. . . . . . . p. 88.

"6. Gynandrophthalma fabrei, Lefèr. . . . . . p. 122.

"7. Etheomorpha suturata, Jac. . . . . . . p. 124.

" 8. Aspidolopha ventralis, Jac. . . . . . . . p. 137.

"9. Epimela viridicollis, Jac. . . . . . . . p. 145.

"10. Cryptocephalus pusaensis, Jac. . . . . . . p. 211.

" 11. Dermorhytis ornatissima, Baly . . . . . . p. 368.

" 12. Dermorhytis igneofasciata, Baly . . . . . p. 370 .

"13. Chrysolampra burmanica, Jac. . . . . . p. 289.

" 14. Pagria kanaraensis, Jac. . . . . . . . p. 360.

By an oversight the references to the first eight and to the tenth figures were omitted in the text. 

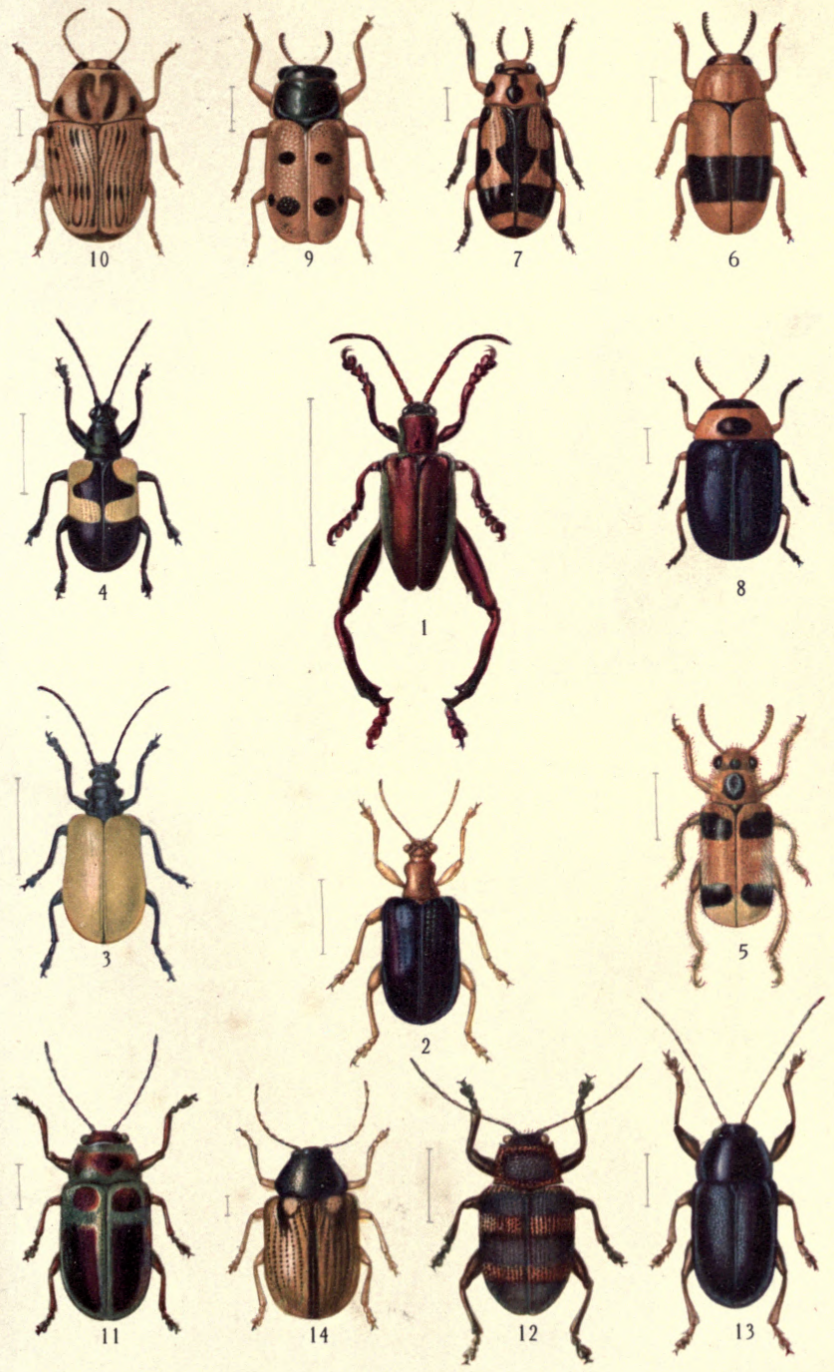


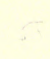





\section{PLATE II.}

Fig. 1. Acrothinium violaceum, Jac. . . . . . . . p. 462.

" 2. Heterotrichus balyi, Chapius . . . . . . . p. 464.

"3. Eurypelta modesta, Fabr. . . . . . . . . p. 464.

„, 4. Trichochrysea viridis, Jac. . . . . . . . . p. 392.

" 5. Scelodonta vittata, Oliv. . . . . . . . . . . . p. 382.

" 6. Tricliona bicolor, Jac. . . . . . . . . p. 476.

„7. Colasposoma downesi, Baly . . . . . . . . p. 442.

" 8. *Colasposoma pretiosum, Baly . . . . . . . . p. 449.

„9. Colasposoma auripenne, Motsch. . . . . . p. 454.

„10. Abirus elongatus, Jac. . . . . . . . . p. 457.

„, 11. Corynodes decennotatus, Baly. . . . . . . p. 492.

„12. Corynodes undatus, Oliv. . . . . . . . . p. 493.

"13. Corynodes pyrospilotus, Baly . . . . . . . . p. 495.

„, 14. Colaspoides subrugosa, Jac. . . . . . . . p. 515.

* In the text, Colasposoma pretiosum, Baly, is referred by mistake to fig. 7 . 


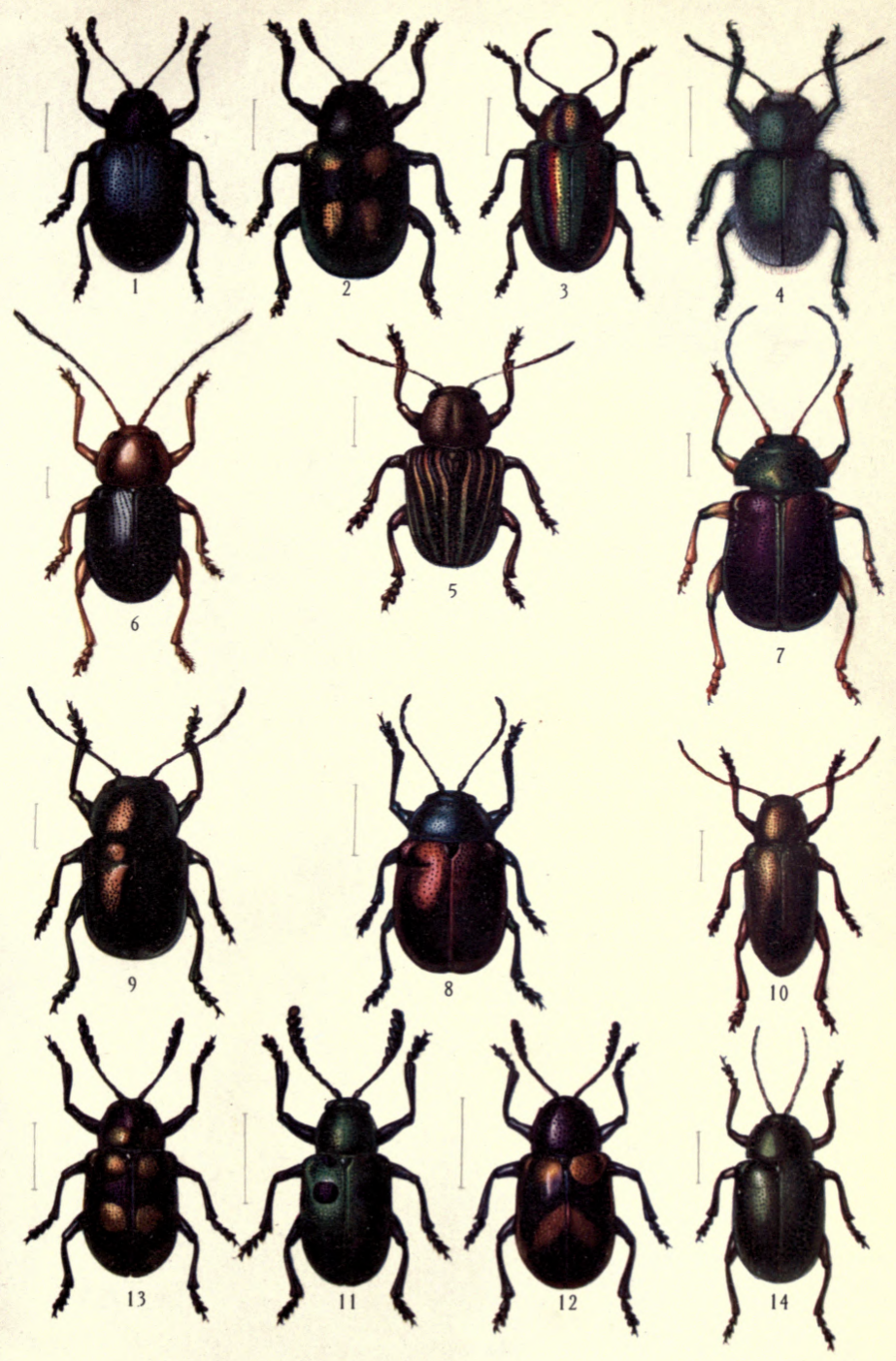








\section{DATE DUE}

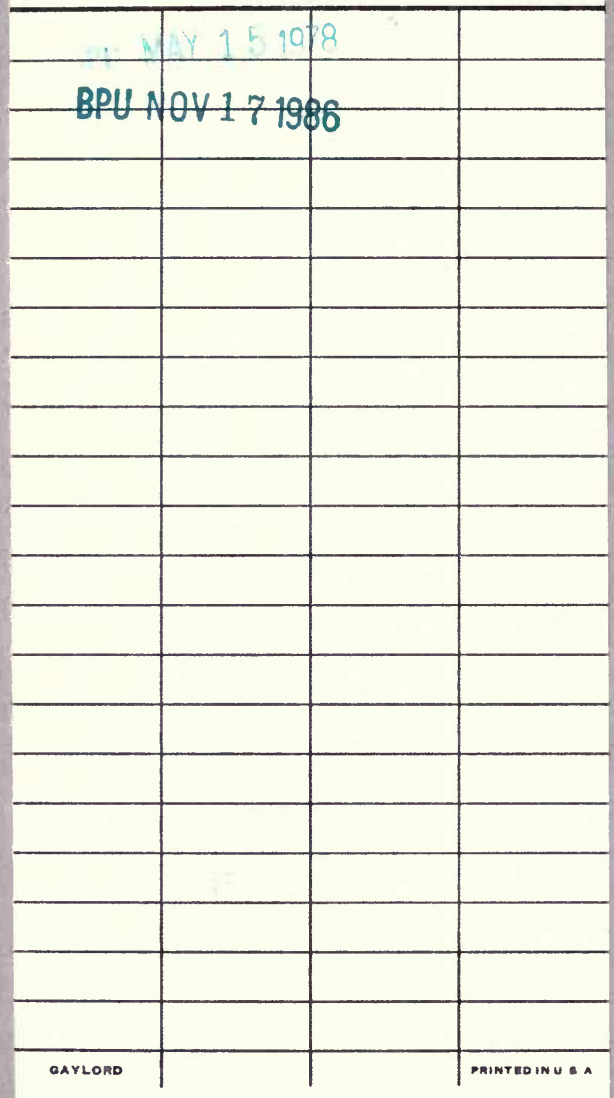




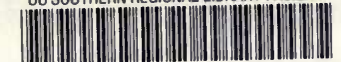

AA $000139786 \quad 8$ 
